\title{
Effekten en kosten van in-vitro-fertilisatie : een prospektieve multicenter studie
}

Citation for published version (APA):

Haan, G. H. M. G. (1989). Effekten en kosten van in-vitro-fertilisatie : een prospektieve multicenter studie. [Doctoral Thesis, Maastricht University]. Rijksuniversiteit Limburg. https://doi.org/10.26481/dis.19891013gh

Document status and date:

Published: 01/01/1989

DOI:

10.26481/dis.19891013gh

Document Version:

Publisher's PDF, also known as Version of record

\section{Please check the document version of this publication:}

- A submitted manuscript is the version of the article upon submission and before peer-review. There can be important differences between the submitted version and the official published version of record.

People interested in the research are advised to contact the author for the final version of the publication, or visit the DOI to the publisher's website.

- The final author version and the galley proof are versions of the publication after peer review.

- The final published version features the final layout of the paper including the volume, issue and page numbers.

Link to publication

\footnotetext{
General rights rights.

- You may freely distribute the URL identifying the publication in the public portal. please follow below link for the End User Agreement:

www.umlib.nl/taverne-license

Take down policy

If you believe that this document breaches copyright please contact us at:

repository@maastrichtuniversity.nl

providing details and we will investigate your claim.
}

Copyright and moral rights for the publications made accessible in the public portal are retained by the authors and/or other copyright owners and it is a condition of accessing publications that users recognise and abide by the legal requirements associated with these

- Users may download and print one copy of any publication from the public portal for the purpose of private study or research.

- You may not further distribute the material or use it for any profit-making activity or commercial gain

If the publication is distributed under the terms of Article $25 \mathrm{fa}$ of the Dutch Copyright Act, indicated by the "Taverne" license above, 


\title{
EFFEKTEN EN KOSTEN VAN \\ IN-VITRO-FERTILISATIE
}

\section{een prospektieve multicenter studie}

\section{PROEFSCHRIFT}

ter verkrijging van de graad wan doctor aan de Rijksuniversiteit Limburg te Maastricht, op gezag van de Rector Magnificus, prof.dr. F.L.M. Bonke, volgens het besluit van het College van Dekanen, in het openbaar te verdedigen op

vrijdag 13 oktober 1989 om 14.00 uur

\author{
door \\ Gregorius Hubertus Maria Gerardus \\ Haan \\ geboren te Heerlen op 14 juni 1958
}


Promotor: prof.dr. F.F.H. Rutten

Co-promotor: dr. J.M.W.M. Merkus

Beoordelingskommissie: prof.dr. J.A Knotnerus (woorzitter)

dr. A.Th. Alberda

dr. J.L.H. Evers

prof.dr. HA Valkenburg

prof.dr. G.H. Zeilmaker

Dit proefschrift is voornamelijk gebaseerd op onderzoek dat werd gefinancierd door de Ziekenfondsraad. De publikatie van dit proefschrift werd mede mogelijk gemaakt door bijdragen van Hoechst Holland N.V., Organon Nederland B.V., Pfizer Central Research, Pharma Import B.V., Schering Nederland B.V. en Wyeth Laboratoria B.V. 
De zuster van de baby doet boter op de buik en dan kijkt ze altijd naar de televisie 
$\therefore$ 


\section{INHOUDSOPGAVE}

LIJST VAN FIGUREN EN TABELLEN

VOORWOORD $\quad 5$

AFKORTINGEN

1. INLEIDING 9

1.1. Beschrijving methode van IVF 9

1.1.1. Verschil van IVF ten opzichte van een spontane konseptie-cyclus 9

1.12. Beschrijving van de IVF-procedure zelf 11

1.2. Voorgeschiedenis van het evaluatie-onderzoek-IVF 13

1.3. Introduktie tot het evaluatie-onderzoek-IVF in Nederland 15

1.3.1. Oorspronkelijke vraagstellingen van het onderzoek 15

1.3.2. Het vergelijkend onderzoek IVF versus tubachirurgie 15

1.3.3. Definitieve vraagstellingen voor het evaluatie-onderzoekIVF 17

1.3.4. Organisatie van het onderzoek 18

1.3.5. Introduktie tot het eindrapport 18

2. MEDISCHE EVALUATIE VAN IVF; TOTAALOVERZICHT

$\begin{array}{lr}\text { 2.1. Introduktie } & 19\end{array}$

2.2. Patiënten en onderzoeksmethode 19

2.2.1. Samenstelling onderzoekspopulatie $\quad 19$

2.2.2. Databeheer en onderzoeksmethoden 20

2.3. Totaalresultaten van IVF in de 5 ziekenhuizen van het onderzoek 23

3. MEDISCHE EVALUATIE VAN IVF; VERKI ARING VOOR VERSCHILLEN IN RESULTATEN

3.1. Seizoensinvloed en leereffekt 27

3.2. Patientkenmerken 29

3.2.1. Leeftijd vrouw 29

3.2.2. Indikatie $\quad 30$

3.2.3. Verzekeringsvorm 38

3.2.4. Aanwezigheid ovaria 39

3.2.5. Infertiliteitsduur en graviditeit $\quad 40$

3.2.6. Samenstelling van de patientenpopulatie in de verschillende ziekenhuizen 41

3.3. Behandelkenmerken c.q. behandel-tussen-resultaten 42

3.3.1. Rangordenummer van de behandeling per paar 42

3.3.2. Beloop van de IVF-behandeling 50

3.3.2.1. Hormoonstimulatie -> follikelpunktie 51

3.3.2.2. Follikelpunktie -> Embryotransfer 62

3.3.2.3. Embryotransfer $\rightarrow$ (klinische) zwangerschap $\quad 72$

3.3.2.4. Resultaat van de klinische zwangerschap 83 
3.4. Verklaringen voor verschillen op multivariate wijze 91

3.4.1. Inleiding 91

3.4.2. Multivariate regressie-methoden 92

3.3.3. Multiwariate analyse voor stap follikelpunktie $\rightarrow>$
embryotransfer

3.4.4. Multivariate analyse voor stap embryotransfer ->
kinische zwangerschap

3.4.5. Multivariate anallyse voor het totaalresultaat: van hormoonstimulatie tot doorgaande zwangerschap 102

3.4.6. Multivariate anallyse voor het resultaat vanaf de follikelpunktie tot doorgaande zwangerschap 106

3.5. Samenvating en konklusies 108

4. EKONOMISCHE EVALUATIE VAN TVF

$\begin{array}{ll}\text { 4.1. Inleiding } & 111\end{array}$

4.2. Personeelskosten 112

4.3. Kosten van apparatuur, ruimte, materiaal en overige kosten 118

4.4. Kosten van pré-medikatie en hormonale stimulatie in de folliku-
laire en luteale fase
122

4.5. Overige kosten binnen de gezondheidszorg 124

4.6. Totaaltelling kostenberekening IVF-behandeling 126

$\begin{array}{ll}\text { 4.7. Koniklusies } & 128\end{array}$

5. ALTERNATIEVE BEHANDELINGEN VOOR IVF 129

5.1. Introduktie $\quad 129$

5.2. Tubachirurgie 129

$\begin{array}{ll}\text { 5.2.1. Medische resultaten } & 129\end{array}$

5.2.2. Globale bepaling van de financieel-ekonomische kosten 136

5.3. Andere vormen van fertiliteitsbehandeling 137

5.4. Geen behandeling 139

5.5. Behoefte aan fertiliteitsbehandeling in het algemeen en IVF in $\begin{array}{lr}\text { het bijzonder } & 142\end{array}$

5.6. Konklusies $\quad 145$

6. EFFEKTEN EN KOSTEN VAN DE IVF-BEHANDELING

$\begin{array}{ll}\text { 6.1. Introduktio } & 147\end{array}$

6.2. Effekten en kosten van de IVE-behandeling; een onderlinge
vergelijking

6.3. Effekten en kosten van de IVF-behandeling; een vergelijking met
alternatieven

6.4. Beleidsimplikaties en beleidskomplikaties 154

SAMENVATTING $\quad 159$

$\begin{array}{ll}\text { SUMMARY } & 163\end{array}$

LITERATUUR $\quad 167$

$\begin{array}{ll}\text { BLJLAGEN } & 187\end{array}$

$\begin{array}{ll}\text { CURRICLLUM VTTAE } & 287\end{array}$ 


\section{LIJST VAN FIGUREN EN TABELLEN}

\section{FIGUREN}

Figuur 2.1. Verloop van de $\mathbb{I}$ VF-behandeling in fasen $\ldots \ldots \ldots \ldots \ldots$

Figuur 3.1. Spektrum van patientgroepen met verschillende prognoses en de samenhang met selektieve doorstroom $\ldots \ldots \ldots . \ldots . \ldots 43$

Figuur 3.2. Kumulatief doorgaand zwangerschapspercentage: theorie versus

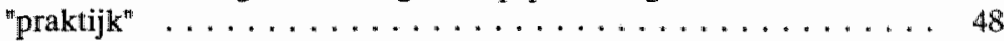

Figuur 3.3. Stappenschema bij de analyses van beloop tijdens en na de IVF-behandeling. ......................... . . 50

Figuur 3.4. De gekorrigeerde doorgaand-zwangerschapspercentages in de verschillende ziekenhuizen . . . . . . . . . . . . . . . . . 105

Figuur 4.1. Gemiddelde en differentiele kosten van IVF bij verschillende omvang van het programma . . . . . . . . . . . . . . . .

\section{TABELLEN}

Tabel 2.1. Indeling medisch registratieformulier IVF in het kader van het evaluatie-onderzoek IVF ................... 21

Tabel 2.2. Resultaten van IVF-behandelingen in de ziekenhuizen van het evaluatie-onderzoek ..................... 23

Tabel 2.3. IVF-tresultaten in de Verenigde Staten . . . . . . . . . . 26

Tabel 3.1. Frekwenties van enkele anamnestische gegevens van IVF-paren met als enige indikatie tubapathologie. . . . . . . . . . .

Tabel 3.2. Kumulatief klinisch zwangerschapspercentage bij een oplopend aantal follikelpunkties per paar .................. 44

Tabel 3.3. IVF-historie wan de behandelde paren in de diverse ziekenhuizen ......................... 45

Tabel 3.4. Kumulatief doorgaand zwangerschapspercentage per gestarte IVF-behandeling . ....................... 48

Tabel 3.5. Bepaling zwangerschapspercentage door middel van een cohortbenadering ......................... . . . 49

Tabel 3.6. Behandelresultaten gedifferentieerd naar $\mathrm{E}_{2}$-patroon . . . . . . 57

Tabel 3.7. Fertilisatiegraad in de verschillende ziekenhuizen . . . . . . . . 69

Tabel 3.8. Resultaten van embryotransfers na cryopreservatie in Clamart (Testart[1987a]) ........................... . . 81

Tabel 3.9. Resultaten van embryotransfers na cryopreservatie in Clamart (Testart[1987b]) . . . . . . . . . . . . . . . . . . 81

Tabel 3.10. Percentage keizersnedes per partus in 1980 in enkele landen waar IVF wordt nitgevoerd

Tabel 3.11. Modelschattingen voor model met als afhankelijke variabele de fertilisatiegraad (BEVRUCHT) en als onafhankelijke variabelen: patientkenmerken, behandeltussenresultaten, behandelvolgnummer en ziekenhuisdummies . . . . . . . . . . 96 
Tabel 3.12. Modelschattingen voor model met als afhankelijke wariabele het aratal beschikbare embryo's (TEMBRYO) en als onafhankelijke variabelen: patientkenmerken, behandeltussenresultaten, behandelvolgnummer en ziekenhuisdummies . . . . . . . . . .

Tabel 3.13. Modelschattingen voor model met afhankelijke variabele

klinische zwangerschap; onafhankelijke variabelen: patientkenmerken en behandelvolgnummer . . . . . . . . . 100

Tabel 3.14. Modelschattingen voor model met afhankelijke variabele klinische zwangerschap; onafhankelijke variabelen:

ziekenthuizen, patientkenmerken en behandelvolgnummer

Tabel 3.15. Modelschattingen voor model met afhankelijke variabele doorgaande zwangerschap; onafhankelijke variabelen: patiêntkenmerken en behandelvolgnummer . . . . . . . . . 103

Tabel 3.16. Modelschattingen voor model met afhankelijke variabele doorgaande zwangerschap; onafhankelijke variabelen: ziekenhuizen, patientkenmerken en behandelvolgnummer

Tabel 3.17. Modelschattingen voor model met afhankelijke variabele doorgaande zwangerschap; onafhankelijke variabelen: patientkenmerken en behandelvolgnummer . . . . . . . . . 107

Tabel 3.18. Modelschattingen voor model met afhankelijke variabele doorgaande zwangerschap; onafhankelijke variabelen: ziekenhuizen, patièntkenmerken en behandelvolgnummer . . . . . 107

Tabel 4.1. Personele kapaciteit bij IVF-programma's van verschillende omvang . . . . . . . . . . . . . . . . . . . . . 114

Tabel 4.2, Loonkosten per full-time-equivalent van IVF-personeel . . . . . 117

Tabel 4.3. Jaarlijkse loonkosten van IVF-personeel bij IVF-programma's

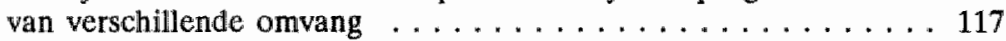

Tabel 4.4. Apparatuur met aanschafprijs en ruimte benodigd voor 375 stimulaties c.q. 300 follikelpunkties . . . . . . . . . . . . . . 119

Tabel 4.5. Extra benodigde apparatuur en ruimte bij uitbreiding van het IVF-programma (ten opzichte van een programma van 375 stimulaties $c_{n} q .300$ follikelpunkties) . . . . . . . . . . . 120

Tabel 4.6. Kosten voor apparatuur en ruimte . . . . . . . . . . . . 121

Tabel 4.7. Materiele kosten per behandeling . . . . . . . . . . . . . 121

Tabel 4.8. Totale kosten voor IVF-programma's van verschillende omvang . 126

Tabel 4.9. Gemiddelde en differentiele kosten per gestarte IVF-behandeling bij uiteenlopende programma's . . . . . . . . 126

Tabel 5.1. Zwangerschapsresultaten bij verschillende typen van

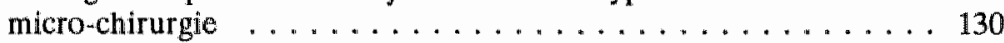

Tabel 5.2. Zwangerschapsresultaten na micro-chirurgie; Brussel $(1971-1981) \ldots \ldots \ldots \ldots \ldots \ldots$. . . . . . . . . . . . . . . . . . . . . . .

Tabel 5.3. Incidentie van EUG en abortus na micro-chirurgie (\% per klinische zwangerschap) . . . . . . . . . . . . . . . 135

Tabel 6.1. Gemiddelde en differentiele kosten per voldragen zwangerschap bij een bepaald maximum aantal IVF-behandelingen . . . . . . . . 149

Tabel 6.2. Kosten per voldragen zwangerschap bij IVF, gedifferentieerd naar enkele patiénikenmerken 


\section{VOORWOORD}

Dit proefschrift is een uitvloeisel van een recente wijziging in het Nederlandse overheidsbeleid ten aanzien van de gezondheidszorg. Enige jaren geleden is door de Nederlandse overheid en haar adviesorganen een beleid op gang gebracht om medische ontwikkelingen expliciet te beoordelen op meer dan alleen medische kriteria. Evaluatie-onderzoek zou geèntameerd dienen te worden en beleid op het terrein van de gezondheidszorg zou nadrukkelijker gekoppeld dienen te worden aan de resultaten van dergelijk onderzoek. Een van de eerste stappen op deze weg werd door de Ziekenfondsraad gezet ten aanzien van de fertiliteitsbehandeling in-vitro-fertilisatie. Alvorens haar beleidsadvies uit te spreken over de financiering van deze relatief nieuwe voorziening wenste men nader onderzoek te laten uitvoeren naar de medischbiologische, de financieel-ekonomische en de psycho-sociale aspekten van deze vorm van kunstmatige voortplanting. Dit onderzoek werd uitgevoerd door de Rijksuniversiteit Limburg in samenwerking met 5 Nederlandse ziekenhuizen: St. Radboud Ziekenhuis in Nijmegen, Academisch Ziekenhuis Vrije Universiteit Amsterdam, Ziekenhuis Dijkzigt in Rotterdam, Academisch Ziekenhuis Leiden en St. Elisabeth Ziekenhuis in Tilburg. De resultaten van deze studie zijn grotendeels weergegeven in dit proefschrift. Eerder dit jaar werden de onderzoeksresultaten aan de Ziekenfondsraad gepresenteerd in de vorm van een eindrapport.

Het proefschrift wijkt voornamelijk op twee onderdelen af van dat eindrapport. Ten eerste zijn de resultaten van het psycho-sociale gedeelte van het evaluatie-onderzoekIVF niet opgenomen. De achtergrond van deze keuze is niet onderschatting van het belang van deze aspekten, maar de konstatering dat dit gedeelte van het onderzoek om diverse redenen beperkt is gebleven (voor nadere tekst en vitleg zij verwezen naar het eindrapport). Het tweede bellangrijke verschil bestaat uit aanvullende analyses met betrekking tot de multivariate modelschattingen in paragraaf 3.4 .

Het evaluatie-onderzoek-IVF heeft gedurende de afgelopen jaren in mijn leven enigszins de plaats overgenomen van de sport. Ik heb er veel energie ingestoken en ik heb gemerkt wat het is om "alles uit de kast te gooien". Maar de kondities waaronder ik mijn konditie kon opbouwen waren optimaal.

Ten eerste wil ik mijn kinderen Joep, Nanneke en Lieke bedanken die in de loop van de onderzoeksperiode zijn geboren en die mij hebben laten ervaren waarom veel mensen zo graag kinderen willen opvoeden en zien ontwikkelen. Zij hebben mij bovendien geleerd met weinig slaap toe te kunnen. Ronny, mijn vriendin en vrouw, maakte het mij mogelijk zoveel aandacht te besteden aan het onderzoek als nodig was. Bovendien voorspelde zij altijd feilloos mijn momenten van fysieke terugslag.

Prof.dr. Frans Rutten, mijn promotor, heeft mij op het spoor van het evalluatieonderzoek gezet en mij de mogelijkheid geboden dit onderzoek in de praktijk van haver tot gort te leren kennen. Mede dankzij hem werden de problemen die ik daarbij tegenkwam mij nooit te gortig. Ik heb hem vooral als mens zeer leren waarderen en hem in de omgang eerder ervaren als kollega dan als opperstalmeester. Mijn co- 
promotor dr. Hans Merkus ben ik dank verschuldigd voor zijn voortdurend oprechte kommentaar tijdens de hele rit, ook all liepen onze belangen soms viteen. Door deze opstelling was hil voor mij een belangrijke steunpilaar. In de begeleiding voor het proefschrift nam hij de verantwoordelijkheid voor het medisch gedeelte op zich. Omdat ik mil als ekonoom had bezig gehouden met medische zaken, wilde hij zich bovendien als gynaecoloog ook nog inzetten voor fondswerving. Zijn inzet was, figuurlijk gesproken, goud watard.

De leden van de Beoordelingskommissie dank ik niet alleen voor het lezen van het manuscript van dil proefschrift. Dr. Bert Alberda en prof.dr. Gerard Zeilmaker waren binnen de ruimte die hen ter beschikking stond altijd bereid om problemen te bespreken. De nestor prof.dr. Hans Valkenburg heeft mij in de Advieskommissie-IVF en later in de Begeleidingskommissie-IVF van de Ziekenfondsraad laten profiteren van zijn vele praktijkervaringen. Prof.dr. Andre Knottnerus en dr. Hans Evers ben ik naast hun voorzitterschap $\mathrm{c}_{\text {.q }}$. lidmaatschap van de Beoordelingskommissie zeer erkentelijk voor de wijze waarop ze mij in de aanloop van het onderzoek hebben gewezen op diverse problemen, mogelijkheden en voetangels bij de onderzoeksopzet.

Vele handen maken licht werk. Hoewel het werk niet licht was, hebben wele personen in de vijf ziekenhuizen belangrijke klussen geklaard voor dit onderzoek: organisatie, registratie en natuurlijk in-vitro-fertilisatie. Zonder andere artsen en biologen, patiènten, secretaressen, verpleegkundigen, laboranten en anderen te kort te willen doen wil ik hier toch met name de kontaktpersonen voor het onderzoek bedanken (Frederika Prak, Rob Bernardus, dr. Cees Waegemaekers, dr. Hans Hollanders en dr. Bob Leerentveld) woor hun enthousiaste medewerking. De IVF-verantwoordelijken in de ziekenhuizen (naast eerdergenoemde personen dr. Jan Vermeiden, prof.dr. Joop Schoemaker, dr. Nico Naaktgeboren, dr. Frans Helmerhorst, dr. Bart Bastiaans, dr. Rob Bots en dr. Marcel Peeters) wil ik eveneens bedanken voor de prettige samenwerking.

Binnen de Rijksuniversiteit Limburg verleenden eveneens vele personen hand- en spandiensten. De steun van $R$ eg van Steen ging echter veel verder: zonder zijn inbreng was dit proefschrift nooil op deze wijze tot stand gekomen. Omdat hij te goed was voor zijn taak bimnen het IVF-projekt heb ik ruimschoots kunnen profiteren van onze vele besprekingen over essentiele stappen in de analyses. Daarnaast deed hij de dingen die gedaan moesten worden zeer nawwkeurig en voorzien van scherpe humor. Zelfs zijn voortijdige vertrek was voor het onderzoek essentieel: zodoende zijn de analyses op tijd in een definitieve vorm gegoten. De secretaressen Kristine Kerkhofs en Maria Kalivas en de student-assistenten Petra van de Berg en Christine Willekes hebben mij vele werkzaamheden uit handen genomen, klusjes die naar mijn gevoel vaak "gisteren klaar" moesten zijn. Prof.dr. Arie Hasman, Math Pieters en Riekie de Vet hebben mij vooral in het begin van het projekt met raad en daad bijgestaan. Als statistische vraagbaak onderweg heeft de sfinx dr. Arnold Kester gefungeerd. Jan van Emmerik verzorgde met een onnavolgbare onverstoordheid de broodnodige lay-out van de ruwe teksten. Voor de vriendschap binnen de vakgroep dank ik vooral dr. Eddy Van Doorslaer en dr. Richard Jansen.

Zowel in de Advieskommissie-IVF als in de Begeleidingskommissie-IVF heb ik goed geluisterd naar de geleverde kommentaren. Hoewel ik ter plekke wel eens onnodig fel 
reageerde op kritiek, heb ik op de terugreis naar Maastricht vele suggesties alsnog ter harte genomen. Van Wim Schellekens heb ik ongemerkt veel geleerd over vergadertechnieken en -taktieken. Verder gaat mijn dank met name uit naar Jaques van der Steur, prof.dr. G. Kloosterman, dr. Han Maathuis, Harry Aarts en P. Starmans.

Ook buiten deze kommissies heb ik goede herinneringen aan de kontakten met de Nederlandse Vereniging voor Reageerbuisbevruchting. Zij komen op een zeer professionele manier - in de positieve zin des woords - op voor de belangen van de IVF-paren. Een enkele keer werd een genuanceerde blik op de feiten afgewisseld door grote feltheid. Ik weet giet of bij mij in die positie de genuanceerdheid de overhand zou hebben behouden.

De Ziekenfondsraad ben ik erkentelijk voor het in ons gestelde vertrouwen - met de bijbehorende financięn - waardoor dit onderzoek mogelijk werd. Ik wens hen veel wijsheid in het bepalen van een weloverwogen beleid ten aanzien van IVF en de andere vormen van fertiliteitsbehandeling in Nederland. De leden van de landelijkewerkgroep-IVF van de Nederlandse Vereniging voor Obstetrie en Gynaecologie dank ik voor de in velerlei opzicht leerzame avonden. Een dergelijke openheid van een beroepsgroep wens ik iedere evaluatie-onderzoeker toe.

Zonder mijn ouders zouden de eicel en zaadcel van toen nooit zijn uitgegroeid tot de auteur van dit proefschrift. 


\section{AFKORTINGEN}

$\begin{array}{ll}\text { AMC } & \text { Academisch Medisch Centrum (Amsterdam) } \\ \text { AZL } & \text { Academisch Ziekenhuis Leiden } \\ \text { AZM } & \text { Academisch Ziekenhuis Maastricht } \\ \text { AZU } & \text { Academisch Ziekenhuis Utrecht } \\ \text { AZVU } & \text { Academisch Ziekenhuis van de Vrije Universiteit (Amsterdam) } \\ \text { BMDP } & \text { Bio-Medical Data Package } \\ \text { cC } & \text { clomifeencitiaat } \\ \text { c.p. } & \text { ceteris paribus } \\ \text { (D)IPI } & \text { (Direkte) Intra-Peritoneale Inseminatie } \\ \text { E } & \text { oestradiol } \\ \text { EDPAF } & \text { Embryo-Derived-Platelet-Activating Factor } \\ \text { EPAT } & \text { Early-Pregnancy-Associated-Thrombocytopeniat } \\ \text { ET } & \text { Embryo-Transfer } \\ \text { EUG } & \text { Extra-Uteriene Graviditeit } \\ \text { fte } & \text { full-time-equivalent } \\ \text { FSH } & \text { Follikel-Stimulerend Hormoon } \\ \text { GIFT } & \text { Gamete-Intra-Fallopian-Transfer } \\ \text { GOF } & \text { Goodness-Of-Fit } \\ \text { hCG } & \text { humaan Chorion Gonadotropine } \\ \text { hMG } & \text { humaan Menopauze Gonadotropine } \\ \text { HSG } & \text { Hystero-Salpingo-Grafie } \\ \text { IUG } & \text { Intra-Uteriene Graviditeit } \\ \text { IVC } & \text { Intra-Vaginale Cultuur } \\ \text { IVF } & \text { In-Vitro-Fertilisatic } \\ \text { KI(D) } & \text { Kunstmatige Inseminatie (met Donorzaad) } \\ \text { LH } & \text { Luteiniserend Hormoon } \\ \text { LHRH } & \text { Luteinising Hormone Releasing Hormone } \\ \text { LSV } & \text { Landelijke Specialisten Vereniging } \\ \text { NVOG } & \text { Nederlandse Vereniging van Obstetrie en Gynaecologie } \\ \text { NVRB } & \text { Nederlandse Vereniging voor Reageerbuisbevruchting } \\ \text { NZR } & \text { Nationale Ziekenhuis Raad } \\ \text { O\&W } & \text { Onderwijs en Wetenschappen } \\ \text { PCO } & \text { Poly-Cysteus Ovarium (syndroom) } \\ \text { OALY } & \text { Quality Adjusted Life Year } \\ \text { RCT } & \text { Randomised Controlled Trial } \\ \text { SPSS } & \text { Statistical Package for the Social Sciences } \\ \text { VNZ } & \text { Vereniging van Nederlandse Ziekenfondsen } \\ \text { WHO } & \text { World Health Organization } \\ \text { WVC } & \text { Welzijn, Volksgezondheid en Cultuur } \\ & \end{array}$




\section{INLEIDING}

\subsection{Beschrijving methode van IVF}

\subsubsection{Verschil van IVE ten opzichte van een spontane konseptie-cyclus}

De term in-vitro-fertilisatie betekent letterlijk 'bevruchting in glas'; de bevruchting in het menselijk lichaam kan men aanduiden met de term fertilisatie in wivo. Eigenlijk wordt bij de methode van in-vitro-fertilisatie (voortaan te noemen IVF) een soort van 'helping hand' geboden aan het niet volledig funktionerende menselijke lichaam. In principe wordt door de IVF-methode slechts een klein gedeelte overgenomen van het naturijijke proces vanaf de follikulaire fase ${ }^{1}$ tot de geboorte van een kind.

Indien het natuurlijk proces eindigt met een partus, dan verloopt dit proces als volgt. Gedurende de follikulaire fase komt in eén van beide ovaria ${ }^{2}$ een follikel ${ }^{3}$ tot rijping. Bij volledige rijping volgt de ovulatie ${ }^{4}$ de follikel barst open en de obcyt ${ }^{5}$ verlaat thet ovarium. Vervolgens wordt de oöcyt door de fimbriae ${ }^{6}$ opgevangen in de tuba ${ }^{7}$. In de tuba wordt de oöcyt langzaam verplaatst richting uterus ${ }^{8}$. Tijdens het afleggen van dit trajekt vindt de fertilisatie plaats: een spermatozoon ${ }^{9}$ dringt door de zona pellucida ${ }^{10}$ en bevrucht de oöcyt. Daarna sluit de oöcyt zich af voor andere spermatozoa. Hierna volgt de fase van de celdelingen: de oöcyt is een embryo ${ }^{11}$ geworden. Het embryo zal innestelen in de uterus. Vervolgens volgt de groei tot foetus en aiteindelijk leiden de barensweeern tot de geboorte van een kind.

Waar biedt IVF nu de helpende hand? In principe alleen in het gedeelte vanaf de ovulatie tot en met de eerste celdelingen (circa 2 dagen in een proces van 9 maanden). Als in de IVF-procedure alles naar wens verloopt, behelst deze procedure het volgende. Kort vór de ovulatie wordt de follikel in het ovarium aangeprikt en leeggezogen. Uit de betreffende vloeistof wordt de obcyt verkregen en deze wordt in het IVF-laboratorium samengebracht met bewerkte spermatozoa. Na bevruchting en celdeling(en) wordt het embryo in de uterus geplaatst.

1) De eerste fase van de menstruaticoyclus, te weten tof an de ovulatie.

2) Eierstokken.

3) Eicelblatasje.

4) Eisprong.

5) Eucel.

6) Vang-armen wan de elleider.

7) Eiletider.

8) Baarmoceder.

9) Zaadcel.

10) De builenste beschermrand wan de oocyt.

11) Wellicht zow strikt genomen de tern pre-embryo beter op zijn plaats zijn (zhe Gezondheidsraad[1986]). In dit rapport zal echer worden aangesloten bij het ingesloper sprakgebruik bij IVI (ook in de internationale literatuur); derhalve zal de term embro worden gehanteerd. 
In de praktijk verloopt het fertilisatieproces en de ontwikkelingen daarna echter lang niet altijd naar wens, noch bij het wolledig naturijije beloop, noch met de hulp van de IVF-methode. Een belangrijke reden waarom fertilisatie in het natuurlijke beloop niet optreedt is een funktioneel defekt aan de tubae. Juist met het oog op deze indikatie is de IVF-methode ontwikkeld; het gedeelte van het proces warin de tubae een rol spelen wordi immers juist overgenomen door de IVF-methode. Toen men er eenmaal in geslaagd was met behulp van deze behandeling een kind ter wereld te brengen (in 1978) is men gaan zoeken naar mogelijkheden om de resultatem van de IVF methode te verbeteren. Hierdoor zijn elementen aan de IVF-procedure toegevoegd die ten behoeve van paren met als enige indikatie dubbelzijdige tubapathologie strikt genomen niet noodzakelijk zijn. Deze elementen hebben er echter wel voor gezorgd, dat de resultaten per behandelcyclus sterk verbeterd zijn. Daarnaast is het mede hierdoor ook mogelijk geworden om paren met fertiliteitsproblemen vanwege (ook) andere indikaties dan dubbelzifdige tubapathologie te behandelen. De ingreep in het natuurlijk proces is daarmee wel verlengd tot 14 a 28 dagen. De belangrijkste aanvillende elementen zijn:

- hormoonstimulatie tijdens (en eventueel voorafgaand aan) de follikulaire fase met als doel gelijktijdige rijping van meerdere follikels; hierdoor kunnen tijdens eén behandelcyclus meerdere obcyten worden verkregen, na fertilisatie mogelijk leidend

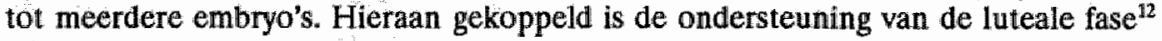
om daarmee de kans op innesteling van het embryo te vergroten. Transfer van meerdere embryo's geeft cen grotere zwangerschapskans, maar ook een grotere kans op meerling-zwangerschap. Derhalve worden niet alle beschikbare embryo's in eén cyclus teruggeplaatst. Niet-teruggeplaatste embryo"s kunnen worden ingevroren om na ontdooien in een latere cyclus te worden teruggeplaatst

- endocrinologische en echoscopische kontrole tijdens de follikulaire fase om daarmee zicht te houden op de ontwikkeling en om deze eventueel te kunnen beinvloeden

- laboratorium-aktiviteiten om de interaktie van vrouwelijke en mannelijke gameten te beoordelen en eventuele problemen te beperken.

Naast de bovenvermelde uitbreidingen van de IVF-procedure met als doel de behandelresultaten te verbeteren zijn in de loop der tijd ook enkele vereenvoudigingen doorgevoerd. De belangrijkste simplifikatie betreft de wijze van follikelpunktie. Tot circa 1986 vond deze verrichting plaats met behulp van een laparoscoop ${ }^{3}$ (transabdominaal $\left.{ }^{14}\right)$. Deze ingreep vond plaats onder volledige anesthesie en de vrouw werbleef zodoende veelal 3 dagen in het ziekenhuis. Sindsdien vinden vrijwel alle lollikelpunkties plaats langs vaginale weg onder echoscopisch zicht. Dit is cen aktiviteit die onder lokale anesthesie kan worden uitgewoerd. Vrijwel altijd kan de vrouw na circa een uur rusten het ziekenhuis verlaten.

Een andere ontwikkeling betreft methoden om het gedeelte van het totale proces dat door de gezondheidszorg van de natuur wordt overgenomen nog verder te reduceren. Deze methoden zijn in meerdere of mindere mate gelieerd aan de IVF; maar de indikatie is veelal niet tubapathologie. Bij gebruik van de gameten van de beide partners zijn de belangrijkste methoden:

12) De tweede fase van de menstruaticoyclus, te weten vanal de ovulatie.

13) Vrij vertald: kijkbuts.

14) Na 3 incisies in de buikwand werd de laparoscoop met bijbehorende bulpmiddelen ingebracht. 
- GIFT: gamete-intra-fallopian-transfer; nadat oucyten (via vooralsnog laparoscopie) en spermatozoa zijn verkregen worden ze samen in de tuba teruggeplaatst. Dit is uiteraard alleen relevant voor vrouwen met minstens és funktionerende tuba.

- (D)IPI: (direkte) intra-peritoneale inseminatie.

- KI: kunstmatige inseminatie, waaronder IUI (intra-uteriene inseminatie).

- IVC: intra-vaginale cultunr; nadat oocyten en spermatozoa zijn verkregen en bewerkt worden ze samen (gescheiden) in een buisje in de vagina geplaatst.

\subsubsection{Beschrijving van de IVF-procedure zelf}

De IVF-procedure is opgebouwd uit een keten wan een antal fasen. Eerder werd al opgemerkt, dat door de IVF-procedure een gedeelte van het natuurlijk proces wordt overgenomen. Dat natuurlijk proces verloopt als een soort afvalrace. Zo geldt ook voor IVF, dat als een bepaalde fase zonder sukses is verlopen, de keten verbroken is en de behandeling in de betreffende cyclus wordt afgebroken zonder het gewenste eindresultaat. Wel kan in een latere cyclus een nieuwe behandeling plaatsvinden. Hoewel de IVF-procedure zeker niet op uniforme wijze wordt uitgevoerd, wordt onderstaand de globale lijn van de behandeling geschetst.

\section{Selektie en informatie}

Alvorens behandeld te worden met behulp van IVF dient het paar zich aan te melden in een IVF-centrum. Voorafgaand aan eventuele plaatsing op een wachtlijst vindt er een 'selektie'-gesprek plaats tussen een gynaecoloog en het paar. Gezamenlijk wordt bekeken of de IVF-methode een zinvolle behandeling is voor de fertiliteitsproblemen van het betreffende paar ${ }^{15}$. Soms worden alsnog gegevens opgevraagd of wordt nog aanvullende diagnostiek uitgevoerd. Dit betreft veelal semenanalyses en testen voor de interaktie van vrouwelijke en mannelijké gameten. Op voorlichtingsavondlen worden in een grotere groep de diverse facetten van de behandeling naar voren gebracht. Ter afronding van de introduktie vindt kort vóor de eerste behandeling nog een informatief gesprek plaats tussen een gynaecoloog en het paar. Op de eerste dag van de daaropvolgende menstruatie mag men dan bellen en kan de eerste IVF-behandeling daadwer* kelijk beginnen.

\section{Hormoonstimulatie}

Meestal wordt vanaf circa de derde cyclusdag ${ }^{16}$ gestart met de hormoonstimulatie (dikwijls wordt hieraan voorafgaand nog een zogenaamde uitgangs-echo gemaakt om te zien of er cysten ${ }^{17}$ aanwezig zijn). De stimulatie bestaat uit een of meerdere van de volgende hormoonpreparaten:

- FSH; Follikel Stimulerend Hormoon; intramusculair

- hMG; Humaan Menopauze Gonadotropine (een kombinatie van FSH en LH (Luteiniserend Hormoony); intramusculair

- clomifeen; oraal

15) In sommige centra wordt men bij anmelding op de wachtlijst geplaatst en windt pas een gesprek plats wanneer rnen aan de beurt is voor de IVF.

16) Cyclusciag $1=$ de eerste dag van de menstruatie.

17) Lege follikelblaasjes. 
- $\mathrm{hCG}$, Humaan Chorion Gonadotropine (intramusculair).

Recent is daar het gebruik van LHRH-analogen bijgekomen (Luteinising Hormone Releasing Hormone); deze worden vanaf de eerste cyclusdag, of al vanaf de luteale fase van de voorafgaande cyclus, toegediend (intranasaal of subcutaan).

Tijdens deze stimulatie wordt de cyclus in meerdere of minder mate gekontroleerd. Hierbij maakt men gebruik van twee indikatoren voor de follikulaire ontwikkeling. Enerzijds maakt men gebruik van visuele gegevens: via, vooral vaginale, echo's wordt het aantal follikels en de diameter van de diverse follikels bepaald. Anderzijds geschiedt de kontrole via endocrinologische bepalingen, ofwel in serum ofwell in urine. Dit betreft vooral metingen van de oestrogeen-waarden. Deze vormen een endocrinologische indikator voor de follikulaire ontwikkeling. Tenslotte wordt in sommige centra nog het LH-nivo gemeten in de laat-follikulaire fase om een eventuele endogene LH-piek te kunnen detekteren. De wijze waarop en de mate waarin kontrole van de follikulaire fase plaatsvindt verschilt sterk per IVF-centrum, niet alleen in Nederland, maar ook wereldwijd.

\section{Follikelpunktie}

Als de follikulaire ontwikkeling goed is verlopen, vindt meestal tussen de $10^{e}$ en de $15^{\circ}$ cyclusdag de follikelpunktie plaats (circa 34 uur na de hCG-injektie ${ }^{18}$ ). Werd tot enkele jaren geleden deze ingreep nog met behulp van een laparoscoop uitgevoerd, tegenwoordig vindt deze in Nederland vrijwel altijd plaats met behulp van een vaginale probe onder echoscopische zicht. Op de probe is een punktiegeleider bevestigd en op het echoscherm is de punktielijn zichtbaar. Na eventuele pre-medikatie, desinfektie en aanbrengen van lokale anesthesie vindt de follikelpunktie plaats. Nadat een follikel in de punktielijn is gebracht wordt deze aangeprikt en leeggezogen met behulp van een vacuumsysteem. De vloeistof wordt opgevangen in een reageerbuisje. Spoelen van de follikels gebeurt vrijwel niet meer (wel wordt het systeem nog gespoeld). Veelal worden meerdere follikels aangeprikt zonder tussentijdse terugtrekking van de punktienaald. In de meeste centra is bij de follikelpunktie laboratoriumpersoneel aanwezig om direkt de obcyten uit de follikelvloeistof af te zonderen. Dit is evenwel niet noodzakelijk, getuige ook de mogelijkheid van de zogenaamde transport-IVF ${ }^{19}$. Na afloop van de follikelpunktie kan de patiente vrijwel onmiddellijk het ziekenhuis verlaten.

\section{In-vitro-fertilisatie}

Als uit de follikelpunktaten oöcyten zijn verkregen, kan de eigenlijke in-vitrofertilisatie worden uitgevoerd. Nadat de oocyten zijn beoordeeld op morfologie worden ze in een prëncubatie-medium geplaatst. Tevens wordt aan de man gevraagd semen te produceren. Dit semen wordt in het IVF-laboratorium voorbewerkt. Enige uren na de follikelpunktie vindt de inseminatie van de oofcyten plaats (meestal in petri-

18) De hCG-injektie wordi veetal rond middernacht toegediend, zodiat de follikelpunktie in de ochtenduren kan platswinden.

19) Bij deze vorn van IVF-behandeling liggen de lokaties voor de follikelpunktie en voor de IVFlaboratorium-rktiviteiten op enige atstand van elkaar. Dat kan varieren van een ruwe 100 meter tot vele kilometers. Kenmerkend is, dat de werkregen follikelwhoistof in buisjes vervoerd wordt naar het IVF-kaboratorium, alwaar de vloeistof vender onderzocht word op de aanwezigheid van oöcyten. Zogezegd wordt in het Dijkzigt Ziekenhuis dit totale skala van transport-IVF uilgevoerd. 
schaaltjes) met een relatief gering aantal, maar goed-beweeglijke spermatozok: Daama worden de schaaltjes in een $\mathrm{CO}_{2}$-stoor geplaatst. Na enige tijd worden de oocyten/embryo's beoordeeld op ontwikkeling en kwaliteit en ewentweel overgeplaatst in een ander medium. Ditzelfde gebeurt kort voor de eventuele embryotransfer (ET).

\section{Embryo-transfer}

Indien er door middel van de in-vitro-fertilisatie een of meerdere embryo's zijn ontstaan, kan er 2 a 3 dagen na de follikelpunktie een embryotransfer worden uitgevoerd. In overleg met het paar wordt dan bepaald hoeveel embryo's er in de baarmoeder zullen worden geplaatst. De transfer zelf is een poliklinische vertichting. In het laboratorium worden de embryo's in een embryo-transfer-katheter gebracht, van elkaar gescheiden door dunne lagen lucht. De patiente ontwangt eventueel enige premedikatie, waarna de ET-katheter in de uterus wordt ingebracht. Dan wordt de katheter leeggespoten en vervolgens wordt deze gekontroleerd op eventueell achtergebleven embryo's. Na afloop kan de patiënte vrijwel onmiddellijk het ziekenhuis verlaten.

\section{Luteale fase en follow-up}

Eigenlijk start deze fase al op de dag van de follikelpunktie; luteale-fase-dag $0=$ de dag van de follikelpunktie. Deze luteale fase wordt vrijwel altijd hormonaal ondersteund in de worm van een of meerdere:

- progestagenen: Progesteron (intramusculair, rectaal of vaginaal), Dydrogesteron (oraal), Hydroxyprogesteron (intramusculair)

- gonadotropine: hCG (intramusculair).

Indien de menstruatie uitblijft wordt meestal circa 2 weken na de embryotransfer een zwangerschapstest uitgevoerd (indien niet in het ziekenhuis, dan toch wel door het paar zelf). Indien de menstruatic 4 a 5 weken na de embryotransfer nog steeds is uitgebleven, wordt echoscopisch onderzoek uitgevoerd. Hierbij wordt gekeken naar het aantal aangelegde vruchtzakken en naar hartaktie. In ieder geval, bij zwangeren en niet-zwangeren, vindt circa 1 maand na de IVF-behandeling een nagesprek plaats, waarbij de stand van zaken en het verdere behandelbeleid worden besproken. Indien geen zwangerschap is opgetreden wordt besproken of een verdere behandeling, met IVF of anderszins, zinvol wordt geacht. Als de IVF-behandeling heeft geresulteerd in een (doorgaande) zwangerschap, zal worden bezien hoe de verdere zwangerschapsbegeleiding zal verlopen (terugverwijzing naar eigen gynaecoloog of anderszins).

\subsection{Voorgeschiedenis van het evaluatie-onderzoek-IVF}

In het onderstaande worden chronologisch de belangrijkste gebeurtenissen voorafgaand aan de start van het evaluatie-onderzoek-IVF beschreven. Voor cen uitgebreider overzicht zij verwezen naar v.Overbeeke[1988].

- De Gezondheidsraad adviseerde in oktober 1984 om IVF vooralsnog alleen te verrichten op de medische indikatie dubbelzijdige tuba-obstruktie indien de IVF. methode grotere sukseskansen zou bieden dan een microchirurgische ingreep (Gezondheidsraad[1984]). 
- Daarop achtte de Commissie voor Beroepszaken van de Ziekenfondsraad in december 1984 het tijdstip nabij om IVF op te nemen in het verstrekkingenpakket ingevolge de Ziekenfondswet.

- In februari 1985 bracht de Ziekenfondsraad spontaan een meerderheidsadvies uit aan de staatssekretaris van WVC (Ziekenfondsraad[1985]). Hierin gaf zij te kennen de behandelmethode in-vitro-fertilisatie eerst expliciet te willen laten onderzoeken op kosten en effekten alvorens te beslissen over eventuele opname van deze voorziening in het verstrekkingenpakket ingevolge de Ziekenfondswet. Zowel de IVF-behandelingen op beperkte schaal als het evaluatie-onderzoek zouden gesubsidieerd dienen te worden krachtens de Ziekenfondswet. Dit advies sloot aan bij een eerder uitgebracht interim-advies inzake grenzen aan de groei van het verstrekkingenpakket (Ziekenfondsraad[1983]). De Ziekenfondsraad wenste de automatische schakel te verbreken tussen het feit dat een diagnostiek of therapie "als een in de kring van Nederlandse specialisten gebruikelijke behandeling" was geaksepteerd en de opname in het werstrekkingenpakket.

- In juli 1985 stemde de staatssekretaris van WVC in met het advies van de Ziekenfondsraad: IVF werd vooralsnog expliciet uitgesloten van het verstrekkingenpakket.

- In december 1985 bracht de Adviescommissie-IVF een advies uit aan de Commissie Verstrekkingen van de Ziekenfondsraad inzake de uitvoering van een wetenschappelijk evaluatie-onderzoek-IVF naar effektiviteit en kosten van IVF en de hieraan deel te nemen zjekenhuizen. Het evaluatie-onderzoek-IVF zou uit twee gedeelten bestaan: een observationeel prospektief evluatie-onderzoek van IVF en een 'randomized controlled trial' (RCT) van IVF versus tubachirurgie.

- In maart 1986 besloot de Ziekenfondraad het wetenschappelijk evaluatie-onderzoekIVF te laten uitvoeren. Dit onderzoek zou worden uitgevoerd door de vakgroep Ekonomie van de Gezondheidszorg van de Rijksuniversiteit Limburg. Het observationeel gedeelte van het onderzoek zou definitief kunnen starten in de 5 aangewezen ziekenhuizen, te weten het Dijkzigt Ziekenhuis in Rotterdam, het St. Radboud Ziekenhuis in Nijmegen, het St. Elisabeth Ziekenhuis in Tilburg, het Academisch Ziekenthuis van de Vrije Universiteit in Amsterdam en het Academisch Ziekenhuis Leiden. Hiertoe werd een subsidie toegezegd voor maximaal 1600 IVFbehandelingen. De start van het gerandomiseerde onderzoek werd afhankelijk gesteld van de uitwoerbaarheid. Deze uitvoerbaarheid zou bepaald dienen te worden aan de hand wan nadere gesprekken met de geselekteerde ziekenhuizen voor dit gerandomiseerde onderzoek ${ }^{20}$.

- De start van het onderzoeksprojekt evaluatie van IVF lag voor de Rijksuniversiteit Limburg op 1 mei 1986. De medische registratie in het kader van het observationeel evaluatie-onderzoek-IVF en daarmee de gesubsidieerde IVF-behandelingen in de zickenhuizen zijn gestart in augustus 1986 .

20) Die gesprekken konden pas na de bestissing wan de Ziekenfondsraad omtrent de uitwoering wan het wetcnschappelijke evaluatie-onderzoek worden gevoerd, omdat tegelijkertijd de keuze van de centra werd bepaald. 


\subsection{Introduktie tot het evaluatie-onderzoek-IVF in Nederland}

\subsection{Oorspronkelijke vraagstellingen van het onderzoelk}

De centrale vraagstelling voor de Ziekenfondsraad is of IVF als behandeling bij fertiliteitsproblemen dient te worden opgenomen in het verstrekkingenpakket en zo $\mathrm{ja}$, onder welke voorwaarden. Deze vraagstelling is binnen het projekt gesplitst in twee deelvragen:

1. Wat zijn de kosten en de effekten van IVF-behandeling voor verschillende patiëntgroepen en hoe groot zijn deze groepen? Deze vraagstelling kan worden beantwoord met behulp van een observationeel onderzoek van IVF.

2. Hoe verhoudt de kosten-effektiviteits-relatie van IVF zich ten opzichte van de kosten-effektiviteits-relatie van tubachirurgie voor verschillende groepen patienten met dubbelzijdige post-infektieuze tuba-pathologie en hoe groot zijn deze patiëntgroepen? Deze vraagstelling kan worden beantwoord met behulp van een vergelijkend onderzoek.

\subsubsection{Het vergelijkend onderzoek IVF versus tubachirurgie}

Terwijl het observationeel onderzoek zonder al te veel problemen van start kon gaan in het najaar van 1986 moesten omtrent de uitvoerbaarheid van het gerandomiseerde vergelijkend onderzoek IVF versus tubachirurgie nog besprekingen worden gevoerd met de hiertoe aangewezen ziekenhuizen. De vergelijking zou alleen dienen plaats te vinden bij paren waarvan de vrouw infertiel is ten gevolge van post-infektieuze tuba-pathologie en waarvan op voorhand geen uitspraak mogelijk zou zijn omtrent de meest kosteneffektieve behandeling. Uit met name onderzoek in Nederland door de werkgroep fertiliteitsprognose was duidelijk dat er een driedeling mogelijk was van tubachirurgisch behandelbare patienten (zie ook hoofdstuk 6):

- een groep met een zwangerschapskans na tubachirurgie van circa $75 \%$; voor deze patienten is tubachirurgie de eerste therapiekeuze

- een groep met een zwangerschapskans na tubachirurgie van circa 20 a $30 \%$; voor deze patiënten is vooralsnog op woorhand geen uitspraak mogelijk over de keuze tussen tubachirurgie en IVF

- een groep met een zwangerschapskans na tubachirurgie van circa $5 \%$; de primaire therapiekeuze zou IVF moeten zijn.

De motivatie voor een gerandomiseerde vergelijking luidde toendertijd in het kort als volgt:

1. De IVF-behandeling wordt voor deze patienten dikwijls pas toegepast na uitgebleven sukses van een tubachirurgische ingreep. Dit leidt mogelijk tot een vertekening in de resultaten tèn nadele van IVF ten gevolge van selektie.

2. Ook bij vergelijking van patiënten bij wie nog geen van beide therapieèn is toegepast, is er nog steeds een redelijke kans op vertekening van de resulterende verbanden ten gevolge van diskutabele vergelijkbaarheid tussen beide populaties, vooral ten gevolge van mogelijke verstorende maar onbekende variabelen; fertiliteitsproblemen worden nog steeds gekenmerkt door een niet geringe mate van onverklaarbaarheid.

In de besprekingen met vertegenwoordigers van de ziekenhuizen werden enkele onoverkomelijke bezwaren geuit tegen de uitvoering van een gerandomiseerde 
onderzoeksopzet. Verreweg het belangrijkste bezwaar luidde als volgt: de relatief geringe kapaciteit voor IVF in vergelifking met die voor tubachirurgie heeft er in het verleden toe geleid dat patienten die mogelijk batal zouden hebben bij ieder der therapiedn eerst tubachirurgie werd aangeboden. Slechts bij blijvende infertiliteit na tubachirurgie werd eventueel IVF aangeboden als behandeling. De patientenpopulatie waarvoor beide therapieen (nog) zinvol zijn is derhalve (vrijwel) beperkt tot de tussengroep van alleen de nieuwe patienten. Een onderzoeksopzet waarbij alleen de nieuwe patienten die tot de tussengroe ${ }^{21}$ behoren zou worden gevraagd deel te nemen aan de RCT werd door de vertegenwoordigers van de ziekenhuizen ethisch niet haalbaar geacht in verband met een hiertoe noodzakelijke voorrangsregeling. Immers, deze patienten zouden voorrang moeten krijgen ten opzichte van patiënten op de bestaande wachtlijsten voor IVF en tubachirurgie ${ }^{22}$. Bovendien lijkt deze tussengroep erg klein te blijven door voorkeuren voor een van beide therapieen van patienten en/of medici. Voor de overige bezwaren voorzien van kommentaar zij verwezen naar bijlage 1.1.

In de gevoerde besprekingen werd door de vertegenwoordigers van de ziekenhuizen wel voortdurend het belang van een vergelijkend onderzoek IVF versus tubachirurgie beklemtoond. Derhalve werd in overleg met deze vertegenwoordigers en met vertegenwoordigers van de werkgroep fertiliteitsprognose (Boer-Meisel, Te Velde, Habbema) een gezamenlijk voorstel ingediend woor een observationeel vergelijkend onderzoek als 'second-best-methode' (december 1986). Gesteld werd dat de relevantie van het vergelijkend onderzoek onaangetast was. De vraagstelling hiervoor luidde immers: hoe verhoudt de kosten-effektiviteits-relatie van IVF zich ten opzichte van die van tubachirurgie voor verschillende groepen patienten met dubbelzijdige tubapathologie en hoe groot zijn deze groepen? Voor de tubachirurgische kant van het vergelijkend onderzoek zou gedeeltelijk worden gebouwd op het eerdere werk van Boer-Meisel c.s. in het kader van de prognose-studie fertiliteitsbevorderende operaties. Aanvullingen op hun werk ten behoeve van een betere vergelijking met de IVFbehandeling zouden wooral betrekking hebben op de volgende punten:

Vooralsnog hadden de analyses betrekking op pré-operatieve 'prediktieve' variabelen; dc overgang naar analyses op basis van daadwerkelijke preoperatleve prediktieve variabelen zou versneld kunnen worden uitgevoerd.

- Vooralsnog waren alleen tubachirurgische ingrepen opgenomen die door BoerMeisel waren uitgevoerd; uitbreiding van de analyses naar tubachirurgische ingrepen in de andere ziekenhuizen zou enerzijds een kompleter beeld van de resultaten van tubach irurgie in Nederland opleveren en anderzijds uitgebreidere analyses mogelijk maken.

- Ook zouden de financieel-ekonomische en de psycho-sociale aspekten bij tubachirurgic kunnen worden onderzocht, zodat een vergelijking tussen IVF en tubachirurgie mogelijk zou worden op basis van de medische, financieelakonomische en psycho-sociale aspekten.

21) Mat de tussengroep word bedoeld de paren waran op woorhand niet duidelijk is welk van beide therapievormen het meest kosten-effektief zou z.jpn.

22) Aargezlen in dere onderzoksopzet patiënten geen nadeel mogen ondervinden wan een weigering tot deelnane atan de $\mathrm{RCT}$ zot deze voorrangsregeling maeter gelden voor alle patienten die in manmerking zouden komen voor de RCT. 
Op basis van de resultaten van dit vergelijkend onderzoek en de medische data van de tubachirurgisch behandelde patiënten zou tevens een inschatting kunnen worden gemaakt van de omvang van de toekomstige patientgroepen woor bedde therapiewormen.

De Begeleidingskommissie Evaluatie-onderzoek-IVF was echter van mening dat woor de vergelijking tussen. IVF en tubachirurgie een observationeel vergelijkend onderzoek zoals voorgesteld weinig zou kunnen toevoegen. Hierop besloot de Commissie Verstrekkingen van de Ziekenfondsraad in februari 1987 het vergelijkende onderzoek IVF versus tubachirurgie niet te laten uitvoeren. Deze Commissie konkludeerde zelf dat hierdoor geen uitspraak gedaan zou kunnen worden over medisch-inhoudelijke kriteria voor de keuze tussen IVF en tubachirurgie bij een bepalde vorm en ernst van tubapathologie.

\subsubsection{Definitieve vraagstellingen voor het evaluatie-onderzoek-IVF}

In verband met het bovenstaande zullen in dit rapport vooral die vragen aan de orde worden gesteld die met behulp van het observationele evaluatie-onderzoek-IVF te beantwoorden zijn. Voor de vergelijking van de IVF-behandeling met de tubachirurgie zal noodgedwongen moeten worden teruggegrepen naar de ons inziens voor de gestelde vraagstelling slechts beperkt bruikbare literatuur.

De vraagstellingen voor het observationeel prospektief evaluatie-onderzoek-IVF zijn (in augustus 1986) neergelegd in een onderzoeksprotokol. De centrale vraagstelling luidt: Hoe zijn kosten en effekten van IVF-behandelingen aan elkaar gerelateerd voor verschillende patiẻntgroepen met fertiliteitsproblemen en hoe groot zijn deze patiëntgroepen?

In de centrale vraagstelling zijn vervolgehs de onderstaande onderdelen onderkend:

1. De effekten van de IVF-behandelingen voor het paar.

Het beoogde eindeffekt is een gezond kind, maar voor een goede beoordeling van IVF als medische voorziening in diverse Nederlandse ziekenhuizen dienen ook diverse andere effekten te worden gesignaleerd, zoals voortijdige beeindiging van de IVF-behandeling, voortijdige beẻindiging van cen opgetreden wangerschap, meerling-zwangerschap, komplikaties tijdens behandeling, zwangerschap of partus, lichamelijke en psychische belasting, mogelijke effekten op lange termijn woor vroww en kind.

2. De financiecl-ekonomische kosten van de diverse fasen in het IVF-proces en van eventuele nabehandeling, hierbij kan onderscheid worden gemaakt in de kosten voor personeel, apparatuur, ruimte, materiaal en overhead.

3. Bepaling van patiéntkenmerken die van invloed zijn op de verhouding tussen kosten en effekten van de IVF-behandeling.

4. Verwerwing van meer inzicht in de optimale methodiek van IVF-behandeling in relatie tor effekten en kosten.

5. Bepaling van de behoefte aan IVF-behandelingen, mede op basis wan bovenstaande bevindingen. 


\subsubsection{Organisatie van het onderroek}

Binnen de Rijksuniversitteit Limburg werkte de projektleider (Ger Haan) voor de analyses vooral veel samen met de onderzoeksassistent van het projekt die de databewerkingen (verzameling, kontroles en analyses) verzorgde ( $R$ eg van Steen). Daarnaast werd overleg gevoend met personen van diverse disciplines (voornamelijk epidiemiologen, ekonomen, informatici, statistici en psychologen). In ieder deelnemend ziekenhuis droeg én persoon de verantwoordelijkheid voor het verloop van het evaluatie-onderzoek in het betreffende ziekenhuis. Deze kontaktpersonen vormden daarmee het aanspreekpunt voor het onderzoeksteam. In voorkomende gevallen kon bij meer ingrijpende problemen met betrekking tot het evaluatie-onderzoek overleg worden gevoerd met de persoon die in het betreffende ziekenhuis verantwoordelijk was voor de IVF-afdeling. Bovengenoemde personen voor de diverse ziekenhuizen waren:

kontaktpersoon

IVF-verantwoordelijken

gynaecollogie biologie

\begin{tabular}{l|lll} 
Leiden & C. Waegemaekers & F. Helmerhorst & N. Naaktgeboren \\
Tilburg & F. Prak & J. Merkus/R. Bots & M. Peeters \\
Rotterdam & R. Leerentveld & A. Alberda & G. Zeilmaker \\
Amsterdam & R. Bernardus & J. Schoemaker & J. Vermeiden \\
Nijmegen & J. Hollanders & J. Hollanders & B. Bastiaans
\end{tabular}

Naast de vrijwel wekelijkse bilaterale kontakten tussen de projektleider en de kontaktpersonen in de verschillende ziekenhuizen was er circa $3 x$ per jaar een zogenaamd Kontaktpersonenowerleg. Hierin werd de stand van zaken met betrekking tot het evaluatie-onderzoek met de kontaktpersonen (en andere geinteresseerden) van de ziekenhuizen besproken.

\subsubsection{Introduktie tot het eindrapport}

De vraagstellingen ten aanzien van IVF zijn in dit verslag weergegeven voor:

- de medisch/biologische facetten: hoofdstukken 2 en 3

- de financieal-ekonomische facetten: hoofdstuk 4.

De belangrijkste alternatieven voor IVF in het kader van behandeling bij fertiliteitsproblemen komen aan de orde in hoofdstuk 5. Daarin wordt tevens aandacht besteed aan de behoefte aan fertiliteitsbehandeling. In hoofdstuk 6 worden de belangrijkste bevindingen van dit eindrapport samengebracht. Hierbij wordt zowel een vergelijking van kosten en effekten bínnen de IVF-populatie gemaakt als een vergelijking tussen IVF-behandeling en met name het alternatief tubachirurgie. 


\section{MEDISCHE EVALUATIE VAN IVF; TOTAALOVERZICHT}

\subsection{Introduktie}

Het uiteindelijke hoofddoel van een IVF-behandeling is de geboorte van een gezond kind. Daarnaast kunnen er allerlei ondergeschikte doelstellingen bestaan, zowel voor het paar dat de behandeling ondergaat als voor het IVF-team dat de behandeling uitvoert. Hierbij kan men denken aan een goed verlopende hormoonstimulatie, een ongekompliceerde follikelpunktie met goede oỏcytopbrengst, semenproduktie waaruit een goede kwaliteit sperma te verkrijgen is, een goed verlopend fertilisatie- en delingsproces, een ongekompliceerde terugplaatsing van embryo's, het bereiken van een zwangerschap en een goed verlopende zwangerschap. De totaalresultaten van de IVF. behandelingen in de diverse ziekenhuizen, vitgedrukt in het verloop tussen de verschillende fasen van de behandeling, worden weergegeven in paragraaf 2.3 . Hieraan voorafgaand wordt in paragraaf 2.2 vermeld hoe het medische gedeelte van het evaluatie-onderzoek is uitgevoerd.

\subsection{Patiënten en onderzoeksmethode}

\subsubsection{Samenstelling onderzoekspopulatie}

In de subsidieregeling van de Ziekenfondsraad die in het kader van het evaluatieonderzoek IVF in Nederland werd opgesteld, waren een drietal beperkingen opgenomen:

1. De subsidieregeling zou alleen worden aangewend voor IVF-behandelingen die volledig onder beheer wan 5 Nederlandse ziekenhuizen zouden worden uitgevoerd.

Het ging daarbij om:

- 4 academische ziekenhuizen, te weten:

Dijkzigt Ziekenhuis, Rotterdam

Academisch Ziekenhuis Leiden

Academisch Ziekenhuis Vrije Universiteit, Amsterdam

St. Radboud Ziekenhuis, Nijmegen

- 1 algemeen ziekenhuis, te weten:

St. Elisabeth Ziekenhuis, Tilburg.

2. De subsidieregeling was gebonden aan wooraf vastgestelde kwota per ziekenhuis voor de periode tot 1 juni 1988 . In totaal zouden er maximaal 1600 lVFbehandelingen worden gesubsidieerd, waarbij als teleenheid de follikelpunktie werd gehanteerd.

3. De subsidieregeling gold alleen voor ziekenfondsverzekerde paren met als indikatie dubbelzijdige tubapathologie. De mannelijke faktor mocht geen (mede)indikatic voor de IVF-behandeling, zijn. 
Het onderzoeksteam realiseerde zich dat de twee latstvermelde beperkingen tot een belangrijke vertekening in de onderzoeksresultaten voor de 5 aangewezen ziekenhuizen wouden kunnen leiden, indien deze centra daarnaast nog andere IVF-behandelingen zouden (blijven) uitwoeren. Derhalve werd er bij de Adviescommissie-IVF op aangedrongen de ziekenhwizen te verplichten ook de gegevens van de nietgesubsidieerde IVF-behandelingen op soortgelijke wijze te verstrekken aan het onderzoeksteam. Deze eis werd opgenomen in de subsidieregeling. Zodoende zijn in het onderzoek de gegevens opgenomen wan nagenoeg alle ${ }^{1}$ reguliere IVF-behandelingen die in de 5 geselekteerde ziekenhuizen volledig onder eigen beheer zijn uitgevoerd in de periode augustus 1986 tot en met mei 1988. Het betreft in total 3092 gestarte IVF-behandelingen, uitgevoerd bij 1462 paren.

\subsection{Databeher en onderzoeksmethoden}

\section{Orgamisatie van het databeheer}

De medische registratieformulieren werden in de ziekenhuizen ingevuld en ter plaatse ook ingevoerd in een geautomatiseerd systeem. Daarnaast was er wekelijks telefonisch kontakt over de "patienten in behandeling". Circa $3 x$ per jaar werden de gegevens uit het geautomatiseerde systeem verstrekt aan het onderzoeksteam. Daar werden de gegevens gekontroleerd op juistheid, volledigheid en interne konsistentie. Problemen hierbij werden teruggekoppeld naar de centra.

\section{Registratieformulieren}

In samenspraak met vertegenwoordigers van de 5 deelnemende ziekenhuizen aan het evaluatie-onderzoek werden de medische registratieformulieren, met bijbehorende handleiding, samengesteld. Belangrijk probleem hierbij was de vertaling in een uniform registratieformulier ${ }^{2}$ van de eigenaardigheden van leder centrum met betrekking tot de IVF-behandeling. Per januari 1987 zijn nog enige aanpassingen in de registratie doorgevoerd.

Daar waar mogelijk is getracht de registratie op patientnivo te reduceren door identicke elementen in de IVF-behandeling per centrum onder te brengen in een IVFbehandelprotokol per centrum. Hierin dienden ten behoeve van het evaluatieonderzoek minimaal diverse nader aangeduide items aan de orde te worden gesteld. Het registratieformulier woor de eerste IVF-behandeling in het kader van het evaluaticonderzoek IVF is gesplitst in 14 hoofdstukken, in te delen in 4 onderdelen (het volledige formulier is opgenomen in bijlage 2.1). Bij het registratieformulier was een toelichting gevoegd omtrent nadere omschrijvingen van diverse skores op items in de registratie. Desalniettemin is enige ruis in deze skores niet geheel uit te sluiten.

1) De volledighteid gebiedt te vermelden, dat enkele patiënten weigerdien toestemming te verlenen hun gegevens ter beschikking te stellen aan het evaluatie-onderzoek. Het gaat hierbij in totaal om 7 IVF. behandelingen.

2) Het evaluatie-onderzoekstean had niet de intentie een uniform behandelschema tot stand te brengen. 


\begin{tabular}{|c|c|c|}
\hline \multicolumn{3}{|c|}{$\begin{array}{l}\text { Indeling medisch registratieformulier IVT in het kader van het evaluatie- } \\
\text { onderzoek IVF }\end{array}$} \\
\hline \multicolumn{2}{|c|}{ Hoofds tuk } & \multirow{2}{*}{$\begin{array}{l}\text { Benaming hoofdstuk } \\
\text { Patiëntengegevens }\end{array}$} \\
\hline Achtergrondgegevens en anamnese & 1 & \\
\hline & 2 & Anamese \\
\hline \multirow[t]{5}{*}{ Indikatie en diagnostiek } & 3 & Algemene infertititaltsdiagnostiek \\
\hline & 4 & Indikatie woor IVF \\
\hline & 5 & Indien indikatie tubapathólogie: HSG \\
\hline & 6 & Idem: Diagnostische laparoscopie \\
\hline & 7 & Indien andere indikatie: dilagn. (ap. (beperkt) \\
\hline \multirow[t]{5}{*}{ IVF-behandel ing } & 8 & Dagelijkse registratie stimulatiefase \\
\hline & 9 & Overige registratie voorafgaand aan punktie \\
\hline & 10 & Folltikelpunktie \\
\hline & 11 & Laboratoriumfase \\
\hline & 12 & Embryotransfer \\
\hline \multirow[t]{2}{*}{ Folllow-up } & 13 & Eerste fase follow-up vanaf luteale fase \\
\hline & 14 & Verwolg followmp tot 3 maanden na partus \\
\hline
\end{tabular}

Aangezien de informatie weergegeven in de hoofdstukken 1 tot en met 7 in principe statisch van karakter is, zijn deze hoofdstukken niet opgenomen in het registratieformulier voor een eventuele volgende IVF-behandeling ${ }^{3}$. Het gedeelte van het registratieformulier dat betrekking heeft op de specifieke IVF-behandeling en de afloop ervan (het zogenaamde dynamische gedeelte van de registratie) is zodanig opgebouwd dat bij tussentijdse beeindiging van de behandeling het resterende gedeelte van het formulier kon worden opengelaten.

Invoer en aanlevering van de data

Door het onderzoeksteam werd een komputerprogramma ontwikkeld binnen dBasell om de medische registratieformulieren in de diverse centra te kunnen laten invoeren. Voordeel hiervan was dat problemen met de invoer in verband met slechte gegevensvermelding op de registratieformulieren reeds gedeeltelijk ter plekke konden worden opgelost. Gebruikersvriendelijkheid van het invoersysteem was bij een dergelijke opzet wel een belangrijke vereiste. Na enige alanloopproblemen, die telefonisch konden worden verholpen, verliep de invoer van de data naar wens. In sommige centra werden de data met behulp van een personal computer ingevoerd. Andere centra voerden de data in via de terminal van de mainframe computer. Hiertoe werd het ontwikkelde invoerprogramma vertaald voor gebruilk binnen het BAZISsysteem.

Circa $3 \mathrm{x}$ per jaar werden de geautomatiseerde data met de bijbehorende registratieformulieren door ieder centrum aangeleverd aan het onderzoeksteam.

3) Wel werd de mogelijkheid geboden om wijzigingen in de gegevens van de hoofdstukken 1 tot en met 7 apart te vermelden. 
Mede om de volledigheid van data te warborgen werd wekelijks op een vast tijdstip telefonisch kontakt onderhouden mer ieder ziekenhuis. Tijdens dat kontakt werden door het riekentuis gemeld:

- de patientnummers van de paren die op dat moment in behandeling waren

- per paar de fase wan de behandeling c.q. de afloop van de behandeling.

Na aanlevering van de data wit het geautomatiseerde bestand werd allereerst gekontroleerd of deze gegevens in overeenstemming waren met de summiere, maar essentidle, informatie uit de telefonische kontakten. Daarna werden de data vanuit het dBaseII-bestand omgezet in SPSS-system-files. Via frekwentietabellen werden de data onderzocht op onmogelijkheden/onwaarschijnlijkheden per item. Vervolgens werden de data per record onderzocht op onderlinge konsistentie. Hiertoe werd door het onderzoeksteam een uitgebreid konsistentieprogramma ontwikkeld. Problemen voortkomend uit deze kontroles werden schriftelijk gemeld aan het betreffende ziekenhuis. Tenslotte werden de eventuele korrekties door het onderzoeksteam ingevoerd.

\section{Data-bewerkingen}

Voor de data-analyses werden de oorspronkelijke variabelen eerst vanuit dBase3-filles omgezet in ASCII-files en van daaruit in SPSS-filles. Dit werd uitgevoerd met behulp van een personal computer. De dataset was oorspronkelijk verdeeld in 8 tiles. Vervolgens werd de dataset per ziekenhuis opgeslagen in 2 files: 1 file woor het 'statische' gedeelte (hoofdstukken 1 tot en met 7) en 1 fille voor het dynamisch gedeelte (hoofdstukken 8 tot en met 14). Tenslotte werden de datasets van de verschillende ziekenhuizen aan elkaar gekoppeld op een main-frame computer (VAX8650). De komplete dataset werd uitgebreid met diverse gekonstrueerde variabelen ten behoeve van de analyses. De eenduidigheid van de records werd gewaarborgd via kodes voor het ziekenhuis, een uniek patiëntnummer binnen het ziekenhuis ${ }^{4}$ en een IVFbehandelnummer binnen het onderzoek. Ten behoeve wan de multivariate logistische regressie-analyses (zle paragraaf 3.4) werd de dataset tevens getransformeerd naar cen BMDP-bestand.

Het bestand werd eind april 1989 afgesloten; enkele gegevens die na deze datum werden ontvangen zijn niet meer in de analyses opgenomen.

4) Indien een para in meer dan een wat de 5 ziekenhuizen van het onderzoek is behandeld met behalp wan IVF tijdens de onderkoksperiode, dan wordt dat binnea de registratie nket onderkend en komt het paar met twee (of meer) patiëntnummers in het bestand voor. Een poging on dit te verhinderen vîs de wariabelen geboortedaum vrouw eerste 3 letters wan de meisjesnam en eerste 2 cjfers wan de postkode stuitte op privacy-bezwaren van de zickenhuizen. De inschatting us dat de frekwentie van deze owerstappen binnen het onderzock relatief zeer gering is geweest. 


\section{Onderzoeksmethode}

De onderzoeksopzet wordt gekenmerkt door de volgende karakteristieken:

- literatuuronderzoek; zowel voor IVF als voor de alternatieve fertiliteitsbehandelingen werden de relevante literatuurbevindingen in kaart gebracht

- patiëntgebonden onderzoek; op patiëntnivo zijn (anoniem) gegevens verzameld met betrekking tot de IVF-behandelingen

- prospektief; vooraf is afgesproken welke data zouden worden verzameld van de IVF-behandelingen in de periode augustus 1986 tot juni $1988^{5}$

- observationeel; binnen het evaluatie-onderzoek is geen vergelijking op experimentele wijze uitgevoerd.

Bij de analyses werd voornamelijk gebruik gemaakt van de volgende analyse-methoden:

- (uitgebreide) kruistabellen ten behoeve van univariate analyses; aangezien vrijwel alle variabelen discreet zijn is gebruik gemaakt van chi-kwadraat-toetsen. Als signifikantie-grens voor de p-waarde is het $5 \%$-nivo gehanteerd; bij een p-waarde tussen 0.01 en 0.05 is in de tabellen een +-teken geplaatst, bij een p-waarde kleiner dan 0.01 een $^{*}$-teken

- regressie-analyses (lineair en $\|$ ogistisch) ten behoeve van multivariate analyses; bij de schattingen zijn de $95 \%$-betrouwbaarheidsintervallen weergegeven.

\subsection{Totaalresultaten van IVF in de 5 ziekenhuizen van het onderzoek}

In tabel 2.2 zijn de totaalresultaten weergegeven van de IVF-behandelingen die gedurende de registratieperiode zijn uitgevoerd in de 5 ziekenhuizen die hebben deelgenomen aan het evaluatie-onderzoek. De volgende zwangerschapsdefinities werden gehanteerd:

- Indien er 26 dagen na de embryotransfer nog geen (definitieve) bloeding is opgetreden, wordt gesproken van een klinische zwangerschap 6 .

- Indien 12 weken $^{7}$ na de embryotransfer de zwangerschap nog intakt is, wordt gesproken van een doorgaande zwangerschap.

De presentaties in tabel 2.2 betreffen de totaalcijfers per ziekenhuis, waarbij geen rekening is gehouden met de samenstelling van de patientenpopulatie per ziekenhuis noch met allerlei andere faktoren die mogelijk invloed hebben op deze resultaten. Met deze opmerking nadrukkelijk in gedachten zijn een aantal totaklverschillen te konstateren tussen de ziekenhuizen; in hoofdstuk $3 \mathrm{zal}$ worden onderzocht in hoeverre onderliggende faktoren van invloed zijn geweest op de behandelresultaten per ziekenhuis.

5) Wel zijn de gegevens van eerder uitgevoerde diagnostiek gedeeltelijk ungevuld op balifs van eerdere werslaglegging.

6) Deze definutie sluit aan bij die wam Jones[1983b]; zie woor een nadere toelichting paragragl 3.3.2.4.

7) Daarmee wordt de grems - afgexien van de twee weken owerbrugging tussen enbryologische en gynaecologische termijnbepaling - twee weken eerter gelegd dan in Nederland gebruikelijk, te weten bij een gymacologische zwangerschapstermijn van 16 weken. In de ulteindelijke onderzoekstata bleek dit verschil nelevant te zijn bij 3 behandelingen die nu als partus immaturus te boek staan in plagts van als spontane abortus (zie verder paragraal 3.3 .2 .4 ). 


\begin{tabular}{|c|c|c|c|c|c|c|c|c|}
\hline \multirow[t]{3}{*}{ Tabel 2.2} & \multicolumn{8}{|c|}{$\begin{array}{l}\text { Resultatein wain IVF-behandelingen in de ziekenhuizen van het evaluatie- } \\
\text { onderzoelk periode augustus } 1986 \text { - jun } 1988 \text {; aantal behandelde paren: } \\
1462\end{array}$} \\
\hline & en in de & eerste $r i$ & de absolt & ute amtal & Len ver & den in & de tweer & \\
\hline & Hormoon & $\begin{array}{l}\text { Punktie } \\
\text { pier horm. }\end{array}$ & $\begin{array}{c}\text { ET } \\
\text { per pun. }\end{array}$ & $\begin{array}{l}k \operatorname{lin} . z w \\
\text { per ET }\end{array}$ & $\begin{array}{l}\text { doorga } \\
\text { per kl }\end{array}$ & $\begin{array}{l}\text { zwange } \\
\text { per }\end{array}$ & per puir & r horm \\
\hline TOTAAL & 3092 & $\begin{array}{l}2466 \\
80 \%\end{array}$ & $\begin{array}{l}2089 \\
85 \%\end{array}$ & $\begin{array}{l}416 \\
19.9 \%\end{array}$ & $\begin{array}{l}323 \\
78 \%\end{array}$ & $15.5 \%$ & $13.1 \%$ & $10.5 \%$ \\
\hline Ziakenhus 1 & 601 & $\begin{array}{l}54 x \\
90 \%\end{array}$ & $\begin{array}{l}465 \\
86 \%\end{array}$ & $\begin{array}{l}79 \\
17.0 \%\end{array}$ & $\begin{array}{l}55 \\
70 \%\end{array}$ & $11.8 \%$ & $10.1 \%$ & $9.2 \%$ \\
\hline Zlekenthuis 2 & 451 & $\begin{array}{l}342 \\
76 \%\end{array}$ & $\begin{array}{l}296 \\
87 \%\end{array}$ & $\begin{array}{l}60 \\
20.3 \%\end{array}$ & $\begin{array}{l}43 \\
72 \%\end{array}$ & $14.5 \%$ & $12.6 \%$ & $9.5 \%$ \\
\hline Zlekenhuis 3 & 536 & $\begin{array}{l}388 \\
72 \%\end{array}$ & $\begin{array}{l}272 \\
70 \%\end{array}$ & $\begin{array}{l}33 \\
12.1 \%\end{array}$ & $\begin{array}{l}28 \\
85 \%\end{array}$ & $10.3 \%$ & $7.2 \%$ & $5.2 \%$ \\
\hline Ziekenhuis 4 & 965 & $\begin{array}{l}757 \\
78 \%\end{array}$ & $\begin{array}{l}648 \\
86 \%\end{array}$ & $\begin{array}{l}146 \\
22.5 \%\end{array}$ & $\begin{array}{l}119 \\
82 \%\end{array}$ & $18.4 \%$ & $15.7 \%$ & $12.3 \%$ \\
\hline Ziekenhuis 5 & 539 & $\begin{array}{l}436 \\
81 \%\end{array}$ & $\begin{array}{l}408 \\
94 \%\end{array}$ & $\begin{array}{l}98 \\
24.0 \%\end{array}$ & $\begin{array}{l}78 \\
80 \%\end{array}$ & $19.1 \%$ & $17.9 \%$ & $14.5 \%$ \\
\hline
\end{tabular}

Ziekenhuis 1: De uitval tot de follikelpunktie is relatief gering. Vanaf de follikelpunktie liggen de totallresultaten iets onder het gemiddelde. Ziekenhuis 2: De behandelresultaten zijn gemiddeld te noemen op vrijwel alle punten.

Ziekenhuis 3: In dit ziekenhuis worden over de gehele linie resultaten geboekt die onder het gemiddelde liggen.

Ziekenhuis 4: De zwangerschapspercentages liggen boven het gemiddelde.

Ziekenhuis 5: Ondanks het feit dat relatief veel follikelpunkties gevolgd kunnen worden door cen terugplaatsing van embryo's liggen de zwangerschapspercentages per embryotransfer het hoogst; dit geldt ook voor de doorgaande zwangerschapspercentages.

Het verloop van de behandelingen in de 5 ziekenhuizen kan ook grafisch worden weergegeven vid de uitval in de verschillende fasen. In figuur 2.1 wordt uitgaande van 100 gestarte behandelingen het gemiddeld verloop geschetst voor de totale populatie en per ziekenhuis.

Uit deze grafiek wordt duidelijk dat voor de totale populatie gemiddeld 80 van de 100 gestarte behandelingen tot een follikelpunktie leiden. Twaalf van deze follikelpunkties 
Figuur 2.1. Verloop wan de IVF-behandeling in fasen

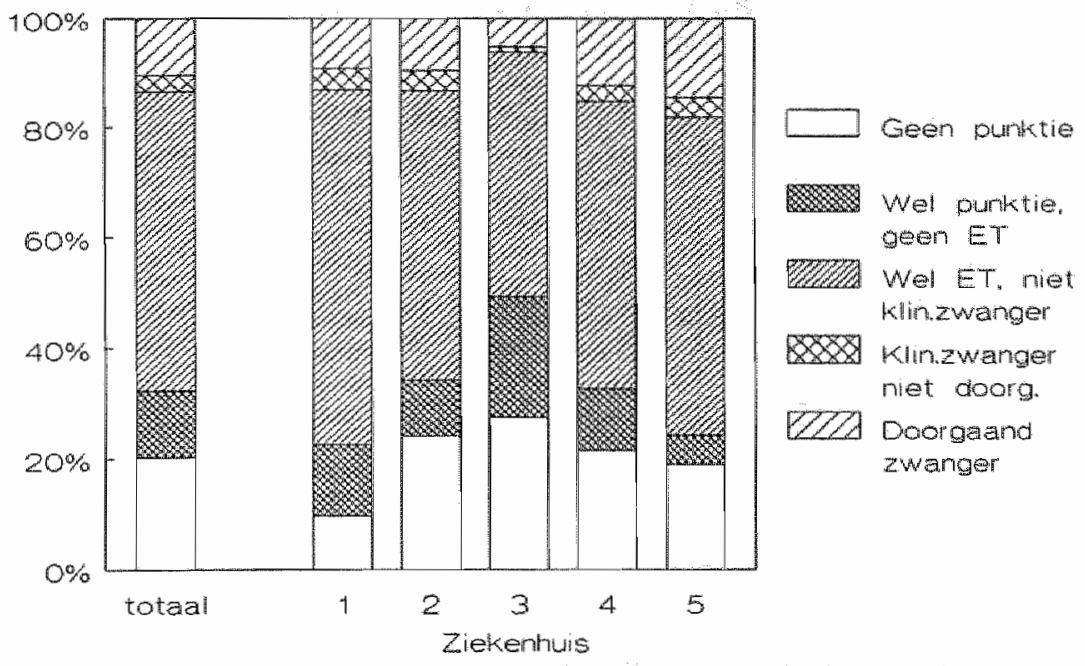

leiden niet tot een terugplaatsing van embryo's. Van de 68 resterende behandelingen waarbij embryo's worden teruggeplaatst in de uterus van de vrouw, leiden er 13 tot een klinische zwangerschap, waarvan 10 tot een doorgaande zwangerschap. Ofwel, uiteindelijk leidt 1 op de 10 gestarte behandelingen tot een doorgaande zwangerschap. De uitval hierna is (in cijfers ${ }^{8}$ ) nagenoeg verwaarloosbaar: $3 \%$. Benadrukt dient te worden dat een paar na een mislukte behandeling kan besluiten tot een volgende IVFbehandeling. Op de sukseskansen na meerdere behandelingen zal in paragraaf 3.3.1. nader worden ingegaan.

Tevens wordt zichtbaar dat er aanzienlijke verschillen in resultaten bestaan tussen de ziekenhuizen. Nogmaals, een verklaring voor deze verschillen zal worden gezocht in het volgende hoofdstuk.

Ter vergelijking woor de bovenstaande Nederlandse resultaten ${ }^{\circ}$ kunnen cijfers dienen van IVF-resultaten in de Verenigde Staten in de jaren 1985 tot en met 1987 (Medical Research International $[1988,1989])$. In de publikatie worden data vermeld van de IVF. resultaten voor 30 klinieken in 1985, 41 klinieken in 1986 en 96 klinieken in 1987. Hoewel er in de publikatie zelf al enkele kanttekeningen geplaatst worden bij de

8) Dat geldt uiterahrd niet voor het individuele paar dat hiermee te maken krijgt.

9) Uit cjffers gepubliceerd in Han[1989a] blijkt dat de gemiddelde resultaten van de 5 wekemiluizem in het onderzock representatief zijn woor de resultaten in Nederland in de betreffende periode. Dit hangt sumen met enerzjds bet relatief grote aandeel wat deze 5 ziekenhuizen in het total aanal IVI-beharidelingen in die periode en anderzijds hel feit dat de resultaten in de andere zekenhuizen gemiddeld soortgelijk whanen (zie ook Zeilmaker[1987]). 
ciffers $^{10}$, zijn de wermelde resultaten waarschijnlijk toch representatief yoor die van de Vereaigde Staten in het algemeen in die jaren.

\section{Tabel 2.3. Wh-resultaten in de Verenigde Staten}

\begin{tabular}{|c|c|c|c|c|c|c|c|c|}
\hline & Hormoon & $\begin{array}{l}\text { Punktie } \\
\text { per horm. }\end{array}$ & $\begin{array}{l}\text { ET } \\
\text { per puinh. }\end{array}$ & $\begin{array}{r}k l i n . z w \\
\text { per } E T\end{array}$ & $\begin{array}{l}\text { doorgaand } \\
\text { per Kl. Zw. }\end{array}$ & $\begin{array}{l}\text { Zwanger } \\
\text { per EI }\end{array}$ & & \\
\hline 985 & 3921 & $\begin{array}{l}2890 \\
74 \%\end{array}$ & $\begin{array}{l}2369 \\
83 \%\end{array}$ & $\begin{array}{l}337 \\
14.11 \%\end{array}$ & $\begin{array}{l}177 \\
53 \%\end{array}$ & $7.4 \%$ & $6.1 \%$ & $4.5 \%$ \\
\hline 1986 & 4867 & $\begin{array}{r}3366 \\
69 \%\end{array}$ & $\begin{array}{r}2864 \\
85 \%\end{array}$ & $\begin{array}{l}485 \\
16.9 \%\end{array}$ & $\begin{array}{l}312 \\
64 \%\end{array}$ & $10.9 \%$ & $9.3 \%$ & $6.4 \%$ \\
\hline 87 & \pm 11800 & $\begin{array}{l}8725 \\
474 \%\end{array}$ & $\begin{array}{l}7561 \\
87 \%\end{array}$ & $\begin{array}{c}1367 \\
18.1 \%\end{array}$ & $\begin{array}{l}991 \\
72 \%\end{array}$ & $13.1 \%$ & $11.3 \%$ & $\pm 8.4 \%$ \\
\hline
\end{tabular}

Voor Frankrijk zijn de resultaten van 42 IVF-centra (waaronder de belangrijkste) sinds 1986 opgenomen in een nationale databank. Van de 6987 follikelpunkties in 1986 waren de data van 5529 behandelingen verwerkt voor een presentatie (de Mouzon[1987]). Een follikelpunktie leidde in $15.4 \%$ van de gevallen tot een zwangerschap (waarschijnlijk wordt bedoeld een klinische zwangerschap).

Ook al betreffen de bovenstaande cijfers gedeeltelijk verschillende tijdsperioden voor Nederland, de Verenigde Staten en Frankrijk, toch kan gekonkludeerd worden dat de IVF-resultaten in Nederland in ieder geval niet slechter zijn dan die in de Verenigde Staten en Trankrijk.

De Nederlandse cijfers sluiten gemiddeld zelfs goed aan bij de resultaten in de grotere IVF-centra met langdurige ervaring. De klinische zwangerschapspercentages per embryotransfer bedragen voor deze IVF-central ${ }^{11}$ global $20 \%$.

10) De data zijn grotendeels achteraf door de klinieken zelf aangeleverd, waarbij zwangerschappen door do cne kliniek werden toegerekend aan het jaar van de IVF-behandeling en door een andere kliniek aan het jaar van de bevalling. Ook hebben lang niet alle klinieken hun medewerking verleend an dit onderzoek, maar bijwoorbeeld een gerenomeerd centrum als. Norfolk wel. Gekonkludeerd kan worden, dat de gepresenteerde cijfers waarschijnlijk een bovengrens voor de resultaten uit die tij anangeven. Voor 1987 kan op basis van de publikatie het aantal gestarte behandelingen alleen bij bendering worden angegeven.

11) Zit talloxe publiksties in met name "Journal of In Vitro Fertilization and Embryo Transfer" en in "Fertility and Sterility" over onder andere Cambridge (Engeland), Melbourne (Australie), Norfolk (V.S.), Clamart (Frankrijk), Wenen (Oostenrijk) en Brussel (Belgie). 


\section{MEDISCHE EVALUATIE VAN IVF; VERKLARING VOOR VERSCHILLEN IN RESULTATEN}

De belangrijkste vraag die in dit hoofdstuk aan de orde wordt gesteld luidt: welke faktoren hebben invloed op de sukseskans van de IVT-behandeling en in welke mate?

In de eerste drie paragrafen van dit hoofdstuk zal getracht worden via een univariate benadering antwoord te geven op bovenvermelde vraag. Daarbij zal telkens eerst. een kort literatuuroverzicht ${ }^{1}$ worden gegeven, waarna de gegevens uit het eigen data-bestand per faktor zullen worden geanalyseerd. Benadrukt dient te worden dat in deze analyses een rechtstreekse relatie wordt gelegd tussen de betreffende faktor en de resultaat-variabelen. Korrektie voor de mogelijk verstorende werking van diverse andere variabelen wordt in deze paragrafen op beperkte schaal toegepast via gestratificeerde analyses. In paragraaf 3.4 wordt op dezelfde vraag een antwoord gegeven met behulp van een multivariate analyse; hierin wordt rekening gehouden met het komplex van beïnvloedende faktoren voor de zwangerschapskans. Speciale aandacht zal hierbij worden besteed aan de faktor "ziekenhuis" ${ }^{n 2}$. In de slotparagraaf zijn de konklusies van de medische analyses opgenomen.

In de univariate analyses zal globaal onderscheid worden gemaakt tussen:

- seizoensinvloed en leereffekt

- patiëntkenmerken bekend voorafgaand aan de IVF-behandeling

- behandelkenmerken c.q. behandel-tussen-resultaten.

Hierbij is de grens tussen behandelkenmerken en patientkenmerken niet altijd scherp te trekken, omdat de specifieke behandeling dikwijls afhangt wan specifieke patiëntkenmerken en van behandel-tussen-resultaten. Daarnaast kan er een sterke samenhang zijn tussen wat bovenstaand behandelkenmerken en patiëntkenmerken zijn genoemd, bijvoorbeeld de semenbeoordeling tijdens en voorafgaand aan de IVF-behandeling.

\subsection{Seizoensinvloed en leereffekt}

Lit. In 1981 gaf Trounson[1984a] aan dat het vooralsnog onduidelijk was welke faktoren nu precies van invloed zijn op de sukseskans van IVF, getuige de schommelingen in de sukseskans, zelfs bij stratifikatie van allerlei belangrijk

1) Aangezien bij publikaties vrijwel nooil het geslacht van de aluteurs wordt aangegeven en de kans op. een manmelijke eerste auteur erg groot is, zal bij een beschrijving van een publikgtie als uitgangspunt de hij-vorm worden gehatuteerd.

2) Misschien zou een splitsing binnen deze faktor ook zinvol zijn, maar dall ligt buiten het bereik van deze studie. 
geachte faktoren. Hij toonde onder andere aan dat gedurende 5 opeenvolgende faren een grote schommeling bestond in het zwangerschapspercentage per kalendermaand (Wood[1985a]). Ook door IVF-medewerkers binnen de Nederlandse centra werd meermalen aangegeven dat er naar hun idee grote fluktuaties in de resultaten bestonden die wellicht samenhingen met de tijd van het jaar (bijwoorbeeld aan het begin of het einde van een tijdsblok van IVFbehandelingen). Daarnaast wordt zowel in de literatuur als in beleidsnota's veelvuldig aangegeven dat met toenemende ervaring binnen een centrum de resultaten van de IVF-behandeling waarschijnlijk zullen verbeteren.

Data Binnen de ziekenhuizen in het onderzoek bestond, met uitzondering van éen ziekenhuis, bij de start van het onderzoek slechts geringe ervaring met de humane IVF als behandelmethode (maximaal 100 behandelingen volledig onder eigen beheer per ziekenhuis). Een leereffekt in de onderzoeksperiode van bijna twee jaar - zichtbaar via een stijgende lijn in de resultaten - zou derhalve niet uitgesloten zijn. Om te bezien in hoeverre seizoensinvloeden en/of leereffekten inderdaad zijn opgetreden zijn de volgende analyses uitgevoerd voor:

- Seizoensinvloeden: per ziekenhuis werden de IVF-behandelingen gerangschikt naar de officielle kwartalen van het jaar, c.q. 1 respektievelijk 2 maanden opgeschoven ${ }^{3}$. Voor de cijfers volgens de indeling in officiele kwartalen zij verwezen naar bijlage 3.1. In deze opstelling zijn geen duidelijke seizoensinvloeden te zien. Het betreft ook slechts een periode van bijna 2 jaren. Wel opvallend is de slechte periode februari-maart 1987, die min of meer in alle ziekenhuizen gelijktijdig bleek te bestaan. Waarschijnlijk betreft het een toevallige samenloop van omstandigheden ${ }^{4}$.

- Leereffekt: bij de bovenvermelde indeling in de tijd was geen duidelijke verbetering te zien, mogelijk samenhangend met een leereffekt. Dat zou eventueel nog te wijten kunnen zijn aan een ongelijke verdeling van de behandelingen in de tijd. Derhalve is ook een indeling in kwartielen gemaakt, d.w.z. de behandelingen worden naar chronologische volgorde in 4 gelijke delen gesplitst. Ook dat beeld is stabiel voor alle ziekenhuizen samen (ondanks de slechte periode in het $\mathbf{1}^{\mathrm{e}}$ kwartaal 1987), getuige bijlage 3.2 . Voor de resultaten per ziekenhuis geldt dat deze in ziekenhuis 1 schommelend waren, in ziekenhuis 2 in het laatste kwartiel sterk verbeterd zijn, in ziekenhuis 3 voortdurend achteruit zijn gegaan, in ziekenhuis 4 konstant zijn gebleven ${ }^{5}$ en in ziekenhuis 5 in het laatste kwartiel verslechterd zijn. Zowel in ziekenhuis 2 als in ziekenhuis 5 is men in het laatste gedeelte van de onderzoeksperiode (gedeeltelijk) overgeschakeld op een ander stimulatie-schema met gebruik van LHRH-analogen (zie paragraaf 3.3.2.1). Al met al kan men konkluderen dat er in de loop van de onderzoeksperiode

3) De wethode van thet voortschrijdend gemiddelde (moving-average).

4) Wel is onder anderen door $\mathrm{v}$. Herwerden[1905] reeds aangetoond dat op het Noordelijk halfrond de konseptie-grad het meesl gering is in februari.

5) Het feit dat de resultaten in ziekenhuis 4 redelijk konstant züj gebleven in de loop der tijd is konform de werwachting dat het "aanvangs-leereffekt" in dit ziekenhuis met een relatief lange IVF" envaring is opgetreden voor de stan wan het evaluatie-onderzoek. 
geen duidelijk leereffekt per ziekenhuis is opgetreden. Waarschijmlijk wordt dit veroorzalakt door het feit dat de ervaring van een IVF-team niet zozeer is opgehangen aan het ziekenhuis, mar veeleer aan de gezamenlijke ervaring van de teamleden met de gehanterde behandelingsmethoden. $\mathrm{Bij}$ een personele wijziging is het derhalve zeer wel mogelijk dat het leerproces (gedeeltelijk) opnieuw begint. Daarnaast kan een IVF-team besluiten een mogelijke verbetering in het behandelprotokol aan te brengen. De onbekendheid met het nieuwe protokol en de bijbehorende implikaties kan (hopelijk tijdelijk) tot slechtere resultaten leiden.

KonkL - de IVF-resultaten varieren vaak sterk in de loop der tijd

- de totaalresultaten worden niet struktureel beter in de loop van de tijd.

\subsection{Patièntkenmerken}

\subsubsection{Leeftijd vrouw}

Lit. De fertiliteit van de wrouw neemt af met het klimmen der jaren. De leeftijd (chronologische ouderdom) is in deze te beschouwen als een indikator voor de biologische ouderdlom (Gindoff[1986]). Biologische redenen waarom op oudere leeftijd de fertiliteit van de vrouw vermindert zijn afname van de "voorraad" primordiale follikels in de ovaria, toenemende luteale defekten en toenemend vroegtijdig zwangerschapsverlies. De menstruele cyclus wordt hierdoor moeilijker te stimuleren met hMG, de innesteling van het embryo levert problemen op en de kans op vroegtijdige beëindiging van een zwangerschap is groter. Wellicht kan toediening van LHRH-analogen een belangrijk hulpmiddel worden Rutherford[1988]. Jones[1986] spreekt (naar biologische maatstaven) wan een perimenopausale patient als op cyclusdag 3 het serum FSH-mivo verhoogd is, maar het LH-nivo nog normaal is.

Volgens Nishimura[1960] kan de leeftijdsspecifieke fertiliteit samenhangen met het grawiditeitsverleden: de fertiliteit is op hogere leefijd bij primair infertielle vrouwen wellicht minder als bij sekundiair infertiele vrouwen.

In de IVF-literatuur is veelvuldig de invloed van de chronologische leeftijd bestudeerd. De resultaten van deze analyses zijn wisselend. In het ene ziekenhuis in Melbourne (Johnston[1985]) werden geen (signifikante) verschillen gevonden woor leeftijdsgroepen naar klinische zwangerschappen, doorgaande zwangerschappen en klinische abortussen per follikelpunktie. Een ander ziekenhuis in Melbourne (Wood[1985a]) meldt echter wel een lagere zwangerschapskans bij vrouwen vanaf 36 jaren. Ook Sharma[1988] ziet slechtere resultaten in de leeftijdsgroep $36-40$ jaar $(n=705)$. Van de groep ouder dan 40 jaren $(n=25)$ haalt bij hen slechts $1 / 3$ de follikelpunktie. Deze groep komt ook bij andere studies als duidelijk minder gunstig naar voren. Vanuit Bourn Hall (Edwards[1984a]) wordt een normaal verloop tot en met de punktie gemeld, maar een lagere implantatiekans (c.q. een hoog abortuspercentage); volgens hen is dit ook in de dierenwereld een bekend verschijnsel op oudere leeftijd. Ook het World Report IVF 1984 (Seppala [1985]) meldt een lagere sukseskans in de leeftijdsgroep ouder dan 40 jaren. 
Een mogelijk probleem bij de vergelijking tussen verschillende centra van de resultaten wan IVF behandeling in de oudere leefijidsgroepen is het feit dat de centra warschijnlijk een werschillend selektie-beleid toepassen voor deze leeftijdsgroep.

Data Bij een indeling van de leeftijd van de vroww in 3 groepen (jonger dan 35 jaar $(n=1974), 35-39$ jaar $(n=1009)$ en vanaf 40 jaar $(n=103)$ is een duidelijke trend zichtbaar vain slechtere resultaten over vrijwel de gehele linie op hogere leeftijd (zie bijlage 3.3). Allereerst leidt op hogere leeftijd een geringer aantal gestarte behandelingen tot een embryotransfer: een signifikant grotere uitval vór de follikelpunktie, gevolgd door een iets grotere uitval tussen punktie en embryotransfer. Ook de zwangerschapsresultaten zijn duidelijk minder op hogere leeftijd: een tendens tot lagere percentages klinische zwangerschappen en een signifikant grotere uitval tussen klinische en doorgaande zwangerschap leiden tot signifikant lagere percentages doorgaande zwangerschappen. Deze laatste percentages bedragen per gestarte behandeling respektievelijk $1.2 .0 \%$, $8.1 \%$ en $3.9 \%$. Benadrukt dient te worden dat het bovengeschetste beeld een trend aangeeft: op hogere leeftijd worden de resultaten minder. Maar in overeenstemming met het natuurlijk proces met betrekking tot fertiliteit geldt bij IVF: naarmate de leeftijd van de vrouw toeneemt geldt steeds sterker dat de zwangerschapskans reduceert, maar er bestaat in de IVF-behandelresultaten kwa leeftijd niet eén duidelijk omslagpunt (zie bijlage 3.3, tabel B3.3.3).

Aangezien de indikatiestelling voor IVF mogelijk een belangrijke verstorende variabele is in het bovengeschetste beeld, zijn de resultaten naar leeftijdsgroep ook geanalyseerd voor alleen de patiëntengroep met als enige indikatie tubapathologie. De trend van slechtere resultaten op hogere leeftijd komt hier versterkt terug (zie bijlage 3.4). In de leeftijdsgroep vanaf 40 jaar bleven 69 behandelingen zonder ook maar eén doorgaand-zwangerschaps-resultaat.

Ook is onderzocht of op oudere leeftijd de resultaten inderdaad beter zijn bij de vrouwen die reeds zwanger zijn geweest. Er bestaat welliswaar op hogere leeftijd een tendens voor sekundair infertiele vrouwen tot een geringere uitval tijdens de IVF-behandeling, maar de zwangerschapsresultaten zijn identiek (zie bijlage 3.5 ).

Konkl. - op hogere leeftijd van de vrouw zijn de IVF-resultaten minder; er is sprake van een trend zonder één duidelijk omslagpunt

- de resultaten op hogere leeftijd worden waarschijnlijk nauwelijks beïnwoed door het graviditeitsverleden.

\subsubsection{Indikatie}

Lit. Oorspronkelijk werd de IVF-behandeling alleen toegepast bij paren met als enige indikatie voor fertiliteitsproblemen pathologie van de tubae. Maar na verloop van tijd werd duidelijk dat IVF ook bij andere indikaties mogelijk een alternatief voor bestaande behandelvormen kon vormen. De resultaten bij de verschillende indikaties zoals vermeld in de literatuur worden hieronder 
aangegeven. Binnen de groep met als indikatie tubapathologie is daarbij getracht ook onderscheid aan te brengen naar de ernst van de tubapathologié. Dit is te meer belangrijk, omdat ook bij tubachirurgische behandeling van deze groep patiënten een dergelijke differentiatie van belang blijkt te zijn (zie paragraaf 5.2.1).

Door deze uitbreiding van het toepassingsgebied kreeg de IVF-methode naast een therapeutische waarde ook betekenis als vorm van diagnostiek. Tijdens de IVF-procedure kan immers buiten het lichaam het fertilisatieproces in stappen worden gevolgd, waardoor meer inzicht ontstaat in de specifieke problemen tijdens het fertilisatieproces bij het individuele paar.

Een probleem bij de vergelijking van de resultaten voor verschillende indikaties is dat er meer dan eén reden kan zijn waarom een paar fertiliteitsproblemen heeft. Veelal wordt in de praktijk echter uitgegaan van ến (hoofd)indikatie. Waarschijnlijk is een vergelijking op (hoofd)indikatie zodoende niet een volstrekt zuivere vergelijking tussen homogene patiëntgroepen kwa indikatiestelling. Ondanks deze kanttekening levert een dergelijke vergelijking mogelijk well in grote lijnen een belangrijke differentiatie in behandelresultaten op.

De resultaten van de IVF-behandeling bij de indikatie tubapathologie komen in grote lijnen overeen met de totale behandelresultaten van de grote IVFcentra, omdat het grootste gedeelte van de behandelingen deze indikatie betreft. Veel interessanter is te trachten binnen deze groep een nadere differentiatie aan te brengen naargelang de aard en mate van de tubapathologie. Hoewel door de IVF-behandeling juist de funktie van de tubae wordt overgenomen, zijn er twee redenen om deze differentiatie te onderzoeken. Enerzijds is het ons inziens niet onredelijk te veronderstellen dat een ziekteproces waarbij de tubae zijn aangedaan ook invloed heeft gehad op de funkties van andere organen die een rol spelen bij het fertilisatieproces (onder anderen Hamilton[1986]). Anderzijds is het belangrijk om te onderzoeken of de patiëntgroepen met tubapathologie - die onderling verschillen vertonen in de kans op zwangerschap na tubachirurgie - bij IVF een (onderling) gelijke kans op zwangerschap hebben of ook bij IVF verschillende prognoses hebben.

Probleem bij de differentiatie binnen de patiêntgroep met tubapathologie is dat de gehanteerde vormen van diagnostiek uiteraard geen van alle volledig sensitief en specifiek zijn. Met andere woorden, een gedeelte van de bevindingen is foutpositief of fout-negatief. Met de diagnostische laparoscopie als gouden standaard vertoont het $\mathrm{HSG}^{7}$ hoge fout-skores (Ismajovich[1986], Maathuis[1972]), ofwel er bestaat zeker niet op alle onderdelen een hoge mate van overeenkomst in de bevindingen van beide vormen van diagnostiek. Konklusie van Ismajovich[1986] hierbij is dat het HSG heperkte betekenis heeft voor de diagnostiek van peritubaire adhaesies, maar wel belangrijke informatie oplevert

6) Afwijkingen aan de tubae worden in de literatuur meermaals in kombinatie met tubapathologie beschreven. In deze rapportage zal bij dit gebruik worden aangestoten.

7) HSG is de afkorting voor Hysterosalpingografie; ofwel een foto wan de baarmoeder waarbij kontrastvloeistof wordt ingespoten. 
voor de beoordeling wan het aspekt en de doorgankelijkheid van de tubae. Henry-Suchet[1984] vindt eveneens nawwelijks overeenkomst tussen de bevindingen van HSG en tuboscopie (discrepantie bij $50 \%$, ofwel absoluut geen verband).

Men mag echter aannemen dat de informatie uit vooral HSG en diagnostische laparoscopie in de praktijk wordt gebruikt (naast de anamnestische gegevens omtrent abdominale operaties) om de ernst wan de tubapathologie te kunnen vaststellen en daarmee de zwangerschapskansen na een eventuele tubachirurgische ingreep als alternatief voor de IVF-behandeling.

Wood[1985a] wond geen verschil in het zwangerschapspercentage per gestarte IVF-cyclus, gedifferentieerd naar de tubaire staat. Deze percentages bedroegen respektievelijk $11 \%$ (51/452) voor de patienten met beiderzijds doorgankelijke tubae, $14 \%$ (18/133) voor patiénten met een doorgankelijke tuba en $9 \%$ $(65 / 728)$ voor de patiënten zonder een doorgankelijke tuba.

Ook Sher[1986] berichtte over een gelijk percentage klinische zwangerschappen per embryotransfer voor behandelingen bij patiènten met bilaterale tubaire occlusies $(n=119)$ en patiénten met minstens een doorgankelijke tuba $(n=40)$.

Omtrent de relatie tussen owariele pathologie en tubapathologie merkte Otubu[1984] op dat bij konijnen de ovariele funktle na salpingostomie was aangetast ". Diamond[1988] geeft mogelijke redenen aan waarom peri-ovariele adhaesies kunnen leiden tot minder goede follikulaire ontwikkeling:

1. de adhaesies kunnen fysiek de groei van de follikels tegenhouden

2. ze kunnen de bloedtoevoer naar de ovaria afremmen

3. het proces dat geleid heeft tot de adhaesies kan ook de ovarièle bloedtoevoer hebben beschadigd (bijvoorbeeld cystectomie, tubectomie); splitsing van de tuba-ovariele bloedvaten leidde immers bij konijnen tot reduktie van het aantal owulaties (McComb[1984]).

Zelf vond Diamond[1988] echter in een kleine studie van 49 patienten met beide ovaria aanwezig geen korrelatie tussen enerzijds de mate van peri-ovariële adhaesies en anderzijds de ovarièle respons". Wel lag het aantal verkregen obcyten signifikant hoger woor behandelingen bij patienten met beiderzijds geen ovariele adhaesies $(n=15)$ versus de restgroep $(n=34)$.

Mahadevan[1985] meldde echter dat ovaria met adhaesies (dat wil zeggen voor meer dan $1 / 4$ bedekt) echografisch signifikant minder follikels $(>12 \mathrm{~mm}$ ) te zien gaven dan ovaria zonder adhaesies bij stimulatie met cc/hMG/hCG. Overigens werd deze bevinding niet meer gevonden bij een vergelijking tussen patienten in plaats van tussen ovaria. De fertilisatiegraad en de delingsgraad van de verkregen oobyten verschilden niet naar herkomst van thet soort ovarium. tussen het ovarim an de zijde wasr een salpingostomie was uitgevoerd (na een eender geinduceerde hydrosalpinx) en the kontrole-owarium.

9) De cycli werden gestimuleerd met behulp van $\mathrm{hMG}$ en hCG. De mate van peri-ovariële adhaesies werd bepalald tijdens een laparoscopische follikelpunktie, waarbij ce skores voor beide ovaria werden opgetetd; de ovariele respons werd bepaald via het serum- $\mathrm{E}_{2}$-nivo en het antal echoscopisch zichtbare follikels. 
Molloy[1987] tenslotte voerde een gematchte studie wit naar de resultaten van IVF bij patienten met 'frozen pelvis" (in iedere groep 51 cycli). Hij vond een duidelijk minder goede follikulaire respons: signifikant meer gecancelde cycli door een slechte $\mathrm{E}_{2}$-respons, lagere $\mathrm{E}_{2}$-waarden, langere stimulatie, minder follikels $(>10 \mathrm{~mm})$, minder oőcyten per follikelpunktie, en een lager zwangerschapspercentage per embryotransfer.

Bij de groep met als indikatie mannelijke subfertiliteit ligt het fertilisatiepercentage lager (onder anderen Cohen[1985], Mahadevan[1983], Johnston[1985], v. Uem[1985], Awadalla[1987]). Maar als de vrouwelijke faktor geen indikatie voor IVF vormt, kan de verminderdle fertllisatiekans in deze groep gedeeltelijk gekompenseerd worden door een hogere implantatiekans (onder anderen Cohen[1985], Johnston[1985], Zeilmaker[1987]). Zodoende kunnen de zwangerschapspercentages per follikelpunktie bij de indikatie mannelijke subfertiliteit soortgelijk worden als in de trest van de IVF-populatie (Yovich[1984a], de Kretser[1985], Yates[1987], Englert[1987]). Als er tevens sprake is van een vrouwelijke infertiliteitsfaktor, dan ligt de totale zwangerschapskans lager dan bij de rest (Cohen[1985]).

Groot probleem bij de indikatie mannelijke subfertiliteit bij IVF is de vraag welke diagnostiek een goede maatstaf biedt en war de grens c.q. het grensvlak ligt tussen goed en slecht semen. Semen dat in de pré.-IVF-terminologie als slecht benoemd zou zijn, kan juist door handelingen dic rondom IVF zijn ontwikkeld bewerkt worden, waardoor vaak toch fertilisatie tot stand kan worden gebracht. Traditioneel wordt de semenkwaliteit beoordeeld op basis van drie faktoren: konsentratie, morfologie en motiliteit. Maar deze kriteria geven slechts een indirekte indikatie van de funktionele mogelijkheden van de spermatozoa. Zodoende leidt een indeling op basis van deze faktoren niet tot homogene groepen. Meer recente methoden voor de bepaling van de funktionele mogelijkheden van de spermatozoa worden door Aitken[1988] aangegeven:

- verschillende vormen van micrografie om de alard van de motiliteit van het sperma te onderzoeken

- acrosoomreaktie-beoordeling met behulp van monoklonale antilichamen ter bepaling van de sperma-oofcyt-interaktie; hiervoor wordt ook nog wel de hamster-eicel-penetratietest gebruikt, maar deze test levert vele foute uitslagen vergeleken met de humane bevruchtingscapaciteit als gouden standaard (onder anderen Yates [1987], Aitken[1988]). Volgens Zeilmaker[1986] is de incidlentie van met name de fout-negatieve uitslagen wan de hamster-eicel-test sterk afhankelijk van technische onvolkomenheden in het laboratorium. Talbert[1987] beweert zelfs dat mede on deze reden de hamster-eicel-test nauwelijks extra prediktieve waarde heeft voor bevruchting naast de bekende semenparameters, warvan motiliteit gedefinieerd als het percentage goedbewegende spermatozoa) de belangrijkste - maar zeker niet de enige - is. 
De faktor manneijke subfertiliteit heeft witeraard een duidelijke relatie met de semenbeoordeling tijdens de IVF-behandeling. Deze laatste variabele komt ter sprake in het gedeelte over het verloop vanaf de follikelpunktie tot de embryotransfer (paragraaf 3.3 .2 .2 ).

Voor IVF-behandelingen bij patiênten met endometriose ${ }^{11}$, die hiervoor reeds behandeld $z i j n_{3}$ meldt Chillik $([1985 \mathrm{a}]: \mathrm{n}=39$, later [1985b]:n=85) in Norfolk een zwangerschapspercentage per follikelpunktie van $30 \%$. In de groep met ernstige endometriose ligt dit percentage lager, mede doordat er een lagere odcytopbrengst is. Chillik[1985b] geeft als mogelijke andere reden voor het verlaagde zwangerschapspercentage een verminderde obcytkwaliteit, waarbij de odcyten weliswaar in staat zijn tot fertilisatie en deling, maar de ontwikkelde embryo"s wellicht minder goed in staat zijn tot implantatie.

Vanuit Melbourne meldt Johnston[1985] bij 89 follikelpunkties bij endometriose-patiènten een zwangerschapspercentage van $14 \%$, eveneens na voorafgaande behandeling van de endometriose. Dit percentage komt vrijwel overeen met dat voor de totale populatie $(n=401)$.

Yovich[1985a] signaleert daarentegen signifikant slechtere zwangerschapsresultaten bij endometriose vergeleken met andere indikaties (totaal $n=592$ paren, ca. 1000 behandelingen) ten gevolge wan een verlaagde odcytopbrengst, een verlaagde fertilisatiegraad en een verlaagde implantatiegraad. Ook Wardle[1985] meldt voor paren met als indikatie endometriose (zonder voorafgaande behandeling van de endometriose en met normaal semen: $\mathbf{n}=15$ ) een duidelijk verlaggde fertilisatiegraad per mature oöcyt (33\% versus 68\%) vergeleken met paren met als indikatie tubapathologie $(n=42)$.

Bovenstaande publikaties stammen alle nog uit de periode van de laparoscopische follikelpunkties. Bij echoscopische follikelpunktie meldt Sharma[1988] voor patienten met ernstige endometriose (83 ET's) een signifikant lager zwangerschapspercentage per embryotransfer ten opzichte van patienten met milde endometriose (79 ET"s) bij cen identiek fertilisatiepercentage. Zij konkludeert hieruit dat bij ernstige endometriose waarschijnlijk problemen bij de implantatie optreden. Overigens is het volgens Buttram[1985b] zo, dat ook na operatieve behandeling van endometriose (al of niet na pre-operatieve danazol-medikatie) de zwangerschapskans negatief samenhangt met de ernst van de endometriose volgens diverse klassifikaties ${ }^{12}$.

In Melbourne,Monash (Mahadevan[1983]) werden bij een groep met onbegrepen infertiliteit 116 follikelpunkties uitgevoerd. De fertilisatiegraad per oocyt lag in deze groep beduidend lager dan in de groep dubbelzijdige tubapathologie $(n=261)$. Soortgelijke resultaten werden gevonden in Melbourne, Royal (Johnstion[1985]).

De term onbegrepen infertiliteit geeft in feite aan dat er geen medische oorzaak voor de infertiliteit is gevonden. Hieraan kunmen twee soorten van redenen

11) Er is sptake van endometriose indien baarmoederslijmvlies buiten haar normale lokalisatie voorkomt.

12) Acosia [1973], American Fertility Society [1979] en Buttram [1985a]. 
debet zijn. Enerzujds bestaat er binnen de wetenschap nog geen volledig begrip van alle facetten van het proces van fertilisatie en implantatie en de problemen die daarbij kunmen optreden. Daardoor is het mogelijk dat bij de huidige stand van de wetenschap geen verklaring kan worden gevonden voor het achterwege blijwen van een zwangerschap. De IVF-methode theeft onder andere voor deze groep patienten mede een diagnostische betekenis. Anderzijds is het zo dat de diagnostische mogelijkheden binnen de huidige stand van de wetenschap niet altijd worden gebruikt ${ }^{13}$, waardoor soms ten onrechte de indikatie onbegrepen infertiliteit wordt gesteld.

Data Verreweg het grootste gedeelte (88\%) wan de IVF-behandelingen werd uitgevoerd bij paren, bij wie tubapathologie een indikatie voor IVF vormde; bij $73 \%$ van de behandelingen was tubapathologie zelfs de enige indikatie. Derhalve is de totale groep kwa indikatie allereerst als volgt in drieen gesplitst:

1. alleen tubapathologie $(n=2243)$

2. tubapathologie in kombinatie met andere faktor $(n=487)$

3. geen tubapathologie $(n=362)$

Binnen de laatste twee groepen is vervolgens een verdere splitsing aangebracht op basis van de indikatie mannelijke subfertiliteit.

Bij vergelijking van de resultaten van de aldus onderscheiden groepen valt op (zie bijlage 3.6) dat het percentage doorgaande zwangerschappen per gestarte cyclus signifikant hoger lïgt bij enerzijds de groep paren met als enige indikatie tubapathologie (11.4\%) en anderzijds de groep zonder tubapathologie en zonder mannelijke subfertiliteit ${ }^{14}(10.9 \%)$ ten opzichte van $6.7 \%$ in de restgroep. Dit "eindverschil" wordt opgebouwd door een verschil in wrijwel alle fasen, met uitzondering van de fase tot de follikelpunktie.

Als de behandelingen bij de groep met als indikatie mannelijke subfertiliteit centraal in de analyses worden gesteld $(n=325)$, dan blijkt dat deze behandelingen signifikant slechtere resultaten te zien geven in bijna alle fasen (zie bijlage 3.7). Het percentage doorgaande zwangerschappen per gestarte cyclus bedraagt bij mannelijke subfertiliteit ongeveer de helft $(5.9 \%$ versus $11.0 \%)$. Dit is nauwelijks te verklaren uit het gemiddeld aantal teruggeplaatste embryo's bij mannelijke subfertiliteit: $3.1+1.4$ versus $2.7 \pm 1.6_{*}^{*}$ de gemiddelde kwalteit ${ }^{13}$ van de teruggeplaatste embryo's lijkt eveneens soortgelijk te zijn. De fertilisatiegraad per oôcyt ligt bij behandelingen met als (mede-)indikatie mannelijke subfertiliteil signifikant lager dan bij de andere behandelingen: $41 \%$ vers us $58 \%$. Binnen de groep met indlikatie mannelijke subfertiliteit wordt bij afwezigheid van een tubaire faktor de verlaagde fertilisatiegraad niet gekompenseerd door een hogere implantatiegraad, getuige het klinisch c.q. doorgaand zwangerschapspercentage per embryotransfer in deze groep ten opzichte van de groep met

13) Indien al op voorhand duidelijk is dat de extrat dignostiek geen invloed zal hebben op he! therapeutisch beleid, walt terughoudendheid in deze overigens sterk te prijzen.

14) Deze groep van behandelingen $(n=266)$ bestati woorniamelijk uit behandelingen met als (mede) indikatie idiopathische infertiliteit $(n=130)$, posth-sterilisatie $(n=76)$ en endometriose $(n=60)$.

15) De wijze waarop deze kwaliteit word beoordeeld komt ter sprake in paragraaf 3.3 .2 .3$. 
mannelijke subfertiliteit en tubapathologie: $17.0 \%$ versus $13.9 \%$ c.q. $14.9 \%$ versus $8.0 \%$.

De behandelingen bij de patiëntengroep met endometriose $(n=306)$ lieten een signifikant grotere uilval zien in de IVF-procedure (zowel woor de follikelpunktie als tussen punktie en embryotransfer), maar de zwangerschapsresultaten per embryotransfer waren soortgelijk als bij de andere behandelingen (zie bijlage 3.8). Er is hierbij geen nadere uitsplitsing gemaakt naar de ernst van de endometriose, ondat deze veelvuldig niet eenduidig was aangegeven.

Behandelingen bij paren met onbegrepen infertiliteit $(n=157)$ leverden enigszins betere zwangerschapsresultaten op dan bij de rest (zie bijlage 3.9): een signifikant lager percentage embryotransfers per follikelpunktie (76\% versus $85 \%)$, samenhangend met cen lagere fertilisatiegraad (47\% versus $57 \%$ ) werd meer dan gekompenseerd door een signifikant hoger klinisch zwangerschapspercentage per embryotransfer $(27.7 \%$ versus $19.6 \%)$. Bij uitsluiting van behandelingen bij paren met een infertiliteitsduur van maximaal 5 jaren bleken de zwangerschapsresultaten niet meer bovengemiddeld te zijn. Voor de groep met kortdurende onbegrepen infertiliteit mag een relatief hoge spontane zwangerschapskans worden verondersteld (zie paragraaf 5.4).

Voor de groep bij wie tubapathologie een indikatie was voor de IVFbehandeling is getracht te komen tot een nadere differentiatie op basis van anamnestische gegevens omtrent abdominale operaties en gegevens van het HSG en de diagnostische laparoscopie. Om daarbij een zuivere groep te kunnen bestuderen is alleen gekeken naar de groep met als enige indikatie tubapathologie. Het gaat hierbij in totaal om 1038 paren, die 2243 IVFbehandelingen hebben ondergaan. Bijna $70 \%$ van de betrokken vrouwen heeft een of meerdere fertiliteitsbevorderende tubachirurgische ingrepen ${ }^{16}$ ondergaan (voornamelijk adhaesiolyse en/of salpingostomie). Andere vormen van fertiliteitsbehandeling (kunstmatige inseminatie, intra-uteriene-inseminatie of hormoonstimulatie in de follikulaire en/of luteale fase) zijn bij $13 \%$ van de IVF-paren met als enige indikatie tubapathologie voorafgaand aan IVF toegepast. Bovenstaande resultaten zijn samengevat in tabel 3 .

Bovendien blijkt uit bijlage 3.10 dat bij ongeveer de helft van deze vrouwen beide tubae volledig aanwezig zijn, bij ruim $30 \%$ sllechts een tuba volledig aanwezig is en bij $15 \%$ beide tubae afwezig zijn. Beide ovaria blijken bij $3 / 4$ van deze vrouwen aanwezig te zijn. 


\section{Tabel 3.1. Frekwenties van enkele anamnestische gegevens van IVF-paren met als enige indikatie tubapathologie.}

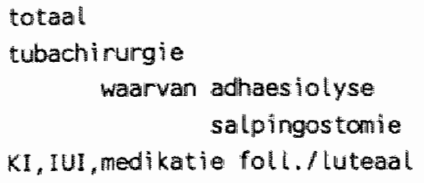

De resultaten van de IVF-behandelingen bij deze groep voor paren die tubachirurgie hebben ondergaan, dan wel adhaesiolyse of salpingostomie in het bijzonder, bleken identiek te zijn aan die voor paren zonder tuba-chirurgie in de anamnese ${ }^{17}$ (zie bijlage 3.11 ).

Een verdere differentiatie op basis van gegevens uit HSG en diagnostische laparoscopie is alleen uitgevoerd bij een nog verder beperkte groep patiënten. Voor de zuiverheid van de vergelijking zijn de gegevens uit het HSG alleen gebruikt (voorzover uitgevoerd en bekend), indien er na het HSG geen abdominale ingreep heeft plaatsgevonden. Dat geldt voor circa $40 \%$ van de paren met als enige indikatie tubapathologie ${ }^{18}$. Om dezelfde reden is van de gegevens van de diagnostische laparoscopie alleen gebruik gemaakt als er daarna geen abdominale ingreep meer heeft plaatsgevonden en als de laparoscopie in het eigen ziekenhuis is uitgevoerd ${ }^{19}$.

Bij vergelijking van de IVF-resultaten tussen subgroepen, samengesteld op basis van gegevens uit HSG of laparoscopie, vallen de volgende belangrijke verschillen op (zie bijlage 3.12):

- de konstatering van een hydrosalpinx op het HSG gaat gepaard met enigszins verminderde zwangerschapsresultaten.

17) Er bestonden in deze overigens nog well verschillen tussen de ziekenhuizen (die niet te verklaren zijn door kleine aantallen, want bijna iedere cel bevatte minimaal 50 embryotransfers). Patiènten met tuba-chirurgie in de anamnese boekten bij IVF in ziekenhujs 1 relatiel minder goede resultaten, maar in ziekenhuis 4 juist relatief betere (voor ziekenhwis 4 werd dit nog wersterkt bij adhaesiolyse). In ziekenhuis 4 haddden evenwel ook relatief weinig patiënten tubachirurgie ondergaan. In ziekenhuis 5 werden bij patienten met salpingostomie in de anamnese relatief betere IVF-resultaten bereikt. De verschillen tussen de ziekenhuizen hangen mogelijk samen met een verschillend selektiebeleid ten aanzien van de keuze tussen tuba-chinurgie en IVF.

18) HSG: $238 \times(23 \%)$ niet vitgevoerd, $800 \mathrm{x}$ wel uitgevoerd: $383 \mathrm{x}$ gevolgo door cen abdoninale operatie, $417 x$ niet gevolgd door een abdominale operatie. Alleen woor deze laatste groep zijn in het evalluatieonderzoek verdere gegevens van het HSG vastgelegd; dit betreft $40 \%$ wan het anntal paren, warbij 895 IVF-behandelingen zijm uitgewoerd.

19) Diagnostische laparoscopie: 1 16x (11\%) niet uitgevoerd, $922 x$ wel uitgevoerd: $413 x$ gevolgd door cen abdominale operatie, 509x niet gevolgd door een abdominale operatie. Alleen voor deze laatste groep zijn verdere gegevens van de diagnostische laparoscopie bekend ( $55 \%$ van de uitgevoerde laparoscopieezen, $49 \%$ wan de paren). Maar alleen indien de laparoscopie in het eigen ziekenhuis is uitgevoerd werden de gegevens ook betrouwbaar genoeg geacht voor verdere analyses; dat betrof 277 paren, waarbij 650 [VT"-behandelingen zijn uitgevoerd. 
- indien de tuba volgens de diagnostische laparoscopie (vrijwel) volledig bedekt is onder adhaesies zijin de zwangerschapsresultaten bij IVF minder goed; dit geldt niet voor bedekte ovaria.

De aanwezigheid van adhaesies aan tuba of ovarium lijkt alleen enige invloed te hebben op de IVF-zwangerschapsresultaten, indien er veel adhaesies aanwezig zijn. De aard van de adhaesies (los versus gefixeerd) lijkt geen invioed te hebben op de zwangerschapsresultaten bij IVF.

Het trekken van vergaande konklusies ten aanzien van de mogelijk prognostische waarde van patientgegevens verkregen uit $\mathrm{HSG}$ en diagnostische laparoscopie is op basis van de uitgevoerde analyses helaas niet verantwoord.

KonkL - de resuitaten van behandelingen op (mede-)indikatie mannelijke subfertiliteit zijn minder goed

- de resultaten van behandelingen op andere indikaties dan mannelijke subfertiliteit sluiten goed aan bij die van behandelingen op de indikatie tubapathologie

- bijna 3/4 van de behandelingen in het onderzoek zijn uitgevoerd bij vrouwen met tubapathologie als enige indikatie; van deze vrouwen had bijna $70 \%$ reeds een of meerdere fertiliteitsbevorderende tubachirurgische ingrepen ondergaan

- de resultaten van IVF bleken geen verband te vertonen met de aan/afwezigheid van fertiliteitsbevorderende tubachirurgie in de anamnese

- er zijn (voorallsnog) slechts aanwijzingen dat de ernst van de tubapathologie van invloed is op de resultaten bij de IVF-behandeling; eenzelfde opmerking geldt voor de ernst van endometriose.

\subsubsection{Verzekeringsvorm}

Data Van de eventuele verschillen naar verzekeringsvorm werd verwacht dat ze sterk zouden samenhangen met de indikatie voor de IVF-behandeling. De financieringssituatie van de IVF-behandeling in Nederland zou mogelijk tot verschillen in de samenstelling van de patiêntenpopulaties van de diverse financieringsbronnen kunnen leiden en dientengevolge tot uiteenlopende behandelresultaten bij deze populaties. Naast een subsidieregeling woor ziekenfondsverzekerden (gelimiteerd in aantal en indikatie) hebben diverse partikuliere verzekeringsmaatschappijen de IVF-behandeling (ook meestal gelimiteerd) vergoed. Ook zijn er IVF-behandelingen door paren zelf betaald of op kosten van het ziekenhuis uitgevoerd. In ons databestand was alleen bekend of het paar partikulier verzekerd of ziekenfondsverzekerd was en in het laatste geval of de behandeling al of niet binnen de subsidieregeling werd uitgevoerd. Bij vergelijking van de resultaten van deze patiëntengroepen blijkt dat de verschillen minimaal zijn (zie bijlage 3.13). Behandelingen uitgevoerd bij partikulier verzekerden $(n=936)$ hebben geleid tot soortgelijke zwangerschapspercentages dan die bij ziekenfondsverzekerden $(n=2156)$. Binnen deze laatste groep waren de resultaten van de subsidie- en de niet-subsidiebehandelingen nauwelijks verschillend, behalve in de fase van follikelpunktie tot embryotransfer: de grotere uitval bij de niet-subsidie-behandelingen werd vooral veroorzaakt door de groep met als (mede-)indikatie mannelijke subfertiliteit. 
De vergelijking tussen de patientengropen gedifferentieerd naar verzekeringsworm wordt uiteraard sterk beinvloed door diverse onderliggende variabelen, zoals indikatie, leeftijd en infertiliteitsduur.

Konkh - de resultaten verschillen niet naat de verzekeringsworm voor de patienten die de behandeling ondergaan; diverse onderliggende variabelen zollen imvloed hebben op dit totaalbeeld.

\subsubsection{Aanwezigheid ovaria}

Lit Voor de IVF-behandeling is de aanwezigheid van minstens cen ovarium noodzakelijk $\mathrm{k}^{20}$. Bij de vergelijking van vrouwen op aanwezigheid van ovaria wordt derhalve de groep vrouwen met beide ovaria vergeleken met de groep met slechts één ovarium. Uiteraard spelen naast deze objectief waarneembare maatstaf ook allerlei andere faktoren op de achtergrond een rol. Zo gaf bijvoorbeeld Wood[1985a] reeds aan dat bij patienten met slechts én ovarium waarschijnlijk vaker een ernstige ziekte in de pelvis is opgetreden.

Reeds meerdere malen is in de literatuur melding gemaakt van een lagere oöcytopbrengst en minder teruggeplaatste embryo's bij patiënten met éen ovarium. Boutteville[1987] kwam tot deze bevindingen in Norfolk woor de tubaire patienten, Dodds[1987] bevestigde dit in een kleine gematchte studie en Lam[1987] sloot zich hierbij aan.

De zwangerschapsresultaten lagen veelal dan ook lager voor patienten met eén ovarium, maar het verschill was niet-signifikant. Het aantal behandelingen in de groep met eén ovarium was dan ook meestal beperkt. Boutteville[1987] vond geen signifikante verschillen tussen tubaire patiënten met én ovarium en beide ovaria in zwangerschapspercentage, noch per ET ( $29 / 121=23.9 \%$ respektievelijk $170 / 694=24.4 \%)$, noch per punktie $(29 / 162=17.9 \%$ resp. $170 / 788=21.5 \%)$. Wood[1985a] vond eveneens geen signifikante verschillen in zwangerschapspercentages, ditmaal per gestarte cyclus: bij de groep met cen ovarium $7.3 \%(=13 / 178)$ versus de groep met beide ovaria $10.1 \%(=124 / 1222)$. En ook Lam[1987] liep vast op het relatief kleine aantal behandelingen in de groep vrouwen met een ovarium; de zwangerschapspercentages per gestarte cyclus bedroegen respekticvelijk $9.7 \%(=7 / 72)$ en $15.6 \%(=87 / 559)$, een nietsignifikant verschil.

Data In ons databestand zijn 652 IVF-behandelingen opgenomen, die zijn uitgevoerd bij vrowwen met én ovarium (zie bijlage 3.14 ), dat is ruim $20 \%$ van alle behandelingen.

Ook hier is een signifikant slechter verloop tijdens de IVF-behandeling zichtbaar: een grotere uitval vóor de follikelpuntie, een kleiner aantal verkregen odcyten per follikelpunktie $(4.9 \pm 3.4$ versus $6.6 \pm 4.5, p<0.001)$ een grotere uitval tussen punktie en embryotransfer, iets minder beschikbare embryo's ( 3.1 \pm 2.6 versus $3.5 \pm 2.8, \mathrm{p}<0.01$ ) en de terugplaatsing van iets minder embryo's per embryotransfer $(2.8 \pm 1.3$ versus $3.1 \pm 1.4, \mathrm{p}<0.001)$.

20) Hierbij dient te worden opgemerkt, dat bij gebruik wan donorobyten deze noodzakelijkheid thied geldt. IVF-behandelingen met gebruik van donoroöcyten ziljn ech ter niet in de registratie opgenomen. 
Hoewel de klinische zwangerschapsresultaten (ook hier) niet-signifikant slechter zijn bij patienten met cén ovarium, geldt dat wel voor het totaaliesultaat: het percentage doorgande zwangerschappen per gestarte cyclus is signifikant slechter: $7.7 \%$ versus $11.2 \%$.

De bovenbeschreven tendens geldt overigens ook binnen vrijwel ieder ziekenhuis in het onderzoek. Ook komt dit beeld terug bij zowel eerste behandelingen (in het kader van dit onderzoek) als bij verwolgbehandelingen (zie bijlage 3.14). Dit. duidt erop dat in het algemeen na de eerste behandeling niet een extra selektie op dit punt wordt uitgevoerd.

Tenslotte werd nog onderzocht, of de groep vrouwen met én ovarium wellicht duidelijk afweek in leeftijdsopbouw. Er bleek evenwel nauwelijks verschil te bestaan in de leeftijdsopbouw van beide groepen; het aandeel vrouwen vanaf 35 jaar lag zelfs iets lager bij de groep met eén ovarium: $32 \%$ versus $37 \%$.

Konkl. - de aanwezigheid wan slechts eén ovarium heeft een negatieve uitwerking op de resultaten van IVF.

\subsection{Infertiliteitsduur en graviditeit}

Lit. In Melbourne, Monash (Wood[1985a]) vond men geen invloed van de infertiliteitsduur (een tweedeling met de grens bij 5 jaar) op de zwangerschapskans. Met betrekking tot de invloed van een eerdere graviditeit vond men in Melbourne,Royal (Johnston[1985]) weliswaar hogere zwangerschapspercentages bij sekundaire infertiliteit van de vrouw, maar het verschil was net niet signifikant ten opzichte van primaire infertiliteit. In het World Report 1984 (Seppalä[1985]) werd wel melding gemaakt van een signifikant verschil. Tenslotte werd in Bourn Hall de invloed van een eerdere voldragen zwangerschap op de implantatiekans onderzocht (Edwards[1984a]); men vond geen verschil.

Data De cijfers van deze paragraaf staan weergegeven in bijlage 3.15. Allereerst is binnen het bestand gekeken naar de resultaten, gesplitst naar de ongewenste infertiliteitsduur volgens een driedeling: maximaal 3 jaar $(n=835), 4-5$ jaar $(n=592)$ en minstens 6 jaar $(n=1643)$. Op zich is het al belangrijk te konstateren dat ruim de helft van de IVF-behandelingen zijn uitgevoerd op het moment dat het betreffende paar al minstens 6 jaar geen zwangerschap (meer) heeft bereikt. De variabele infertiliteitsduur is te beschouwen als een indikator voor de ernst van de onderliggende fertiliteitsproblemen. De resultaten blijken over de gehele linie signifikant slechter te zijn naarmate de infertiliteitsduur toeneemt. Ook hier bestaat niet ến duidelijk omslagpunt (evenals eerder bij de variabele "leeftijd wan de vrouw"); er is sprake van een trend.

De invloed van een eerdere klinische zwangerschap is op twee manieren onderzocht: enerzijds via het graviditeitsverleden van de vrouw in het algemeen, anderzijds via het graviditeitsverleden van de vroww binnen de huidige relatie. 
Na een eerder doorgemaakte graviditeit zijn de IVF-resultatem over vrijwel de gehele linie signifikant beter. De resultaten wan de behandelingen die zijn uitgevoerd bij vrouwen die weliswat eerder zwanger zijn geweest maar niet binnen de haidige relatie, sluiten beter aan bij de resultaten van behandelingen bij vrouwen die nog nooit zwanger zijn geweest dan bij die van vrouwen die binnen de huidige relatie al zwanger zijn geweest. Binnen de groep met een eerdere klinische zwangerschap van de vrouw ligt het percentage doorgaande zwangerschappen per gestarte cyclus signifikant lager voor de groep die binnen de huidige relatie nog geen zwangerschap hebben bereikt: $8.6 \%$ versus $12.6 \%$. Hiermee wordt bewestigd dat fertiliteitsproblemen dikwijls voortkomen uit de interaktie van de betrokken partners en niet altijd (alleen) te herleiden zijn tot een fertiliteits-stoornis bij én van beide partners. In het vervolg van dit rapport zal dan ook bij het bestuderen van de invloed van een eerdere klinische zwangerschap gekeken worden naar de situatie binnen de huidige relatie.

Tenslotte is onderzocht of de infertiliteitsduur een verschillende invloed heeft bij primair dan wel sekundair infertiele paren, aangezien sekundair infertiele paren in het algemeen (uiteraard) korter ongewenst infertiel zijn (7.2 jaren \pm 3.7 versus 4.4 jaren $\pm 3.6, p<0.001$ ). Bij primair infertiele paren ligt de scheiding tussen goede en minder goede resultaten bij een infertiliteitsduur van circa 5 jaar, terwijl die grens bij sekundair infertiele paren eerder ligt, te weten rond 3 jaar. Deze grenzen zijn uiteraard wederom niet absoluut, maar ze geven een trend aan. Overigens is de leeftijd van de vrouw bij primair c.q. sekundair infertiele paren niet signifikant verschillend: 32.2 jaar \pm 3.5 versus 32.1 jaar \pm 4.0 ; aandeel van vrouwen ouder dan 35 jaren: $22 \%$ versus $26 \%$.

Konkl. - ruim de helft van de IVF-behandelingen in het onderzoek is uitgevoerd ten tijde van een infertiliteitsduur woor het paar van minimaal 6 jaren

- de resultaten worden minder bij oplopende infertiliteitsduur; er is sprake van een trend zonder éen duidelijk omslagpunt

- een graviditeit binmen de huidige relatie in de anamnese hangt positief samen met de IVF resultaten

\subsubsection{Samenstelling van de patientenpopulatie in de verschillende zidekenhuizen}

Het is zeer aannemelijk dat de samenstelling van de patientenpopulatie per ziekenhuis verschilt. Ieder zuekenhuis is meestal in staat aan te geven, welke patientengroepen met een relatief slechte prognose bij hen relatief vaak voorkomen. Voor de patientenkenmerken die eerder in dit hoofdstuk zijn besproken zal hieronder worden aangegeven in hoeverre patienten met die kenmerken relatief vaak voorkomen in een bepaald ziekenhuis. Daarmee wordt, gezien het voorgaande, nilet beweerd dat een relatief hoge frekwentic van patiënten met bepaalde kenmerken de totale resultaten van de IVF. behandelingen in het betreffende ziekenhuis belangrijk beinvloeden. Dit punt komt wel nadrukkelijk aan de orde in paragraaf 3.4 .

Indien de samenstelling van de patientenpopulatic per ziekenhuis wordt aangegewen met behulp van frekwentie-overzichten is het moeilijk uit de 
veetheid aan cijfers de essentiele verschillen te determineren. Ten behoeve van de eenwoud en de helderheid is daarom gekozen voor een vergellijking tussen de ziekenhuizen met behulp van een korrelatie-matrix. In bijlage 3.16 is aangegeven welke korrelaties op patiëntnivo signifikant waren. De bevindingen op behandelnivo waren overigens soortgelijk.

Opvallende elementen voor de verschillende ziekenhuizen zijn:

- in ziekenhuis 1 hebben patiènten relatief dikwijls (mede) andere indikaties dan tubapathologie

- in ziekenhuis 2 hebben bijna alle patiënten alleen als indikatie tubapathologie

- in ziekenhuis 3 lijkt de samenstelling van de patientenpopulatie het meest overeen te stemmen met het totaalbeeld

- in ziekenhuis 4 zijn patienten in het algemeen iets ouder en al langer ongewenst infertiel, hebben relatief vaker alleen de indikatie tubapathologie, maar hebben ook minder vaak tubachirurgie ondergaan

- in ziekenhuis 5 zijn patiênten daarentegen in het algemeen iets jonger en minder lang ongewenst infertiel; ook hier komt relatief meer alleen de indikatie tubapathologie voor.

\subsection{Behandelkenmerken c.q. behandel-tussen-resultaten}

Allereerst zal onderzocht worden of bij opeenvolgende IVF-behandelingen de sukseskans per behandeling gelijk blijt en wat de uiteindelijke sukseskans is van een IVF-procedure, eventueel bestaande uit meerdere pogingen. Daarna zal per fase van de behandeling worden nagegaan welke faktoren mogelijk invloed uitoefenen op de resultaten. De analyses in deze paragraaf zijn voornamelijk op unilaterale wijze uitgevoerd.

\subsubsection{Rangordenummer van de behandeling per paar}

Intuïtief zou gedlacht kunnen worden dat de zwangerschapspercentages bij oplopend rangordenummer van de behandeling zullen afnemen, omdat bij hogere volgnummers een selektie van patiënten overblijft met een geringere kans op zwangerschap. Immers, de zwangerschappen zullen bij een IVFbehandeling meer dan evenredig optreden bij patiënten met een gunstige prognose (in onderstaande figuur de linkerzijde van het spektrum)

Maar het lijkt redelijk om te veronderstellen dat aan het andere uiteinde van hel spektrum paren met een relatief ongunstige prognose bij IVF eerder het advies zullen krijgen van eventuele verdere IVF-pogingen af te zien. Hoe scherp deze laatste sellektie in de praktijk wordt uitgevoerd is vooraf moeilijk in te schatten, maar kan achteraf wel worden geanalyseerd ${ }^{21}$.

21) In paragraaf 3.4 .5 is bij paren met een mislukte behandeling een vergelijking gemaakt van de prognoses bij die mislukte behandeling tussen paren die aanslluitend nog een IVFwbehandeling hebben ondergaan en paren die aansluitend zijn gestopt met IVF-behandelingen. 
Figuur 3.1. Spektrum van patiëmtgroepen met verschillende prognoses en die samenhang met selektieve doorstroom

$\begin{array}{llll}\text { zeer gunstige } & \text { gunstige } & \text { ongunstige } & \text { zeer ongunstige } \\ \text { prognose } & \text { prognose } & \text { prognose } & \text { prognose } \\ & \text { MrTh }\end{array}$
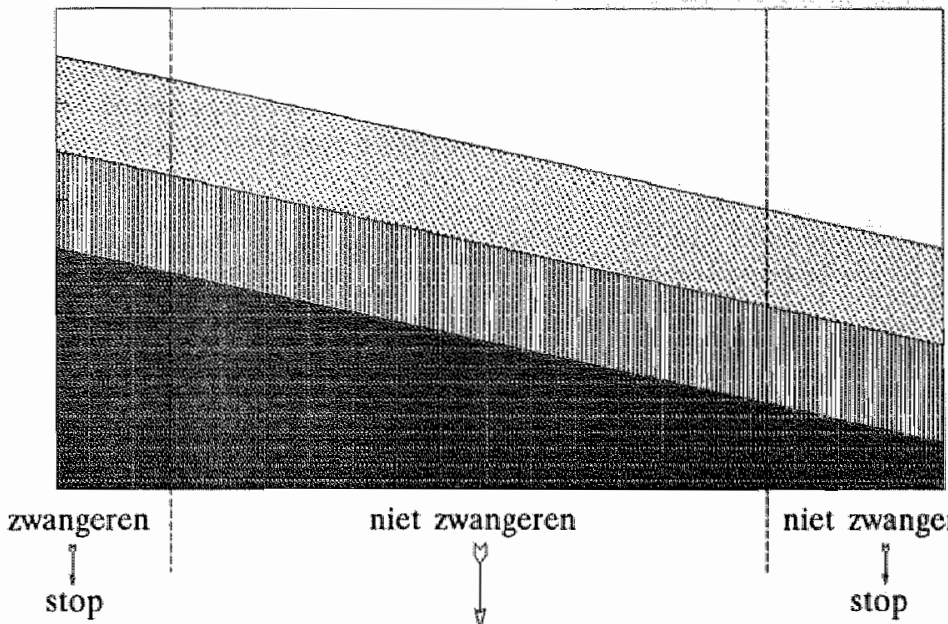

niet zwangeren

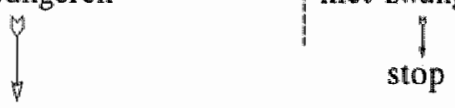

vervolgbehandeling

De suskseskans voor een specifiek paar zal vrijwel gelijk blijven bij iedere poging, of zelfs mogelijk verbeteren door aanjassing van de behandeling aan de eerdere ervaringen. Indien paren met een relatief ongunstige prognose eerder zal worden geadviseerd de IVF-procedure te beeindigen, dan zall de gemiddelde kans op een zwangerschap voor de resterende groep hoger zijn dan voor de totale groep nog-niet-zwangeren. Het is ons inziens niet mogelijk op voorhand aan te gewen hoe de resultaten bij oplopende wolgnummers van behandelingen zich zullen verhouden, aangezien de selektie bij de doorstroom naar vervolgIVF-behandelingen globaal gesteld aan beide uiteinden van het spektrum van prognosegroepen optreedt. Mede ten gevolge van verschillen in het selektiebeleid ten aanzien van doorstroom naar vervolg-IVF-behandelingen kunnen ook verschillen ontstaan tussen diverse studies op het terrein van suksespercentages bij oplopende behandelvolgnummers.

Lit. Er bestaan verschillende manieren om te onderzoeken hoe de resultaten zijn bij opeenvolgende behandelingen. Wood[1985a] keek naar het stimulatievolgnummer en vond geen verschil in zwangerschapspercentages bij cen oplopend stimulatievolgnummer. Sharma[1988] meldde vanuit Londen eveneens

22) Iedere gestarte IVR-behandeling krijgt dan een oplopend volgnummer. 
geen enkel verschil in zwangerschapspercentages bij een oplopend volgnummer, noch per stimulatievolgnummer, noch per follikelpunktievolgnummer, noch per wolgnummer van de embryotransfer (totale aantal gestarte cycli: 2232). Daarbij moet wel worden opgemerkt dat de indeling ver was doorgevoerd, waardoor in de hogere kategorieen het aantal waarnemingen gering was ${ }^{23}$.

Ook Guzick[1986b] vond geen signifikante verschillen tussen opeenvolgende behandelingen. Daarnaast berekende hij een kumulatief-klinisch-zwangerschapspercentage bij cen oplopend aantal follikelpunkties voor de behandelingen in Norfolk in de periode september 1981-april 1985. Het kumulatief-klinischzwangerschapspercentage geeft hier aan hoeveel procent van de paren na een bepaald aantal follikelpunkties een klinische zwangerschap heeft bereikt.

\section{Tabel 3.2. Kumulatief klinisch zwangerschapspercentage bij een oplopend aantal follikelpunkties per paar}

$\begin{array}{lcccccc}\text { Eollikelpunktievalqnumer } & 1 & 2 & 3 & 4 & 5 & 6 \\ \text { aantal punkties } & 530 & 238 & 114 & 53 & 24 & 13 \\ \text { aantal klint. zwang. } & 72 & 31 & 20 & 9 & 2 & 2 \\ \text { * klin. zwang./punktie } & 13.6 \% & 13.0 \% & 17.5 \% & 17.0 \% & 8.3 \% & 15.4 \% \\ \text { kumulatief \% klin.zwanger } & 13.6 \% & 24.8 \% & 37.2 \% & 47.8 \% & 52.2 \% & 59.6 \%\end{array}$

Bron: Guzick[1986b].

Ofwel na 6 follikelpunkties zou bijna $60 \%$ van de paren een klinische zwangerschap hebben bereikt. Guzick had het totale bestand echter op twee manieren ingeperkt, waardoor een relatief gunstig beeld werd geschetst van de totale resultaten. Enerzijds berekende hij het kumulatief percentage op basis van de follikelpunktie en niet op basis van de gestarte behandeling, waardoor gecancelde cycli niet meetelden. Anderzijds sloot hij behandelingen bij paren met als (mede-)indikatie mannelijke subfertiliteit uit, een relatief ongunstige groep.

Paterson[1987] hanteerde nog een andere methode om de IVF-resultaten na meerdere pogingen te presenteren: een cohortbenadering. Hij meldde vanuit Monash de zwangerschapsresultaten van een cohort van 200 paren die na hun eerste follikelpunktie minstens 39 maanden (ruim 3 jaren) zijn gevolgd wat betreft de resultaten wan IVF-behandeling(en). In totaal werden bij dit cohort van 200 paren 496 behandelingen gestart (gemiddeld 2.5 per paar), 455 follikelpunkties uitgevoerd (gemiddeld 2.3 , 370 'verse' embryotransfers (gemiddeld 1.9) verricht en 33 embryotransfers na cryopreservatie. Voor dit cohort bedroeg het percentage klinische zwangerschappen per follikelpunktie $15.4 \%$ en het bijbehorende percentage voor doorgaande zwangerschappen

23) Tot en met volgnummer 3 liepen de zwangerschapspercentages af en vanaff volgmummer 4 kregen ze een grillig verloop, waarschijnlijk door de kleine aantallen. Immers, behandelingen met een volgnummer $\geq 4(n=135)$ werden nog gesplitst in volgnummer 4,5 en $\geq 6$. 
$10.3 \%$. Van de 200 vrouwen in her cohort werden 63 wouwen minstens 1 keer klinische zwanger via IVF $(32 \%$; inklusief zwangerschappen na 'cryo'embryotransfers). Minstens 1 doorgaande zwangerschap via IVF werd bereikt door 48 vrouwen (24\%); het merendeel van deze vrouwen (38) bereikte dit doel in het $1^{e}$ jaar vanaf opname in het cohort, 6 vrouwen in hun $2^{\circ}$ jaar en 4 vrouwen nog daarna.

Data Ook in het eigen bestand is op diverse manieren nagegaan of opeenvolgende IVF-behandelingen verschillende resultaten lieten zien. In totaal werden binnen de onderzoeksperiode 1462 paren met behulp van de IVF-methode behandeld in de 5 deelnemende ziekenhuizen. Een gedeelte van deze paren had ook reeds vóor de onderzoeksperiode minstens eén IVF-behandeling ondergaan, hetzij in het betreffende ziekenhuis hetzij elders. De verdeling van de paren over deze groepen is per ziekenhuis weergegeven in onderstaande tabel. Daaruit blijkt dat in totaal $70 \%$ van de behandelde paren binnen de onderzoeksperiode nog niet eerder met behulp van IVF is behandeld; alleen in ziekenhuis 4 ligt dit aandeel lager, namelijk op ruim $50 \%$. En ongeveer $90 \%$ van de paren is ook niet eerder met IVF behandeld buiten het huidige IVF-ziekenhuis.

Tabel 3.3. TVF-historie van de behandelde paren in de diverse ziekenhuizen (tussen haakjes staat het procentuele aandeel per ziekenhuis)

total nieww in dit volstrekt nieuw

ziekenthuits

\begin{tabular}{llll}
\hline ziekenthuis 1 & 312 & $268(86 \%)$ & $227(73 \%)$ \\
ziekenhuis 2 & 208 & $192(92 \%)$ & $168(81 \%)$ \\
ziekenhuis 3 & 232 & $226(97 \%)$ & $195(84 \%)$ \\
ziekenhuis 4 & 465 & $394(85 \%)$ & $250(5 \%)$ \\
ziekenthuis 5 & 245 & $222(91 \%)$ & $183(75 \%)$ \\
\hline Total & 1462 & & $1023(70 \%)$
\end{tabular}

Allereerst werden de resultaten vergeleken, gerangschikt naar oplopend stimulatievolgnummer (zie bijlage 3.17 ). De resultaten tijdens de IVF. behandeling (percentage uitval voór de follikelpunktie en percentage embryotransfers per follikelpunktie) waren soortgelijk, maar de zwangerschapspercentages wertoonden een signifikant dalende tendens bij oplopend volgnummer. De groep behandelingen met een volgnummer $\geq 4$ is bij deze analyses samengenomen in ên kategorie. Bij gestarte behandelingen met een volgnum-

24) In deze beide percentages zijn alleen de zwangerschappen opgenomen die resulteerden wit embryoterugplaatsingen in de behandelcychus. Dal gelid niet worr de kumulatieve cijlers, daarin aijn ook de zwangerschappen opgenomen die zijn ontskan via embryotransfers na cryopreservatie (aantal) doorgaande zarangerschappem: 4). 
mer $\geq 6 \quad(n=122)$ werden silechts 3 doorgaande zwangerschappen bereikt $(2.5 \%)$.

Bij een indeling op basis van het volgnummer van de hormoonstimulatie is een kiitische kanttekening geplaatst vanuit de ziekenhwizen: sommige paren hebben reeds vele behandelingen gehad in de beginperiode van de IVF in Nederland; daardoor krijgen behandelingen die nu bij deze paren worden uitgevoerd een hoog stimulatie-volgnummer. Ons inziens is niet op voorhand aan te geven hoe deze historie de eerder weergegeven analyses beinvloedt. De vraag is namelijk of de paren met deze, soms extreem, hoge stimulatie-volgnummers een relatief gunstige of ongunstige zwangerschapsprognose hebben bij IVF. Om tegemoet te komen aan deze kritiek zijn derhalve twee aanvullende analyses uitgevoerd:

- ten eerste werden de analyses beperkt tot de paren die bimnen de onderzoeksperiode hun allereerste IVE-behandeling hebben ondergaan; vóor de onderzoeksperiode zijn zij niet met behulp van IVF behandeld, noch in het betreffende ziekenhuis, noch elders (tabel B3.17.2)

- ten tweede werd alleen gekeken naar het volgnummer van de stimulatie binnen het onderzoek, het zogenaamde behandel-volgnummer; dit werd gedaan zowel woor alle paren als voor alleen volstrekt nieuwe IVF-paren (tabellen B3.17.3 en B3.17.4).

Beide analyses leverden hetzelfde beeld op als eerder geschetst: min of meer gelijke resultaten tot en met de embryotransfer, maar een signifikant dalend zwangerschapspercentage bij oplopend volgnummer van de gestarte behandeling.

Vervolgens werd nagegaan of het bovenbeschreven beeld ook geldig is voor jeder ziekenhuis. Hiertoe werden de behandelingen binnen de onderzoeksperiode verdeeld in twee groepen: de eerste behandeling van ieder paar en alle eventuele vervolgbehandelingen (zie bijlage 3.18). Als de zwangerschapsresultaten van de eerste behandelingen binnen het onderzoek per ziekenhuis worden vergeleken met die van de vervolgbehandellingen is er min of meer een tweedeling in de ziekenhuizen te onderkennen: enerzijds zijn in de ziekenhuizen 1 en 5 de zwangerschapsresultaten voor beide kategorieèn vrijwel identiek, anderzijds zijn de zwangerschapsresultaten in de andere ziekenhuizen aanzienlijk minder bij vervolgbehandelingen ten opzichte wan de eerste behandelingen binnen het evaluatie-onderzoek ${ }^{25}$. Het percentage doorgaande zwangerschappen (uitgedrukt per embryotransfer, per follikelpunktie of per hormoonstimulatie) ligt bij deze laatste 3 ziekenhuizen voor vervolgbehandelingen op circa $2 / 3$ van het percentage voor de eerste behandeling.

Ook is onderzocht of een dergelijke dalende zwangerschaps-trend bij oplopend volgnummer geldt voor de teleenheid follikelpunktie (zie bijlage 3.19). Ook hier zijn de behandelingen met een volgnummer $\geq 4$ samengenomen in een kategorie. De resultaten van deze analyses wijken enigszins af van de analyses op basis van het stimulatie-volgnummer. Het meest opvallende is dat het percentage embryotransfers per follikelpunktie signifikant stijgt bij een oplopend follikelpunktie-volgnummer. Dit is mogelijk het gevolg van een selektieproces,

25) Ten gevolge wan het kleine antal wamemingen per cel zijn deze verschillen overigens aileen in ziekenhuis 4 signifikant. 
waarbij paren met uitblijvend sukses geadviseerd wordt van verdere TVFbehandeling af te zien. Een andere reden kan zijn een intensievere hormoonstimulatie na eerder falen van de behandeling. De klinische zwangerschapspercentages vertonen een kleine opwaartse knik bij de $3^{*}$ follikelpunktie. De doorgaande zwangerschapspercentages blijven echter bij oplopend volgnummer een dallende trend vertonen; als percentage per embryotransfer zijn deze verschillen signifikant, als percentage per follikelpunktie niet.

Uit het eigen cijfermateriaal is ook af te leiden wat gemiddeld de uiteindelijke sukseskans bedraagt bij meerdere IVF-behandelingen. Dit is op twee manieren uitgewerkt, namelijk via de berekening van het kumulatief-doorgaandzwangerschapspercentage en via een cohortbenadering.

\section{Kumulatief zwangerschapspercentage}

Bij de berekening van het kumulatief zwangerschapspercentage is gekozen voor de hormoonstimulatie als teleenheid en voor de doorgaande zwangerschap als eindresultaat. Redenen woor deze laatste keuze zijn de volgende:

- bijna iedere doorgaande zwangerschap eindigt in de geboorte van (minstens) een kind, het uiteindelijke doel van de behandeling

- bij de berekening van kumulatieve zwangerschapspercentages mag in theorie ieder paar maximaal eén keer "positief skoren", dat wil zeggen met een zwangerschap voorkomen in de registratie ${ }^{26}$.

Het kumulatief-doorgaand-zwangerschapspercentage geeft hier aan welk percentage van de paren na een bepaald aantal opeenwolgende IVFbehandelingen een doorgaande zwangerschap zal hebben bereikt. Op basis van de resultaten vermeld in tabel B3.17.1 is onderstaande berekening opgesteld. Daarbij zijn voor de $6^{\circ}$ behandeling de resultaten gehanteerd behorend bij de behandelingen met volgnummer $\geq 6$. In de rij "kumulatief $\%$ doorgaand zwanger" is uitgegaan van de gesignaleerde zwangerschapspercentages bij de diverse hormoonstimulatie-volgnummers. Verder is nog het (theoretisch) kumulatief-doorgaand-zwangerschapspercentage weergegeven dat zou gelden als het zwangerschapspercentage voor alle verwolgbehandelingen gelijk zou zijn aan dat van de eerste behandeling, te weten $12,2 \%$.

26) Binnen de onderzoeksperiode is slechts voor ten vrouw twee keer een doorgaande zwangerschap via IVF geregistreerd. 


\begin{tabular}{ll}
\hline Tabel 3.4. & $\begin{array}{l}\text { Kumulatief doorgaand twangerschapspercentage per gestarte IVF- } \\
\text { behandeling }\end{array}$
\end{tabular}

\begin{tabular}{lccccccc} 
Hornoons timulat evolgnummer & 1 & 2 & 3 & 4 & 5 & 6 \\
\hline aantal hormoonstimulaties & 1158 & 845 & 548 & 281 & 138 & 132 \\
\% doorgaand zwanger/hormoon & $12.2 \%$ & $10.5 \%$ & $10.2 \%$ & $7.5 \%$ & $9.4 \%$ & $2.5 \%$ \\
kumulatlef \% doorgaand zwanger & $12.2 \%$ & $21.4 \%$ & $29.5 \%$ & $34.7 \%$ & $40.9 \%$ & $42.3 \%$ \\
theoretisch kum. \% doorg. 2wanger & $12.2 \%$ & $22.9 \%$ & $32.3 \%$ & $40.5 \%$ & $47.8 \%$ & $54.1 \%$
\end{tabular}

Ofwel, onder de veronderstelling dat lieder paar na een IVF-behandeling die niet tot een doorgaande zwangerschap heeft geleid volhardt in de IVF-procedure tot en met de derde behandeling, zal bijna 30\% van de paren een kind krijgen via de IVF-methode; bij yoortzetting tot en met de zesde behandeling loopt dit percentage op tot ruim $40 \%$. De cijfers van tabel 3.4 zijn grafisch weergegeven in figuur 3.2 .

Figuur 3.2. Kumulatief doorgaand zwangerschapspercentage: theorie versus "praktijk"

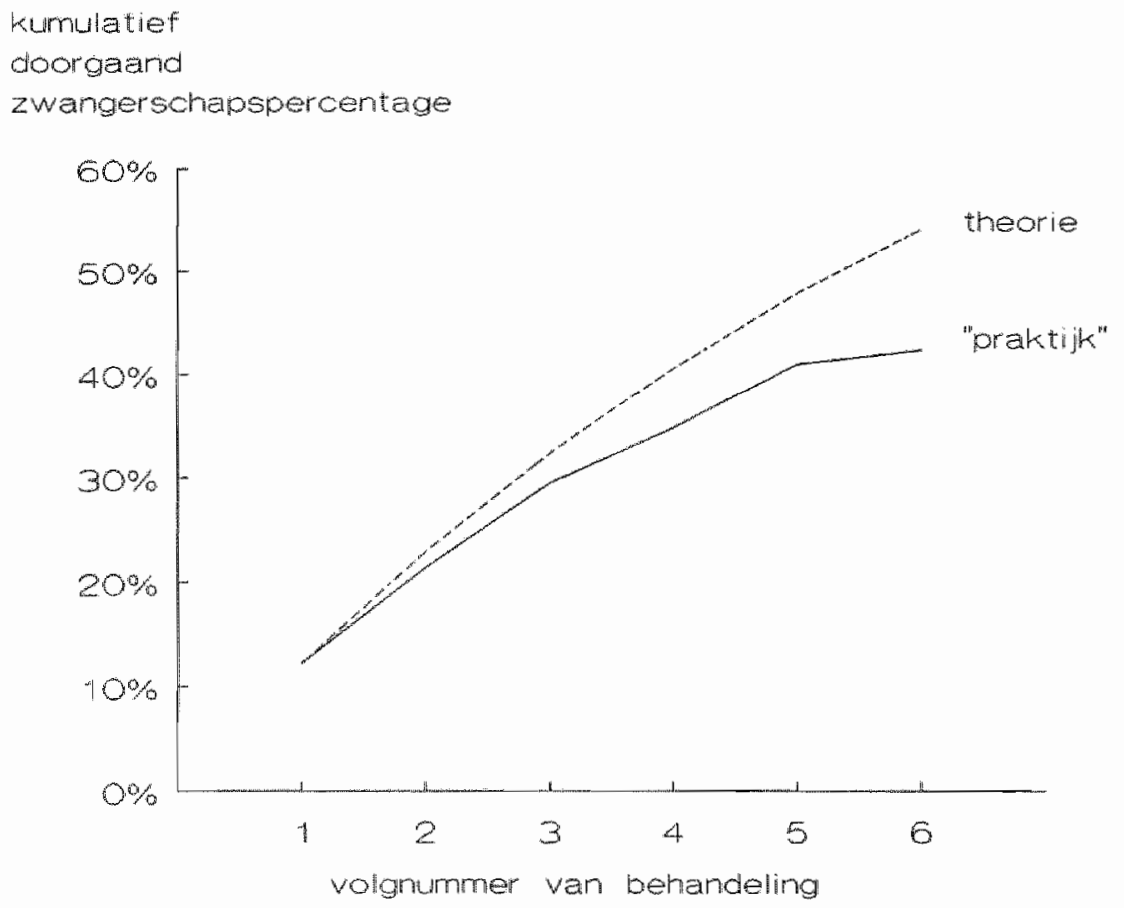


In deze figuur is duidelijk zichtbaar dat het geschatte kumulatieve zwangerschapspercentage in de "praktijk" vooral vanaf de 4 behandeling sterk afwijkt van het theoretisch berekende percentage ${ }^{27}$. Dit is een andere manier om aan te geven dat het zwangerschapspercentage enigszins daalt bij oplopend. volgnummer wan de behandeling.

In de praktijk wordt meestal niet vollaan aan de bovenvermelde veronderstelling die ten grondslag ligt aan de berekening van het kumulatief zwangerschapspercentage. Vele paren zien na eén of meerdere mislukte pogingen af van verdere IVF-behandelingen. De redenen hiervoor kunnen sterk uiteenlopen van een kleine kans op sukses of een ervaren grote psychische belasting tot financiele onhaalbaarheid.

Om zicht te krijgen op de realistische mogelijkheden van een volledige IVFprocedure, eventueel bestaande uit meerdere IVF-behandelingen, is ons inziens een cohortbenadering beter geschikt.

\section{Cohortbenadering}

Als cohort is genomen de patientgroep die in het eerste jaar van het onderzoek (augustus 1986 tot en met juni 1987) minstens 1 gestarte IVF-behandeling heeft. gehad. Dit cohort is vervolgd tot het einde van de onderzoeksperiode, hetgeen impliceert een minimale follow-up-duur van bijna 1 jaar. In tabel 3.5 zijn enkele belangrijke gegevens van deze benadering weergegeven.

\section{Tabel 3.5. Bepaling zwangerschapspercentage door middel van een cohortbenadering}

$\begin{array}{lc}\text { totaal aantal paren } & 852 \\ \text { paren met minstens 1 follikélpunktie } & 800 \\ \text { paren met minstens 1 embryotransfer } & 715 \\ \text { paren met klinische zwangerschap } & 253 \\ \% \text { van totaal aantal paren } & 29.7 \% \\ \text { paren met doorgaande zwangerschap } & 203 \\ \text { \% van totaal aantal paren } & 23.8 \% \\ \text { per paar geniddeld aantal hormoonstinulaties } & 2.51 \\ & 1.97 \\ \text { paren met } 2 \times \text { een klinische zwangerschap } & 1.64 \\ \text { paren met } 2 \times \text { een doorgaande zwangerschap } & 13\end{array}$

27) Dit effekt zou nog verder worden versterkt indien woor de schatting van de kumulatieve percentlages in de praktijk was geabstraheerd van de selektieve doorstroom na de $3^{e}$ behandeling (zie paragraaf 3.4 .5 voor vergelijking wan de prognoses wam "doorstromers" vensus "afvallers"). 
Wa en follow-up-periode van minimaal 1 jaar sinds de eerste behandeling biljkt bljna 25\% van de paren na een of meterdere (gemiddeld 2.5) IVF: behandelingen een doorgaande awangerschap te hebben bereikt via de IVF. methode.

Voor de volledigheid zijn in bijlage 3.20 dezellde gegevens gepresenteerd:

- bij eliminatie van de paren waarbij het nooit tot een follikelpunktie is gekomen

- bij eliminatie van de paren die voorafgaand aan de onderzoeksperiode reeds een IVF-behandeling hadden ondergaan.

Het bowenvermelde percentage van paren met een doorgaande zwangerschap (bijna $25 \%$ ) werd door bovenstaande eliminaties echter nauwelijks beinvloed.

Konkl. - $70 \%$ van de paren in het evaluatie-onderzoek-IVF was voorafgaand aan de onderzoeksperiode niet met behulp van IVF behandeld

- de ontwikkeling van de resultaten bij oplopend volgnummer van de IVFbehandeling is mede afhankelijk van het selektiebeleid ten aanzien van vervolg-IVF-behandelingen

- in het evaluatie-onderzoek-IVF namen de resultaten af bij oplopend volgnummer van de behandeling

- in het onderzoek bedroeg het kumulatief doorgaand zwangerschapspercentage per gestarte behandaling na 3 behandelingen bijna $30 \%$ en na 6 behandelingen ruim $40 \%$; met name bij hogere volgnummers blijwen de gerealiseerde percentages achter bij de te verwachten percentages (op basis van onafhankelijkheid van de sukseskans per behandeling)

- bij een minimale follow-up-duur van 1 jaar is bijna $1 / 4$ van de behandelde vrouwen doorgaand zwanger (gemiddeld aantal behandelingen 2.5 ).

\subsubsection{Beloop van de IVF-behandeling}

De resultaten van de IVF-behandeling zijn in de voorafgarande paragraaf in een aantal fasen weergegeven. De onderstaande analyses zijn toegespitst op deze verschillende stappen. Schematisch ziet het stappenschema er als volgt uit ${ }^{28}$;

28) In principe zal iemand slechts een bepaalde stap kunnen bereiken, indien de woorgaande stappen susksesvol zijn gezet. Uitzonderingen op deze regel zijn echter mogelijk. Bjwoorbeeld, het is mogelijk dat jemand zwanger wordt in de behandelcyclus zonder dat er een follikelpunktie of een embryotransfer is uitgewoeld. In dat geval is de zwangerschap binnen de registratic niet vastgelegd, omdat een dergelijke IVF-behandeling in de registratie als afgestoten is beschouwd. Ook is het mogelijk dat ondanks een abortus of een EUG een (andere) vruch goed doorgroeil en de klinische zwangerschap witeindelijk toch untmondt in de geboorte van een kind. Dat is uiteraard wel meegenomen in de negistratie. 
Figuur 3.3. Stappenschema bij de analyses van beloop tijdens en na de IVP. behandeling"

Hormoonstimuliatie

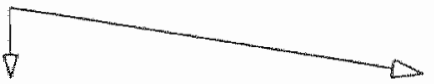

Follikelpunktile Camoellation
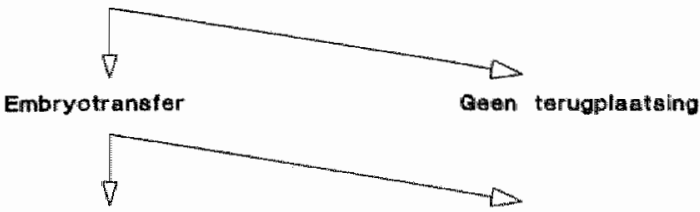

Klinische zwangerschap Gen of pre-klinisohe wangersohap
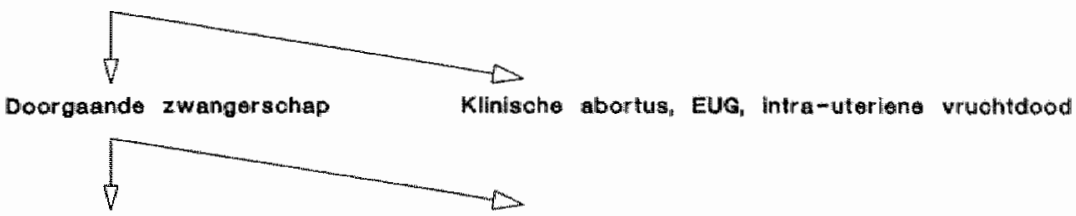

Levendgeboren kind Doodgeboren kind

\subsubsection{Hormoonstimulatie $\rightarrow$ follikelpunktie}

\section{A. Inleiding}

Data Van iedere 5 gestarte IVF-behandelingen is er eén beèindigd voór de follikelpunktie; dit wordt ook wel aangeduid als een cancellation-rate van $20 \%$ (totaal aantal cancellations: 626). De frekwenties van de opgegeven redenen voor vroegtijdige stopzetting van de behandeling zijn weergegeven in bijlage $3.21^{29}$. In de helft van de cancellations was er sprake van afwijkende follikelgroei (sterk uiteenlopend per ziekenhuis, van $1 / 3$ in ziekenhuis 1 tot $9 / 10$ in ziekenhuis 5). Endogene LH-pieken werden (vrijwel) alleen gekonstateerd in ziekenhuis 2 en ziekenhuis 3 (daar in 40\% van de cancellations); in ziekenhuis 5 werd dan ook meestal slechts een LH-bepaling uitgevoerd en in ziekenhuis 4 werd vrijwel nooit meer het LH-nivo bepaald. Derhalve werd voortijdige ovulatie als reden voor cancellation vrijwel alleen in ziekenhuis 4 aangegeven (in ziekemhuis 4 bij $1 / 4$ van de cancellations). Hiermee wordt meteen duidelijk dat een stimulatie die niet optimaal verloopt en om die reden wordt stopgezet, in diverse ziekenhuizen een andere opgave van reden voor cancellation kan krijgen, mede afhankelijk van de uitgevoerde kontroles voor de bepaling van het verloop van de follikulaire fase.

29) Per behandeling konden wee redenen voor cancellation worden aangegeven. 
Gestarte IVF behandelingen die zeer vroegtijdig worden stopgezet kwamen zelden voor, slechts $6 \%$ van de cancellations $(1 \%$ van de gestarte behandelingen) vond pliats voór de $8^{\circ}$ cyclusdag. In de loop van de periode van het evaluatie-onderzoek is dit percentage geleidelijk zelfs gedaald, aangezien men veelal voorafgaand aan de hormoonstimulatie een kontrole-echo introduceerde; indien daarbij cysten werden gesignaleerd was dat veelal reden de stimulatie wit te stellen tot een latere cyclus ${ }^{30}$.

Konkl - van de 100 gestarte IVF-behandelingen zijn er 20 gestaakt vór de follikelpunktie, waarvan 1 vóor de 8 cyclusdag

- de opgegeven redenen voor vroegtijdige beeindiging zijn weinigzeggend.

\section{B. De follikulajre fase medikatie en kontroles.}

\section{Lit. Medikatie}

Hodgen[1986] geeft een beschrijving wan de ontwikkeling van follikels en hormoonproduktie als achtergrond voor de werking van hormoontoedieningen. Tijdens iedere cyclus bereiken uit een cohort van (bijna) synchroon ontwikkelende follikels slechts een of enkele het stadium van pre-ovulatoire Graafse follikel. In de natuurlijke cyclus mondt dit via een selektiemechanisme vrijwel altijd uït in cén dominante follikel en een enkelvoudige ovulatie. Welnu, hormoonstimulatie moet er voor zorgen dat er meerdere dominante follikels redelijk synchroon tot ontwikkeling komen (door middel van $h M G$ in gekombineerde FSH/LH-vorm of in pure FSH-vorm) en dat deze follikels ook tot volledige rijpheid komen voor de ovulatie (door middel van hCG).

Kerin[1986] geeft nadrukkelijk aan dat de respons tijdens de follikulaire fase verschilt nargelang de toegediende medikatie. Bij kontrole van de cyclus dient bij de interpretatie van de respons hiermee rekening te worden gehouden. Vergelijking van de resultaten van diverse medikatieschema's binnen een ziekenhuis dan wel tussen centra is uiterst moeilijk, aangezien diverse andere faktoren een verstorende invloed op het geheel kunnen hebben.

Om enigszins aan dit probleem tegemoet te komen werd in Melbourne, Australid door de IVF-teams van Monash University en van Royal Women"s Hospital een zeer interessante cross-over-trial uitgevoerd met betrekking tot de gehanteerde cc/hMG-protokols in beide ziekenthuizen (Rogers[1986]). In ieder ziekenhuis werden gerandomiseerd 30 patienten volgens het protokol van het andere ziekenhuis gestimuleerd/gekontrolecrd tot de tijdstipbepaling van de follikelpunktie; het restant van de behandeling verliep volgens het eigen protokol. Daarbij trad slechts Eén duidelijk verschil op: de frekwentie van eem endogene LH-piek: $3 \%$ versus $35 \%$. Een hoge frekwentie van endogene LHpieken heeft organisatorische konsekwenties (de noodzaak tot het uitvoeren van

30) Er is binnen de [VF-registratie sprake van een gestarte behandeling indien de eerste stimulatie in de vorm van hMG, FSH of clomifeencitraat is toegediend. Indien nai een kontrole-echo (en eventueel na eerdere toediening van LHRH-analogen) besloten werd niet over te gaan tot de toediening van hMG, FSH of clomifeencitrast dan werd derhalve niet van een gestarte IVF-behandeling gesproken. 
veel LH-bepalingen en veelvuldig, en onvoorspelbaar, een omzetting van het tijdstip van de follikelpunktie naar onregellmatige werkuren). De auteurs geven zelf een mogelijke verklaring voor dit verschil: de lage frekwentie van endogene LH-pieken bij het protokol met een hoge dosering hMG laat in de follikulaire fase kan veroorzaakt worden door een mogelijke stimulans hiervan op de produktie van endogene LH-piek-inhibatoren. De belangrijkste konklusie uit deze studie lijkt evenwel de konstatering, dat beide centra met beide protokollen in totaliteit vergelijkbare resultaten boeken. Tenslotte stellen de auteurs zichzelf nog de (onbeantwoorde) vraag of de opgetreden verschillen nu veroorzaakt zijn door het gehanteerde stimulatieprotokol, door het behandelteam, door het totale behandelprotokol of door een verschillende samenstelling van de populaties? Zolang deze vraag door een gering aantal waarnemingen niet kan worden beantwoord moet de bovenvermelde konklusie met enige voorzichtigheid worden getrokken.

LHRH-analogen worden door IVF-teams steeds meer toegevoegd aan de medikatie ten behoeve van optimalisatie van de follikulaire ontwikkeling. Met behulp van deze analogen kan de ovariële funktie voorafgaand aan een stimulatieprotokol worden onderdrukt, waardoor waarschijnlijk een sterk synchroon-ontwikkelend cohort follikels kan worden bereikt. Mogelijke voordelen van het gebruik van LHRH-analogen bij IVF zijn (onder andere (Andreyko[1987] en Rutherford[1988]):

- een grotere oöcytopbrengst

- betere follikelrijping, met name bij zogenaamde 'poor responders'

- flexibiliteit in de bepaling van de start van de stimulatie

- verlaging van het LH-nivo bij PCO-patienten ${ }^{31}$

- reduktie van het optreden van endogene LH-pieken

- betere zwangerschapsresultaten. ${ }^{\prime}$

In Clamart werd een gerandomiseerde trial uitgevoerd bij "normale responders" (Frydman[1988]). De resultaten werden vergeleken tussen enerzijds 94 stimulaties met relatief langdurig gebruik van LHRH-analoog (Suprefact $300 \mu \mathrm{g} 2 \mathrm{x}$ daags vanaf cyclusdag 2 gedurende gemiddeld 13 dagen en minstens 5 dagen 4 ampullen hMG per dag) en anderzijds 92 stimulaties met kortdurig gebruik van LHRH-analogen, de zogenaamde 'flare-up-methode' (Decapeptyl 0.1mg per dag vanaf cyclusdag 1 en hMG vanaf cyclusdag 3). De fertilisatiegraad lag bij het korte LHRH-protokol hoger (70\% versus $56 \%$ ), maar de awangerschapsresultaten lagen daarentegen iets hoger bij het lange L.HRH-protokol. De totaalresultaten zijn derhalve vergelijkbaar. Daarnaast biedt het korte LHRHprotokol volgens de auteurs nog het voordeel dat hierbij zowel minder $L H R H_{\text {, }}$ als minder hMG (20 ampullen versus 32 ) nodig is.

Bij (niet-gerandomiseerde) vergelijking wan de zwangerschapsresultaten in Clamart tussen behandelingen met gebruik van LHRH-analogen (korte en lange protokol samen) en behandelingen zonder gebruik van LHRH-analogen (al dan niet geprogrammeerde IVF-behandelingen) blijkt dat de zwangerschapsresultaten signifikant veel beter zijn in de groep met gebruik van LHRH-analogen: het 
doorgaand zwangerschapspercentage per gestarte behandeling bedraagt $18.3 \%$ versus $8.4 \%$. Hoewel de wergelijkbaarheid van de stimulatieschema's niet alleen wordt aangetast door een mogelijk verschil in de samenstelling wan de patiantenpopulatie maair ook door een tijdsverschil, is het werschil in resultaten indrukwekkend.

Aan het bezwaar yan een mogelijke invloed van tijdsfaktoren werd door Rutherford[1988] tegemoet gekomen. Deze vergeleek (observationeel) de behandelresultaten van IVF in een bepaalde periode tussen $328 \mathrm{cc} / \mathrm{hMG}$ stimulaties en 83 stimulaties met langdurig gebruik van LHRH-analogen (Busereline, nasaal) met $\mathrm{hMG}$. De patienten in de tweede groep leken een slechtere prognose te hebben, met name door het relatief vaak voorkomen van PCO. Toch werden over de gehele lijn ${ }^{32}$ signifikant betere resultaten geboekt bij gebruik wan de LHRH-analogen, resulterend in een klinische zwangerschapspercentage per gestarte cyclus van $36 \%$ versus $15 \%$.

Het belang van de toediening van hCG is in de literatuur veelvuldig aan de orde gesteld. Zo werd bijyoorbeeld aangetoond dat na toediening van slechts $2000 \mathrm{IE}$ hCG relatief vaker geen obcyten werden verkregen dan bij hogere dosering ( 5000 of 10000 IE) (Abdalla[1987]). Ook zijn meerdere studies uitgewoerd naar de planning voor het optimale moment van toediening van hCG. Laufer[1984] keek hierbi] naar het interval tussen hMG en hCG: uitstel van $h C G$-toediening tot 48 a 72 wur na de laatste $h M G$ ging gepaard met een significant lagere fertilisatiegraad ten opzichte van het interval hMG-hCG van 24 wur (57\% versus $84 \%$ ). Ben-Rafael[1987] vond daarentegen een signifikant verschil in de andere richting met betrekking tot de zwangerschapspercentages (bij 2 hMG per $\mathrm{dag}^{33}$ ) tussen groepen met een interval hMG-hCG van 24 uur $(15 \% ; \mathrm{n}=34)$ versus 48 uur $(35 \% ; \mathrm{n}=23)$.

Zowel Levran[1985] als Quigley[1985] geven aan dat de timing van de HCG erg belangrijk is. Volgens hen dient dit te gebeuren aan de hand van de oestrogeenontwikkeling. De beste resultaten worden bij beiden gevonden indien de hCG gegeven wordt op de $6^{\circ} \mathrm{dag}$ van de oestradiol-stijging. Hoewel de konklusic identiek is, zijn in de studies verschillende definities gehanteerd woor:

- wat is het baseline-nivo: het laagste nivo voor de kontinue stijging dan wel het gemiddelde van cyclusdag 3 en 4

- vanaf wanneer is er sprake van stijging: bij de eerste stijging dan wel als het oestradiol-nivo $150 \%$ van het baseline-niwo bedraagt.

Casper[1987] gaat nog een stap verder en beweert dat de timing van de $\mathrm{HCG}$ geindividualiseerd dient te gebeuren met behulp van de parameter serum- $E_{2}$ per follikel groter dan $10 \mathrm{~mm}^{3 / 4}$. Ook volgens Wikland[1984] zijn de echoscopische en endocrinologische bevindingen beide nodig voor een juiste planning van de

32) Bij gebruik van LHRH-analogen was sprake van signifikant betere resultaten met betrekking tot onder andere de cancellation-rate, het astal verkregen obcyten en het aantal verkregen embryo's.

33) Bij 3 hMG per dag werd geen werschil tussen beide groepen gesignaleerd.
34) De HCO dient te worden toegediend als deze ratio groter is dan 1100 pmoln. De follikels werden geneten op cyclusdag 12 of 13 . 
hCG-toediening, gezien de slechto korrelatie tussen beide vormen van informatie. Op dit laatste wordt hieronder nader ingegaan.

\section{Kontroles}

Hoewel in de natuurlijke cyclus een grote korrelatie bestaat tussen de groei van de follikulaire diameter en de stijging van de oestrogenen, lijkt dat niet te gelden woor gestimuleerde cycli (Wikland[1984]).

De follikulaire groei is uiterlijk zichtbaar via de echoscopisch gemeten follikelgrootte, terwijl de funktionele komponent, de hormoonsecreties, gemeten kan worden via hormoonbepalingen.

Kerin[1986] geeft aan dat bij gestimuleerde cycli het cohort van dominante follikels asynchroon is in zowel omvang als funktionele maturatie en dat iedere follikel op ieder moment verschillende hoeveetheden oestradiol bijdraggt aan het perifere bloed. Bovendien varièren zogenaamde "zwangerschaps-kapabele" follikels in diameter van 14 tot $30 \mathrm{~mm}$. Als vuistregel wordt derhalve aangegeven om hCG toe te dienen bij follikels van 16 a $20 \mathrm{~mm}$ bij een goede oestradiol-respons (circa $1.5 \mathrm{nM}$ per follikel $>18 \mathrm{~mm}$ ).

Nader[1987] probeerde na te gaan wanneer er sprake is van synchrone dan wel asynchrone follikulaire groei. Hij makte hiertoe een indeling van het $E_{2}$ patroon tot en met de hCG-injektie in ${ }^{35}$ :

- een zogenaamd 'plateau'-patroon $(n=16)$, waarbij $\mathbb{E}_{2}$ degressief' stijgt; zijn hypothese luidde dat hier sprake was van synchrone follikulaire groel.

- een zogenaamd 'leap"-patroon $(n=26)$, waarbij $E_{2}$ progressief stijgt; hier was volgens zijn hypothese sprake van asynchrone follikulaire groei.

De fertilisatiegraad ${ }^{36}$ per oöcyt was identiek $(78 \%(39 / 50)$ versus $74 \%(73 / 99))$, maar de delingsgraad ${ }^{37}$ lag signifikant hoger voor de behandelingen met een 'plateau'-patroon $(72 \%(36 / 50)$ versus $50 \%(49 / 99))$. Naar de mening van. Nader werd hierdoor zijn hypothese bevestigd dat de aard van de follikulaire groei valt af te leiden uit het vertoonde $\mathrm{E}_{2}$-patroon.

Er is veelvuldig onderzoek gedaran naar de relatie tussen echoscopische en endocrinologische metingen. Zo vond Hull[1986] op de dag van de HCGtoediening ${ }^{38}$ geen korrelatie tussen enerzijds het serum- $\vec{E}_{2}$-nivo en anderzijds:

- de diameter van de grootste follikel. De methode van onderzoek was transversaal; bij vergelijkingen van de echometingen en de serum- $\mathrm{E}_{2}$. bepalingen op individueel behandelnivo hebben diverse onderzoeken wel een lineair verband gevonden tussen het serum- $\mathrm{E}_{2}$-nivo en de diameter van de grootste follikel. Als mogelijke verklaring voor deze tegenstelling zou wolgens Hull de volgende redenering kunnen gelden: bij cen spontane cyclus produceert de dominante follikel ruim $90 \%$ van de $\mathrm{E}_{2}$, maar in gestimuleerde cycli produren diverse follikels $E_{2 *}$ Deze redenering bleek echter niet afdoende, want hij vond ook geen korrelatie tussen het serum- $E_{2}$-nivo en:

Behandelingen bij paren met als (mede-)indikatie mannelijke subfertiliteil en behandelingen met een endogene LHopiek werden van de studie uitgestoten.

36) Gedefinieerd alls het berciken van het stadium met 2 afzonderlijke pronuclei.

37) Gedefinieerd alls het bereiken van het stadium met minstens 2 blastomeren na fertilisatic.

38) Het onderzoek werd uitgevoerd bij 38 eycli gestimuleerd met hMG/hCG. 
- het antal follikels

- de gemiddelde diameter van alle follikels.

Indien alleen rekening wordt gehouden met de echoscopische waarnemingen, vindt Wood [1985a] geen signifikant verschil in zwangerschapspercentage per gestarte cyellus naar maximale follikeldiameter of aantal follikels groter dan 15 $\mathrm{mm}_{3}$ zoals bepaald tijdens de meest recente echo ${ }^{39}$. Leerentveld[1987] komt tot soortgelijke bevindingen.

Indien alleen rekening wordt gehouden met de oestrogeen-bepalingen meldt Wood[1985a] eveneens geen signifikant verschil in zwangerschapspercentage per gestarte cyclus naar het stijgingspercentage van $\mathrm{E}_{3}$, het maximale nivo van $\mathrm{E}_{2}$. Ook was er geen verschil bij differentiatie naar het maximale $\mathbb{E}_{2}$-nivo per mature oogyt en het interval in dagen tussen het maximale $E_{2}$-nivo en de follikelpunktie.

Laufer[1986] ging na of er verschillen in het verloop van de IVF-behandeling bestonden naargelang het serum- $E_{2}$-patroon ná de HCG-toediening ${ }^{40}$. Hij vond geen werschil in de fertilisatiegraad, in de delingsgraad en in het progesteronniwo in de luteale fase bij een indeling van de behandelingen op basis van de kriteria ' $E_{2}$ gestegen op dag na $\mathrm{HCG}$-injektie?" en ' $E_{2}>500 \mathrm{pg} / \mathrm{ml}$ op dag HCG? ${ }^{* 41}$.

Naderhand meldt Navot[1987] uit dezelfde onderzoeksgroep dat behandelingen bij anovulatoire patienten met $E_{2}$ op de dag van de hCG $>500 \mathrm{pg} / \mathrm{ml}$ en $E_{2}$ gestegen op de dag ná de HCG signifikant hogere zwangerschapsresultaten hadden opgeleverd dan behandelingen met een ander patroon (12/22 t.o.v. 5/30). Eveneens vanuit dezelfde groep geeft Pellicer[1987] aan dat de zogenaamde "low-responders" cen relatief kleine kans hebben om in een volgende cyclus een normale respons en een follikelpunktie te bereiken (ook bij toevoeging van cc aan de hMG): $32 \%$ (=26/82); dat geldt in mindere mate voor een deelgroep van deze 'low-responders', namelijk de groep waarbij een kontinue langzame stijging van $\mathrm{E}_{2}$ optreedt.

In Clamart werd de grems voor 'high' versus 'low' responders met betrekking tot het serum- $\mathrm{E}_{2}$-nivo op het moment van $\mathrm{HCG}$-toediening gelegd bij $1000 \mathrm{pg} / \mathrm{ml}$ (Frydman[1986b]). Men vindt op basis van kleine aantallen (35 follikelpunkties) grote verschillen in zwangerschapspercentages. Een hoog $E_{2}$-nivo laat in de follkulaire fase lijkt bovendien samen te hangen met een betere kwaliteit van de luteale fase in termen wan progesteron-produktie en zwangerschapspercentage per embryotransfer (Jones[1983a]). Op basis hiervan wordt gekonkludeerd

39) Overigens is de meest recente echo in deze studie niet noodzakelijkerwijs 2 of 3 dagen vór de follikelpunktie ultgewoert, hetgeen de resultaten wan de analyses kan hebben beinvloed.

40) Hek onderzoek werd uitgevoend bij 144 tubaire patienten voor IVF die gestimuleerd werden met $\mathrm{MMC}$ en hCO.

41) Wel kwam tij tot de - ons inziens nogal tendentieuze - konkusic, dat behandelingen met een laag $\mathbb{E}_{2}$-nivo op de dag van de hCG en een daling de dag ema niet tot een follikelpunktie moeten leiden. Dit was gebaseend op het feit, dat 14 follikelpunkties met een dergelijk $\mathrm{E}_{2}$-patroon niet tot een zwangerschap hadden geleid.

42) Als kriterium geldt een maximum $E_{2}$-nivo $<300$ pgrml; dit geldt voor 51 patiënten in Ge studie. 
dat als de invloed van de oestrogenen inderdaad voornamelijk wordt uitgeoefend op de uteriene receptiviteit en minder op de odcytkwaliteit, in een geprogrammeerd IVF-programma te overwegen is om bij "low-Iesponders" de embryo's in een volgende cyelus terug te plaatsen (dus na cryopreservatio). Later onderzocht dezelfde onderzoeksgroep (Forman[1988]) de resultaten op basis van een indelling van het serum- $\mathrm{E}_{2}$-nivo op hat moment van $\mathrm{hCG}$. toediening in decielen. Alleen in het hoogste deciel werd een signifikant lager zwangerschapspercentage gekonstateerd ${ }^{43}$. Daarnaast werd er een signifikant positieve korrelatie gevonden tussen enerzijds het pre-ovulatoire nivo van $E_{2}$ en anderzijds het nivo van zowel $E_{2}$ als van progesteron in de luteale fase, maar niet met de ratio $E_{2} /$ progesteron in de vroeg-luteale fase.

Ook in Norfolk (v.Uem[1986]) werd nitgebreid aandacht besteed aan de resultaten van de IVF-behandeling bij verschillende $\mathrm{E}_{\mathrm{z}}$-patronen (gedefinieerd aan de hand van $E_{2}$-verloop tijdens de hMG-stimulatie, tijdens het interval hMG-hCG en ná de hCG-toediening). De indeling in $E_{2}$-patronen ${ }^{\text {t4 }}$ was als volgt:

- A-patroon: $\quad E_{2}$ stijgt tijdens $\mathrm{hMG}$-stimulatie, in interval $\mathrm{hMG} / \mathrm{HCG}$ en ná HCG-toediening

- B-patroon: $\quad E_{2}$ stijgt tijdens $h M G$-stimulatie daalt in interval hMG$\mathrm{HCG}$ en stijgt weer na $\mathrm{HCG}$

- G-patroon: $\mathrm{E}_{2}$ stijgt tijdens hMG-stimulatie en in interval hMG-HCG, maar daalt na $\mathrm{HCG}$-toediening.

De zwangerschapsresultaten bij deze $\mathrm{E}_{2}$-patronen waren duidelijk verschillend, waarbij een kontinue stijging van de oestradiolen samenhing met betere resultaten.

Tabel 3.6. Behandelresultaten gedifferentieerd naar $\mathbf{E}_{2}$-patroon

$\begin{array}{lll}\text { aantal follikel- } & \% \mathrm{klini} \text { sche zwanger } & \text { doorgaand zwanger } \\ \text { punkties } & \text { per punktie } & \text { per punktie }\end{array}$

\begin{tabular}{lllr}
\hline A-patroon & 503 & $23 \%$ & $16 \%$ \\
Q-patroon & 138 & $17 \%$ & $11 \%$ \\
G-patroon & 147 & $14 \%$ & $9 \%$
\end{tabular}

Leerentveld[1988] vond evenwel bij dezelfde indeling van $\mathrm{E}_{2}$-patronen geen signifikante verschillen in de klinische zwangerschapspercentages per follikelpunktie $(n=322)$.

43) De - ons inziens tendentieuze - tittel wan het artikel luidde op basis hiervan: "Evidence of an adverge effect of elewated serum estradiol concentrations on embryo implantation".

44) Het oestradiol-niwo werd dagelijks bepaald ot de dag van de follikelpunktie. Een eerdere publikatie wan deze studie (Jones[1983a]) had betreklking op veel minder $(\mathrm{n}=175)$ warneningen. 
Mettler[1987] vond met behulp van een case-control-studie eveneens geen enkel duidelijk verband tussen al of niet bereikte zwangerschappen (na een embryotransfer) en gegevens over de $\mathbb{E}_{2}$. De individuele verschillen binnen de groepen zwangeren $(\mathrm{n}=42)$ en niet-zwangeren $(\mathrm{n}=45)$ waren té groot om duidelijke verschillen tússen de groepen te detekteren. De gegevens van de $\mathrm{E}_{2}$ werden door haar op allerlet manieren in de analyses opgenomen:

- het maximum nivo van $\mathrm{E}_{2}$

- de dag waarop de $E_{2}$ maximaal is (ten opzichte van de dag van de follikelpunktie)

- de ontwikkeling van $\mathrm{E}_{\mathfrak{2}}$ op diverse manieren bepaald (onder andere via dagelijkse ontwikketing en via ontwikkeling ten opzichte van de base-line)

- de $E_{2}$ per follikel

- mate van endocriene respons, gemeten via een zelf opgesteld schema.

Zelfs in de luteale fase was de spreiding binnen de groepen zwangeren en nietzwangeren in progesteron, $E_{2}$ en $B-h C G$ zo groot dat pas vanaf luteale-fasedag 12 a 14 sprake was van signifikante verschillen tússen de groepen.

De diskussie omtrent de vraag welke kontroles tijdens de follikulaire fase nu wel of niet nodig zijn om goede keuzes te kunnen maken tijdens de behandeling, werd nadrukkelijk aangewakkerd door de introduktie van de zogenaamde 'programmed-IVF'. In Clamart werden in de periode september 1985 -december 1985 een 35-tal IVF-behandelingen anders dan anders uitgevoerd (Frydman[1986b]):

- de datum van de follikelpunktie werd reeds lang vooruit gepland (punktie op cyclusdag 13 om circa 9 uur 's morgens)

- de cyclus voorafgaand aan de behandeling werd gedereguleerd met behulp van een anticonceptiepil

- de stimulatie vond plaats volgens een vaststaand schema (o.a. HCG op cyclusdag 11 om 23 uur)

- er werden geen kontroles (echo, oestrogenen, LH) uitgevoerd; wel werd direkt voorafgaand aan de eventuele follikelpunktie gekontroleerd of er geen voortijdige ovulatie was geweest.

Uit deze 35 gestarte behandelingen resulteerden 7 klinische zwangerschappen (20\% per cyclus). De voordelen van de geprogrammeerde methode van IVFbehandeling zijn:

- geen noodzaak tot diverse ziekenhuisbezoeken (over soms grote afstand)

- geen noodzaak tot endocrinologische bepalingen

- mogelijkheid tot goede planning voor patient en ziekenhuis (onder andere minder weekendwerk ${ }^{45}$ ).

Later werd uitgebreider cijfermateriaal van Clamart gepubliceerd (Rainhorn[1987]: 296 geprogrammeerde IVF-behandelingen versus 356 gekontroleerde IVF-behandelingen (niet-gerandomiseerd, wel vergelijkbare populaties). In het laatste gedeelte van die studie werd bij de geprogrammeerde

45) Patton[1988] gaf aan dat met behulp van orale contraceptiva de IVF-behandelingen van patiènten redelijk gepland kunnen worden. Maar hoewel de folikel punkties hierdoor voornamelijk plaatsvonden op maandag tot en met wrijdag, moest met name het laboratorium-personeel toch veel werk in het weekend blijven verrichten. 
IVF-behandelingen toch 1 serum- $E_{2}$-bepaling gedaan, eventueel resulterend in uitstel van de HCG-toediening. Toch vond ook in die periode bij $88 \%$ van de geprogrammeerde IVF-behandelingen de follikelpunktie op het vooraf geplande tijdstip plaats. Ondanks het feit dat bij de geprogrammeerde IVF-behandelingen veelal maximaal 2 embryo's werden teruggeplaatst in de behandelcyclus in verband met de mogelijkheid van cryopreservatie, waren de resultaten in beide groepen volledig vergelijkbaar: het klinisch wwangerschapspercentage per embryotransfer bedroeg $19 \%$, het doorgaand zwangerschapspercentage per follikelpunktie $10 \%$.

Data Onderstaand komt eerst de mogelijke invloed van het gehanteerde medikatieschema en van het interval hMG/FSH - hCG aan de orde; daarna wordt aandacht besteed aan de endocrinologische en echoscopische kontroles.

\section{Medikatie}

In bijlage 3.22 zijn voor de diverse ziekenhuizen de resultaten weergegeven bij verschillende gehanteerde medikatieschema's. Hoewell uiteraard diwerse andere variabelen een verstorende invloed op dit beeld kunnen hebben, lijkt de voorzichtige konklusie gerechtvaardigd dat er niet zoiets bestaat als hét juiste medikatieschema. De resultaten van de schema's lijken sterk bepaald te worden door het gebruik in de specifieke ziekenhuizen (en eventueel bij specifieke patiènten). Well lijkt de rol van het pure FSH als medikatie uitgespeeld, mede door de recente introduktie van het gebruik van LHRH-analogen. Bij gebruik van $\mathrm{LHRH}$-analogen valt voor cellen met een redelijk aantal waarnemingen (minstens 80 stimulaties) het volgende op:

- in ziekenhuis 2 is de cancellation-rate bij LHRH-gebruik signifikant verlaagd (geen LHRH: 32\%, kortdurend'LHRH: 15\%, langdurend LHRH 23\%); ook worden in ziekenhuis 2 bij kortdurige toediening van LHRH-analogen signifikant hogere doorgaande zwangerschappen per gestarte behandeling bereikt $(15.6 \%$ versus $7.3 \%)$

- in ziekenhuis 5 geldt juist een verhoogde cancellation-rate bij LHRH-gebruik (geen LHRH: 16\%, kortdurend LHRH: 27\%).

De verklaring voor deze tegenstelling tussen ziekenhuis 2 en ziekenhuis 5 is waarschijnlijk gelegen in het feit dat in ziekenhuis 2 LHRH grotendeels bij cen ongeselekteerde groep patienten is toegediend, terwijl in ziekenhuis 5 LHRH werd gebruikt op indikatie (vooral op basis van slecht verlopen follikulaire ontwikkeling bij een eerdere IVF-behandeling).

Daarnaast is gekeken naar de mogelijke invloed van het interval tussen $\mathbf{h M G / F S H}$ en hCG. De resultaten van deze analyses zijn per ziekenhuis opgenomen in bijlage 3.23. In ziekenhuis 2 en ziekenhuis 5 bedraagt het interval vrijwel altijd 28-32 uren, terwijl ziekenhuis 1 en ziekenhuis 3 bij een dergelijk interval juist signifikant slechtere resultaten laten zien. ziekenhuis 3 scoort betere resultaten bij een relatief kort interval ${ }^{\text {to }}$ (korter dan 28 uren),

46) De relatief minder goede resultatem wan ziekenhuis 3 bij het interval 28.32 uren houden waarschijnlijk sterk verband met andere onderliggende oorzaken, mede gezien de sterke konsentratie van deze behandelingen in een bepaalde tijdsperiodie (de tweeda helft van de onderzoeksperiode). 
zilekenhuis 1 daarentegen juist bij relatief lange intervallen (33-38 uren en 52 60 uren). Tenslotte bedraagt in ziekenhwis 4 het interval bijna altijd 33-38 uren. Een konklusie uit het bowenstaande is moeilijk te trekken. Waarschijnlijk heeft het medikatieschema cen belangrijke invloed op het "ideale" interval. De term ideaal is herbi] tussen aanhalingsiekens geplaatsi, omdat het interval hMG/FSH - hCG in het algemeen waarschijnlijk een redelijk ruime werkbare range heef.

\section{Kontroles}

Aangezien de data wan de gecancelde cycli veelal ontoereikend waren voor de uit te voeren analyses, is alleen gekeken naar behandelingen die geleid hebben tot een follikelpunktie. In de analyses is aandacht besteed aan enerzijds het nivo van de oestrogenen op de dag wan de hCG-toediening en de ontwikkeling de dag erna en anderzijus aan de samenhang tussen de endocrinologische en de echoscopische metingen.

\section{Oestrogenen: nivo op dag $\mathrm{HCG}^{47}$ en procentuele werandering op dag na $\mathrm{HCG}$ t.0,y. dag HCG}

Het nivo van de oestrogenen op de dag van de hCG-toediening werd, in navolging wan Clamart, in decielen verdeeld om te kijken of er een samenhang, met de zwangerschapsresultaten bestaat. Aangezien de ziekenhuizen verschillende methoden hanteerden om de oestrogenen te bepalen, zijn deze analyses per ziekentuis uitgevoerd. Het doorgaand zwangerschapspercentage per follikelpunktie lag in ieder ziekenhuis voor de behandelingen behorend bij de onderste 4 decielen ruim onder dat van de overige behandelingen (zie bijlage 3.24 ). Voor het $1^{\text {t }}$ deciel gold dit nog in versterkte mate (met uitzondering van ziekenhuis 1). In ziekenhuis 4 en ziekenhuis 5 lag dit percentage voor het $10^{\mathrm{e}}$ deciel duidelijk onder dat van de decielen ' 5 tot en met 9'; in ziekenhuis 1, ziekenhuis 2 en ziekenhuis 3 was dit niet het geval. Een mogelijke reden voor deze laatste uiteenlopende bevinding is dat de serum- $\mathrm{E}_{2}$-metingen in ziekenhuis 4 en ziekenhuis 5 sneller een verandering in oestrogeen-nivo waarnemen dan oestrogeenbepalingen in de urine in de andere ziekenhuizen.

Ten behoeve van de analyses naar de mogelijke invloed van de verandering in oestrogenen op de dag na de HCG ten opzichte van de dag van de HCGtoediening, zijn de behandelingen in drie groepen verdeeld:

- daling; hiermee wordt bedoeld een procentuele daling van minstens $10 \%$

- plateau; de procentuele wijziging is kleiner dan $10 \%$

- stijging; er is sprake van een procentuele stijging van minstens $10 \%$.

In bijlage 3:24 staan voor de verschillende bovengenoemde kategorieën de percentages doorgaande zwangerschappen per follikelpunktie vermeld. De benodigde gegevens voor deze analyses waren overigens slechts voor bijna de

47) Als de HCG is toegediend net na middernacht (op de uren 00, 01, 02 of 03), dan is ten behoeve van onderstaande analyses de dag van de HCG-toediening zogezegd 1 dag vervroegd. 
helft van de follikelpunkties beikend ${ }^{45}$. Dit kan de basis zijn geweest woor een selektie; achterliggende gedachte is dan dat de oestrogeenbepalingen alleen worden woortgezet indien de woorafgaande ontwikkelingen onduidelijk of wisselvallig zijn geweest. De onderstaande analyses zijn uitgevoerd voor de groep behandelingen waarvoor wel metingen zijn vastgelegd tot en met de dag na de hCG. Of deze analyses geldigheid hebben voor de totale populatie is onzeker.

Het percentage doorgaande zwangerschappen per follikelpunktie lag voor alle behandelingen in het onderzoek tezamen op $13.1 \%$. Voor de verschillende katagorieèn bedroegen deze percentages:

- $9.0 \%$ voor de behandelingen met een dalend patroon $(\mathrm{n}=100)$

- 13.5\% voor de behandelingen met een plateau-patroon $(n=207)$

- $12.8 \%$ voor de behandelingen met een stijgend patroon $(n=843$ )

- $13.5 \%$ voor de behandeling met ontbrekende data $(n=1316)$.

Alleen de resultaten voor behandelingen met een dalend oestrogenen-patroon lagen signifikant lager.

\section{Korrelatie tussen follikelmetingen en oestrogeenbepalingen}

De korrelaties tussen enerzijds de oestrogeenbepalingen en anderzijds de echoscopische follikelmetingen zijn per ziekenhuis voor verschillende dagen bekeken. De resultaten van deze analyses zijn uitgebreid weergegeven in bijlage 3.25. De globale konklusies van deze analyses luiden als volgt:

- er werd vrijwel nergens een signifikant verband gevonden tussen de waargenomen oestrogeen-waarden en de meting van de grootste follikel ${ }^{49}$

- er was vrijwel overal sprake van epen sterk positief verband tussen de gemeten oestrogeen-waarden en het gesignaleerde aantal follikels $\geq 10 \mathrm{~mm}$; dit gold per ziekenhuis zowel voor alle behandelingen tezamen als voor de uitsplitsing naar het aantal verkregen oöcyten door middel van de follikelpunktie.

Konkl. - ervaring met een bepaald medikatieschema (met bijbehorende follikulaire ontwikkeling) lijkt belangrijker dan de keuze van het medikatieschema zelf

- mogelijk leidt gebruik van LHRH-analogen in de toekomst tot betere IVFresultaten over de gehele linie

- een relatief lage oestrogeen-waarde op de dag van de HCG leidt tot lagere doorgaande zwangerschapspercentages; een relatief erg hoge oestrogeenwaarde lijkt eveneens geen gunstige invloed te hebben op het resultaat van de behandeling

- een daling van de oestrogenen na HCG-toediening gaat gepaard met lagere resultaten

- er bestaat een duidelijke samenhang tussen het oestrogeen-nivo en het aantal follikels $\geq 10 \mathrm{~mm}$

48) In ziekenhuis 3 waren van een redelijk gedeelte wan de behandelingen met follikelpunktie de benodigde gegevens bekend; dat geldt in mindere mate in ziekenhuils 4 , zickenhuis 1 en ziekenhuis 5 , terwijl in ziekerthuis 2 slechts zelden de oestrogeen-metingen op beide dagen waren geregistreerd.

49) Alleen in ziekemhuis 3 was deze korrelatie zowel 3 als 2 dagen voor de follikelpunkile signifikant. 


\section{Komplikaties ten gevolge van hyperstimulatie en follikelpunktie}

Lit. Toediening van hoge doses medicijnen om de groei van hormonen te stimuIeren (zogenaamde hyperstimulatie) kan ondanks veelal nauwkeurige echoscopische en endocrinologische kontroles (McCardle[1983], Haning[1983], Blankstein[1987]) leiden tot komplikaties in verschillende gradaties. Met de opkomst van de LHRH-analogen wordt de frekwentie en ernst van deze komplikaties mogelijk nog verhoogd (Forman[1989], Golan[1989], Ezratty [1989]). Maar de terminologie met betrekking tot deze komplikaties is geenszins eenduidig. Bijvoorbeeld, de term ovarium hyperstimulatie syndroom onvat een breed spektrum van asymptomatische patienten met abnormale laboratoriumwaarden tot levensbedreigende komplikaties (onder anderen Borenstein[1989]). Tijdens echoscopische follikelpunkties kunnen komplikaties ontstaan zoals beschadiging van de bloedvaten en infekties.

Evers[1989] makkt melding van opname van 4 patienten (varierend van 12 tot 24 uur) op een totaal van 697 gestarte behandelingen c.q. 500 follikelpunkties $(0.6 \% \mathrm{c.q} .0 .8 \%)$. Redenen voor opname waren persisterende buikklachten en/of vagale collaps, telkens zonder aanwijzingen voor infekties. In hetzelfde artikel wordt aangedrongen op algemene openheid over ernstige komplikaties, aangezien zeer ernstige komplikaties - zelfs maternale mortaliteit - blijkbaar wel optreden, maar nog niet gepubliceerd zijn. Howe[1988] geeft aan dat patiënten met pelvis-infekties of adhaesies in de anamnese mogelijk een verhoogd risiko lopen op infekties bij echoscopische transvaginale follikelpunkties. Hij maakt tevens plausibel dat profilactische antibiotica dit risiko zouden kunnen reduceren.

Data In het eigen databestand zijn de komplikaties ten gevolge van hyperstimulatie en follikelpunktie helaas niet eenduidig vastgelegd, mede ten gevolge van bovenvermelde definitie-problemen.

Konkl. - de incidentie van ernstige komplikaties ten gevolge van hyperstimulatie en follikelpunktie lijkt vooralsnog gering; maar de - iatrogene - soms zeer ernstige aandoeningen dwingen tot zeer grote oplettendheid

- de bovenvermelde komplikaties dienen voor de toekomst zo goed mogelijk te worden gedefinieerd en nauwkeurig te worden geregistreerd.

\subsubsection{2, Follikelpunktie $\rightarrow$ Embryotransfer}

Van de 2466 punkties leidden er 377 (15\%) niet tot een embryotransfer: $40 \mathrm{x}$ werden er geen oöcyten verkregen, $2 \mathrm{x}$ werd er geen sperma verkregen, $2 \mathrm{x}$ was het sperma geinfekteerd, $1 x$ werden er sperma-antistoffen gesignaleerd, $1 x$ werd de embryotransfer afgezegd in verband met uterien bloedverlies na de follikelpunktie. Bij de 331 andere follikelpunkties leidde de inseminatie van de obcyt(en) met spermatozoa niet tot terug te plaatsen embryo's (bij 82 follikelpunkties werden geen goede oöcyten verkregen; daarnaast werd er in de groep zonder terug te plaatsen embryo's verhoudingsgewijs vaker minder goed sperma gesignaleerd, was relatief vaker de indikatie mannelijke subfertiliteit gesteld en werden signifikant minder oöcyten verkregen per follikelpunktie (4.30 \pm 3.4 versus $6.7 \pm 4.4, \mathrm{p}<0.001$ ). 


\section{A Wijze van follikelpunktie}

Lir. De eerste meldingen in de literatuur over transwesicalle echoscopische follikelpunkties zijn wan Lenz [1981,1982]. Daarna volgden al snel de ontwikkeling van de transabdominale en de transvaginale echoscopische follikelpunkties. De lichamelijke belasting van de echoscopische follikelpunkties is zonder twijfel veel geringer dan die van de laparoscopische. Maar aanvankelijk leek het erop dat met behulp van de echoscopische follikelpunkties ten gevolge van een lagere oocytopbrengst minder goede zwangerschapsresultaten werden bereikt. Lewin[1985] meldde echter bij een gerandomiseerde vergelijking tussen laparoscopische versus echoscopische follikelpunkties $(n=20)$ nawwelijks verschillen in oobytopbrengst en fertilisatiegraad. Later rapporteerde hij over een gerandomiseerde studie (iedere groep $n=60$ ) weliswaar een hogere oöcytopbrengst en derhalve ook meer teruggeplaatste embryo's bij laparoscopische follikelpunkties versus transvesicale echoscopische punkties, maar het percentage klinische zwangerschappen was identiek in beide groepen (Lewin[1986]). Als een van de voordelen van echoscopische follikelpunkties is in de literatuur ook vermeld het vermijden van blootstelling van oodcyten aan $100 \% \mathrm{CO}_{2} /$ algehele anesthesie. Boyers[1987] onderzocht in dit kader bij laparoscopische follikelpunkties $(n=305)$ het verschil in fertilisatiegraad tussen eerste en laatste oöcyt. Bij een tijdsinterval tussen eerste en laatste oöcyt van meer dan 5 minuten werd (bij gelijke maturiteit van de oöcyten) een duidelijk verschil in fertilisatiegraad gevonden tussen de eerste en de laatste oöcyt (69\% respektievelijk $56 \%$ ); bij kleinere tijdsintervallen was er geen verschil. Hieruit konkludeerde Boyers dat blootstelling van odcyten aan $\mathrm{CO}_{2}$ /algehele anesthesie de fertilisatiegraad verlaagt ${ }^{50}$.

Binnen de groep echoscopische follikelpunkties zijn tevens vergelijkingen gemaakt tussen de verschillende 'routes' voor de punktienaald. Zo vergeleek onder anderen Janssen-Caspers[1988] gerandomiseerd de echoscopische follikelpunktie langs abdominale weg $(n=24)$ met die langs vaginale weg $(\mathrm{n}=23)$. De laatste methode had een signifikant verhoogde oöcytopbrengst (bij gelijk aantal gesignaleerde follikels) en werkte bovendien sneller en patiëntvriendelijker.

Inmiddels is de diskussie over de optimale wijze van follikelpunktie voldoende uitgekristalliseerd om tot de konklusie te kunnen komen dat de transvaginale echoscopische follikelpunktie de voorkeur verdient, tenzij deze methode om bijzondere redenen niet mogelijk is. De behandeling kan onder lokale anaesthesie worden uitgevoerd waarna de patiënte ter konkrole circa een uur bedrust moet houden. Mede hierdoor is de follikelpunktie patientvriendelijker geworden, terwijl de zwangerschapsresultaten zeker niet minder zijn. Dat laatste is overigens momenteel vrijwel niet meer objektief vast te stellen, omdat de overige redenen ertoe geleid hebben dat vrijwel alle follikelpunkties echoscopisch transvaginal worden uitgevoerd.

50) Strikt genomen mag de konklusie alleen maar zijn dat langdurige blootstelling van oöcyten aatn $\mathrm{CO}_{2}$ /algehele anesthesie de fertilisatiegraad verlaggt. 
De vrag of tijdens aen follikelpunktie het spoelen van de follikels zinvol is, werd onder andere door Clarke[1985] onderzocht. Hij vond geen verschil in obcytopbrengst per follikel bij vergelijking van twee strategieen: enerzijüs de strategie om ledere follkel te spoelen, anderzijds die van niet-spoelen der follikels.

Data In totad zijn er in de onderzoeksperiode nog 89 follikelpunkties laparoscopisch uitgevoerd (4\%), voornamelijk in ziekenhuis 1 en ziekenhuis 3 tijdens de startperiode van het onderzoek De oocytopbrengst was bij deze wijze van punkieren identick aan die bij echoscopische follikelpunkties in deze twee ziekenhuizen. In totaal werden van de echoscopische follikelpunkties er 17 niettransvaginaal uitgewoerd (1\%), waarvan 13 transwesical. Alleen in ziekenhuis 1 worden follikels gespoeld, indien er geen oocyt is aangetroffen in de follikelvloeistof; dit resulteert overigens niet in een relatief hoog gemiddeld aantal oocyten voor ziekenhuis 1 (zie punt $B$ hieronder).

Konkl. - de follikelpunktie wordt vrijwel altijd transwaginaal uitgevoerd onder echoscopisch zicht.

\section{B. Oogyten: aantal en kwaliteit}

Lit. Onder andere Wood[1985a] wond cen sterk verband ${ }^{51}$ tussen het aantal werkregen oocyten en het zwangerschapspercentage per gestarte cyclus. Fishel[1985b] meldde dat bij een hogere oöcytopbrengst niet alleen meer embryo's worden verkregen, maar dat dan ook een hoger percentage der (rest)embryo's doordeelt tot blastocyst; met andere woorden waarschijnlijk is ook de kwaliteit van de individuele embryo's beter bij een verhoogde oöcytopbrengst.

De oöcytbeoordeling op maturiteit naar morfologisch uiterlijk van het corona/cumulus-komplex volgens Marrs[1984] blijkt goed te korreleren met de cytoplasmatische maturatie na het vrijmaken van de cöcyt (Yee[1985]).

Mahadevan[1987] tenslotte geeft aan dat de fertilisatiekans groter is bij mature oocyten, gezien het aantal spermatozoa dat gebonden is door de zona pellucida.

Data Voor het aantal gepunkteerde oöcyten (ingedeeld in 3 kategorien: $1-2,3-8, \geq 9$ ) geldt cen hele duidelijke, signifikante trend in dle zwangerschapsresultaten (zie bijlage 3.26 ): het klinisch zwangerschapspercentage per follikelpunktie bedroeg respektievelijk $7.1 \%, 16.7 \%$ en $23.7 \%$. Het gemiddeld aantal verkregen oöcyten per follikelpunktie verschilt signifikant tussen enerzijds ziekenhuis 1 , ziekenhuis 2 en ziekenhuis $3(5.5 \pm 3.5)$ en anderzijds ziekenhuis 4 en ziekenhuis $5(7.0$ $\pm 4.5)$.

51) Hij drukt dit verband uil in een kwadratische vergetijking (met $\mathbf{n}=$ het aantal oöcyten): wwangerschapspercentage $=5.6 \mathrm{n}-0.3 \mathrm{n}^{2}$. Het voordeel van het hanteren van een kwadratische vergelijking ten opzichte van een lineaire vergelijking met een konstante biedt twee theoretische woordelen: de parabool gant door de oorsprong (waar geldt: geen cöcyten, dus geen zwangerschap) en er wordt een limiet gesteld aan het zwangerschapspercentage bij een toenemend aantal oöcyten. 
Voor de beoordeling van de maturiteit van de oocyten is in de registratie de cerdergenoemde indeling van Marrs[1984] gehanteerd. Van de verkregen oöcyten werd hierbij $74 \%$ als prima beoordeeld ${ }^{52}$ en nog eens $13 \%$ als goed, dus $87 \%$ als prima tot goed. Daarnaast werden er relatief veel oobyten als postmatuur c.q. gedegenereerd beoordeeld in ziekenhuis 3 en ziekenhuis 1. Gezien de verdeling van de skores van de beoordeling der oöcyten en de subjektiviteit van deze beoordeling is in de analyses voor de mogelijke invloed van de 'kwaliteit' van de oocyt gebruik gemaakt van een tweedeling: oocyten die als prima werden beoordeeld versus de rest. In de registratie is niet precies per individuele oöcyt bekend of er fertilisatie/celdeling is opgetreden; wel zijn per follikelpunktie de beoordelingen van alle oöcyten bekend en tevens de celstadia en kwaliteitsbeoordelingen van alle eventueel ontwikkelde embryo's. De mogelijke invloed van de oocytkwaliteit op de fertilisatiegraad kon dan ook alleen op het nivo van de follikelpunktie worden onderzocht. Daaruit bleek (zie bijlage 3.26) dat het gemiddelde fertilisatiepercentage per ooscyt opliep bij een toenemend aandeel van oöcyten waarvan de cumulus/corona als prima werden beoordeeld: vanaf een fertilisatiegraad wan $40 \%$ indien er alleen minder goede oöcyten werden verkregen tot $62 \%$ indien alleen prima oöcyten werden verkregen.

Bij een moeizaam verlopen follikelpunktie $(n=223)$ werden gemiddeld iets minder oocyten verkregen $(5.1 \pm 4.0$ versus $6.4 \pm 4.3)$.

Konkl - het aantal verkregen oöcyten heeft een duidelijke invloed op de resultaten

- de kwaliteit van de verkregen oöcyten lijkt van invloed te zijn op de fertilisatiegraad.

\section{Punktie na endogene LH-piek'}

Lit. Talbert[1988] geeft een aardig overzicht van feiten rondom een endogene LHpiek (waarvoor overigens verschillende definities bestaan):

1. Een endogene LH-piek komt relatief vaker voor bij stimulatie met alleen hMG $(20$ a $30 \%)$ in vergelijking met stimulatie met ac/hMG (circa $10 \%$ ).

2. Mogelijke oplossingen woor endogene LH-pieken:

- LH-piek voorspellen met serum-progesteron en vervolgens een hCGinjektie toedienen

- preventie van endogene LH-piek met behulp van LHRH-analogen.

3. Omtrent de zwangerschapsresultaten na een endogene LH-piek bestaat verschil van mening:

- Lejeune[1986] vindt (na stimulatie met cc/hMG) significant lagere zwangerschapspercentages na een endogene LH-piek (waarbij niet voldaan is aan de minimale kriteria: minstens 1 follikel $>19 \mathrm{~mm}$ en serum- $\mathrm{E}_{2}$ $>400 \mathrm{pg} / \mathrm{ml}$ per follikel $>17 \mathrm{~mm}$ ) versus na hCG-medikatie. Dit stemt overeen met bevindingen van Trounson[1982], maar niet met die van Lopata[1983] en van Edwards[1984b]; maar bij de laatste 2 studies werden cycli met een endogene LH-piek zonder grote follikels beêindigd.

52) In ziekenhuis 3 gold dit voor $50 \%$, in ziekenhuis 1 voor $60 \%$, in ziekenhuis 2 voor $70 \%$, in ziekenhuis 5 voor $80 \%$ en tenslotte in ziekenhuis 4 yoor $90 \%$. 
Ook Eibschitz[1986] vindt na stimulatie met co/hMG significant lagere zwangerschapspercentages na een endogene $\mathrm{LH}$-piek $(\mathrm{n}=97$ ) versus na $\mathrm{HCG}$ medikatie $(n=217)$; dit verschil wordt nog versterkt bij een $E_{2}$-nivo $<1200$ $\mathrm{pg} / \mathrm{ml}$. Opvallend is het hele hoge percentage follikelpunkties dat na een endogene LH wiek geen oocyten oplevert: $56 \%$ versus $25 \%$ bij de andere oycli.

- Volgens diezelfde Eibschitz[1986] zijn de zwangerschapsresultaten identiek als alleen gekeken wordt naar follikelpunkties mét oöcytopbrengst nat een endogene LH-piek. Huang[1987] vindt bij hMG-medikatie eveneens geen sigmifikant verschil in het klinisch zwangerschapspercentage per follikelpunktie tussen punkties na een endogene LH-piek (waarbij direkt na detektie van de endogene. $L H$-piek hCG werd toegediend en de punktie 24 uur na de endogene piek werd uitgevoerd) $(4 / 41=9.8 \%$ ) versus punkties na alleen $\mathrm{HCG}(7 / 61=11.5 \%)$. Deze bevinding is niet werwonderlijk bij dergelijke kleine aantallen. Wel meldde hij signifikante verschillen voor het aandeel immature oocyten, de fertilisatiegraad en de delingsgraad. Macnamee[1987] vond eveneens geen verschil in zwangerschapsresultaten, indien de planning van de follikelpunktie werd gebaseerd op 4-uurlijkse LH-bepalingen.

Data Bij follikelpunkties na een endogene LH-piek liggen de zwangerschapsresultaten signifikant lager dan bij follikelpunkties zonder endogene LH-piek (zie bijlage 3.27). Als alleen de behandelingen in beschouwing worden genomen met minstens 2 LH-bepalingen, dan zwakt dit verschil weliswaar af, maar de tendens blijft intakt: het klinisch zwangerschapspercentage per follikelpunktie bedraagt dan respektievelijk $7.6 \%$ en $13.7 \%{ }^{\mathrm{s} \%}$.

Bij ruim 10\% van alle follikelpunkties werd minstens 1 post-mature oocyt gezien. Daarbij bestaat een grote spreiding tussen de ziekenhuizen: ziekenhuis 3 en ziekenhuis 1 circa $25 \%$, ziekenhuis 2 en ziekenhuis $55 \%$ en ziekenhuis 4 vrijwel $0 \%$; dit verschil wordt waarschijnlijk mede weroorzaakt door de wijze van beoordeling. Na een gesignaleerde endogene LH-piek ligt het percentage follikelpunkties met minstens 1 post-mature oocyt circa $2 x$ zo hoog.

Konkl - omtrent de invloed wan een endogene LH-piek op de resultaten bestaat verschil van mening; in het evaluatie-onderzoek werd wel een (negatieve) invloed gesignaleerd.

\section{Fertilisatie}

\section{Semen/sperma}

Lit. Traditioneel wordt de semenkwaliteit beoordeeld met behulp van 3 parameters: de konsentratic, de morfologie en de motiliteit. Het basisidee achter deze 
beoordeling is dat konseptie alleen (beter zou zijn "met grotere kans") mogelijk is vanaf een bepaald minimum aantal goed beweeglijke, morfologisch normale spermatozoa. De eerdergenoemde 3 kriteria vormen echter slechts een indirekte indikatie voor de funktionele mogelijkheden van de in het semen aanwezige spermatozoa. Dientengevolge leidt een indeling gebaseerd op deze kriteria niet tot volledig homogene groepen.

De WHO-normen voor de 3 traditionele semenparameters (aantal $>20^{*} 10^{6} / \mathrm{ml}$, motiliteit $>40 \%$ en morfologisch normaal $>60 \%$ ) worden steeds meer verlaten. In Bourn Hall (Hewitt[1985]) bijvoorbeeld worden de grenzen gelegd bij: aantal $>10^{*} 10^{6} / \mathrm{ml}$, motiliteit $>20 \%$ en morfologisch normal $\left.>20 \%\right)$. Anallyses in Bourn Hall (Rowland[1984]) met betrekking tot de motiele-sperma-konsentratie (=spermakonsentratie * motiliteitspercentage) laten zien dat IVF ook behoorlijke resultaten kan opleveren bij erg lage motiele-sperma-konsentraties (minder dan $0.5^{*} 10^{6} / \mathrm{ml}$ ): 7 van de 15 behandelde paren werden zwanger na een of meerdere pogingen. Cittadini[1988] vindt eveneens geen duidelijk verband tussen het aantal motiele spermatozoa/ml ( 1 uur na vervloeien) en de fertilisatiegraad. Eerder was reeds bekend dat de parameter spermakonsentratie op zich niet van invloed is op de fertilisatiegraad (Cohen[1985], Mahadevan[1984]).

De belangrijkste traditionele semenparameter voor de fertilisatiegraad bij IVF is volgens Mahadevan[1987] de spermamotiliteit, hoewel met name Edwards [1984b] ook bij lage motiliteit sukses heeft. Mahadevan[1987] staaft zijn bewering met gegevens over de korrelatie tussen de spermamotiliteit en het antal spermatozoa dat gebonden is door de zona pellucida.

De parameter morfologie is door Kruger[1986] nader aangescherpt. Bij toepassing van zijn striktere normen konstateert hij vervolgens een sterk signifikant verschil in fertilisatiegraád per oöcyt tussen cycli met maximaal $14 \%$ morfologisch normaal sperma: 37\% (104 obcyten, 22 punkties) versus cycli met minimaal $15 \%$ morfologisch normaal sperma: $85 \%$ (702 oöcyten, 168 punkties). Dit komt overeen met de bevindingen van Mahadevan[1984], Rogers[1983] en Aitken[1982] voor IVF-behandelingen bij de indikatie onbegrepen infertiliteit. Later heeft Kruger[1988] ook de groep patiènten met maximaal 14\% morfologisch normaal sperma met strikte kriteria (een zelf opgestelde morfologie-index) gesplitst; de fertilisatiegraad per oöcyt verschilde signifikant tussen beide groepen en bedroeg:

$-8 \%$ bij normale morfologie $<4 \%$ en morfologie-index $<30 \%$

- $64 \%$ bij normale morfologie tussen 4 en $14 \%$ en morfologie-index $>30 \%$.

Belangrijk probleem bij het hanteren van de parameter morfologisch normaal sperma is de sterk subjektieve beoordeling, waardoor wergelijking tussen diverse laboratoria erg moeilijk wordt. Het lijkt alleen mogelijk binnen ieder laboratorium apart het eventueel te hanteren grens-percentage zelf te bepalen.

Andere vormen van diagnostiek ter bepaling van de funktionele mogelijkheden van de spermatozoa worden onder andere dloor Aitken[1988] aangegeven:

- voor de bepaling van de aard van de motiliteit van het sperma worden vooral verschillende vormen wan micrografie toegepast 
- voor onderzoek naar de sperma-odcyt-interaktie wordt naast de meer traditionele hamster-eicel-penetratie-test veel energie gestoken in de ontwilkkeling van monoclonale antilichamen ten behoeve van het signaleren van acrosoomreakties.

Met betrekking tot de mogelijke invloed van het gebruikte medium bij IVF lifkt de konklusie gerechtvaardigd dat bij diverse media vrijwel identieke resultaten zijn bereikt (onder anderen Dodson[1986] en Wood[1985b]).

Een recente ontwikkeling is de methode van de intra-vaginale cultuur (IVC). Ranoux [1988b] maakt melding van deze behandelmethode, waarbij de fertilisatie en verdere kultuur van de oofcyten niet in het laboratorium plaatsvinden, maar in een buisje ('tube) in de vagina. De obcyten worden met het sperma, en zonder $\mathrm{CO}_{2}$, in dit buisje gebracht waar het geheel 44 tot 50 uren blijft. Daarna worden er maximaal 4 embryo's geselekteerd voor een embryotransfer. Eerst (okt. "85-feb.'86) werden 100 laparoscopische follikellpunkties gevolgd door IVC: 84 embryotransfers, 20 klinische zwangerschappen, 15 bevallingen. Daarna (juli'86-jan.'87) werden de traditionele IVF-methode en de IVC-methode gerandomiseerd onderzocht (in beide groepen 80 behandelingen). De resultaten waren volstrekt vergelijkbaar. Als voordelen van de IVC-methode worden vermeld:

- er is geen $\mathrm{CO}_{2}$-incubator meer nodig

- het psychologische voordeel dat de patient meer in het proces wordt ingeschakeld.

Deze voordelen waren yoor de IVF-centra in Nederland niet direkt reden om de cxperimentele IVC-methode ook toe te passen. Belangrijk nadeel is immers dat er geen zicht meer is op het verloop van het fertilisatieproces.

Sinds januari 1987 is dezelfde onderzoeksgroep in Frankrijk bezig om met behulp van een cryo-rietje van $200 \mu l$ (en dus minder kweekmedium) de inseminatie uit te voeren met als doel uiteindelijk een bio-oplossend rietje in de uterusholte te plaatsen (Ranoux[1988a]).

Bellinge[1986] suggereert tenslotte nog dat semen invloed kan hebben op het endometrium. Hij voerde een gerandomiseerd onderzoek uit, waarin bij de ene groep de normale IVF behandeling werd uitgewoerd, terwijl bij de andere groep tijdens de IVF Cyclus semen hoog in de vagina werd geïnsemineerd (totale $n=113$ ). Het klinisch zwangerschapspercentage lag bij de geìnsemineerde IVFgroep signifikant hoger dan bij de kontrole-groep: $30 \%$ versus $11 \%$.

Data Het gemiddelde fertilisatiepercentage per oöcyt voor alle verkregen oöcyten tijdens de periode van het evaluatie-onderzoek bedraagt $56 \%$. Ofwel, ruim de helft van de verkregen odcyten wordt bevrucht. Wel bestaat er een grote spreiding in dit percentage. Reeds eerder is aangegeven dat de fertilisatiegraad varieert naargelang de indikatie en de kwaliteit van het cumulus/coronakomplex, zoals beoordeeld direkt na de follikelpunktie. Hieronder wordt op nog twee andere manieren een onderverdeling van de fertilisatiegraad aangebracht. 


\section{Fertilisatiegraad werdeeld naar zickenhuis}

Voor alle offyten die bij follikelpunkties in de verschillende ziekenhuizen zijn verkregen is de fertilisatiegraad per obcyt in de verschillende ziekenhuizen weergegeven in tabel 3.7 .

\section{Tabel 3.7. Fertilisatiegraad in de verschillende ziekenhuizen}

$\begin{array}{ll}\text { ziekenhuis 1 } & 56 \% \\ \text { ziekenhuis 2 } & 65 \% \\ \text { ziekenhuis 3 } & 43 \% \\ \text { ziekenhuis 4 } & 52 \% \\ \text { ziekenhuis 5 } & 68 \%\end{array}$

Ofwel, de gemiddelde fertilisatiegraad lag in ziekenhuis 3 onder het gemiddelde, terwijl die in de ziekenhuizen 5 en 2 boven het gemiddelde uitkwamen.

Ook blijkt dat in ziekenhuis 3 relatief valak geen enkele oocyt werd bevrucht (bij $1 / 4$ van de follikelpunkties mét oöcytopbrengst), terwijl dat in ziekenhuis 5 slechts bij 1 op de 20 follikelpunkties met oocytopbrengst voorkwam. In de ziekenhuizen 2 en 5 werd in ongeveer de helft van de follikelpunkties minstens $3 / 4$ van de verkregen oöcyten bevrucht.

\section{Fertilisatiegraad verdeeld naar de parameter spermamotiliteit na opwerking}

In onze registratie van de IVF-behandelingen is met betrekking tot deze parameter tussentijds een wijziging aangebracht in de antwoordmogelijkheden. Aanvankelijk werden hiervoor kwasi-objektieve aniwoordkategoriesn gehanteerd $(\geq 40 \%, 30 \%-40 \%,<30 \%)$. Per 1987 werden deze antwoordkategorieen verwangen door subjektieve door ieder ziekenhuis zelf te definieren kwalifikaties (goed, matig, slecht) ${ }^{55}$. De oude indeling liet geen verschil in fertilisatiepercentage per odcyt zien. Bij de nieuwe indeling werd voor goed beweeglijk sperma ( $n=1871$ ) gemiddeld wel een hoger fertilisatiepercentage genoteerd dan voor matig/slecht motiel sperma $(n=290): 58 \%$ versus $42 \%$ s6.

Bij een splitsing van de behandelresultaten naar de parameter spermamotiliteit na opwerking volgens de nieuwe indeling bestaat er dan ook een signifikant verschil in het percentage embryotransfers per follikelpunktie: $88 \%$ voor semen met goed motiel sperma versus $73 \%$ woor semen met matig/slecht motiel

55) Dit is in overeenstemming met de eerdere konstatering dat de beoordelling wan de semenparameters sterk subjektief is warardoor het de voorkeur verdient ieder laboratorium zijn cigen grenzen in deze te laten bepalen en hanteren. De verdeling van zowel de oude als de nieuwe skores is per ziekerihuis wergegeven in tabel $B 3.28 .2$ Bij de nieuwe indeling is in leder ziekenhuis bij circa $85 \%$ van de beoordelingen na opwerking sprake van een goede spermamotiliteit. Uit het totaalberdd blijkt in ieder geval dat de oude indeling niet zonder meer ower de nietwe indeling te herwerdelen is.

56) Bij onderverdeling van de behandelingen met matig c.g. slecht beweeglijk sperma bedragen de percentages respektievelijk $48 \%(n=208)$ en $28 \%(n=82)$. 
sperma (zie biflage 3.28). Dit signifikante verschil geldt ook voor bijna ${ }^{57}$ ieder ziekenhuis apart.

De zwangerschapsresultaten bleken ook bij de niewwe indeling voor de spermamotiliteit niet voor deze faktor gevoelig te zijn. Voor de indikatie mannelike subfertiliteit op zich gold echter (zie cerder) niet alleen een signifikant verlaagde fertlisatiegraad, maar ook signifikant lagere zwangerschapspercentages. Dit is als volgt te verklaren: hoewell bij mannelijke subfertiliteit sprake is van een duidelijk verlaagde kans op goede spermamotiliteit na opwerking (zonder mannelijke subfertiliteit $89 \%$, met 64\%), is toch nog bij $2 / 3$ van die behandelingen het semen na opwerking goed beweeglijk.

De relatie tussen de beoordeling van het semen voorafgaand en na afloop van de opwerking is ook onderzocht. Hierbij is gekeken naar cen eventueel positief verband tussen enerzijds de beoordeling van konsentratie en motiliteit van het semen vór opwerking (aantal motiele spermatozoa/ml al dan niet $>8 \times 10^{6}$ ) en anderzijds de beoordeling van de spermamotiliteit ná opwerking van het semen. Er werd echter geen verband gevonden.

Tot slot dient te worden vermeld dat binnen de registratie $28 \mathrm{x}$ melding is gemaakt van het (mede)gebruik van donorspermatozoa (waarvan $21 \mathrm{x}$ in ziekenhuis 4).

Konkl. - een slechte spermamotiliteit gaat gepaard met een verminderde fertilisatiegraad, maar leidt niet tot mindere zwangerschapsresultaten

- nieuwe parameters en vormen van diagnostiek voor de semenkwaliteit zijn in ontwikkeling waardoor nadere specifikaties in de prognoses van de IVFresultaten mogelijk lijken te worden

- de beoordeling van de kwaliteit van de oöcyten en het semen is erg subjektief

\section{E. Tweede inseminatie}

Lit. Yovich[1984a] en Trounson[1984c] konkludeerden (op basis van onderzoeken met weinig warnemingen) dat reinseminatie dan wel mag leiden tot pronuclei en celdeling, maar geen levensvatbare zwangerschappen oplevert. Belangrijker is de konstatering van Trounson[1984c] dat reïnseminatie met eigen semen (indien na 12 14 uur nog geen spoor van fertilisatie aanwezig is) niet tot een hogere fertilisatiegraad leidt dan "afwachten's8: $15 \%$ (11/71) versus $21 \%$ (19/92). Met andere woorden: het optreden van fertilisatie later dan 12 a 14 uur na de eerste inseminatie kan zeker niet zonder meer worden toegeschreven aan de uitgevoerde relinseminatie; het kan ook het vertraagde resultaat van de eerste inseminatie zijn. Reïnseminatie met donorzaad leidde wel tot een hogere fertilisatiegraad: $35 \%(23 / 65)$.

57) Aleen in ziekenhuis 5 is het versehil niet signifikant (zie bijlage 3.28 ),
58) Met afwachten wend bedoeld, dat er weliswagr na 12 a 14 uur geen fert maar er gexu reïsenainatice volgde. Later werd 12 a 14 uur geen fertilisatic werd gesignaleerd, 
Data Indien in de registratie sprake is van een tweede inseminatie, dan heeft dit betrekking op het nivo van de follikelpunktie en niet (perse) op dat van de odcyt. Een tweede inseminatie kan om twee redenen zijn uitgevoerd. In verband met ongelijke maturiteit van de verkregen oöcyten kan worden besloten om een gedeelte van de oobcyten later te insemineren dan de rest. Ook kan het zo zijn dat in eerste instantie alle oöcyten zijn geinsemineerd. Indien bij beoordeling een deel van de oöcyten niet lijkt te zijn bevrucht, kan besloten worden tot reînseminatie van deze oócyten.

Ziekenhuis 1 voert bijna altijd een tweede inseminatie uit (bij $94 \%$ van alle follikelpunkties). Bij ongeveer de helft van de tweede inseminaties worden alle oobyten gereinsemineerd onder het motto "baat het niet, dan schaadt het niet". De andere tweede inseminaties betroffen vertraagde inseminaties van minder mature oocyten. ziekenhuis 3 heeft in totaal bij $23 \%$ van de follikelpunkties een tweede inseminatic uitgevoerd en ziekenhuis 2 bij $6 \%$.

Konkl - het nut van reînseminaties is dubieus.

\section{F. Gebruikt serum en tijdsintervallen}

Data Exklusief ziekenhuis 4 werd in $97 \%$ van alle follikelpunkties het serum van de patiënte gebruikt voor toevoeging aan de media. In de enkele gevallen waarin ander serum werd gebruikt, werd dit nadrukkelijk ingegeven door het feit dat het eigen serum van de patiĕnte antilichamen bevalte die de fertilisatie van de werkregen oöcyten nadelig zouden kunnen belnvloeden. In ziekenhuis 4 werd tot 1987 voornamelijk patiëntenserum gebruikt. Daarna gebruikte men voor de eerste 2 oöcyten gepooled serum vań zwangere vrouwen en voor het restant serum van de patiënte. Deze keuze werd ingegeven door de veronderstelling dat de fertilisatiekans groter zou zijn bij gebruik van serum van reedls zwangergeworden-vrouwen (aangezien binnen onze registratie de fertilisatie niet per individuele oöcyt kan worden bepaald, kon door het onderzoeksteam niet worden nagegaan in hoeverre er verschil bestaat in de fertilisatiegraad bij gebruik van verschillende media voor verschillende oócyten afkomstig uit een follikelpunktie). Het gebruik van het gepooled serum bij de IVF-behandeling heeft ten gevolge van onzorgvuldigheden in de procedure van de rapportage over de screening van dit serum geleid tot de zogenaamde Hepatitis B-aflaire. Aangezien dit incident door een aparte kommissie volledig is uitgediept, ligt het voor de hand hier te volstaan met een werwijzing naar het rapport van deze kommissie $^{60}$ en naar Alberda[1989]. Het incident is, getuige de hierboven weergegeven cijfers, niet representatief voor de praktijk van de IVF-behandeling in Nederland.

59) Ziekenhuis 4 en ziekenhuis 5 hebben ieder $1 x$ de oobyten in twee gedeelten geïnsemineerd.

60) Verslag van de Commissie voor Onderzoek van de Hepatitis-B-besmetting in het Dijkzigi-ziekenhuis te ziekenhuis 4; aprill 1988. 
De gemiddelde tijdsintervallen tussen de follikelpunktie, de platsing van de obcyten in een pre-incubatiemedium, de inseminatie van de odcyten en de transfer wan ontstane embryo's zijn in de verschillende ziekenhuizen vijwel identiek. Hoewell deze intervallen wan behandeling tot behandeling nog wel uiteenlopen, lijken de verschillen in de behandelresultaten tussen de ziekenthuizen hieruit niet verklaard te kunnen worden.

Konkl. - vrijwel altijd wordt voor de IVF-media serum van de vrouw gebruikt; derhalve is de situatie die leidde tot de Hepatitis B-affaire in ziekenhuis 4 niet representatief voor de IVF-praktijk in Nederland

- de tijdsintervallen tussen verschillende aktiviteiten gedurende de periode vanaf de follikelpunktie tot en met de embryotransfer lijken niet van invloed op de resultaten van de behandeling.

\subsubsection{Embryotransfer $\rightarrow$ (klinische) zwangerschap}

\section{A. Teruggeplaatste embryo's: aantal en kwaliteit}

\section{Lit. Aantal embryo's}

Het aantal teruggeplaatste embryo's heeft een sterke invloed op het klinische zwangerschapspercentage per embryotransfer:

- in Bourn Hall (okt.'80-april'83): per embryotransfer met respektievelijk 1, 2 en 3 embryo's bedroegen de percentages $15 \%, 25$ a $30 \%$ en $35 \%$ (Edwards[1984a])

- in Melbourne,Monash ('80-'82): per embryotransfer met respektievelijk 1, 2 en 3 embryo's bedroegen de percentages $10 \%, 20 \%$ en $25 \%$ (Trounson[1984a])

- in Victoria,Australie: per embryotransfer met respektievelijk $1,2,3$ en 4 embryo's bedroegen de percentages $9 \%, 15 \%, 18 \%$ en $25 \%$. Wel blijft het aantal gesignaleerde vruchtzakken per teruggeplaatste embryo min of meer gelijk (gemiddeld $8 \%$ ), onafhankelijk van het aantal teruggeplaatste embryo's (Gronow[1985])

- in Norfolk lijkt de invloed van het aantal teruggeplaatste embryo's veel minder sterk: bij embryotransfers met minstens 4 embryo's lag het klinisch zwangerschapspercentage per embryotransfer slechts $1,5 \mathrm{x}$ zo hoog als bij embryotransfers met 1 embryo (Garcia[1984], Jones[1984])

- door Testart[1986a| wordt een literatuuroverzicht gegeven van de resultaten voor embryotransfers met respektievelijk $1,2,3$ en minimaal 4 embryo's: $15 \%(\mathrm{n}=1164), 25 \%(\mathrm{n}=726), 29 \%(\mathrm{n}=339)$ en $34 \%(\mathrm{n}=131)$.

Er zijn ook theoretisch modellen opgesteld om de invloed van het aantal embryo's op de zwangerschapskans te benaderen: 
- Jones[1984] hield in zijn model alleen rekening met het aantal teruggeplaatste embryos ${ }^{61}$

- Speirs[1983] hield in zijn modelmatige benadering naast het aantal teruggeplaatste embryo's ook rekening met de uterusreceptiviteit ${ }^{62}$.

De relevantie van deze modellen is vooral gelegen in het toetsen van veronderstellingen omtrent mogelijke wisselwerkingen tussen embryo's met betrekking tot de implantatie in de uterus.

\section{Kwaliteit van de embryo's}

Er zijn in de literatuur diverse methoden beschreven om de kwaliteit van de embryo's te kunnen beoordelen, variërend van erg subjektieve methoden tot min of meer objektieve maatstaven en kijkend naar het ontwikkelingsstadium dan wel de morfologie. Het belang van een kwalifikatie van de embryo's is door Yovich[1984c] aangegeven: slechts $40 \%$ van de embryo's is in staat tot suksesvolle implantatie.

Winston[1985] verdeelde derhalve 419 embryo's (uit periodes met goede resultaten) met behulp van een sterk subjektieve beoordeling woor de kwaliteit in drie groepen: slechte embryo's (17\% van de embryo's), redelijke embryo's (55\%) en goede embryo's (28\%). In totaal werden er 49 vruchtzakken gevormd (11.7\% per embryo). Als echter alleen slechte embryo's werden teruggeplaatst, ontstond er geen enkele zwangerschap. Probleem bij een dergelijke analyse is dat bij een transfer van embryo's van verschillende kwaliteit niet te achterhalen is welke embryo goed geïmplanteerd is.

Claman[1987] bekeek de kwaliteit aan de hand van het ontwikkelingsstadium 40 uur na inseminatie. Hij maakté onderscheid tussen embryotransfers met minstens 1 embryo dat 40 uur na inseminatie het 4-cellig stadium had bereikt $(n=117)$ en de andere embryotransfers $(n=105)$; het percentage doorgaande zwangerschappen per embryotransfer verschilde signifikant: $18 \%$ voor de eerste groep versus $2 \%$ voor de andere.

Cummins[1986] vergeleek 2 methoden om de embryokwaliteit te beoordelen: de subjektieve morfologische beoordeling op een 4-puntsschaal ${ }^{63}$ en de meer

61) Jones ging uit van de binomiaal $(a+b)^{n}=1$,

met $a=z$ wangerschapsincidentie bij embryotransfers met 1 embryo

$b=$ kans op mislukking

$\mathrm{n}=$ aantal tenggeplaatste embryo's.

62) $\mathrm{P}$ (zwangerschap 1 embryo $)=\mathrm{E} \cdot \mathrm{U}$, met

$\mathrm{E}=$ kans op implantatie bij wolledig receptieve patient (voor leder embryo gelijk; dus er wordt geen rekening gehouden met eventuele 'kruis-stimulatie')

$U=$ kans dat de uterus van deze patient receptief is voor oen goed enbryo.

Hierop woortbordurend geldt: $\mathbb{P}$ (eenling $/ 2$ embryo's) $=\mathrm{E}(1-\mathrm{Ey}) \cdot 2$

$P$ (wweeling 2 embryo's $)=E * E * U$

dus $P$ (zwangerschap $\mid 2$ embryo's) $=P$ (eenling $/ 2$ embryo's) $+P$ (tweeling $\mid 2$ enbryo's).

63) De subjektieve kwaliteitsbeoordeling is gebaseerd op een publikatie van Mohr[1984]. 
objektieve methode van de embryo-groeivoet ${ }^{64}$. Beide methodlen bleken sterk onderling samen te hangen en enigszins cen voorspellende waarde te hebben voor de zwangerschapskans ${ }^{6 s}$. Probleem bij de methode van de embryo-groeivoet is dat ongeveer $90 \%$ van de periode van celdeling bestaat uit de interfase waarbij het aantal cellen gelijk blijft. Dit impliceert dat het observatie-moment een enorme bron van vertekening kan opleveren; wordt de groeivoet net na de celdeling bepaald of tijdens de interfase en in dit laatste geval: is de interfase net begonnen of bijna afgelopen?

O'Neill[1986] probeert de embryokwaliteit te beoordelen met behulp van een andere objektieve, niet-invasieve, niet-destruktieve methode: de bepaling van de zogenaamde EDPAF (embryo-derived-platelet-activating-factor). Een levensvatbaar embryo produceert voorafgaand aan de implantatie in de uterus een oplosbare platelet-activerende faktor, waardoor het bloed-platelet-nivo afneernt als eerste teken van zwangerschap (thrombocytopenia in de pre-implantatieperiode na de embryotransfer). Bij een kleine steekproef vond men alleen zwangerschappen bij embryo's met EDPAF en thrombocytopenia, onafhankelijk van de morfologische kwaliteit van het embryo.

Door monitoring van EPAT ("early pregnancy-associated thrombocytopenia'), EDPAF en het endocriene profiel van de vrouw in de luteale fase kan de levenswatbaarheid van het embryo worden gevolgd vór de embryotransfer en tijdens de implantatieperiode (O'Neill[1985]). Onderzoeken in deze richting hebben vooralsnog nauwelijks betekenis voor de IVF-praktijk.

\section{Data Aantal embryo's}

Het klinisch zwangerschapspercentage per embryotransfer laat een fraaie stijgende trend zien bij een oplopend aantal teruggeplaatste embryo's (zie bijlage 3.29); waar dit percentage slechts $7 \%$ bedraagt bij 1 teruggeplaatste embryo is het opgelopen tot circa 30\% bij een transfer van 5 of 6 embryo's. Deze stijgende zwangerschapspercentages gelden ook voor ieder individueel ziekenhuis ${ }^{66}{ }^{6}$. ziekenhuis 4 en ziekenhuis 2 hanteerden binnen de onderzoeksperiode een relatief terughoudend beleid met betrekking tot het maximale aantal terug te plaatsen embryo's; in deze beide ziekenhuizen gold een absoluut maximum van 4 . De drie andere centra hanteerden als kriterium: maximaal 4 goede embryo's; bij embryo's van mindere kwaliteit was niet een strikt maximum gesteld. Daarnaast werden er ook soms aöcyten teruggeplaatst die volgens de uiterlijke beoordeling niet waren bevrucht. Het is echter een bekend

64) Deze groewoet werd gedefinieerd als de ratio wan enerzijos het interval tussen inseminatie en het tijdstip wasrop exn embryo wordt gezien in een bepaald celstadium en anderxijds het interval tussen inseminatie en het ijjdstip warop het embryo dit stadium bereikt zou hebben bij een hypothetische "ideale" groeivoet voor celdelimg van bijna 12 uur.

65) De morfologische beordeling was in deze beter dan de methode van de embryo-groeivoet.

66) Alleen in ziekenhuis 4 werd bij de terugplaatsing van 4 embryo's een neenwartse knik in de algemene trend wargenomen. Volgens ziekenhuis 4 zelf werd dit gegeven werklaard door hun beleid met betrekling tof het maximaal aantal terug te platsen embryo's. Dit maximum is in het algemeen gesteld op 4 embryo"s en bij cen terugplaatsing van alleen goede embryo"s is het maximum op 3 gesteld. De zwangerschapsresultaten binnen de onderzocksperiode sluiten owerigens niet aan bij deze gedachtengang (zie volgende pagina). 
gegeven dat sommige oöcyten pas na relatief lange tijd alsnog bevrucht raken en gaan delen. In totaal werden er 13 transfers uitgevoerd met alleen als onbewrucht beoordeelde oocyten; dit leidde tot 1 klinische abortus zonder hartaktie.

\section{Kwaliteit van de embryo"s}

Als maatstaf voor de embryokwaliteit werd een tweedeling gemaakt op basis van enerzijds het bereikte celstadium voor de embryotransfer en anderzijds een morfologische beoordeling van het embryo. De kwaliteit van een embryo wordt als prima aangeduid indien de ontwikkeling minimaal het 4-cellig stadium theeft bereikt ên het embryo morfologisch als perfekt is beoordeeld. Zo niet, dan wordt het embryo als minder goed aangeduid. Indien gestratificeerd voor het aántal teruggeplaatste embryo's een splitsing wordt gemaakt naargelang de verdeling in prima en minder goede embryo"s, dan ontstaat er voor de zwangerschapsresultaten zeker geen eenduidig beeld ten gunste van de als prima aangeduide embryo's (zie bijlage 3.30). De verklaring voor het ontbreken van een fraai positief verband tussen de aldus weergegeven embryokwaliteit en de zwangerschapskans kan tweeledig zijn. Enerzijds kan de subjektieve morfologische beoordeling ontoereikend zijn, anderzijds kan de mate van receptiviteit van de uterus van de vrouw een sterk verstorende variabele zijn.

Bij de bovenvermelde analyse is per stratum van aantal teruggeplaatste embryo"s de mogelijke invloed van de embryokwaliteit onderzocht. Om de invloed van het aantal teruggeplaatste embryo's en de embryokwaliteit van deze embryo's tezamen te kunnen onderzoeken is het gewenst tot een soort index te komen voor aantal ên kwaliteit van de teruggeplaatste embryo's. Deze index is binnen het onderzoek samengesteld door de betekenis van een goed embryo voor de zwangerschapskans in te schatten ten opzichte wan die van een minder goed embryo. Enerzijds zou kunnen worden teruggegrepen op de verhouding tussen de klinische zwangerschapspercentages bij transfers van 1 prima embryo ten opzichte van die van 1 minder goed embryo. Deze verhouding bedroeg ongeveer $1.5: 1$. Anderzijds werd uit het overzicht van bijlage 3.30 wel duidelijk dat deze verhouding onmogelijk cen juiste weergave van de werkelijkheid zou kunnen zijn. Derhalve is ten behoeve van de berekening van de index (ET-INDEX) voor de embryokwaliteit van een embryotransfer een tussenpositie ingenomen: aan de prima embryo's werd een gewicht 1.25 toegekend. De gemiddelde embryokwaliteit van een embryotransfer is dan gelijk aan het kwotient van de index en het aantal teruggeplaatste embryo's. Bij vergelijking van de gemiddelde embryokwaliteit tussen embryotransfers die al dan niet tot een klinische zwangerschap hebben geleid blijkt er geen verschil te bestaan. Ook blijkt dat de gemiddelde kwaliteit van de teruggeplaatste embryo's niet terugloopt bij een oplopend aantal embryo's. Dit zou suggereren dat een toename in het aantal verkregen embryo's (bijwoorbeeld ten gevolge van een andere vorm van stimulatie) niet ten koste zou gaan van de kwaliteit van de verkregen embryo's. De invloed van de variabele ET-index is verder nog onderzocht door middel van regressie-analyses (zie paragraaf 3.4 .3 ).

Tenslotte is nog onderzocht of de mogelijkheid om voor een transfer een selektie te kunnen maken uit aanwexige embryo's een positieve invloed heeft 
op de zwangerschapsresultaten. Indien er selektie mogelijk is, is er sprake van een surplus aan embryo's. Aangezien deze selekte pas relevant wordt bij de aanwezigheid van meerdere embryo's, zijn de analyses alleen uitgevoerd voor embryotransfers van minimaal 3 embryo's. Bij vergelijking tussen embryotransfers met zonder een surplus aan embryo's zijn geen verschillen te zien in het percentage doorgaand zwangerschappen per embryotransfer (zie bijlage 3.31). Bij stratifikatie naar het aantal teruggeplaatste embryo's is het opvallend dat het doorgaand zwangerschapspercentage telkens hoger is bij de embryotransfers zonder keuzemogelijkheid (zonder surplus). Dit beeld wordt echter sterk beinvloed door het grote aandeel van ziekenhuis 4 in de groep embryotransfers met 3 of 4 embryo" en een surplus aan embryo"s. Daarom is het zinvol de resultaten per ziekenhuis te vergelijken tussen embryotransfers met en zonder keuzemogelijkheid van terug te plaatsen embryo's. Het totaalbeeld per zickenhwis laat bij deze vergelijking geen verschil zien (zie bijlage 3.31, tabel B3.31.3). Verdere opmerkingen:

- het klinisch zwangerschapspercentage per embryotransfer ligt vaak lets hoger bij aanwezigheid van een surplus aan embryo's, het doorgaand zwangerschapspercentage ligt daarentegen vaak toch iets lager; ofwel bij de embryotransfers met een aanwezig surplus aan embryo's is sprake van een grotere uitval. Een verklaring hiervoor ontbreekt; de verklaring lijkt in ieder geval niet gezocht te kunnen worden in een hogere odcytopbrengst die het gewolg zou kunnen zijn van een meer ingrijpende hormoonstimulatie. Eerder is immers gekonstateerd dal bij behandelingen met een hogere oöcytopbrengst juist een enigszins lagere uitval te zien was tussen klinische en doorgaande zwangerschap

- bij embryotransfers met 3 embryo's zijn in ziekenhuis 4 en in ziekenhuis 2 zelfs beduidend lagere doorgaande zwangerschapspercentages behaald indien er een surplus aan embryo's was (tabel B3.31.4). Bij embryotransfers met 4 embryo's én een surplus aan embryo's zijn daarentegen in ziekenhuis 2 iets betere en in ziekenhuis 4 veel betere zwangerschapsresultaten te signaleren dan bij afwezigheid van een surplus. Het gepropageerde beleid van ziekenhuis 4 om bij een surplus aan embryo's maximaal 3 goede embryo's te selekteren voor een transfer in de lopende behandelcyclus resulteert niet in een relatief hoog zwangerschapspercentage voor embryotransfers van 3 embryo's met de aanwezigheíd van een surplus, integendeel. Het doorgaand zwangerschapspercentage per embryotransfer ligt voor deze groep (18.2\%) opvallend lager dan voor enerzijds de embryotransfers van 3 embryo's zonder aanwezigheid van een surplus $(25.8 \%)$ en anderzijds de embryotransfers van 4 embryo's met anwezigheid van een surplus $(24.2 \%)$.

Konkl. - het aantal teruggeplaatste embryo's heeft een zeer belangrijke invloed op de zwangerschapskans

- ook de subjektjef beoordeelde kwaliteit van de teruggeplaatste embryo's lijkt een positieve verband te vertonen met de zwangerschapskans; meer objektieve maatstaven zijn in ontwikkeling

- in het onderzoek heeft de aanwezigheid van een keuzemogelijkheid voor de terug te plaatsen embryo's niet geleid tot hogere percentages doorgaande zwangerschappen. 


\section{B. Verlloop van de embryotramsfer}

Lit Het verloop van de embryotransfer lijkt volgens Feichtinger[1984a], op basis van een gering aantal waarnemingen, invloed te hebben op de zwangerschapskans. Wood[1985a] spreekt dat nadrukkelijk tegen op basis van een veel groter aantal waarnemingen $(n=870)$. Het verloop van de embryotransfer heeft wolgens hem hooguit invloed bij erg moeizaam verlopen embryotransfers en uiteraard bij niet-gellukte embryotransfers.

Data Na een moeizaam verlopen embryotransfer worden weliswaar lagere zwangerschapspercentages gesignaleerd in vergelijking met normaal verlopen embryotransfers, maar de verschillen zijn niet-signifikant (zie bijlage 3.32). De aanwezigheid van bloed bij de transfer lijkt volstrekt niet van belang te zijn voor de zwangerschapsresultaten.

Konkl - het verloop van de embryotransfer heeft nauwelijks invloed op de resultaten.

\section{Medikatie luteale fase}

Lit. Lee[1987] geeft een uitgebreide literatuurbeschrijving van feiten en onderzoek met betrekking tot luteale-fase-defekten. Vroeg in de follikulaire fase draagt FSH bij aan de vorming van oestradiol; dit oestradiol zorgt op haar beurt weer voor een toename van de FSH-receptoren op de granulosa-cellen. Deze FSH stimuleert vervolgens weer de vorming van LH-receptoren. Welnu, kenmerkend voor een cyclus met een luteale-fase-defekt is dat het corpus luteum ten gevolge van een tekort aan LH/hCG-receptoren onvoldoende reageert op de ontwikkeling van hCG vanaf ongéveer de $9^{\circ}$ dag na de ovulatie. Hierdoor produceert het corpus luteum te weinig progesteron. Dat progesteron prepareert nu juist het endometrium door de werking van immunologische reakties tegen te gaan; hierdoor wordt een implantatie mogelijk en kan een ontstane vroege zwangerschap gekontinueerd worden. Luteale-fase-defekten zijn nat hun waarneembare gevolgen te onderscheiden in een te korte luteale fase en een luteale fase van normale lengte met een verlaagd progesteron-nivo. De prevalentie van luteale-fase defekten in de totale infertiele populatio bedraagt minder dan $5 \%$, maar ligt hoger bij een aantal groepen patibnten, walaronder wrouwen met een herlhaalde spontane abortus, vrouwen waarbij LHRH-analogen of clomifeencitraat is toegediend, perimenopausale vrouwen en patienten met onbegrepen infertiliteit.

O'Neill c.s. (O'Neill[1985], Gidley-Baird[1986]) geven de volgende argumentatie voor toediening van h $\mathrm{CG}$ in de luteale fase. Hoewel circa $45 \%$ van de embryo's morfologisch gezien in staat moet zijn om een zwangerschap tot stand te brengen, blijkt dat slechts $15 \%$ van de embryo's daadwerkelijk implanteert. Dat zou kunnen worden veroorzakt door maternale faktoren. Bij $3 / 4$ van de nietzwangere vrouwen na IVF bleek het oestradiol-nivo in de eerste luteale week 
sterk verhoogd en het progesteron-nivo normal ${ }^{67}$. Aangetoond is dat een kunstmatig werhoogd oestradiol-nivo in de post-conceptie periode implantatie verhindert. En aangezien oestradiol en progesteron tot op zekere hoogte een tegengestelde werking op cellulair niwo hebben zou kunstmatige verhoging van het progesteron-niwo wellicht de zwangerschapskans kunnen verhogen. Bij de vervolgens uitgevoerde gerandomiseerde studie $(n=60)$ bleek in de groep zonder Iuteal support $(n=25)$ niemand zwanger te zijn en in de groep thet $1500 \mathrm{IE}$ hCO op luteale-fase-dag $1,3,5$ en $7(n=35)$ werd $40 \%$ zwanger (14/35).

Trounson[1986a] en Wood[1985a] bestrijden de zin van progesteron-suppletie in de luteale fase. Een verhoogd progesteron-nivo tijdens de luteale fase woor zwangeren heeft op zich weinig betekenis, aangezien dit volgens hen waarschifnlijk veroorzaakt wordt door een oververtegenwoordiging in de groep zwangeren van patiënten met veel follikels, oocyten en embryo's. Deze patiënten hebben uiteraard gemiddeld meer corpora lutea en daardoor een hoger progesteron-nivo in de vroeg-luteale fase ${ }^{6 .}$.

Belaisch-Allart[1987] voerde een gerandomiscerd, dubbel-blind onderzoek uit naar de mogelijke invloed van luteale ondersteuning. Hij konstateert weliswaar een hoger klinische zwangerschapspercentage per embryotransfer voor de groep met luteale ondersteuning (dydrogesteron) ten opzichte van de placebo-groep, maar het verschil is niet-signifikant: $21.6 \%$ versus $15 \%$ (totale $\mathrm{n}=258 \mathrm{ET}$ "s). Daarmee kan dit onderzoek in een rijtje van andere studies worden geplaatst (onder anderen Leeton[1985]) die meestal in dezelfde richting wijzen, maar geen signifikante verschillen opleveren.

V. Steirteghem[1988] geeft aan dat de opkomst van het gebruik van LHRHanalogen naar zijn mening studies naar de luteale ondersteuning vrijwel onmogelijk heeft gemaakt. Hij maakt melding van 2 gerandomiseerde studies die zijn uitgevoerd voor IVF en GIFT tezamen:

1. Vergelijking van de resultaten na ovulatie-induktie met behulp van $\mathrm{cc} / \mathrm{hMG}$ tussen cycli met luteale progesteron-suppletie en geen luteale ondersteuning (totale $n=168$ ); het klinisch swangerschapspercentage per follikelpunktie bedroeg respektievelijk $17.6 \%$ en $13 \%$. Het verschil was echter nietsignifikant, terwijl de studie doodbloedde door de opkomst van de LHRHanalogen. Want bij gebruik van deze analogen vond altijd luteale ondersteuning plaats.

2. Vergelijking van de resultaten na stimulatie met behulp van LHRHanalogen/hMG tussen twee vormen van luteale ondersteuning: progesteron én oestradiol versus $\mathrm{HCG}$ (totale $n=91$ ): het klinisch zwangerschapspercentage is identiek woor beide groepen: $26 \%$.

Bij (observationele) vergelijking van de resultaten tussen behandelingen met al dan niet luteale ondersteuning wordt wel een signifikant verschil gesignaleerd.

67) In Nortolk (Muasher[1984a]) werden overigens vrijwel geen signifikante werschillen gevonden in het nivo wan de oestradiolen en van progesteron in de lhteale fase tussen zwangeren en niei-zwangeren (met witrondering vam luteale fase-dag 11).

68) Vanwege dezelfoe reden zijn de progesteron-niwo's wan gestimuleerde WF cycli hoger dan die wan naluurijike cycli. 
Maar de vraag blifft onbeantwoord in hoeverre de betere resultaten worden veroorzaakt door het gebruik van de LHRH-analogen (met ondersteuning in de luteale fase) of door de luteale ondersteuning zelf.

De vraag of luteale ondersteuning werkelijk noodzakelijk is, blijkt evenwel niet unaniem positief te worden beantwoord. Hoewel v.Steirteghem[1988] daar zonder meer vanuit ging en Smith[1989] dit in een gerandomiseerd onderzoek $(n=115)$ aantoont, blijkt dit volgens Belaisch-Allart[1989] in een ander gerandomiseerd onderzoek $(n=451)$ geenszins het geval te zijn.

Data Hoewell luteale ondersteuning in de een of andere worm een vast onderdeel wormt van de IVF-behandeling in alle 5 de ziekentuizen, is het nut van een dergelijk beleid diskutabel (indien er geen gebruik is gemaakt van LHRHanalogen). Een vergelijking tussen behandelingen met en zonder luteale ondersteuning is echter binnen deze studie onmogelijk door een gebrek aan behandelingen uit de laatstgenoemde groep. De zwangerschapsresultaten binnen de werschillende ziekenhuizen verschillen niet-signifikant tussen verschillende wijzen van luteale ondersteuning, met uitzondering van de behandelingeth in ziekenhuis 2 met Progesteron en Pregnyl (zie bijlage 3.33). Bij dit verschil kan echter dezelfde onbeantwoordbare vraag worden gesteld als hierboven bij het artikel van Van Steirteghem: worden de betere resultaten veroorzaakt door de LHRH-analogen of door (wijziging in) de luteale ondersteuning? Beỉde veranderingen in het beleid zijn immers gelijktijdig doorgevoerd.

Konkl. - de zin van medikamenteuze ondersteuning van de luteale fase blijft dubieus: de resultaten bij ondersteuning zijn veelal iets beter, maar de verschillen zijn niet-signifikant; ieder ziekenhuis in het onderzoek geeft luteale ondersteuning

\section{Cryopreservatie}

Lit. De eerste partus ten gevolge van een embryotransfer na cryopreservatie en ontdooien staat op naam van het Dijkzigt-ziekenhuis ${ }^{69}$ en dateert van december 1983 (Zeilmaker[1984]).

Trounson $([1985]$, , $1986 \mathrm{~b}])$ geeft een goed overzicht van de stand van zaken rond cryopreservatie in 1986. In de literatuur werden in die tijd zwangerschapspercentages (zwangerschap verschillend gedefinieerd) na cryopreservatie en ontdooien gemeld uiteenlopend van:

- $11 \%$ tot $28 \%$ per patiént mét een embryotransfer

- $8 \%$ tot $14 \%$ per patient waarvan embryo"s zijn ingevroren.

Mohr[1985] geeft aan dat het aandeel embryo's dat na cryopreservatic en ontdooien nog minstens $50 \%$ intakte blastomeren heeft circa $40 \%$ bedragt ${ }^{2}$

69) Overigens werd door de auteurs van het artikel niet geheel uitgestoten dat de zwangerschap in de betreffende cyclus spontaan was ontstaan, hoewel de kans hierop zeer klein mag worden geacht.

70) Daarbij is geen verschil gekonstateerd tussen embryo"s die als goed c.q. siechl waren gekwalificeerd; wel lag het percentage intakte blastomeren iets hoger voor 8-cellens ten opzichle van 4-cellem. 
Verder kan nog worden opgemerkt dat lang niet na iedere follikelpunktie embryo's kunnen worden ingevroren. De uitgebreide mogelijkheden tot geselektecrde resultaatvermeldingen met betrekking tot cryopreservatie maken een goede vergelijking derhalve moeilijk.

In Monash, Melbourne zelf waren de resultaten ongeselekteerd (Freeman $[1986]):$

- van 205 patienten werden embryo's ingevroren die bijna alle zijn ontdooid (396 van 402 embryo's)

- 229 embryo's (58\% van de ontdooide embryo's) werden teruggeplaatst bij 144 patiënten ( $70 \%$ van alle patiënten met ingevroren embryo's)

- dit leidde tot 16 zwangerschappen ${ }^{71}$, dus $11 \%$ per embryotransfer.

Faktoren die volgens Trounson[1986b] van invloed kunnen zijn op de resultaten na cryopreservatie zijn:

- het aantal teruggeplaatste embryo's; gemiddeld implanteert $8 \%$ van het aantal teruggeplaatste embryo's

- het ontwikkelingsstadium van de embryo's ten tijde van de cryopreservatie; dit kan variëren van het pronucleï-stadium ${ }^{72}$ tot en met het blastocyst-stadium (zie ook Testart[1986b]). Overigens groeit slechts $40 \%$ van de bevruchte oöcyten in vitro door tot het blastocyst-stadium

- de embryokwaliteit in termen van regulariteit en fragmentatie; Mandelbaum[1988] geeft hiervan aan dat de overlevingsgraad ${ }^{73}$ voor normale embryo's signifikant hoger is dan voor embryo's met fragmenten of ongelijke blastomeren: $67 \%$ versus $51 \%$

- het resultaat in de reguliere IVF-cyclus: het zwangerschapspercentage per 'cryo-ET' was lager bij patiënten die in de reguliere cyclus niet zwanger waren geworden $(n=120)$ ten opzichte van degenen die wel zwanger waren geworden in de reguliere IVF-cyclus $(\mathrm{n}=22): 6 \%$ respektievelijk $41 \%$

Naast de embryo- en receptiviteitsparameters zijn er ook technische parameters die invloed hebben op de resultaten na cryopreservatie, onder andere de gebruikte cryoprotectant; Mandelbaum[1988] signaleerde een signifikant lagere overlevingsgraad per embryo bij gebruik van alleen propanediol in vergelijking met propanediol in kombinatie met sucrose: $32 \%$ versus $62 \%$ (totale $\mathrm{n}=687$ ).

Vanuit Clamart maakt Testart regeimatig melding van onwaarschijnlijk goede resultaten van embryotransfers na cryopreservatie. Aanvankelijk rapporteert Testart[1987a] over 104 paren waarvan alle ingevroren embryo's inmiddels zijn ontdooid. Er is bij deze paren niet altijd een embryotransfer uitgevoerd tijdens de cyclus van de follikelpunktie. De embryotransfers na cryopreservatie vonden voor $2 / 3$ plaats in spontane cycli terwijl bij $1 / 3$ van de cycli 1 ampul hMG werd toegediend op de cyclusdagen 6,8 en 10 met soms hCG; er werd geen luteale ondersteuning gegeven.

71) Dit is waanschijnlijk inklusief bio-chemische awangerschappen.

72) Het is mogelijk oöcyten in te vriezen. Vooralsnog leidt dit volgens een literatuurowerzicht van Mandelbaum[1988) echter tot lage overlevingsgraden (circa 30\%) en bij de overlevende oöcyten leidt de inseminatie tot lage fertilisaliegraden ( 30 a $40 \%$, met uitzondering van cen onderzoek wan Chen). Overlewing wordt gedefinieerd als minimaal $50 \%$ van de blastomeren nog intakt. 
Tabel 3.8. Resultaten van embryotransfers na cryopreservatie in Clamurt (Testart [1987a])

\begin{tabular}{lcc} 
& verse ET's & ET's na cryo-ontoool \\
\hline aantal mbryo's beschikbaar & 166 & 151 \\
aantal embryo's teruggeplaatst & 166 & $93(62 \%$ van 157$)$ \\
aantal ET's & 63 & 77 \\
gem. aantal embryo"s terug per ET & 2.6 & 1.2 \\
aantal ktim. zwang. (\% per ET) & $8(13 \%)$ & $19(25 \%)$
\end{tabular}

Dus bij embryotransfers na cryopreservatie werden hogere zwangerschaps. percentages bereikt ondanks een gemiddeld lager aantal teruggeplaatste embryo's. Hierbij kan de kanttekening worden geplaatst dat waarschijnlijk alleen de sterkste embryo's het invriezen en ontdooien hebben overleefd. Maar zelfs het gemiddeld aantal ingevroren embryo's per "cryo-ET" lag lager dan het gemiddeld aantal teruggeplaatste embryo"s bij de "verse ET's" 74 . Volgens Testart moet de verklaring voor de verschillen in de zwangerschapsresultaten dan ook niet zozeer gezocht worden in verschillen in de embryokwaliteit, maar veel meer in de uteriene receptiviteit. Deze zou in de gestimuleerde cyclus wel eens danig verstoord kunnen zijn. Even later meldt Testart[1987b] opnieuw resultaten van cryopreservatie over de periode februari '85-juni ' 86 ; deze zijn weergegeven in tabel 3.9.

\section{Tabel 3.9. Resultaten van embryotransfers na cryopreservatie in Clamart (Testart[1987b])}

$\begin{array}{ll}\text { aantal cycli met ontdooien } & 130 \\ \text { aantal enbryo's cryo/ontdooid } & 193 \\ \text { aantal embryo's teruggepleatst } & 124(64 \text { vain 193) } \\ \text { aantal ET "s } & 100 \\ \text { aantal chentische zwang. (* per ET) } & 26(26 \%) \\ \text { aantal doorg. zwang. (\% per ET) } & 17(17 \%)\end{array}$

Hij geeft verder nog aan dat het suksespercentage mede wordt beinvloed door:

- het ontwikkelingsstadium van de embryo's ten tijde van de cryopreserwatie, waarbij 4-cellers de beste resultaten lieten zien

74) Hier speelt nog dootheen, dat de indruk bestaat dat men in Clamart voonover mogelijk probeert de relatief (en subjektief) beste embryo"s te reserveren voor cryopreserwatie. Ook het relatief lage zwangerschapspercentage per verse embryotransfer wijst in deze richting. 
- de kwalliteit van de embryo's ten tijde van de cryopreservatie, deze is van invloed op de overlevingskans na ontdooien.

Kort daarna geeft 'Testart[1988] de resultaten van februar' '85 - december ' 86 op een andere manier weer. Hij kijkt nu alleen naar cycli warbij embryo's zijn ingevroren (meer dan cens werden er geen embryo's teruggeplaatst in de cyclus van (ci follikelpunktie) en vergelijkt de implantatiekans per embryo tussen 'verse ET's' en 'cryo-ET's' ${ }^{75}$ :

- bij gycli met slechts 1-3 embryo's beschikbaar was deze implantatiekans per embryo signifikant lager voor 'cryo-embryo's' ten opzichte van 'vers teruggeplaatste embryo's": $6 \%$ versus $16 \%$

- bij cycli met minstens 4 embryo's beschikbaar was de implantatiekans gelijk voor beide typen embryo's: $11 \%$.

V. Steirteghem[1987] meldt de resultaten met betrekking tot ingevroren embryo's (na IVF en/of GIFT) van een ander centrum met een goede reputatie op het gebied van de cryopreservatie: Brussel in de periode november ' 85 oklober " 86 :

- van de 636 ingevroren 'embryo's' (waaronder 183 in het pronucleï-stadium) zijn er inmiddels 288 ontdooid.

- hiervan waren 126 embryo's (44\%) geschikt voor een transfer ${ }^{76}$; het percentage bleek mede afhankelijk te zijn van de kwaliteit van de embryo's wóor de cryopreservatie

- de 126 teruggeplaatste embryo's leidden via 110 transfers tot 20 zwangerschappen, waarvan 18 doorgaand ( $16 \%$ per ET).

Mandelbaum[1988] geeft aan dat een algemene verhoging van de zwangerschapsresultaten bij IVF door middel van de optie van cryopreservatie in 1986 in ieder geval nog een illusie was. Immers, voor het totaal aantal embryotransfers gold (bij een beleid waarbij maximaal 4 embryo's per cyclus worden teruggeplaatst) het volgende:

- bij $84 \%$ van de embryotransfers was geen sprake van overtollige embryo's die ingevroren zowden kunnen worden; het percentage klinische zwangerschappen per embryotransfer bedroeg in deze groep $22 \%$

- slechts bij 179 embryotransfers (16\%) was sprake wan de aanwezigheid van extra embryo's die werden ingevroren; het percentage klinische zwangerschappen per 'verse ET bedroeg in deze groep $23 \%(n=41)$. Bij de 'cryo-ET's' in deze groep werden nog 17 extra klinische zwangerschappen bereikt.

Voor de groep behandelingen waarbij de follikelpunktie heeft geleid tot een embryotransfer én het invriezen van extra embryo's, wordt het klinisch

75) Hel is niet getteel duidelijk hoe de onderstaande konstateringen te rijmen zijn met de eerdere signatering dat 'cryo-ET"s" tot hogere zwangerschapsresultaten hebben geleid, ondanks een gemiddeld lager aantal teruggeplaatste embryo's. Vragen als deze zijn overigens niet zeldzaam bij vergelijking van publikaties van Testart e.a. over de resultaten bij cryopreservatie. De presentatic van het ciftermateriaal is nlet altijd voldoendle inzichtelijk voor een onderlinge wergellijking.

76) Bij 147 'embryo's' ( $51 \%$ ) was nog minstens de belft van de blastomeren intact na ontdooien; maar 21 hiervan bleken bij mader inzien toch niet geschikt voor een embryotransfer in verband met een ernstige beschadiging van de zona pellucida of het uilblijven in vivo van celdeling na het pronuclëstadium. 
Wwangerschapspercentage per follikelpunktie ${ }^{77}$ door middel van het gebruik wan cryopreservatie verhoogd van $23 \%$ naar $32 \%$. Helaas gold slechts voor $16 \%$ van de embryotransfers dat er embryo's konden worden ingevioren. In totaal is het gemiddellde klinisch zwangerschapspercentage per "verse ET" - inklusief de zwangerschapsresultaten van de bijbehorende 'cryo-ET's - door middel van de cryopreservatie slechts verhoogd van $22 \%$ naar $24 \%$.

Data Tijdens de periode van het evaluatie-onderzoek IVF was er 218 keer sprake van cryopreservatie van een of meerdere embryo's, ruim $3 / 4$ van deze cryopreservaties werd uitgevoerd in én ziekenhuis. Voor dat ziekenhuis geldt dat bij ruim $1 / 4$ van de embryotransfers ${ }^{78}$ embryo"s werden ingevroren; in de helft van deze gevallen zijn maximaal 2 embryo's ingevroren.

De embryotransfers na cryopreservatie hebben woor een gedeelte betrekking op embryo's die zijn ingevroren tijdens behandelingen die hebben plaatsgevonden in de periode voor de start van het evaluatie-onderzoek. Hieronder wordt volstaan met het vermelden van de resultaten van embryotransfers die na cryopreservatie zijn uitgevoerd in de periode van het evaluatie-onderzoek. Binnen de registratic is alleen vanuit ến ziekenhuis melding gemaakt van dergelijke embryotransfers. Bij patienten die in dat ziekenhuis zijn gepunkteerd, zijn tijdens de onderzoeksperiode in totaal 42 embryotransfers na cryopreser* vatie uitgevoerd, leidend tot 2 (klinische en) doorgaande zwangerschappen: 1 eenling en 1 tweeling. Dit betekent een doorgaand zwangerschapspercentage per 'cryo-ET' van $5 \%{ }^{79}$. Dit komt overeen met het totaalbeeld in Nederland tijdens de onderzoeksperiode (Haan[1989a]).

KonkL - de resultaten van de cryopreservaties zijn in Nederland vooralsnog van dien aard dat hierdoor geen wezenlijke bijdrage wordt geleverd aan de zwangerschapsresultaten van de IVF-populatie

- de resultaatvermeldingen van cryopreservaties in publikaties uit Clamart en Brussel lijken aan enige vertekening onderhevig te zijn.

\subsubsection{Resultaat van de klinische zwangerschap}

Lit. Alvorens nader in te gaan op de afloop van de bereikte klinische zwangerschappen met behulp van een IVF-behandeling, kan het verhelderend werken eerst aandacht te besteden aan de zwangerschaps-terminologíe. Jones[1983b] maakt onderscheid in de volgende soorten zwangerschappen:

77) Het klinisch zwangerschapspercentage per follikelpunktie is in dit geval gelijk ann dat per "werse E $\mathrm{T}$, indien de 'cryo-ET's' niet als teleenheid voor de embryotransfers worden beschouwd, maar de zwangerschapsresultaten erwan wel worden meegerekend bij die van de bijbelyorende "verse $\mathrm{Er}^{\mathrm{T}}$.

78) Dit komt overeen met ruim 1/5 van de follikelpunkties.

79) Er is hierbij nog afgezien van de vele malen, warbij het ontooien wan embryo's niet geregultexud heeft in een embryoterugplaatsing. Overigens zijn er ook in die cycli kontroles witgevoerd ten behoeve van de timing van de eventuele embryotransfer. 
- menstruele abortus:

- preklinische abortus:

- klimische abortus:

- vitale zwangerschap:

Hieruit kan worden afgeleid dat de term klinische zwangerschap van toepassing is op zwangerschappen waarbij de menstruele bloeding minstens is uitgesteld tot 28 dagen na de follikelpunktie.

Lancaster[1985] merkt nog op dat er in de IVF-praktijk gewerkt wordt met twee soorten van termijnbepalingen voor de zwangerschapsduur:

- de gynaccologische termijnbepaling, waarbil gerekend wordt vanaf de eerste dag van de laatste menstruatie

- de embryologische termijnbepaling, waarbij gerekend wordt vanaf het moment van fertilisatie.

Globaal geldi:

gynaecologische termijnbepaling $\approx$ embryologische termijnbepaling +2 weken.

Jones[1983b] geeft ook aan dat zijns inziens cijfers omtrent zwangerschappen in de kategorieen menstruele abortus en preklinische abortus sterk vertekend kunnen worden door de aard van de test en het gevolgde medikatieschema in de luteale fase. Maar wellicht kunnen de resultaten van $\mathrm{HCG}$-testen wel informatie verschaffen over de vermoedelijke afloop van de zwangerschap. Volgens Conlino[1986a] kan men met behulp van het plasma-hCG-nivo op Iuteale-fase-dag 9 niet alleen zwangerschappen detekteren, maar vormt deze parameter ook een aardige discriminant voor het verdere verloop van de zwangerschap. Het onderzoek betrof een multi-center-studie, waarbij geen hCGmedikatie werd toegediend binnen 9 dagen voor de bepaling. Bij nadere bestudering wan de publikatie blijkt dat in verband met grote standaardafwijkingen alleen de bio-chemische zwangerschap vroegtijdig (dat wil dus zeggen op lutealc-fase-dag 9) enigszins voorspelbaar is. Deze informatie op dat moment lijkt, mede gezien de onvermijdelijke onzekerheid ervan, in ieder geval voor het paar zinloos. Maar wellicht kan zij wel bijdragen aan een beter begrip van het implantatieproces en het verdere verloop. Zo merkt dezelfde Confino[1986c] op dat het HCG-patroon bij zwangerschappen verschilt tussen:

- spontane zwangerschappen zonder IVF en doorgaande zwangerschappen ontstaan uit embryotransfers van 1 embryo

- afgebroken zwangerschappen ontstaan uit embryotransfers van 1 embryo

- zwangerschappen ontstaan uit embryotransfers van meerdere embryo's: cyclisch verloop van $\mathrm{HCG}$

Zijn hypothese luidt dat de (cyclische) HCG-daling samenhangt met het afsterven van embryo('s) na aanvankelijke implantatie. worden gehanteend. Waarschijnlijk wordt met vitaliteit bedoeld: positieve hartaktie gesignaleerd en minimale zwangerschapsduur van 20 weken. 
De uitval tussen klinische en doorgaande zwangerschap bestaat in feite uit twee kategorieen:

- klinische abortus, al of niet na de signalering van een of meerdere vruchtzakken met al of geen hartaktie

- extra-uteriene graviditeit (EUG).

Indien de incidentie van klinische abortus en EUG bij IVF vergeleken wordt met die in de natuurlijke cyclus of bij andere vormen van fertiliteitsbehandeling is het belangrijk te beseffen dat de populaties waarschijnlijk verschillen vertonen in samenstelling.

Zo is bekend dat de kans op een spontane abortus in de 'normale' populatie verhoogd is:

- op hogere leeftijd (Schullman[1985], Jansen[1982], Gindoff[1986]); het percentage spontane abortus per klinische zwangerschap liep in deze studies op: $10 \%$ in de leeftijdsgroep $20-29,12$ a $15 \%$ in de groep $30-34,18$ a $20 \%$ in de groep $35-40,34 \%$ in de groep $40-44$ en ruim $50 \%$ in de leeftijdsgroep vanaf 45 jaren

- als de vrouw reeds een spontane abortus heeft gehad (Jansen[1982]); zonder eerdere abortus lag het percentage op circa $10 \%$, terwijl het bij 1 of meerdere eerdere abortussen was opgelopen tot 20 a $30 \%$.

Het percentage klinische abortus per klinische zwangerschap na een IVFbehandeling bedraagt in de literatuur 25 a $30 \%$ (onder andere in Bourn Hall (Edwards[1984a]), Norfolk (Jones[1984]), Melbourne (Trounson[1984a]) en bij] het World Collaborative Report uit 1984 (Seppala [1985]) en in Australie (NPSU[1985])). Terwijl Edwards[1984a] en duidelijk verhoogd abortuspercentage konstateert op hogere leeftijd en voor transfers van meerdere embryo's, kan dit laatste verband niet bevestigd worden door de data uit Norfolk (Jones[1984], Muasher[1984b]). De bevinding van een hoger abortuspercentage op hogere leeftijd wordt echter bevestigd door de data van een multi-centre-studie in Australie (NPSU[1985]).

Het percentage EUG per klinische zwangerschap na een IVF-behandeling bedraagt in de literatuur 2 a $6 \%$ in vergelijking met circa $1 \%$ in de normale populatie (onder anderen Martinez[1986], Seppäla[1985], NPSU[1985], Cohen[1987b]). De gemelde percentages EUG's vertonen overigens een grote spreiding. Hoewel deze spreiding gebaseerd kan zijn op toeval (het betreft. immers kleine aantallen), zijn in de literatuur ook diverse plausibele verklaringen aangedragen en getoetst. Yovich[1985b] vergeleek 190 embryotransfers met plaatsing hoog in de uterus met 406 embryotransfers met plaatsing lager in de uterus. Het zwangerschapspercentage bleek nagenoeg identiek te zijn (respektievelijk 24 en 56 klinische zwangerschappen), maar het percentage EUG per klinische zwangerschap lag in de eerste groep $8 \times$ zo hoog (4 EUG's versus 1 EUG). De kleine aantallen laten op dit punt evenwel geen algemene konklusie toe. Cohen[1987b] meldde een incidentie van EUG per klinische zwangerschap van $5 \%$ bij 0 of 2 doorgankelijke tubae en van $10 \%$ bij 1 doorgankelijke tuba. Tussen het optreden van EUG bij de IVF-behandeling en een EUG in de anamnese vond hilj geen samenhang.

De uitval na het bereiken van een doorgannde zwangerschap is procentueel gering. In Australie (NPSU[1985]) werd een totale perinatale sterfte bij IVF 
gesignaleerd wat $4.7 \%$ (prendaal $3.6 \%$ en neonatal $1.1 \%$ ), gesplitst woor eenlingen $3.8 \%$ en voor meerlingen $4.7 \%$. De nationale perinatale sterfte ligt in Australie op $1.2 \%$. De relatiel hoge perinatale sterfte bij IVF hing gedeeltelijk samen met een relatief hoge mata van praematuriteit van de partussen. Van de doorgaande zwangerschappen was in totaal $27 \%$ praematuur ${ }^{81}$. Ook de incidentie van een laag geboortegewicht $(<2500 \mathrm{~g})$ was hoog: $34 \% \%$. Diamond [1987] kon deze resultaten niet bevestigen: van de 45 kinderen uit 39 doorgaande zwangerschappen waren er slechts 3 praematurur $(7 \%$ ). De incidentie van laag geboortegewicht was $16 \%$ (voor eenlingen $3 \%$, woor tweelingen $60 \%$ ).

De transfers van meerdere embryo"s tegelijkertijd hebben niet alleen de Kinische zwangerschapspercentages bij IVF laten stijgen, maar ze hebben ook geleid tot een relatief hoge incidentie van meerlingzwangerschappen na een IVF-behandeling. In centra zoals Bourn Hall in Cambridge en Monash University in Melbourne worden om die reden maximaal 3 embryo's teruggeplaatst; het percentage tweelingzwangerschappen per klinische zwangerschap bedraagt woor deze centra 10 a $15 \%$ (Edwards[1984a], Leeton[1983]), hetgeen circa $10 \mathrm{x}$ zo hoog is als in de totale populatie.

In de multi-centre-studie in Australie (NPSU[1985]) wordt per doorgaande zwangerschap een meerling-zwangerschaps-percentage gemeld van $24 \%$ (alleen tweeling-zwangerschappen 20\%); bij transfers van minimaal 3 embryo's lag het percentage de helft hoger: $36 \%$ (alleen tweeling-zwangerschappen 30\%).

Lancaster[1985] merkt over het optreden van meerlingzwangerschappen bij IVF nog op dat infertiele paren een meerlingzwangerschap dikwijls zien als een mogelijkheid tot de realisatie van een zogenaamde 'instant' familie. De medische risiko's en de maatschappelijke konsekwenties worden dan niet erkend. Een ethisch belangrijke kwestie wordt gevormd door de mogelijkheid van embryo-reduktie na implantatie van meerdere embryo's (overigens zeker niet alleen van toepassing bij IVF). Brandes ${ }^{84}[1987$ ] (uit het Rambam Hospital) meldt bijvoorbeeld de reduktie van een vijfling tot een drieling in de $10^{\circ}$ week. Het percentage keixersnedes per doorgaande zwangerschap bedroeg bij een wereldwijd onderzoek onder 65 IVF-centra 49\% (Seppalad[19851) en in Australie (NPSU[1985]) 43\% B5. Als vergelijkingsmateriaal kan een studie van Notzon[1987] dienen. Deze stelde een overzicht samen van het percentage keizersnedes per partus in diverse landen in de loop der jaren. De cijfers voor de belangrijkste IVF-landlen zijn onderstaand weergegeven.

81) Pracmaturiteil is hierbij in overeenstemming met wHO gedefinifeerd als een (gynaecologisclye) zwangerschapsdutur ten tjde van de partus korter dan 37 volledige weken. Bij cenlingen $(n=392)$ lag dit percentage lager: $19 \%$; daarentegen was het bij tweelingen $(n=104) 49 \%$ an bij drielingen $(n=17) 94 \%$

82) Gedifferentieerd: woor eenlingen $15 \%$ voor tweelingen $54 \%$ en voor drielingen $92 \%$.

83) Hierbij ging het voomamelijk om transfers van 3 of 4 embryo's. Transfers van 5 of 6 enbryo's kwamen zeer zelden voor.

84) Enkele citaten uit die publikatie luiden. "If unwanted multiple pregnancy occurs, the parents should have the option of reducing the number of fetuses" $\mathrm{en}$ "When reduction of the number of embryos in a multiple pregnancy was decided upon, a thorough explanation and discussion with the couple should be persued". De (rethorische) wraag is of deze diskussie niet beter voorafgand aan de embryotransfer had kunnen plaatsvinden.

85) Gedifferentieerd: $39 \%$ bij eenlingen, $55 \%$ bij weelingen en $77 \%$ bij drielingen. 
Tabel 3.10. Percentage keizersnedes per partus in 1980 in enkele landen wagr IVF wordt uitgevoerd

$\begin{array}{lr}\text { Verenigde Staten } & 17 \% \\ \text { Australie } & 13 \% \\ \text { Frankrijk } & \pm 10 \% \\ \text { Engeland } & 9 \% \\ \text { Nederland } & 5 \%\end{array}$

Ondanks het feit dat deze percentages nogal verschillen per land; kan in het algemeen wel gesteld worden dat IVF-bevallingen veel vaker ( 3 a 5 zo vaak) via een keizersnede verlopen. Vraag blijft echter in hoeverre het verhoogde percentage bij IVF te maken heeft met de IVF-behandeling zelf. Notzon[1987] gaf bijwoorbeeld aan dat in alle landen het percentage keizersnedes hoger lag bij eerst-geboorten en bij een hogere leeftijd van de vrouw (onder dan 34). Daarnaast valt niet uit te sluiten dat zwangerschappen die dikwijls na een lange infertiliteitsduur zijn bereikt door paar en wellicht ook arts gevolgd worden met een, rationeel gezien, overmatige medische zorg.

Bij naturlijke cycli hebben wolgens Schulman[1985] 40 a $50 \%$ van de geimplanteerde embryo's chromosomale afwijkingen (maar vrijwel al deze embryo's gaan langs natuurlijke weg 'verloren"). Daarenboven komt Cohen[1986a] tot de konklusic dat slechts $10 \%$ van de uit IVF verkregen embryo's cytologisch normaal is. En hoewel niet alle verkregen embryo's worden teruggeplaatst in de uterus, bestaat toch al sinds jaar en dag de angst dat bij IVF de kans op abnormaliteit groter is dan bij spontaan ontstane zwangerschappen. Deze angsi is voornamelijk ingegeven door twee belangrijke verschillen tussen de IVFpraktijk en de natuurlijke cyclus:

- er worden buiten het menselijk lichaam handelingen uitgevoerd met humane gameten

- er worden veelal meerdere embryo's tegelijkertijd teruggeplaatst.

Ten behoeve van cen vergelijking van de risiko's op abnormaliteit bij IVF ten opzichte van de normale populatie bouwt Schlesselman[1979] een framework op ter referentie voor de IVF-resultaten. Maar ook zijn konklusie blijft dat cen vergelijking van IVF met "normalal' uiterst moeilijk is. De incidentic van specifieke kongenitale of chromosomale afwijkingen is bij pasgeborenen nu eenmaal zeer gering. En als er al relatief grote verschillen gesignaleerd zouden worden, dan blijft nog de onzekerheid of die verschillen nu samenhangen met de IVF-procedure of met een verschil in samenstelling van de populaties. Zo lijkt bijvoorbeeld de incidentie van trisomy 21 bij amniocentese sterk toe te nemen op hogere leeftijd: vanaf 35 tot circa 41 jaar oplopend van $0.3 \%$ tot $1.5 \%$, daarna snel oplopend tot ca. $5 \%$ (Ferguson-Smith[1983]). Een ander probleem wordt dikwijls (in het buitenland) gevormd door een onvolledige of niet-centrale registratie van afwijkingen, zowel bij IVF-zwangerschappen als in de algemene gynaecologische/obstetrische praktijk. In Australie (NPSU[1985]) lijkt dit probleem redelijk aangepakt te zijn. Bij een studie in 12 TWF-centra werd in de groep (levend-en dood-)geboren kinderen bij $2.6 \%$ een ernstige kongenitale afwijking gesignaleerd (bij eenlingen $1.8 \%$, bij meerlingen $3.4 \%$ ), 
terwijl dit percentage voor de totale populate in Australie $1.5 \%$ bedragt. De verschillen waren echter niet signifikant.

Data Binnen het evaluatie-anderzoek is, in aansiuiting op Jones[1983b], de term klinische zwangerschap gedefinieerd als geen menstruatie $\leq 26$ dagen na de embryotransfer. Derhalwe wordt met een klinische abortus bedoeld een klinische, uteriene zwangerschap die niet resulteert in een doorgaande wangerschap. De grens woor een doorgalande zwangerschap is gelegd bij 12 weken na de embryotransfer ${ }^{87}$ (hetgeen min of meer overeenkomt met een gynaccologische termijn wan 14 weken); bovendien moet er hartaktie zijn gesignalleerd. Van een partus immaturus wordt gesproken bij een termijn van 12 tot 26 weken vanaf de embryotransfer (hetgeen min of meer overeenkomt. met een gynaecologische termijn van 14 tot 28 weken).

Van de 416 klinische zwangerschappen waren er 93 miet doorgaand $(22 \%)$; hiervan eindigden er 69 in een abortus, 23 in een EUG en 1 in een kombinatie van EUG en abortus. Derhalve bedroeg het percentage abortus c.q. EUG per klinische zwangerschap $17 \%$ respektievelijk $6 \%$.

Over de relatie tussen het optreden van een EUG en/of een spontane abortus bif een IVF-behandeling en anderzijds fertiliteitsbevorderende tubachirurgie, EUG of abortus in de anamnese kan het volgende worden opgemerkt. In totaliteit bedroeg (op behandelnivo) het percentage EUG, abortus c.q. tubachirurgie in de anamnese respektievelijk $22 \%$, $14 \%$ en $62 \%$. Bij IVFbehandelingen resulterend in een EUG waren de percentages voor EUG en tubachirurgie in de anamnese enigszins verhoogd, te weten $39 \%$ en $83 \%$. Zo ook golden voor IVF-behandelingen resulterend in een spontane abortus de volgende percentage voor abortus en tubachirurgie in de anamnese: $23 \%$ en $71 \%$. Vergaande konklusies kunnen evenwel uit het bovenstaande niet worden getrokken. Enerzijds is hiertoe het aantal waarnemingen te beperkt: een relatief gering aantal waarnemingen in de groepen IVF-behandelingen resulterend in een $\mathbb{E U G}$ c.q. abortus. Anderzijds is het zeer wel denkbaar dat er een verstoring wordt veroorzaakt door faktoren zoals leeftijd van de vrouw en konditie van de tubae van de vrouw.

Van de 323 doorgaande zwangerschappen zijn er 10 (c.q. $7^{87}$ ) gesindigd in een partus immaturus.

86) In afwikking wam Jones is gekozen voor cen wegrenzing gerekend vanaf de dag van de embryotransfer in plaats van de dag van de follikelpunktile in verband met de mogelijkheid embryotransfers uit de voeren na cryopreservatic/ ontdooien. Dit onderscheid is van theoretisch belang, omdat in de praktijk het interval tussen follikelpunktie en embryotransfer in eten behandelcyclus niet per definitie gelijk is aan 2 dagen. In de praktijk heeft dit onderscheid uiteraard nagenoeg geen betekenlls.

87) De grens van 14 weken is enigszins afwijkend van de in Nederland gebruikelijke grens van 16 weken. In alle eerlijkheid moet de auteur erkennen dat niet meer geheel duidelijk is waarom van de gebruikelijke grens is afgeweken. Kontrole van de data op deze afwijking in definitie leert dat in 3 gevallen de awangerschap is beethdigd tussen de $12^{*}$ en $14^{*}$ week na de embryotransfer ( $\approx$ gnaecologische termijn wan 14 a 16 wekenj, telkens dichtbij de kritische grens van de $14^{\text {e }}$ week. Bij de in Nedertand gebruikelijke definitie van doorgande zwangerschap zouden derhalve 3 partus immaturus veranderen in een spontane abortus; dararmee zou het aantal partus immaturus dalen tot 7 . 
Het percentage doorgaande zwangerschappen per klinische zwangerschap lag in de groep embryotransfers met meer dan 2 teruggeplaatste embryo's zeker niet lager dan in de groep embryotransfers met 1 of 2 teruggeplaatsie embryo's (integendeel: $79 \%$ versus $70 \%$ ).

De doorgaande zwangerschappen die hebben geleid (of hoogstwaarschijilijk zullen leiden) tot een partus van minstens én levendgeboren kind betrof voor ruim $70 \%$ eenlingen; $5 \%$ waren drie- $(n=14)$ of vierlingen $(n=2)$. Het gemiddeld aantal teruggeplaatste embryo's per embryotransfer verschilde: in de ziekenhuizen 2,3 en 4 bedroeg het 2.8 , in ziekenhuis 13.1 en tenslotte in ziekenhuis 5 3.8.

Dientengevolge is er ook een verschil in meerlingzwangerschappen te verwachten tussen de ziekenhuizen. In bijlage 3.34 (tabel B3.34.1) is voor de doorgaande zwangerschappen, zowel in totaal als per ziekenhuis aangegeven hoeveel vruchtzakken met positieve hartaktie zijn gesignaleerd. Hierbij is een splitsing aangebracht naar het aantal teruggeplaatste embryo"s. Hieruit is het volgende af te leiden:

- het percentage meerlingen (per doorgaande zwangerschap) liep op van circa $20 \%$ bij transfers van 2 a 3 embryo's via circa $35 \%$ bij transfers van 4 a 5 embryo"s naar circa $45 \%$ bij transfers van meer dan 5 embryo's

- het percentage drie-/vierlingen was gelijk voor transfers van 3 a 4 embryo's in vergelijking met transfers van meer dan 4 embryo's (zeer kleine aantallen; 16 drie-(vierlingen)

- het percentage meerlingen lag in ziekenhuis 5 relatief hoog: ruim $40 \%$ ten opzichte van 20 a $25 \%$ in de andere ziekenhuizen; dit hangt samen met het relatief vaak terugplaatsen van meer dan 4 embryo's.

Over het verloop van de zwangerschäp en de situatie rondom de partus zijn in bijlage 3.34 (tabel B3.34.2) data opgenomen woorzover de doorgaande zwangerschappen binnen de registratieperiode hebben geresulteerd in een partus van minstens eén levendgeboren kind $(n=294)$. De belangrijkste bevindingen zijn de volgende:

- 15\% van de zwangerschappen ging gepaard met als ernstig gerapporteerde komplikaties; bij meerlingzwangerschappen was dit $28 \%$

- alle partussen vonden in het ziekenhuis plats, waarvan $20 \%$ poliklinisch; bij meerlingen bedroeg dit latste percentage $2 \%$. Bijna $75 \%$ van de partussen wond langs vaginale weg plaats; bij de meerlingen was dat ruim $50 \%$ - $38 \%$ wan de geboren kinderen had een laag geboortegewicht $(<2500 \mathrm{~g})$; bij eenlingen was dit $9 \%$, bij meerlingen $69 \%$. Een erg laag geboortegewicht $(<1500 \mathrm{~g})$ werd gekonstateerd bij $7 \%$ van de kinderen; bij eenlingen was dit $1.8 \%$, bij meerlingen $12.8 \%$. Internationaal geldt een incidentie van erg laag geboortegewicht van circa $1 \%$ (Verloove-Vanhoorick[1.987])

- de zwangerschapstermijn was pre-term ( $<37$ weken) bij $30 \%$ van die partussen; bij eenlingen was dit $15 \%$, bij meerlingen $65 \%$ (erg-pre-term $(<32$ weken) respektievelijk $5 \%, 2.5 \%$ en $11 \%$ ); de pre-term-c.q. de erg-pre-termincidentie wordt voor Nederland geschat op respektievelijk $5.4 \%$ (Kloosterman[1977]) en 0.6\% (Verloove-Vanhorick[1987])

- 7 kinderen zijn neonataal owerleden (binmen 28 dagen), hetgeen overeenkomt met een neonatale sterfte van $1.8 \%$; dit trad bijna alleen op bij 
meerlingzwangerschappen (waarbij minstens én kind nog leeft). De neonatale sterfte bedroeg in 1984 in Nederland $0.5 \%$ (LMR[1988])

- bij 6 kinderen was sprake van minstens éen kongenitale afwijking, 4x resulterend in neonatale sterfte (waarvan $2 x$ anencefalie)

- het mannelijk geslacht was enigszins in de meerderheid bij de geboren kinderen: $52 \%$.

Konnkl. - het percentage klinische abortussen per klinische zwangerschap leverde in het evaluatie-onderzoek-IVF een getal op (17\%) dat te verwachten was op basis van de leeftijdssamenstelling van de populatie; bij vergelijking met internationale IVF-resultaten is het percentage in het onderzoek relatief laag

- het percentage EUG's per klinische zwangerschap lag in het onderzoek op $6 \%$. Dit getal sluit aan bij de internationale IVF-resultaten en ligt hoger dan in de natururlijke cyclus; onduidelijk is in hoeverre de verhoogde incidentie samenhangt met de samenstelling van de patièntenpopulatie dan wel met de IVF-methode

- de procentuele uitval na het bereiken van cen doorgaande zwangerschap is gering

- het percentage meerlingen per doorgaande zwangerschap bedroeg $30 \%$, oplopend van circa $20 \%$ bij transfers van 2 a 3 embryo's tot circa $45 \%$ bij transfers van meer dan 5 embryo's; het percentage drie-/vierlingen per doorgaande zwangerschap bedroeg 5\%; de incidentie was gelijk bij transfers van 3 a 4 embryo's ten opzichte van transfers van meer dan 4 embryo's

- van de zwangerschappen die geleid hebben tot de partus van minstens én levendgeboren kind:

* ging $15 \%$ gepaard met als ernstig gerapporteerde komplikaties

* vonden alle partussen in het ziekenhuis plaats: $1 / 5$ deel werd poliklinisch uitgevoerd en $3 / 4$ langs vaginale weg

${ }^{*}$ had $38 \%$ van de kinderen een laag geboortegewicht; $7 \%$ had een erg laag geboortegewicht

* was $30 \%$ van de partussen pre-term; erg-pre-term was $5 \%$

* bedroeg de neonatale sterfte $1.8 \%$

- alle bovenvermelde problemen traden relatief vaker op bij meerlingzwangerschappen

- de incidenties van bovenvermelde problemen waren ook voor enkelvoudige zwangerschappen veclal hoger dan in de 'normale populatie'. Het is onduidelijk of dit veroorzaakt wordt door de patiêntenpopulatie (selektiebias) dan wel door de IVF-behandeling. 


\subsection{Verklaringen voor verschillen op multivariate wijze}

\subsubsection{Inleiding}

In de vorige paragrafen is per separate faktor uitgebreid stilgestaan bij de mogelijke invloed wan diverse faktoren op de resultaten van de IVF-behandeling. De faktoren waren globaal te verdelen in 2 groepen: enerzijds patiëntgegevens die reeds voorafgaand aan de eerste IVF-behandeling bekend (zouden kunnen) zijn, en anderzijds behandelkenmerken, tussenresultaten van de behandeling en gegevens over het patientenpaar die pas tijdens de behandeling worden verkregen. Deze analyses waren primair univariaat van karakter: er werd een relatie gelegd tussen een individuele, mogelijk verklarende, variabele en een bepaald (tussen)resultaat. Daar waar zinvol en mogelijk werd deze relatie tevens bekeken binnen diverse kategorieën van mogelijk verstorende andere variabelen, bijvoorbeeld binnen ieder ziekenhuis apart. Het voordeel van deze methode is de begrijpelijkheid van de analyse. Daartegenover staat het nadeel dat er geen garantie bestaat dat gevonden relaties in werkelijkheid bestaan en dat nietgevonden relaties in werkelijkheid inderdaad niet bestaan. Dit is het gevolg van het feit dat de invloed van andere variabelen niet of slechts in beperkte mate in de beschouwing wordt meegenomen.

Er bestaan ook methoden die de mogelijke invloed van diverse variabelen op een bepaald (tussen)resultaat tegelijkertijd bepalen. Bij dergelijke multivariate methoden bestaat derhalve de mogelijkheid om bij het leggen van relaties rekening te houden met een komplex verband tussen variabelen. Nadeel van dergelijke methoden is echter dat deze ingewikkelder zijn. Derhalwe dient bij de presentatie van de resultaten van dergelijke analyses het midden gevonden te worden tussen enerzijds begrijpelijkheid voor de geïnteresseerde lezer en anderzijds diepgang van de wetenschappelijke finesses.

In deze paragraaf zal allereerst enige achtergrondinformatie worden gegeven over de gehanteerde multivariate regressie-methoden (paragraaf 3.4.2). Daarna zal getracht worden met behulp van multivariate regressie-methoden meer zicht te krijgen op twee belangrijke stappen in de IVF-behandeling: de stap van follikelpunktie naar embryotransfer en de stap van embryotransfer naar het al dan niet bereiken van een klinische zwangerschap (paragrafen 3.4 .3 en 3.4.4). Hierbij zullen naast patientkenmerken en de faktor ziekenhuis eveneens behandel-tussenresultaten als verklarende variabelen worden gebruikt. In deze analyses zal blijken dat de sukseskans bij IVF in eerste instantie voornamelijk afhankelijk blijkt to zijn van tussenresultaten van de IVF-behandeling. Maar deze tussenresultaten zijn uiteindelijk toch weer mede afhankelijk van de verklarende variabelen patientkenmerken en de faktor zickenhuis.

Veel belangrijker voor de vraagstelling van dit onderzoek zijn dan ook de multivariate regressie-analyses die trachten het verband aan te geven tussen enerzijds diverse patièntkenmerken die wooraf bekend zijn en de faktor ziekenhuis en anderzijds het eindresultaat van de IVF-behandeling: wel of geen kind. Als eindpunt van de IVF-behandeling is voor deze analyses om prakt ische redenen gekozen voor het al dan niet bereiken van een doorgaande zwangerschap. Als beginpunt van de IVF-behandeling wordt beschouwd de start van de ovulatie-induktie met cc, hMG of FSH. In paragraaf 3.4 .5 zullen deze analyses 
worden gepresenteerd. Daarnaast zal in die paragraaf aandacht worden besteed aan enkele algemene methodologische diskussiepunten ten aanzien van de wijze waarop de multwariate analyses voor dit onderzoek zijn uitgevoerd. Voor de volledigheid zijn in paragraaf 3.4.6 de modelschattingen ook uitgevoerd met de follikelpunktie (in plaats van de hormoonstimulatie) als beginpunt.

\subsubsection{Multivariate regressie-methoder}

Biij multivariate regressie-technieken ${ }^{88}$ wordt de invloed van een verklarende variabele geschat op een afhankelijke variabelle, rekening houdend met de invloed van diverse andere verklarende variabelen die in het model zijn opgenomen. De schattingen zijn mede afhankelijk van de set van opgenomen verklarende variabelen. In principe is het ook mogelijk om bij deze analysemethoden de onderlinge verbanden tussen de verklarende variabelen expliciet op te nemen in het model via interaktie-termen: zogenaamde effekt-modifikatie (Bouter[1988]). Daarmee worden schattingen verkregen die beter de aard van de relaties met de afhankelijke variabele weergeven. Daar staat echter tegenover dat de interpretatie van dergelijke modelschattingen vaak veel moeilijker wordt, vooral bij logistische regressievergelijkingen. Om deze reden is ervoor gekozen in principe alleen modelschattingen uit te voeren met de hoofdtermen als verklarende variabelen.

In het onderstaande zal gebruik worden gemaakt van twee soorten van multivariate regressie: lineaire regressie en logistische regressie. Bij lineaire regressie wordt een lineaire relatie verondersteld tussen de afhankelijke variabele (y) en diverse verklarende variabelen (x) en een konstante term (a). In formule:

$$
y=a+\Sigma\left(b_{i} x_{i}\right)
$$

Hierin is a de geschatte waarde voor y in de basiskategorie, dus de kategorie waarin alle andere verklarende variabelen de waarde 0 aannemen. De $b_{i}{ }^{3}$ s geven aan hoe ceteris paribus de afhankelijke variabele (y) wijzigt bij een verandering in een bepaalde verklarende variabele $x_{i}$. De ceteris paribus klausule (afgekort c.p.) is uiterst belangrijk voor een juiste interpretatie van de resultaten van regressie-analyses. Met ceteris paribus wordt bedoeld "onder verder gelijkblijvende omstandigheden". Bij vergelijking van twee groepen van behandelingen wordt dus alleen een verschil beschouwd voor de betreffende verklarende variabele; alle anderen variabelen worden geacht geen wijziging te ondergaan.

Als de afhankelijke variabele niet een kontinue variabele of een intervalvariabele is, maar een dichotome variabele dan verdient het gebruik van logistische regressievergelijkingen de voorkeur, zeker als (Cleary[1984]): 
- de onafhankelijke variabelen niet multivariaat normaal verdeeld zijn, zoals in extremo als alle onafhankelijke variabelen kategorisch zijn (vaak zelfs dummies)

- de gemiddelde waarde van de afhankelijke variabele buiten de range 0.25 0.75 valt.

Bij logistische regressie wordt een lineair verband verondersteld tussen de log odds van de afhankelijke variabele $(\log$ odds $(y) \equiv \operatorname{logit}(y))$ en diverse verklarende variabelen ( $\mathrm{x}$ ) en een konstante term (a). In formule:

$$
\begin{array}{ll}
\log \text { odds }(y)=a+\sum\left(b_{i} x_{i}\right) \\
\text { waarbij: } & - \text { logodds de natuurlijke logarithme van de odds is } \\
& - \text { voor de odds }(O(y)) \text { geldt: } O(y)=P(y) /\{1-P(y)\} \\
& \text { met } P(y) \text { de kans op een bepaalde gebeurtenis (in dit geval } \\
& \text { bijwoorbeeld een klinische zwangerschap) }
\end{array}
$$

Zodoende kan de vergelijking omtrent de log odds worden herschreven als:

$$
P(y)=1 /\left\{1+e^{-\left(a+\sum b x_{i}\right)}\right\}
$$

Hieruit blijkt dat een logistisch model altijd waarden voor $\mathrm{P}(\mathrm{y})$ oplevert tussen 0 en 1.

Ook hier behoort bij de konstante term de waarde wan de log odds van y c.q. de kans op $y$ in de basiskategorie. Uit de schattingen $b_{i}$ 's kunnen de zogenaamde odds-ratio's worden afgeleid voor de betreffende variabele. De oddsratio voor 2 groepen is de odds van de ene groep gedeeld door de odds van de andere groep (bijvoorbeeld de groep mét indikatie mannelijke subfertiliteit versus de groep zonder die indikatie), ofwel voor de odds-ratio (OR) geldt:

$$
\mathrm{OR}=\left\{\mathrm{P}_{\mathbb{1}} /\left(1-\mathrm{P}_{1}\right)\right\} /\left\{\mathrm{P}_{0} /\left(1-\mathrm{P}_{0}\right)\right\}=\left\{\mathrm{P}_{1} / \mathrm{P}_{0}\right\} *\left\{\left(1-\mathrm{P}_{0}\right) /\left(1-\mathrm{P}_{1}\right)\right\}
$$

Belangrijk voor de interpretatie van odds-ratio is te weten dat deze bij benadering gelijk is aan de risk-ratio. De risk-ratio of het relatieve risiko (RR; bij zwangerschap is de term risiko verwarrend) is gelijk aan de kans op zwangerschap in de ene groep gedeeld door de kans op zwangerschap in de andere groep:

$$
R R=P_{1} / P_{0}
$$

Het verschil tussen odds-ratio (OR) en risk-ratio ( $R R$ ) bestaat dus uit de faktor $\left\{\left(1-P_{0}\right) /\left(1-P_{1}\right)\right\}$. Bij kleine waarden van $P$ is dit verschil veelal beperkt; bijvoorbeeld indien $P_{0}=0.12$ en $P_{1}=0.08$, dan geldt:

$$
\begin{aligned}
& \mathrm{RR}=0.08 / 0.12=0.67 \\
& \mathrm{OR}=0.75 *(0.88 / 0.92)=0.75 * 0.957=0.64
\end{aligned}
$$


Indien het bovenstaande voorbeeld betrekking heeft op zwangerschapskansen, dan luidt de interpretatie als volgt: de kans op zwangerschap in groep 1 is c.p. $2 / 3 x$ zo groot als die in groep 0 (de basisgroep); de odds op zwangerschap is in groep 1 evencens c.p. circa $2 / 3 \times 20$ groot (om precies te zijn $0.64 \times$ zo groot) als die in groep 0. Eefi odds-ratio van 1 (dus ook $R R=1$ ) betekent dat de odds c.q. de kans op zwangerschap voor beide deelpopulaties gelijk is. Hierop aansinitend: indien het betrouwbaarheidsinterval woor de odds-ratio de waarde 1 bevat, is de invloed van de betreffende variabele in het geschatte model nietsignifikant. Bij kategotische variabelen geldt de odds-ratio ten opzichte van de basiskategorie (de 'baseline'), bij intervalvariabelen ten opzichte van de voorgaande kategorie.

Een belangrijke veronderstelling bij logistische regressie is (Lee[1986]) dat - in dii geval - de odds op een zwangerschap een lineair en additief verband heeft met de risikofaktoren (onafhankelijke variabelen) op een logistische scharl, hetgeen wil zeggen:

- lineair: voor een risikofaktor op intervalschaal geldt dat de odds-ratio voor opeenvolgende kategoriedn konstant is

- additief: de odds-ratio voor 2 of meer faktoren is gelijk aan het produkt van de oddsratio's van de individuele risiko-faktoren ${ }^{89}$.

De resultaten van schattingen van logistische regressievergelijkingen zijn athankelijk van het gehanteerde modlel. Daarmee wordt bedoeld dat een toevoeging of eliminatie van een verklarende variabele de resultaten voor de andere variabelen kan beinvloeden.

In de gepresenteerde tabellen van paragraaf 3.4 worden de volgende notaties gehanteerd:

- als bij een variabele geen nadere aanduiding tussen haakjes staat, betreft het een dummy-variabele met waarde 0 indien niet van toepassing en de waarde 1 indien wel van toepassing.

Bijvoorbeeld:

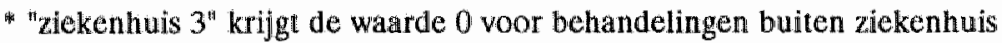

3 en de waarde 1 voor behandelingen in ziekenhuis 3 .

" "mannelijke subfertiliteit" krijgt de waarde 1 indien deze indikatie aanwezig is bij het betreffende paar en de waarde 0 indien dat niet het geval is.

- voor de andere variabelen staat tussen haakjes het aantal gehanteerde kategorieen aangegeven; de indeling is per variabele oplopend; Bijwoorbeeld:

* de variabele "infertiliteitsduur" is ingedeeld in 3 katcgorieën: < 3 jaar,

$3-5$ jar en > 5jaar.

* voor de variabele "oobyten" is het werkelijke aantal oocyten opgenomen, niet samengevoegd in kategorieèn. 
- in principe is de variabele zodanig gedefinieerd dat de basiskategorie de groep behandelingen betreft met de meest gunstige prognose;

Bijvoorbeeld:

" de basiskategorie voor de variabele "infertiliteitsduur" is de kategorie $<3$ jaar infertiel.

* de basiskategorie voor de dummy "mannelijke subfertiliteit" is de groep behandelingen uitgevoerd bij paren zonder deze indikatie.

- in de eerste kolom worden bij de lineaire regressies per verklarende variabele de schattingen vermeld voor de regressiekoefficienten; voor de logistische regressies worden de waarden van de odds (bij de konstante term c.q. de ziekenhuisdummies) vermeld dan wel de waarden van de odds-ratio's (voor de andere variabelen).

- de signifikantie/betrouwbaarheid van de invloed van de betreffende verklarende variabele wordt op 2 manieren aangegeven: via het $95 \%$ betrouwbaarheidsinterval of via de t-waarde (kritieke grens voor signifikantie op 5\%-nivo is 1.96 (absolute waarde)).

- bij de lineaire regressies wordt het percentage verklaarde variantie van de afhankelijke variabele door middel van het gehanteerde model weergegeven door $R^{2}$; voor alle gepresenteerde schattingen van de logistische regressiemodellen geldt dat de p-waarde van de Hosmer-Lemeshow goodnessof-fit boven het signifikantienivo van $5 \%$ bleef. Daarmee wordt aangegeven dat de geschatte modellen een goede beschrijving geven van de data (Lemeshow[1982],Engelman[1985]).

\subsubsection{Multivariate analyse voor stap follikelpunktie $\rightarrow$ embryotransfer}

Om inzicht te krijgen in het verloop van de stap vanaf de follikelpunktie tot de embryotransfer kan in een modelmatige benadering gekozen worden uit verschillende opties voor de te verklaren, afhankelijke variabele:

- al dan niet een embryotransfer na de follikelpunktie

- het aantal teruggeplaatste embryo's bij de transfer

- de gemiddelde fertilisatiegraad van de verkregen oöcyten

- het aantal beschikbare embryo's voor embryotransfer.

In onze analyses is gekozen voor de laatste 2 variabelen. De eerste variabele is dermate globaal dat een groot gedeelte vain de informatie verloren zou gaan. Voor de tweede variabele geldt dat binnen de verschillende ziekenhuizen keuzes kunnen worden gemaakt, waardoor deze variabele niet meer volledig het verloop van de stap vanaf de follikelpunktie tot de embryotransfer weergeeft. Dit geldt met name indien in de behandelcyclus minder embryo's worden teruggeplaatst dan er beschikbaar zijn. De laatste variabele vormt dan cen betere weergave van het verloop van de behandeling tot de embryotransfer.

De variabelen fertilisatiegraad (BEVRUCHT) en totaal aantal beschikbare embryo's (TEMBRYO) zijn beide variabelen met een ratio-schaal; daarbij is de eerste variabele kontinu en de tweede diskreet. Voor deze beide wariabelen zijn 
analyes uitgewoerd met behulp van lineaire regresise "Als onafhankelijke, verklarende variabelen werden de faktoren opgenomen die volgens de bevindingen van de worige paragraal mogelijk van belang zouden zijn. Deze variabelien werden alle verplicht opgenomen in het model (geen "stepwiseregression").

Naist een konstante term zijn in het model ziekenhuisdummies opgenomen. On perfekte kollinearitelt te wermijden moest een ziekenhuils-dummy worden weggelaten wit het model. Daarvoor is de ziekenhuis-dummy van ziekenhuis 5 gekozen, aangezien dat ziekenhuis met de meest gunstige resultaten de zogenaamde 'baseline-kategorie" kon vormen.

\section{Afhankelike variabele: BEVRUCHT (=fertilisatiegraad)}

Een apart probleem bij deze analyses wordt gevormd door de variabele SEMEN (spermamotiliteit na opwerking). Van deze faktor is in paragraaf 3.3.2.2 aangegeven dat deze volgens de nieuwe (subjektieve) indeling waarschijnlijk van invloed is, maar niet volgens de oude ("objektiever) indeling. Een vertaling van de oude in de nieuwe skore bleek daarbij niet goed mogelijk te zijn (zie bijlage 3.28). Zodoende is het alleen zinvol om te werken met de nieuwe indeling. Daarmee worden echter alle behandelingen van 1986 uit deze schatingen geweerd. Derhalve is er naast een lineaire regressievergelijking van een model mét de verklarende variabele SEMEN ook een schatting uitgevoerd met het model zónder deze verklarende variabele om te zien of de schatingen voor de andere variabelen hierdoor sterk wijzigden.

Hieronder worden de regressiekoefficienten en de bijbehorende t-waarden eerst weergegeven voor het model inklusief de verklarende variabele SEMEN (dus exklusief de gegevens van behandelingen uit 1986) en daarna voor het model exklusief de verklarende variabele SEMEN. De betrouwbaarheidsintervallen worden - in verband met de zeer geringe verschillen - alleen weergegeven voor het eerste model.

De $\mathrm{R}^{2}$ bedroeg voor het eerste model 0.15 en voor het tweede model 0.14 . Dergelijke lage waarden woor $\mathrm{R}^{2}$ zijn voor schattingen op individueel nivo zeer gebruikelijk. Desondanks kunnen de schattingen op groepsnivo wel degelijk betekenis hebben (zie onder anderen v.Vliet[1988]).

Allereerst kan worden gekonstateerd dat de schattingen voor de andere verklarende variabelen dan SEMEN nauwelijks verschillen tussen de beide modellen, wellicht met uitzondering van de variabele mannelijke subfertiliteit. De spermakwaliteit na opwerking en de kwaliteit van de verkregen oöcyten zijn beide van groot belang voor de fertilisatiegrad. Opvallend is dat de indikatie onbegrepen infertiliteit (in tegenstelling tot de indikaties mannelijke subfer-

90) De variabele fertilisaticgraad heeft een rarge van 0 to w met 1. Met behulp van de modtelschatügen bij lineaire regressie kunnen waarden buiten dit interval worden verkregen. Derhalve zou theoretisch gezien logisische regressie de voorkeur genieten. Mar aangezien veel warnemingen van de afhankelijke variabete in de range $0.25-0.75$ liggen is dit theoretisch bezwar in de praktijk minder 


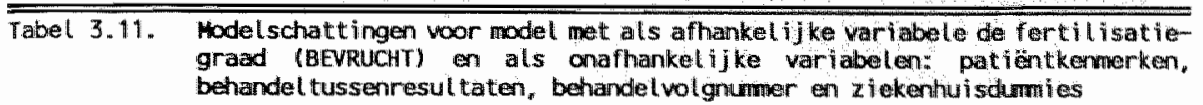

\begin{tabular}{|c|c|c|c|}
\hline Variabele & $b$ & (95: BI) & twaande \\
\hline mannelijke subf. & $=0.121-0.16$ & $(-0.16,-0.08)$ & $-5.36 / \mathrm{mm} 7.58$ \\
\hline antilichamen & $-0.11 /-0.09$ & $(-0.20,-0.02)$ & $-2.40 /-2.17$ \\
\hline onbegrepen inf. & $-0.02 /-0.03$ & $(-0.08,0.04)$ & $-0.64 \gamma-1.98$ \\
\hline ovariêctomie & $0.06 / 0.06$ & $(0.03,0.10)$ & $3.52 / 3.68$ \\
\hline infertili teitsduur (3) & $-0.04 /-0.04$ & $(-0,05,-0.02)$ & $-4.83 /-5.06$ \\
\hline leertijd vrouw 236 & $0.01 / 0.01$ & $(-0.02,0.04)$ & $0.88 / 0.64$ \\
\hline beharnde ( nummer (4) & $0.00 / 0.01$ & $(-0.01,0.01)$ & $0.10 / 0.93$ \\
\hline endogene $L H$-piek & $-0.03 /-0.03$ & $(-0.08,0.02)$ & $-1.08 /-1.21$ \\
\hline semen & $-0.13 /-$ & $(-0.17,-0.09)$ & $-6.571-$ \\
\hline goede/alle oöcyten(4) & $0.06 / 0.06$ & $(0.04,0.07)$ & $8.22 / 9.47$ \\
\hline z iekenthuis 1 & $-0.05 /-0.04$ & $(-0.10,-0.01)$ & $-2.31 /-1.78$ \\
\hline ziekenhuis 2 & $-0.00 /-0.0$ & $(-0.05,0.05)$ & $-0.16 /-0.35$ \\
\hline$z$ iekenhuis 3 & $-0.19 /-0.17$ & $(-0.24,-0.14)$ & $-7.47 /-7.13$ \\
\hline zjekenhuis 4 & $-0.18 /-0.18$ & $(-0.22,-0.14)$ & $-8.68 /-8.95$ \\
\hline konstante & $0.59 / 0.54$ & $(0.52,0.65)$ & $16.47 / 16.35$ \\
\hline
\end{tabular}

tiliteit en antilichamen) geen signifikant negatieve invloed heeft op de fertilisatiegraad. Dat geldt eveneens voor de leeftijd van de vrouw: op hogere leeftijd is de gemiddelde fertilisatiegraad niet verlaagd. Ook is te zien dat bij een oplopend behandelnummer de gemiddelde fertilisatiegraad blijkbaar niet afneemt. Indien de vrouw nog slechts eén ovarium bezit, ligt de fertilisatiegraad signifikant hoger. Bij een langere infertiliteitsduur wordt daarentegen een lagere fertilisatiegraad gesignaleerd.

Rekening houdend met de in het model opgenomen patiëntkenmerken en behandelgegevens blijft gelden dat de gemiddelde fertilisatiegraad in de ziekenhuizen 3 en 4 signifikant lager liggen dan in ziekenhuis 1 . Dat geldt in mindere mate voor ziekenhuis 1 .

\section{Afhankelijke variabele: TEMBRYO (=aantal beschikbare embryo's)}

De grootste invloed op het aantal beschikbare embryo's gaat (uiteraard) uit van het aantal verkregen oocyten ${ }^{91}$ : bij 1 extra oöcyt wordt, ceteris paribus, 0.4 extra embryo verkregen. Maar los daarvan speelt blijkbaar ook de kwaliteit van de oöcyten een rol. De betekenis van de andere variabelen is te verklaren uit het samenspel van enerzijds het verkregen aantal oobcyten uit de follikelpunktie en anderzijds de invloed van die variabelen op de fertilisatiegraad. Het negatieve verband tussen een endogene LH-piek met het aantal verkregen odcyten wordt

91) Dit blijkt ook uil de (niet-gepresenteerde) gestandaardiseerde schattingmaarden. 


\begin{tabular}{|c|c|c|c|c|}
\hline \multirow[t]{17}{*}{ Tabel 3.12} & \multicolumn{4}{|c|}{ 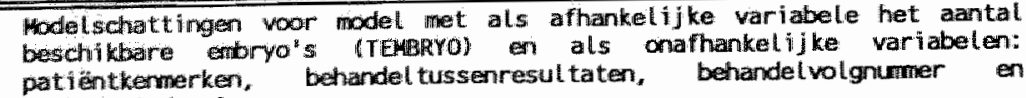 } \\
\hline & Variabele & b & $(95 \%$ BI & twaarde \\
\hline & marinet ijke subf. & -0.95 & $(-1.23,-0.68)$ & -6.89 \\
\hline & antl lichamen & $=0.52$ & $(-1.09,0.05)$ & -1.79 \\
\hline & conbegrepen int. & -0.35 & $(-0.73,0.04)$ & -1.77 \\
\hline & dvarlectomie & 0.19 & $(-0.03,0.41)$ & 1.72 \\
\hline & infertill teitsduur (3) & -0.26 & $(-0.36,-0.16)$ & -5.12 \\
\hline & Left tijd wroum $\geq 36$ & -0.17 & $(-0.36,0.03)$ & -1.67 \\
\hline & behande lnummer (4) & 0.05 & $(-0.04,0.13)$ & 1.14 \\
\hline & endogene LH-piek & -0.47 & $\left(-0.82_{w}-0.13\right)$ & -2.68 \\
\hline & obcyten (aancal) & 0.38 & $(0.36,0.40)$ & 36.23 \\
\hline & goede/alle oócyten(4) & 0.35 & $(0.26,0.43)$ & 8.01 \\
\hline & ziekenhuis: & -0.47 & $(-0.75,-0.19)$ & -3.26 \\
\hline & zjekenhuis 2 & -0.32 & $(-0.63,-0.01)$ & -2.04 \\
\hline & zhekenhuis 3 & -1.17 & $(-1.47,-0,86)$ & -7.40 \\
\hline & zinekenturis 4 & -1.27 & $\{-1,53,-1,01\}$ & -9.60 \\
\hline & konstante & 1.24 & $(0.77,1.70)$ & 5.24 \\
\hline
\end{tabular}

dan ook mede ingegeven door een lagere oöcytopbrengst. Zo geldt voor wrouwen met slechts eén ovarium dat de signifikant positieve relatie met de fertilisatiegraad gedeeltelijk teniet wordt gedaan door een lagere odcytopbrengst.

Rekening houdend met de in het model opgenomen patientkenmerken en behandelgegevens blijkt dat het aantal beschikbare embryo's in ziekenhuïs 5 signifikant hoger is dan in alle andere ziekenhuizen.

De $\mathrm{R}^{2}$ voor het onderstaande model bedroeg 0.43 .

Samengevat kunnen voor deze fase wan de IVF-behandeling (mede) naar aanleiding van de multivariate analyses de volgende konklusies worden getrokken:

-. de behandelgegevens aantal en kwaliteit van de verkregen oöcyten en spermamotiliteil na opwerking spellen een belangrijke rol in deze fase van de behandeling

- de indikaties mannelijke subfertiliteit en antilichamen hebben een negatieve invloed in deze fase; dat geldt in mindere mate voor de indlikatie onbegrepen infertiliteit.

- een ovariectomie in de anamnese leidt (gegeven het aantal verkregen oocyten) niet tot een verlaagd aantal embryo's. De invloed op de fertilisatiegraad is immers gunstig.

- langdurige infertilliteit gaat gepaard met slechte resultaten in deze fase; de infertiliteitsduur kan ook beschouwd worden als een indikator poor 
onderliggende problemen in het fertilisatieproces, die blijkbaar door de IVFbehandeling niet volledig kunnen worden opgelost

- bovenstaande opmerkingen voor de infertiliteitsduur gelden in veel mindere mate voor de leeftijd van de vrouw

- de resultaten in deze fase van de behandeling blijken niet te verschillen tussen de behandelvolgnummers

- rekening houdend met diverse patiëntkenmerken en behandelgegevens blijwen er aanzienlijke verschillen tussen de ziekenhuizen bestaan.

\subsubsection{Multiwariate analyse voor stap embryotransfer $\rightarrow$ klinische zwangerschap}

De grootste uitval in de IVF-behandeling treedt op in deze fase. Daarom is uitvoerig onderzocht in hoeverre het klinische zwangerschapspercentage afhankelijk is van diverse verklarende variabelen. Als afhankelijke variabele is de dummy-variabele klinische zwangerschap gebruikt; deze krijgt de waarde 0 indien na een embryotransfer geen klinische zwangerschap is opgetreden en de waarde 1 indien uit een embryotransfer wel een klinische zwangerschap resulteert.

Met de bovenvermelde dummy als afhankelijke variabele is gekozen voor logistische regressievergelijkingen als analysemethodiek. Als onafhankelijke variabelen zijn een tweetal sets gebruikt:

1. Aantal en kwaliteit van de teruggeplaatste embryo's; deze bleken een dermate grote invloed op de zwangerschapskans te hebben, dat de invloed van alle andere variabelen hierbij in het niet viel. Maar aangezien het aantal en de kwaliteit wan de teruggeplaatste embryo's in feite een tussenresultat van de IVF-behandeling vormt is vervolgens onderzocht in hoeverre de onderstaande variabelen van invloed zijn op de sukseskans.

2. Alleen variabelen met betrekking tot patientkenmerken, behandelvolgnummer en uitvoerend ziekenhuis (modelschatting niet "stepwise').

In het onderstaande wordt allereerst kort ingegaan op de analyses zoalls vermeld onder punt 1; daarna zullen de analyses onder punt 2 nadrukkelijk aan de ordle komen.

1. Verklarende variabelen: aantal en kwaliteit van de teruggeplaatste embryo's

De kans op een klinische zwangerschap wordt in belangrijke mate beinvloed door het aantal en de kwaliteit van de teruggeplaatste embryo's. De modelschattingen zijn weergegeven in bijlage 3.35. Voor een model waarin beide elementen zijn opgenomen als verklarende variabelen geld ceteris paribus dat de odds op een klinische zwangerschap na een transfer van 2 embryo's ongeveet $1.7 \mathrm{x}$ zo hoog is als na een transfer van slechts 1 embryo. Ditzelfde verhoudingsgetal gellt eveneens voor de vergelijking van embryotransfers van 3 à 4 embryo's ten opzichte van transfers van 2 embryo's alsook voor de vergelijking van embryotransfers van minstens 5 embryo's ten opzichte van 
transfers van 34 embryo's. Indien minstens 2 prima ${ }^{92}$ embryo's worden teruggeplaatst is de zwangerschapskans (onafhankelijk van het aantal teruggeplaatste embryo's) ongeveer $1.4 \mathrm{x}$ zo groot als anders. Maar aantal en kwaliteil van de teruggeplaatste embryo's vormen eigenlijk een tussenstap; zij worden op hun beurt weer beimvloed door de variabelen zoals besproken in de vorige paragrafen. Derhalve zal in het onderstaande een rechtstreeks verband worden gelegd tussen die variabelen en het (klinische) zwangerschapsresultaat.

2. Verklarende wariabelen: patientkenmerken, behandelvolgnummer en uitvoerend zickenhuis

Aangezien het aanlal beschikbare (en daarmee ook het aantal teruggeplaatste) embryo's op haar beurt sterk afhankelijk blijkt te zijn van onderliggende faktoren (zie tabel 3.12) is in het onderstaande getracht een rechtstreeks verband te leggen tussen deze onderliggende faktoren en het klinische zwangerschapsresultaat. Allereerst is alleen gekeken naar de mogelijke invloed van diverse variabelen met betrekking tot patientkenmerken en het behandelvolgnummer op het klinisch zwangerschapspercentage per embryotransfer.

\section{Tabel 3.13. Modelschattingen voor model met afhankelijke variabele klinische zwangerschap; onafhankelijke variabelen: patiëntkenmerken en behandelvolgnummer}

\begin{tabular}{|c|c|c|c|}
\hline & OR & BI & \\
\hline mannelijke subf. & 0.63 & $0.44_{4}-0.90$ & \\
\hline antill chamen & 1.09 & $0.56-2.13$ & \\
\hline onbegrepen inf. & 1.66 & $1.11-2.47$ & \\
\hline Ovariëctomie & 0.85 & $0.66-1.08$ & \\
\hline grav./inf. duur & 0.70 & $0.58-0.85$ & \\
\hline Leef tijd wroum 236 & 0.81 & $0.65-1.02$ & \\
\hline beharide ( vo lgnummer ( interval) & 0.85 & $0.77-0.93$ & \\
\hline konstante & 0.42 & $0.344-0.52$ & $\%$ zwanger: $29.49 \%(25.30-34.05)$ \\
\hline
\end{tabular}

De indikatie mannelijke subfertilliteit levert een sterk verlaagde odds op een klinische zwangerschap na een embryotransfer; deze ligt op circa $2 / 3$ van de rest. Ook het graviditeitsverleden in kombinatie met de infertiliteitsduur heeft een signifikante invloed op de odds op een klinische zwangerschap: bij langdurige primaire infertiliteit van het paar is deze odds 0.7 ten opzichte van de rest. Volgens deze schattingen is de odds op een klinische zwangerschap voor een bepaald behandelvolgnummer ceteris paribus een fraktie 0.85 van die voor eên behandelvolgnummer lager (signifikant). De invloeden van cen hoge

92) A cerder gedefiniest als: minstens het ontwikkelingsstadium van 4-celler en morfologisch
beoondeeld als perfekt. 
leeftijd van de vrouw en van de aanwezigheid van slechts een ovarium zijn beide negatief, maar net-niet-signifikant. De indikatie antillchamen blijkt in deze fase geen invloed meer te hebben op de sukseskans, terwijl de indikatie onbegrepen infertiliteit een signifikant hogere odds op een klinische zwangerschap opleverde: paren met als indikatie onbegrepen infertiliteit hebben na een embryotransfer, ceteris paribus, een odds op een klinische zwangerschap die ruim $1.6 \mathrm{x}$ zo hoog is als voor andere paren. Bij de analyses in paragraaf 3.2 is gebleken dat dit effekt niet meer optreedt bij een infertiliteitscuur langer dan 5 jaren.

Uit de odds voor de konstante term kan het bijbehorende zwangerschaps percentage worden berekend. Dit geeft de sukseskans weer voor behandelingen die voor alle overige variabellen een skore in de basiskategorie bezitten ${ }^{9 \%}$, dus onder andere niet als indikatie mannelijke subfertiliteit en geen ovariectomic gehad.

Indien nu in het bovenstaande model de konstante wordt varvangen door 5 dummies voor de diverse ziekenhuizen, dan blijkt dat de schattingen yoor de andere variabelen nauwelijks veranderen. Uit de schattingen voor de ziekenhuisdummies kan worden afgeleid in hoeverre de samenstelling van de patientenpopulatie in de diverse ziekenhuizen verantwoordelijk is voor verschillen in de suksespercentages. In onderstaande tabel zijn in de kolom "\% klin. zwanger" voor de diverse ziekenhuizen de klinische zwangerschapspercentages per embryotransfer aangegeven voor de behandelingen met de meest gunstige prognose.

Tabel 3.14. Modelschattingen voor model met afmankelijke variabele klinische zwangerschap; onafhankelijke variabelen:ziekenhuizen, patiëntkenmerken en behandelvolgnummer

\begin{tabular}{|c|c|c|c|c|}
\hline $\begin{array}{l}\text { z iekenhuis } 1 \\
\text { z jekenhuis } 2 \\
\text { ziekenhu is } 3 \\
\text { z iekenhu is } 4 \\
\text { z jekenhulis } 5\end{array}$ & OR & BI & $\begin{array}{c}\% \text { klin. zwanger } \\
25.71 \% \\
29.84 \% \\
13.74 \% \\
33.11 \% \\
33.83 \%\end{array}$ & $\begin{array}{c}B 1 \\
20.77-31.35 \\
23.85-36.61 \\
13.77=24.97 \\
27.71-38.99 \\
28.07-40.11\end{array}$ \\
\hline $\begin{array}{l}\text { man. subf. } \\
\text { ant il ichamen } \\
\text { onbegrep. inf. } \\
\text { ovar iectomine } \\
\text { vrouw } 236 \\
\text { graw inf. dur } \\
\text { beh. volgno. }\end{array}$ & $\begin{array}{l}0.66 \\
1.17 \\
1.63 \\
0.85 \\
0.79 \\
0.71 \\
0.85\end{array}$ & $\begin{array}{l}0.46-0.94 \\
0.60-2.31 \\
1.09-2.45 \\
0.66-1.08 \\
0.63-0.99 \\
0.58-0.86 \\
0.77-0.94\end{array}$ & & \\
\hline
\end{tabular}

93) De basiskategorie is in principe de kategorie met de meest gunstige voonultzichter op suktseg. bij de TVI behandeling. Eerder is aangegewen dat in principe bij de medische werklarende wariabelen de wasde 1 de relatief ongunstige groep representeerde en de warde 0 de relatief gunstige. Achteraf buijkt dit principe voor de variabele onbegrepen infertiliteit niet te gelden, ondat de inwowd van deze faktor (in totaliteit) in de andere richting bleek te werken dan tijdens de konstruklie wan deze wariabele werd werwacht. De 0-kategorie is voor deze varabele dus de ongunstige groep. 
Rekening houdend met de geselekteerde variabelen als indikatoren voor verschillen tussen de ziekenhuizen in de samenstelling van de patiëntenpopulatie en met een eventueel verschil in het skala van behandelvolgnummers, blijkt dat het 95\%-betrouwbaarheidsinterval van de resultaten in ziekenhuis 3 volledig onder dat van de ziekenhuizen 4 en 5 ligt.

\subsubsection{Multivariate analyse voor het totaalresultaat: van hormoonstimulatie tot doorgaande zwangerschap}

Indien binnen het databestand het totale trajekt van een IVF-behandeling in beschouwing wordt genomen, startend vanaf de hormoonstimulatie en eindigend bij een doorgaande zwangerschap als benadering voor de geboorte van (minstens) én levensvatbaar kind, dan springt een tweetal grote verschillen in resultaten in het oog:

- de verschillen tussen groepen behandelingen bij patienten met uiteenlopende kenmerken; in de vorige paragraaf zijn diverse verschillen in resultaten gesignaleerd op basis van voornamelijk indikatie, (in)fertiliteitsverleden, leeftijd van de vrouw en behandelvolgnummer

- de verschillen tussen de 5 ziekenhuizen: het gemiddeld doorgaand zwangerschapspercentage ligt voor het ziekenhuis met de beste resultaten 2.8x zo hoog als dat voor het ziekenhuis met de minste resultaten; maar ook is gesignaleerd dat de patiëntenpopulaties van de ziekenhuizen van elkaar werschillen op separate patiëntkenmerken (zie paragraaf 3.2.6)

Het is zeer goed denkbaar dat de verschillen in resultaten zowel tussen patiëntgroepen als tussen ziekenhuizen vertekend zijn door hun onderlinge verband. Derhalve zijn multivariate logistische regressie-analyses uitgevoerd, waarbij als verklarende variabelen juist die variabelen zijn opgenomen die verband houden met de bovenvermelde verschillen.

Allereerst is onderzocht in hoeverre diverse patiëntkenmerken van invloed zijn op de sukseskans van de IVF-behandeling in zijn geheel. Daartoe is een model geschat met alleen deze patientkenmerken en het behandelvolgnummer als verklarende variabelen, naast een konstante. De afhankelijke variabele is doorgaande zwangerschap, met de waarde 1 indien na de start van de hormoonstimulatie een doorgaande zwangerschap via IVF wordt bereikt en de waarde 0 indien dat niet het geval is. 
Tabel 3.15. Modelschattingen voor model met mankelijke variabele doorgande zwangerschap; onafhankelijke wariabelen: patientkenmerken en behandelvolgnummer

\begin{tabular}{|c|c|c|c|}
\hline & $\mathrm{OR}$ & $\mathrm{BI}$ & \\
\hline $\begin{array}{l}\text { mannel jjke sulbf } \\
\text { onbegrepen inf. } \\
\text { ovar lectonie } \\
\text { vrouw } 236 \\
\text { grav. Hinf. duur } \\
\text { behandel wolgno. } \\
\text { konstante }\end{array}$ & $\begin{array}{l}0.48 \\
1.54 \\
0.65 \\
0.58 \\
0.64 \\
0.86 \\
0.23\end{array}$ & $\begin{array}{l}0.31-0.72 \\
1.02-2.32 \\
0.50-0.85 \\
0.45-0.75 \\
0.52-0.79 \\
0.77-0.95 \\
0.19-0.29\end{array}$ & $\begin{array}{l}\text { *oorgaand zwanger per behandel ing: } \\
18.82 \%(15.61-22.50)\end{array}$ \\
\hline
\end{tabular}

Het zwangerschapspercentage van $18.8 \%$ geldt alleen voor paren die voor alle faktoren een skore in de basiskategorie bezitten, dus onder andere zonder de indikatie mannelijke subfertiliteit en de vrouw jonger dan 35 jaren.

Bij deze analyse, waarin het (bijna) uiteindelijke resultaat van de IVFbehandeling wordt gerelateerd aan de start van de behandeling, blijkt de invloed van diverse patiëntkenmerken ${ }^{94}$ op de totale sukseskans aanzienlijk te zijn. Indien de indikatie mannelijke subfertiliteit is gesteld is de odds op een doorgaande zwangerschap bij de start van de IVF-poging, ceteris paribus, ongeveer 0.5 ten opzichte van andere behandelingen. Andere signifikante patientkenmerken die de odds op een doorgaande zwangerschap negatief beinvloeden zijn de aanwezigheid van slechts én ovarium (odds-ratio van 0.65), de leeftijd van de vrouw ouder dan 35 (odds-ratio van 0.58) en een langdurige primaire infertiliteit (odds-ratio van 0.64). Ook hier levert de indikatie onbegrepen infertiliteit een relatief gunstige prognose op, namelijk een oddsratio van ruim 1.5 . In paragraaf 3.2 .2 is reeds aangegeven, dat deze relatief gunstige prognose alleen betrekking heeft op de groep met kortdurende onbegrepen infertiliteit. In bijlage 3.36 is derlualve het model geschat met als enige wijziging een extra verklarende wariabele, te weten de interaktieterm van onbegrepen infertiliteit met al dan niet primaire langdurige infertiliteit. Daaruit blijkt ook bij multivariate analyse dat de prognose bij onbegrepen intertiliteit sterk samenhangt met de infertiliteitsduur. Ten behoeve van de begrijpelijkheid van de resultaten van de multivariate analyses is onderstaand deze athankelijkheid niet verder expliciet opgenomen in de modelschattingen.

Tenslotte blijkt dat het behandelvolgnummer een signifikante invloed heeft op de uiteindelijke sukseskans per behandeling: de odds op een doorgalande zwangerschap bij een bepaald behandelvolgnummer is telkens een faktor 0.86 lager dan die bij het voorafgaande behandelvolgnummer.

94) De verlalarende variabele "antilichamen" is, in tegenstelling tot het model in de vorige paragraal in deze presentatie niet meer opgenomen in het model, agngezien deze niet belangrijk bleok te zijn. Voor de modelschattingen met deze variabele zij venwezen maar Haan[1989a]. 
Indien in het bovenstaande model de konstante wordt vervangen door 5 dummies voor de diverse ziekenhuizen, dan blikt dat de schattingen voor de andere variabelen wederom nawwelijks veranderen. Uit de schattingen voor de ziekenhuisdummies kan worden afgeleid in hoeverre de samenstelling van de patientenpopulatie in de diverse ziekenhuizen verantwoordelijk is voor verschillen in de suksespercentages van de IVF-behandelingen. In onderstaande tabel zijn in de kolom ox doorgaand zwanger voor de diverse ziekenhuizen de doorgaande zwangerschapsercentages per gestarte behandeling aangegeven voor de groep behandelingen met de beste prognose.

\begin{tabular}{|c|c|c|c|c|c|}
\hline \multirow[t]{2}{*}{ Tabel 3.16. } & \multicolumn{5}{|c|}{$\begin{array}{l}\text { Modelschattingen voor model met afhankelijke variabele doorgaande } \\
\text { zwangerschap; onafhankelijke wariabelen: ziekenhulzen, patientkenmerken } \\
\text { en behandelvolgnummer }\end{array}$} \\
\hline & & $\mathrm{OR}$ & BI & I\% doorg. zwanger & BI bij \% \\
\hline & 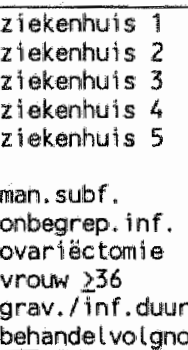 & $\begin{array}{l}0.49 \\
1.50 \\
0.65 \\
0.56 \\
0.64 \\
0.86\end{array}$ & $\begin{array}{l}0.33-0.75 \\
0.99-2.27 \\
0.49-0.85 \\
0.43-0.72 \\
0.52-0.79 \\
0.78-0.96\end{array}$ & $\begin{array}{l}16.65 \% \\
17.05 \% \\
9.78 \% \\
22.73 \% \\
23.77 \%\end{array}$ & $\begin{array}{r}12.82-21.33 \\
12.82-22.31 \\
6.87-13.74 \\
18.38-27.77 \\
18.90-29.43\end{array}$ \\
\hline
\end{tabular}

Ook hier is zichtbaar dat de verschillen in suksespercentages tussen de ziekenthuizen slechts in zeer geringe mate worden genivelleerd door korrektie voor patientkenmerken en het behandelvolgnummer. De vermelde percentages voor de verschillende ziekenhuizen gelden wederom alleen voor de behandelingen bij die paren die woor alle opgenomen variabelen in het model een skore in de basiskategorie hebben.

Veel illustratiever in dit verband is het antwoord op de vraag hoe de zwangerschapspercentages in de verschillende ziekenhuizen zouden zijn geweest indien in leder ziekenhuis de "gemiddelde populatie" van het onderzoek zou zijn behandeld, met andere woorden na korrektie voor verschillen in de samenstelling van de patiemtenpopulatie. Daartoe zijn in bijlage 3.37 de zwangerschapspercentages (met bijbehorende betrouwbaarheidsintervallen) berekend uit de modelschattingen woor de log odds van de ziekenhuisdummies in het model zoals hierboven weergegeven. De resultaten van die berekeningen zijn grafisch weergegeven in figuur 3.4. 
Figuur 3.4. De gekorrigeerde doorgaand-zwangerschapspercentages in de verschill lende ziekenhuizen; gemiddelde met $95 \%$-betrouwbaarheidsinterval

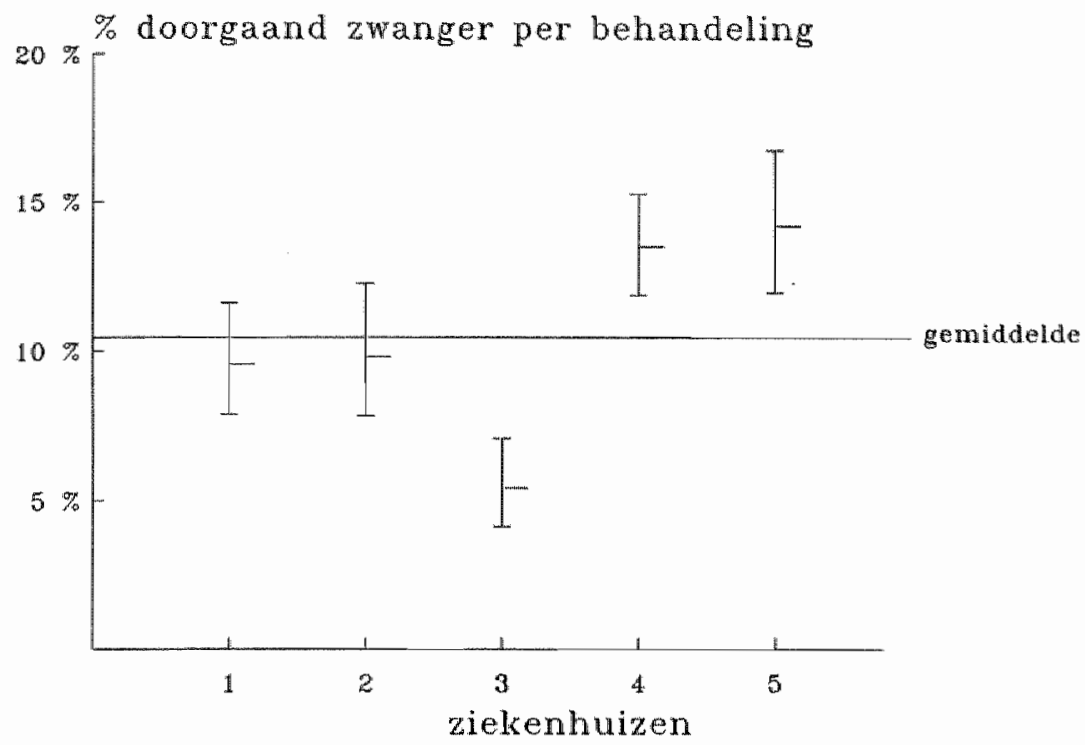

Uit deze figuur blijkt dat de zwangerschapspercentages na korrektie voor verschillen in de samenstelling van de patièntenpopulatie nog steeds aanzienlijk verschillen tussen de ziekenhuizen. In feite wijken de gekorrigeerde percentages nauwelijks af van de ruwe, ongekorrigeerde percentages. Ofwel:

- hoewel de analyses laten zien dat er aanmerkelijke verschillen in resultaten bestaan tussen behandelingen bij diverse patientgroepen

en

- hoewel de patientgroepen, gedifferentieerd naar medische patientkenmerken die van invloed blijken te zijn op de resultaten, niet gelijk verdeeld zijn over de ziekenhuizen,

toch blijken de verschillen tussen de ziekenhuizen in de samenstelling van de patientenpopulaties nawwelijks invloed te hebben op de verschillen in de resultaten tussen de ziekenhuizen. De invloeden nivelleren elkaar blijkbaar.

Strikt genomen is niet voldaan aan de veronderstellingen van regressiettechnick: onafhankelijkheid van de waarnemingen; immers een paar kan meerdere keren binnen de onderzoeksperiode zijn behandeld en derhalve meerdere keren in 
het databestand voorkomen. Daarom is op twee manieren onderzocht of deze afwijking wan de veronderstellingen invloed heeft op de modelschattingen ${ }^{95}$ :

1. Door de modelschattingen alleen uit te voeren voor de eerste behandeling in de onderzoeks periode (zie bijlage 3.38 ). Het aantal waarnemingen is geringer en de variabele behandelvolgnummer is uiteraard niet meer in het model opgenomen. Uit de resultaten van de analyse blijkt dat de schattingen voor de odds-ratio's in grote lijnen hetzelfde zijn gebleven; wel worden de betrowwbaarheidsintervallen ruimer, ten gevolge van het geringer aantal waarnemingen.

2. Door te onderzoeken of de patientkenmerken een andere invloed op de zwangerschapskans hebben bij eerste c.q. vervolgbehandelingen binmen de onderzoeksperiode (zie bijlage 3.39). Alle interaktietermen tussen de dummyvariabele "vervolg" ( = al dan niet vervolgbehandeling) en de diverse patientkenmerken blijken (ruimschoots) niet in het model te worden opgenomen. Ofwel, de invloed van de patientkenmerken op het doorgaand zwangerschapspercentage is niet essentieel anders bij eerste behandelingen dan bij verwolgbehandelingen.

Ook is nog onderzocht of er sprake is van selektieve doorstroom naar vervolgIVF-behandelingen na een eerder mislukte IVF-poging. Daartoe is op basis van de schattingen van het model behorend bij tabel 3.16 voor de gemiddelde sukseskans bij een bepaald behandelwolgnummer een vergelijking uitgewoerd tussen 2 patientgroepen ${ }^{\circ}$ : een groep die na de betreffende (mislukte) poging een nieuwe IVF-poging heeft ondernomen en een andere groep die na de (mislukte) poging gestopt is met de IVF-procedure. De wijze waarop deze vergelijking is uitgevoerd is weergegeven in bijlage 3.40 . De konklusie luidt dat er voor de nog-niet-zwangeren zeker tot en met behandelvolgnummer 3 geen sprake lijkt te zijn van selektieve doorstroom naar vervolgbehandelingen.

\subsubsection{Multivariate analyse voor het resultaat vanaf de follikelpunktie tot doorgaande zwangerschap}

Analoog aan de analyses die zijn uitgevoerd woor het totaalresultaat van de IVF-behandelingen zijn ook de eindresultaten geanalyseerd uitgaande van de follikelpunktie. Wederom is eerst gekeken in hoeverre patiëntkenmerken de doorgaande zwangerschapspercentages beinvloeden (zie tabel 3,17 ). De afhankelijke variabele doorgaande zwangerschap krijgt de waarde 1 indien er een doorgaande zwangerschap is opgetreden en de waarde 0 bij alle andere follikelpunkties.

95) Alleen de schattingen voor de modellen met een konstante term worden in de bijlagen weergegeven. Voor de modallen met de ziekenhuisdummies gelden identielke overeenkomsten.

96) Aangezien de modelschattingen voortkomen vit ons eigen databestand is vergelijking met de groep behandwingen die tot een doorgaande zwangerschap hebben geleid niet zo zinvol; de gemiddelde sukseskuns voon deze groep wan behandelingen, berekend op basis van de modelschattingen, ligt uiteraard hoger dan voor de groep van behandelingen die miet tot een doorgaande zwangerschap
hebben geleid. 
Tabel 3.17. Modelschattingen voor model met afhankelijke variabele doorganande zwangerschap; onafhankelijke wariabelen: patientkenmerken en behandelvolgnummer

\begin{tabular}{|c|c|c|c|}
\hline & $\mathrm{OR}$ & BI & \\
\hline $\begin{array}{l}\text { man. subf. } \\
\text { onbegrep. Inf. } \\
\text { ovariectomie } \\
\text { vrouw } \geq 36 \\
\text { grav. / inf. duur } \\
\text { behandelvolgno } \\
\text { konstante }\end{array}$ & $\begin{array}{l}0.44 \\
1.52 \\
0.74 \\
0.64 \\
0.68 \\
0.86 \\
0.28\end{array}$ & $\begin{array}{l}0.29-0.67 \\
1.00-2.31 \\
0.56-0.97 \\
0.50-0.83 \\
0.55-0.84 \\
0.77-0.96 \\
0.22-0.35\end{array}$ & $\begin{array}{l}\text { doorgand zwanger per punliktie: } \\
21.69 \%(18.07-25.81)\end{array}$ \\
\hline
\end{tabular}

De warden van de odds wijken niet of nawwelijks af van die bij de analyses voor de totaalresultaten, vitgaande van de hormoonstimulatie. Derhalve kan gekonkludeerd worden dat de invloed van de diverse patientkenmerken op de resultaten van de behandeling, uitgaande van de follikelpunktie, min of meer identiek is aan de eerder beschreven invloed, uitgaande van de hormoonstimulatie.

Ook bij deze analyses is tenslotte de konstante in het model vervangen door de 5 dummies voor de verschillende ziekenhuizen. In de kolom \% doorgaand zwanger staan de zwangerschapspercentages per follikelpunktic woor de behandelingen met de beste prognose. Ook dit beeld komi overeen met de bevindingen in de vorige paragraaf.

Tabel 3.18. Modelschattingen voor model met afhankelijke varigbele doorgaande zwangerschap; onafhankelijkevariabelen: ziekenhuizen, pattientkenmerken en behandelvolgnummer

\begin{tabular}{|c|c|c|c|c|}
\hline & OR & BI & \% doorg. Zwariger & (l) bis \\
\hline 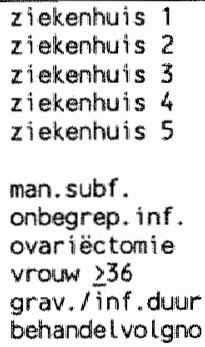 & $\begin{array}{l}0.47 \\
1.51 \\
0.73 \\
0.62 \\
0.69 \\
0.87\end{array}$ & $\begin{array}{l}0.31-0.71 \\
0.99-2.30 \\
0.55-0.96 \\
0.48-0.81 \\
0.55-0.85 \\
0.78-0.97\end{array}$ & $\begin{array}{l}17.40 \% \\
20.29 \% \\
12.38 \% \\
25.84 \% \\
27.26 \%\end{array}$ & $\begin{array}{r}13.38-22.32 \\
15.36-26.32 \\
8.72-17.29 \\
20.98-31.38 \\
21.95-33.44\end{array}$ \\
\hline
\end{tabular}




\subsection{Samenvatting en konklusics}

De resultaten van de univariate en multivariate analyses komen grotendeels met elkar overeen. Indien de resultaten van de IVF-behandelingen worden geanalyseerd dan blijkt dat de tussenresultaten in latere fasen van de behandeling sterk afhankelijk zijn van de tussenresultaten in de eerdere fasen. Zo bestaat er een sterke samenhang tussen het verloop van de follikulaire fase, het aantal verkregen oocyten, het aantal verkregen en teruggeplaatste embryo's en het percentage klinische zwangerschappen per embryotransfer. Mede om deze reden is naast de analyses van de diverse fasen in de IVF-behandeling nadrukkelijk aandacht besteed aan de analyses 'van begin tot bijna-eind': de IVF-benandeling in termen van doorgaande zwangerschappen per gestarte IVFbehandeling.

1. De totaalresultaten van de IVF-behandelingen in de 5 ziekenhuizen binnen het evaluatie-onderzoek waren als volgt:

het percentage doorgaande zwangerschappen per gestarte IVFbehandeling was ruim 10\%; dit is internationaal gezien een goed resultaat woor IVF-behandelingen.

Per 1000 gestarte behandelingen:

- eindigden er circa 200 vóor de follikelpunktie

- werd een klinische zwangerschap bereikt bij 135 behandelingen ( $13.5 \%$ )

- leidden van de klinische zwangerschappen $1 / 4$ niet tot de geboorte van (minstens) een kind, ofwel in totaal vond er 100 keer een partus plaats van (minstens) een levensvatbaar kind (10\%)

- leidde van de 100 doorgaande zwangerschappen er bijna 70 tot de geboorte van een eenling; van de ongeveer 30 meerlingen was er 5 keer sprake van de geboorte van een drie- of vierling

- trad 3 keer (c.q. 2 keer) een partus immaturus op.

Rekening houdend met vervolg-IVF-behandelingen geldt:

- indien alle paren slechts 1 IVF-behandeling zouden ondergaan zou $12 \%$ van deze paren cen kind krijgen

- indien alle paren 3 behandelingen zouden ondergaan, voorzover een voorgaande behandeling geen kind heeft opgeleverd, dan zou $30 \%$ van de paren een kind via IVF verkrijgen

- indien deze procedure wordt voortgezet tot 6 behandelingen, dan zou ruim $40 \%$ van de paren een kind via de IVF-methode krijgen.

- bij een minimale follow-up-periode van 1 jaar ${ }^{97}$ vanaf de eerste IVFbehandeling zou bijna $25 \%$ van de paren een doorgaande zwangerschap hebben bereikt (bij gemiddeld 2.5 IVF-behandeling)

- de zwangerschapsresultaten van cryopreservaties zijn vooralsnog dermate gering dat deze nauwelijks invloed hebben op de resultaten in termen van zwangerschappen per follikelpunktie

97) De maximale follow-up periode is 2 jaren voor paren die hun eerste IVF-behandeling in het begin van de evaluatie-onderzoeksperiode hebben ondergatn. De gemiddelde follow-up periode is $1.5 \mathrm{jaar}$. 
2. De resultaten van de IVF-behandeling lopen uiteen, wanneer gekeken wordt naar specifieke patiëntkenmerken die voorafgaand aan de behandeling bekend zijn:

- de totaalresultaten zijn vooral bepaald door de behandelingen op de indikatie tubapathologie: tubapathologie was bij $90 \%$ van de behandelingen (mede-)indikatie en bij $75 \%$ de enige indikatie

- van de paren met tubapathologie als enige indikatie bleek 70\% voorafgaand aan de IVF-behandeling reeds een of meerdere fertiliteitsbevorderende tubachirurgische ingrepen ${ }^{98}$ te hebben ondergaan, terwijl bij bijna $15 \%$ (ook) een andere vorm van behandeling wegens fertiliteitsproblemen was uitgevoerd

- de resultaten bij IVF voor de groep die reeds een tubachirurgische operatie hadden ondergaan waren vergelijkbaar met die van de andere behandelingen bij paren met als enige indikatie tubapathologie

- het percentage doorgaande zwangerschappen per gestarte IVFbehandeling was voor paren met als (mede-)indikatie mannelijke subfertiliteit (10\% van de behandelingen) slechts de helft van hetzelfde percentage bij andere paren

- voor paren met fertiliteitsproblemen zonder aanwijsbare oorzaak (5\% van de behandelingen) lag dit percentage 1.5 keer hoger dan voor de andere paren. Dit bleek alleen te gelden bij een relatief korte infertiliteitsduur.

- indien bij de vrouw in het verleden eén ovarium was verwijderd $(20 \%$ van de behandelingen), dan lag het percentage doorgaande zwangerschappen voor deze paren op circa $2 / 3$ van dat van de andere paren.

- voor paren die voorafgaand aan de IVF-behandeling in hun relatie geen klinische zwangerschap hadden bereikt (65\% van de behandelingen), was deze verhouding $3 / 4$

- er bestond een duidelijke trend ${ }^{9 \%}$ tot lagere awangerschapspercentages bij oplopende leeftijd van de vrouw en bij een langere infertiliteitsduur: bij vrouwen vanaf 36 jaar (25\% van de behandelingen) was de verhouding ten opzichte van andere paren 0.6 , bij paren met een infertiliteitsduur langer dan 5 jaren ( $50 \%$ van de behandelingen) $2 / 3$.

3. De totaalresultaten van de IVF-behandelingen in de onderzoeksperiode vertoonden grote verschillen per ziekenhuis:

- de verschillen tussen de totaalresultaten van de 5 ziekenhuizen bleken nauwelijks be:̈nvloed te worden door verschillen in de samenstelling van de patiëntenpopulatie per ziekenhuis

- de totaalresultaten wan het algemene ziekenhuis lagen ook na korrektie voor samenstelling van de patiëntenpopulatie als enige signifikant boven het gemiddelde.

98) Deze situatie wordt uiteraard sterk mede-bepaald door het feil dat IVF een relatief nieuwe behandelvorm is.

99) Het' gaat hierbij om trends, waarbij er geen sprake is van eén eenduidig omslagpunt in de resultaten. Een absolute leeftijdsgrens voor IVF-behandelingen kan dan ook niei worden aangegeven. Terughoudendheid ten aamzien van behandelingen bij vronwwen op hogere leeftijd is echter wel op zijn plaats. 
4. Tevens is onderzocht in hoeverre behandelkenmerken, naast de patientkenmerken, van invloed zijn geweest op de resultaten van de IVFbehandeling:

voorzover de behandelkenmerken te registreren zijn moet gekonstateerd worden dat deze nauwelijks wan invloed waren op de resultaten

- de stellige indruk bestaat dat vele elementen van cen specifieke behandeling moeilijk op systematisch wijze of zelfs geheel niet te registreren zijn. Encrzijds betreft dit vaardigheden en deskundigheid van de individuele medewerkers van een IVF-team, zoals deskundigheid en intuitie bij de beoordeling van de ontwikkeling in de follikulaire fase, vaardigheid bij de follikelpunktie en de embryotransfer, vaardigheid en deskundigheid bij handelingen in het laboratorium. Anderzijds betreffen de behandelkenmerken faktoren (die soms lange tijd onopgemerkt blijven) zoals (gewijzigde) omgevingsfaktoren bij de follikelpunktie, in het laboratorium en bij de embryotransfer; te denken valt hierbij aan toxiciteit wan materialen en dergelijke, kwaliteit van de gebruikte media in het laboratorium, funktioneren van de stoof ${ }^{100}$. Kenmerkend voor de IVF-behandeling is dat indien er bij eén van de onderdelen van de IVFbehandeling iets niet goed verloopt, de keten die moet leiden tot een zwangerschap vrijwel zeker verbroken wordt.

Wellicht zijn de verschillen in de totaalresultaten tussen de ziekenhuizen (na korrektie voor patientkenmerken) juist een weerspiegeling van deze nietregistreerbare faktoren.

Uiteraard moeten de bovenvermelde resultaten worden bezien in het licht van de mogelijke alternatieven voor de IVF-behandeling. Maar aangezien bij een groot gedeelte van de paren de vrouw reeds eerder een of meerdere tubachirurgische ingrepen heeft ondergaan en ook bij een gedeelte van de paren nog andere vormen van fertiliteitsbehandeling zijn toegepast, zal er voor een groot gedeelte van de onderzoekspopulatie geen reèel alternatief meer zijn geweest. Ofwel, het alternatief was voor hen 'niets doen'. Dit beeld zal overigens in de komende jaren enigszins kunnen veranderen. Immers, indien IVF niet meer alleen gezlen wordt als laatste redmiddel, dan zal na verloop van tijd het gedeelte van de paren van wie de vrouw vooralgaand aan de IVF een tubachirurgische ingreep heeft ondergaan afnemen. De vergelijking tussen IVF en mogelijke reęle alternatieven komt aan de orde in hoofdstuk 6 .

100) Zeilmaker[1987] heeft hiverwan een reffend voorbeeld gegeven: eer defiekt aan de automatische temperatuurregeling van de broedstoof in het laboratorium werd lange tijd niet opgemerkt, waardoor de resultaten (tot oktober 1985 ) beperkt bleven. 


\section{EKONOMISCHE EVALUATIE VAN IVF}

\subsection{Inleiding}

Belangrijke vragen die in dit hoofdstuk aan de orde komen luiden:

- wat zijn de gemiddelde kosten per gestarte IVF-behandeling en hoe zijn deze kosten opgebouwd uit de verschillende kostenkategorieèn?

- treedt er een verandering op in omvang en samenstelling van de kosten per gestarte IVF-behandeling bij wijziging van de omvang van het IVF-programma van een ziekenhuis?

De uitgangspunten voor de berekeningen in deze paragraaf luiden als volgt:

- De financieel-ekonomische kostenberekeningen voor de IVF-behandeling hebben betrekking op de periode ná het evaluatie-onderzoek IVF; met andere woorden, benodigde tijd voor extra aktiviteiten in het kader van dat onderzoek wordt buiten beschouwing gelaten.

- In de berekening is uitgegaan van een totaalprogramma van een min of meer aparte afdeling waarin de IVF-behandelingen centraal staan. Daarmee wordt bedoeld dat de IVF-behandelingen in de regel niet worden uitgevoerd door personeel, dat voornamelijk taken heeft buiten de $\mathbb{I V F}^{1}$. Wel kan dit soort personeel worden ingeschakeld bij de IVF om daarmee dienstroosters rond te krijgen.

- Tevens wordt verondersteld dat de IVF-behandeling plaatsvindt in een ziekenhuis, waarbij de differentiele kosten ${ }^{2}$ van overhead beperkt blijven tot energieverbruik, schoonmaak en onderhoud ${ }^{3}$.

- De kosten van een IVF-behandeling zijn teruggerekend naar de kosten per gestarte behandeling. Deze keuze is voornamelijk ingegeven door het feit dat een IVFbehandeling plaatsvindt binnen een totaalprogramma. Voor de dagelijkse personeelsplanning is het moeilijk rekening te houden met uitwal. Bowendien is gebleken dat slechts $1 \%$ van de gestarte behandelingen is afgebroken vór cyclusdag 8 (zie paragraaf 3.3.2.1). De berekeningen zijn echter zodanig weergegeven dat naar wens een andere opstelling kan worden doorgerekend (bijvoorbeeld indien er sprake is van transport-IVF).

- In de berekening van de kosten per IVF-behandeling is ook geen splitsing aangebracht naar patiëntgroepen ${ }^{4}$. Met name tijdens de follikulaire fase bestaat er

1) Deze veronderstelling is moodzakelijk om een redelijk onderbouwde berekening te kunnen opstellen. Hiermee is niet aangegeven dat een andere setting woor IVF-behandelingen niet mogelijk zou zijn.

2) Met het begrip differentiële kosten wordt aangegeven het verschil in kosten tussen twee siluaties: in dit geval het verschil tussen het al dan niet aanwezig zijn wan een IVF-programma in een ziekenthuis.

3) In de praktijk zijh in ieder geval de algemene beheerskosten (zoals woor direktie financiële en personele zaken) reeds opgenomen in het budget van het ziekenhuis.

4) Indien de kosten per IVF-behandeling duidelijk zouden verschillen tussen groepen met uiteenlopende patièntkenmerken $n_{n}$ dan zou cen dergelijke uitsplissing op zijn plaats zijn geweest. Voor de behandelresultaten wan de IVF-behandeling is een dergellike splitsing wel nadrukkelijk aangebracht. En bij relatering van de kosten aan de effekten zou dus een verschil in kosten wan belang zijn geweest. 
wel degelifk een redelijke spreiding ten aanzien van de uitgevoerde kontroles en de toegediende medikatie. Hoewel deze verschillen onder andere zullen leiden tot een verschillende tijdsbesteding van de IVF-medewerkers kan echter, redenerend vanuit een tolaalprogramma gebaseerd op beschikbaarheid van personeel, worden gesteld dat de kosten woor patientgroepen nawwelijks zullen verschillen.

De financieel-ekonomische behandelingskosten voor IVF kunnen worden gesplitst in de volgende kostenkategoriedn:
a. personeelskosten
b. kosten apparatuur, ruimte en materiaal
c. kosten medicijnen.

Deze drie kostenkategorieën komen suksessievelijk aan de orde in de volgende paragrafen. In paragraaf $4.5 \mathrm{zal}$ enige aandacht worden besteed aan extra kosten binnen de gezondheidszorg, onder andere ten gevolge van zwangerschapsbegeleiding en van behandeling tijdens en ma de partus. Vervolgens zal in paragraaf 4.6 een totaaltelling worden opgesteld voor IVF-programma's van verschillende omvang. Het hoofdstuk wordt afgesloten met de konklusies in paragraaf 4.7 .

\subsection{Personeelskosten}

De personeelskosten kunnen op twee manieren worden bepaald:

- enerzijds via bepaling van de arbeidsinzet bij diverse afzonderlijke aktiviteiten in het IVF-proces

- anderzijds via een opstelling van benodigde arbeidskapaciteit voor een totaal IVFprogramma.

De benadering vanuit een totaalprogramma verdient nadrukkelijk de voorkeur. Een van de belangrijkste eisen aan een IVF-programma is dat er (vrijwel) altijd personeel beschikbaar moet zijn. Tussen de dikwijls kortdurende aktiviteiten bestaan vele pauzes. Dat geldt met name voor aktiviteiten die tijdens onregelmatige diensten moeten worden uitgevoerd. Een IVF-programma wordt derhalve uit de and dex problematiok gekenmerkt door grote schommelingen in de aktiviteiten; de ongelijkmatige spreiding van de werkzaamheden leidt voor het IVF-personeel tot een taakuitoefening die te karakteriseren is als "hollen of stilstaan". De benadering van tijdmeting per separate aktiviteit houdt geen rekening met deze problemen die inherent zijn aan de IVFbehandeling. De vrijwel kontinue bereikbararheid (ook in de weekeinden) van personeel, vooral in de laboratoria, leidt er tevens toe dat in verband met werkbaarheid op langere termijn en met CAO-regelingen de personele kapaciteit verdeeld moet zijn over voldoendle personen.

Een kostenopstelling via bepaling van de personeelsinzet bij diverse afzonderlijke IVFaktiviteiten is derhalve slechts te beschouwen als achtergrond-informatie bij een meer reele kostenberekening via een totaal IVF-programma. Een raming van de 'netto' tijdsbesteding door personen van de verschillende disciplines aan afzonderlijke IVF. aktiviteiten is opgenomen in bijlage 4.1. Hieruit resulteert een gemiddelde tijdsbesteding per gestarte behandeling van ruim 6 uur arts, 7.5 uur bioloog/analist, bijna 5 uur verpleegknndige en 2.5 uur sekretaresse. De tijdsbesteding per bepaalde discipline is mede athankelijk van de taakverdeling in een IVF-centrum. 
Zo geldt onder andere dat alle gynaecologische werkzaamheden weliswaar altijd onder verantwoordelijkheid van een gynaecoloog dienen te worden uitgevoerd, maar dat het praktische werk van een gynaecoloog bij IVF voor een groot gedeelte kan worden uitgevoerd door een basisarts. Dit geldt ook, maar in mindere mate voor de werkzaamheden in het IVF-laboratorium; de praktische werkzaamheden kunnen voor een groot gedeelte worden uitgevoerd door een analist. Maar de verantwoordelijkheid blijft volledig berusten bij de academicus in het laboratorium: de bioloog. Deze persoon dient dan ook (viijwel) kontinu aanwezig dan wel beschikbaar te zijn.

Ook zijn sommige aktiviteiten door verschillende disciplines uit te voeren, bijvoorbeeld registratie, kontakten met patiënten en assistentie bij de follikelpunktie en bij de embryotransfer.

De door een arts uit te voeren IVF-werkzaamheden zijn vaak verdeeld over meerdere personen. Hierdoor zijn de diensten gemakkelijker te verdelen. Bovendien kunnen op deze manier de artsen die IVF-aktiviteiten verrichten ook andere taken uitvoeren, bijvoorbeeld andere vormen van kunstmatige voortplanting, tubachirurgie, fertiliteitsspreekuur en algemene gynaecologie. Voor een basisarts ligt dit laatste echter een stuk moeilijker. Deze zal voor haar/zijn volledige aanstelling (die natuurlijk ook minder dan full-time kan zijn) IVF-taken dienen uit te voeren. Na een inwerkperiode kan een basisarts binnen de IVF-praktijk als een volwaardige kracht worden beschouwd. In navolging van de ziekenhuizen 4 en 5 wordt de IVF-praktijk in steeds meer ziekenhuizen voor een belangrijk dee $\rrbracket$ gedragen door een of meerdere basisartsen.

Voor het laboratorium-personeel geldt een soortgelijk verhaal voor de praktische werkzaamheden. Ook voor hen geldt dat het in principe prettiger werkt als de IVFaktiviteiten door meerdere schouders worden gedragen. In de praktijk is dat niet altijd goed realiseerbaar, tenzij het IVF-personeel in het laboratorium ook voor andere laboratorium-werkzaamheden kan worden ingeschakeld (bijvoorbeeld bij aktiviteiten van andere vormen van kunstmatige voortplanting). De verantwoordelijkheid in het laboratorium berust nadrukkelijker bij de academisch-geschoolde: de bioloog.

Onderstaand zal voor IVF-programma's van verschillende omvang een indikatie worden gegeven van de benodigde full-time-equivalenten (afgekort: fte) per discipline. Deze indikaties zijn mede afgeleid van de huidige praktijk in de verschillende ziekenhuizen. Deze praktijk verschilde evenwel sterk tussen de ziekenhuizen (rekening houdend met de omvang van de IVF-programma's). Enerzijds bestaat bij de onderzoekers de stellige overtuiging dat er door alle IVF-teams in een relatief krappe bezetting vaak jarenlang veel energie in de opbouw van het IVF-programma is gestoken, met name ook in de weekenddiensten. De roep om uitbreiding van het team is derhalve zeer begrijpelijk. Anderzijds kunnen de onderzoekers zich bij vergelijking van de organisatie en de personeelsbezetting per ziekenhuis niet aan de indruk onttrekken dat de efficièntie van de organisatie van de IVF-werkzaamheden sterk warieert. Hoe is het anders te verklaren dat een IVF-programma in het ene ziekenhuis verzorgd wordt door een team dat ongeveer 1.5 keer zo groot is als dat van een ander ziekenhuis met een IVFprogramma van vrijwel gelijke omvang. De verklaring hiervoor is niet te winden in slechtere resultaten bij het ziekenhuis met het relatief kleine IVF-team, integendeel. Ook bestaat niet de indruk dat de patiënten er minder aandacht zouden krijgen.

5) Dexe is naast het gevoerde beleid ten aanzien van aard en aantal van de kontroles tijdens de follikulaire fase ook sterk afhankelik van de strukturerigg van de dagelijksic aktiviteiten. 
Evenmin is het 20 dat juist dit team de kroon spant in het maken van lange werkweken. Misschien is het war dat een goede organisatie-struktuur gemakkelijker te introduckren en te handhaven is in een perifeer ziekenhuis.

Ondanks de soms grote verschillen in omvang en samenstelling van de bestaande IVFteans is getracht een zo realistisch mogelijke inschatting te maken van de benodigde personele kapaciteit voor IVF-programma's van verschillende omvang. Hierbij is rekening gehouden met enerzijds diverse huidige bezettingen, soms door historische of praktische redenen ingegeven, en anderzijds hetgeen het meest efficient zou zijn. Dit heeft geresulteerd in twee varianten: in de eerste variant ligt meer de nadruk op het element van een efficiente organisatie, in de tweede wariant is dichter aangesloten bij de huidige praktijk in een aantal ziekenhuizen. Overigens is in beide varianten niet de meest extreme positie ingenomen. De eerste variant zal worden aangeduid met de term 'efficient', de tweede met de term 'praktijk'.

Tabel 4.1. Personele kapaciteit bij IVF-programma's van verschillende omvang ipersonele kapacitelt weergegeven in fte's; veronderstelde witval vór de follikelpunktie: 20\%; telkens wordt wóbr de schuine streep het cijfer van de efficięnte vartant weergegeven en na de schuine streep het cijfer van de praktijk-varianty

\begin{tabular}{|c|c|c|c|c|c|c|c|c|}
\hline & \multirow{2}{*}{\multicolumn{3}{|c|}{$\begin{array}{l}\text { arts } \\
\text { total gnalocoloog basisarts }\end{array}$}} & \multicolumn{3}{|c|}{ lab personeel } & \multirow{2}{*}{$\begin{array}{l}\text { verpleeg } \\
\text { kundige }\end{array}$} & \multirow{2}{*}{$\begin{array}{l}\text { sekretar } \\
\text { resse }\end{array}$} \\
\hline & & & & totaal & bialoog & anal ist & & \\
\hline $\begin{array}{l}375 \text { stimulaties } \\
300 \text { punties }\end{array}$ & $1.6 / 2.5$ & $0.6 / 1.0$ & $1.0 / 1.5$ & $2.7 / 3.2$ & $1.0 / 1.2$ & $1.7 / 2.0$ & $1.5 / 2.0$ & $0.5 / 1.0$ \\
\hline $\begin{array}{l}500 \text { stinulaties } \\
400 \text { punkties }\end{array}$ & $2.0 / 3.25$ & $0.6 / 1.25$ & $1.4 / 2.0$ & $2.7 / 3.2$ & 1.0 & 1.7 & $1.8 / 2.5$ & $0.7 / 1.0$ \\
\hline $\begin{array}{l}750 \text { stimulaties } \\
600 \text { punkties }\end{array}$ & 2.614 .0 & $0.8 / 1.5$ & $1.8 / 2.5$ & $3.2 / 3.7$ & $\pi .0 / 1.2$ & $2.2 / 2.5$ & $2.4 / 3.5$ & $11.0 / 1.5$ \\
\hline $\begin{array}{l}1250 \text { stimulatie } \\
1000 \text { punties }\end{array}$ & $4.0 / 6.0$ & $1.0 / 2.0$ & $3.0 / 4.0$ & $4.5 / 5.5$ & $1.3 / 1.5$ & $3.2 / 4.0$ & $3.5 / 5.0$ & $1.4 / 2.0$ \\
\hline
\end{tabular}

Essentieel zijn de volgende konstateringen:

1. De IVF-behandeling wordt gekenmerkt door weel korte werkzaamheden, waarbij de pauzes tussen aktiviteiten niet optimaal te gebruiken zijn; bovendien is er relatief veel sprake van weekendwerk. Dit heeft tot gevolg dat bij uitbreiding van het IVFprogramma zeker niet evenredig meer personeel (en apparatuur en ruimte) nodig is.

2. In de praktijk van een ziekenhuis kan de verdeling van het aantal fte"s aan personeel over de werschillende disciplines afwijken van de opstelling in bovenstaande tabel. Dit hangt samen met de verdeling van de taken tussen de disciplines'.

6) Vooral de taken van de verplegkundigen vatieren sterk per ziekentuis. Taken die soms door verpleegkundigen, soms door anderen worden uitgevoerd zijn bijwoorbeeld (tussen haskjes staat telkens wie deze aktiviteil anders uilvoert): verzorging van een stuk organisatie en registratie (arts, selkretaresse), patientenkontakten (arts, sekretaresse), assistentie bij de follikelpunktie en embryotransfer (analist), assistentie (nicmand) of uitwoering (arts) wan de echo-kontroles. 
Bij vergelijking van deze tabel met de bevindingen in tabel $B 43$ valt op dat het verschil tussen de theoretische $100 \%$ benutting van de personele kapaciteit en de inschatting voor de praktijksituatie bij 300 follikelpunkties het grootste is voor het laboratorium-personeel? ". Binnen de laboratoria heerst dan ook de opvatting dat een bepaalde minimum-kapaciteit aan IVF-laboratorium-personeel noodzakelijk is zelfs bij een programma van 300 punkties, wil men de diensten op een behoorlijke manier kunnen verdelen. Dit is het gevolg van een grote onregelmatigheid van korte aktiviteiten juist in het laboratorium. Bif groei van het IVF-programma is in het laboratorium nauwelijks uitbreiding nodig: de grote aantallen maken de stroon een stuk regelmatiger. Daardoor dalen de kosten per behandeling bij een grotere omvang van het IVF-programma.

Ook is de noodzakelijke personele bezetting nog op een andere manier berekend. Uitgangspunt bij deze benadering was de vraag: hoeveel fte's aan personeel is van iedere discipline noodzakelijk om een IVF-programma te kunnen uitvoeren, waarbij op bepaalde gedeelten van de dag eén of meerdere personen van een bepaalde discipline aanwezig zijn? Deze berekening is alleen uitgevoerd voor het IVFprogramma van 300 follikelpunkties ( 375 stimulaties), omdat hierbij naar verwachting de relatief hoogste mate van (onvermijdelijke) inefficientie zou optreden. Voor de berekening zij verwezen naar bijlage 4.2. De hileruit resullterende benodigde personele kapaciteit sluit goed aan bij thet beeld van de berekeningen in tabel 4.1 .

Tenslotte kan getracht worden de personele bezetting te vertalen in een kostenopstelling. Indien wordt uitgegaan van behandelingen in een academisch ziekenhuis ten behoeve van ziekenfondsverzekerden kunnen voor de leden wan het IVF-team de richtgetallen wan variant $A$ in tabel 4.2 worden aangehouden voor de te hanteren salarisschalen en de bijbehorende loonkosten (inklusief sociale premies). De bepaling van het honorarium voor de gynaecoloog en eventueel de bioloog hoort uiteindelijk thuis bij de honorarium-onderhandelingen tussen de financiers en de specialisten. De totale loonkosten per persoon kunnen dientengevolge in niet geringe mate afwijken van het gehanteerde richtgetal van $f 100,000,-$. Voor de volledigheid zijn derhalve in variant $B$ ook de berekeningen uitgevoerd onder de veronderstellingen: - de loonkosten van een gynaecoloog zijn gelijk atn het norminkomen: $180.000_{\text {; }}$ - de loonkosten van een bioloog bedragen $f 130.000,-8$.

7) Voor de bepaling van de personele bezetting van het laboratorium is werondersteld dat hel niet strikt noodzakelijk is te allen tjde met lwee personen aanwezig te zijn bij het werrichten van aktiviteitten met gameten of (pré-jembryo"s. In sommige centra wordt deze eis gehanteerd ter albsolute voorkoming van patiêntverwisseling. Allereerst kaln hiervan alleen maar sprake wijn indien ar aansluitend soortgctijk: aktiviteiten moeten worden uitgevoerd ten behoeve van verschillende paren; dit geldt zeker in de weekeinden niet altijd. Bovendien is het nog mar de vraig of dergelijke, op zich zecre crinstige foutch nu juist te vermijden zijn door de aamuexigheid van een extra - tokkijkend - persoon.

8) In praktijk zijn cok loonkosten mogelijk van circa f70.000, woor wen bioloog in een IVF-laboratorium. 
Tabel 4,2. Loonkosten per foll-time-equivalent van IVF-personeel

\begin{tabular}{|c|c|c|c|}
\hline & \multicolumn{2}{|c|}{ Variant $A$} & \multirow{2}{*}{$\begin{array}{l}\text { Variant } \mathrm{B} \\
\text { Loonkasten }\end{array}$} \\
\hline & BBPA-sichad & loonkosten & \\
\hline gynaecoloog & 12 & $f 100.000$ & $f 180.000$ \\
\hline basisarts & 10 & $f 70.000$ & ongewijizigd \\
\hline bioloog & 12 & $f 100.000$ & $f 130.000$ \\
\hline matist & 7 & $f 60.000$ & ongewi j zigd \\
\hline verpleegkund ige & 7 & $f 60.000^{1}$ & ongewijzigd \\
\hline sekr. Jadm, med. & 6 & +50.000 & ongewijzigd \\
\hline
\end{tabular}

1) Zowel voor and ist als woor verpleegkundige is rekening gehouden mett een onregelmat igheidstoes lag van $10 \%$

Op basis van deze bedragen kan het overzicht van de personele bezetting bij IVFprogramma's van verschillende omvang (tabel 4.1) worden vertaald in cen loonkostenoverzicht (tabel 4.3 ).

\section{Tabel 4.3, Jaarlijkse Ioonkosten van IVF-personeel bij IVT-programma's van verschillende omvang ( $x$ f1000,-)}

"in de eerste rij staat bij ieder onvang van het programma het bedrag voor de efficiënte variant en in de tweede rij het bedrag voor de praktijk-variant; bij gynacoloog, bholoog en bij het total staat vóór de streep de variant met loonkosten per fte. vam $f 100.000$, - en na de streep de hogere variant)

\begin{tabular}{|c|c|c|c|c|c|c|c|}
\hline & $\begin{array}{c}\text { gynaecolo } \\
A / B\end{array}$ & asisarts & $\begin{array}{c}\text { bioloog } \\
\text { A/B }\end{array}$ & analist & $\begin{array}{l}\text { verpleeg- } \\
\text { kundige }\end{array}$ & $\begin{array}{l}\text { sekreta- } \\
\text { resse }\end{array}$ & $\begin{array}{c}\text { TOTAAL } \\
\text { A/B }\end{array}$ \\
\hline 375 st imulaties & $60 / 100$ & 70 & $100 / 130$ & 102 & 90 & 25 & $447 / 525$ \\
\hline 300 punkties & $100 / 180$ & 105 & $120 / 156$ & 120 & 120 & 50 & $615 / 731$ \\
\hline 500 stimulaties & $60 / 108$ & 98 & $100 / 130$ & 102 & 108 & 35 & $503 / 581$ \\
\hline 400 punkties & $125 / 225$ & 140 & $120 / 156$ & 120 & 150 & 50 & $705 / 841$ \\
\hline 750 stimulaties & $80 / 144$ & 126 & $100 / 130$ & 132 & 144 & 50 & $632 / 726$ \\
\hline 600 punkties & $150 / 270$ & 175 & $120 / 156$ & 150 & 210 & 75 & $880 / 1036$ \\
\hline 1250 stimulaties & $100 / 180$ & 210 & $130 / 169$ & 192 & 210 & 70 & $912 / 1031$ \\
\hline 1000 punkties & $200 / 360$ & 280 & $150 / 195$ & 240 & 300 & 100 & $1.270 / 1475$ \\
\hline
\end{tabular}


Uit deze tabel wordt duidelijk dat de veronderstelling over de loonkosten van een gynaecoloog c.q. een bioloog een belangrijke faktor vormt in de totaalbedragen voor personeelskosten. Bij de relatief hoge variant voor de loonkosten zijn de personeelskosten circa $15 \%$ hoger dan bij de relatief lage variant. Aangezien her benodigde personeel met name in het laboratorium niet sterk fluktueert met een groei van het IVF-programma zijn in de personele kosten aanmerkelijke schaalvoordelen zichtbaar.

\subsection{Kosten van apparatuur, ruimte, materiaal en overige kosten}

De apparatuur en ruimte die voor IVF in gebruik is, wordt in de praktijk niet uitsluitend aangewend voor IVF-werkzaamheden; bijvoorbeeld de apparatuur en ruimte in het laboratorium wordt ook bij de andere gepraktiseerde vormen van kunstmatige voortplanting gebruikt. Toch zal de apparatuur en ruimte in het onderstaande volledig worden toegeschreven aan de IVF-procedure in verband met het samenspel van een aantal redenen:

- alle apparatuur en ruimte dient in ieder geval aanwezig te zijn bij het uitoefenen van een IVF-praktijk

- door de benodigde apparatuur en ruimte te vergelijken bij een verschillende omvang van het IVF-programma kan worden bepaald bij welke omvang apparatuur en ruimte efficiënt worden ingezet voor IVF-behandelingen. Als bij diverse programma's van verschillende omvang tijd overblijft om de apparatuur c.q. de ruimte ook nog voor andere doeleinden te gebruiken is dat een bijkomend voordeel voor het ziekenhuis. Als kompensatie maakt het IVF-team ook in beperkte mate gebruik van andere nietberekende faciliteiten in het ziekenhuis.

- toerekening van apparatuur en ruimte op basis van procentuele inzet voor verschillende doeleinden (inklusief beschikbaarheid) is enerzijds zeer omslachtig en levert anderzijds geen grote wijziging op in de kostprijs per IVF-behandeling, aangezien het IVF-gebruik in deze vaak verreweg het meest omvangrijk is.

Onderstaand is een inventarisatie opgesteld van de benodigde apparatuur ten behoeve van een IVF-programma van 375 stimulaties c.q. 300 follikelpunkties. 


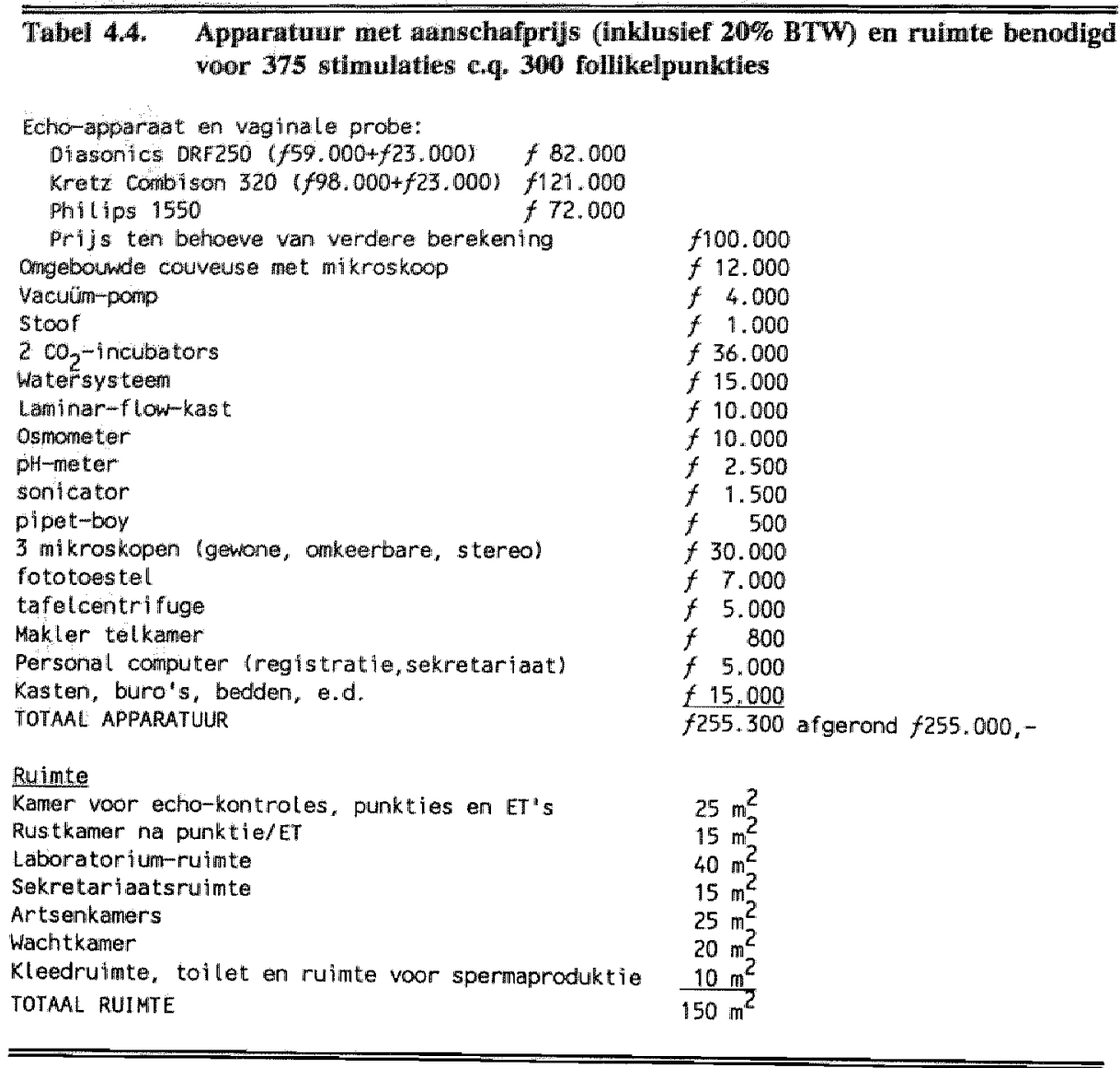

Zoals in de vorige paragraaf reeds opgemerkt geldt ook voor apparatuur en ruimte, dat toename van het aantal behandelingen geenszins tot een evenredige toename van de benodigde middelen leidt. De middelen zullen intensiever worden aangewend ten behoeve van IVF-behandelingen. Een indikatie voor benodigde extra middelen bij uitbreiding van het IVF-programma is onderstaand opgenomen (in vergelijking met het overzicht bij 300 follikelpunkties): 
Tabel 4,6. Kosten voor apparatuur en ruimte

\begin{tabular}{|c|c|c|c|c|c|}
\hline & \multirow{2}{*}{\multicolumn{2}{|c|}{\begin{tabular}{|l|} 
apparatuur \\
aanschaf- jaarlijkse \\
prijs kosten
\end{tabular}}} & \multicolumn{2}{|c|}{ ruinte } & \multirow{2}{*}{$\begin{array}{l}\text { totale jaarlijkse } \\
\text { vaste kosten } \\
\text { voor apparatuur en ruinte }\end{array}$} \\
\hline & & & $\begin{array}{l}\text { agntal } \\
m^{2}\end{array}$ & $\begin{array}{l}\text { jaarlijkse } \\
\text { kosten }\end{array}$ & \\
\hline $\begin{array}{l}375 \text { sthmulaties } \\
300 \text { punkties }\end{array}$ & $f 255.000$ & $f 53.424$ & $150 \mathrm{~m}^{2}$ & $f 52.500$ & $f 105.924$ \\
\hline $\begin{array}{l}500 \text { stimulaties } \\
400 \text { punkties }\end{array}$ & $f 255.000$ & $f 53.424$ & $150 \mathrm{~m}^{2}$ & $f 52.500$ & $f 105.924$ \\
\hline $\begin{array}{l}750 \text { stimulaties } \\
600 \text { punkties }\end{array}$ & $f 360.000$ & $f 75.422$ & $220 \mathrm{~m}^{2}$ & $f 77.000$ & $f 152.422$ \\
\hline $\begin{array}{l}1250 \text { stimulaties } \\
1000 \text { punkties }\end{array}$ & $f 510.000$ & $f 106.848$ & $300 \mathrm{~m}^{2}$ & $f 105.000$ & $f 211.848$ \\
\hline
\end{tabular}

\section{Materiele kosten per behandeling}

In tabel 4.7 worden de materiele kosten aangegeven voor een IVF-behandeling, verspreid over de fasen van de behandeling. Bij een volledige behandeling zouden de materiele kosten $f 225$, - bedragen.Uitgaande van een uitval vóor de follikelpunktie van $20 \%$ en een uitval tussen follikelpunktie en embryotransfer van $15 \%$, kan het gemiddelde bedrag per gestarte behandeling worden vastgesteld ${ }^{10}$ op $f 170,-$. De eerder besproken kosten voor oestrogeen-bepalingen (zie bijlage 4.1) die apart gedeklareerd worden, bedragen $4 \mathrm{x} f 45,-=f 180,-$.

\section{Tabel 4.7. Materiẻle kosten per behandeling}

\begin{tabular}{|c|c|c|}
\hline Fase van de IVF & kosten & middelen \\
\hline Follikelpunktie & $f 75 .-$ & $\begin{array}{l}\text { gebruik punktienaald en afdekmateriaal, verbruik van } \\
\text { steriel materiaal (spult ten, buisjes, handschoenen, kon- } \\
\text { doom), pre-medikatie }\end{array}$ \\
\hline In-Vitro-Fertllisatio & f75.- & medium, disposables, muizen, e.d. \\
\hline Embiryotransfor & $f 75, \ldots$ & ET-kathe ter, handschoenen, e.d. \\
\hline
\end{tabular}

1) Terwijl de goedkope punktienaalden (zoals MDT) meestal maar eén keer worden gebruikt, worden de duurtere naalden (bijvoorbeeld Labotect) circa $20 \mathrm{x}$ gebruikt, waarbij ze ledere keer geslepen worden. De kostprijs per follikelpunktie bedraagt voor beide typen naalden $f 30,-$ a $f 40_{n^{-}}$- (met uitzondering van MDT-naald die sleclits $f 12,-$ kost, maar ook kwalitatief minder goed wond geacht).

\section{Overige kosten}

Tenslotte is naast bovengenoemde kostenposten nog een stelpost opgenomen van $f 10.000$,- voor literatuur, reiskosten, en dergelijke.

10) Berekening: $[0.8 \times 0.15(f 150)]+[0.8 \times 0.85 \times f 225]=f 171 ;$ afgerond $f 170$. 
Hoewel het medikatieschema nogal verschilt, mag men voor de kostenberekening uitgaan van de "gemiddelde" medikatie. De 'gemiddelde" ovulatie-induktie ${ }^{11}$ bevat: 18 ampullen hMG, 2 ampullen FSH, 1.5 tablet $c$ en 1.6 ampul hCG ( $5000 \mathrm{IE}$ ).

Bij gebruik van LHRH-anallogen verandert het medikatieschema enigszins. Er wordt dan alleen hMG en hCG toegediend, waarbij met name bij langdurig gebruik van LHRH-analogen ook meer c.q. langer hMG nodig is. Het belangrijkste kostenverschil bestaat evenwel uit het gebruik van de LHRH-analogen zelf ( 1 flacon a $10 \mathrm{ml}$ per 2 weken). Voor de kostenberekening zal alleen dit verschil worden opgenomen.

Voor de luteale ondersteuning is tijdens de onderzoeksperiode in de meeste ziekenhuizen met verschillende medikatieschema's gewerkt. De oorzaak hiervoor is soms een wisseling van schema in de loop van de tijd, soms ook het naast elkaar hanteren van verschillende schema's afgestemd op de behandeling bij de betreffende patiënte. De medikatieschema's verschillen niet alleen van elkaar met betrekking tot de gebruikte stoffen, maar ook met betrekking tot:

- de toedieningswijze: injekteren (intramusculair), rectaal of vaginaal inbrengen van zetpillen, slikken wan tabletten

- de start van de medikatje: vanaf de dag van de follikelpunktie of vanaf de dag van de embryotransfer

- de frekwentie en beẻindiging van de medikatie: veelal wordi standaard bij iedere patiente op een aantal ( 3 a 5) vaste dagen luteale ondersteuning gegeven of wordt gedurende een periode van 14 dagen $7 x$ luteale ondersteuning gegeven. Maar bij een enkel schema wordt de ondersteuning bij uitblijvende menstruatie voortgezet tot de $14^{\mathrm{e}}$ zwangerschapsweek.

Al met al is het nogal omslachtig om woor ieder gehanteerd schema de totale kostprijs weer te geven. Derhalve zal mede op basis van het prijsoverzicht een globale kostprijs voor de luteale ondersteuning worden gegeven, geldend voor alle behandelingen die tot een follikelpunktie hebben geleid ${ }^{12}$.

Voor de prijzen wan de medicijnen is vitgegaan van de prijs vermeld in het Farmacotherapeutisch Kompas 1988 (Ziekenfondsraad (1988)), verhoogd met 6\% BTW. Vanaf januari 1988 geldt de volgende COTG-richtlijn voor de honorering van apotheekhoudenden: per receptregel mag de apotheker voor ziekenfondsverzekerden een opslag berekenen van $f 11.29$ inkl.BTW; voor partikuliere patienten is dit bedrag $f 12.10$ inkl. BTW per receptregel (met een maximum hoeveellheid per geneesmiddel voor gebruik van 3 maanden). Zodoende werd het prijsoverzicht samengesteld dat is opgenomen in bijlage 4.3 .

11) De 'gemiddelde' ovulatie-induktie komt in de praktijk niet voor in deze kombinatie. Het gemiddelde is bepaaid voor alle gestarte behandelingen, inklusief behandelingen die niet tot een follikelpunktie hebbern geleid (zie bijlage 4.1).

12) Indien de follikelpunktie niet leidde tot een embryotransfer, werd de luteale ondersteuning uiteraard stopgezet. 
De gemiddelde kostprijs voor een ovulatie-induktie bedraagt derhalve $\mathrm{e}^{13 *}$

- zonder gebruik van LHRH-analogen:

medicijnen: $(18 \times f 23.32)+(2 \times f 45.58)+(1.5 \times f 37.09)+(1.6 \times f 10.25)$

opsilag ${ }^{14}: 2.5 \times f 11.29$

totalat:

Afgerond totaal:

- bij gebruik van LHRH-analogen:

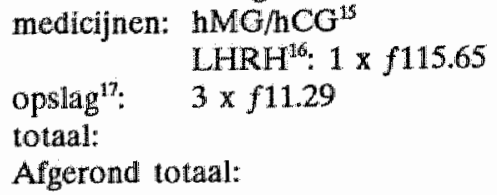

De kostprijs voor luteale ondersteuning bij behandelingen mét een follikelpunktie varieert enigszins tussen de diverse gehanteerde medikatieschema's in de verschillende ziekenhuizen (weergegeven in bijlage 4.4):

- alleen Pregnyl (ziekenhuis 4 ): $f 45$.

- alleen Duphaston (ziekenhuis 3, merendeel in ziekenhuis 5): $f 70$.-

- Duphaston en Pregnyl (bij kwart van de behandelingen in ziekenhuis 5): $f 115 .--$ Progestine en Proluton (ziekenhuizen 1 en 2): $f 110$ - a $f 150$.-

Op basis van deze cijfers wordt een gemiddelde kostprijs voor luteale ondersteuning na een follikelpunktie gehanteerd van $f 75,-$. Indien vervolgens rekening wordt gehouden met een uitval van $20 \%$ vóor de follikelpunktie, resulteert een gemiddelde kostprijs voor luteale ondersteuning per gestarte behandeling van $f 6 \mathrm{O}_{2}=$.

Het totaalbedrag per gestarte IVF-behandeling nodig voor medicijnen in de follikulaire en luteale fase bedraagt derhalve:

f670,- zonder gebruik van LHRH-analogen

f790,- bij gebruik van LHRH-analogen.

Gebruik van LHRH-analogen bij de IVE-behandeling is van recente datum, maar kan in de toekomst wellicht op ruime schaal worden toegepast. In de verdere berekeningen zal het gemiddelde bedrag van deze beide variarten worden aangehouden $(f 730,-)$.

13) Indien meerdere preparaten beschikbaar zijin woor dezelfde stof is in de berekening uitgegaxn van de goedkoopste variant. Bit gebruilk van LHRH-amalogen lijki wooralsnog sprake te zijn van minder uitval voor de follikelpunktie en met hogere awangerschapspercentages (2le hoofdstuk 3i); bij de verdere berekeningen wordt hiervan geabstratheerd.

14) In die praktijk wordt naasi de hCG in nim de helf van de stimulaties zonder LHRH-gebruik alleen hMG of alleen FSH voorgeschreven. Voor de berekening van het aantal receptregels voor hMG/TSH/cc word derhalve uitgegaan van 1.5 receptregel. Voor het opslagbedrag per receptregel is (in verband anet het minieme totaawerschil) uitgegaan var die voor de ziekenfondsverzekerde.

15) De kostprijs hiervan is gelijk verondersteld gan die bij stimulatie zonder LHRH-gebruik (zie eerder).

16) Voor de kostenberekening van de LHRH -analogen is uitgegaan van hel gebruik van de neusspray bij kortdurende LHRH-stimulate; er kan dan worden volstann met 1 flacon. Bij langdurend LHRH. gebuik zijn veetay 2 flacons noodzakelijk, maar daar staat tegenower dat LuHRH-toediening via injukthes weer goedkoper is.

17) Bif LHRH-gebruik wordt ngast de hCG alleen hMG toegediend. 


\subsection{Overige kosten bimmen de gezondheidszorg}

Hoewel de kosten in dieze paragraaf niet rechtstreeks bij de IVF-behandeling behoren, waren ze niet opgetreden als de IVF-behandeling niet had plaatsgevonden. Derhalve dienen ze bij een volledige kostenopstelling te worden vermeld. Daarbij blifft diskutabell op welk moment gestopt moet worden met kostentoerekening aan de IVF. De kosten uit deze paragraaf zullen pro memorie worden benoemd ${ }^{18}$.

De kosten verbonden aan de behandeling van komplikaties die ten gevolge van de IVFbehandeling zijn opgetreden zijn bij terugrekening naar een gestarte IVF-behandeling gemiddeld genomen waarschijnlijk gering. De meest voorkomende komplikatie vormt het zogenaamde hyperstimulatie-syndroom, waarbij een cysteuze vergroting van de ovaria optreedt. Hoewell deze komplikatie veelvuldig gepaard gaat met hevige pijnen, komt hyperstimulatie in ermstige vorm (leidend tot een opname) waarschijnlijk niet vaak voor bij IVF.

Indien met behulp van IVF een klinische zwangerschap tot stand wordt gebracht, resulteert dit niet altijd in een doorgaande zwangerschap. Bij een klinische abortus zal in circa de helft van de gevallen een curettage plaatsvinden. Dit kan zowel in dagbehandeling als met een opname geschieden. De tijdsduur van de ingreep is ongeveer een half uur (aanwezig: gynaecoloog, anesthesist, verpleegkundige). Bij opname geldt een gemiddelde verpleegduur van 2.5 dag (LMR [1988]). Hoewel het percentage klinische abortussen bij IVF relatief hoog ligt (in dit onderzoek $17 \%$ per klinische zwangerschap), bedraagt het percentage klinische abortussen per gestarte IVFbehandeling slechts $2.3 \%$. De kosten voor medische behandeling van een klinische abortus na een IVF-behandeling zouden dus bif toerekening naar de kosten per gestarte IVF-behandeling gedeeld moeten worden door circa 43.

Bij een EUG zal vooralsnog veelal een operatie nodig zijn. De tijdsduur van de ingreep onder volledige narcose bedraagt circa 1 uur (aanwezig: gynaecoloog, 2 verpleegkundigen, anesthesist, anesthesie-verpleegkundige). Daarna volgt een ligduur van circa 7 dagen (totale ligduur bij opname gemiddeld 9.5 dag (LMR[1988]). Hot percentage EUG's per gestarte IVF-behandeling bedroeg in dit evaluatie-onderzoek $0.75 \%$. Indien voor de kostenberekening wordt verondersteld dat bij ledere $\mathrm{EUG}$ ten gevolge van een IVF-behandeling operatief wordt ingegrepen, dan dienen de kosten van een operatieve EUG-behandeling gedeeld te worden door 133 ten behoeve van een kostentoerekening naar de kosten per gestarte IVF-behandeling.

Het is uiterst gekompliceerd om goed zicht te kriijgen op de vraag in hoeverre de zwangerschapsbegeleiding bij een zwangerschap die ontstaan is uit een IVF. behandeling afwijkt van een normale zwangerschapsbegeleiding. Enerzijds wordt een wisselend ${ }^{19}$ gedeelte van de zwangerschapsbegeleiding verzorgd buiten het ziekenhuis waar de IVF-behandeling heeft plaatsgevonden. Anderzijds is onduidelijk of de

18) In bijlage 4.5 is een zeer globale schatting gemaakt van deze kosten; deze raming komt uil op een bedrag van $f 360$, -bij toerekening naar eem gestarte IVF-behandeling.

19) Met wissetend wordt zowel bedoeld dat er verschillen bestaan tussen ziekenhuizen in het beleid ten aanzien van de zwangerschapsbegeleiding van WF-zwangeren, alsook dat de wijze van zwangerschapsbegeleiding afhankelijk is van het specifieke paar en hun kontakten met het IVF-team de werwijzend gynaecoloog en eventueel en verloskundige of huisarts. 
vergelijkingsmaatstaf 'normale zwangerschapsbegeleiding" moet worden gezocht bij de gemiddelde zwangere populatie, bij de zwangere populatie die (al of niet langdurig) onder behandeling van een gynaecoloog is geweest of nog anderszins. En dan nog blijft de vraag in hoeverre de extra zwangerschapsbegeleiding van IVF-zwangeren, voorzover het eenlingen betreft, een zaak van voorbijgaande aard is.

Wel geldt dat een gedeelte van de extra zwangerschapsbegeleiding wordt veroorzaakt door het gegeven dat bijna $30 \%$ van de doorgaande zwangerschappen meerlingwwangerschappen betreffen. Maar omgerekend naar een gestarte IVF-behandeling levert dit een percentage meerling-zwangerschappen per gestarte IVF-behandeling op van $3 \%$. De extra kosten ten gevolge meerlingzwangerschappen na een IVF-behandeling zouden derhalve bij toerekening naar een gestarte IVF-behandeling gedeeld moeten worden door 33. De gemiddelde verpleegduur bij meerlingzwangerschappen bedroeg in Nederland gemildeld 12.2 dagen versus 4.4 dagen bij normale bevallingen (LMR[1988]).

Hetgeen in het bovenstaande is gesteld ten aanzien van de zwangerschapsbegeleiding is in grote lijnen ook van toepassing op de plaats van de partus en de daarbij aanwezige medische zorg. Bij een partus immaturus kan worden uitgegaan van een ligduur van 5 dagen na de partus. De incidentie van partus immaturus per gestarte IVF-behandeling bedroeg tijdens het evaluatie-onderzoek circa $0.3 \%$.

Bij een pre-term partus en/of de geboorte van een kind met een laag geboortegewicht zal de ligduur en de intensiteit van de zorg sterk afhangen van de situatie van het kind (de kinderen) en mogelijk ook van de lokatie. Mede gezien het relatief grote aandeel meerlingen is de neonatale zorg bij IVF relatief dikwijls erg intensief. Hellas laat de registratie binnen het onderzoek geen eenduidige konklusies toe omtrent de frekwentie, de intensiteit en de duur van deze zorg. Wel is reeds eerder vermeld dat $30 \%$ van de doorgaande zwangerschappen pre-term (vór 37 weken) zijn beëindigd en dat $38 \%$ van de geboren kinderen een laag geboortegewicht $(<2500 \mathrm{~g})$ had. Maar niet bij al deze zwangerschappen en bij al deze kinderen was extra medische zorg vereist.

Hoewel het vrijwel onmogelijk is goed zicht te krijgen op de mate waarin het zogenaamde "fertility-shopping" optreedt, is het wel uiterst belangrijk te beseffen dát het optreedt. Met deze term wordt aangegeven dat een gedeelte van de paren met fertiliteitsproblemen alles in het werk zullen stellen om met medische hulp een kind te krijgen. Daarvoor is men soms bereid desnoods een tange lijdensweg af te leggen langs diverse vormen van diagnostiek, fertiliteitsbevorderende behandelingen en kunstmatige voortplanting. Het is daarbij moeilijk aan te geven welke invloed de introduktie van de IVF-behandeling op het gebruik van de gynaecologische voorzieningen heeft gehad. Van de paren die in de onderzoeksperiode zijn behandeld op basis van tubapathologie als enige indikatie bleek $70 \%$ reeds een of meer fertiliteitsbevorderende tubachirurgische ingrepen te hebben gehad en $15 \%$ een of meerdere keren behandeld te zijn met behulp van intra-uteriene inseminatie of medikatie in de follikulaire en/of luteale fase (zie paragraaf 3.2.2). Indien de IVFmethode niet als "eindstation' wordt beschouwd, zal dit percentage in de toekomst echter affemen. Voorzover die cerdere behandelingen niet tot het gewenste resultaat hebben geleid, is een dergelijke afname te beschouwen als een besparing binnen de gezondheidszorg ten gevolge van de IVF. Anderzijds zal de mogelijkheid van de IVFbehandeling voor diverse paren een stimulans vormen het medisch circuit (opnieuw) gedeeltelijk te doorlopen. 


\subsection{Totaaltelling kostenberekening IVF-behandeling}

In de onderstaande kostenopstelling van tabel 4.8 zijn alle behandelkosten van IVF opgenomen, zoals deze in het voorgaande zijn berekend. Uitgesloten zijn derhalve alleen de overige kosten binnen de gezondheidszorg.

Tabel 4.8. Totale kosten voor IVF-programma's van verschillende omvang (in duizenden guldens)

(woór c.q. ná de streep staan kosten vermeld bi) loonwarlant A c.q. B)

\begin{tabular}{|c|c|c|c|c|c|c|}
\hline & $\begin{array}{l}\text { perso } \\
\text { efficient } \\
\text { A/8 }\end{array}$ & $\begin{array}{l}\text { praktijk } \\
\qquad / B\end{array}$ & $\begin{array}{l}\text { apparatuur. } \\
\text { ruimte en } \\
\text { ov. kosten }\end{array}$ & $\begin{array}{l}\text { materiaal, } \\
\text { oest.bep." en } \\
\text { medikatie }\end{array}$ & $\begin{array}{l}\text { tota } \\
\text { efficiënt } \\
A / B\end{array}$ & $\begin{array}{c}\text { praktijk } \\
\mathrm{A} / \mathrm{B}\end{array}$ \\
\hline $\begin{array}{l}375 \text { stimulaties } \\
300 \text { punkties }\end{array}$ & $447 / 525$ & $615 / 731$ & 116 & 405 & $968 / 1046$ & $1136 / 1252$ \\
\hline $\begin{array}{l}500 \text { stimulaties } \\
400 \text { punkties }\end{array}$ & $503 / 581$ & $705 / 841$ & 116 & 540 & $1159 / 1237$ & $1361 / 1497$ \\
\hline $\begin{array}{l}750 \text { stimulaties } \\
600 \text { punkties }\end{array}$ & $632 / 726$ & $880 / 1036$ & 16.2 & 810 & $1604 / 1698$ & $1852 / 2008$ \\
\hline $\begin{array}{l}1250 \text { stimulaties } \\
1000 \text { punkties }\end{array}$ & $912 / 1031$ & $1270 / 1475$ & 222 & 1350 & $2484 / 2603$ & $2842 / 3047$ \\
\hline
\end{tabular}

Uit de totale kosten voor een IVF-programma kunnen ook de gemiddelde kosten per gestarte behandeling worden berekend en de differentiele kosten per groep van behandelingen bij uitbreiding van het IVF-programma. Deze resultaten zijn cijfermatig weergegeven in tabel 4.9 en grafisch in figuúr 4.1.

Tabel 4.9. Gemiddelde en differentiële kosten per gestarte IVF-behandeling bij uiteenlopende programma's (in guldens)

\begin{tabular}{|c|c|c|c|c|c|c|}
\hline & $\begin{array}{c}\text { totale ko } \\
\text { INF-progra } \\
\text { efficiënt } \\
\text { A/B. }\end{array}$ & $\begin{array}{c}\text { sten vari het } \\
\text { mena }(x \text { 1000) } \\
\text { praktiljk } \\
\text { A/B }\end{array}$ & $\begin{array}{l}\text { gemiddel } \\
\text { per beha } \\
\text { effictuent } \\
\text { A/B }\end{array}$ & $\begin{array}{c}\text { e kosten } \\
\text { deling } \\
\text { prakt } 1 . j k \\
A / B\end{array}$ & $\begin{array}{c}\text { different } \\
\text { per behan } \\
\text { effociënt } \\
\text { A / B }\end{array}$ & $\begin{array}{l}\text { Le kosten } \\
\text { Ling } \\
\text { praktiJk } \\
\text { A/g }\end{array}$ \\
\hline $\begin{array}{l}375 \text { stimulaties } \\
300 \text { punkties }\end{array}$ & $968 / 1046$ & $1136 / 1252$ & $2581 / 2789$ & $3029 / 3339$ & - & - \\
\hline $\begin{array}{l}500 \text { stimulaties } \\
400 \text { punkties }\end{array}$ & $1159 / 1237$ & $1361 / 1497$ & $2318 / 2474$ & $2722 / 2994$ & $1528 / 1528$ & $1800 / 1960$ \\
\hline $\begin{array}{l}750 \text { stimulaties } \\
600 \text { punkties }\end{array}$ & $1604 / 1698$ & $1852 / 2008$ & $2139 / 2264$ & $2469 / 2677$ & $1696 / 1739$ & $1909 / 2016$ \\
\hline $\begin{array}{l}1250 \text { stimulaties } \\
1000 \text { punikties }\end{array}$ & $2484 / 2603$ & $2842 / 3047$ & $1987 / 2082$ & $2274 / 2438$ & $1733 / 17799$ & $1950 / 2051$ \\
\hline
\end{tabular}


Figun 4.1. Gemiddelde en differentiele kosten wan IVT bij verschillende omvang wan het programma

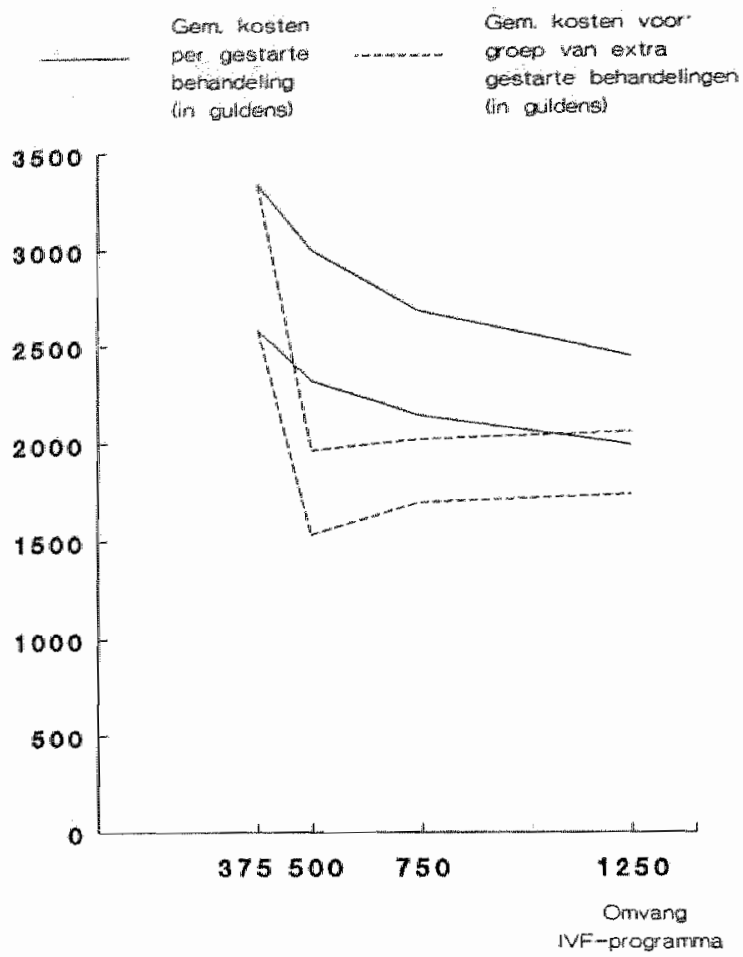

Uit de resultaten wordt duidelijk dat de gemiddelde kosten per gestarte IVFbehandeling lager worden bij een groei van het programma per centrum. Dit wordt vooral veroorzaakt door de noodzakelijke basiskapaciteit aan personeel, apparatuur en ruimte. De differentidla kosten per gestarte behandeling (bovenop de eerste 375 stimulaties) zijn aanmerkelijk lager dan de gemiddelde kosten van de eerste 375 behandelingen; ze nemen wel enigszins toe vanaf een programma van 500 behandelingen. Desalniettemin is een landelijk IVF-programma van bijvoorbeeld 2500 IVFbehandelingen per jaar goedkoper te realiseren via 2 centra met 1250 behandelingen (4.97 a 6.09 miljoen guldens) dan via 5 centra met 500 stimulaties ( 5.80 a 7.49 miljoen guldens) ten gevolge van de benodigde basiskapaciteit voor ieder IVF-centrum. 


\subsection{Konklusies}

Indien besloten wordt tot het verlenen van erkenningen aan laboratoria dan wel ziekenhuizen én tot vergoeding wan de kosten van de IVF-behandeling, dan zal omtrent de gewenste omvang van de verschillende centra een afweging gemaakt moeten worden tussen enerzijds een verlaging van de kosten van de IVF-behandeling en anderzijds de bereikbaarheid van de medische voorziening. De schaalvoordelen van een groter IVF-programma dienen te worden beoordeeld in relatie tot de grotere afstand die het patientenpaar moet afleggen naar het IVF-ziekenhuis.

Op basis van de bovenstaande berekening kan globaal worden gesteld:

- De behandelingskosten van een IVF-behandeling varieren bij de lage variant voor de loonkosten van 12600 , a $f 3000$, in een centrum dat jaarlijks circa 400 stimulaties uitwoert tot $f 2000$, a $f 2300$, in een centrum met 1250 stimulaties. Ofwel de kosten van een IVF-behandeling zijn in dit laatste geval met circa $1 / 4$ gereduceerd. Dit is vooral een gevolg van de benodigde basiskapaciteit aan personeel, apparatuur en ruimte en wan schaalvoordelen: bij een groot programma zullen de aktiviteiten meer gestroomlijnd kunnen verlopen, wasurdoor er relatief minder leegloop zal ontstaan.

- In de hoge variant voor de loonkosten veranderen bovenstaande bedragen in 72800 ,a $f 3300$,- voor een centrum met jaarlijks circa 400 IVF-stimulaties c.q. in $f 2100$,a $f 2400$,- voor een centrum met jaarlijks 1250 stimulaties; de reduktiefaktor blijft circa $1 / 4$.

Ten aanzien wan de bereikbaarheid van IVF-centra kan globaal het volgende worden opgemerkt. De patiënt dient tijdens de behandeling meerdere keren het ziekenhuis te bezoeken in verband met kontrole van de follikulaire ontwikkeling ${ }^{20}$, de punktie van de follikels, de embryotransfer en het nagesprek.

- Tijdens de onderzoeksperiode onderging ongeveer de helft van de behandelde patiènten hun IVF-behandeling(en) in de 5 ziekenhuizen van het onderzoek buiten een straal van circa $50 \mathrm{~km}$ van hun woonhuis.

- Indien gekeken wordt naar de geografische spreiding van de behandelparen in de 5 ziekenhuizen, dan is te konstateren dat bijna $60 \%$ van de paren afkomstig was uit de provincies Noord-Holland, Zuid-Holland en Utrecht (zie bijlage 4.6). Dat beeld komt overeen met de geografische spreiding van de wachtijisten voor de 5 ziekenhuizen. De vraag blijft grotendeels onbeantwoord in hoeverre deze geografische spreiding ook overeenkomt met die van de paren die met behulp van IVF zinvol behandeld kunnen worden. Het procentuele aandeel van de totale bevolking van de provincies Noord-Holland, Zuid-Holland en Utrecht samen bedraagt ongeveer $45 \%$. Maar daarnaast wordt algemeen aangenomen dat de prevalentie van fertiliteitsproblemen hoger ligt in de Randstad.

20) De frekwentie wan de bezoeken aan het ziekenhuis tijdens de follikulaire lase in verband met kontroles verschilt sterk per ziekenhuis. 


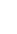




\section{ALTERNATIEVE BEHANDELINGEN VOOR IVF}

\subsection{Introduktie}

Paren die voor een IVF-behandeling in aanmerking komen, kunnen op talloze faktoren van elkaar verschillen. In hoofdstuk 3 is onderzocht in hoeverre de sukseskansen bij een IVF-behandeling afhangen van specifieke kenmerken van het paar en van de behandeling. Daaruit kwam duidelijk naar woren dat er niet 6én sukseskans voor IVF bestaat, maar dat deze kans sterk samenhangt met diverse onderzochte kenmerken. Indien op groepsnivo een afweging moet worden gemaakt tussen verschillende vormen van behandeling voor fertiliteitsproblemen, clan dient hiermee nadrukkelijk rekening te worden gehouden. In dit hoofdstuk zal op basis wan literatuurgegevens aandacht worden besteed aan de meest belangrijke andere vormen van therapie bij onvervulde kinderwens. Waar mogelijk zal ook voor deze behandelvormen worden getracht een differentiatie aan te brengen in de sukseskansen op basis van patientkenmerken. Aangezien de belangrijkste indikatie woor de IVF-behandeling wordt gevormd door afwijkingen aan de tubae zal de tubachirurgie als belangrijkste alternatief worden besproken. Daarnaast zullen in paragraaf 5.3 diverse andere behandelvormen de revue passeren, terwijl in paragraaf 5.4 enkele literatuurgegevens zullen worden gepresenteerd voor het alternatief 'geen behandeling'. In paragraaf 5.5 zal enige aandacht worden besteed aan de behoefte aan fertiliteitsbehandeling. Het hoofdstuk wordt afgesloten met konklusies.

\subsection{Tubachirurgie}

\subsubsection{Medische resultaten}

De term tubachirurgie wordt in de literatuur gehanteerd als een verzameinaam voor diverse soorten van fertiliteitsbevorderende abdominale ingrepen aan de tubae en/of ovaria. Publikaties met betrekking tot tubachirurgie hebben soms betrekking op het totale spectrum van deze ingrepen, soms ook zijn ze toegespitst op een bepaald type tubachirurgie.

Bij de vergelijking van zwangerschapspercentages na tubachirurgie op basis van literatuuronderzoek doemen een dantal belangrijke problemen op dic de vergelijkbaarheid niet bevorderen:

1. De follow-up-duur verschilt dikwijls tussen de diverse populaties in de beschreven onderzoeken. Na een fertiliteitsbevorderende operatie kan de vrouw in iedere cyclus zwanger worden. Bij een langere follow-up zal derhalve een groter gededie van de 
geoperecrde populatie zwanger zijn geworden. Hoewel er in te theorie methoden bestaan om de onderlinge vergelikbaarheid van resultaten te bevorderen, wordt daar in de publikatie-praktijk nauwelijks mee gewerkt. In het gunstigste geval word de follow-up-duur vermeld.

2. Ook is niet altijd duidelijk, evenals bil publikaties over de IVF-resultaten, wat in de publikatic nu precies de definitie voor zwangerschap is: een klinische zwangerschap, een intra-uteriene zwangerschap, een doorgaande zwangerschap, etcetera?

3. Hoe kunnen de resultaten zo gerangschikt worden dat de vermeldingen betrekking hebben op min of meer homogene groepen?

Uit literatuurstudies van Hedon[1983], Luber[1986] en Lavy[1987] is een overzicht afgeleid voor de zwangerschapsresultaten bij verschillende typen van microchirurgische tubachirurgie; dit is weergegeven in tabel 5.1.

\section{Tabel 5.1. Zwangerschapsresultaten bij verschillende typen van micro-chirurgie}

$\begin{array}{lc}\text { Hersteloperatie na sterilisatie: } & 50 \text { à } 80 \% \\ \text { fimbrioplastiek: } & 40 \text { à } 50 \% \\ \text { Adhaes iolyse } & 20 \text { à } 60 \% \\ \text { Salpingostonie: } & 20 \text { à } 30 \% \\ \text { Herhalde chirurgie: } & 15 \%\end{array}$

Hedon[1983] geeft daarbij te kennen dat de resultaten van micro-chirurgie naar zijn mening nauwelliks meer zullen veranderen, tenzij een effektieve preventie kan worden bereikt van post-operatieve adhaesieformatie en/of een methode kan worden ontwikkeld die regeneratie van het tubaire epithelium mogelijk maakt. Ook het gebruik van lasertechnieken - warbij adhaesieformatie kan worden gereduceerd - lijkt vooralsnog geen hogere zwangerschapspercentages op te leveren, maar hoogstens een korter interval tussen de operatie en de zwangerschap, getuige de gepubliceerde ervaringen bij distale salpingostomie (Daniell[1986], Bateman[1987]) en bij adhaesiolyse (Tulandi[1986]).

Schoysman[1984] vermeldt de zwangerschapsresultaten van Brussell voor de periode 1971-1981 (zie figuur 5.2), waarbij gesteld kan worden dat de operaties zijn uitgevoerd door een ervaren chirurgisch team.

Minstens zo belangrijk bij vermelding van de zwangerschapsresultaten na tubachirurgie is nast de indeling naar type ingreep een indeling naar de ernst van de aandoening.

1) De life-table analysis wordt bij medische studies vooral gehanteerd indien het belangrijk is zicht te krijgen op hel inturval tussen een irgreep an het moment van overlijken, zogenamde overlevingskurves (zie onder anderen Benederti(1981). Bij de fertiliteitsbevorderende chirurgie is eigenliik eenzelfde soort interval van belang, alleen bestat het eindpunt wan het interval nu wit een prettige gebeurtenis: een zwangerschap. Andere manieren om rekening te bouden met een verschil in follow-up zijn [Guzick[1986a], Cramer|1979)):

de "fecundability-rate", gedefinieerd als het aantal concepties gedeeld door het totaal aantall followup-oycli parametrische schattingsmethoden gebaseerd op cen twecdeling in patienten (genezen/niel-genezen") eth en makndelijkse zwangerschapskans woor de "genezenen". 
Tabel 5.2. Zwangerschapsresultaten na micro-chirargie* Brussel (1971-1981)

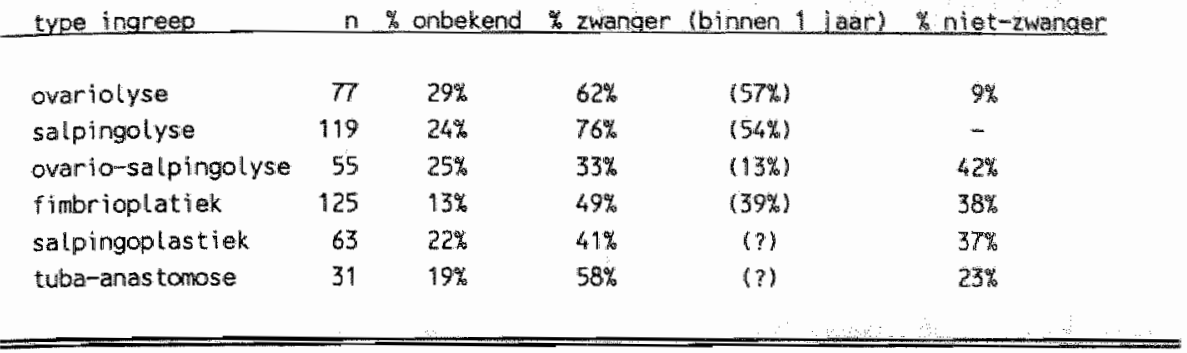

Op dit terrein zijn inmiddels vele studies verricht, kijkend naar een of meerdere parametters tegelijkertijd. Hieronder volgt een bloemlezing. Een gedetaillende beschrijving van de gehanteerde indelingen is daarbij veelal achterwege gelaten, omdat de indelingen dikwijls sterk gebonden zijn aan de individuele beoordelaar en moeilijk te vertalen zijn in algemeen toepasbare aanduidingen die rechtstreeks bruikbaar zijn in een andere praktijk. De doelstelling van onderstaande opsomming is dan ook wooral aan te geven dat een nadere differentiatie op basis van de ernst van de aandoening mogelijk en per kliniek zinvol is.

Hulka[1978] komt op basis van een (retrospektief bepaalde) skore voor adnexale adhaesies tot een driedeling in zwangerschapspercentages: $38 \%$ bij de groep met geringe adhaesies $(n=16), 13 \%$ bij de groep met matige adhaesies ( $n=47)$ en $0 \%$ bij de groep met ernstige adhaesies $(n=9)$. Caspi[1979] meldt soortgelijke bevindingen bij een vierdeling. Later presenteert Hulka[1982] een klassifikatieschema op basis van 4 "onafhankelijke" dichotome skores, bepaald tijdens de diagnostische laparoscopie.

Johnston[1981] erkent dat operaties aan extreem verdikte tubae of aan een zeer dunwandige hydrosalpinx slechte resultaten opleveren. Een operatie bij salpingitis isthmica nodosa is veel hoopvoller, maar brengt volgens McComb[1986] wel een verhoogd risiko op een EUG met zich mee.

Bij salpingostomie voor distale fimbriele obstruktie leidt (retrospektieve) splitsing van de populatie op basis van de ernst van de tubapathologie volgens Rock[1978] tó een driedeling in zwangerschapskansen: geringe tubapathologie $(n=15) 86 \%$; matige tubapathologie $(n=34) 26 \%$ en ernstige tubapathologie $(n=50) 8 \%$. Dit zijn minimumpercentages, aangezien de follow-up-duur per patient verschilt.

In Nederland is door Boer-Meisel, te Velde en Habbema veelvuldig onderzoek verricht om prognostische variabelen te bepalen voor de sukseskans na tubachirurgie bij hydrosalpinx-patiënten. Aanvankelijk maakte men hiervoor gebruik van per-operatieve bevindingen (Boer-Meisel[1985,1986]). Men deed onderzoek bij 108 patiénten met komplete fimbriele obstruktie naar mogelijke prognostische faktoren woor de zwangerschapskans na salpingostomie. In totaal kwamen er na de ingreep 50 klinische zwangerschappen (46\%) tot stand, waarvan 24 woldragen (22\%), 7 abortussen (7\%) en 19 EUG's $(18 \%)$. De mediaan voor het interval tussen de operatie en de eerste 
zwangerschap bedroeg 1.0 .5 cycli met een range van 1 tot 58 cycli. Voor de verdere analyses wordt een intra-uteriene graviditeit (UUG's = doorgaande $z$ wangerschappen + abortusseny een sukses genoemd; een mislukking bestaat derhalve uit een EUG of geen zwangerschap.

Met behulp van Bayesjaanse discriminantanalyse met 4 prognostische variabelen (bepaald direkt aansluitend aan de operatie) konstrueert Boer-Meisel een driedeling met sukseskansen in termen van intra-uteriene graviditeit: goede groep $(n=27) 77 \%$; middengroep $(n=44) 21 \%$ (maar veel EUG's); slechte groep $(n=37) 3 \%$ (en veel EUG*s).

Later heeft Boer-Meisel[1988] getracht om voor deze patiënten (beperkt tot die met beiderzijds hydrosalpin; $\mathrm{n}=98$ ) alleen op basis van pre-operatieve bevindingen prognostische variabelen te bepalen woor de kans op een IUG na tubachirurgie. Van het HSG werden hiertoe de volgende dummy-variabelen (met tussenpositie voor onbekend) gebruikt:

- patroon mucosa: normaal-abnormaal

- diameter hydrosalpinx: medium/groot-klein ( $<15 \mathrm{~mm}$ )

- rekbaarheid ampulla: aanwezig-afwezig

De laatste twee variabelen lijken eenzelfde faktor te meten.

Hoewel de konklusies uit deze studie omtrent de invloed van diverse prognostische variabelen plausibel zijn, blijft de cijfermatige weergave van de resultaten in de verschillende prognose-groepen noodgedwongen dubieus. Het geringe aantal waarnemingen tezamen met het probleem van ontbrekende data vormt hiervoor de belangrijkste oorzaak. Bovendien blijft de vooralsnog slechts gedeeltelijk beantwoorde vraag: hoe zijn ongelijke skores in de beoordelingen voor het linker- en rechteradnex te verwerken in de prognose ten aanzien van een zwangerschapskans?

Aansluitend werd voor dezelfde groep patiënten nog de prognostische waarde onderzocht van enkele parameters uit HSG en diagnostische laparoscopie (te Velde[1989a]):

$\mathrm{HSO}$ (zie boven):

Diagnostische laparoscopie:

aard van mucosa-patroon, diameter hydrosalpinx, rekbaarheid van de ampulla (de laatste 2 variabelen metten waarschijnlijk eenzelfde faktor)

omvang adhaesies, aard adhaesies, dikte tubawand, diameter hydrosalpinx (de laatste 2 variabelen meten waarschijnlijk eenzelfde faktor).

Voor ledere parameter werd zowel links als rechts een skore gegeven: positief, neutraal of negatief; zodoende zijn er 6 kombinaties mogelijk voor iedere parameter. De skores voor iedere parameter apart werden in verband gebracht met het zwangerschapsresultaat. Er lijkt een (enkelvoudig) verband met alle parameters te bestaan, behalve met de parameters 'omvang adhaesies' en 'diameter hydrosalpinx' (bepaald tijdens de laparoscopie). Een gunstig mucosa-patroon in eén van beide tubae lijkt woldoende, terwijl voor de andere faktoren juist én ongunstige skore doorslaggevend negatief lijkt te zijn. Bovenstaande voorzichtige konklusies zijn evenwel opgesteld op basis van univariate analyses, watbij geen rekening kon worden gehouden met diskongruente skores op de diverse faktoren.

Andere onderzoeksgroepen hebben soortgelijke prognostische variabelen gevonden voor de zwangerschapskans na tubachirurgie. Donnez[1986a] konkludeert dat de intrauteriene-zwangerschapskans bij fïmbrioplastiek/salpingostomie wordt beïnvloed door 
morfologische eigenschappen van de tubae rekbaarheid; dikte van de tubawand en fimbriëel celpercentage. Hij komt tot een tweedeling in prognose-groepen:

- bij fimbriêle phimosis of bij volledige okklusie met normale ampullaire diameter $(\mathrm{in}=159)$ : IUG ruim $50 \%$

- bij volledige okklusie met ampullaire rekbarheid $>15 \mathrm{~mm}(\mathrm{n}=56)$ : $1 U \mathrm{G}$ slechts $25 \%$ met een EUG-percentage van $10 \%$.

Na salpingolyse ( $n=42)$ werd een percentage IUG's van $64 \%$ gevonden. De follow-up periode bedroeg 1 tot 6 jaar na operatie.

Mage[1986] zocht naar prognostische variabelen voor de zwangerschapskans na distalle salpingostomie (beiderzijds of eenzijdig bij enig overgebleven tuba; $n=76$ ). Hij lette daarbij op:

- de ernst van de tuba-afwijking; skore op basis van:

- HSG: aard van mucosa-patroon

- laparoscopie: * mate van distale okklusie

* aspekt tubawand

Bij verschillen tussen de skores voor beide tubae werd de gunstigste totaalskore gehanteerd.

- adhaesievorming; skore op basis van adhaesie-skore voor zowel tubae als ovaria. Er werd geen korrelatie gevonden tussen de beide gehanteerde skores. Bij ernstige tuba-afwijkingen en/of ernstige adhaesies $(n=42)$ lag het percentage IUG's beduidend lager dan bij de andere groepen $(\mathrm{n}=34)$, resp. $7 \%$ en $50 \%$. Het percentage EUG's bedroeg in beide groepen $9 \%$.

De literatuurvermeldingen over zwangerschapsresultaten na een adhaesiolyse lopen sterk uiteen. Globaal kan gesteld worden dat het doorgaand zwangerschapspercentage varieert tussen 20 en $60 \%$ indien de primaire ingreep adhaesiolyse is geweest (onder anderen Bronson[1977], Gomel[1983b], Caspi[1981], Lavy[1987]). Maar de zwangerschapsresultaten blijken sterk afhankelijk te zijn van de aard en de omvang van de adhaesies. Zo meldt Caspi[1981] bij 101 paren -minimale infertiliteitsduur 2 jarenna een adhaesiolyse een zwangerschapspercentage wan $45 \%$, varierend van $65 \%$ in de groep met relatief weinig adhaesies tot $25 \%$ in de groep met zeer veel adhaesies (vierdeling in groepen naar de mate van adhaesie-vorming).

Davis[1986] vergelijkt de resultaten van behandeling van endometriose via enerzijds laparotomie (uit de literatuur) en anderzijds laparoscopische behandeling met een $\mathrm{CO}_{2}$ laser (eigen onderzoek). De klinische zwangerschapspercentages bedroegen respektievelijk 55 à $65 \%$ en ruim $40 \%{ }^{2}(n=158)$. De laser-techniek leidt waarschijnlijk dus ook hier niet tot betere zwangerschapsresultaten.

Bij hersteloperaties na sterilisatie ligt de intra-uteriene zuangerschapskans globalal op $50-80 \%$ (Paterson[1984], Spivak[1986]). Maar de zwangerschapskans is sterk gereduceerd na een fimbriëctomie en indien na een sterilisatie minder dan $3 \mathrm{~cm}$ van de tubae resteert; bij herstel aan slechts een zijde is de zwangerschapskans ook enigszins geringer.

2) Het doorgaand awangerschapspercentage bij laparoscopische behandeling met een $\mathrm{CO}_{2}$ iaser bedroeg $23 \%$ bij een follow-up wan 15 maanden. 
Voor de korrektie van cormuale obstrukties is men met de komst van de microchirurgie grotendeels overgestapt van reimplantatie naar reanastomose. Donnez[1986b] meldt cen voldragen-zwangerschapspercentage van $44 \% \quad(n=82$ patienten met symmetrische cornuale blokkade). Winston[1980] en Gomel[1983a] voerden soortgelijke studies wit en wonden percentages van respektievelijk $37 \%$ en $56 \%$.

Paterson[1984] stelt voor paren met als indikatie tubapathologie de volgende voorkeur voor micro-chirurgie respektievelijk $\mathrm{NVF}^{3}$.

$\begin{aligned} \text { micro-chirurgie: } & \text { - hersteloperaties (exkl. fimbriectomie en tubae }<3 \mathrm{~cm} \text { ) } \\ & \text { - onvolledige laterale tubaire okklusie } \\ & \text { - mediale tubaire okklusie } \\ & \text { - peritubaire of periovariele adhaesies } \\ \text { in-vitro-fiertilisatie: } & \text { - volledige laterale tubaire okklusie } \\ & \text { - na sterilisatie via fimbriectomie } \\ & \text { - rekonstrueerbare tubalengte }<3 \mathrm{~cm}\end{aligned}$

Indien de konklusies uit bowenstaande onderzoeken voor de tubachirurgie gebruikt worden voor een vergelijking met de resultaten na IVF dan is het belangrijk om rekening te houden met de volgende drie kanttekeningen (naast de vermelde problemen bij onderlinge vergelijking tussen publikaties over tubachirurgie-resultaten; zie begin van deze paragraaf):

1. Patienten die tubachirurgie ondergaan hebben ten opzichte van de normale populatie uiteraard een verlaagde kans op een spontane zwangerschap. Bij sommige wrouwen is die kans (nagenoeg) nihil, bij anderen is die kans weliswaar verlaagd maar nog wel aanwezig. Indien alle zwangerschapsresultaten gedurende een lange periode na de tubachirurgie worden toegeschreven aan de tubachirurgische ingreep, dan heeft dit invloed op de vergelijking met de resultaten na een IVF-behandeling. Voor paren die een IVF-behandeling ondergaan geldt immers eveneens dat zij weliswaar een (sterk) verlaagde kans hebben op een spontane zwangerschap, maar ook bij hen is deze kans zeker niet voor iedereen nihil (zie paragraaf 5.4). Voor een rechtwaardige vergelijking tussen de zwangerschapsresultaten na tubachirurgie en na IVF zouden derhalwe voor beide vormen van therapie de zwangerschapsresultaten op langere termijn bekeken moeten worden. Bij paren die een IVF-behandeling hebben ondergaan zouden dan niet alleen de IVF-zwangerschappen moeten worden meegeteld, maar ook de spontaan ontstane zwangerschappen in de periode na de IVF-behandeling. Dit laatste is niet ingegeven door het feit dat deze spontane zwangerschappen op enige wijze het gevolg van een eerdere IVF-behandeling zouden zijn, maar door het feit dat bij de zwangerschapsresultaten na tubachirurgie de zwangerschappen niet te splitsen zijn in zwangerschappen die al of niet voortkomen uit de tubachirurgische ingreep.

2. Indien de suksespercentages bij tubachirurgie worden uitgedrukt in termen van bereikte intra-uteriene graviditeiten, dan is dat niet zonder meer vergelijkbaar met de suksespercentages bij IVF in termen van klinische of doorgaande zwangerschap. Overigens is het zeer begrijpelijk dat bij de analyses van de resultaten na tubachirurgie de variabele IUG gekozen is als suksesmeting. Deze variabele mag

3) Paterson baseert zijin konklusie op eigen onderzoek, bestaande vil een gering aantal waarnemingen (met uitzondering voor de hersteloperaties na sterilisatie). Maar zijn konklusie sluit aan bij diverse deelbevindingen uit de literaturur. 
geacht worden aan te geven in hoeverre de funktionele beperking van de tubaire faktor is opgeheven door de ingreep ${ }^{4}$. In verband met het geringe aantal waarnemingen in de studies met betrekking tot tubachirurgie is deze variabele genomen in plaats van de variabele doorgaande zwangerschappen. Hoewel thet totaalbeeld van de analyses met uitsplitsing naar diverse prognostische variabelen niet behoeft te wijzigen door de overstap wan intra-uteriene graviditeit naar doorgaande graviditeit zullen de bijbehorende suksespercentages uiteraard wel lager worden.

3. $\mathrm{Na}$ de (in principe eenmalige) tubachirurgische ingreep kunnen meerdere zwangerschappen optreden. Indlien de IVF-behandeling leidt tot een doorgaande zwangerschap betreft dit bij ruim 1/4 meerlingzwangerschappen. Het feit dat er na eén ingreep meerdere kinderen geboren kunnen worden geldt derhalve niet alleen voor tubachirugie; bij IVF geldt in dat geval echter wel een verhoogd risiko op komplikaties.

De incidentie van EUG respektievelijk spontane abortus is na micro-chirurgie redelijk hoog. In tabel 5.3. zijn de percentages per klinische zwangerschap aangegeven $(\mathrm{n}=$ aantal klinische zwangerschappen).

\section{Tabel 5.3. Incidentie van EUG en abortus na micro-chirurgie (\% per klinische zwangerschap)}

\begin{tabular}{llrcc} 
Literatuurwerwizing] & aard tubachirurgie & $n$ & $\%$ EUG & abortus \\
\hline Boer-Meisel[1985] & salpingostomie & 50 & $38 \%$ & $14 \%$ \\
Winston[1981] meta-analyse & salpingostomie & $10 \%$ & $24 \%$ & $18 \%$ \\
Jansen[1982]) meta-analyse & salpingostomie & 560 & $16 \%$ & $27 \%$ \\
& salpingolyse & 691 & $9 \%$ & $14 \%$ \\
& tataal & 1778 & $13 \%$ & $17 \%$ \\
Trimbos-Kemper[1985] & salpingostomie & 95 & $34 \%$ & onbekend \\
Lavy[1987] meta-analyse & adhaesiolyse & 142 & $4 \%$ & onbekend \\
& fimbrioplastiek & 80 & $10 \%$ & onbekend \\
& salpingostomie & 239 & $28 \%$ & onbekend
\end{tabular}

1) Schatting op basis van de vermelde gegewens in de publikatie

Het percentage EUG's per klinische zwangerschap bedraagt derhalwe na salpingostomie 20 a $40 \%$. Indien de EUG's worden uitgedrukt in het percentage per tuba-operatie dan bedraagt dit 10 a $15 \%$. De incidentie van EUG's lijkt sterk afhankelijk te zijn van de ernst van de tubaire aandoening. Globaal kan gesteld worden dat bij patiënten met minder ernstige tuba-afwijkingen het klinische zwangerschapspercentage na salpingostomie hoger ligt en het aandeel EUG's daarbij relatief gering is. Daarentegen ligt het klinische zwangerschapspercentage bij patienten met ernstige tuba-afwijkingen laag en blijkt een relatief groot aandeel van deze zwangerschappen een EUG te zijn

4) Evenzo is het zeer begrijpelijk dat bij IVF een klinische zwangerschap als suksesmeting wordt gehanteerd. 
(onder anderen Boer-Meisel[1985]). Het percentage spontane abortus na salpingostomie bedraagt 15 . $25 \%$ per klinische zwangerschap. Voor andere vormen van microchirurgische tuba-operaties ligt het percentage lager.

Gekonkludeerd kan worden dat het percentage EUG c.q. spontane abortus per tubachirurgische ingreep gemiddeld circa 10 15\% voor EUG bedraagt respektievelijk 5 a $10 \%$ voor spontane abortus. Per IVF-behandeling waren deze percentages respektievelijk $0.75 \%$ en $23 \%$ (zie paragraaf 4.5 ).

\subsubsection{Globale bepaling yan de financieel-ekonomische kosten}

Voor de bepaling van de kosten van tubachirurgie is geen echt kostenonderzoek uitgevoerd. Wel is getracht enkele nuanceringen aan te brengen bij het totaalbedrag dat tot stand komt bij de hantering van tarieven voor de diverse onderdelen van de behandeling. De onderstaande berekening dient ter vergelijking met de IVF-behandeling. Derhalve zullen aktiviteiten die voorafgaand aan de behandeling min of meer bij beide behandelwijzen tot soortgelijke kosten hebben geleid niet apart worden vermeld.

Voor de berekening van de kosten van tubachirurgie werd als startpunt gekozen het moment waarop de patiërnt wordt opgenomen ten behoeve van de tubaire ingreeps. Op de dag van opname (of daaraan voorafgaand) wordt een thoraxfoto gemaakt en soms een elektrocardiogram (ECG); daarnaast worden er enkele laboratoriumbepalingen uitgevoerd (schatting totale kosten $f 50,-$ ). De tubachirurgische ingreep vindt plaats op de tweede opnamedag. De tarieven voor 'plastische rekonstruktie van de tubae met mikrochirurgische techniek" bedragen ${ }^{6}$ in totaal $f^{2400,-. ~ N a ~ o n g e v e e r ~} 2$ uur uitslapen wordt de patiente (met infuus) overgebracht naar een verpleegafdeling. De patiěnte krijgt vibramycine en decadron toegediend (totale kosten circa $f 50,-$ ). Daarna blijft de patiënte eigenlijk alleen nog maar ter obserwatie liggen. Normaliter heeft de patiënte op de $4^{e}$ à $5^{\text {e }}$ opnamedag weer een normale ontlasting. Indien het herstel na de operatie normaal verloopt, krijgt de patënte vanaf de dag na de operatie nauwelijks medische zorg en heeft ze ook slechts lichte verpleegkundige zorg nodig?.

Hoewel de patienten veelal in totaal 9 a 10 dagen worden opgenomen in verband met een tuba-operatie, is de noodzaak van de laatste 2 a 3 dagen dubieus. In totaal kan dus een bedrag worden bepaald voor de opname in verband met een tubachirurgische ingreep van $f 7000,-$, bestaande uit:

Ingreep zelf:

$f 2400,-$

Verpleegdagen: $9 \times f 500^{-}=$ $f 4500$,

Extra verrichtingen en antibiotica:

f 100 , -

5) Het voorafgaande gynaecologische konsult heeft ook bij een IVF behandeling plaatsgevondem. Daamaast wordt werondersteld dat de diagnostiek is afgerond ten behowe van de keuze tussen (onder andere) tubachirurgie en $\Gamma \mathrm{F}$, en dat na deze keuze nauwelijks nog aanuullende diagnostiek nodig is. In werkelijkheid is an deze wenonderstelling niet helernal voldaan: patienten worden veelwuldig niet (nogmaals) onderzocht met behulp van cen HSG of dagnost ische laparoscopie alworens de keuze voor de IVF behandeling wordt gemaakt. Damemtegen wordt bij patienten die hoogstwaarschijnlijk in aanmerking komen voor een lubaire ingreep wel veelal nog een diagnostische laparoscopie uitgevoerd indien de informatie uit een eventueel voorgande laparoscopie onbetrouwbaar is om welke redten dan ook.

6) Op basis van de tarieven wan het CBSHI1987] kan het volgende overzicht worden opgestell (inklusief $5.7 \%$ towslag op de standdaardtarieven): Hlonorarium: gynaccoloog: $5581,-$, anaesthesioloog $f 358,-$, assistentie $f 145,-$, OK-gebruik: $f 1325$, dius total $f 2409 w^{*} ;$ afgerond $f 2400$,-

7) Persoonlijke mededeling dr. M. Boer-Meisel, bynaecologe. 
Voor de kosten van de verpleegaagen kunnen 2 nuanceringen worden aangebracht:

- enerzijds kan de ligduur wasschijnlijk zonder problemen met 2 dagen worden ingekort

- anderzijds behoeven deze patienten slechts lichte medische zorg; veronderstelling: de werkelijke kosten per verpleegdag bedragen voor deze patienten geen $1500_{3}$ mat slechts $f 350$,

Indien deze nuanceringen worden verwerkt in de kalkulatie van de kosten voor een tubachirurgische ingreep, dan resteert een totaalbedrag van $f 4950,-\ldots$. Howel deze nuancering erg globaal van karakter is, benadert deze laatste berekening waarschijnlijk beter de werkelijke kosten dan de formele tarief-opstelling.

\subsection{Andere vormen van fertiliteitsbehandeling}

Naast de methode van in-vitro-fertilisatie bestaan er inmiddels diwerse andere vormen van kunstmatige voortplanting. Onder kunstmatige voortplanting wordt hier verstaan een medische behandelvorm, waarbij op de een of andere wijze gameten buiten het lichaam worden gebracht en worden bewerkt met als doel de kans op een zwangerschap te vergroten.

In deze paragraaf worden de voor- en nadelen van de meest belangrijke vormen van kunstmatige voortplanting naast de IVF besproken. Daarnaast wordt kort ingegaan op de medikamenteuze behandeling van endometriose.

\section{Kunstmatige inseminatie (KI)}

De term kunstmatige inseminatie is een verzamelnaam voor diverse vormen van inseminaties (Glass[1979]). De belangrijkste, variant is de intra-uteriene inseminatie (IUI). Bij IUI wordt sperma direkt ingebracht in de uterusholte. Andere varianten zijn de intracervicale inseminatie (die soms wordt ondergebracht bij de IUI) en de intravaginale inseminatie. Het tijdstip van de inseminatie wordt veelal bepaald op basis van de uitslagen van LH-bepalingen en eventueel van echoscopische kontrole. Vaak vinden er 2 \& 3 inseminaties per behandelcyclus plaats. Daarnaast wordt bij behandelcycli van IUI ook soms hormoonstimulatie toegepast (Hewitt[1985]). Ten opzichte van de IVF is de oocytmaturatie minder goed te beoordelen en is het aantal embryo's minder goed beheersbaar. Kanttekening bij de vermelding van zwangerschappen ten gevolge wan een IUI is dat (afhankelijk van de selektie voor de behandeling) een gedeelte vaun de zwangerschappen spontaan kan zijn ontstaan.

Een belangrijke konstatering uit de literatuur is dat verreweg de meeste awangerschappen bij intra-uteriene inseminaties blijken te worden bereikt in de eerste behandelcyclus (Sher[1984], Kerin[1984], Toffie[1985], te Velde[1989b]).

Allen[1986] geeft in 1985 een literatuuroverzicht van de resultaten van IUI, bestaande uit 18 studies met verschillen in onder andere populatiesamenstelling (indikatie), aantal behandelcycli per paar, aantal inseminaties per cyclus en methode van timing van de inseminatie. Het zwangerschapspercentage per patiënt $(n=714)$ bedroeg voor alle 
studies gezamenlijk $28 \%$ maar daarbij was sprake van een grote spreiding. Het percentage spontane abortus per klinische zwangerschap bedroeg $26 \%$.

Naar indikavie gesplitst waren de zwangerschapspercentages:

- mamnelijke subfertiliteit $(\mathrm{n}=84): 18 \%$ per paar ( 1 optimistische studie uitgezonderd)

- cervicale faktor $(n=58)$ : $\quad 60 \%$ per paar

- immunologische faklor $(n=40): 22 \%$ per paar.

Ook Confino[1986b] konstateert duidelijke verschillen naargelang de indikatie. In zijn onderzoek werd IUI uitgevoerd bij 64 paren ( 238 behandelcycli; 2 a 3 inseminaties per cyclus). De zwangerschapsresultaten gesplitst naar indikatie waren:

- oligospermie (27 paren, 108 cycli): geen klinische zwangerschap

- antilichamen of cervical hostility ( 37 paren, 130 cycli): klinisch zwangerschapspercentage $50 \%$ per paar ofwel $15 \%$ per cyclus.

Bradshaw [1987] meldt zwangerschapsresultaten van kunstmatige inseminaties, waarbij gebruik is gemaakt van donorzaad (KID): van de totale behandelde populatie $(n=234$ met als belangrijkste indikatie mannelijke subfertiliteit) is $89 \%$ zwanger na 12 behandelcycli.

\section{Gamete-Intra-Fallopian-Transfer (GIFT)}

De procedure wan de GIFT loopt tot de follikelpunktie vrijwel parallel aan de procedure van de IVF-behandeling. De follikelpunktie wordt bij de GIFT-methode nog veelal laparoscopisch uitgevoerd, waarna de verkregen odcyten tezamen met spermatozoa in de tuba(e) worden geplaatst. Gezien dit laatste is toepassing van de GIFT-methode alleen zinvol indien er sprake is van minstens een doorgankelijke tuba.

Asch[1987] meldde op basis van een multi-center-studie bij 800 GIFT-follikelpunkties een klinische zwangerschapspercentage van $34 \%^{8}$ en een doorgaand awangerschapspercentage van $25 \%$.

Bij een observationeel vergelijkend onderzoek vond Johnston[1987] tussen GIFT $(n=334)$ en IVF $(n=549)$ geen signifikant verschil in het klinisch zwangerschapspercentage per follikelpunktie (respektievelijk $24 \%$ en $20 \%$ ), terwijl het doorgaande zwangerschapspercentage signifikant hoger lag bij de GIFT" (16\% versus $10 \%)$.

Maar verschillen in de populatie-samenstelling van IVF en GIFT in bovenstaande studies, met name met betrekking tot de indikatie, maken een vergelijking tussen beide behandelmethoden dubieus. Daarentegen voerdde Leeton[1987] een gerandomiseerde studie $(n=75)$ uit tussen IVF en GIFT voor patienten met als indikatie onbegrepen

8) Cresplitst nagr indikgtie bedroeg he Klinisch zwangerschapspercentage per follikelpunktie bij grotere groepen:

onbegrepen infertiliteit $(n=499) 35 \%$, manneljke subfertiliteit $(n=84) 18 \%$ en endometriose $(n=91) 38 \%$.

9) De klinische en doorgande zwangerschapspercentages per follikelpunktie waren voor de GIFI per indikatiegebied: onbegrepen infertiliteit $(n=185): 26 \% \mathrm{c.q} .17 \%$, endometriose $(n=113): 25 \%$ c.q. $19 \%$, mannelijke sublertiliteilt $(n=32) \quad 13 \%$ c.q. $0 \%$. 
infertiliteit of mannelijke subfertiliteit. Hij vond geen signifikant verschil in zwangerschapspercentages.

De GIFT-procedure heeft ten opzichte van de IVF-procedure voor- en nadelen:

- voordelen: * het laboratorium-werk wordt beperkt

* de fertilisatie vindt in het menselijk lichaam plaats

- nadelen: * follikelpunktie en transfer worden nog veelal laparoscopisch onder volledige narcose uitgevoerd

* er wordt geen (diagnostische) informatie verkregen omtrent de fertilisatiekapaciteit.

In verband met dit laatste nadeel is door Quigley[1987] in overweging gegeven om een eerste GIFT-poging te kombineren met IVF, zodat toch informatie wordt verkregen omtrent de fertilisatiecapaciteit (de gecombineerde behandelingen in zijn eigen onderzoek hadden betrekking op IVF-paren, waarvan de vrouwen anatomisch normale tubae hadden). Matson[1987] geeft aan dat deze werkwijze alleen zinvol is als er voldoende goede oöcyten overblijven voor IVF.

\section{Medicamenteuze behandeling endometriose}

HenzI [1988] vergeleek via een gerandomiseerd, dubbelblind, multicenter onderzoek $(\mathrm{n}=213)$ twee medicamenteuze therapiees voor behandeling van endometriose: Danazol (oraal) en nafarelin (nasaal GnRH); iedere therapie werd 6 maanden toegepast. De resultaten van deze studie luidden:

- de voordelen van beide therapiën zijn vrijwel identiek, te weten:

* een vergelijkbare reduktie van de endometriose (bij circa $80 \%$ van de patiënten)

* van de vrouwen die zwanger wilden worden $(n=149)$ was bijna $40 \%$ zwanger binnen 1 jaar na het einde van de therapie (geen verschil tussen de therapieên)

- de nadelen van beide therapieèn waren verschillend:

* anderssoortige bijwerkingen (de ernst is moeilijk vergelijkbaar, maar de bijwerkingen van GnRH lijken als minder ernstig te worden ervaren).

\subsection{Geen behandeling}

Het is uiterst moeilijk in te schatten wat de kans op een spontane zwangerschap is voor paren die een gynaecoloog bezoeken in verband met fertiliteitsproblemen. Deze kans is namelijk sterk afhankelijk van allerlei onderliggende faktoren voor de problematiek.

Vanuit de life-table-analysis kunnen een aantal relevante berekeningen worden gemaakt (Cramer[1979]) voor de theoretische kans op een zwangerschap in relatie tot de tijd. Onder de veronderstelling dat de kans op een zwangerschap per cyclus (f) in iedere cyclus gelijk blijft, geldt:

- de kumulatieve zwangerschapskans $(F)$ is gelijk aan:

$$
F=f+f(1-f)+f(1-f)^{2}+\ldots+f(1-f)^{n-1}=1-(1-f)^{n}
$$

- het gemiddeld aantal cycli tot het bereiken van een zwangerschap bedraagt $1 / \mathrm{f}$ 
- de maandelikse zwangerschapskans is aan te geven op basis van de infertiliteitsduur met behulp wan de vergelijking $f=1-(1-F)^{1 / \text { th }}$. Bijvoorbeeld, de waarde van $f$ waarvoor $95 \%$ van de paren binnen 24 maanden zwanger is ( $F=0.95, n=24$ ), bedraagt $\mathrm{f}=0.12$. Met andere woorden, indien een paar binnen 24 maanden niet zwanger is geworden, dan kan met grote $(95 \%)$ zekerheid worden gesteld dat hun wwatigerschapskans per maand niet groter is dan 12\%. Bij een infertiliteitsduur van 5 jaar geldt dat de zwangerschapskans per maand zeer waarschijnlijk de $5 \%$ niet overstijgt.

Maar hoewel de zwangerschapskansen voor paren die met langdurige fertiliteitsproblemen sterk gereduceerd kunnen zijn, is het optreden van spontane zwangerschappen in deze groep geen zeldzaamheid. Uiteraard speelt het element van de patiuntenselektie (onder andere nauwkeurighelid van de indikatiestelling, infertiliteitsduur) hierin een belangrijke rol.

Glass [1979] beredeneert het belang van kontrole-groepen bij de evaluatie van de resultaten van een behandeling wegens fertiliteitsproblemen. Indien de kans op een spontane zwangerschap weliswaar gereduceerd is maar niet afwezig, dan is het niet korrekt de zwangerschappen na behandeling volledig toe te schrijwer aan de betreffende behandeling. In zijn algemeenheid blijkt uit een vergelijking van studies mét cen kontrolegroep ten opzichte van studies zonder een kontrolegroep dat de eerste groep van studies veel vaker de onderzochte behandeling als effektief beschouwen ${ }^{10}$.

Ook Leridon[1984] maakt berekeningen waarmee hij het belang van kontrolegroepen aangeeft. Hij berekent:

- de proportie van paren die nog niet zwanger zijn na een bepaald aantal maanden bij een bepaalde 'fecundability' (= maandlelijkse conceptievoet) in de totale populatie

- de geniddelde 'fecundability' in de volgende maand na een bepaald aantal maanden infertiliteit

- de proportie van minder fertiele paren die na een bepaald aantal maanden nog niet zwanger zijn geworden, maar binnen 1 jaar vanaf dat moment wel zwanger zullen zijn.

Bijwoorbeeld: na 4 jaren heeft circa $1 \%$ van de paren nog steeds geen zwangerschap bereikt (bij een 'fecundability" van de totale populatie van gemiddeld 20 a $40 \%$ ); de gemiddelde zwangerschapskans woor deze paren in de eerstvolgende maand is slechts $45 \%$, marar binnen 1 jaar zal volgens de theorie circa $40 \%$ van deze groep alsnog spontaan zwanger worden. In werkelijkheid bestaat de groep met fertiliteitsproblemen echter voor een gedeelte uit (vrijwel) volledig infertiele patienten, die deze theoretische percentages zullen verlagen. Desalniettemin bijft het een faktor die wel degelijk van invloed is.

In het onderstaande worden enkele studies gepresenteerd waarin onderzoek is uitgevoerd naar de frekwentie van spontaan ontstane zwangerschappen bij paren met fertilliteitsproblemen.

10) 20 wordt onder andere verwezen naar een studie van foulds, waaruit blijkt dat in het algemeen 83\% van de: studies zonder kontrolegroep de onderzochte behandeling effektief vonden, terwill dat silechts bij $20 \%$ van de studies mét kontrolegroep het geval was. 
Roh[1987] zette IVF-afhankelijke zwangerschapsresultaten ${ }^{11}$ af tegen IVFonafhankelijke ${ }^{12}$ zwangerschapsresultaten na IVF; de follow-up duur was gemiddeld 2 jaar. Hij maakte onderscheid tussen de groep met als indikatie beiderzjds afgeslloten tubae $(n=123)$ en de groep patienten met nog minstens ecen doorgankelijke tuba $(n=151$; circa de helft met endometriose). Bij de groep met beiderzijds afgesloten tubae werd geen enkele IVF-onafhankelijke zwangerschap gekonstateerd. Bij de groep met minstens 1 open tuba werden daarentegen 18 IVF-onafhankelijke zwangerschappen gekonstateerd (12\% van de paren), waarvan ruim $3 / 4$ binnen 6 maanden na de IVF. behandeling. Verwijzend naar Leridon[1984] stelt hij dat de gevonden $12 \%$ bij de IVF. groep met minstens 1 open tuba (zeg binnen 1 jaar) beduidend lager ligt dan de theoretische $40 \%$ zwangeren binnen 1 jaar na 4 jaar infertiliteit. Ofwel, deze IVF. groep heeft een kans op een spontane zwangerschap, maar die is duidelijk verlaggd ten opzichte van de normale populatie met een vergelijkbare infertiliteitsduur.

Ben-Rafael[1986] heeft 149 patiènten vervolgd die door middel van een IVFbehandeling niet zwanger waren geworden. Hiervan werden er in total 13 zwanger. Maar ook hier gold dat de spontane zwangerschapskans vooral nog aanwezig was bij vrouwen met ến doorgankelijke tuba: van de 34 patiênten met 1 doorgankelijke tuba zonder verdere indikaties werden er 9 zwanger (27\%). Rekening houdend met de follow-up-duur van deze vrouwen bedroeg het theoretisch kumulatief spontane zwangerschapspercentage na 1 jaar 38\%. Jarrell[1986] kwam in een kleine studie tot soortgelijke bevindingen.

Haney[1987a] registreerde 19 spontane klinische zwangerschappen voor de eerste 245 geaksepteerde IVF-paren in hun klinick (follow-up duur variêrend): 4 vóor de eerste IVF-behandeling, 12 na mislukte IVF en 2 na suksesvolle IVF. De infertiliteitsduur van de paren met een spontane zwangerschap was $5.7 \pm 3.2$ jaar. De indikaties van deze paren waren verschillend: endometriose, onbegrepen infertiliteit, mannelijke subfertiliteit en tubapathologie.

Bij paren met onbegrepen infertiliteit ${ }^{13} \quad(n=47)$ vond Rousseau[1983] zonder behandeling een kumulatief doorgaand zwangerschapspercentage ${ }^{1 / 4}$ na 2.5 jaar van $50 \%$. Soortgelijke resultaten werden gevonden door Barnea[1985 $]^{1.5}(\mathrm{n}=58)$ : het kumulatief zwangerschapspercentage zonder behandeling bedroeg na 6 maanden $35 \%$, na 2 jaren $75 \%$. Binnen een fertielle populatie wordt dit laatste percentage van $75 \%$ behald binnen circa 9 maanden. Ook Lenton[1977] geeft aan dat de kumulatieve zwanger-

11) Ook biochemische zwangerschappen werden meegeteld als WV afharikelihke zwangerschap, indien het serum-B hCG-nivo $>10 \mathrm{mlU} / \mathrm{ml}$ op de $10^{\mathrm{m}}$ dag na de enbryotransfer en daarna nog minstens een keer hoger lag. Zo ook bij IVF-onahnankelijke zwangerschappen, warbij alleen rwangenschapstesten werden uifgevoerd indien de menstruatie minstens een week uilbleef.

12) Een IVFonafhankelijke zwangerschap werd hierbij gedefinieerd als een zwangerschap die miet het direkte resultaat van een embryotransfer was bij een wrouw die teruminste een stlmulaticmoyclus in het kader van cen IVF behandeling had ondergaan. Niet duddelijk uit de teks is in hoeverre zwangerschappen ziljn opgetreden in IVF-behandeloycli zonder embryotransfer.

13) De volgende testen lieten geen afwijkingen zien: semenanalyse, post-coítum-test premenstruele endometrium-biopsie, HSG en laparoscopie. De gemiddelde infertiliteitsduur bedroeg 4 jaar \pm 3 maanden. De groep met onbegrepen infertiliteil vormde $3 \%$ van de onderzochte infertiele populatie.

14) Het klinisch zwangerschapspercentage bedroeg $65 \%$.

15) Hier vormde de groep met als indikatie onbegrepen inferthiteit $2 \%$ van de onderzochte infertiele onderzoekspopulatie. 
schapspercentages bif paren met onbegrepen infertiliteit $(n=91)$ beduidend lager liggen dan in de normale populatie. Hij konstateert in zijn onderzoek een kumulatief zwangerschapspercentage na 7 jaren bij primaire onbegrepen infertiliteit $(n=80)$ van $36 \%$, bij sekundaire infertiliteit ligt dit percentage veel hoger (79\%), maar dat heeft slechts betrekking op 11 paren.

Yates[1987] meldt kumulatieve spontane zwangerschapspercentages na 2 jaren voor paren met als indikatie mamnelijke subfertiliteit: bij een spermakonsentratie < $5 * 10^{6} / \mathrm{ml}$ bedroeg dit $23 \%$ en bij een spermakonsentratie van 5 a $20 * 10^{6} / \mathrm{ml}$ was dit zelfs $44 \%$.

Wood[1984] geeft nog aan dat de kans dat paren na 1 jaar ongewenste onbegrepen infertiliteit in het volgende jaar een spontane zwangerschap bereiken mede afhankelijk is van de leeftijd van de vrouw: bij een vrouw van $20,30 \mathrm{c.q}$. 40 jaar bedraagt deze kans volgens hem respektievelijk $76 \%, 57 \%$ en $40 \%$

\subsection{Behoefte aan fertiliteitsbehandeling in het algemeen en IVF in het bijzonder}

Ramingen van de behoefte aan fertiliteitsbehandelingen worden noodgedwongen gekarakteriseerd door globaliteit. In deze paragraaf wordt op verschillende manieren getracht enig inzicht te verschaffen in de behoefte aan fertiliteitsbehandeling in Nederland. Gezien de beperkte (onderbouwing van) data ${ }^{16}$ op dit terrein zijn de opmerkingen in deze paragraaf slechts beschouwingen.

Allereerst kan worden gekeken naar de leeftijdsopbouw van de Nedlerlandse bevolking en met name naar de te verwachten ontwikkelingen voor het aantal vrouwen in de leeftijdskategorie 25 tot en met 40 jaren. In bijlage 5.1 zijn enige schattingen hieromtrent weergegeven. Gekonkludeerd mag worden dat de groep die mogelijk een beroep zall doen op fertiliteitsbehandeling gedurende de komende 5 jaren toeneemt. Bovendien blijkt deze toename specifiek op te treden voor vrouwen in de leeftijdsgroep 30-40 jaar. Aangezien in. Nederland de afgelopen jaren een tendens heeft bestaan om vrijwillig de eerste zwangerschap uit te stellen ${ }^{17}$, zall de behoefte aan fertiliteitsbehandeling om deze redenen nog eens extra toenemen. Vanaf ongeveer thet Jaar 2000 zal de popullatie in de leeftijdsgroepen $25-40$ jaren echter drastisch afnemen.

Voor de schatting van het gedeelte van de paren dat ongewenst infertiel is, wordt in Nederland sinds jaar en dag uitgegaan van $10 \%$. Waarschijnlijk is dit percentage gebaseerd op berekeningen van Tietze [1956], die aangaf dat $90 \%$ van de fertiele paren binnen 1 jaar zwanger is. Indien deze berekening wordt gehanteerd voor de bepaling

16) Behoefterataing op basis van medische gegevens bleek onmogelijk. Bij een vergelijkend onderzoek NVI" versus tubachirurgie hadden de data van de patièten die een tuba-ingreep hadouen ondergaan als bron wan informatie kunnen dienen. Mogelijk kan in de tockomst de Scenario-studie Gynaecologie data opleveren die butikbaar zijn voor een behoefteraming.

17) In Nederland werd in 1970 het eerste kind geboren bij een gemiddeld leefujd van de vrouw van 24.5 jaar, in 1985 was dat 26.5 jaar (188). Deze tendens is ook terug te zien bij een indeling valn de leeftijd van de vrouw in leefihjiggroepen: steeds minder kinderen worden geboren bij wrouwen jonger dan 25 jaren en steeds meer bij vrowwen in de leeftijd van 30-34 jaren wan 35-39 jaren (CBS[1986]). 
van de behoefte aan fertiliteitsbehandelingen, dan leidt dit uiteraard tot een overschatting: zeker niet ieder paar dat binnen 1 jaar niet zwanger is geworden wordt uiteindelijk behandeld voor fertiliteitsproblemen. Zowel in de Verenigde Staten (Hirsch[1987]) als in Denemarken (Rachootin[1981]) bleek bij onderzoek onder vrouwen met fertiliteitsproblemen dat bif primaire infertiliteit slechts de helft van de vrouwen een arts raadpleegde; bij sekundaire infertiliteit lag dit percentage nog lager: 20 a $30 \%$. Ook zal niet ieder paar dat vanwege fertiliteitsproblemen een arts raadpleegt uiteindelijk door een gynaecoloog worden behandeld.

Gekonkludeerd mag worden dat het gedleelte van de paren dat wegens fertiliteitsproblemen door een gynaecoloog behandeld zal worden eerder in de orde van $5 \%$ dan van $10 \%$ zal liggen.

Voor schattingen wan de specifieke behoefte aan IVF-behandeling geldt in nog sterkere mate dat alleen enkele globale beschouwingen mogelijk zijn. Allereerst is voor de 5 ziekenhuizen van het evaluatie-onderzoek IVF begin 1987 een inventarisatie opgesteld van de wachtlijsten voor IVF. De uitgebreide beschrijwing hiervan is weergegeven in bijlage 5.2 .

De optelsom van de wachtlijsten in de betrokken 5 ziekenhuizen bedroeg bijna 2600 paren. Geschoond voor dubbeltellingen op de verschillende wachtlijsten bleven er ruim 2400 over. Hiervan had $1 / 4$ reeds een of meerdere IVF-behandelingen ondergaan. Daarmee is meteen duidelijk dat voor de behoeftebepaling niet kan worden volstaan met het antwoord op de vraag hoeveel paren IVF-behandeling zouden willen; immers een paar kan bij vitblijvend sukses mogelijk opnieuw een poging wagen.

Rekening houdend met deze laatste belangrijke kanttekening is nog steeds geen kompleet overzicht geschetst van de behoefte aan IVF in Nederland voor het moment warrop het wachtlijstonderzoek betrekking had (begin 1987). Enerzijds:

- zijn de wachtlijsten van de andere IVF-centra in Nederland niet meegenomen (een poging hiertoe van de Landelijke Werkgroep-IVF van de NVOG is gestrand)

- is er geen rekening gehouden met paren die alléen in het buitenland stonden ingeschreven

- hebben de lengte van diverse wachtlijsten, de gehanteerde kriteria en financieringsproblemen diverse paren mogelijk weerhouden van aanmelding voor IVF. Anderzijds:

- zijn de bestaande wachtlijsten niet volledig geschoond van paren die niet meer in aanmerking wensen te komen voor IVF-behandeling

- wordt paren vaak geadviseerd zich alvast aan te melden voor IVF in afwachting van het resultaat van een andere behandelwijze.

De uiteindelijke richting van de invloed van beide soorten wan kanttekeningen op de reële omvang van de wachtlijst voor IVF in Nederland is moeilijk in te schatten.

Over de regionale spreiding van de paren op de wachtlijsten van de 5 ziekenhuizen in het onderzoek kan worden opgemerkt dat circa $60 \%$ van de paren afkomstig was uit de provincies Noord-Holland, Zuid-Holland en Utrecht (zie bijlage 5.2, tabel B5.2.2). Deze verdeling komt nagenoeg overeen met de regionale spreiding van de behandelde paren in de 5 ziekenhuizen tijdens de registratieperiode (september 1986 tot juni 1988 ). 
Tenslotte nog een opmerking ower de wachttijden van paren die in de onderzoeksperiode zijn beftandeld. De wachtijd tot de eerste behandeling bedroeg gemiddeld 1.5 jas (binnen 2 jaar is $3 / 4$ van de populatie behandeld). Voor partikulier verzekerden was de wachtijd gemiddeld een half jaar korter dan voor ziekentondsverzekerden. De gemiddelde wachttijd was her langst in Rotterdam (bijna 2.5 jaar), gevolgd door Amsterdam (bijna 2 jaar), Leiden/Nijmegen (15 maanden) en Tilburg ( 9 maanden). Wel lijken de wachttijden enigszins natar elkaar toe te groeien. Bij vergelijking van de wachttijon in beide helften van de onderzoeksperiode ontstaat het volgende beeld: in Rotterdam en Amsterdam namen de wachttijden geleidelijk iets af, in Leiden bleven ze gelijk en in Nijmegen en Tilburg nam de wachtijid enigszins toe.

Gebrek aan datamateriaal met betrekking tot de incidentie, prevalentie en verdeling van de indikaties voor fertiliteitsproblemen werd in Engeland gesignaleerd door het Warnock-rapport (Warnock[1984]). Hull[1985] heeft een poging ondernomen om een behoefteraming voor fertiliteitsbehandeling in het algemeen en voor IVF in het bijzonder op te stellen. Hij komt uiteindelijk tot een berekening van 216 potentieel nieuwe IVF-paren per miljoen inwoners per jaatr. Er zijn bij dit onderzoek evenwel een aantal belangrijke kanttekeningen te plaatsen:

- Het gemiddeld totaal aantal (niet alleen nieuwe) paren dat een specialist bezoekt wordt gebruikt voor berekeningen omtrent incidemtie. Mede door deze onjuiste weronderstelling wordt berekend dat $1 / 6$ van de paren ooit specialistische hulp inschakelt in verband met fertiliteitsproblemen; dit is ongeveer het drievoudige van onze eerdere inschatting van 5 a $10 \%$.

- De specifieke behoefte aan IVF-behandeling wordt alls volgt bepaald:

- bij de betrokken paren waren de belangrijkste indikaties:

$\begin{array}{ll}\text { - ovulatiestoornissen } & 21 \% \\ \text { - onbegrepen infertiliteit } & 28 \% \\ \text { - mannelijke subfertiliteit } & 26 \% \\ \text { - tubaire faktor } & 14 \%\end{array}$

- geschikt voor IVF-behandeling werd geacht 0.8 van de paren met als indikatic tubaire faktoren 0.25 van de paren met als indikatie onbegrepen infertiliteit (te weten de groep met en infertiliteitsduur langer dan 5 jaren). De veronderstellingen omtrent de relatieve bijdrage van IVF bij de diverse indikaties zijn diskutabel.

Derhalve zou circa $18 \%$ van de paren die in verband met fertiliteitsproblemen een specialist bezoekt in aanmerking komen voor een IVF-behandeling; opgemerkt wordt nog dat waarschijnlijk niet ieder van deze paren ook daadwerkelijk IVF-behandeling zou willen.

- De representativiteit van de gegevens in het onderzoek is twijfelachtig: het onderzoek is sllechts uitgevoerd in een district, waarbij 708 paren een specialist hebben geraadpleegd in verband met fertiliteitsproblemen.

De uiteindelijke invloed van deze kanttekeningen op de uitkomsten van de berekening is moeilijk in te schatten. Duidelijk is echter dat de schatting woor het gebruik van specialistische hulp in werband met fertiliteitsproblemen bij toepassing op de Nederlandse situatie sterk zou moeten worden bijgesteld in neerwaartse richting. 


\subsection{Konklusies}

Tubapathologie is de meest voorkomende indikatie voor IVF. Derhalve is de belangrijkste alternatieve behandeling voor de IVF-paren tubachirurgie. Indien er reeds een of meerdere fertiliteitsbevorderende tubachirurgische ingrepen zijn vitgevoerd, dan is eigenlijk het meest reele alternatief woor IVF: geen behandeling.

1. Over de effekten en kosten van fertiliteitsbevorderende tubachirurgie kan worden opgemerkt:

- De klinische zwangerschapsresultaten na tubachirurgie variëren sterk naargelang de aard van de ingreep en de ernst van de aandoening:

- de variatie strekt zich uit van bijna nihil tot percentages van $80 \%$

-ingrepen met relatief gunstige resultaten zijn refertilisaties en fimbrioplastiek; relatief slechte resultaten worden behaald bij herhatal-operaties

-op basis van enkele gegevens van het HSG en de diagnostische laparoscopie omtrent de ernst van de aandoening lijkt een goede prognose voor de sukseskans van een tubachirurgische ingreep mogelijk. De doorgaande zwangerschapsresultaten varièren sterk tussen de verschillende groepen (tussen bijna nihil en circa 60\%). Belangrijke parameters zijn de aard van het mucosapatroon, de rekbaarheid van de ampulla en omvang/aard van de adhaesies.

- De incidentie van met name EUG"s is na tubachirurgie relatief hoog: per klinische zwangerschap 20 a $40 \%$, per fertiliteitsbevorderende tubaire operatie 10 a $15 \%$. De incidentie van EUG's lijkt relatief hoger te zijn bij een aandoening van relatief ernstiger aard.

- De kosten voor ziekenhuis-opname in verband met een tubachirurgische ingreep bedragen volgens de tarieven circa $f 7000_{,} ;$de werkelijke kosten van de opname liggen eerder in de orde van $f 5000,-$.

2. Bij een beleid van 'niets doen' is het spontane klinische zwangerschapspercentage:

- voor paren met als indikatie tubapathologie van wie de vrouw beiderzijds afgesloten tubae heeft nagenoeg nihil

- voor paren van wie de vrouw nog minstens eén open tuba heeft: na 1 jaar minstens $10 \%$. Dit percentage van $10 \%$ ligt overigens ver onder thet theoretisch te verwachten percentage op basis van de infertiliteitsduur

- voor de paren met andere indikaties dan tubapathologie (onbegrepen infertiliteit, mannelijke subfertiliteit) sterk variërend (tussen $25 \%$ en $75 \%$ na 2 jaren), afhankelijk van de uitgevoerde selektie.

3. Bij kunstmatige inseminaties blijken verreweg de meeste zwangerschappen te worden bereikt in de eerste behandelcyclus. De zwangerschapsresultaten variëren sterk per indikatie: bij een cervicale faktor lijkt de prognose gunstig, bij antilichamen en met name mannelijke subfertiliteit minder gunstig (voorzover geen gebruik is gemaakt van donorspermatozoa). 
4. Bij minstens cén đoorgankelijke tuba kan onder andere de GIFT-behandeling een alternatief voor IVF vormen; de resultaten lijken vergelijkbaar. De GIFT-procedwre blijft echter minder aantrekkelijk zolang voor deze procedure nog laparoscopie noodzakelijk is; ook wordt bij de GIFT-procedure (ten opzichte van IVF) minder diagnostische informatie verkregen.

5. Omtrent de behoefte aan fertiliteitsbehandeling in Nederland kan het volgende worden opgemerkt:

- de groep personen die mogelijk gebruik zal maken van fertiliteitsbehandeling zal gedurende de komende 5 jaren toenemen; daarna zal geleidelijk een daling optreden

- het gedeelte van de paren dat wegens fertiliteitsproblemen door een gynaecoloog behandeld zal worden ligt eerder in de orde van grootte van $5 \%$ dan van $10 \%$

- in februari 1987 stonden op de wachtlijsten van de 5 ziekenhuizen van het evaluatie-onderzoek-IVF 2400 paren ingeschreven; 1/4 van deze paren had reeds een of meerdere IVF-behandelingen ondergaan

- de wachttijd tot de eerste IVF-behandeling bedroeg in het onderzoek gemiddeld 1.5 jaar; de wachttijden voor partikulier verzekerden waren gemiddeld een half jaar korter dan die voor de ziekenfondsverzekerden. De verschillen in de wachttijden tussen de ziekenhuizen zijn geleidelijk iets afgenomen. 


\section{EFFEKTEN EN KOSTEN VAN DE IVF- BEHANDELING}

\subsection{Introduktie}

In dit hoofdstuk zullen de bevindingen uit de eerdere hoofdstukken worden samengebracht. Enerzijds zullen de effekten en kosten worden vergeleken tussen de IVF-behandelingen onderling (paragraaf 6.2), anderzijds zal een globale vergelijking trachten te worden gemaakt tussen de effekten en de kosten van IVF versus tubachirurgie (paragraaf 6.3). Tenslotte zal worden ingegaan op beleidimplikaties en beleidskomplikaties. Voorafgaand zal echter een korte beschouwing worden gewijd aan de problemen bij de bepaling van een kosten-effektiviteits-verhouding voor fertiliteitsbehandeling in het algemeen en voor IVF in het bijzonder.

Bij kosten-effektiviteits-studies is het gebruikelijk de kosten af te zetten tegen de verkregen gezondheidswinst. Deze gezondheidswinst kan op twee manieren optreden:

- enerzijds via levensverlenging

- anderzijds via verbetering van de kwaliteit van leven.

Beide vormen van gezondheidswinst kunnen worden samengebracht in de maatstaf "voor kwaliteit gekorrigeerde winst in levensjaren" (QALY" = "Quality Adjusted Life Years") ${ }^{1}$. Bij toepassing van deze benadering op fertiliteitsbehandelingen kan worden opgemerkt dat er geen reden is om te veronderstellen dat de levensduur van beide partners wordt verlengd door de geboorte van een kind. Dit geldt wellicht in iets mindere mate voor een verbetering van de levenskwaliteit, maar een duidelijke verbetering van de levenskwaliteit op langere termijn is in ieder geval nog niet aangetoond (Bromham[1986]).

In dit verband dient de vraag gesteld te worden met welk doel fertiliteitsbehandeling nu precies plaatsvindt:

1. met het doel een ongewenst infertiel paar een kind te laten kriggen en/of

2. met het doel een kind het levenslicht te laten zien.

Ad 1: In het eerste geval mag alleen gekeken worden naar de effekten in termen van gezondheidswinst voor het paar zoals boven beschreven. Indien een dergelijk effekt beperkt is, worden de kosten in relatie tot de behaalde gezondheidswinst relatief hoog. Dit geldt niet alleen voor de $\mathbb{1 V F}$-behandeling, maar voor fertiliteitsbehandeling (en fertiliteitsdiagnostiek) in het algemeen.

1) Voor een uitgebreide literatuurbeschrijwing zj verwezen naar Bonsel[1988]. 
Ad 2: In het tweede geval wordt zogezegd gestreefd naar gezondheidswinst van een nog niet bestaand individu ${ }^{2}$. De vraag is of dit standpunt redelijk is. Intuitief zullen velen deze vraag onmiddellijk negatief beantwoorden. Essentieel voor het antwoord op deze vraiag is waar de grens yan menselijk leven wordt gelegd en in hoeverre deze grens een absoluut dan wel relatief karakter draagt (zie onder anderen De Wert[1988]). Fertiliteitsbehandelling houdt zich bezig met het tot stand brengen van menselijk leven en bevindt zich daarmee op het laagste punt van een helling. Hogerop in deze helling zijn gezondheidszorgvoorzieningen te platatsen die zich bezighouden met menselijk leven in een verder stadium: suksessievelijk prenatale diagnostiek, prenatale zorg en neonatale zorg. Bovendien wordt in Nederland in een aantal kwesties rondom fertiliteitsbehandeling door sommige geledingen wel expliciet gekozen voor het belang van het nog niet aanwezige kind. Bij de argumentatie voor opheffing van de anonimiteit wan een zaaddonor en bij de principiele uitspraak liever homoseksuele partners vit te sluiten van gebruik van kunstmatige voortplanting wordt (al dan nilet op terechte gronden) gekozen voor de belangen van een nog niet gekrederd individu. Ondanks deze overwegingen is ons inziens fertiliteitsbehandeling in eerste instantie niet gericht op het belang van een (nog niet bestaand) kind.

Zonder nadrukkelijk een keuze te maken in bovengenoemde doelstellingen kunnen de kosten per voldragen zwangerschap mede als basis dienen voor de standpuntbepaling met betrekking tot IVF als behandelmethode bij fertiliteitsproblemen.

In het verlengde van het bovenstaande wordt soms de vraag gesteld: in hoeverre is fertiliteitsbehandeling gezondheidszorg? In de ruime definitie van gezondheid zoals door de WHO aangegeven ${ }^{3}$ bestaat hierover geen diskussie. Maar ook bij beperking van de definitie voor gezondheid c.q. ziekte kan infertiliteit gezien worden als een ziekte. Immers, een van de natuurlijke mogelijkheden van het menselijk lichaam is verstoord: de natuurlijke mogelijkheild tot voortplanting. Dat deze verstoring niet levensbedreigend is heeft infertiliteit gemeen met talloze andere verstoringen in het menselijk lichaam waarvoor medisch handelen algemeen geaksepteerd is.

Daarnaast wensen sommigen de IVF-behandeling niet als fertiliteitsbehandeling te beschouwen, aangezien de IVF-methode niet de oorzaak van de verstoring wegneemt; de IVF-behandeling biedt als het ware 'slechts' een 'helping-hand' om het gestelde doel mogelijk te bereiken. Mar ook wat dit betreft bevindt de IVF-behandeling zich in goed gezelschap: onder andere de volledige niet-kuratieve zorg en open-hart-operaties ${ }^{4}$.

\subsection{Effekten en kosten van de IVF-behandeling; een onderlinge vergelijking}

Op basis van het observationele evaluatie-onderzoek-IVF is alleen een vergelijking mogelijk tussen de effekten en kosten van verschillende groepen IVF-behandelingen.

2) Strikt genomen dient in dit geval ook de theoretische vraag gesteld te worden in hoeverre rekening moet worden gehouden met de eventuele gezondheidswinst van verdere generaties.

3) "Heath is a state of complete physical, mental and social well-being and not merely the absence of disease or infirmity" (Konstitutie van de World Health Organization, 1948).

4) Bij open-hart-operaties is de behandeling evenmin gericht op de oorzaak van het probleem. er wordt eveneens "slechts" een 'omleiding' gemaakt (alleen windt bij de IVF-methode deze "omleiding" plaats met gameten buiten het menselijk lichaam). 
Impliciet kan dit worden beschouwd als een vergelijking van de IVF-behandeling met het alternatief 'geen (verdere) fertiliteitsbehandeling'. Aangezien bij eon groot gedeelte van de paren in het evaluatie-onderzoek de vrouw reeds een of meerdere fertiliteitsbevorderende ingrepen had ondergaan en/of bij het paar reeds een andere vorm van kunstmatige voortplanting was toegepast is deze vergelijking zeker niet irreelel voor de situatie tijdens de onderzoeksperiode.

Voor de effekten en kosten van de IVF-behandeling moeten ten behoveve van de berekeningen in dit hoofdstuk twee globaliserende veronderstellingen worden gemaakt: 1. Voor de financieel-ekonomische kosten van een IVF-behandeling wordt uitgegaan van een gemiddeld bedrag van $f 2500,-$, inklusief medicijnen en laboratoriumbepalingen. In hoofdstuk 4 zijn diverse varianten berekend, van toepassing bij verschillende veronderstellingen en werschillende omvang van de IVF-programma's. Hoewel de omvang van de IVF-programmaxs in de verschillende IVF-centra mogelijk afhankelijk zal zijn van een eventuele selektie van te financieren IVF-behandelingen is omwille van de leesbaarheid gekozen voor een richtgetal. Dit getal blijft recel bij een beperkte financiering van IVF-behandelingen indien in die situatie gekozen zou worden voor een beperking van het aantal IVF-centra (in plaats van de toestemming aan vele centra voor een klein IVF-programma).

2. Als medische effektmaat wordt gekeken naar het percentage doorgaande zwangerschappen per gestarte IVF-behandeling. Dit vormt een nauwkeurige benadering voor het bijbehorende percentage voldragen zwangerschappen met minstens een levendgeboren kind: de zogenaamde 'take-a-baby-home-rate'; bij de afsluiting wan de dataset was dit eindresultaat niet van alle doorgaande zwangerschappen bekend.

Meerling-geboorten worden zodoende in de berekeningen gelijkgesteld aan singuliere partus. Omtrent de meerlingen-geboorten wordt dus impliciet verondersteld dat de voor- en nadelen elkaar op groepsnivo kompenseren. Ook voor de zogenaamde medische "tussenresultaten" van de IVF-behandeling wordt bij de gekozen effektmeting impliciet verondersteld dat de bijbehorende effekten elkaar kompenseren. Met andere woorden, bij behandelingen zonder een doorgaande zwangerschap wordt verondersteld dat de voor- en nadelen op groepsnivo tegen elkaar opwegen van resultaten zoals bereikte fertilisatie, bereikte klinische zwangerschap, optreden van EUG of abortus.

Onder deze veronderstellingen bedragen de kosten per voldragen zwangerschap voor TVF-behandeling gemiddeld $\mathbf{f 2 5 . 0 0 0 , -}(f 2500,-/ 0.10)$.

Indien wordt uitgegaan van eventueel meerdere IVF-behandelingen dan kunnen zowel de gemiddelde alls de differentiele kosten per voldragen zwangerschap worden berekend. Dit is in tabel 6.1 uitgevoerd uitgaande wan een vast bedrag per IVFbehandeling van $f 2500$, en van de resultaten zoals weergegeven in hoofdstuk 3 (tabel 3.4). Met de differentiële kosten worden bedoeld de gemiddelde kosten voor de extra behandelingen; bijvoorbeeld de gemiddelde kosten per voldragen zwangerschap van de $2^{*}$ en $3^{*}$ behandelling gezamenlijk bedragen $f 24.200,-$, terwijl die woor de $1^{*}$ behandeling f20.500,- bedragen. De differentiêle kosten per voldragen zwangerschap nemen derhalve in deze opstelling met name toe bij een uitbreiding vam maximaal 3 naar maximaal 6 IVF-behandelingen. Hierbij dient echter een kanttekening te worden geplaatst. Indien bij de hantering van een relatief gering maximum aantal IVFpogingen per paar de IVF-behandelingen worden gespreid over vele (kleine) centra in plaats van gekonsentreerd in enkele grotere centra, dan zal het bedrag van $f 2500$,- per 
Tabel 6.1. Gemiddelde en differentiele kosten per voldragen zwangerschap bij een bepaald maximum aantal IVF-behandelingen

(de bedragen zijn afgerond en vermeld in guldens; woor de berekeningen

is ut tgegaen varn een cohort van 1000 startende paren?

\begin{tabular}{|c|c|c|c|c|c|c|c|c|}
\hline \multirow{2}{*}{$\begin{array}{l}\text { maximaal } \\
\text { adntal } \\
\text { pogingen }\end{array}$} & \multirow{2}{*}{\multicolumn{2}{|c|}{$\begin{array}{l}\text { aantal be- } \\
\text { handel inger } \\
\text { totaal diff. }\end{array}$}} & \multicolumn{2}{|l|}{ kosten } & \multirow{2}{*}{\multicolumn{2}{|c|}{$\begin{array}{l}\text { voldragen } \\
\text { zwangerschappen }\end{array}$}} & \multirow{2}{*}{\multicolumn{2}{|c|}{$\begin{array}{l}\text { kosten per voldragen } \\
\text { Iwangerschap }\end{array}$}} \\
\hline & & & totaal & differen- & & & & \\
\hline 1 & 1000 & 1000 & .000 & 000 & 122 & 122 & & \\
\hline 3 & 2664 & 1664 & 6.660 .000 & 4.160 .000 & 294 & 172 & 22.650 & \\
\hline 6 & 4615 & 1951 & 11.537 .500 & 4.877 .500 & 423 & 129 & 27.275 & $37.810^{\frac{1}{1}}$ \\
\hline
\end{tabular}

1) De situatie van maximaal 6 behandelingen is vergeleken met die van maximaal 3 behandelingen.

gestarte behandeling nilet toereikend zijn, waardoor ook de (gemiddelde en differentiele) kosten per voldragen zwangerschap zullen stijgen.

Ook kan een nadere differentiatie worden aangebracht voor de kosten per voldragen zwangerschap op basis van patiéntkenmerken (zie tabel 6.2). Een dergelijke berekening is alleen illustratief voor de verschillen tussen de IVF-behandelingen onderling.

Voor de berekeningen is gebruik gemaakt van de zwangerschapspercentages uit de univariate analyses ${ }^{5}$. Ook hier geldt dat het bij een relatief beperkt IVF-programma voor de kosten van belang is of dit programma gekonsentreerd wordt in enkele grotere centra ${ }_{*}$ in de berekeningen is wederom een gemiddeld bedrag van $f 2500$,- aangehouden.

De verschillen in de kosten per voldragen zwangerschap ten aanzien van de indikatiestelling, de leeftijd van de vrouw en het infertiliteitsverleden van het paar zijn aanzienlijk; ze verschillen een faktor 1.4 a 1.9. Met name geldt dat de kosten per voldragen zwangerschap bij de indikatie mannelijke subfertiliteit bijna $2 \times$ zo hoog zijn als bij andere indikaties (tijdens de onderzoeksperiode was bij $10 \%$ van de IVFbehandelingen de indikatie mannelijke subfertiliteit gesteld). Overigens zij nogmaals vermeld dat de bovenvermeldle twee- of driedelingen altijd een geforceerd karakter behouden ten aanzien van de scheiding in resultaten: de groepen in een bepaalde kategorie zijn niet volstrekt homogeen. Dat geldt zelfs voor bijvoorbeeld de indikatiestelling: ook bij de indikaties tubapathologie en mannelijke subfertiliteit bestaan gradaties in de ernst wan de aandoening.

5) Strikt genomen was gebruik van de uitkomsten van de multivariate analyses wenselijker gewweest. Deze laatste analyses teweren echter geen zwangerschapspercentages op, maar alleen odds-ratio"s. Uit deze oddsratio"s kunnen niet zonder meer zwangerschapspercentages worden berekend voor behandelingen die zijn uitgevoerd bij patiënten met bepaalde patiëntkenmerken. In de praktijk van dit onderzoek is gebleken dat de resultaten van de univariate en de multivariate analyses goed op elkaar aansluiten (zie ook voetnoot bij tabel 6.2). 


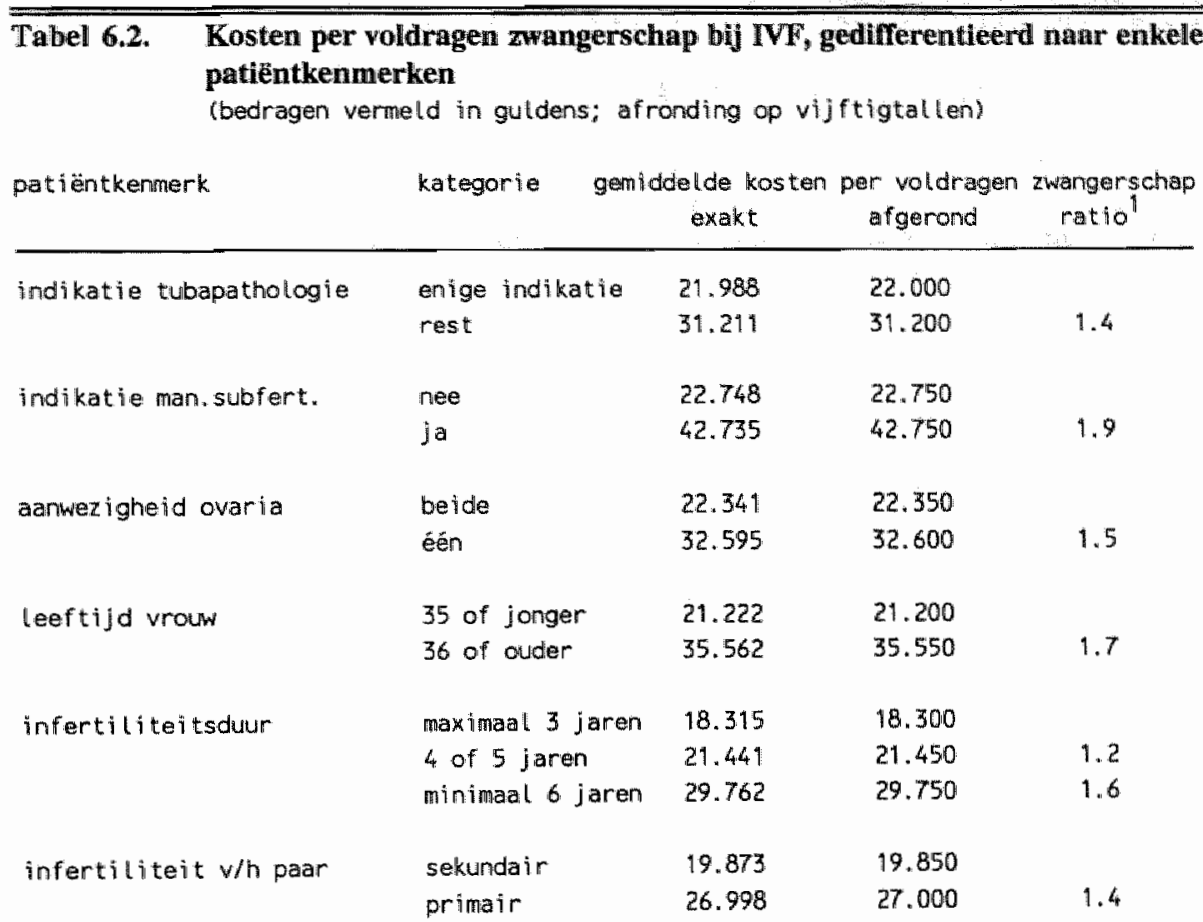

1) Met de ratio wordt de verhouding aangegeven van de gemiddelde kosten per voldragen zwangerschap in de bijbetrorende kategorie ten opzichte van die in de andere kategorie voor het betreffende patiëntkenmerk. Aangezien in de berekeningen voor de kosten per voldragen zwangerschap is uilgegann van een vast gemiddeld kostenbedrag komen de vermelde ratio"s voor de kosten per voldragen zwangerschap overeen met de ratio's voor alleen de effektmaat. Ze sluiten ook goed aan bij de odddsratio's uilt de multiwariate analyses (zie paragraaf 3.4 .5 ). De ratio vermeld bij een infertiliteitsduur van minimaal 6 jaren is berekend ten opzichte van de kategorie maximaal 3 jaren infertiel; ten opzichte van de kategorie 4 of 5 jaren infertiel is de raio 1.4.

Tenslotte kan een illustratie worden gegeven van thet belang van een zorgvuldige afweging bij de keuze omtrent spreiding van IVF-behandelingen over ziekenhuizen. Indien de resultaten tijdens de onderzoeksperiode worden gedifferentieerd naar ziekenhuis, dan blijkt de ratio in de kosten per voldragen zwangerschap tussen het ziekenhuis met de beste resuitaten en het ziekenhuis mel de minste resultaten 2.8 te bedragen. 
In de worige paragraaf is een vergelijking gemaakt tussen de resultaten binnen de IVFpopulatic. Deze vergelijking is relevant woorzover er voor het paar geen alternatieve behandelvorm (meer) bestaat. Aangezien een relatief groot gedeelte van de IVF-paren in de onderzoekspopulatie reeds een of meer fertiliteitsbevorderende tubachirurgische ungrepen had ondergatan is deze wergelijking relevant voor de sitwatie tot op heden. Indien IVF een vaste plaats temidden van de fertiliteitsbehandelingen heeft ingenomen zal, afgezien van een na-ijl-effekt, IVF niet meer worden aangeboden als laatste redmiddel (hender of last resort'). Met name voor patienten met de indikatie tubapathologie zal dan een zorgvuldige afweging gemaakt dienen te worden tussen de allernatieven tubachirurgie en IVF. Vooraf zal zo goed mogelijk een prognose moeten worden gemaakt van de resultaten bij beide behandelmethoden. Dit is ook vanuit kostenoogpunt belangrijk, omdat daarmee (gedeeltelijk) voorkomen kan worden dat bij uitblijwend sukses het andere alternatief alsnog wordt toegepast.

In het observationele evaluatie-onderzoek-IVF zijn uitgebreid de effekten en de kosten van de IVF-behandeling onder de loupe genomen. Met het wegvallen wan een vergelijkend onderzoek moest voor soortgelijke gegevens omtrent andere vormen van fertiliteitsbehandeling in hoofdstuk 5 grotendeels gebruik worden gemaakt van informatie uit de literatuur. Het grootste gedeelte van de IVF-onderzoekspopulatie bestond uit paren bij wile de indikatie tubapathologie was gesteld. De belangrijkste alternatieve behandeling voor de IVF-populatie is derhalve tubachirurgie. Alleen voor dit alternatief is in hoofdstuk 5 tevens een globale berekening van de kosten opgesteld. Om deze redenen zal in dit hoofdstuk alleen een globale vergelijking kunnen worden gemaakt tussen IVF en tubachirurgie.

De kosten van tubachirurgie zijn geraamd op $f 5000$, à $f 7000$, (zie paragraaf 5.2 .2 ). De gemiddelde kosten per gestarte IVF-behandeling zijn in de lage variant voor de loonkosten berekend op $f 2600$, - a $f 3300$,- voor een IVF-programma van jaarlijks bijna 400 gestarte behandelingen, geleidelijk dalend tot $f 2000$ a $f 2300$ voor een erg groot IVF-programma (jaarlijks 1250 gestarte behandelingen). In de relatief hoge variant voor de loonkosten waren deze bedragen respektievelijk $f 2800,-$ a $f 3300$, - c.q. $f 2100$,a $f 2400, \cdots$ Derhalve is de kostenverhouding tussen tubachirurgie en een IVF. behandeling bij een relatief klein IVF-programma gelijk aan 2 a 2.5 en bij een groot IVF-programma 2.5 a 3 , ofwel globaal gezien 2 i 3 .

Deze kostenverhoudingen worden nauwelijks beïnvloed door rekening te houden met de extra kosten binnen de gezondheidszorg die het gevolg ziju van de fertiliteitsbehandeling. De totale kosten per tubachirurgische ingreep behorend bij voornamelijk behandeling bij abortus en $E U G$, perinatale en neonatale zorg zijn warschijnlijk iets hoger dan die bij IVF per gestarte cyclus. Bij IVF zijn de kosten van de neonatale zorg van relatief groot belang in een totaal extra kostenbedrag per gestarte cyclus van bij benadering $f 360$,- (zie bijlage 4.5 ). Bij tubachirurgie zijn voornamelijk de kosten van behandeling van EUG's van belang in verband met de 
hoge incidentie: bij benadering $f 500,-$ a $f 750,-6$. Toevoeging van deze kosten aan de kosten die rechtstreeks bij de therapie behoren verandert echter nauwelijks iets aan de eerder weergegeven kostenverhouding tussen tubachirurgie en IVF.

In nog veel sterkere mate dan voor IVF geldt voor de resuitaten van de tubachirurgie dat de spreiding van de zwangerschapspercentages erg groot is. In hoofdstuk 5 is aangegeven dat deze spreiding wordt veroorzaakt door verschillen in de aard van de ingreep en in de ernst van de aandoening. Een vergelijking op voorzieningen-nivo tussen IVF en tubachirurgie op basis van gemiddelde effekten en kosten is dan ook om deze redenen niet zinvol. Op het voorzieningen-nivo kan in verband met de bovenvermelde kostenverhouding wel gekonkludeerd worden dat IVF en tubachirurgie alternatieven voor fertiliteitsbehandeling vormen; het interval voor het percentage voldragen zwangerschappen per tuba-ingreep omvat immers het gebied dat wordt bestreken door 2 a 3 keer het percentage voldragen zwangerschappen per gestarte IVFcyclus.

Voor een aanduiding op het nivo van patlëntgroepen omtrent de te prefereren therapie zijn nadere gegevens over IVF en tubachirurgie nodig. Het gemiddelde suksespercentage voor IVF bij paren met als enige indikatie tubapathologie bedroeg in het onderzoek $11.4 \%$; voor IVF bij alle paren waarbij (mede) de indikatie tubapathologie was gesteld bedroeg het $10.5 \%$. Rondom deze gemiddelde skores bestond een spreiding die voornamelijk werd veroorzaakt door patiëntkenmerken, het rangordenummer van de behandeling en het ziekenhuis waar de IVF-behandeling werd uitgevoerd. Hoewel er aanwijzingen waren dat de ernst van de tubapathologie enige invloed had op de IVF-resultaten kon dit niet duidelijk worden aangetoond.

De spreiding in het percentage voldragen zwangerschappen per ingreep is bij tubachirurgie echter veel groter dan bij het soortgelijke percentage voor IVF: bij tubachirurgie varieert dit resultaat tussen vrijwel nihil en circa $75 \%$. Bij prognosestelling op basis van gegevens van het HSG en de diagnostische laparoscopie omtrent de ernst van de aandoening lijkt het mogelijk de patiẻnten die eventueel in aanmerking komen voor tuba-chirurgie dusdanig in te delen dat drie groepen ontstaan ten aanzien van de kans op een woldragen zwangerschap na de ingreep:

- een groep waarvoor deze kans duidelijk groter is dan 2 a 3 keer de bijbehorende kans per gestarte IVF-behandeling, ofwel groter is dan de bijbehorende kans bij 2 a 3 IVF-behandelingen ${ }^{7}$ van 30 a $35 \%$; bij die patienten verdient tubachirurgie de voorkeur

- een groep waarvoor deze kans duidelijk kleiner is dan 30 a $35 \%$; bij die patiènten verdient IVF de voorkeur

- een groep waarvoor deze kans ligt in de orde van grootte van 30 a $35 \%$; bij die patiënten kan mogelijk mede op basis van een afweging van de kans op komplikaties (voornamelijk EUG bij tubachirurgie en meonatale komplikaties bij IVF) en de

6) De kosten van behandeling van een EUG zijn, overeenkomstig de berekening bij IVF, ingeschat op $f 5000$. . Bij een incidentie van EUG per fertiliteitsbevorderende tuba-ingreep wan 10 \& $15 \%$ resulteren de vermelde bedragen.

7) Hoewel in hoofdstuk 3 is gesignaleerd dat de sukseskansen afnemen bij een oplopend rangordenumancr wan de behandeling is deze andere wijze van wergelijking tussen tubachirurgie en IVF hier toegestaan. Enerzijds treedt de daling in sukseskansen bij oplopend rangordenummer van de IVF-behandeling met name op vanat volgnummer 4 , anderzijds wordt de globale vergetijking tussen tubachinurgie en IVF door deze abstraktie geen geweld aangedaan. 
leeftija van de vroutw een beslissing worden genomen omtrent de therapiekeuze. Na tubachirurgie lijken immers bij en ernstige aandoening niet alleen de zwangerschapskansen gereduceerd te zijn, maar ook de kansen op een EUG verhoogd te zijh. Op hoge leeftijd heeft de tubachirurgische behandeling het nadeel dat de kans op een zwangerschap na enige tijd door het natuurlijk beloop verder wordt gereduceerd.

Hierbij zij nogmaals nadrukkelijk aangegeven dat vergelijking van de resultaten van IVF uit dit onderzoek met de resultaten van tubachirurgie op basis van de literatuur bemoeilijkt wordt door onduidelijkheden omtrent zwangerschapsdefinities in de literatuur en door methodologische verschillen (zie paragraaf 5.2.1). In de literatuur worden met betrekking tot tubachirurgie veelal analyses uitgevoerd op basis van de suksesmeting klinische zwangerschap of intra-uteriene zwangerschap; het percentage voldragen zwangerschappen per ingreep ligt beduidend lager.

\subsection{Belloidsimplikaties en beleidskomplikaties}

In dilt rapport zijn met name ten aanzien van de IVF-behandeling vele gegevens opgenomen die van belang zouden kunmen zijn voor het beleid. Anderzijds is er met betrekking tot de afweging tussen IVF en mogelijke alternatieven voor deze laatste kategorie nauwelijks additioneel onderzoek verricht. In verband met het wegvallen van het vergelijkende onderzoek. IVF versus tubachirwrgie konden alleen de literatuurbevindingen worden vermeld. De vraag is nu: in hoeverre kan met behulp van de gegevens in dit rapport beleid worden gevoerd?

Allereerst is het belangrijk te benadrukken dat beleid ten aanzien van IVF alleen kan plaatswinden in het licht van het totale fertiliteitsprogramma van therapieen (en diagnostiek). Bijwoorbeeld uitsluiting van IVF uit het verstrekkingenpakket en handhaving van tubachirurgie in het pakket zou irrationeel zijn. Eenzelfde opmerking kan worden gemaakt ten aanzien van enig ander ongelijk beleid voor beide therapieen, zoals opname van de ene voorziening in het basispakket en van de andere voorziening in het aanvullende pakket, of introduktie van een eigen bijdrage voor een van beide therapieen. Een đergelijk beleid zou onherroepelijk tot een imefficiente aanwending van middelen leiden: de afweging IVF wersus tubachirurgie kan niet onder gelijke kondities worden gemaakt, waardoor de therapie met de meest gunstige randvoorwaarden waarschijnlijk vaker wordt toegepast dan gewenst zou zijn op basis van het gestelde in de vorige paragraaf. Eenzelfde soort opmerking kan worden gemaakt ten aanzien van de wachttijden voor beide therapieen. Zolang de wachttijd voor IVF beduidend langer is dan die voor tubachirurgie blijft een ewenwichtige afweging tussen beide therapieen niet goed mogelijk. Indien IVF wordt opgenomen in het verstrekkingenpakket zal voor nieuwe patienten op de een of andere manier gestreefd moeten worden naar een gelijkschakeling van de wachttijden voor beide therapieèn.

Voor de andere indikaties dan tubapathologie zijn min of meer in het verlengde van de IVF-methode diverse andere behandelmethoden voor fertiliteitsproblemen (verder) 
ontwikkeld die grotendeels nog niet in het verstrekkingenpakket zijn opgenomen, zoals GIFT, (D)IPI en IUI. Onewenwichtig beleid ten aanzien van enerajjds IVF en anderzijds deze andere methoden kan tot soortgelijke problemen leiden als hierboven geschetst.

Indien besloten zou worden tot opname van IVF in het verstrekkingenpakket en de wens zou bestaan om daarbij op de een of andere wijze rekening te houden met de gekonstateerde differentiatie in de resultaten bij IVF, dan luidt de vraag in hoeverre dit kan worden verwezenlijkt.

Indien deze selektie zou moeten worden afgedwongen ('regulation by directive" y) via vergunnings- en financieringsregelingen dan staan hiertoe ons inziens wellicht een aantal mogelijkheden open:

1. Een eventuele maximering van het aantal te vergoeden MF-behandelingen per paar is relatief eenvoudig te realiseren. Beperking van de vergoeding van verdere IVFpogingen zou in dat geval gevolgd moeten worden door beperking van de financiering van andere fertiliteitsbehandelingen (na afloop van een bepaald aantal

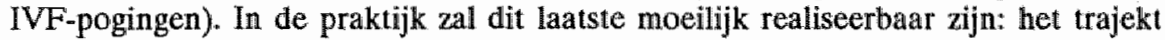
van de individuele patiènt door de Nederlandse gezondheidszorg is moeilijk te volgen.

2. In verband met de relatief grote verschillen in de resultaten per ziekenhuis is te overwegen een nadere selektie te maken wan ziekenhuizen c.q. laboratoria die in aanmerking zouden komen voor financiering. Vooralsnog zou een dergelijke selektie gekoppeld moeten zijn aan een vergunningen-regeling. In de toekomst krijgen financiers wellicht de mogelijkheid hiertoe meer eigen initiatief te ontplooien. Er zou in dit kader kunnen worden gedacht aan een totaalbudget voor fertiliteitsbehandeling per centrum met verrekening per bereikte doorgaande zwangerschap. Zonder nadere afspraken stuit een dergelijke konstruktie echter op vele praktische bezwaren (zie bijlage 6.1.).

De vraag is: hoe kan bruikbare informatie worden verzameld over de resultaten in een bepaald ziekenhuis c.q. laboratorium, rekening houdend met de samenstelling van de behandelde populatie? Binnen het evaluatic-onderzoek-IVF was het mogelijk deze benodigde informatie te verzamelen voor de 5 betrokken ziekenhuizen/laboratoria. Maar het is nog maar de vraag of in de toekomst goede informatieverzameling mogelijk is omtrent de resultaten van de IVF-behandelingen per centrum en omtrent de splitsing hierwan naar patientgroepen. Op basis van het aantal gefinancierde behandelingen zou enige vorm van kontrole kunnen plaatsvinden; maar bij dreigende problemen met financiers is selektieve gegevenswerstrekking over resultaten niet uitgesloten.

8) Zolang een verstrekking niet expliciet is uitgesloten van het verstrekkingenpakkket is deze impliciet opgenomen wanneer de voorzliening binnen de medische beroepsgroep algemeen geaseptecrd is. In icder geval is voor de meeste van die andere behandelmethoden voor fertiliteitsproblemen (evenals voor IVT) nog geen tarief vastgesteld.

9) Voor een nadere beschrijving van de (on) mogelijkhedern wan "regulation by directive' en 'regulation by" incentive' in de gezondheidszorg zij verwezen naar Haan[1987]. Darar wordt onder andere aangegeven dat 'regulation by incentiwe' de voorkeur geniet, mar niet allijd mogelijk c.q. effekt ief is. 
Voor een eventuelle selektie van ziekenhuizen c.q. laboratoria zijn nog twee inhoudelijke opmerkingen van belang:

- De Gezondheidsraad[1986] spreekt in haar advies over kunstmatige voortplanting de voorkeur uit voor de vestiging van IVF-centra in de academische ziekenhuizen. Datar zouden de wetenschappelijke ontwikkelingen met betrekking tot de fertiliteitsproblematiek het beste ten goede kunnen komen aan enerzijds de patiëntenzorg en anderzijds het wetenschappelijke onderzoek en onderwijs. Gezien de resultaten in de 5 ziekenhuizen van het evaluatie-onderzoek-TVF en de globale gegevens van enkele andere IVF-centra in Nederland lijkt een dergelijke voorkeur ten aanzien van de patièntenzorg niet (meer) opportuun. Daarnaast vindt wetenschappelijk onderzoek en onderwijs ook plaats in niet-academische ziekenhuizen.

- Transport-IVF blijkt soortgelljke resultaten te kunnen opleveren als de normale IVF-procedure. Essenticel volgens de mening van vele betrokkenen is daarbij een intensief kontakt tussen enerzijds de gynaecologen van het ziekenhuis waar de hormoonstimulatie en de follikelpunktie plaatsvinden en de biologen en gynaecologen in het centrum waat de in-vitro-fertilisatie en de embryotransfer plaatsvinden. Dit kontakt is nodig om voortdurend op de hoogte te blijven van kleine veranderingen in de behandelingsprocedure. In theorie kan dat kontakt goed worden geregeld; in de praktijk blijkt het moeilijk dit ook voortulurend te blijven waarmaken. Maar indien een dergelijk intensief kontakt wel realiseerbaar is, dan biedt transport-IVF de mogelijkheid om tegemoet te komen aan overwegingen/eisen ten aanzien wan zowel efficientie als bereikbaarheid van de IVFbehandeling. Enerzijds kan met name in het laboratorium geprofiteerd worden van schaalvoordelen, anderzijds kan de gemiddelde reisafstand voor de patient worden gereduceerd gedurende de periode walarin ziekenhuis-bezoek meermaals moodzakellijk is.

Bij uitbreiding van de transport-IVF-methode naar vele ziekenhuizen ontstaan echter duidelijk problemen. Enerzijds geldt voor het zogenaamde toeleveringsziekenhuis dat het aantal IVF-behandelingen daardoor in diverse ziekenhuizen te gering zal worden c.q. blijven om een goede kwaliteit van de behandeling te kunnen garanderen. Anderzijds geldt voor zowel het toeleverings-ziekenhuis als voor het centrale laboratorium/ ziekenhuis dlat ten gevolge van de versnippering wan aandacht een intensief kontakt vrijwel onmogelijk wordt.

3. Selektie op basis van verschillen in de resultaten gebaseerd op medische patiêntkenmerken lijkt slechts mogelijk via 'regulation by incentive'. De belangrijkste prikkel om de gynaecoloog tot een evenwichtig advies c.q. een evenwichtige beslissing te لaten komen omtrent de keuze tussen IVF en een mogelijk alternatief bestaat uit het verstrekken van gedetailleerde prognoses omtrent de zwangerschapskansen bij IVF en bij de alternatieven, gekombineerd met een kostenvergelijking voor beide therapieen. Dit eindrapport hoopt hierin een bijdrage te leveren ten aanzien wan in ieder geval de IVF-methode. Daarnaast moeten de voorwaarden bij de verschillende alternatieven soortgelijk zijn.

Regulering door middel van dwang lijkt bij IVF ten aanzien van patientselektie vooraf op basis van medische patiëntkenmerken moeilijk realiseerbaar. Naleving van deze vooraf gestelde kriteria is achteraf moeilijk te kontroleren. Een andere mogelijkheid zou kunnen zijn maximering van het aantal te vergoeden IVFbehandelingen voor de Nederlandse (ziekenfonds)populatie. Daartoe zouden echter 
gegevens bekend moeten zijn omtrent de totale behoefte aan fertiliteitsbohandeling en de bijdrage van IVF daarin. Bowendien zou deze behoefteraming nog gespecificeerd moeten worden naar de frekwentieverdeling wan de patientkenmerken waarvoor selektie wenselijk zou worden geacht. Al met al is dit (voorlopig) een onmogelijke opgave.

Een dergelijke maximering zou ook zinloos zijn indien deze niet gekoppeld zou worden aan een vaststelling van een plafond voor met name tubachirurgie. Financiering van IVF zou ten aanzien van de indikatie tubapathologie, na verloop van tijd, immers tot een reduktie in het gebruik van tubachirurgie moeten leiden. Deze reduktie kan de komende jaren wellicht worden gemitigeerd door een toename in de potentiele populatie voor fertiliteitsbehandeling.

In het bovenstaande zijn de volgende konklusies vervat:

- Een beslissing over IVF moet worden bezien in het totale beeld van de fertiliteitsbehandeling.

- IVF vormt op voorzieningen-nivo een resel alternatief voor tubachirurgie.

- Op het nivo van patiëntgroepen is een nadere afweging tussen IVF en tubachirurgie mogelijk op basis van de prognosekansen en de kosten bij beide therapievormen; prognoses zijn in redelijke mate op te stellen op basis van patientkenmerken.

- Regelingen op het gebied van vergunningen en financiering kunnen slechts een beperkte betekenis hebben bij de realisering van een evenwichtige afweging tussen therapiean yoor fertiliteitsproblemen.

- De resultaten bij IVF verschillen sterk tussen ziekenhuizen (ook na korrektie voor samenstelling van de patientenpopulatie); uitsluiting op voorhand van algemene ziekenhuizen als IVF-centra of als toeleverings-ziekenhuizen bij transport-IVF is voor een goede patiëntenzorg zeker niet op zij̄n plaats. 



\section{SAMENVATTING}

\section{Inleiding}

Dit proefschrift is gebaseerd het evaluatie-onderzoek-IVF dat in opdracht van de Ziekenfondsraad is uitgevoerd door de vakgroep Ekonomie van de Gezondheidszorg van de Rijksuniversiteit Limburg. Het onderzoek is observationeel en prospektief opgezet en heeft betrekking op ruim 3000 IVF behandelingen bij bijna 1500 paren. Het betreft alle reguliere IVF-behandelingen die in de periode augustus 1986 tot en met mei 1988 hebben plaatsgevonden in de volgende 5 centra: Dijkzigt Ziekenhuis Rotterdam, Academisch Ziekenhuis Vrije Universiteit Amsterdam, Academisch Ziekenhuis Leiden, St. Radboud Ziekenhuis Nijmegen, St. Elisabeth Ziekenhuis Tillburg.

De medisch-biologische en de financieel-ekonomische aspekten van de IVFbehandeling worden belicht. Deze elementen kunnen in een afgewogen besluitworming worden geplaatst naast met name ethische, juridische en psychosociale maatstaven.

Voor een vergelijkend onderzoek tussen IVF en tubachirurgie (hetzij gerandomiseerd, hetzij observationeel) werd geen goedkeuring verleend. De vergelijking tussen IVF en medische alternitieven is dan ook voor de alternatieven gebaseerd op literatuurgegevens.

\section{IVF; medisch-biologisch}

Van iedere 100 gestarte IVF-behandelingen leiden er gemiddeld 10 tot de geboorte van (minstens) eén levensvatbaar kind (dit is vrijwel gelijk aan het aantal bereikte doorgaande zwangerschappen). Bij $30 \%$ van de doorgaande zwangerschappen is er sprake wan een meerlingzwangerschap; mede hierdoor treden er relatief vaak komplikaties op tijdens de zwangerschap en rondom de partus.

Als ieder paar 1 behandeling zou ondergaan zou het gemiddelde suksespercentage in termen van doorgaande zwangerschap per gestarte behandelling $12 \%$ bedragen. Gesteld dat leder paar (bij uitblijwend sukses in voorgaande IVF-behandelingen) zou doorgaan tot en met 3 behandelingen, dan zou 30\% van de paren een doorgaande zwangerschap hebben bereikt. Bij voortzetting tot en met de $6^{\text {a }}$ behandeling zou dit percentage oplopen tot ruim $40 \%$.

Aangezien tijdens de onderzoeksperiode lang niet alle paren de IVF-procedure zo lang wilden voortzetten is in het onderzoek ook op een andere wijze gekeken naar de sukseskans op termijn. Bij een follow-up periode van minimaal 1 jaar vanaf de eerste IVF behandeling bleek bijna $25 \%$ van de paren een doorgaande zwangerschap te hebben bereikt (bij gemiddeld 2.5 gestarte behandelingen c.q. 2 follikelpunkties).

Er bestaan grote verschillen in resultaten zowel tussen patikntgroepen met bepaalde medische kenmerken als tussen de ziekenhuizen waar de behandeling. is uitgevoerd. Deze verschillen bleken in het onderzoek ook onafhankelijk van elkaar te blijven bestaan. De sukseskans was met name werlaagd bij:

- paren met mannelijke subfertiliteit alls (mede-)indikatie 
- vrouwen met nog slechts een ovarium

- vrowwen op hogere leeftijd

- paren met een langer durende infertiliteit.

De resultaten per ziekenhuis - in termen wan doorgand zwangerschapspercentage per gestarte behandeling - verschilden maximaal circa een faktor 2.5 (ook na korrektie woor de samenstelling van de patiẻntenpopulatie).

De zwangerschapsresultaten met behulp van cryopreservatie van een surplus aan embryo's en terugplaatsing in een latere cyclus zijn van dien aard dat deze extra stap in het IVF-programma vooralsnog nauwelijks iets toevoegt aan die zwangerschapsresultaten per gestarte IVF-behandeling.

\section{IVF; Financieel-economisch}

Uitgaande van een IVF-programma van jaarlijks 375 gestarte behandelingen (circa 300 follikelpunkties) bedragen de gemiddelde totale kosten per gestarte behandeling $f 2600,-$ a $f 3300,-$ Bij uitbreiding wan het programma binnen een IVF-centrum treedt een alanmerkelijk schaalvoordeel op:

- bij uitbreiding van het programma tot 750 gestarte behandelingen (verdubbeling) bedragen de gemiddelde kosten per gestarte behandeling $f 2100,-$ a $f 2700,-;$ de gemiddelde kosten van de 375 extra behandelingen bedragen in dit geval $f 1700,-a f 2000,-;$ dit is een reduktie van $1 / 3$ ten opzichte van de eerste 375 behandelingen.

- bij vitbreiding van het programma tot 1250 gestarte behandelingen bedragen de gemiddelde kosten per gestarte behandeling $f 2000$, a $f 2400$, Ofwel, programma's in de orde van grootte van 750 gestarte behandelingen (circa 600 follikelpunkties) zijn veel efficiënter dan programma's die half zo groot zijn. Uitbreiding tot programma's in de orde van grootte van 1250 gestarte behandelingen voegt uit efficientieoverwegingen op ziekenhuisnivo weinig meer toe, op landelijk nivo wel. De schaalvoordelen hangen woornamelijk samen met de noodzakelijke basisvoorzieningen voor ieder IVF-centrum.

Ook dient cen afweging te worden gemaakt tussen enerzijds kostenverlaging bij minstens gelijkblijvende kwaliteit en anderajds bereikbaarheid van de woorziening. Aangezien de schaalvoordelen vooral optreden in de kosten van het laboratorium biedt de mogelijkheid van transport-IVF hier wellicht uitkomst. Ook in de atanleverende ziekenhuizen bij deze transport-IVF lijkt een IVF-programma van redelijke omvang een noodzakelijke voorwaarde voor het behoud van kwaliteit op termijn.

De gemiddelde kosten per gestarte behandeling zijn niet alleen afhankelijk van de omvang van het IVF-programma, maar ook van met name:

- de intensiteit van de kontrole tijdens de fase van de hormoonstimulatie

- de verhouding academisch-geschoold versus het overige personeel bij de IVFaktiviteiten

- de logistiek in de organisatic. 


\section{Effekten en kosten van IVF}

Doel van de IVF-behandeling is de geboorte van (minstens) eén levensvatbaar kind na een voldragen zwangerschap. De gemiddelde kosten van een voldragen zwangerschap bedragen gemiddeld $f 25.000$, - (indien de extra kosten bimnen de gezondheidszorg wan zwangerschapsbegeleiding en perinatale zorg worden meegenomen bedragen de gemiddelde kosten per gestarte behandeling circa f30.000,-).

Indien ieder paar slechts eén IVF-behandeling zou ondergaan dan bedragen de gemiddelde kosten per voldragen zwangerschap ruim $f 20.000,-$. Bij uitbreiding tot maximaal 3 pogingen bedragen de gemiddelde kosten per voldragen zwangerschap voor de $2^{8}$ en de $3^{\circ}$ behandeling ruim $f 24.000, \ldots$ Bij uitbreiding tot maximaal 6 pogingen loopt dit bedrag voor de $4^{\mathrm{a}}$ tot en met de $6^{6}$ behandeling op tot bijna $f 38.000,-$. Een maximering van het aantal behandelingen lijkt derhalve uit kosten-effektiviteits-overweging en om verdelingsredenen zinvol.

Voor de gemiddelde kosten per voldragen zwangerschap is ook een differentiatie aan te brengen naar de lokatie van de behandeling. Onder de veronderstelling van gelijke kosten per behandeling in ieder ziekenhuis verschilden in de onderzoeksperiode de kosten per voldragen zwangerschap tussen de ziekenhuizen maximaal circa een faktor 2.5. Een selektie van ziekenhuizen c.q. laboratoria lijkt derhalve zinvoi; een geschikt toetsingskriterium hiervoor is evenwel moeilijk te vinden of moeilijk in de praktijk te hanteren. Enerzijds gaat globale kwaliteitstoetsing gepaard met meetbaarheids-problemen. Anderzijds is voor de konkrete toetsing op zwangerschapsresultaten goede dataverzameling vereist voor alle centra (ook omtrent samenstelling van de patièntenpopulatie), nu en in de toekomst.

Uitsluiting van algemene ziekenhuizen voor IVF-behandeling is uit kosteneffektiviteits-overwegingen met betrekking tot patiëntenzorg niet te verdedigen.

Onder de veronderstelling dat de gemiddelde kosten per behandeling niet wezenlijk verschillen tussen diverse patiëntgroepen met uiteenlopende medische kenmerken bedragen de kosten per voldragen zwangerschap voor behandelingen op (mede-)indikatie mannelijke subfertiliteit bijna $f 43.000,-$ als gevolg van het relatief lage suksespercentage. Ook voor behandelingen bij andere patiêntgroepen met relatief lagere suksespercentages (zie eerder) liggen de gemiddelde kosten per voldragen zwangerschap boven het gemiddelde, namelijk op $f 30.000$,-à $f 35.000$,-

\section{Medische alternatieven voor IVF}

De bovenstaande resultaten kunnen worden gezien als een vergelijking tussen IVF en het alternatief "niets doen" (zonder rekening te houden met spontane zwangerschappen en met de eventuele kosten van 'fertility shopping').

De vergelijking met andere fertiliteitsbehandelingen is vooral gebaseerd op literatuurgegevens. Aangezien tubapathologie de meest voorkomende indikatie voor IVF vormt, is tubachirurgie de belangrijkste alternatieve therapie. 
De medische resultaten in termen van voldragen zwangerschap per ingreep varieren bij tubachirurgie tussen vrijwel nihil en circa $75 \%$. Opgemerkt dient te worden dat de zwangerschap (in tegenstelling tot bij de IVF-behandeling) kan optreden in ledere cyclus na de tubaire operatie. Enerzijds kan dit soms lang op zich laten wachten, anderzijds zijn meerdere zwangerschappen mogelijk. De variatie in de resultaten na tubachirurgie hangt grotendeels samen met:

- de aard van de aandoening

- de ernst van de aandoening.

De kosten van tubachirurgie bedragen $f 5000,-$ a $f 7000,-$ Indien de extra kosten van gezondheidszorg worden meegenomen direkt woortkomend uit de ingreep, dan is met name de relatief hoge frekwentie van buitenbaarmoederlijke zwangerschappen (circa 10 a $15 \%$ per tubachirurgische fertiliteitsbehandeling) van belang; dit leidt globaal tot een kostenverhoging van $10 \%$.

\section{IVF versus tubachirurgie}

Aangezien de kosten voor tubachirurgie 2 a 3 keer zo hoog zijn als die voor een IVF-behandeling en de spreiding in medische resultaten vooral bij tubachirurgie erg groot is, moet zonder twijfel worden gekonkludeerd dat IVF en tubachirurgie op het voorzieningen-nivo als alternatieven te beschouwen zijn op basis van kosten-effektiviteits-overwegingen. Er zijn immers zowel patientgroepen die uit kosten-effektiviteits-owerwegingen beter behandeld kunnen worden met behulp van IVF als groepen die beter behandeld kunnen worden met tubachirurgie.

Op het nivo van patiëntgroepen zijn redelijke woorspellingen mogelijk omtrent de meest kosteneffektieve behandeling, maar deze zijn moeilijk te vertalen in beleid:

- selektie vooraf van te financieren behandelingen bij bepaalde patiëntgroepen is moeilijk kontroleerbaar

- instelling van een plafond voor te financieren behandelingen vereist gedetailleerde kennis over de behoefte aan fertiliteitsbehandeling (onder andere ook omtrent de verdeling near de aard en de ernst van de aandoening) nu en in de toekomst; deze informatie is slechts zeer beperkt voorhanden.

Met de aanwezige informatie omtrent de sukseskansen - gespecificeerd voor diverse medische kenmerken - en omtrent de kosten van zowel IVF als tubachirurgie is het wel mogelijk in het kontakt tussen gynaecoloog en het paar tot een afgewogen keuze te komen. Het beleid dient er dan op gericht te zijn de mogelijkheden te scheppen om deze afgewogen keuze ook inderdaad te kunnen laten plaatsvinden: de fysieke en financiele toegankelijkheid tot de beide alternatieven moet min of meer identiek worden.

\section{Fertiliteitsbehandeling als gezondheidszorg}

In hoeverre fertilliteitsbehandeling een verbeterde gezondheidssituatie oplevert voor het betrokken parar blijft diskutabel. Levensverlenging treedt niet op (mag verondersteld worden) en het is nog maar de vraag in hoeverre fertiliteitsbehandeling op termijn leidt tot een verandering van de levenskwaliteit van beide partmers. 


\section{SUMMARY}

\section{Introduction}

For several years, Dutch health authorities have been trying to develop a policy of deferred adoption of new technologies in the social insurance package. In the try-out period, the technology is provided only on a limited scale under defined conditions. Simultaneously, a cost-effectiveness analys is is carried out. One of the first studies under this policy was that of in-vitro fertilization (IVF). It was conducted by the University of Limburg by order of the Health Insurance Executive Board, which is the advisory board to the Dutch government on behalf of the social insurers. This observational prospective study included all 3092 started IVF treatments - with regard to 1462 couples - from August 1986 to June 1988 in 5 Dutch hospitals: Dijkzigt Hospital Rotterdam, Free University Hospital Amsterdam, Academic Hospital Leiden, St. Radboud Hospital Nijmegen and St. Elisabeth Hospital Tilburg. In this thesis, study results on the medical and economic aspects of the IVF treatment are presented. The comparison to other fertility treatments was mainly based on literature review.

\section{IVF; medical aspects}

In terms of benefits, the total "take-at-least-one-baby-home-rate" per started IVF treatment was $10 \%$, which is in agreement with international standards. This figure is much more realistic than the often used measure "percentage of clinical pregnancies per embryo transfer". Thirty percent of on-going pregnancies were multiple pregnancies; that was one of the reasons for more than usual pregnancy and perinatal complications.

After their first IVF treatment, $12 \%$ of women achieved an on-going pregnancy. With continuation to 3 treatments after earlier failures, this percentage would have been increased to almost $30 \%$ and with further continuation to 6 treatments the cumulative on-going pregnancy rate would have been $42 \%$. But during the research period, couples were mostly not prepared to continuc for so many episodes.

Therefore, alternatively the results in the long run were also derived from a cohort approach. Following a cohort of 852 pairs for at least one year after their first IVF treatment within the research period, almost $25 \%$ of the women achieved an on-going pregnancy (with a mean number of started treatments in that group of 2.5 and a mean number of follicle aspirations of 2 ).

There were substantial differences in results between patient groups with certain medical characteristics and between hospitals. These differences were confirmed by a multivariate logistic regression model in which both patient and hospital variables were included as independent variables. In particular, the success rates were reduced for couples with indication malie factor, women with one ovary remained, older women and long-term infertile couples. Differences between 
hospitals were found up to a factor of 25 , also after correction for differences in patient casemix betwewn the hospitals.

Additional pregnancy results from deferred transfers of frozen-thawed embryos are almost negligible if they are being related to the ultimate pregnancy results per started IVF-treatment. This is partly due to the relatively small number of started IVF-treatments which lead to transfers of frozen-thawed embryos.

\section{IVF; economic aspects}

The costs of the IVF treatment were highly dependent on the treatment protocol (medication and monitoring), the size of the IVF programme, the task division between academic and other personnel, the logistics of the organization, and assumptions on physicians' fees. In the Netherlands, since a few years TVF treatment is almost exclusiwely offered as an outpatient service.

For an IVF programme of 375 started treatments annually, average costs per started IVF treatment are between NLG 2600 and 3300 (NLG $1=$ US $\$ 0.50$ ). The costs with an expanded programme are lower:

- average costs are NLG 2100 to 2700 for a programme of 750 treatments; the average costs for the additional 375 treatments (the differential costs) are NLG 1700 to 2000 , a reduction of $1 / 3$ with regard to the costs for the first 375 treatments.

- average costs are NLG 2000 to 2400 for a programme of 1250 started treatments.

This implies that programmes of about 750 started treatments annually are much more efficient than smaller programmes. Although hospital-scale efficiency can not be further improved upon by expanding the programme, on a national scale, it is much more efficient to have only a few hospitals with very large programmes than a large number of hospitals with smaller programmes. This result mainly derives from the need for a basic of facilities and its associated fixed set-up costs.

When weighing fficiency against spatial accessibility of the treatment, transportIVF might become a useful option. On the one hand patients can receive a substantial part of the treatment within their own region, whereas on the other hand the economies of scale for the IVF laboratories can still be maintained. To assure good quality, cooperating hospitals at least ought to have a substantial IVF programme.

\section{Effects and costs of IVF}

Ultimate goal of IVF treatment is the birth of a (or at least one) baby. Average treatment costs per achieved full-term pregnancy are NLG 25,000. Including the additional health care costs concerned with pregnancy and perinatal care, the average costs increase to about NLG 30,000 . But these averages can be 
differentiated with regard to patient groups, hospitals and number of treatments per couple.

Assuming average costs per started treatment are not very different between patient groups with certain medical characteristics, the average costs per achieved full-term pregnancy for IVF treatments on the indication male factor amount to almost NLG 43,000. For other patient groups with relatively low success rates this figure is between NLG 30,000 and 35,000 .

The average costs per achieved full-term pregnancy differed between the hospitals by a factor of up to 2.5. Therefore, sellection of hospitals or laboratories could be considered. But useful criteria are hard to find and/or it will be difficult to verify the adherence to the criteria in practice. However, there is no cost-effectiveness argument with regard to patient care to exclude or to disfavour general hospitals a priori for IVF treatment.

The average IVF treatment costs per achieved full-term pregnancy are NLG 20,000 for only the first treatment. If couples continue to a second and third treatment episode after earlier failures, the average costs per achieved full-term pregnancy become NLG 24,000 for these second and third treatment episodes. This figure increases to almost NLG 38,000 for the fourth to sixth treatment episodes. On efficiency and equity grounds, limiting the number of treatment episodes per couple could be considered.

\section{Medical alternatives for IVF}

Earlier mentioned results can be regarded as a comparison between IVF and doing nothing, not taking into account spontaneous pregnancies and the costs of so-called "fertility shopping", i.e. the phenomenon that some couples try their luck in more than one center.

Comparison to other fertility treatments is mainly focussed on tubal surgery. Since almost $90 \%$ of IVF-treated patients in the study population had tubal pathology and since tubal surgery has always been paid for, tubal surgery is a goad reference point for the cost-effectiveness of IVF. The average percentage of on-going pregnancies after tubal surgery is about $30 \%$, with a range from almost zero to about $75 \%$, depending on type and seriousness of tubal pathology. It should be noted that - in contrast to IVF - pregnancy as a result of tubal surgery can occur at any menstrual period, because fertility capacity has been reconstructed. On the one hand this pregnancy may take some time, on the other hand it is possible to have more than one (single) pregnancy.

The costs per: tubal surgery are between NLG 5,000 and 7,000. Including additional health care costs related to tubal surgery - especililly for treatment of extra-uterine pregnancies - these figures increase with about $10 \%$. 


\section{IVF versus tubal surgery}

On treatment lewel, costs per on-going pregnancy for three IVF treatments are approximately equivalent to those of one tubal reconstructive operation. Between patient groups there are however great differences in results, both for IVF and for tubal surgery. In terms of efficiency, some patient groups are better off with IVF, others with tubal surgery. As long as tubal surgery is regarded as a regular fertility treatment to be publicly financed, there are no costeffectiveness arguments for not financing IVF.

On pattent level, the decision on treatment preference could be made on basis of a comparison of the prognosis in both alternatives. Acceptable regulatory measures for insurance are difficult to formulate in these circumstances. Minimally, policy should assure that the choice of treatment is not influenced by unequal conditions of physical or financial accessibility.

\section{Fertility treatment; health care to be financed?}

During the study period, the entire structure of health insurance has come into question in the Netherlands. The discussion with regard to financing IVF therefore is more or less overruled by a discussion on if and how to finance all fertility treatments. Part of the discussion will concern the question whether fertility treatment - successful or not - increases the couple"s health situation. Additional life years for the treated couple are not to be expected and an increase of the couple's quality of life in the long run is questionable. 


\section{LITERATUUR}

Abdalla H, et al [1987], The effect of the dose of human chorionic gonadotropin and the vpe of gonadotropin stimulation on oocyte recovery rates in an in vito fertilization program, Fertillsteril., $48,6,958-963$.

Ackerman $S$, et al [1984], Quality Control Testing for Human in Vitro Fertilization Using a Mouse Bubiyo Culture System, Fertit.Steril, $41,2,11 S$.

Acosta A, et al [1973], A Proposed Classification of Pelvic Endometriosis, Obstet. Gyllec,42,1,19-25.

Aitken $R$, et al [1982], Am analysis of sperm function in cases of unexplained infertility: conventional criteria, mowement characteristics, and fertilizing capacity, Fertil. 3 terill, 38,212 .

Auken $R$ [1988]. Assessment of sperm function for IVF, Hum Reprod.,3,1,89-95.

Alberda $A_{4}$ et al [1987], Resultaten wan in vitro-fertilisatie in het Academisch Ziekenhuis Rotrerdam $\times$ Dijkzigt in 1986, Ned.Tijd. Geneesk.,131,48,2194-2198.

Alberda A, et al [1989], Hepatitis B-virusinfectie bij wrouwen behandeld met in vitro-fertilisatie, Ned. Tijds. Geneesk., 133,1,20124.

Allen $N$, et al [1986], In rauterine insemination: a critical rewiew, Fiertil.Steril. $44,5,569.580$.

Amentican Fertility Society [1979], Classification of endometriosis, Fertil.Steril.,32,6,639-634.

Andreyko J, et al [1987], Therapeutic. Uses of Gonadotropin-Releasing Hormone Analogs Obst. Oynecol. Sur., $42,1,1-21$.

Asch $R_{1}$ al [1986a], Pregnancy after translaparoscopic gamete intrafallopian transfer, The Lancel 1034 .

Asch $\mathbb{R}$, et al $[1986 \mathrm{~b}$, Prehminary experiences with gamete inirafatlopian transfer (GIFT), Fertil.Steril.,45,3,366-371.

Asch R [1987], Results fo the multicentric international cooperative study of Gifre, Presentatie 5e wereldkongres wan In Vitro Fertilisatie en Embryotransfer, Norfolk, s-10 april.

Assen F van [1977], A simple Scoring System To Determine the Operability and Prognosis in Tubal Surgery, Fentil. Steril.,28,3,285.

Awadalia $S_{*}$ et al [1987], In vitro fertiliation and embayo transfer as an treatment for mate factor inlertibly, Fertil. Steril. $47,5,807,811$.

[3ardieri R [1988], New therapy for endometriosis, New Engl. Journ. Med. „512-514.

Barlow P, et. al [1988], Early pregnacy loss and obstetrical risk ather in vitro fertilization and embryo replacement, Hum.Reprod.,3,4,671-675.

Barnea E, et al [1985], Long.Term Prognosis of Infertile Couples With Normal Basic Inwestigations: A Liffe-Table Analysis, Obstet. Gynecol, $66,1,24-26$.

Bateman B, et al [1987], Surgical management of distal tubal obshruction - are we making progress?, Fert. Sterill. $48,523-542$.

Belaisch Allart J, et al [1985], Various Techniques for oocyle-recovery in an in-vitro fertilization and embryo transfer, J.IVE/ET,2,2,99-104.

Belaisch-Alart J, et al [1987], The effect of dydrogesterone supplementation in an IVF programme, Human Reprod., 2,3,183 185 . 
Buelaisch Allar I, al [1589] Does dydrogesterone or hCG supplententation after IVF improve the success ate in LH-rh analogue hMO stimulation gycles. Analysis of two multicentric studies. Abstracts VI wereidkongres wan IVT Jeruzalem, 79.

Bellinge $B_{\beta}$ et al [1986], The ennuence of patient insenithation on the implantation rate in an in vito fentiluation and emibryo transfier program, Fertilsteril, $46,2,2522256$.

Ben-Rafael $Z$, el all [1986], Treatmetit-independent pregnancy after in witro fertilization and embryo transfer trital, Fertil steril $, 45,4,564-567$.

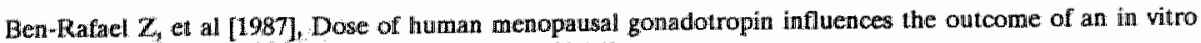
wertilization program, Fertilsisterill,48,6,964-968.

Benedeti $J_{\text {, }}$ et $[1981]$; Life tables and Survival functions, In: Dixon W (ed): BMDP Statistical Soffware 1981. University of Callfornia Press, Berkeley,557-575.

Bernardus R [1988, Nieuwe technieken in de voortplaringsgeneeskunde, Medifo, 22-47.

Blamkstein $J$, et al \1987], Ovarian hypertimulation syndrome: prediction by number and size of preovulatory ovarian follicless. Fertil. Steril $47,4,597-602$.

Boer-Meisel $\mathrm{M}_{1}$ et al [1985]; The Impact of in-Vitro Fertilization on Tubal Surgery for Complete Fimbrial Obstruction, Ann.NY,Acad. Sci $442,533-535$.

Boer-Meisel $\mathrm{M}_{*}$ et al [1986], Predicting the pregnancy outcome in patients treated for hydrosalpirix: a prospective study, Fertil.Steril $4,45,1,23-29$.

Boer-Meisel $\mathrm{M}_{1}$ et al $[1988]$, The significance of pre-operative hysterosalpungography for preclicting the pregnancy outcome in patients with a bilateral hydrosalpinx, Niet gepubliceerd.

Bonnicksen A, Blank R [1988], The Government and in vitro fertilization (IVF): views of IVF directors, Fertil.steril., 49,3,396-398.

Bonsel $G_{3}$ et al [1988], De kosten en effecten van harttransplantatie, deelrapport 2C: Kwaliteit van leven voor en na hartransplantatie = Resultaten, Inst. Maatsch. Gezondheidszorg, Erasmus Universiteit Rotterdam.

Borenstein $R$, et al [1989], Severe ovarian hyperstimulation symdrome: impact of abdominal paracentesis. Absitracts VI wereldkongres van IVI Jeruzalem,96.

Bouter L $s_{i}$ Dongen M wan [1988], Bpidemiologisch onderzoek, opzet en interpretatie, Bohn, Scheltema \& Tolkema, Utrecht.

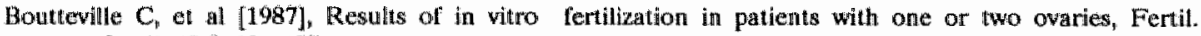
Steril $, 47,5,821-827$.

Boyers $S_{n}$ et 41987$]_{n}$ A paired analysis of in vitro fertilization and cleavage rates of first - versus last recovered preovulatory hurman oocytes exposed to varying intervals of $100 \% \mathrm{CO} 2$ pneumoperitoneum and general anesthesia ${ }_{; 1}$ Fertil. Steril. $48,6,969-97.4$.

Bradshaw $K$, et al [1987], Cumulative pregnancy rattes for donor insemination according to ovullatory function and tubal status, Fertil.Steril.,48,6,1051-1054.

Brandes $j_{i}$ et al [1987], Reduction of the number of embryos in a multiple pregnancy: quintuplet to triplet, Fertil.Steril, $48,2,326 \cdot 327$.

Breslow $\mathbb{N}$, Day $\mathbb{N}$ [1980], Statistical methods in cancer research,wol. 1. the analysis of case-control studies, LARC scientific publications, no 32,Lyon. 
Bromham D, et al [1986]. Psychometric ewaluation of thistress and anxiety in infertile oouples. Abstract and presentation 12th World Congress on Int.Fed. of Fertsocieties,Singapore. In: Taoh $\mathrm{E}_{\mathrm{y}}$ et al (ed.). Handbook of abstracts HI, Obst.Gyn 674 .

Bronssom: $R_{s}$ Wallach E $[1977]$, Lysis of periadnexal adhesions for correction of infertility, Fertil.Steril., $28,6,613-619$.

Brosens I, et all [1983], Tubal Pregnancy: Salpingostomy Versus Salpingostomy, Fertill.Steril,39,3,384-385.

Burke R [1985], Prognostic Value of Subacute Focal Intlammation of the Endometrium, with Special Reference to Pelvic Adhesions as Observed on Laparoscopic Examinalion, J.Reprod.Med. $30,9,646-650$.

Buster J [1985], Embryo Donation by Uterine Flushing and Embryo Transfer, Clinics in Obst. Gyn.,12,4, $815-824$

Buttram V [1985a], Evolution of the Revised American Fertility Society Classification of Endometriosis; Fertilisteril., 43,3,347-352.

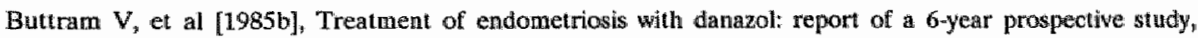
Fertil.Steril., 43,3,353-360.

Byrd W, et al [1987], Treatment of refractory infertility by transcervical intrauterine insemination of washed spermatozoa, Fentil.Steril.,48,6,921-927n

CBS (Centraal Bureau woor de Statistiek)/Ministerie van WVC [1986], Compendium Gezondheidsstatistiek Nederland, Staatsuitgeverij, Den Haag.

CBSH (Centraal Bureat voor de administratie der Specialistenhonorering) [1987], Tarievenboek.

Casper $R$, et al [1987], In vitro fertilization: determination of follicular maturation for timing of hurman chorionic gonadotropin admimistration, Fertill.Steril.,47,2,345-349.

Caspi $E_{4}$ et al [1979], The importance of periadnexal adhesions in tubal reconstructive surgery for infertility Fertil.Steril., $31,3,296-300$.

Caspi E, Halperin Y [1981], Surgical Management of Periadnexal Adhesions, Int.J.Fertil.,26,1,49-52.

Chillik $\mathrm{C}_{3}$ et al $[1985 \mathrm{a}]$, The role of in vilro fertilization in infertile patients with endometriosis, Fiertil. Sierill., $44,1,56-61$.

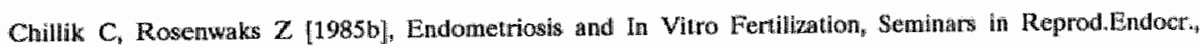
$3,4,377-380$.

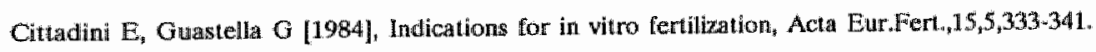

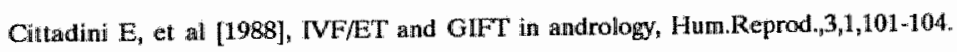

Claman $P$, et al [1987]. The Impact of Embryo Quality and Quantity on Implantation and the Establishment or Viable Pregnancies, J.IVF/E T,4,4,2:18;222.

Clarke $G_{3}$ et al [1985], To flush or not to flush, Proceedings Fert.Society of Austratia, 1985,13.

Cleary P [1984]:" The Amalysis of Relationship Involving Dichotomous Dependent Variables, J, Health Soc. Beh, 25,334-348.

Coben $J[1983]$, The imperatives of surgery in the penspectives of an IVF; Acta Eur. Fert.,14,3,217-219.

Cohen J, et al [1984a], Application of in-vitro fertilisation in castes of poor post-coilal test, Thie Lancel,583.

Cohen J, ef al [1984b], Male infertility successfully treated by in-vitro fertilisation, The Lancet, 1239-1240. 


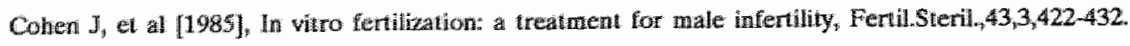

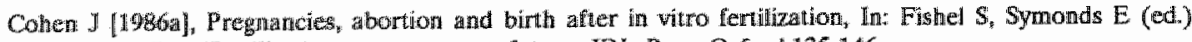
In Vitro Fertilisation: past, prestent, future, IRL Press, Oxford, 135-146.

Colien $\mathrm{J}$, al [1986b]. Transwaginal Sonographically Controlled Ovarian Puncture for Oogve Retrieval lor in Vitro Ferilization, J.TWH/ET, $3,5,309-313$.

Cohem $J_{1}$ et al [1987a], Results of planned in-vitro fertillzation programming through the pre-administration of the ontrogen-progesterone combined pill, Humain Reprod.,2;1,7-9.

Cohen I [1987b], IVF* pregnancies: results of an international survey, Presentatie wiflde wereldkongres IVF/ET, Norfollik.

Collins $J$ a al [1983]. Treatment-independent pregnancy among infertile couples, New Engl.J.Med.,309,20,1201-1206.

Confino $\mathrm{E}$, et al [1986\%], The predict ive value of hCG $\mathrm{B}$ subunit levels in pregnancies achieved by in vitro fertilization and embryo transfer: an international collaboratiwe study, Fertil.steril.,45,4,526-531.

Confuno E, et al [1986b], Inirauterine inseminations with washed human spermatozoa, Fertil.Steril.,46,1,55-60.

Confino $\mathrm{E}$, th al [1986 c], Doet cyclic human chorionic gonadotropin secretion indicate embryo loss in in witro fertilizution, Fertil.Steril.,46,5,897-903.

Cooper G [1986], An Amalysis of the Costs of infertility Treatment, Amer. Joum. Public Health,76,8.

Cramer D, et al [1979], Statistical methods in evaluating the outcome of inferility therapy, Fertil.Steril, $32,1,80-86$.

Cummins $J_{n}$ et al [1986], A Formula for Scoring Human Embryo Growh Rates in in Vitno Fortilization: Its Value in Predicting Pregnancy and in Comparison with Visual Estimates of Embryo Quality, J.TVF/ET, $3,5,284-205$

Daniell J, et al [1986], Clinical results of terminal salpingastomy with the use of the CO2 laser: report of the intra abdominal laser study group, FertillSteril.,45,2,175-178.

Davis G [1986], Instruments \& Methods; Management of endometriosis and its associated adhesions with the $\mathrm{CO} 2$ laser laparascope, Obstet. Gynecol, $68,3,422-425$.

De Wert $G$, Geraedts J [1988], $W F_{n}$ pre-embryo-research en ethick, Metamedica,106-123.

DeCherrey A, Kase $\mathbb{N}$ [1981]. A comparison of treament for bilateral fimbrial occlusion, Fertil.Steril, $35,2,162-160$.

DeCherncy A, Lavy $G$ [1986], Oocyte Recovery Methods in In Vitro Fertilization, Clin.Obstel.Gynec, $29,1,171-179$

Dellenbach P, et al [1985], Transwaginal sonographically controlted follicle puncture for cocyte retrieval, Fertilisteril, $44,5,656-662$.

Dennerstein L, Morse C [1985], Psychological Issues in IVF, Clin.Obst.Gyn, 12,4,835-845.

Deutinger J, al [1986], Pregnancy-specific parameters in early pregnancies after in vitro fertilization: prediction of the course of pregnancy, Fertil.Steril. $46,1,77-80$.

Diamond $\mathrm{E}[1979 \mathrm{x}]$, Lysis of postoperatiwe pelwic adthesions in infertility, Fertilsteril, $31,3,287-295$.

Diamond $\mathrm{E}$ [1979b], A comparison of gross and microsurgical techniques for repair of cornual occlusion in infertillty: a retrospective study, 1968-1978, Fertil.Steril, 32,4,370-376. 
Diamond $M_{4}$ et al [1987], Weight of Babies Conceived in Vitro, JIVF/ET, $4,5,291-293$.

Diamond $M$, et al [1988], The effect of periowarian adhesions on follicular dlewelopment in patients undergoing ovarian stimulation for in vitro fertilization-embryo transfer, Fertilisteril, $49,11,100-103$.

Dodds W, ef al [1987], In vitro fertilization and embryo transfer in patients with one ovaly, Fertul. Steril,48,2,249-253.

Dodson $\mathrm{M}$, et al [1986], A detailed program rewiew of in witro fertilization with a discussion and compatison of alternative approaches, Surgery, Gynecol.\& Obstet,162,89-104.

Donnez J, Casanas-Roux F [1986a], Prognostic factom of fimbrial microsurgery, Fertil.steril $46,2,200-204$.

Donnez J, Casanas-Roux F [1986b], Prognostic factors influencing the pregnancy rate after microsurgical cornual anastomosis, Fertil.Steril, $46,6,1089-1093$.

Doody M, et al [1987], Linear regression analysis of ultrasound follicular growth series: statistical relationship of growth rate and calculated date of growth onset to total growth period, Fertilsterit,47,3,436-440.

Dunstan $\mathrm{G}$ [1984], The moral status of the human embryo: a tradition recalled, Jour. med. ethics, 1,38-44.

Edwards $R$, et al [1984a], Facrors Influencing the Success of in Vitro Fertilization for Allewiating Human Infertility, J.IVF/ET, $1,1,3-23$.

Edwards $R[1984 b]$, The current clinical success of human in vitro fertilization, In: Feichtinger $W$, Kemeter $P$ (ed.) Recent progress in human in vitro fertilization. Wenen,9-.

Edwards R [1988], The roles of the individual and organizations in the ethical dicision-making process, Hum.Reprod., 3,1,11-19.

Eibschitz $I$, et al [1986], In vitro fertilization management and results in stimulated cycles with spontaneous. luteinizing hormone discharge, Fertil.Steril.,45,2,231-236.

Emperaire J, et al [1984], Early prognosis for IVF pregnancies through plasma oestrogens, The Lancet, 1151.

Engelman L. [1985], Stepwise logistic regression. In Dixon W, et al (ed.), BMDP statistical software University of California Press,Berkely,330-344.

Englert $Y$, et al [1987], Higher pregnancy rates after in vitro fertilization and embryo transfer in cases with spenm defects, Fertil.Steril.,48,2,254-257.

Es J van [1986a], Non-Cotlale voortplanting, Medisch Contact,41, 23,715.

Es J van [1986b], Kunstmatige voortplanting, Medisch Contacl,41,46,1,475.

Ethics committee of the Americam Fertility Society [1988], Ethical considerations of the mew reproductive technologies, Supp. Fertil.Steril,49,2.

Evers J, Hamilton C [1989], Transvaginale follikelpunktics: een evaluatie wan de methode. Ned.Tijds. Geneeskunde (geaksepleerd).

Ezratty V, Cohen J [1989], Ovarian hyperstimulation syndrome with GnRH agonist. Abstracts VI meneld. kongres van IVF, Jeruzalem, 108 .

Fanta J [1985], Legal Issues Raised by in Vitro Fertilization and Embryo Transffer if the United States, J.IVF/ET, 2,2,65-86.

Fayez J [1983], An assessment of the role of operative laparoscopy in tuboplasty, Fertil.Sterill, 39,4,476-479. 
Feichtinger W, Kemeter P [1983], A simplified technique for fertilization and culture of human preimplantation emonyos in vitro, Acta Eur.Fert, 14,2,125-128.

Feichuinger W, Kemeter P [1984a], Organization and Computerized Analysis of in Vitro Fertilization and Embryo Transfer Programs, J.IVF/ET,1,1,34-41.

Feichtinger W, Kemeter P [1984b], Laparoscopic or Ultrasonically Guided Follicle Aspiration for in Vitro Fertilization, J.IVF/ET,1,4,244-249.

Ferguson-Snith M (ed.) [1983], Early prenatál diagnosis, British Medical Bulletin,39,4,301-408.

Frifimar $\mathrm{Sh}$, et al [1986]; The effectiveness of $\mathrm{CO}$ laser and electromicrosurgery in adhesiolysis: a comparative study, Fertil. Steril.45,3,407-411.

Fishel S [1985a], Oocyte maturation and fertilization in vitro, Acta Eur. Fert,16,1,13-19.

Fishel $S_{\mathrm{x}}$ et al [1985b], Factors Influencing Human Embryonic Development In Vitro, Ann. NY.Acad.Sciences, 442, 343-356.

Fleming $J$, Igllesias $T$ [1985a], Human Fertilisation in witro cormpared with nature, The Lancet, 168.

Forman $\mathbb{R}$, et al [1988], Evidence for an adverse effect of elevated serum estradiol concentrations on embryo implantation, Fertill, Sterii ,49,1,118-122,

Forman $\mathrm{R}$, et al [1989], Severe ovarian hyperstimulation syndrome associating LHRH agonists and gonadotropins in IVF. A review of a European series and a proposal for prevention. Abstracts VI

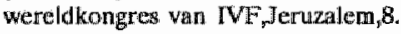

Forrest M, Andersen B [1986], Ordinal scale and statistics in medical researeh, Brit. Med. J.,292,537-538.

Frantzen $C_{y}$ Schlösser $H$ [1982], Microsurgery and postinfectious tuball infertility, Fertil.Steril, 38,4,397-402,

Freeman L, et al [1986], Cryopreservation of human embryos: progress on the clinical use of the technique in human IVF, J,IVFEET,3,53.

Frydman $R_{4}$ et al [1986a], An obstetric assessment of the first 100 births from the in vitro fertilization. program at Clamart, France, Am.J. Obst.Gynec.,154,3,550-555.

Frydman R, et al [1986b], A new approach for follicular stimulation for in vitro fertization: programed oocyte retrieval, Fertil.Steril.,46,4,657-662.

Frydman R, et al [1988], LHRH agonists in IVF: different methods of utilization and comparison with previous owulation stimulation treatments, Hum.Reprod.,3,4,559-561.

Garcia $C_{n}$ Mastroianni L. [1980], Microsurgery for treatment of adnexal disease, Fertil.Steril.,34,5,413-424.

Garcia J, el al [1984], In Vitro Fertilization in Norfolk, Virginia, 1980-1983, J.IVFVET,1,1,24-28.

Garcila $\mathrm{J}_{*}$ at al [1985], Reconstructive pelvic operations for in vitro fertilization, Am.J.Obstet.Gynecol., $153,2,172-178$.

Oarcia J [1986], Preliminary laparotomy for in Vitro Fertilzation, J.IVF/ET,3,2,85-86.

Gardner M, Altman D [1986], Confidence intervals rather than $P$ values: estimation rather than hypothesis. testing, Brit. Med.Jour,,292,746-750.

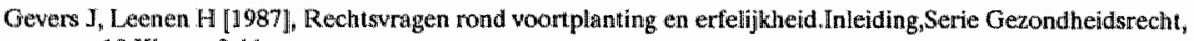
19, Kluwer, 9 -11.

Gezondheidsraad [1984], Interim-advies inzake in vitro fertilisatie, Den Hag,no. 33. 
Gezondheidsraad [1986], Advies inzake kunstmatige voortplanting, Den Hagg,no. 26.

Gianaroli L, et al [1984], The Diagnostic Value of in-Vitro Fertilization and Embryo Thransfer, Acta Eur.Fert. $15,4,249-252$.

Gidley-Baird $A$, et al [1986], Failure of implantation in human in vitro fertilization and embryo transfer patients: the effects of altered progesterone/estrogen ratios in thunans and mice, Fertil.Steril., $45,1,69-74$.

Gindoff P. Jeweliwicz R [1986], Reproductive potential in the older woman, Fertill.Steril, 46,6,989-1001.

Glass R, Ericsson $\mathbb{R}$ [1979], Spontaneous cure of male infertility, Fertil.Steril $, 31,3,305-308$.

Golan A, et al [1989], Ovarian hyperstimulation syndrome in D-TRP6-RH-LH/hMG induction of owulation. for: IVF/ET. Abstracts VI wereldkongres van IVF, Jeruzatem, 56.

Gomel V [1977], Laparoscopy Prior to Reconstructive Tubal Surgery for Infertility, J.Reprod.Med, $18,5,251-253$.

Gomel V, Swolin K [1980a], Salpingostomy: microsurgical teclinique and results, Clin.Obst.Gynecol., $23,4,1243-1258$.

Gomel V [1980b], Classification of operations for tubal and peritoneal factors causing infertility, Clin.Obstel. Gynecol., 23,4,1259-1260.

Gomel V [1983a], An odyssey through the oviduct, Fertil.Steril .39,144.

Gomel V [1.983b], Salpingo-ovariolysis by laparoscopy in infertility, Fertil.Steril.,40,5,607-611.

Gomel $V$ [1983c], Surgical correction of Sequela of Pelvic Inflammatiory Disease, J.Reprod.Med ,28,10, 718-726.

Gosden $\mathbb{R}$ [1985], Maternal Age: A Major Factor Affecting the Prospects and Outcome of Pregnancy, Ann.NY.Acad. Sciences,442,45-57.

Gronow M, et al [1985], Aspects of Multiple Embryo Transfer, Ann NY.Acad.Sci.,442,381-386.

Guxick D, et al [1986a], A parametric method for comparing cumulative pregnancy curves following infertility therapy, Fertil.Steril.,37,4,503-507.

Guzick $D$, et al [1986b], Cumulative pregnancy rates for in vitro fertilization, Fertil.Steril.,46,4,663-667.

Haan G, Rutten F [1987], Economic appraisal, health service planning, and budgettary management for health technologies, In: Drummond $M$ (ed.): Economic Appratsal of Health Technology in the European Community. Oxford University Press, Oxford,135-146.

Haan $G$, et al [1989a], Evaluatie van in-vitro-fertilisatie. Rijksuniversiteit Limburg, Maastrtcht.

Haan $G$, Rutten $F[1989 b]$, IVF in Nederland na het evaluatie-onderzoek; beleicssimplikaties ell beleids komplikaties. Ned.Tijds. Obst.Gyn.(geaksepteerd).

Hall E van [1986], Over manipulatie wan de menselijke woortplanting, Medisch Contact,41,46,1479-1482.

Hamilton $C$, et al [1986], Ovulatory disorders and inflammatory adnexal damage: anglected cause of the failure of fertility microsurgery. Brit.J.Obst,Gyn, $93,282-$.

Haney A, et al [1987a], Treatment-independent, ireatment-associated, and pregnancies after additional therapy in a program of in vitro fertilization and embryo transfer, Fertil.Steril, $47,4,634-638$.

Haney A [1987b], What is efficacious infertility therapy?, Fertil.Steril.48,543-545. 


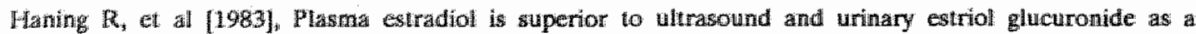
predichor of owarian hyperstimulation during induction of owalation with menotropins, Fertil. siterill $, 40,1,37-36$.

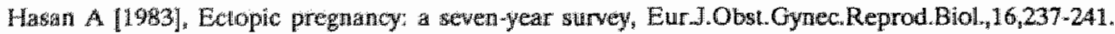

Haspels A [1986]. In witro fertlisatie: anele ethische problemen, Medisch Contact,41,23,726-727.

Hedon $B$, e al [1983], In vituo fertilization and microsurgery, Acta Eur.Fer, 14,1,17-22.

Henry-Suchet J, al [1981], Chamydia Trachomats associated with chronic inflammation in abalominal pecimens irom women selected for tuboplasty, Fertil. Steril.,36,5,599-605.

Henry-Suchet J, al [1984], Propnostic Value of Tuboscopy ws. Hysterosalpingography before Tuboplasty, J.Reprod.Med.,29,8,609-612.

Herid $M_{\text {, ef }}$ al [1988], Administration of nasal nafarelin as compared with oral danazol for endometriosis, New Eingl. I. Med. $318,8,483-4,489$.

Herwierden $M$ wan [1905], Bijdrage tot de kennis van menstruele cyclus en puerperium, Dissertatie, Utrecht.

Hewitt $J_{n}$ at [1985], Treatment of idiopathic infertility cervical mucus hostility, and male infertility: artificial irrsemination with husband's semen or in vitro fertilization, Fertil.Steril.,44,3,350.355.

Hirsch $M$, Mosher $W\lceil 1987\rceil$, Characteristics of infertile women in the United States and their use of infertility serwices, Fertil.Steril.,47,4,618-625.

Hodgen $\mathrm{G} \| 1986 \rrbracket$, Ovarian Function for Multiple Follicle Maturation, Clin.Obst.Gynec, 29,1,127-140.

Howe R, et al [1988], Jelvic infection after transvaginal wiltrasound-guided ovum retrieval. Fertil. Steril ,49,4, $7260722 \%$.

Howles $\mathrm{C}_{n}$ et al [1988], Progesterone supplementation in the late follicular phase of an in-vitro fertilization cycle: a "matural" way to time oocyte recovery?, Hum Reprod, $3,4,409-412$

Huang $K_{\text {, }}$ et al [1987], The outcome of continued treatment of luteinizing hormone-surged cycles in in witro fertilization with the use of human menopausal gonadotropin, Fertil.Steril,47,5,816-820.

Hulka J, al [1978], Classification of adnexal adhesions: a proposal and evaluation of its progmostic value, Fertil.Steril.,30,6,661-665.

Wulka I [1982], Adneval adhesions: A prognostic staging and classification system based on a fiveyear survey of fertility sturgery tresilts Chapel Hill, North Caroling, Am.J.Obst.Gynec.,144,2,141-148.

Hull Mts, et al [1986] "Correligtion of senum estradiol levels and ultrasound monitoring to assess follicular maturation, Fertil. Steril $, 46,1,42-45$.

Hull $\mathrm{MG}_{1}$ Glawener $\mathrm{C}$ [1984a], Malie infertility and in-vitro-fertilisation, The Lancet,231.

Hull $\mathrm{MO}^{3}$ er al [1984b], Human in-witro fertilisation, in cases viwo sperm penetration of cervical mucus, and unexplained infertility, The Lancet, $245-246$.

Hull $\mathrm{MG}_{0}$ Glazener $\mathrm{C}\lceil 1984 \mathrm{c}\rfloor$, In-vitro fertilisation, The Lamot, 808.

Hull $\mathrm{MG}_{\mathrm{r}}$ et al [1985], Population study of causes, treatment, and outcome of infertility, Brit.Med.Journ.291, 1.693-1697.

Ismajovich $B_{1}$ et al $1986 \%$, The accuracy of hystersalpingography versus laparoscopy in evaluation of infertile women., Int . vourn.Gymaec. Obst.,24,9-12.

Jansen $\mathrm{C}_{3}$ et al [1986], In-vitro fertilisation and embryo-transfer whth transport of oocytes, "The Lancet, 676. 

Jansen P [1982], Spontaneous abortion incidence in the treatment of intertility, AmJ.Otst.Gynec, 143,4 ,
$451-473$.

Janssen-Caspers $H$, et al [1988], Utrasonically guided percutaneous and transwaginal follicle aspiration; a comparative study, Hum. Reprod, 3,3,337-339.

Jarrell $J_{n}$ et al [986], An in vitro fertilization and embryo transfer pilot study: Treatment-dependent and treatment- independent pregnancies, Am.J.Obst.Gynec., 154,2,231-235.

Johnston I, ef al [1981], Preoperatiwe Assessment for Tubal Surgery and in vitro Fertilization, Aust.NZJ]. Obst.Gynaec, 21,153-155.

Johnston J [1972], Econometric methods, McGraw-Hill,New York.

Johnston W, et a! [1985], Patient Selection for in Vitro Fertilization: Physical and Psychological Aspects, Ann.NY. Acad.Sci, 442,490-503.

Johnston W [1987], The place of GIFT in treatment of the infertile patient, Presentatie se wereldkongres van In Vitro Fertilisatie en Embryotransfer, Norfolk.

Jones $G_{n}$ et al [1986], The premenopausal patient in in vitro fertilization: the use of gonadotropin-releasing hormone, Fertil.Steril, $46,5,885-891$.

Jones $\mathrm{H}$, et al [1983a], The importance of the follicular phase to success and failure in in vitro fertilization, Fertil.Steril., 40,3,317-321.

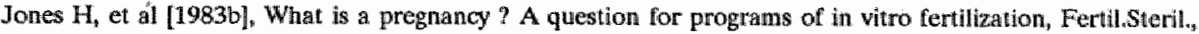
$40,6,728-733$.

Jones H, et al [1984], Three years of in witro fertilization at Norfolk, Fertil.Steril,42,6,826-834.

Jones H [1986a], In vitro fertilization: questions and answiers, Journ.Am.Med.Ass.,255,1,106.

Jones $H[1986 \mathrm{~b}]$. The impact of In Vitro Fertilization on the Practice of Gynecology and Obstetrics, Int.J.Fertil., 31,2, 99-111.

Jones H, Schrader C [1987], The process of human fertilization: implications for moral status, Fertil.Steril., $48,2,189-192$.

Katayama $P$, et al [1979], Computer analysis of etiology and pregnancy rate in 636 cases of primary infertility, Am.J.Obst. Gynec, $135,2,207-214$.

Kelsey $J_{\text {, el al }}$ [1986], Methods in obserwational epidemiology, Oxford Univensily Press, New York.

Kerin $J_{\text {" }}$ et al [1984], Improved conception rate after intratterine insemination of washed spermatozon from men with poor quality semen, The Lancet, $533-535$.

Kerin J, Warnes G [1986], Monitoring of Ovarian Response to Stimulation in In-Vitro Fertilization Cycles, Clin.Obst.Gynec., 29,1,158-170.

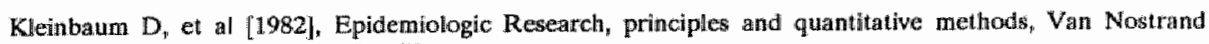
Reinhold Comprany, New York.

Kloosterman G (red.) [1977], De voortplanting van de mens. Leerboek voor obstetrie en gynaecologie, Centen, Haarlem.

Kreiner D, et al [1987], Follicular fluid estradiol and progesterone are markers of preovulatory oocyte quality, Fertil. Steril.,48,6,991-994. 


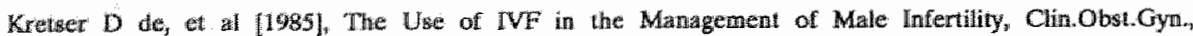
$12,4,767-773$.

Knuger T, at al $[1986]$ : Sperm morphologic features as a prognostic factor in in witro fertilization, Fertil. Steril $10,46,1118 \times 1123$.

Kruger $T$, al [1988], Predicive value of abnornal sperm morphology in in vitro fertilization, Fertil.Steril., $49,1,112,117$.

LMM (Landehjke Medische Registratie) [1988], LMR Jaarbok 1986, Stichting Intormatiecentrum voor de Genondheidsworg, Wrecht.

Lam S, et all [1987], Outcome of Patients with One Owary in an in Vüro Fiertilization Program, J.IVF/ET,4,6, $319-323$

Luncister P [1985], Obstetrue Outcome, Clin. Obst. Gyn.,12,4,847-864.

Laprec $\mathrm{R}$ [1987], "Technology assessment: op macro-miveau: besluitvorming mel betrekking tot in vitro fertilisatic; Medisch Contact,42,1.5,459-461.

Larwson B [1982], Late results of salpingostomy combined with salpingolysis and owariolysis by electromicro. surgery in 54 women, Fertill Sterill, 37,2,156-160,

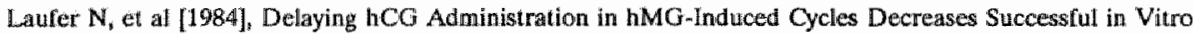
Fiartilization of Human Oocyltes, Fertil.Steril $, 41,2,53 \mathrm{~S}$.

Lawfer $\mathbb{N}_{\text {, }}$ et $[1986$ ], The association between preomulatory serum 17 B-estradiol pattern and conception in human menopausal gonadotropin human chorionic gonadotropin stimulation, Fertil.Steril.,46,1, $73-76$.

Lavy $G$, et al [1987], Ectopic pregnancy: its relationship to tubal reconstructive surgery, Fertil.Steril.,47,4, 5.43-556.

Lee Ch [1987], Luteal Phase Defects, Obst.Gynec.Survey,42,5,267-274.

Lee $\nabla[1986]$, An Insight on the Use of Multiple Logistic Regression Analysis to Fistimate Association between Risk Factor and Disease Occurence, Int.J.Epid.,15,1,22-29.

Leenen II [1987], De gezondheidsrechtelijke status van het embryo, Gevers $J$, Leenen $H$ (red.), Rechtsvragen

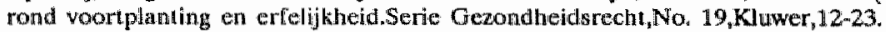

Leerentveld $\mathrm{R}$, al [1987], Monitoring of clomiphene citrate stimulation by means of plasma 178-oestradiol determinations and ulmasonographic follicle measurements in in-vitro fertilization cycles, Human Reprod. $2,3,187-190$.

Leerentweld $\mathrm{R}$ [1988], Ultrasound and plasme 17B-oestradiol in the follicular phase - particularly in IVF cycles, Dissertatie, pamans, Den Hagg.

Leeton J, et 41 [1983], In vitro fertilization and embryo-transfer, the Monash group experiences 1981-1983, Acta Eur: Fert., $14,2,95-100$.

Leeton $J_{\text {, at al }}$ [1985], Support of the luteal phase in In Vitro Fertilization programs: results of a controlled trigl with intramuscular prollution, J.IVF/ET,2,166-169.

Leeton J, al a1987], A controlled study between the use of gamete intrafallopian transfer (GIFI) and in vitro fertilization and embryo transfer in the managenent of idiopathic and male infertility, Fertil.Sterill $48,605-607$.

Leiblum $\mathrm{S}$, et all [1987], Unsuccessful in vitro fertilization : A follow-up study, J.IVF/E T, 4, 1,46-50. 
Lejeune $B_{n}$ et all [1986], in Vitro fertilization and embryo transler as related to endogenous tuteinining hormone rise or human chorionic gonadotropin adminisiration, Fentil.sterit. $45_{8} 3,377-383$.

Lemeshow S, Hosmer D [1982]. A rewew of goodness of tut statistic for wise in the devellopment of logitstic regression models, AmJ.Epid.,115,1,92-107.

Lenton $E_{0}$ et al [1977], Long-term follow-up of the apparently nornal couple with a complaint of infertility" Fertil. Steril., 28,9,913-919.

Lenz $S$, et al [1981], Collection of human oocytes for in witro fertilisation by ultrasonically guided follicular puncture, The Lancet, 1163-1164.

Lent S, Lauritsen I [1982], Ultrasonically guided pereutaneous aspiration of human folltcles under local

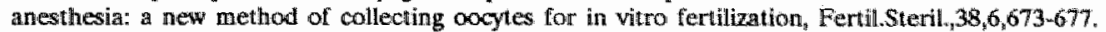

Lenz S [1984a], Ultrasonically guided aspiration of human aocytes, Wilrasound in Med.28 Biol, 10,5,625-628.

Lenz S [1984b], Ultrasonjc-Guided Follicle Puncture Under Local Anesthesia, J.IVF/ET,1,4,239-243.

Leridon H, Spira A [1984.j. Problens in measuring the effectiveness of infertility therapy, Fertil. Steril, 41,4 , $580-586$.

Levinson C, Marlow J [1980], Evaluation of patients for microsurgery, Clin, Obst. Gynec, 23,4,1195-1200.

Lewran $D$, et al [1985], Analysis of the outcome of in vitro fertilization in relation to the timing of human. chorionic gonadotropin administration by the duration of extradiol rise in stimulated gycles, Fertiü.Steril $, 44,3,335-341$.

Lewin A, et al [1985], Comparative study of ultrasonically guided percutaneous aspiration with local anesthesia and laparoscopic aspiration of follicles in an in vitro fertilization program, A.m.J.Obst. Gynec, $151,5,621-625$.

Lewin $A$, et all [1986], Ultrasonically guided oocyte collection under local anesthesia: the first choice method for in witro fertilization - a comparative sturly with laparoscopy, Fertil.Steril, $46,2,257-261$.

Limpens P [1986], Kostenonderzoek op het klinisch-chemisch laboratorium, Academisch Ziekenthuis Maastricht. Doktoraalskriptie Katholieke Hogeschool Tilburg.

Lopata A [1983], Concepts in human in vitro fertilization and embryo transfer, Fertil.Steril.,40,289.

Laber $K_{\text {, }}$ ef al [1986]. Results of microsurgical treatment of tuball infertility and early second wook laparoscopy in the post-petvic inflammatory disease patient: Implications for in vitro fertilization, Am.J.Obstet. Gynacol., 154,6, 1264-1270.

Maathuis $J_{\text {, }}$ et al $[1972 \rrbracket$. A comparison of the results of hysterosalpingography and laparowopy in the diagnosis of fallopian tube dystunction, Fertil.Steril, $23,6,428-431$.

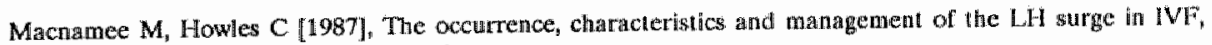
Human Reprod., 2(suppl.1), 46.

Maddala G [1983], Limited-dependent and qualitative variables in econometrics, Cambridge University Press, $79-91$.

Mage G, Bruhat M [1983], Pregnancy following salpingostomy: comparison between CO2 laser and electro. surgery procedures, Fertil.Steril., $40,4,472-475$.

Mage $G$, et al [1986], A preoperative classification to predict the intraulerine and pregnancy rates after distall tubal microsurgery, Fertil.Steril $, 46,5,807-810$. 


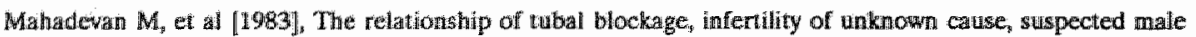
infertility, and endometiosis to success of in vitro fentilization and embryo transfer. Fertil.Steril.,40,6, $755-762$

Mahadevan $M_{s}$ Trounson A [1984], The influence of seminal characteristics on the success rate of human in witro fertilization, Fertil steril, $42,400-405$.

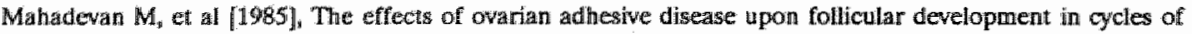
controlled stimulation for in vitro fertilization, Fertil. Steril.44,4,489-492.

Mahadevan M, ef al [1987], Effect of Oocyte Quality and Sperm Characieristics on the Number of Spermaltozoa Bound to the Zona Pellucida of Human Oogles Inseminated in Vitro, J.IVT/ET,4,4, $223-22 \pi$.

Malestein A wan [1986], In witro fertllisatie in het ziekenfondspakket, Medisch Contact,41,23,722-724.

Mandelbaum S, et al [1987], Relationship of antispern antibodies to oocyte fertilization in in witro fertilization-embryo eransfer, Fertil.Steril., $47,4,644-651$.

Mandelbaum J, et al [1988], Cryopreservation of human embryos and oocytes, Hum.Reprod.,3,1,117-119.

Marrs $\mathrm{R}$, et al [1984], Effect of variation of in vitro culture thechniques upon oocyte fertilization and embryo dewelopment in human ün vittro fertilization procedures, Fertil.Steril.,41,4,519-523.

Marrs R [1986a], Laboratory Conditions for Human in-Vitro Fertilization Procedures, Clin.Obst.Gynec $29,1,180-189$.

Marrs $R$ [1986b], Does the method of oocyte collection have a major influence on in vitro fertilization, Fitilisteril $*$ 46,2,193-195.

Martinez F, Trounson A [1986], An analysis of factors associated with ectopic pregnancy in a human in vitro fertilization program, Fertil.Steril.,45,1,79-87.

Matson Ph, et al [1987], The in vitro fertillzation of supermumerary oocytes in a gamete intrafallopian transfer program, Fertil.Steril f $_{4} 47,5,802 \backsim 806$.

McCardle C, et al [1983], The diagnosis of ovarian hyperstimulation (OHS): the impact of ultrasound. Fertil. Steril., 39,4,464, 467 .

Mccomb P, Delbeke [. [1984], Decreasing the number of owulations in the rabbit with surgical division of the blood vessels between the fallopian tube and ovary, Jowm.Reprod.Med, $29,827$.

McComb P [1986], The determinants of sucessful surgery for proximal tubal disease, Fertil Steril.,46,6, $1002 \cdot 1004$.

MoGaughey $R$, al [1987], Correlation of estrogen lewels with oocytes aspirated and with pregnancy in a program of climicall tubal transfer, Fertil.Steril., $48,98-106$.

Mclntosh $y_{1}$ et al [1980], Predicting the luteinizing hormone surge: Relationship between the duration of the Collicular and luteal phases and the length of the human menstrual cycle, Fertill,Steril, 34,2,125-130.

Medical Researeh International [1988], In vitro fertilization/embryo transfer in the United States: 1985 and 1986 results from the Natjonal IVIF/ET Registry, Fertill.Steril.,49,2,212-215.

Medical Research Intermational [1989], In vitro fertilization/embryo transfer in the United States: 1987 results fron the National IVF/ET Registry, Fertil.Steril.51,1,13-18.

Mettler L, Michelmam H [1987], Estradiol Values Under Gonadotropin Stimulation in Relation to the Outcome of Pregnancies in in Vitro Fertilization and Embryo Transfer, J,IVF/ET,4,6,303-306. 


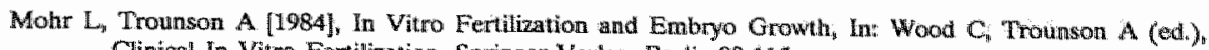
Clinical In Vitro Fertilization, Sprimger-Verlag, Berlin $99-115$.

Mohr L, Trounson A [1985], Cryopreservation of Human Embryos, Anng NY.Acad,Sci,4,4, 2,537-543.

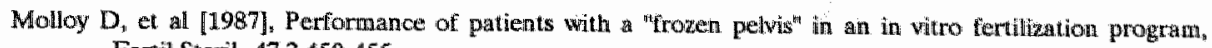
Fertill Steril. $47,3,450-455$.

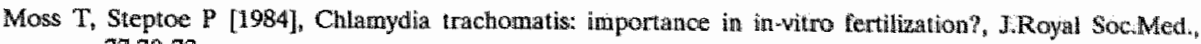
$77,70-72$.

Mouzon J de [1987], French experience and results of a aational collaborative prospective data recording system on IVF.ET, Presentatie Se wereldcongres van In Vitro Fertilisatie en Enz layotransfer, Norfolk.

Muasher $S_{1}$ et al [1984a], The value of Peripheral Estradiol and Progesterone in the Luteal Phase to the Succcess and Falure of in Vitro Fertilization and Embryo Transfer in hMG/hCG-Stimulated Normal Menstrual Cycles, Fertil.Steril $\mathrm{s}, 4,2,16 \mathrm{~s}$.

Muasher S, et al [1984b], Bienefits and risks of multiple transfer with in vitro fertilisation, The Lancet,570.

Mushin D, et at [1985], Children of IVF, Clin,Obst,Gyn, 12,4,865-876.

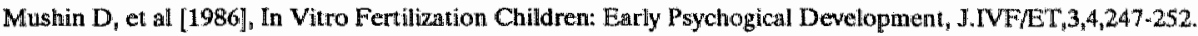

Mygatt $G$, et al [1982], In vitro tertilization rates after varicocele repair, J.Urology, 127, 1103-1104.

NPSU (National Perinatal Statistics Unit Fertility Society of Australia) [1985】, In vitro fertilization pregnancies Australia and New Zealand 1979-1984, NationaL Perinatal Statistics Unit,Sydney"ISSN 0816-6889.

Naaktgeboren $N$, et al [1985], Success of in vitro fertilization ard embryo transfer in relation to the cause of infertility, Acta Eur.Fert., $16,4,281-287$.

Nader $S_{4}$ et al [1987], Pattems of fncrease in Serum Estradiol in Response to Ovarian Stimulation and Their Relationship to Oocyte Fertilization and Cleavage in Vitro, J.IVT/ET,4,6,307-311.

Nagamani M, ef al [1984], Gynecology; Factors influencing fertility arter atopic pregnancy, Am. J. Obst. Gynac, $149,5,533-534$.

Navot $\mathrm{D}$, et al [1987], Periovulatory 17B-estradiol pattern in conceptional and nonconceptional cyctes during menotropin treatment of anovulatory infertility, Fertill.Steril, $47,2,234-237$.

Nishimura $\mathrm{H}_{\mathrm{s}}$ Shikata $\mathrm{A}[1960]$. High embryonic mortality of the mouse fetuses from the elderly primigravid mothers, Okjjimas Folia Anat. ipn. 36,15:1-154.

Norusis M [1985], sPSS $X$ advanced statistics guide, McGraw-hill Book Company, New York.

Notzon F, et al [1987], Comparisons of National Cesarean-Section Rates, Obstet Gynecol.Survey,42,8,506-508.

O"Brien $B_{4}$ et al [1983], Microsurgical repair of the fallopian lubes, Royal Austr.Conlsurgeons, $161-167$.

O'Brien P [1984], Procedures for Comparing Samples with Multiple Endpoints, Biometr.40,1079-1087.

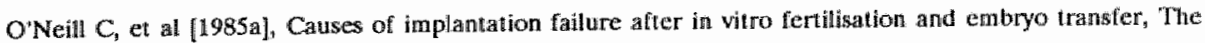
Lancel, 615 .

O'Niell C, et al [1985b], Matemal Recognation of Pregnancy prior to Implantation: Methods for Monitoring Enbryonic Variability in Vitro and in Vivo, Ann. NY.Acad Sciences, 442,429-439.

O'Neill C, Saunders D [1986], Assessment of embryo quality, "The Lancet,1035. 
o'shed $\mathbb{R}$, et al [1985], Endometriosis and in-witro fertilisation, The Lancet,723.

Otubo J, Winsion R [1984], Ovarian Function After Salpongostomy in Mechanucally Induced Hydrosalpinges in Fabbits Fertil.Steril, $41,2,11 \mathrm{~S}$.

Owerbeeke $\mathrm{O}$ van, Witte I de [1988], Reageerbuisbevruchting in Nederland; aspecten van in vitro fertilisatie; vi-uilgeverij, Ansterdam.

Patetson P [1984]; Indications for the Treatment of Tubal Infertility Patients by Microsurgery or in Vitro Fiertilization, Aust.NZJ.Obst.Gynec, 24,262-264.

Paterson P [1985], Factors Influencing the Success of Microsurgical Tuboplasty for Sterilization Reversal, Obstet.Gynecol, Survey,64-65.

Paterson P, Chan C [1987], What Proportion of Couples Undergoing Unrestricted In Vitro Fertilization Treatments Can Expect to Bear a Child?, J.IVF/ET,4,6,334-337.

Patton G [1982], Pregnancy outcome following microsurgical fimbrioplasty, Fertil.Steril.,37,2,150-155.

Patton Ph, et all [1987], Microsurgical reconstruction of the proximal oviduct, Fertil.Steril.,47,1,35-39.

Pation Ph, al al [1988], The use of oral contraceptives to regulate oocyte retriewall, Fertil.Steril.,49,4,716-718.

Peelers M, et al [1988], Chlamydia trachomatis, Infertiliteit en In Vitro Fertilisatie, Ned.Tijds.Geneesk., $132,31,1438-1441$.

Pellicer $A_{\text {, }}$ et al [1987], Outcome of in vitro fertilization in women with low response to ovarian stimulation, Fertill.Steril., 47,5,812-815.

Pepperell R, McBain J [1985], Unexplained infertility: a review, Brit.J.Obst.Gynaec.,92,569.580.

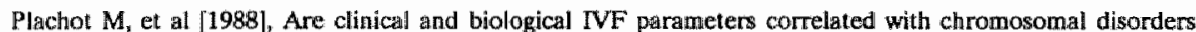
in early life: a multicentric study, Hum.Reprod, 3,4,627-635.

Poindexter A, Doody K [1985], Advances in Human In Vitro Fertilization and Embryo Transfer, Seminars in Reprod. Endocr.,3,2,201-210.

Pollisar L, et al [1982], Regression Analysis in Health Services Research: The Use of Dummy Variables, Med.Care, 20,9,959-966.

Pring D, et all [1986], Pregnancy after perurethral transvesical cocyte recovery and in-vitro fertilisation, "The Lancelt, 1395-1396.

Pryor $J_{\mathrm{b}}$ et al [1984], In-vitro fertilisation for men with obstructive azoöspermia, The Lancet,762.

Quigley $M$, ef al [1985], Timing human chorionic gonadotropin administration by days of estradiol rise, Fertil,Steril., 44,6,791-795.

Quigley $M_{2}$ et al [1987], Simultaneous in vitro fertilization and gamete intrafallopian transfer (GIFT), Fertil.Steril., 47,5,7974801.

Rachootin P, Olsen J [1981], Social selection in seeking medical care for reduced fecundity among women in Denmark, J.Epid.Comm.Health,35,262-264.

Rainhorn J, et al [1987], One year's experience with programmed cocyle netrieval for IVF, Hum.Reprod,2,6, $491-494$.

Randolph J, et al [1986], Comparison of real-time ultrasonography hysterosalpingography, and laparoscopy/ hysteroscopy in the evaluation of uterime abnormalities and tubal patency, Fertil.Steril-4,6,5,892-896.

Ranoux C, et al [1988a], Human Egg Fertilization in Capillary Tubes, J.IVF/ET, 5, 1,49-50. 
Ranoux C, et al [19880]. A new in vitro fertilization technique: intravaginal culture, Fertilsteril,49,654657.

Reinthaller A, et al [1986], Factors influencing successful in witro fertilization and embryo transfer, a matched pair study, Fentil.Steril., $46,3,511-513$.

Rock J, et al [1978], Factors Infuencing the Success of Salpingostony Techniques for Distal Finbrial Obstruction, Obst.Gynec, $52,5,591-596$.

Rogers B, et al [1983], Sperm morphology assessment as an indicator of human fertifizing capacity, Journal Androl, 4,119.

Rogers $P$, et al [1986], Cross-over trial of superowulation protocols from two major in vitro fertilization centers, Fertil.Steril., $46,3,424,431$.

Roh 8 , et all [1987], In vitro fertilization and embryo transfer: treatment-dependent versus *independent pregnancies, Fertil.Steril.48,6,982-986.

Romeu A, et al [1987], Results of in vitro fertilization attemps in women 40 years of age and older: the: Norfolk experience, Fertil.Steril.,47,1,130-136.

Rompelman D [1987], De vastgoedmarkt in 1986/1987, Tijds. VastGoedMarkt,1,30 jan.

Ross L. [1983], Diagnosis and treatment of infertile men: a clinical perspective, J.Urology ,130,847-854,

Rousseau $S$, et al [1983], The expectancy of pregnancy for "normal" infertite couples, Fertil.Steril, 40,6 , $768-772$.

Rowland $G$, et al [1984], Selection of infertile men for in-vitro fertilisation, The Lanoet,1150-1151.

Rutherford A, et al [1988], Improwement of in witro fertilisation after treatment with buserelin, an agonist of juteinising hormone releasing thormone, Brit.Med.Journ.,296,1765-1768.

Salat-Baroux $J_{k}$ et al [1984], Study of the Luteal Phase After Ovulation and in Vitro Fertilization, Fertil. Steril., $41,2,16 \mathrm{~S}$.

Sarrel $\mathrm{Ph}$, DeCherncy A [1985], Psychotherapeutic intervention for treatment of couples with secundary infertility, Fertil. Steril.,43,897-900.

Schachter J, Shafer M [1985], Female Adolescents With Chlamydia. 'Tomorrow's Candidates for in Vitro Fertilization, West.J.Med.,143,1,100-101.

Schellekens W [1986], In vitro fertilisalie (nog) niet in het ziekenfondspakket, Medisch Contaci,41,31,991-993,

Schellekens. W, v.d.Steur J [1989], In vitro ferillisatie: in het zickenfondspakket? in het basispakket? Verslag wan de discussies binnen de Ziekenfondsraad. Medisch Contact,44,15,499-501.

Schlesselman J [1979], How does one assess the risk of abnormalities from human in witro fertilixation?, Am.J. Obst, Gynecol.,135-148.

Scholten M [1982], Kostprijsberekening in een klinisch-chemisch laboratorium, Katholieke Hogeschool Titburg.

Schoysman R [1984], Tubal microsurgery versus in vitro fertilization, Acta Eur.Fert, 15; 1,5-13.

Schulman J, et all [1985], Genetic aspects of in Vitro Fertilization, Ann.NY.Acad.Sci,442,466-475.

Sellors J, et al [1988], Tubal factor infertility: an association with prior chlamydial infection and asympiomatic salpingitis, Fertil.Steril.,49,3,451-457. 
Sepptata M [1985], The World Collaborative Report on in Vitro Fertizalition and Embryo Replacement: Current Stale of The Art in January 1984, Amn. NY.Acad.Sci.,442,558-563.

Shatma $W_{n}$ et al [1988], An analysis of factors influencing the establishment of a clinical pregnancy in an ultrasound-based ambulatory in vifro fertilization program, Fertil.Steril.,49,3,468-478.

Sher $G_{n}$ et al [1984], In vitro sperm capacitation and transcervical intrauterine insemination for the treatment of refractory infertility: Phase 1, Fertil.Steril, $41,2,260-264$.

Sher $G$, et al [1986], In Vitro Fertilization and Embryo Transfer: Two-Year Experience, Obst.Gynec., $67,3,309-315$

Siegler A [1977], Surgical treatments for tutboperitoneal causes of infertility since 1967, Fertil.Steril., $28,10,1019-1032$

Siegler A [1982], Replacement, repair, and removal of fallopian-tubes, Fertil.Steril.,37,5,611-612

Smith $B_{n}$ et al [1984], Ultrasonic Assessment of Endometrial Changes in Stimulated Cycles in an in Vitro Fertilization and EmbryoTransfer Program, J.IVF/ET,1,4,233-238.

Smith $E_{1}$ et al [1989], Does hCG luteal phase support improve the outcome of TVF in patients hyperstimulated with buserelin and $\mathrm{hMG}$. Abstracts VI wereldkongres van IVF, Jeruzalem, 79.

Soules. M [1985], The in vitro fentilization pregnancy rate: let's be honest with one another, Fertil.Steril., $43,4,511-513$.

Sournia J [1982】, Etude economique de lat fecondation in vitro, Bull.Acad.Nat.Med.,166,7,983-986.

Speirs A, et al [1983], Analysis of the benefits and risks of multiple embryo transfer ${ }_{n}$ Fertil.Steril, $39,4,468-471$.

Spivak $M_{i}$ et al [1986], Microsurgical reversal of sterilization, A six-year study, Am.J.Obst.Gynec, 154,2, $355-361$.

Steirteghem A van, et al [1987], Cryopreservation of human embryos obtained after gamete intra-Fallopian transfer and/or in-vitro fertilization, Hum.Reprod.,2,7,593-598.

Steirteghem A van, et al [1988], The luteal phase after in vitro fertilization and related procedures, Hum Reprod, 3,2, 161-164.

Steptoe P, Webster J [1985a], Laparoscopy for Oocyte Recovery, Ann.NY.Acad.Sci. 442,178-181.

Steptoe P [1985b], The Selection of Couples tor in Vitro Fertilization and Embryo Replacement, Ann.NY. Acad $.5 c i, 442,487-489$.

Steur J wd [1986], Gezondheidszorg bij beperkte middelen: samenwerking gewenst, Medisch Contact,41,24, 757.758 .

Stuckey $B$, et al [1987] , Continuous gonadotropin-releasing hormone for ovulation induction in polycystic disease, Fertil.Sterill,48,6,1055-1057.

Sueldo C, Montoro L [1988], In Vitro Fertilization: Simple or Complex?, J.IVF/ET, 5,1,1-2.

Talbert $\mathrm{L}_{x}$ et al [1987], Semen parameters and fertilization of human oocytes in vitro" a multivariable analysis, Fertil.Steril., 48,2,270-277.

Talbert $\mathbb{1}$, [1988], Endogenous luteinizing hormone surge and superovulation, Fertil.Steril.,49,1,24-25.

Taylor $P$, et al [1986], "Ultrasound reseue": A successful alternative form of oocyte recovery in patients with periovarian adhesions, Am.J.Obst.Gynec.,154,2,240-244. 
Tejada R [1986], Semantic Used in the Nomenclature of In Vitro Fertilization or Lets's All Be More Proper, J.INF/ET, 3,6,341-342.

Tesarik $J$, et al [1983], Oocyte recowery, in vitro insemination, and transfer into the owiduct after its microsurgical repair at a single laparotomy, Fertil.Steril, $39,4,472,-475$.

Testart $J_{\text {, et al }}[1986 a$ ], Relationships between embryo transfier results and ovarian response and in witro fertilization rate: analysis of 186 human pragnancies, Fertil.Steril.,45,2,237-243.

Testart $\mathrm{J}_{\mathrm{s}}$ et al [19866], High pregnancy rate after early human embryo freezing, Fertil.Steril.,46,2,268-272.

"Testart J [1987a], Evidence of uterine inadequacy to egg implantation in stimulated in vitro fertilization cycles, Fertil.Steril., 47,5,855-857.

Testart J, et al [1987b], Factors influencing the success rate of human embryo freezing in an in vitro fertilization and embryo transfor program, Fertil.Steril,40,1,107-112.

Testar I [1988], Results of in vitro fertilization with embryo cryopreservation and a recommendation for uniform reporting, Fertil.Sterill, $49,1,156-158$.

Tietze C [1956], Statistical contributions to the study of human fertility, Fertil.Steril.,7,88-95.

Tjiam K, et al [1985], Prevalence of antibodies to Chlamydia trachomatis, Neisseria gonornoeae, and Mycoplasma hominis in infertile women, Genitourin Med,61,175-178.

Toffle $\mathbb{R}$, et al [1985], Intrauterine insemination: the Univerty of Minnesota experience, Fertil.Steril.y $43,5,743-747$.

Trimbos-Kemper T, et al [1985], Adhesion formation after tubal surgery: results of eight-day-laparoscopy in 188 patients, Fertil.Steril.,43,395.

Trotnow $S$, et al [1983], Bilateral Tubal Pregnancy Following in vitro Fertilization and Embryo Transfer, Arch.Gynecol. 234,75-78.

Trounson A, Wood C [1981], Extraoorporeal Fertilization and Embryo Transfer, Clin.Obst.Gynaec., $8,3,681-713$.

Trounson A, et al [1982], Effect of delayed insemination on in vitro fertilization, culture and transfer of human embryos, Joum.Reprod.Fertil,,64,285.

Trounson A, et al [1983], Pregnancy established in an infertile palient after translier of a donated embryo fertilised in vitro, Brit.Med.J. $.2866,835-838$.

Trounson A, Wood C [1984a], In Vitro Fertilization Resuits, 1979-1982, at Monash University, Queen Vicioria, and Epworth Medical Centres, J.IVF/ET,11,1,42-47.

Trounson A [1984b], In vitro fertilization. Problems of the future, Dr.J.Hosp.Med.,104-110.

Trounson A, Webb ] [1984c], Fertilization of human oocytes following reinsemination in vitro, Fertil.Steril., $41,6,816-819$.

Trounson A, Freemann L [1985], The Use of Embryo Cryopreservation in Human IVF Programmes, Clin. Obst.Gyn., 12,4,825-833.

Trounson A, et all [1986a], The effect of progesterone supplementation around the time of oocyte recovery in patients superovulated for in vitro fertllization, Fertil.Sterill,45,4,532-535.

Trounson A [1986b], Preservation of human eggs and embryos, Fiertil.Steril.,46,1,1-12.

Trounson A [1986c], The need for Appropriate Controls in Studies on Human in Vitro Fertilization, J.IVFFET, 3,4, 258. 


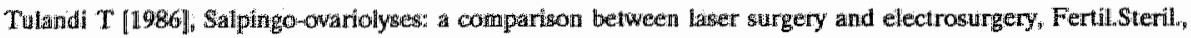
$45,4,499-491$.

Uem I van, et al [1985], Male factor evaluation in in witro fertilization: Norfolk experience, Fenil Steril. $44,3,375-383$.

Uep J van, et al [19860], Climical Aspects whithegard to the Occurence of an Endogenous Luteinizing Hornone surge in Gonadotropin-Induced Normal Menstrual Cycles, J.IVF/ET,3,6,345-349.

Vartyas I, et all [1982] Correlation of ultrasonic measuremenit of ovarian follicle size and serum estradiol levelg in ovulatory patients following clomiphene citrate for in vitro fertilization, Am.J.Obst.Gynec., 569.573 .

Vasiguex $\mathrm{G}$, et all $1985 \rrbracket$, Tubal mucosa and ectopic pregnancy, Br.J.Obst.Gynaec,90,468-474.

Veeck I, [1985], Extracorporeal Maturation: Norfolk 1984, Ann. NY.Acad.Sci.442,357-367.

Vekemans $M$, et al [1987], In-vitro fertilization with donor sperm after failure of artificial insemination, Human Reprod, 2,2,121-125.

Velde $\mathrm{E}$ te, et al $[1984]$, In vitro-bewruchting en embryotransplantatie van experiment tot behandelingsmethode bij infertiliteit, Ned.Tijds.Geneesk.,128,43,2039-2045.

Velde $\mathrm{E}$ te et al [1989a], The significance of preoperative hysterosalpingography and laparoscopy for predicting the pregnancy outoome in patients with a bilateral hydrosalpimx, Eur.J.Obst.Gyn.Reprod. Biol, (geaksepteerd).

Velde E te, et al [1989b], Intrauterine insemination of washed husband's spermatiozoa: a controlled study. Fertil.Sterill, $51,1,182-185$.

Velden W vd [1986], In vitro fertilisatie: Nederland loopt achter, Medisch Contact,41,23,724-726.

Verloove-Vanhoorick $S_{*}$ Verwey $R$ [1987], Project on preterm ans small for gestational age infants in the Netherlands 1983, Dissertatie. Oegstgeest.

Vilet $\mathbb{R}$ van, Van Doorslaer E [1988], Disaggregation of the demand for hospital care, Applied Economics,20, 969-984.

Wallach E, et al [1983], Experience with 143 cases of tubal surgery, Fertil.Steril.,39,5,609-617.

Walters L [1987], Ethical aspects of whe new reproductive technologies, Presented at fifth worldcongres IVF, Norfolk.

Wardie $\mathbb{P}$, ell al [1985], Endornetriosis and ovulatory disorder: reduced fertillisation in vitro compared with tubal and unexplaincel infertility, The Lancet, $236-239$.

Warnock M [1984], Report of the committee of inguiry into human fertilisation and embryology, London.

Weström L [1985], Influence of Sexually Transmitted Diseases on Siterility and Ectopic Pregnancy, Obstet. Gynecol. Surwey, $56-58$.

Whituaker $P$, et all [1983], Unsuspected pregnancy loss in thealthy women, The Lancet, 1126-27.

Wikland M, et al [1983], Collection of human oocytes by the use of somography, Fertil.Steril, $39,5,603-608$.

Wikland M, Hamberger L [1984], Ultrasound as a Diagnostic and operative Tool for in Vitro Foertilization and Embryo Replacement prograns, J.IVF/ET, 1,4,213-216.

Wiltbank $\mathrm{M}_{*}$ et al [1985], Treatment of Infertile Patient by Intrauterine Insemination of Washed Sperma* tozoa, Andrologia, 17,1,22,-30. 
Winston R [1980], Microsurgery of the fallopian tube: from fantasy to reality, Fertil.Steril.,34, $6,521-530$.

Winston R [1981], Progress in Tubal Surgery, Clin.Obst.Gynaec, $8,3,653-679$.

Winston R, Hillier S [1985], Embryo Quality and Pregnancy Rates in In-Vitro Fertilisation, Lancet, 283284.

Wol D, et al [1986], Undetected ovulation in in vitro fertilization-embryo transfer patients, Fertil.Sterill, $46,5,892-896$.

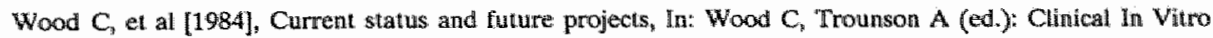
Fertilization. Springer Verlag, Berlijn,11-26.

Wood $C_{x}$ et al [1985a], Factors influemcing pregnancy rates following in vitro fertilization and ernbryo transfer, Fertil.Sterill., $43,2,245-250$.

Wood C, Trounson A [1985b], Current State and Future of NF, Clin.Obst.Gyn. $12,4,753-766$.

Wood C, Downing B [1986], In-vitro fertilization and tubal micro-surgery - their status compared, Brit.J, Obst.Gynec.,93,1,3-5.

Yates C, Kretser D de [1987], Male-Factor Infertility and in Witro Fertilization, J.TVF/ET,4,3,141-147.

Yee $B_{1}$ et al [1985], Direct assessment of human cocyte maturity with high ironidase dispersion, Abstracts 411st anual meeting American Fertility Society.

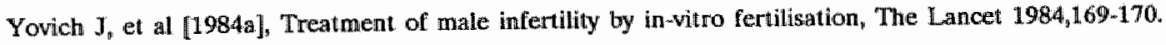

Yovich J, et al [1984b], In-vitro fertilisation of odcytes from women with serum antisperm antibodies, Lanoet, 369-370.

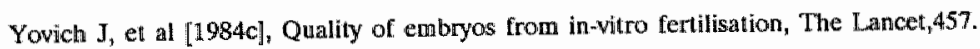

Yovich $\mathrm{J}_{x}$ et al [1985a], In-vitro fertilisation for endometriosis, The Lancet, 552.

Yowich $J_{\text {, et al }}[1985 \mathrm{~b}$ ], Embryo transfer technique as a cause of ectopic pregnancies in in vitro fertilization. Fertil.Steril., 44,3,318-321.

Yowich J, et al [1986], Development Assessment of Twenty in Vitro Fertilization (IVF) Infants at Their First Birthday, J.IVF/ET, 3,4,253-257.

Zarutskie $P$, et al [1987], Endocrine changes in the late-follicular and postovulatory intertvals as determinants of the in vitro fertilization pregnancy rate, Fertill Steril, $47,1,137-143$.

Zeimaker G, et al [1984], Two pregnancies following transfer of intact trozen-thawed embryos, Fertil.Steril, $42,2,293-297$.

Zeilmaker, $G_{i}$ Rijkmans $C$ [19866], Experience with the hamster test in an IVF laboratory, Int.Jlourn. Andrology, supp 6, 123-129.

Zeilmaker $G$, et al [1987], Resultaten van het laboratorium woor in vitro-fertilisatie van de Erasmus universiteit te Rotterdam, Ned.Tijds.Geneesk,131,48,2198-2201.

Zenzes $\mathrm{M}$, et al [1987], Confirmation of an abnormal (non-Poisson) distribution of sperm from some infertile men in the hamster-ovum test, Fertil.Steril.,48,6,1018-1024.

Ziekenfondsraad [1983], Interim-adwies inzake grenzen aan de groei van het werstrekkingenpakket.

Ziekenfondsraad [1985], Advies inzake in vitro fertilisatie, Annstelveen.

Ziekenfondsraad [1988], Farmacotherapeutilisch Kompas. 


\section{BIJLAGEN:}

Bijlage 1.1: Bexwaren tegen de uitvoering van het gerandomiseerd

onderzoek IVF versus tubachirurgie . . . . . . . . . . . . . 189

Bijlage 2.1: Registratieformulier voor het evaluatie-onderzoek IVF … . . 191

Bijlage 3.1. Resultaten per ziekenhuis, gesplitst (op basis van eerste dag laatste menstruatie) naar officiële kwartalen ........... 200

Bijlage 3.2. Resultaten, gesplitst in kwartielen; zowel totaal als per

ziekenhuis . . . . . . . . . . . . . . . . . . . . 203

Bijlage 3.3. Resultaten gesplitst naar leeftijd vrouw . . . . . . . . 205

Bijlage 3.4. Resultaten per leeftijdsgroep voor indikatie 'alleen

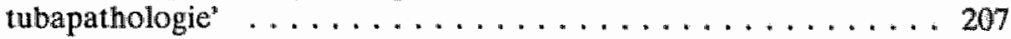

Bijlage 3.5. Resultaten per leeftijdsgroep, gesplitst naar eerdere graviditeit . 208

Bijlage 3.6. Resultaten, gesplitst naar indikaties tubapathologie en

mannelijke subfertiliteit . . . . . . . . . . . . . . . . . . 209

Bijlage 3.7. Resultaten, gesplitst naar mannelijke subfertiliteit en eventueel andere indikaties . . . . . . . . . . . . . . . . . . . 209

Bijlage 3.8. Resultaten, gesplitst naar indikatie endometriose . . . . . . 210

Bijlage 3.9. Resultaten, gesplitst naar indikatie onbegrepen infertiliteit met splitsing naar infertiliteitsduur . . . . . . . . . . 210

Bijlage 3.10. Uitgebreide kruistabel van aanwezigheid tubae/ovaria voor paren met als enige indikatie tubapathologie $\ldots \ldots \ldots \ldots .211$

Bijlage 3.11. Resultaten voor paren met als enige indikatie tubapathologie, gesplitst naar al dan niet tubachirurgie gehad . ......... 212

Bijlage 3.12. Resultaten voor paren met als enige indikatie tubapathologie, gesplitst naar bevindingen HSG en diagnostische laparoscopie . . 213

Bijlage 3.13. Resultaten, gesplitst naar verzekeringsvorm $\ldots \ldots \ldots \ldots \ldots 215$

Bijlage 3.14. Resultaten, gesplitst naar aanwezigheid ovaria; ook gestratificeerd naar eerste/ vervolgbehandeling en per ziekenhuis . . . . . . . . . . . . . . . . . . 216

Bijlage 3.15. Susksespercentages, gesplitst naar infertiliteitsduur en graviditeit ......................... 218

Bijlage 3.16. Signifikante korrelaties op patientnivo tussen patientkenmerken en ziekenhuisdummies . . . . . . . . . . . . . . 220

Bijlage 3.17. Resultaten, gesplitst naar volgnummer van de hormoonstimulatie . . . . . . . . . . . . . . . . 221

Bijlage 3.18. Resultaten per ziekenhuis, gesplitst voor eerste behandeling en vervolgbehandelingen binnen de onderzoeksperiode . . . . . 225

Bijlage 3.19. Resultaten, gesplitst naar punktienummer . . . . . . . 226 Bijlage 3.20. Varianten voor de berekening van het zwangerschapspercentage via een cohortbenadering . . . . . . . . . . . . . . . . 228

Bijlage 3.21. Frekwenties redenen voortijdige besindiging IVF $(n=626) \ldots 228$

Bijlage 3.22. Resultaten per ziekenhuis gesplitst naar gehanteerd medikatieschema . . . . . . . . . . . . . . . . . . . . . . . 229

Bijlage 3.23. Resultaten per ziekenhuis gesplitst naar interval hMG/FSH hCG . . . . . . . . . . . . . . . . . . . . . . . 229

Bijlage 3.24. Resultaten, gesplitst naar nivo en patroon van de oestrogenen .. 230 Bijlage 3.25. Korrelatie tussen follikelmetingen en oestrogeenbepalingen . . 231 
Bijlage 3.26. Resultaten, gesplitst naar aantal verkregen oöcyten en beoordeling van de maturiteit ................... . . 234

Bijlage 3.27. Resultaten na al dan niet signalering van endogene LH-piek . . . 235

Bijlage 3.28. Gegevens over resultaten en incidentie met betrekking tot spermamotiliteit na opwerking van het semen . . . . . . . 236

Bijlage 3.29. Resultaten, gesplitst naar aantal teruggeplaatste embryo's; totaal en per zickenhuils . . . . . . . . . . . . . . . 239

Bijlage 3.30. Resultaten, gesplitst naar aantal teruggeplaatste embryo's en indeling kwallieit van deze embryo's .............. 242

Bijlage 3.31. Resultaten, gesplitst naar al dan niet surplus aanwezig bij minstens 3 teruggeplaatste embryo's . . . . . . . . . . . . 244

Bijlage 3.32. Resultaten gesplitst naar verloop van de embryotransfer . . . . 249

Bijlage 3.33. Resultaten naar medikatieschema luteale fase . . . . . . . . . 250

Bijlage 3.34. Gegevens over doorgaande zwangerschappen na IVF . . . . . . . 251

Bijlage 3.35. Invloed aantal en kwaliteit van embryo's op klinische zwangerschap . . . . . . . . . . . . . . . . . . . 255

Bïjlage 3.36. Multivariate analyse: van hormoon tot doorgaand zwanger; extra verklarende variabele de interaktieterm van onbegrepen infertiliteit met primaire langdurige infertiliteit . . . . . . . 257

Bijlage 3.37. Berekening van gekorrigeerde doorgaandzwangerschapspercentages $\ldots \ldots \ldots \ldots \ldots \ldots \ldots \ldots \ldots$

Bijlage 3.38. Multivariate analyse: van hormoon tot doorgaand zwanger; alleen woor de eerste behandeling . . . . . . . . . . . . . . 262

Bijlage 3.39. Multivariate analyse: van hormoon tot doorgaand zwanger; extra verklarende variabelen: de interkatietermen tussen VER VOLG en de patięntkenmerken

Bijlage 3.40. Vergelijking van de gemiddelde sukseskans van "doorstromers" versus "afvallers"

Bijlage 4.1. Raming van personeelsinzet van verschillende disciplines bij de diverse IVF-aktiviteiten . . . . . . . . . . . . . 266

Bijlage 4.2 . Berekening van benodigd personeel op basis van noodzakelijke

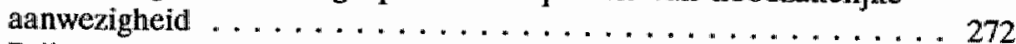

Bijlage 4.3. Prijzen van medicijnen in gebruik bij IVF-behandelingen . . . . . 274 Bijllage 4.4. Medikatieschema's met betrekking tot luteale fase-

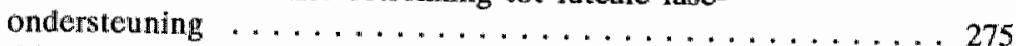

Bijlage 4.5. Globale schatting van de overige kosten binnen de gezondheidszorg na een IVF-behandeling . . . . . . . . . . 276

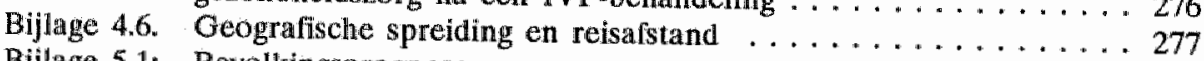

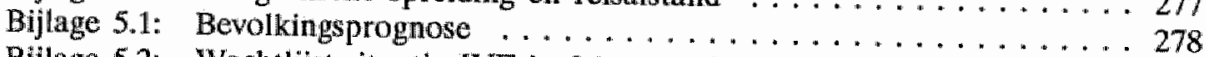

Bijlage 5.2: Wachtlijst-situatie IVF in februari $1987 \ldots \ldots \ldots \ldots \ldots \ldots \ldots . \ldots . \ldots 279$

Bijlage 6.1. Argumenten voor en tegen financiering op basis van resultaten. .281 
Bijlage 1.1: Bezwaren tegen de uitvoering van het gerandomiseerd onderzoek IVF versus tubachirurgie

Het belangrijkste bezwaar van de kant van vertegenwoordigers van de ziekenhuizen tegen het vergelijkingsonderzoek in gerandomiseerde vorm (RCT) was dat de noodzakelijke voorrangsregeling voor nieuwe patienten in de tussengroep ethisch niet haalbaar werd geacht. Dit argument is nader beschreven in de hoofdtekst. Daarnaast werden nog enige andere bezwaren geuit. Deze zijn in het onderstaande verwoord en voorzien van kommentaar.

- Een dergelijke RCT is ethisch onverantwoord, aangezien tubachirurgie uit de tijd raakt door de snelle ontwikkelingen bij IVF.

Het is zeer aannemelijk dat er patiëntgroepen met tubapathologie blijven bestaan, waarvoor tubachirurgie de meest aangewezen therapie is (vooral afhankelijk van type en ernst van de aandoening en de leeftijd van de patiěnte); de zwangerschapspercentages na een tubachirurgische behandeling bedragen voor sommige patientgroepen immers 70 a $80 \%$.

- De driedeling (primair tubachirurgie, primair IVF, tussengroep) is niet objektief mogelijk en is mede afhankelijk van de wensen van het paar.

Hoewel oordelen in de medische wetenschap vrijwell altijd een subjektief element bevatten, hebben reeds diverse gynaecologen met redelijk sukses getracht de resultaten van met name tubachirurgie te differentiëren naar onderliggende faktoren (al dan niet in samenhang). Het is logisch dat verbeteringen in de IVFbehandeling de grenzen van de driedeling kunnen beïnvloeden. Uiteraard dient het paar de uiteindelijke beslissing te nemen over de therapiekeuze, maar deze keuze zal afhankelijk zijn van de suksesverwachting bij beide behandelingen.

- In de gerandomiseerde onderzoeksopzet zou de diagnostische laparoscopie essentiële informatie dienen op te leveren ten behoeve van de analyse van de tussengroep. De diagnostische laparoscopie wordt tegenwoordig echter veelal niet meer herhaald in de aan het onderzoek deelnemende ziekenhuizen, indien een IVF-behandeling geindiceerd is. Zodoende is de informatie minder volledig en minder betrouwbaar.

Deze konstatering is juist. De informatie verkregen van de verwijzend specialist met betrekking tot anamnese en diagnostiek maakt een herhaling van de (belastende) diagnostische laparoscopie ten behoeve van de therapiekeuze IVF en de IVF-behandeling zelf veelal ongewenst. Dit hangt samen met het feit, dat men ernaar streeft de follikelpunkties zoveel mogelijk onder echoscopische zicht uit te voeren. Deze methode is minder belastend voor de patient en kan meestal in dagbehandeling plaatsvinden. De kombinatiemogelijkheid van diagnostiek en follikelpunktie, die bij laparoscopie bestaat, is bij deze methode evenwel uitgesloten. Overigens vindt bij de keuze van tubachirurgische behandeling wel veelal nog een (herhaalde) diagnostische laparoscopie plaats.

- De tijdspanne van het RCT-onderzoek en het eenmalige karakter van het resultaat leidt tot beleidsirrelevantie.

$\mathrm{Na}$ een tubachirurgische ingreep is het noodzakelijk gedurende minimaal 2 jaren eventuele zwangerschapsresultaten te signaleren. Dat zou volgens sommigen betekenen, dat na afloop van de laatste tubachirurgische ingreep in het onderzoek de analyse minimaal 2 jaren op zich zal moeten laten wachten. Het lijkt er evenwel op (volgens de literatuur en de ziekenhuizen zelf), dat de resultaten van de tubachirurgie een min of meer konstant nivo hebben bereikt, dat ook de komende jaren niet zal wijzigen. Dat impliceert, dat in de analyse de volledig 
bekende medische resultaten voor tubachirurgische ingrepen in de eerste periode van het onderzoek geextrapoleerd kunnen worden naar de slechts gedeeltelijk bekende medische resultaten van de tubachirurgische ingrepen in de laatste periode van het onderzoek. Hierbij kan onder andere gebruik worden gemaakt van de life-table-methodiek.

Het volgens de ziekenhuizen eenmalige karakter van het resultaat van de RCT wordt veroorzaakt door de eventuele verbetteringen in de IVF-behandeling. Dit argument geldt voor ieder onderzoek naar een technologie in ontwikkeling. De beleidsrelewantic schwilt in het tijdig zicht krijgen op de technologie tijdens haar ontwikkeling. Een woordeel voor de analyse van eventuele snelle ontwikkelingen bij IVF is dat het zwangerschapsresultaal van een IVF-behandeling snel bekend is. 


\section{Bijlage 2.1:Registratieformulier voor het evaluatie-onderzoek IVF}

In het evaluatie-onderzoek werd ten behoeve van de medische registratie op behandelnivo gebruik gemaakt van een zelf ontworpen registratieformulier. In deze bijlage is het volledige formulier opgenomen dat ingevuld diende te worden bij een eerste IVF-behandeling van een paar in het kader van het evaluatie-onderzoek-IVF. Bij latere IVF-behandelingen van het paar in het kader van het evaluatie-onderzoek kon worden volstaan met de hoofdstukken 8 tot en met 14. Voor de hoofdstukken 1 tot en met 7 konden eventuele wijzigingen op een apart formulier worden vermeld. 

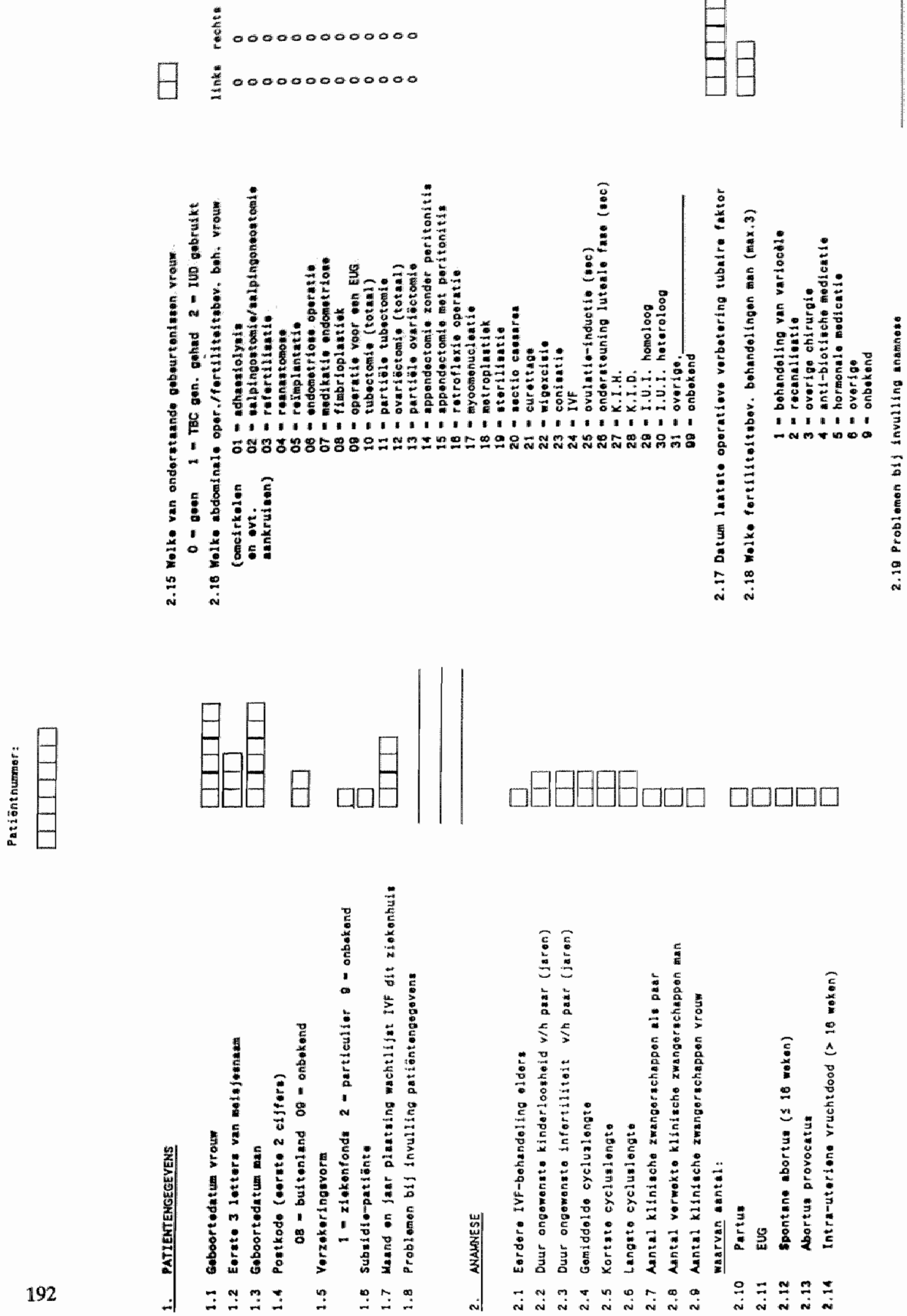


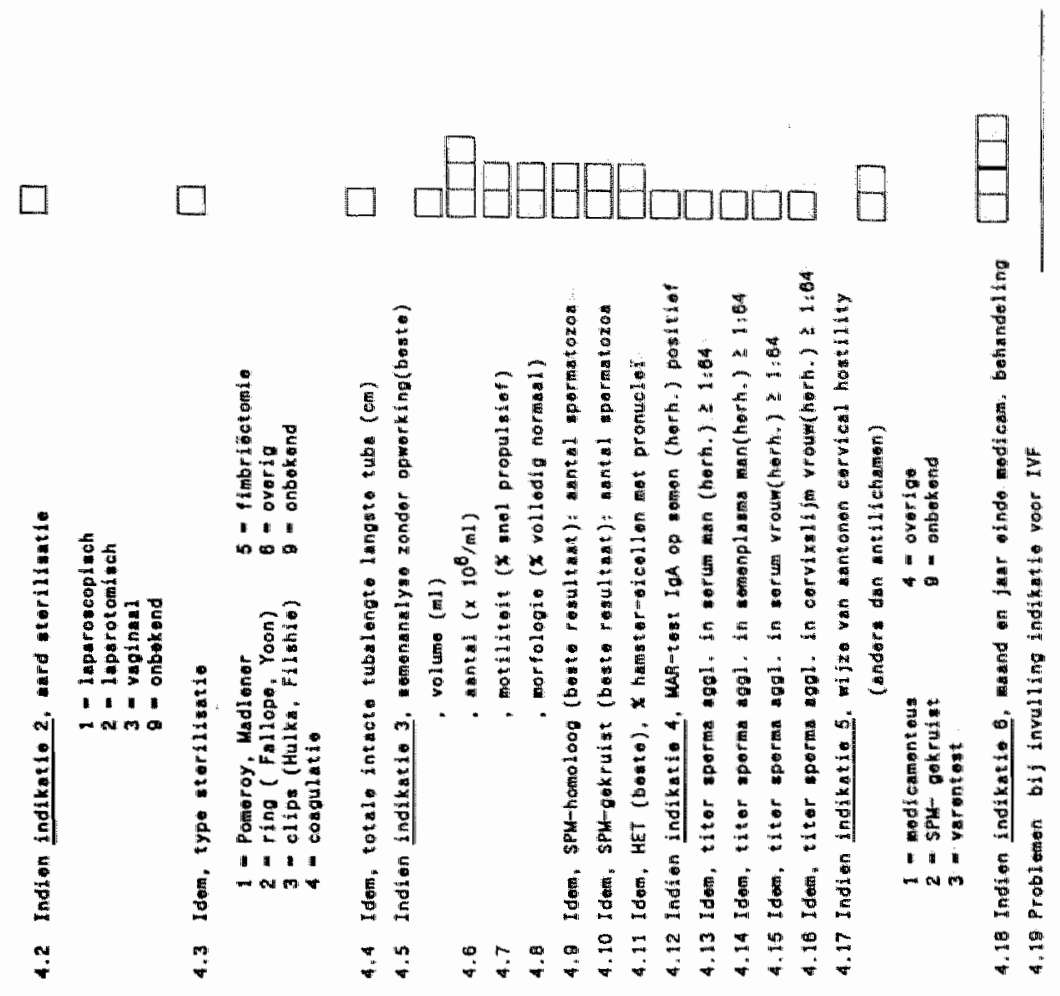

$\square$
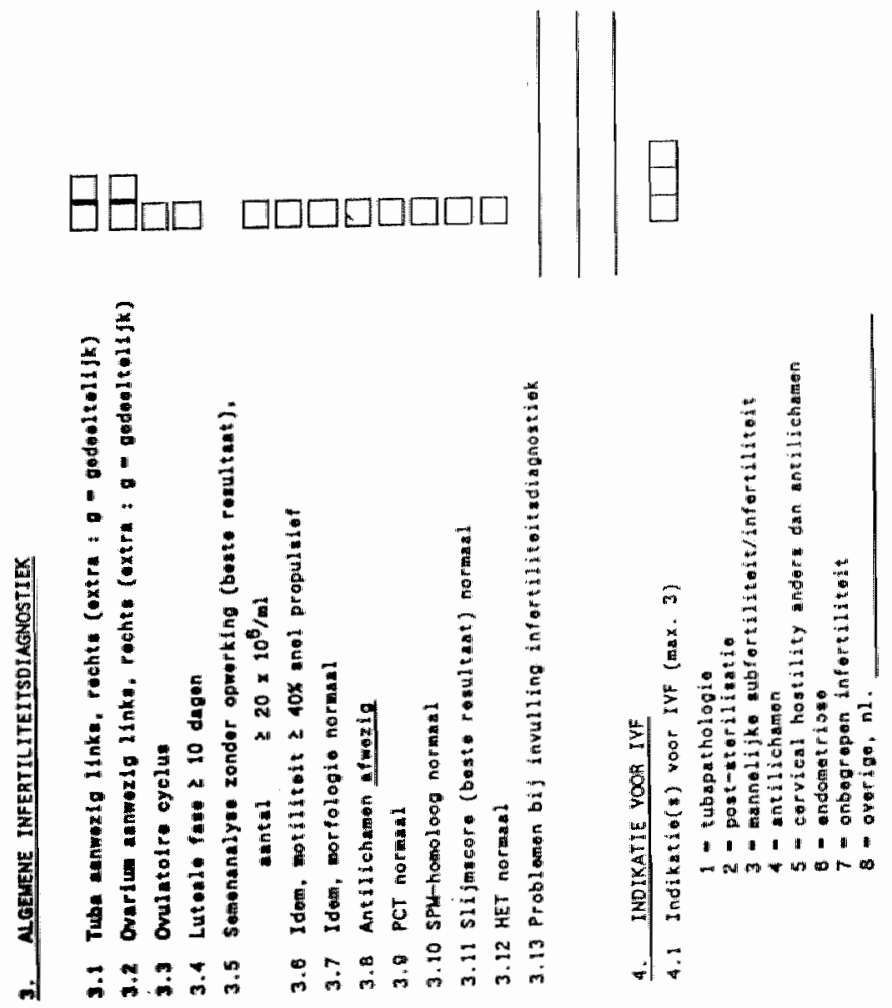
目
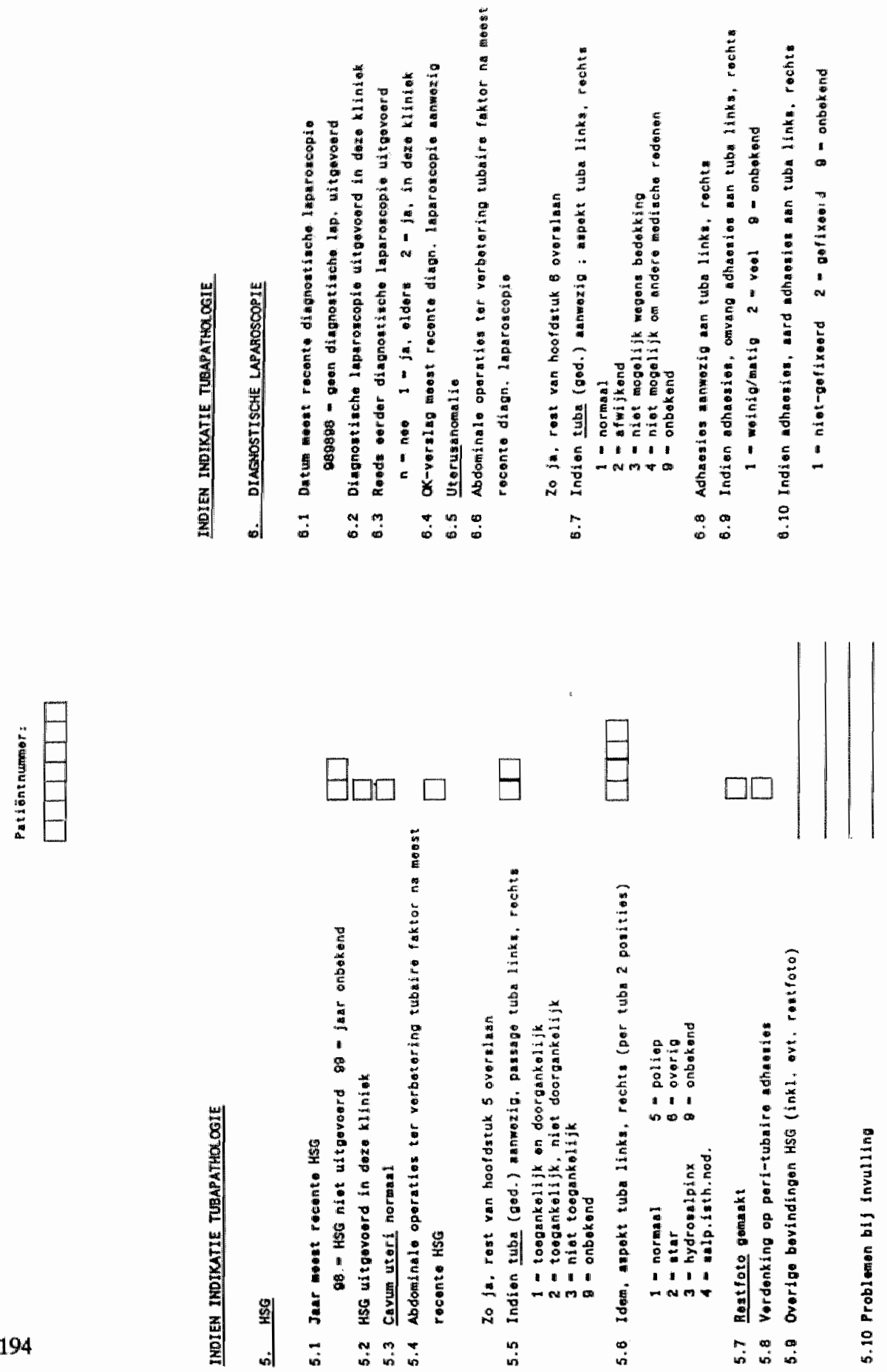

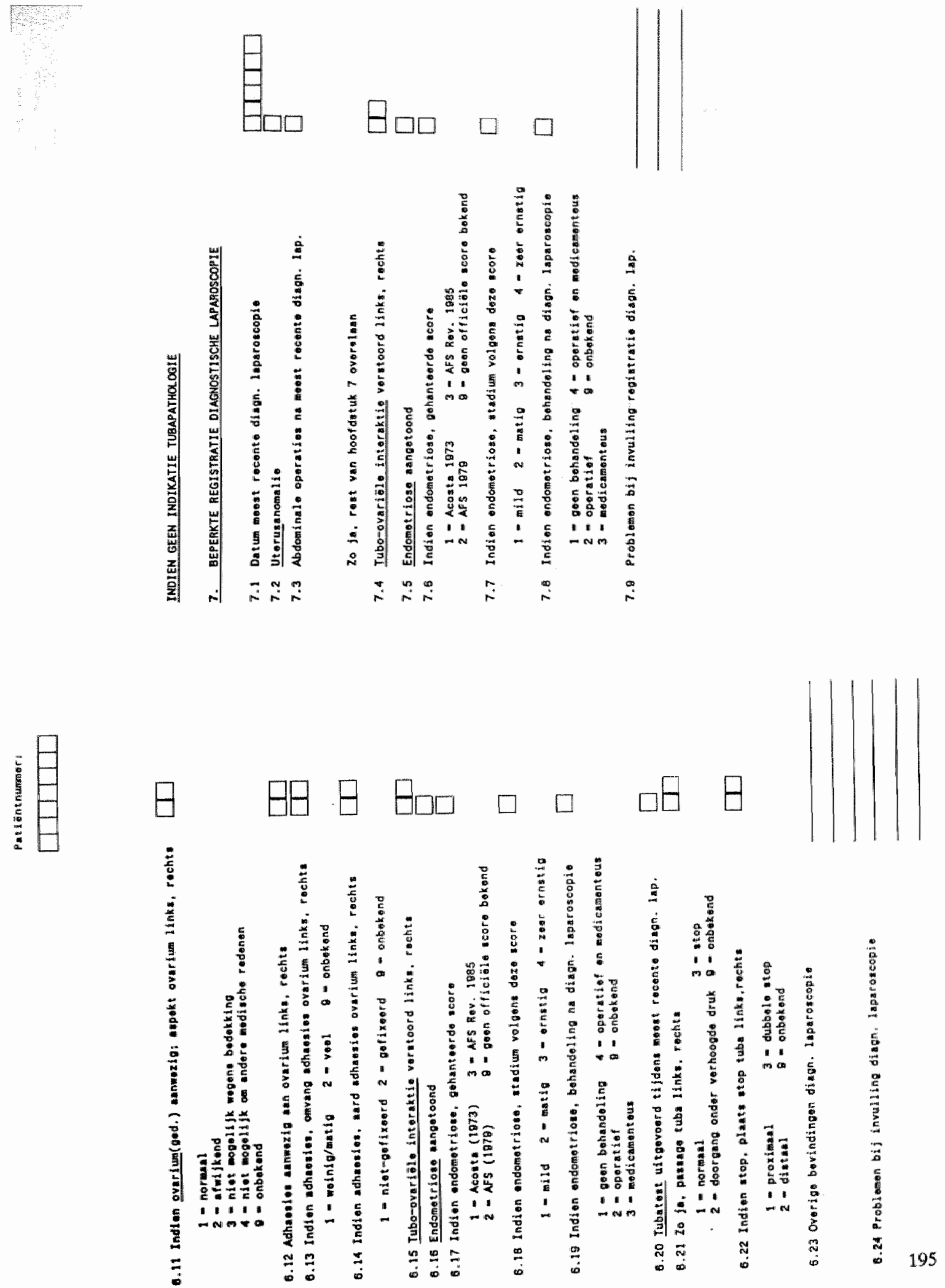


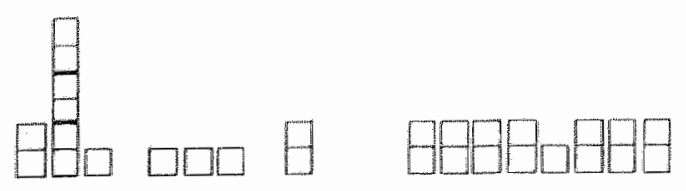

H
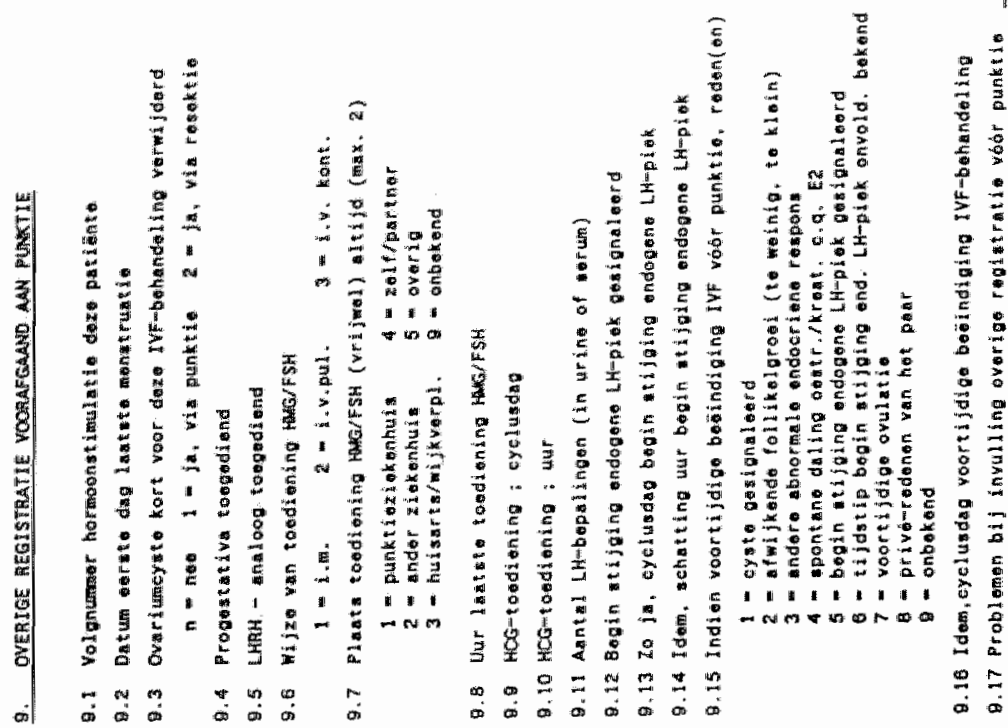

要

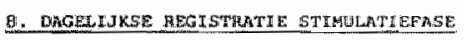

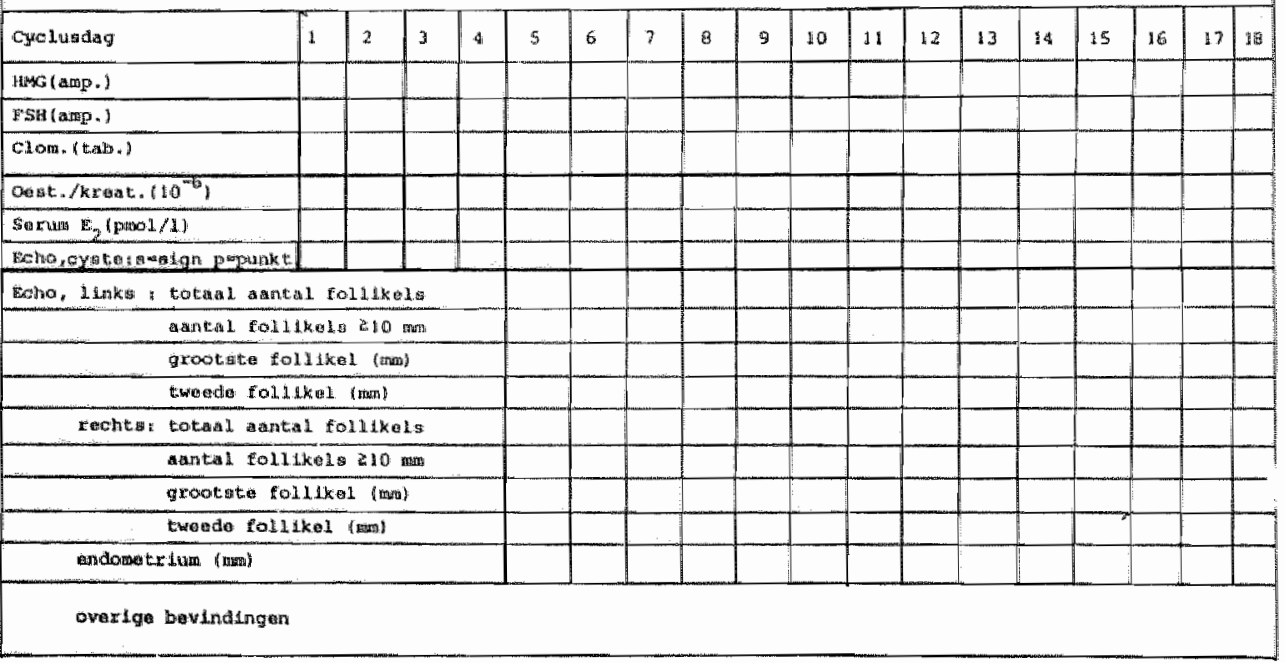

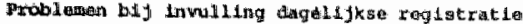



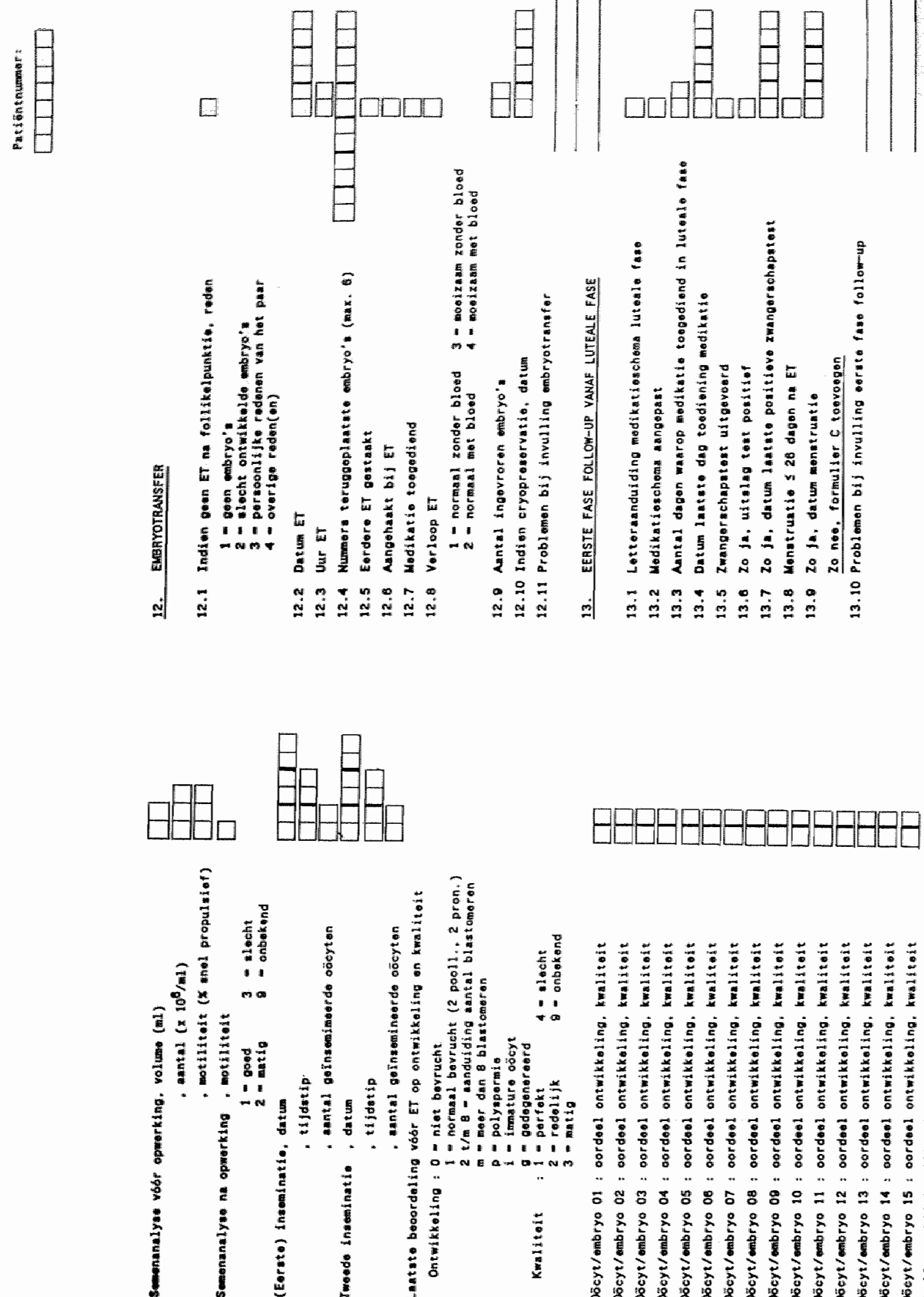

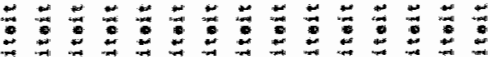
$\vec{E} \vec{E} \bar{E} \overrightarrow{\mathrm{E}} \mathrm{E} \overrightarrow{\mathrm{E}}$

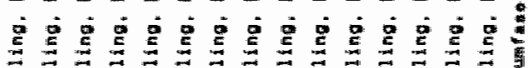

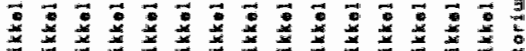

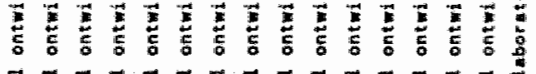

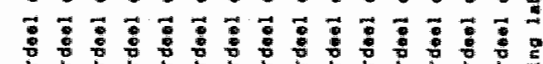

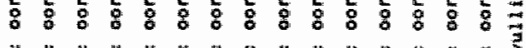

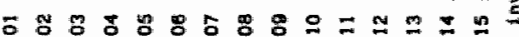

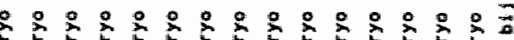

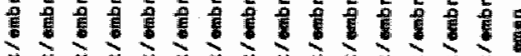

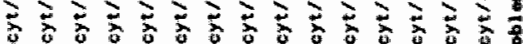

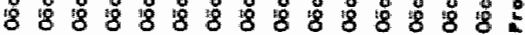

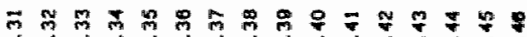

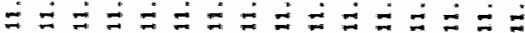



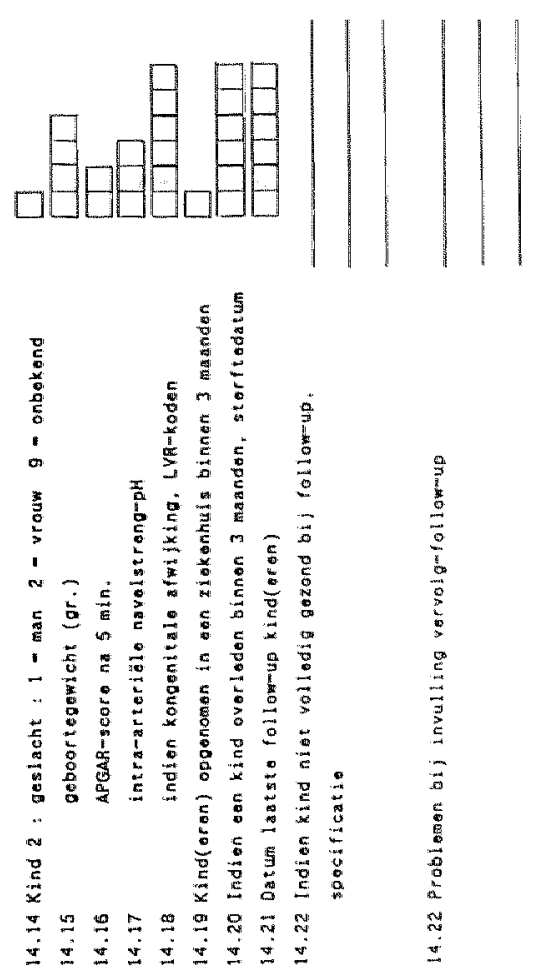

睍
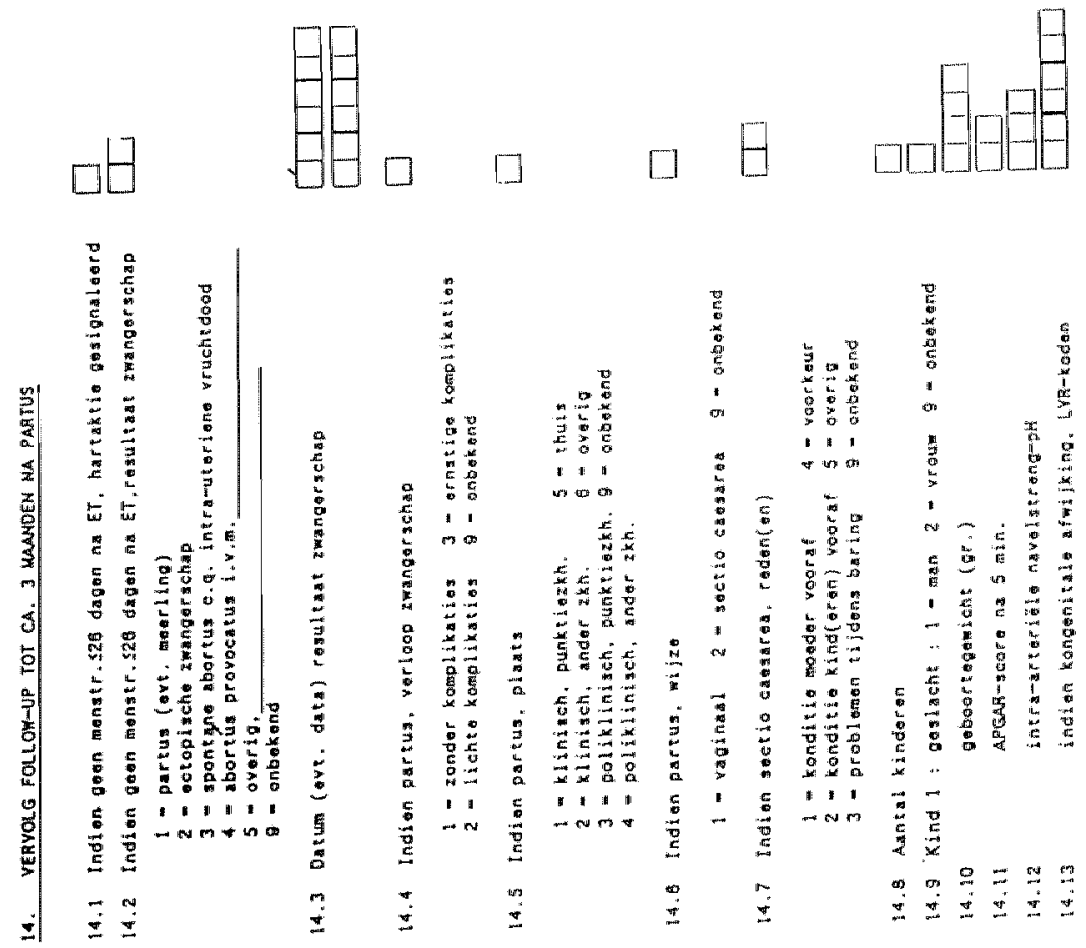
Bijlage 31. Resultaten per ziekenhuis gesplitst (op basis van eerste dag laatste menstruatie) naar officiede kwartallen

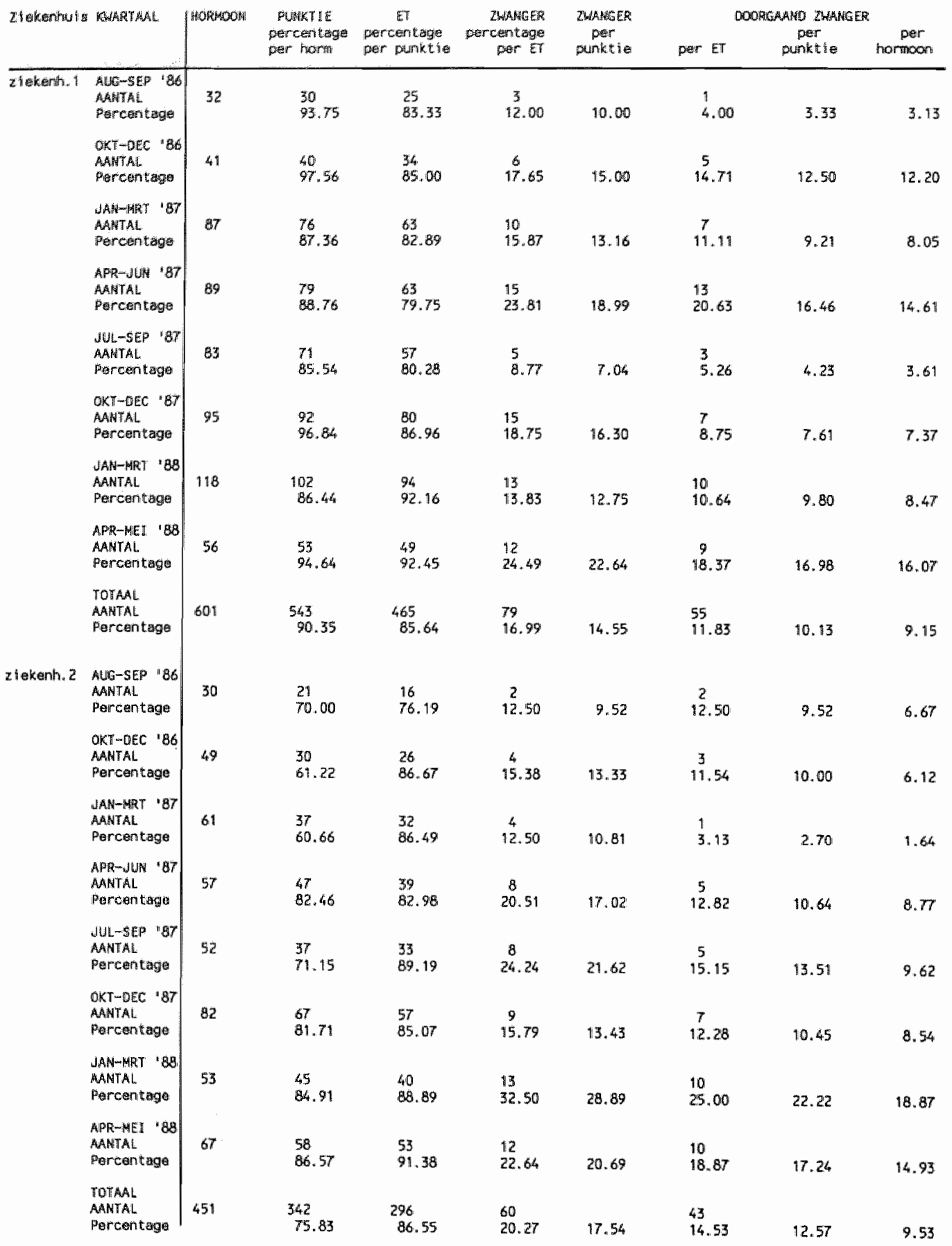




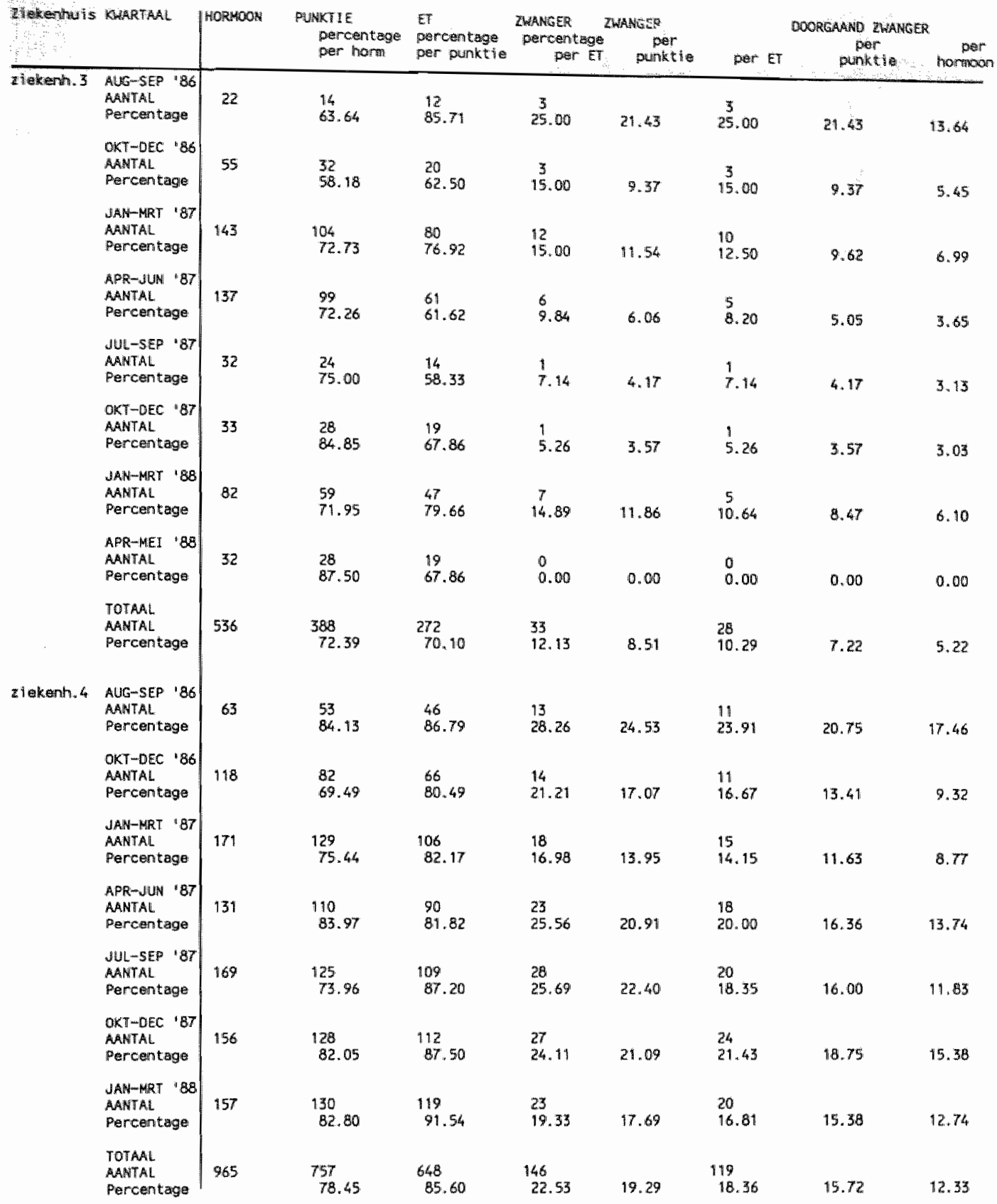




\begin{tabular}{|c|c|c|c|c|c|c|c|c|c|}
\hline 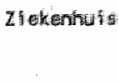 & MUAFTAA & 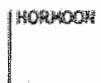 & $\begin{array}{l}\text { Pukfite } \\
\text { percentage } \\
\text { per thong }\end{array}$ & $\begin{array}{c}E T \\
\text { percentaigs } \\
\text { per puith }\end{array}$ & $\begin{array}{l}\text { Thathere } \\
\text { percentage } \\
\text { perer ET }\end{array}$ & 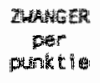 & per ET & $\begin{array}{l}\text { Ahato ZWAM } \\
\text { per } \\
\text { purnititie }\end{array}$ & hernos \\
\hline \multirow[t]{9}{*}{2 teverifn. 5} & 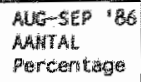 & 33 & $\begin{array}{l}32 \\
56.97\end{array}$ & 90.62 & $\begin{array}{c}87 \\
27.59\end{array}$ & 25.00 & $\begin{array}{c}7 \\
24.14\end{array}$ & 21.88 & 21.21 \\
\hline & $\begin{array}{l}\text { OKT-OEC "BG } \\
\text { AAVIAL } \\
\text { Percertage }\end{array}$ & 57 & $\begin{array}{l}52 \\
51.23\end{array}$ & $\begin{array}{l}49 \\
94,23\end{array}$ & $\frac{13}{26.53}$ & 25.00 & $\begin{array}{l}10 \\
20.41\end{array}$ & 19.23 & 17.5 \\
\hline & 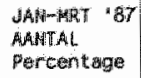 & 23 & $\begin{array}{l}74 \\
89.16\end{array}$ & $\begin{array}{l}70 \\
94.59\end{array}$ & $\begin{array}{l}15 \\
214,43\end{array}$ & 20.27 & $\begin{array}{l}12 \\
17.14\end{array}$ & 16.22 & 14.46 \\
\hline & $\begin{array}{l}\text { APR-JUth } B 7 \\
\text { AAkTAL } \\
\text { Percentage }\end{array}$ & 92 & $\begin{array}{l}69 \\
75.00\end{array}$ & $\begin{array}{l}63 \\
91.30\end{array}$ & $\begin{array}{l}20 \\
31,75\end{array}$ & 28.99 & $\begin{array}{l}15 \\
23.81\end{array}$ & 21.74 & 16.30 \\
\hline & $\begin{array}{l}\text { WUL_SEP "BT } \\
\text { AAHTAL } \\
\text { Percentago }\end{array}$ & 64 & $\begin{array}{l}48 \\
75.00\end{array}$ & $\begin{array}{l}42 \\
87.50\end{array}$ & $\begin{array}{l}11 \\
26.19\end{array}$ & 22.92 & 21.43 & 18.75 & 14.106 \\
\hline & $\begin{array}{l}\text { OKT-DEC "B7 } \\
\text { AAMTAL } \\
\text { Porkentage }\end{array}$ & 73 & $\begin{array}{l}50 \\
68.49\end{array}$ & $\begin{array}{l}48 \\
96.00\end{array}$ & $\begin{array}{l}12 \\
25.00\end{array}$ & 24,00 & $\begin{array}{l}10 \\
20.83\end{array}$ & 20.00 & 13.70 \\
\hline & $\begin{array}{l}\text { JAH-MRT "89 } \\
\text { AANTAL } \\
\text { Percentaga }\end{array}$ & 90 & $\begin{array}{l}76 \\
84.44\end{array}$ & $\begin{array}{l}73 \\
96,05\end{array}$ & $\begin{array}{l}13 \\
17.81\end{array}$ & 17.11 & $\begin{array}{l}12 \\
16.44\end{array}$ & 15.79 & 13.33 \\
\hline & $\begin{array}{l}\text { APR-ME1 } \\
\text { AANTAL } \\
\text { Percentage }\end{array}$ & 47.00 & $\begin{array}{l}35 \\
74.47\end{array}$ & $\begin{array}{l}34 \\
97.14\end{array}$ & 17.65 & 17.14 & $\begin{array}{l}3 \\
8.82\end{array}$ & 8.57 & 6.38 \\
\hline & $\begin{array}{l}\text { POTAAL } \\
\text { MANTAL } \\
\text { :rentaga }\end{array}$ & 539 & $\begin{array}{l}436 \\
80.89\end{array}$ & $\begin{array}{l}408 \\
93.58\end{array}$ & $\begin{array}{l}98 \\
24.02\end{array}$ & 22.48 & $\begin{array}{l}78 \\
19.12\end{array}$ & 17.89 & 14.47 \\
\hline
\end{tabular}


Biilage 3.2. Resultaten, gesplitst in kwartielen; zowell totaal als per ziekenhuis

\begin{tabular}{|c|c|c|c|c|c|c|c|c|}
\hline WekTLL & HORHOON & $\begin{array}{l}\text { PUNKTIE } \\
\text { percentage } \\
\text { per horit }\end{array}$ & $\begin{array}{l}\text { Et } \\
\text { percentage } \\
\text { per punktio }\end{array}$ & $\begin{array}{l}\text { ZWANGER } \\
\text { percentagie } \\
\text { per ET }\end{array}$ & $\begin{array}{l}\text { ZWAMEGER } \\
\text { per } \\
\text { punktio }\end{array}$ & $\begin{array}{l}\text { DORGAANO } \\
\text { TMangier } \\
\text { par ET }\end{array}$ & $\begin{array}{c}\text { Doorcakid } \\
\text { twanger } \\
\text { per } \\
\text { punktio }\end{array}$ & 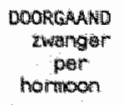 \\
\hline \multicolumn{9}{|l|}{ Toteal } \\
\hline 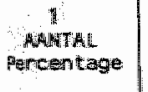 & 773 & $\frac{589}{76.20}$ & $\begin{array}{l}490 \\
83.19\end{array}$ & $\begin{array}{l}104 \\
21.22\end{array}$ & 17.66 & $\begin{array}{l}80 \\
16.33\end{array}$ & 13.58 & 10.35 \\
\hline $\begin{array}{c}2 \\
\text { Hanthe } \\
\text { Pencentage }\end{array}$ & 773 & $\begin{array}{l}616 \\
79.69\end{array}$ & $\begin{array}{l}497 \\
80.68\end{array}$ & $\begin{array}{l}96 \\
19.32\end{array}$ & 15.58 & $\begin{array}{l}77 \\
15.49\end{array}$ & 12.50 & 9.96 \\
\hline $\begin{array}{c}3 \\
\text { Amintial. } \\
\text { Percentiage }\end{array}$ & $\pi 73$ & $\begin{array}{l}617 \\
79.82\end{array}$ & $\begin{array}{l}526 \\
85,25\end{array}$ & $\begin{array}{l}106 \\
20.15\end{array}$ & 47.18 & $\begin{array}{l}77 \\
14.64\end{array}$ & 12.48 & 9.96 \\
\hline $\begin{array}{c}4 \\
\text { AundThIL } \\
\text { Paricentage }\end{array}$ & $\pi 73$ & $\begin{array}{r}64,4 \\
83.31\end{array}$ & $\begin{array}{l}57.6 \\
89.44\end{array}$ & $\begin{array}{l}110 \\
19.10\end{array}$ & 17.08 & $\begin{array}{l}89 \\
15.45\end{array}$ & 13.82 & $11.5 \%$ \\
\hline $\begin{array}{c}\text { TOTAAL } \\
\text { MANTAL } \\
\text { Parcentage }\end{array}$ & 3092 & $\begin{array}{l}2466 \\
79.75\end{array}$ & $\begin{array}{l}2089 \\
84,71\end{array}$ & $\begin{array}{l}416 \\
19.91\end{array}$ & 16.87 & $\begin{array}{l}323 \\
15.46\end{array}$ & 13.10 & 10.45 \\
\hline Lyeknth.1 & & & & & & & & \\
\hline $\begin{array}{c}1 \\
\text { HAHTAL } \\
\text { parentage }\end{array}$ & 150 & $\begin{array}{l}136 \\
90.67\end{array}$ & $\begin{array}{l}114 \\
83.82\end{array}$ & $\begin{array}{l}17 \\
14.91\end{array}$ & 12.50 & $\begin{array}{l}12 \\
10,53\end{array}$ & 8.82 & 8.00 \\
\hline $\begin{array}{c}2 \\
\text { Antital } \\
\text { Percentiage }\end{array}$ & 150 & $\begin{array}{l}130 \\
86.67\end{array}$ & $\begin{array}{l}105 \\
80.77\end{array}$ & $\begin{array}{l}19 \\
18.10\end{array}$ & 14.62 & $\frac{15}{14.29}$ & 11.54 & 10.00 \\
\hline $\begin{array}{c}3 \\
\text { MAMTAL } \\
\text { Perconitage }\end{array}$ & 150 & $\begin{array}{l}139 \\
92.67\end{array}$ & $\begin{array}{l}147 \\
84.17\end{array}$ & $\begin{array}{l}21 \\
117.95\end{array}$ & 15.41 & $\begin{array}{l}12 \\
10.26\end{array}$ & 8.63 & 8.00 \\
\hline 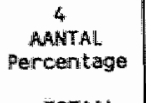 & 151 & $\begin{array}{l}138 \\
91.39\end{array}$ & $\begin{array}{l}129 \\
93.48\end{array}$ & $\begin{array}{l}22 \\
17.05\end{array}$ & 15.94 & $\begin{array}{l}16 \\
12.40\end{array}$ & 41,59 & 10.60 \\
\hline $\begin{array}{c}\text { TOTAML } \\
\text { MAMTAL } \\
\text { Parcentage: }\end{array}$ & 601 & $\begin{array}{l}543 \\
90.35\end{array}$ & $\begin{array}{l}465 \\
85.64 .4\end{array}$ & $\begin{array}{l}79 \\
16.99\end{array}$ & 14.55 & $\begin{array}{l}55 \\
11.83\end{array}$ & 10.13 & 9.15 \\
\hline ziokenh.2 & & & & & & & & \\
\hline 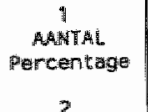 & 113 & $\begin{array}{l}70 \\
61.95\end{array}$ & $\begin{array}{l}58 \\
62.186\end{array}$ & $\begin{array}{c}9 \\
15.52\end{array}$ & 12.86 & $\begin{array}{l}6 \\
10.34\end{array}$ & 8.57 & 5.31 \\
\hline $\begin{array}{c}2 \\
\text { AHANTAL } \\
\text { Percentage } \\
3\end{array}$ & 113 & $\begin{array}{l}87 \\
76.99\end{array}$ & $\begin{array}{l}74 \\
85.06\end{array}$ & $\begin{array}{l}15 \\
20.27\end{array}$ & 17.24 & 112.16 & 10.34 & 7.96 \\
\hline 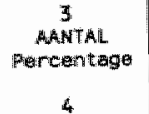 & 113 & $\begin{array}{l}87 \\
76.99\end{array}$ & $\begin{array}{l}76 \\
B 7.36\end{array}$ & $\begin{array}{l}13 \\
17.11\end{array}$ & 14.94 & $\begin{array}{l}10 \\
13.16\end{array}$ & 11.49 & 8.85 \\
\hline $\begin{array}{c}4 \\
\text { AANTiAL } \\
\text { Percentage } \\
\text { ToTAAL }\end{array}$ & 112 & $\begin{array}{l}98 \\
87.50\end{array}$ & $\begin{array}{l}88 \\
89.80\end{array}$ & $\begin{array}{l}23 \\
26.14\end{array}$ & 23.4 .7 & $\begin{array}{l}18 \\
20.45\end{array}$ & 18.37 & 16.07 \\
\hline $\begin{array}{c}\text { TOTAAL } \\
\text { MAlNTAL } \\
\text { Percentiage }\end{array}$ & 451 & $\begin{array}{c}342 \\
75.83\end{array}$ & $\begin{array}{l}296 \\
86.55\end{array}$ & $\begin{array}{l}60 \\
20.27\end{array}$ & 17.54 & $\frac{43}{14.53}$ & 12.57 & 9.53 \\
\hline
\end{tabular}




\begin{tabular}{|c|c|c|c|c|c|c|c|c|}
\hline MHARTIEL & Hor $4000 \%$ & $\begin{array}{l}\text { puthrte } \\
\text { puencentege } \\
\text { per hormi }\end{array}$ & 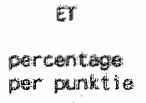 & $\begin{array}{r}\text { IWAGER } \\
\text { percentage } \\
\text { per E? }\end{array}$ & $\begin{array}{l}\text { TWAHCED } \\
\text { perr } \\
\text { puinctie }\end{array}$ & 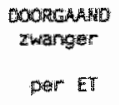 & 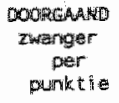 & $\begin{array}{c}\text { Doopichatho } \\
\text { zwanger } \\
\text { per } \\
\text { hornoor }\end{array}$ \\
\hline \multicolumn{9}{|l|}{ Zfokeng } \\
\hline 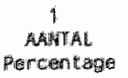 & 134 & $\begin{array}{l}84 \\
62.69\end{array}$ & $\begin{array}{l}64 . \\
76.19\end{array}$ & $\begin{array}{l}11 \\
17.99\end{array}$ & 13.90 & $\stackrel{9}{14.06}$ & 10.71 & 6.72 \\
\hline $\begin{array}{c}2^{2} \\
\text { AATALL } \\
\text { Parcentioget }\end{array}$ & 134 & $\begin{array}{l}104 \\
77.61\end{array}$ & 67 & $\frac{9}{13.43}$ & 8.65 & 13.43 & 8.65 & 6.72 \\
\hline $\begin{array}{c}3 \\
\text { AAHALAL } \\
\text { Prentage }\end{array}$ & 134 & $\frac{98}{73.13}$ & 60.35 & $\frac{5}{7.58}$ & 5.10 & 4.06 & 4.08 & 2.99 \\
\hline 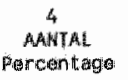 & $134_{4}$ & $\frac{102}{76.12}$ & $\begin{array}{l}75 \\
73.53\end{array}$ & $\begin{array}{l}8 \\
10.67\end{array}$ & 7.84 & 8.00 & 5.88 & 4.48 \\
\hline 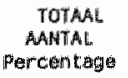 & 536 & $\begin{array}{l}388 \\
72.39\end{array}$ & $\begin{array}{l}272 \\
70.40\end{array}$ & $\begin{array}{l}33 \\
12.13\end{array}$ & 8.51 & $\begin{array}{l}28 \\
10.29\end{array}$ & 7.22 & 5.22 \\
\hline \multicolumn{9}{|l|}{ zhenen } \\
\hline $\begin{array}{c}1 \\
\text { AANTAL } \\
\text { Porcontage }\end{array}$ & $2 k_{1} 1$ & $\begin{array}{l}181 \\
75.70\end{array}$ & $\begin{array}{l}142 \\
78.45\end{array}$ & $\begin{array}{l}35 \\
24.65\end{array}$ & 19,34 & $\begin{array}{l}29 \\
20.4 .2\end{array}$ & 16.02 & 12.03 \\
\hline $\begin{array}{c}2 \\
\text { AAltTAL } \\
\text { Percentage }\end{array}$ & 241 & $\begin{array}{l}192 \\
79.67\end{array}$ & $\begin{array}{l}165 \\
85.94\end{array}$ & $\begin{array}{l}33 \\
20.00\end{array}$ & 17.19 & $\begin{array}{l}26 \\
15.76\end{array}$ & 13.54 & 10.79 \\
\hline $\begin{array}{c}3 \\
\text { AANTAL } \\
\text { Percentage }\end{array}$ & 241 & $\begin{array}{l}189 \\
75.10\end{array}$ & $\begin{array}{l}160 \\
80,40\end{array}$ & $\begin{array}{l}40 \\
25.00\end{array}$ & 22.10 & $\begin{array}{l}30 \\
18.75\end{array}$ & 16.57 & 12.45 \\
\hline $\begin{array}{c}4 \\
\text { AANTAL. } \\
\text { Percentage }\end{array}$ & 24,2 & ${ }^{203} 83.88$ & $\begin{array}{l}181 \\
89.16\end{array}$ & $\begin{array}{l}3 B \\
20.99\end{array}$ & 18.72 & $\begin{array}{l}34 . \\
18.78\end{array}$ & 16.75 & 14.05 \\
\hline $\begin{array}{c}\text { TOTAAL } \\
\text { AANTAL } \\
\text { Percientage }\end{array}$ & 965 & $\begin{array}{l}757 \\
78.45\end{array}$ & $\begin{array}{l}648 \\
85.60\end{array}$ & $\begin{array}{l}146 \\
22.53\end{array}$ & 19.29 & $\begin{array}{l}119 \\
18.36\end{array}$ & 15.72 & 12.33 \\
\hline \multicolumn{9}{|l|}{ ziakemin. 5} \\
\hline $\begin{array}{c}1 \\
\text { AANTAL } \\
\text { Porcontage }\end{array}$ & 135 & $\begin{array}{l}124 \\
911.85\end{array}$ & $\begin{array}{l}117 \\
94,35\end{array}$ & $\begin{array}{l}31 \\
26.50\end{array}$ & 25.00 & $\begin{array}{l}24 \\
20.51\end{array}$ & 19.35 & 17.78 \\
\hline $\begin{array}{c}2 \\
\text { MARAL } \\
\text { poreon tago }\end{array}$ & 135 & $\begin{array}{l}107 \\
79.26\end{array}$ & $\begin{array}{l}98 \\
91.59\end{array}$ & $\begin{array}{l}26 \\
26.53\end{array}$ & 24.30 & $\begin{array}{l}21 \\
21.43\end{array}$ & 19.63 & 15.56 \\
\hline $\begin{array}{c}3 \\
\text { AMINTAL } \\
\text { Pureoritage }\end{array}$ & 135 & $\begin{array}{l}97 \\
71.85\end{array}$ & 99 & $\begin{array}{l}22 \\
24.72\end{array}$ & 22.68 & $\begin{array}{l}18 \\
20.22\end{array}$ & 18.56 & 13.33 \\
\hline $\begin{array}{c}4 \\
\text { AANTAL } \\
\text { Percentage }\end{array}$ & 134 & 800.60 & $\begin{array}{l}104 \\
96.30\end{array}$ & $\begin{array}{l}19 \\
18.2 \pi\end{array}$ & 17.59 & $\begin{array}{l}15 \\
1.4 .42\end{array}$ & 13.89 & 11.19 \\
\hline $\begin{array}{l}\text { TOTAAL } \\
\text { AANTAL } \\
\text { Percentisge }\end{array}$ & 539 & $\begin{array}{l}436 \\
80.89\end{array}$ & $\begin{array}{l}408 \\
93.58\end{array}$ & $\begin{array}{l}98 \\
24.02\end{array}$ & 22.48 & $\begin{array}{l}78 \\
19.12\end{array}$ & 117.89 & 14.47 \\
\hline
\end{tabular}


Billage 3,3. Resultaten gesplitst naar leeftijd vrouw

Tabel Ba3.1. Leaftild wrouw ingedesid in 3 groepen

\begin{tabular}{|c|c|c|c|c|c|c|c|c|c|}
\hline $\begin{array}{l}\text { HEERT JOSGROEP } \\
\text { WROH }\end{array}$ & HORMOOW & $\begin{array}{l}\text { PUAKTIE } \\
\text { percentage } \\
\text { per homi }\end{array}$ & $\begin{array}{l}\text { ET } \\
\text { percentage } \\
\text { per punktie }\end{array}$ & $\begin{array}{r}\text { ZWAMGER } \\
\text { perCentEge } \\
\text { per ET }\end{array}$ & $\begin{array}{c}\text { ZHAWGER } \\
\text { per } \\
\text { punktí }\end{array}$ & 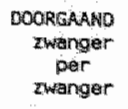 & $\begin{array}{c}\text { Doorchaing } \\
\text { ztwanger } \\
\text { per ET }\end{array}$ & $\begin{array}{c}\text { pookchano } \\
\text { zwangar } \\
\text { part } \\
\text { punkt te }\end{array}$ & 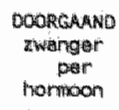 \\
\hline 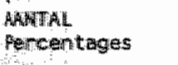 & 6 & $\begin{array}{l}4.67 \\
66.67\end{array}$ & 75.00 & $\begin{array}{l}0 \\
0.00\end{array}$ & 0.00 & . & 0.00 & 0.00 & 0.00 \\
\hline $\begin{array}{l}\text { leaft t jd \& } 35 \\
\text { Adwith } \\
\text { Perncentages }\end{array}$ & 1974 & $\begin{array}{l}1619 \\
82.02\end{array}$ & $\begin{array}{r}138 \\
85.48\end{array}$ & $\begin{array}{l}289 \\
20.88\end{array}$ & 17.85 & 82.04 & $\begin{array}{l}237 \\
47.12\end{array}$ & 16.64 & 12.01 \\
\hline 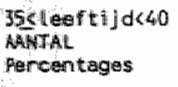 & 1009 & $\begin{array}{l}767 \\
76.02\end{array}$ & $\begin{array}{l}640 \\
83.44\end{array}$ & $\begin{array}{l}118 \\
18.44\end{array}$ & 15.38 & 89.49 & $\begin{array}{l}82 \\
42.81\end{array}$ & 10.69 & 8. 13 \\
\hline 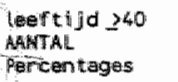 & 103 & $\begin{array}{l}76 \\
73.79\end{array}$ & $\begin{array}{l}62 \\
81.58\end{array}$ & 19.52 & 11.84 & 44.44 & $\begin{array}{l}4 \\
6.45\end{array}$ & 5.26 & 3.88 \\
\hline $\begin{array}{l}\text { TDNAML } \\
\text { AMTALL } \\
\text { Piercentages }\end{array}$ & 3092 & $\frac{2466}{79.75^{*}}$ & $\begin{array}{l}2089 \\
84.71\end{array}$ & $\begin{array}{l}416 \\
19.91\end{array}$ & 16.87 & $77.64^{*}$ & $\frac{3.23}{15.46^{*}}$ & $13: 10^{*}$ & $10.45^{*}$ \\
\hline
\end{tabular}

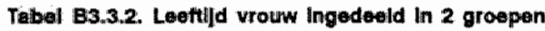

\begin{tabular}{|c|c|c|c|c|c|c|c|c|c|}
\hline $\begin{array}{l}\text { JOALEER/OUL } \\
\text { DER IOAN } 36\end{array}$ & HORNOON & $\begin{array}{l}\text { PUNXTIE } \\
\text { percentage } \\
\text { per horm }\end{array}$ & $\begin{array}{l}\text { ET } \\
\text { percentage } \\
\text { per punktite }\end{array}$ & $\begin{array}{r}\text { ZWANGER } \\
\text { percentage } \\
\text { per ET }\end{array}$ & $\begin{array}{c}\text { TWAWGER } \\
\text { Per } \\
\text { punktio }\end{array}$ & $\begin{array}{c}\text { DOORCAAND } \\
\text { Zwanger } \\
\text { per } \\
\text { zwangeir }\end{array}$ & $\begin{array}{c}\text { DOWRGAAPAD } \\
\text { Zwanger } \\
\text { per ET }\end{array}$ & $\begin{array}{c}\text { DOORGAAND } \\
\text { zhanger } \\
\text { pers } \\
\text { punktio }\end{array}$ & $\begin{array}{c}\text { DOORGAAND } \\
\text { zwarkger } \\
\text { pier } \\
\text { hormionn }\end{array}$ \\
\hline $\begin{array}{l}\text { ANTIAL } \\
\text { Paircentage }\end{array}$ & 6 & $\frac{4}{66.67}$ & $\frac{3}{75.00}$ & $\begin{array}{l}0 \\
0.00\end{array}$ & 0.00 &. & $\begin{array}{l}0 \\
0.00\end{array}$ & 0.00 & 0.00 \\
\hline 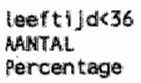 & 2233 & $\begin{array}{l}1830 \\
81.95\end{array}$ & $\begin{array}{l}1570 \\
85.79\end{array}$ & $\begin{array}{l}3.27 \\
20.83\end{array}$ & 17.87 & 80.43 & $\frac{263}{16.75}$ & 14.37 & 111.78 \\
\hline $\begin{array}{l}\text { Leeft t y d } 36 \\
\text { AHATAL } \\
\text { Percentage }\end{array}$ & 853 & $\begin{array}{l}63.2 \\
74.09\end{array}$ & ${ }^{516} 81_{\ldots .65}$ & $\begin{array}{l}89 \\
17.25\end{array}$ & 14.08 & 67.42 & $\begin{array}{l}60 \\
11,63\end{array}$ & 9.49 & 7.03 \\
\hline $\begin{array}{l}\text { TOTAML } \\
\text { AANTAL } \\
\text { Percentage }\end{array}$ & 3092 & $\begin{array}{c}2466 \\
79.75^{*}\end{array}$ & $\frac{2089}{84.71}+$ & $\begin{array}{l}416 \\
19.91\end{array}$ & $16.87^{*}$ & $77.64^{*}$ & $\frac{323}{15.46^{+}}$ & $13.10^{*}$ & $10.45^{*}$ \\
\hline
\end{tabular}




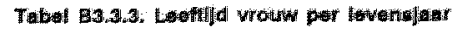

\begin{tabular}{|c|c|c|c|c|c|c|c|c|c|}
\hline AEET UD W/KOU & 40 a & $\begin{array}{l}\text { PUHakt E } \\
\text { percentage } \\
\text { por hom }\end{array}$ & $\begin{array}{c}\text { Er } \\
\text { percentigne } \\
\text { per purntite }\end{array}$ & $\begin{array}{l}\text { XWA HeE } \\
\text { percentage } \\
\text { par ET }\end{array}$ & $\begin{array}{c}\text { ZWAHGE: } \\
\text { per } \\
\text { punktio }\end{array}$ & 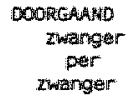 & $\begin{array}{c}\text { DOORGAANo } \\
\text { zwanger } \\
\text { per ET }\end{array}$ & 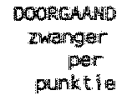 & 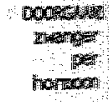 \\
\hline 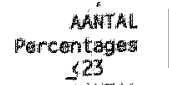 & 6 & 66.67 & $\begin{array}{c}3 \\
75.00\end{array}$ & 0.00 & 0.00 & " & $\begin{array}{l}0 \\
0.00\end{array}$ & $0: 00$ & (1) \\
\hline 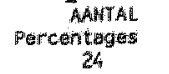 & 11 & 100.09 & $\begin{array}{c}14 \\
100.00\end{array}$ & 36.316 & 36.36 & 100.00 & 35.36 & 36.36 & $34 x$ \\
\hline 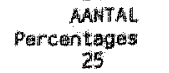 & 39 & $B 4,62$ & $\begin{array}{l}29 \\
87.88\end{array}$ & $\begin{array}{c}10 \\
34.48\end{array}$ & 30.30 & 70.00 & $24 \cdot 14$ & 21.2 & 7.6 \\
\hline $\begin{array}{c}\text { ABNIIA } \\
\text { Peir contage: } \\
26\end{array}$ & 53 & 81.13 & $\begin{array}{l}36 \\
83.72\end{array}$ & 46.67 & 13.95 & 66.67 & 11.4 & 9.30 & 7tow \\
\hline $\begin{array}{r}\text { AHINA } \\
\text { Peiremtages } \\
27\end{array}$ & 76 & $\begin{array}{l}64 \\
84 i\end{array}$ & $\begin{array}{l}55 \\
85.94\end{array}$ & 16.36 & 14.06 & $\pi 7.78$ & 12.73 & 10.94 & 9 \\
\hline $\begin{array}{r}\text { AAHIAL } \\
\text { Parcentigas } \\
28\end{array}$ & 90 & $\begin{array}{l}78 \\
86.67\end{array}$ & $\begin{array}{l}61 \\
78.21\end{array}$ & $\frac{17}{27.87}$ & 21.79 & 288.24 & $\begin{array}{c}15 \\
24.59\end{array}$ & 19.23 & 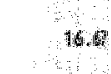 \\
\hline $\begin{array}{r}\text { ANHTAL } \\
\text { Poireontegess } \\
59\end{array}$ & 160 & $\begin{array}{l}136 \\
85.00\end{array}$ & $\begin{array}{l}120 \\
.88 .24\end{array}$ & $\begin{array}{c}28 \\
23.33\end{array}$ & 20.59 & 85.71 & $\begin{array}{c}24 \\
20.00\end{array}$ & 17.65 & 15. \\
\hline 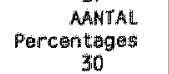 & 203 & $\begin{array}{l}17 \\
84 \\
84\end{array}$ & $\begin{array}{l}147 \\
85.96\end{array}$ & $\begin{array}{c}32 \\
21.77\end{array}$ & 18.71 & 78.13 & $\frac{25}{17.01}$ & $1: 4 \ldots 2$ & 423 \\
\hline $\begin{array}{r}\text { AANTAL } \\
\text { Porcentiggas } \\
31\end{array}$ & 224 & $\begin{array}{l}192 \\
85.71\end{array}$ & $\begin{array}{l}159 \\
82.81\end{array}$ & $\begin{array}{l}30 \\
18.88\end{array}$ & 15.62 & 90.00 & $\begin{array}{c}27 \\
16.98\end{array}$ & 14.06 & Iget \\
\hline $\begin{array}{l}\text { AANTAL } \\
\text { Parcartagers } \\
32\end{array}$ & 242 & $\begin{array}{l}499 \\
82.23\end{array}$ & $\begin{array}{l}172 \\
86.435\end{array}$ & $\begin{array}{c}38 \\
22.09\end{array}$ & 19.10 & 81.58 & $\frac{31}{18.02}$ & 15.58 & 12 \\
\hline $\begin{array}{r}\text { AANTAL } \\
\text { Percontragas } \\
33\end{array}$ & 304 & $\begin{array}{l}238 \\
78.29\end{array}$ & $\begin{array}{l}213 \\
89.50\end{array}$ & $\begin{array}{c}41 \\
19.25\end{array}$ & 17.23 & 85.37 & $\begin{array}{l}35 \\
16.43\end{array}$ & 14.71 & 11.3 \\
\hline $\begin{array}{l}\text { AANTALI. } \\
\text { percent tages }\end{array}$ & 304 & $\begin{array}{l}246 \\
80.92\end{array}$ & $\begin{array}{l}203 \\
82.52\end{array}$ & $\begin{array}{l}43 \\
21.18\end{array}$ & 17.48 & 813.72 & $\begin{array}{l}36 \\
17.73\end{array}$ & 14.63 & 110 \\
\hline $\begin{array}{r}\text { AHATAL } \\
\text { Percenteges } \\
35\end{array}$ & 268 & $\begin{array}{l}208 \\
77.61\end{array}$ & $\begin{array}{l}178 \\
85.58\end{array}$ & $\frac{31}{17.42}$ & 14.90 & 70.97 & $\frac{22}{12.36}$ & 10.58 & 施 \\
\hline $\begin{array}{r}\text { AANTAl } \\
\text { Percentages } \\
36\end{array}$ & 259 & $\begin{array}{l}211 \\
81.47\end{array}$ & $\begin{array}{l}186 \\
88.15\end{array}$ & $\begin{array}{l}304 \\
20.43\end{array}$ & 18.01 & 68.42 & $\begin{array}{l}26 \\
13.98\end{array}$ & 12.32 & 10: \\
\hline $\begin{array}{r}\text { AANTAL } \\
\text { Percottrages } \\
37\end{array}$ & 233 & $\begin{array}{l}175 \\
75.11\end{array}$ & $\begin{array}{l}145 \\
32.86\end{array}$ & $\begin{array}{l}24 \\
16.55\end{array}$ & 13.71 & 79.17 & $\begin{array}{c}19 \\
13.10\end{array}$ & 10.86 & 息膘 \\
\hline $\begin{array}{r}\text { AANTAl } \\
\text { Percentrages } \\
38\end{array}$ & 200 & $\begin{array}{l}150 \\
75.00\end{array}$ & $\begin{array}{l}120 \\
80.00\end{array}$ & $\begin{array}{l}22 \\
18,33\end{array}$ & 14.67 & 811.82 & $\begin{array}{c}18 \\
15.00\end{array}$ & 1.2 .00 & 9.4 \\
\hline $\begin{array}{c}\text { AANTAL } \\
\text { Porceritiagotgi } \\
39\end{array}$ & 170 & $\begin{array}{l}129 \\
75.88\end{array}$ & $\begin{array}{l}111 \\
86.05\end{array}$ & $\begin{array}{l}20 \\
18.02\end{array}$ & 15.50 & 60.00 & $\begin{array}{c}12 \\
10.81\end{array}$ & 9.30 & 7.0 \\
\hline $\begin{array}{r}\text { AANTAL } \\
\text { Perconteges } \\
40\end{array}$ & 147 & $\begin{array}{l}102 \\
69.39\end{array}$ & $\begin{array}{l}78 \\
76.47\end{array}$ & $\begin{array}{l}14 \\
17.95\end{array}$ & 13.73 & 50.00 & 8.97 & 6.86 & 4.7 \\
\hline AANTAL. & 89 & 60 & 53 & 7 & & & 3 & & \\
\hline Porcentrogurs & & 74.16 & 90,30 & $13: 21$ & 10.61 & 4.2 .86 & 5.66 & 4.55 & 然。 \\
\hline 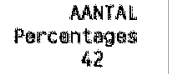 & 13 & 69.23 & $\frac{9}{100.00}$ & $22^{2} 22$ & 22.22 & 50.00 & 11.11 & 11.11 & 74 \\
\hline $\begin{array}{r}\text { AANTAL } \\
\text { Porcentages } \\
\text { TOFAAL }\end{array}$ & 1 & 100.00 & 0.00 & . & 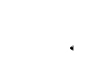 & . & . & . & $\theta$ \\
\hline $\begin{array}{r}\text { ARNTAL } \\
\text { Papcenteges }\end{array}$ & 3092 & $\begin{array}{l}2466 \\
79.75\end{array}$ & $\begin{array}{l}2089 \\
84.71\end{array}$ & $\begin{array}{l}416 \\
19.91\end{array}$ & 16.87 & $\pi 7.64$ & $\begin{array}{l}323 \\
15.46\end{array}$ & 13.10 & He日 \\
\hline
\end{tabular}


Bijlage 3.4. Resultaten per leeftijdsgroep voor indikatie 'alleen tubapathologie'

\begin{tabular}{|c|c|c|c|c|c|c|c|c|c|}
\hline 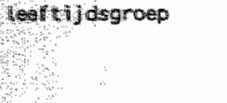 & HORMOON & $\begin{array}{l}\text { PUAkTI IE } \\
\text { percentage } \\
\text { peir horm }\end{array}$ & $\begin{array}{l}\text { ET } \\
\text { percentage } \\
\text { par punkt le }\end{array}$ & $\begin{array}{l}\text { DWAGER } \\
\text { percentage } \\
\text { per ET }\end{array}$ & $\begin{array}{l}\text { ZWANGER } \\
\text { per } \\
\text { punktie }\end{array}$ & 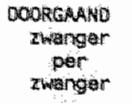 & $\begin{array}{c}\text { DoOngaANo } \\
\text { Ewanger } \\
\text { par ET }\end{array}$ & $\begin{array}{c}\text { ToobaAAD } \\
\text { rwanger } \\
\text { per } \\
\text { punkt }\end{array}$ & 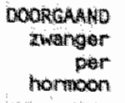 \\
\hline foraring & 6 & 6.6 .67 & $\frac{3}{75} .00$ & $\begin{array}{l}0 \\
0.00\end{array}$ & 0.00 & " & 0.00 & 0.00 & 0.00 \\
\hline 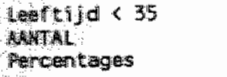 & 1487 & $\frac{1206}{81.10}$ & $\begin{array}{r}1069 \\
88.64\end{array}$ & $\begin{array}{l}237 \\
22.17\end{array}$ & 19.65 & 81.01 & $\begin{array}{l}192 \\
17.96\end{array}$ & 15.92 & 12.91 \\
\hline 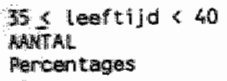 & 681 & $\frac{532}{73.12}$ & $\begin{array}{l}456 \\
85.71\end{array}$ & $\begin{array}{l}85 \\
18.64\end{array}$ & 15.98 & 74.12 & $\begin{array}{l}63 \\
13.82\end{array}$ & 11.84 & 9,25 \\
\hline 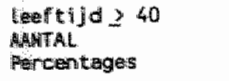 & 69 & $\begin{array}{l}47 \\
68.12\end{array}$ & $\begin{array}{l}37 \\
78.72\end{array}$ & 10.81 & 8. 51 & 0.00 & 0.00 & 0.00 & 0.00 \\
\hline $\begin{array}{l}\text { FDTALL } \\
\text { MHITIAL } \\
\text { Percentages }\end{array}$ & 2243 & $\frac{1789}{79} .76$ & $\begin{array}{r}1565 \\
8 \pi .48^{+}\end{array}$ & $\begin{array}{l}326 \\
20.83\end{array}$ & $18.22^{*}$ & $78.22^{*}$ & $\frac{255}{16.29^{\prime \prime}}$ & $14.25^{*}$ & $11.37^{*}$ \\
\hline
\end{tabular}


Bülage 3.5. Resultaten per leefijidsgroep gesplitst naar eerdere graviditeit

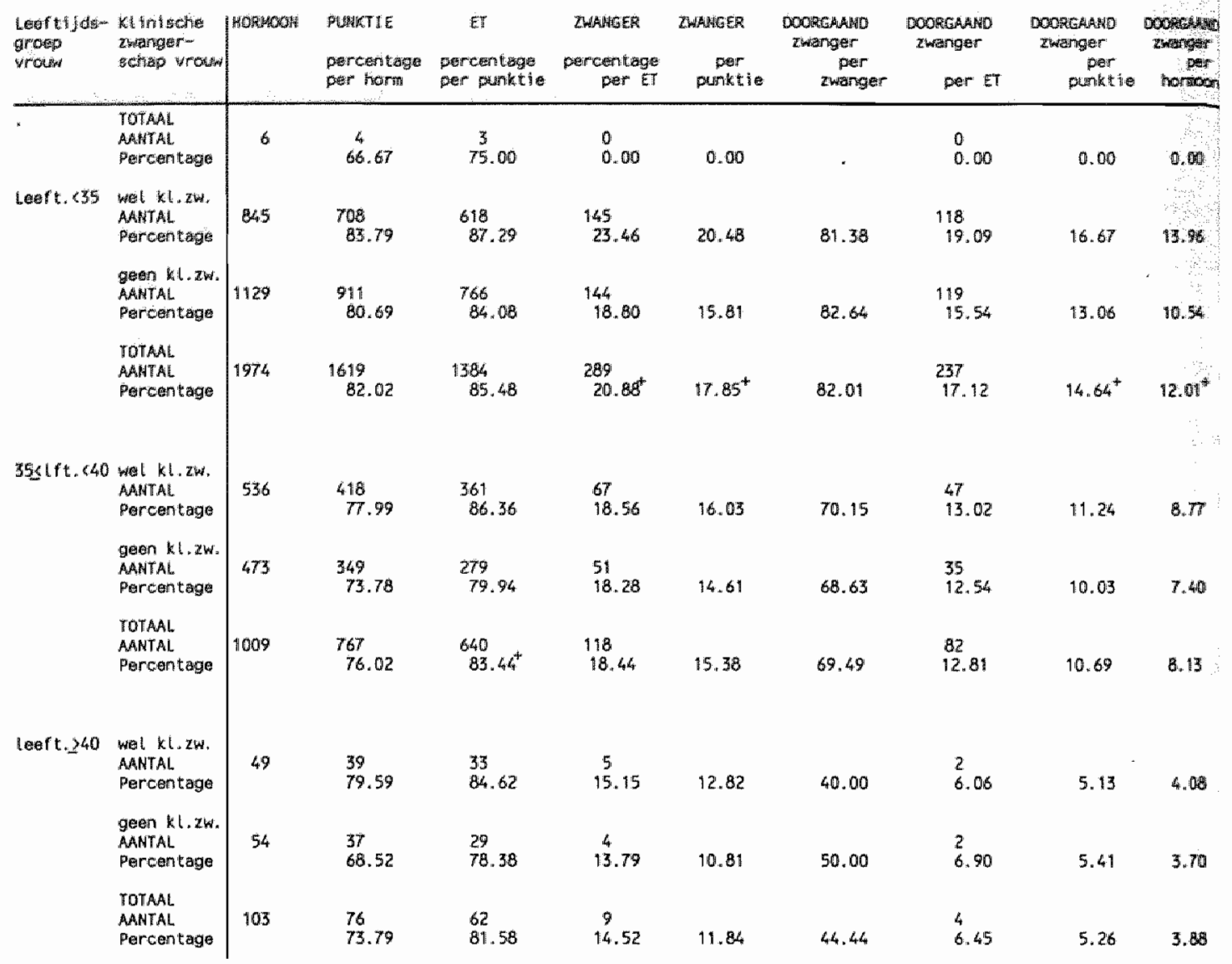


Biilage 3.6.Resultaten, gesplitst naar indikaties tubapathologie en mannelijke subfertiliteit

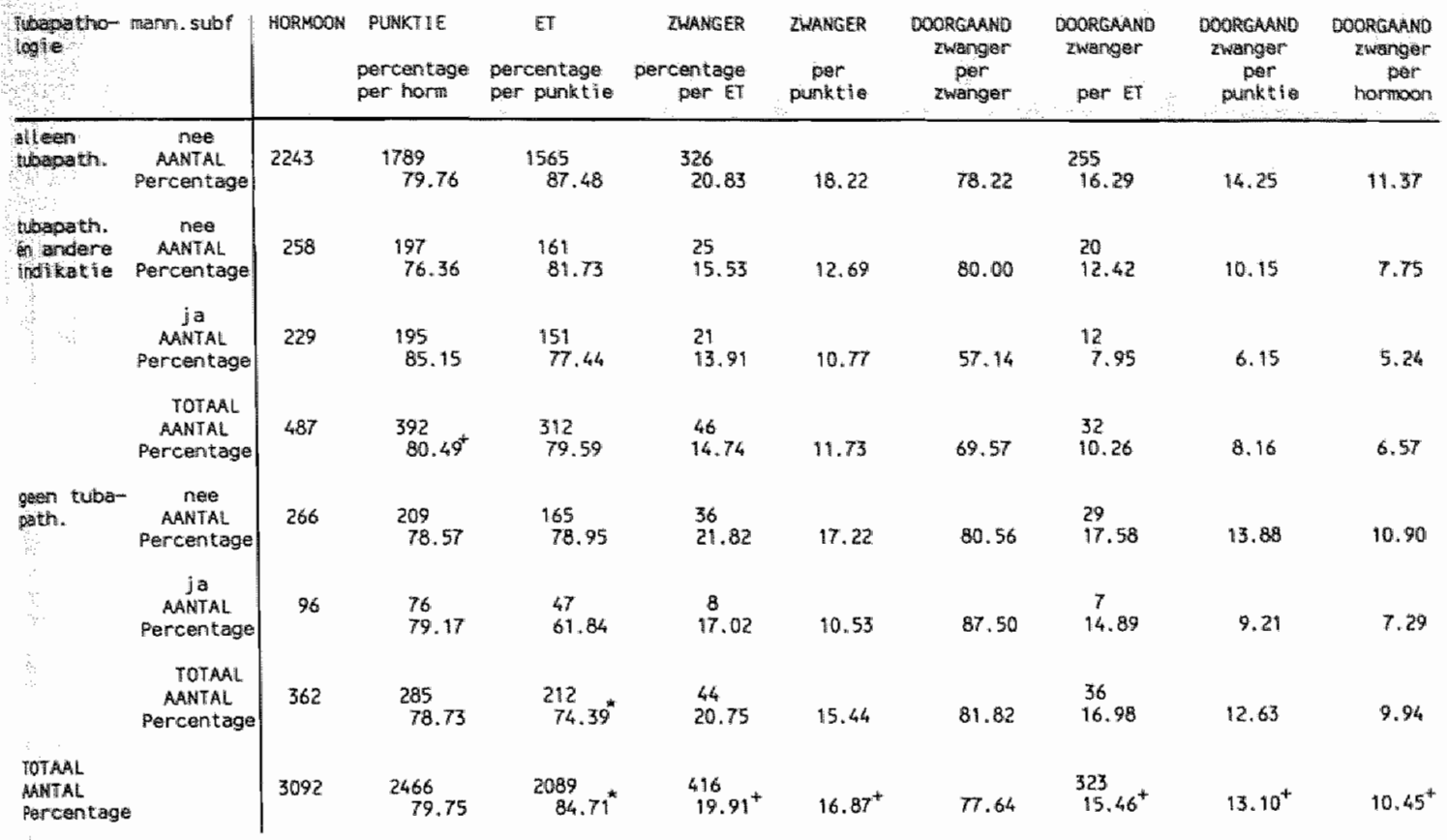

Biilage 3.7.Resultaten, gesplitst naar mannelijke subfertiliteit en eventueel andere indikaties

\begin{tabular}{|c|c|c|c|c|c|c|c|c|c|c|}
\hline Menn subif. & $\begin{array}{l}\text { andere } \\
\text { indikatio }\end{array}$ & HORHOON & $\begin{array}{l}\text { PUMKTIE } \\
\text { pericentage } \\
\text { per horm }\end{array}$ & $\begin{array}{l}\text { ET } \\
\text { percentage } \\
\text { per punktie }\end{array}$ & $\begin{array}{l}\text { ZWANGER } \\
\text { percentage } \\
\text { per ET! }\end{array}$ & $\begin{array}{l}\text { ZWANGER } \\
\text { por } \\
\text { punktie }\end{array}$ & $\begin{array}{c}\text { DOORGAAND: } \\
\text { zklanger } \\
\text { per } \\
\text { ziwanger }\end{array}$ & $\begin{array}{l}\text { OOORGAAMD } \\
\text { Zwainger } \\
\text { per ET }\end{array}$ & $\begin{array}{c}\text { DOORGAAND } \\
\text { zwanger } \\
\text { pier } \\
\text { punktie }\end{array}$ & $\begin{array}{r}\text { DOORGAAND } \\
\text { zwanger } \\
\text { par } \\
\text { tormoon }\end{array}$ \\
\hline nee & $\begin{array}{l}\text { totaal } \\
\text { AANTAL } \\
\text { Percentage }\end{array}$ & 2767 & $\begin{array}{l}2195 \\
79.33\end{array}$ & $\begin{array}{l}891 \\
86.15\end{array}$ & $\begin{array}{l}387 \\
20.47\end{array}$ & 17.63 & 78.55 & $\begin{array}{l}30 N_{4} \\
10.08\end{array}$ & 13.85 & 10.99 \\
\hline Ja & $\begin{array}{l}\text { nee } \\
\text { AANTAL } \\
\text { Percentage }\end{array}$ & 40 & $\begin{array}{l}32 \\
80.00\end{array}$ & $\begin{array}{l}20 \\
62.50\end{array}$ & $\frac{3}{15.00}$ & 9.38 & 100,00 & $\frac{3}{15.00}$ & 9.38 & 7.50 \\
\hline & $\begin{array}{c}\text { gean fubapath } \\
\text { AANTAL } \\
\text { Percentage }\end{array}$ & 56 & $\begin{array}{l}44 \\
78.57\end{array}$ & $\begin{array}{l}27 \\
61.36\end{array}$ & $\frac{5}{18.52}$ & 11.36 & 807.00 & $\$ 4.81$ & 9.09 & 7.14 \\
\hline & 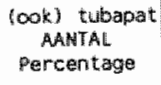 & 229 & $\begin{array}{l}195 \\
85.15\end{array}$ & $\frac{151}{77.44}$ & $\begin{array}{l}21 \\
13.91\end{array}$ & 100.77 & 57.94 & $\frac{1.2}{7.95}$ & 6.15 & 5.24 \\
\hline & $\begin{array}{c}\text { totad } \\
\text { AANTAL } \\
\text { percontage }\end{array}$ & 325 & $\begin{array}{l}271 \\
83.318\end{array}$ & $\frac{198}{73.06}$ & $\begin{array}{l}29 \\
14.65\end{array}$ & 10.70 & 65.52 & $\begin{array}{l}19 \\
9.60\end{array}$ & 7.01 & 5.85 \\
\hline 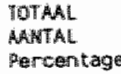 & & 3092 & $\begin{array}{l}2466 \\
79.75\end{array}$ & $\begin{array}{l}2089 \\
84.71^{*}\end{array}$ & $\begin{array}{l}416 \\
19.91^{+}\end{array}$ & $16.87^{1 / 4}$ & 77.64 & $\frac{323}{15.46}$ & $93.100^{\circ}$ & $10.45^{*}$ \\
\hline
\end{tabular}


Bijlage 3.8, Resultaten, gesplitst naat indikatie endometriose

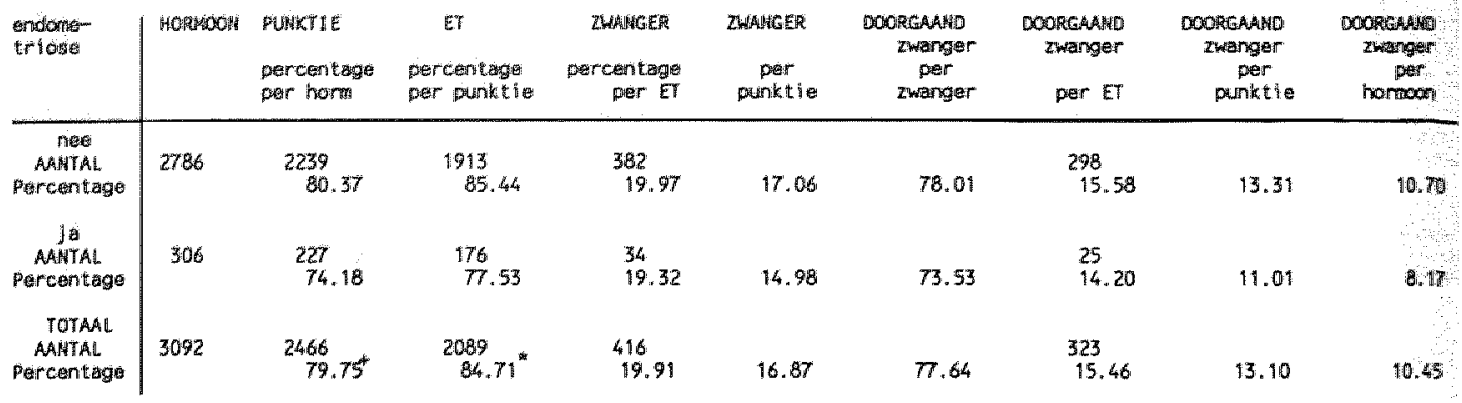

Bijlage 3.9. Resultaten, gesplitst naar indikatie onbegrepen infertiliteit met splitsing naar infertiliteitsduur

\begin{tabular}{|c|c|c|c|c|c|c|c|c|c|c|}
\hline $\begin{array}{l}\text { Onbegr. } \\
\text { infert. }\end{array}$ & $\begin{array}{l}\text { Inforthil } \\
\text { teitsodur }\end{array}$ & HORMON & $\begin{array}{l}\text { PUNKTIE } \\
\text { percenttage } \\
\text { per harm }\end{array}$ & $\begin{array}{l}\text { ET } \\
\text { percentage } \\
\text { per puiniktlie }\end{array}$ & $\begin{array}{l}\text { ZWAMGER } \\
\text { Percentage: } \\
\text { per EI }\end{array}$ & $\begin{array}{l}\text { TWAEGGER } \\
\text { punkti }\end{array}$ & $\begin{array}{c}\text { DOCRGAAANA } \\
\text { zwanger } \\
\text { per } \\
\text { zwanger }\end{array}$ & $\begin{array}{c}\text { DOORGAAND } \\
\text { zwanger } \\
\text { per ET }\end{array}$ & $\begin{array}{c}\text { DOORGAAND } \\
\text { z'wanger } \\
\text { per } \\
\text { punktie }\end{array}$ & 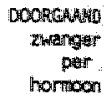 \\
\hline $\begin{array}{c}\text { nee } \\
\text { AAMTAL } \\
\text { Porcentago }\end{array}$ & total & 2935 & $\begin{array}{l}2343 \\
79.83\end{array}$ & $\begin{array}{l}1995 \\
85.15\end{array}$ & $\begin{array}{l}3901 \\
19.55\end{array}$ & 16.65 & $\pi .44$ & $\begin{array}{l}302 \\
15.14\end{array}$ & 12.89 & 10.29 \\
\hline ja & $\begin{array}{l}55 \text { Jaren } \\
\text { AANTAL } \\
\text { Porcentage }\end{array}$ & 42 & $\begin{array}{l}39 \\
92.86\end{array}$ & $\begin{array}{l}3.4 \\
87.18\end{array}$ & $\begin{array}{l}13 \\
38.24\end{array}$ & 33.33 & 84.62 & $\begin{array}{l}11 \\
32.35\end{array}$ & 28.21 & 26.19 \\
\hline & $\begin{array}{l}\text { 2. } 6 \text { Jaren } \\
\text { AANTAL } \\
\text { Percentage }\end{array}$ & 115 & $\begin{array}{l}84 \\
73.04\end{array}$ & $\begin{array}{l}60 \\
71.43\end{array}$ & $\begin{array}{l}13 \\
21.67\end{array}$ & 15.48 & 76.92 & $\begin{array}{l}10 \\
16.67\end{array}$ & 11.90 & 8.70 \\
\hline & $\begin{array}{l}\text { totasl } \\
\text { AANTAL } \\
\text { Percentago }\end{array}$ & 157 & $\begin{array}{c}123 \\
78.34^{4}\end{array}$ & $\begin{array}{c}94 \\
76.42\end{array}$ & $\begin{array}{c}26 \\
27.66\end{array}$ & $21.14^{*}$ & 80.77 & $\begin{array}{c}21 \\
22.34\end{array}$ & $17.07^{+}$ & 13. $30^{*}$ \\
\hline $\begin{array}{l}\text { TOTAAL } \\
\text { AANTAL } \\
\text { Parcentage }\end{array}$ & & 3092 & $\begin{array}{l}2466 \\
79.75\end{array}$ & $\begin{array}{l}2089 \\
84.71^{*}\end{array}$ & $\begin{array}{l}416 \\
19.91^{+}\end{array}$ & 16.87 & 77.64 & $\begin{array}{l}3.23 \\
15.46\end{array}$ & 13.10 & 10.45 \\
\hline
\end{tabular}


Bijlage 3.10. Uitgebreide kruistabel vam aanwezigheid tubae/ovaria voor paren met als enige indikatie tubapathologie

\begin{tabular}{|c|c|c|c|c|c|c|c|c|c|c|c|c|}
\hline 3 & $\begin{array}{l}\text { tub } \\
\text { aan }\end{array}$ & & af & $\begin{array}{l}\text { tub } \\
\text { tan }\end{array}$ & $\begin{array}{l}\text { rec } \\
\text { ged }\end{array}$ & 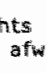 & $\begin{array}{l}\text { Ovar } \\
\text { aan }\end{array}$ & mi & niks & $\begin{array}{l}\text { ovar } \\
\text { aan }\end{array}$ & $d$ & $\begin{array}{l}\text { chits } \\
\text { atin }\end{array}$ \\
\hline 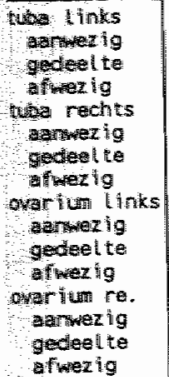 & 667 & 5 & 312 & $\begin{array}{r}495 \\
18 \\
134 \\
651\end{array}$ & $\begin{array}{l}27 \\
22 \\
18 \\
67\end{array}$ & $\begin{array}{r}141 \\
19 \\
160 \\
- \\
320\end{array}$ & $\begin{array}{r}639 \\
53 \\
176 \\
544 \\
56 \\
268 \\
868\end{array}$ & $\begin{array}{r}22 \\
4 \\
11 \\
20 \\
5 \\
12 \\
= \\
37\end{array}$ & $\begin{array}{r}6 \\
2 \\
125 \\
87 \\
6 \\
40 \\
- \\
- \\
133\end{array}$ & $\begin{array}{r}594 \\
47 \\
270 \\
\\
634 \\
61 \\
216 \\
763 \\
20 \\
128 \\
911\end{array}$ & $\begin{array}{r}7 \\
3 \\
111 \\
8 \\
5 \\
8 \\
10 \\
6 \\
5 \\
- \\
21\end{array}$ & $\begin{array}{r}66 \\
9 \\
30 \\
9 \\
1 \\
96 \\
95 \\
11 \\
- \\
- \\
- \\
106\end{array}$ \\
\hline
\end{tabular}

Uit deze tabel blijkt onder andere dat voor de groep paren met als enige indikatie tubapathologie geldt:

- tubae beiderzijds volledig aanwezig 499x (48\%), minstens éen tuba volledig aanwezig $819 x(79 \%)$ beide tubae afwezig $181 \mathrm{x}(12 \%) \mathrm{c.q} .160 \mathrm{x}(15 \%)$

- ovaria beiderzijds wolledig aanwezig $763 \times$ (74\%). 
Biflage 3.11 Resultaten voor paren met als enige indikatie tubapathologie gesplitst naar al dan net tubachirurgie gehad

\begin{tabular}{|c|c|c|c|c|c|c|c|c|c|}
\hline 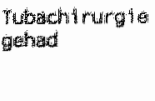 & Hothorom & 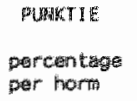 & $\begin{array}{c}\text { ET } \\
\text { percentage } \\
\text { per punt }\end{array}$ & $\begin{array}{l}\text { ZMANitg } \\
\text { percentage } \\
\text { per ET }\end{array}$ & $\begin{array}{l}\text { 2WAGlater } \\
\text { per } \\
\text { punktite }\end{array}$ & 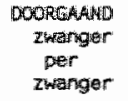 & $\begin{array}{l}\text { DOONGANANG } \\
\text { Iwanger } \\
\text { pier ET }\end{array}$ & $\begin{array}{l}\text { DOOREAAND } \\
\text { Iwanger } \\
\text { per } \\
\text { pukntit }\end{array}$ & 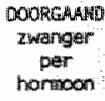 \\
\hline 畔e & 696 & $\begin{array}{l}559 \\
80.32\end{array}$ & $\begin{array}{l}491 \\
57.84\end{array}$ & 96 & 17.17 & 84.38 & $\begin{array}{l}81 \\
16.50\end{array}$ & 14.49 & 11.64 \\
\hline s. & 154,7 & $\frac{1290}{79.51}$ & $\begin{array}{l}1074 \\
87.32\end{array}$ & $\begin{array}{l}230 \\
21.42\end{array}$ & 18.70 & 75.65 & $\begin{array}{l}174 . \\
16.20\end{array}$ & 14.15 & $1: 2.25$ \\
\hline
\end{tabular}

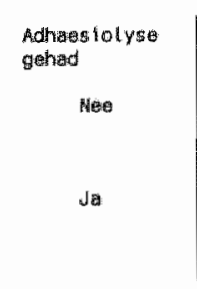

918

1325

Soliphingos tomile genard

Nee

Jロ

Totral

\begin{tabular}{|c|c|c|c|c|c|c|c|c|}
\hline 1238 & $\begin{array}{l}995 \\
80.37\end{array}$ & $\begin{array}{l}879 \\
88.34\end{array}$ & $\begin{array}{l}180 \\
20.48\end{array}$ & 18.09 & 79.44 & $\frac{143}{16.27}$ & 14,37 & 11.55 \\
\hline 1005 & $\begin{array}{l}794 \\
79.00\end{array}$ & 886.40 & $\begin{array}{l}146 \\
21.28\end{array}$ & 18.39 & 76.71 & $\begin{array}{l}912 \\
16.33\end{array}$ & 14.11 & 11.14 \\
\hline 2243 & $\begin{array}{c}1789 \\
79.76\end{array}$ & $\begin{array}{l}1565 \\
87.48\end{array}$ & $\begin{array}{l}326 \\
20.83\end{array}$ & 18.222 & 78.22 & $\begin{array}{l}255 \\
16.29\end{array}$ & 14.25 & 111.37 \\
\hline
\end{tabular}


Biillage 3.12. Resultaten voor paren met als enige indikatie tubapathologie, gesplitst naar bevindingen HSO en diagnostische laparoscopie

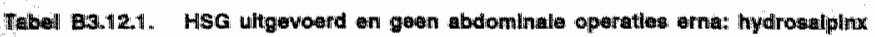

tresultaten miet getoetst)

\begin{tabular}{|c|c|c|c|c|c|c|}
\hline$\therefore$ & WORY & PUIN/HOR & ET/PUA & KL. DMANGIET & $00.2 \mathrm{~W} / \mathrm{PUN}$ & DC. ZW/HOR \\
\hline totata i & 895 & $81 \%$ & $87 \%$ & $22.8 \%$ & $15.8 \%$ & $12.7 \%$ \\
\hline 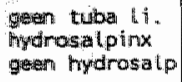 & $\begin{array}{l}134 \\
176 \\
585\end{array}$ & $\begin{array}{l}77 \% \\
83 \% \\
81 \%\end{array}$ & $\begin{array}{l}82 x \\
90 \% \\
87 \%\end{array}$ & $\begin{array}{l}19.1 \% \\
19.1 \% \\
24.78\end{array}$ & $\begin{array}{l}14.6 \% \\
13.7 \% \\
16.7 \%\end{array}$ & $\begin{array}{l}11.2 \% \\
11.4 \% \\
13.5 \%\end{array}$ \\
\hline $\begin{array}{l}\text { geen tuba re. } \\
\text { hydrasalp } p \text { inx } \\
\text { gen hydros.alp }\end{array}$ & $\begin{array}{l}133 \\
177 \\
585\end{array}$ & $\begin{array}{l}75 \% \\
86 \% \\
80 \%\end{array}$ & $\begin{array}{l}86 \% \\
85 \% \\
87 \%\end{array}$ & $\begin{array}{l}26.78 \\
14.6 \% \\
24.5 x\end{array}$ & $\begin{array}{r}18.0 \% \\
9.2 \% \\
17.5 \%\end{array}$ & $\begin{array}{r}13.5 \% \\
7.9 \% \\
14.0 \%\end{array}$ \\
\hline $\begin{array}{l}\text { hyirasa plox } \\
\text { ti. ent of re. }\end{array}$ & 256 & $84 \%$ & $88 \%$ & $17.5 \%$ & $12.0 \%$ & $10.2 \%$ \\
\hline
\end{tabular}

\section{Ronklusies:}

- deze groep is kwa behandelresultaten vergelijkbaar met de totale populatie van paren met als enige indikatie tubapathologie.

- bij aanwezigheid van de tuba zijn de zwangerschapsresultaten in de groep zonder hydrosalpinx iets beter dan in de groep met een hydrosalpinx.

Tabel B3.12.2. Dlagnostleche lapsroweople ultgevoerd In elgen klinlok on geen abdominale operatiee elma (rosultaten niet getoetst):

\begin{tabular}{|c|c|c|c|c|c|c|}
\hline & HORN & PUW/HOR & ET/PLNA & KL. ZWA.NG/ET & DG. ZW/PUN & $\mathrm{DG} .2 \mathrm{~W} / \mathrm{HOR}$ \\
\hline TOTAAL & 650 & $78 \%$ & $83 \%$ & $19.3 \%$ & $11.9 \%$ & $9.2 \%$ \\
\hline \multicolumn{7}{|l|}{ adtares ios tuba } \\
\hline $\begin{array}{l}\text { geen tuba li. } \\
\text { tuba bedekt } \\
\text { tuba niet bed. }\end{array}$ & $\begin{array}{r}131 \\
89 \\
430\end{array}$ & $\begin{array}{l}72 \% \\
78 \% \\
80 \%\end{array}$ & $\begin{array}{l}86 \% \\
78 \% \\
83 \%\end{array}$ & $\begin{array}{l}13.6 \% \\
13.0 \% \\
22.1 \%\end{array}$ & $\begin{array}{r}9.6 \% \\
5.8 \% \\
13.7 \%\end{array}$ & $\begin{array}{r}6.9 \% \\
4.5 \% \\
10.9 \%\end{array}$ \\
\hline $\begin{array}{l}\text { gleen tube re } \\
\text { tuba tbedekt } \\
\text { tublo niet bed. }\end{array}$ & $\begin{array}{r}123 \\
65 \\
462\end{array}$ & $\begin{array}{l}80 \% \\
66 \% \\
79 \%\end{array}$ & $\begin{array}{l}89 \% \\
86 \% \\
81 \%\end{array}$ & $\begin{array}{l}14.8 \% \\
10.8 \% \\
21.7 \%\end{array}$ & $\begin{array}{r}7.1 \% \\
9.3 \% \\
13.5 \%\end{array}$ & $\begin{array}{r}5.7 \% \\
6.2 \% \\
10.6 \%\end{array}$ \\
\hline 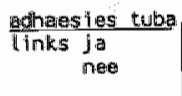 & $\begin{array}{l}358 \\
153\end{array}$ & $\begin{array}{l}80 \% \\
76 \%\end{array}$ & $\begin{array}{l}81 \% \\
85 \%\end{array}$ & $\begin{array}{l}23.3 \% \\
16.2 \%\end{array}$ & $\begin{array}{l}12.9 \% \\
12.0 \%\end{array}$ & $\begin{array}{r}10.3 \% \\
9.2 \%\end{array}$ \\
\hline mechtes ja & $\begin{array}{l}318 \\
197\end{array}$ & $\begin{array}{l}75 \% \\
79 \%\end{array}$ & $\begin{array}{l}80 \% \\
83 \%\end{array}$ & $\begin{array}{l}21.2 \% \\
21.1 \%\end{array}$ & $\begin{array}{l}12.9 \% \\
14.2 \%\end{array}$ & $\begin{array}{r}9.8 \% \\
11.2 \%\end{array}$ \\
\hline \multicolumn{7}{|c|}{ ind ten adhaess ies, ontvang } \\
\hline $\begin{array}{c}\text { hinks, gering } \\
\text { veet }\end{array}$ & $\begin{array}{l}108 \\
247\end{array}$ & $\begin{array}{l}84 \% \\
76 \%\end{array}$ & $81 x$ & $20.7 x$ & $10.91 \%$ & B. $5 x$ \\
\hline 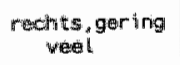 & $\begin{array}{l}13.4 \\
177\end{array}$ & $\begin{array}{l}74 \% \\
77 \%\end{array}$ & $\begin{array}{l}79 \% \\
82 \%\end{array}$ & $\begin{array}{l}21.8 \% \\
22.2 \%\end{array}$ & $\begin{array}{l}13.7 \% \\
13.6 \%\end{array}$ & $\begin{array}{r}9.7 \% \\
10.5 \%\end{array}$ \\
\hline \multicolumn{7}{|c|}{ indien edhaesiles, aard } \\
\hline $\begin{array}{r}\operatorname{liniks}, \text { los } \\
\text { ffix }\end{array}$ & $\begin{array}{l}1111 \\
200\end{array}$ & $\begin{array}{l}79 \% \\
79 \%\end{array}$ & $\begin{array}{l}84 \% \\
81 \%\end{array}$ & $\begin{array}{l}21.6 \% \\
23.4 \%\end{array}$ & $\begin{array}{l}14.8 \% \\
12.7 \%\end{array}$ & $\begin{array}{l}11.7 \% \\
10.0 \%\end{array}$ \\
\hline rechts: los & $\mid 121$ & $\begin{array}{l}76 \% \\
75 \%\end{array}$ & $\begin{array}{l}84 \% \\
81 \%\end{array}$ & $\begin{array}{l}18.2 \% \\
21.4 \%\end{array}$ & $\begin{array}{l}10.9 \% \\
12.4 \%\end{array}$ & $\begin{array}{l}8.3 \% \\
9.3 \%\end{array}$ \\
\hline
\end{tabular}




\begin{tabular}{|c|c|c|c|c|c|c|}
\hline A & 1000 & 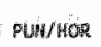 & thengsh & 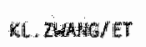 & $D G .7 \mathrm{~W} / \mathrm{P} / \mathrm{M}$ & DE. $2 W /$ HOW \\
\hline 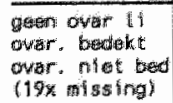 & $\begin{array}{r}87 \\
118 \\
426\end{array}$ & $\begin{array}{l}68 \% \\
89 \% \\
79 \%\end{array}$ & $\begin{array}{l}614 \\
759 \% \\
24 \%\end{array}$ & $\begin{array}{l}14.6 \% \\
21.3 \% \\
19.4 \%\end{array}$ & $\begin{array}{l}0.54 \\
14.74 \\
11.64\end{array}$ & $\begin{array}{r}5.3 \% \\
11.92 \\
9.2 \%\end{array}$ \\
\hline 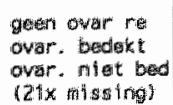 & $\begin{array}{r}48 \\
103 \\
478\end{array}$ & $\begin{array}{l}35 \% \\
79 \% \\
774\end{array}$ & $\begin{array}{l}86 \% \\
814 \\
834\end{array}$ & $\begin{array}{l}14.7 \% \\
16.2 \% \\
19.5 \%\end{array}$ & $\begin{array}{l}4.8 \% \\
14.8 \% \\
11.7 \%\end{array}$ & $\begin{array}{r}4.2 \% \\
11.7 \% \\
9.0 \%\end{array}$ \\
\hline \multicolumn{7}{|c|}{ 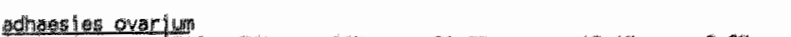 } \\
\hline 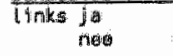 & $\begin{array}{l}348 \\
176\end{array}$ & $79 \%$ & $\begin{array}{l}32 \text { 端 } \\
85 \%\end{array}$ & $\begin{array}{l}21.2 \% \\
16.4 \%\end{array}$ & $\begin{array}{l}12,44 \\
11.74\end{array}$ & $\begin{array}{l}9.4 \% \\
9.0 \%\end{array}$ \\
\hline rachts de & $\begin{array}{l}331 \\
235\end{array}$ & $\begin{array}{l}76 \% \\
77 \%\end{array}$ & $\begin{array}{l}82 \% \\
44 \%\end{array}$ & $\begin{array}{l}18.28 \\
18.3 \%\end{array}$ & $\begin{array}{l}11.54 \\
12.9 \%\end{array}$ & $\begin{array}{l}8.84 \\
9.4 \%\end{array}$ \\
\hline \multicolumn{7}{|c|}{ 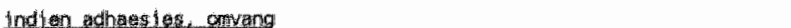 } \\
\hline 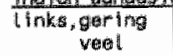 & $\begin{array}{l}146 \\
193\end{array}$ & $\begin{array}{l}77 \% \\
8 \% 4\end{array}$ & 804 & $\begin{array}{l}22.2 \% \\
21.2 \%\end{array}$ & $\begin{array}{l}13.4 \% \\
12.1 \%\end{array}$ & $\begin{array}{r}10.3 \% \\
9.8 \%\end{array}$ \\
\hline $\begin{array}{l}\text { rechtis, grarting } \\
\text { veat }\end{array}$ & 125 & $\begin{array}{l}71 \% \\
8004\end{array}$ & $\begin{array}{l}80 \% \\
85 \%\end{array}$ & $\begin{array}{l}28.240 \\
14.4 \%\end{array}$ & $\begin{array}{r}18.0 \% \\
8.3 \%\end{array}$ & $\begin{array}{r}12.8 x \\
6.72\end{array}$ \\
\hline \multicolumn{7}{|c|}{ Ind ien aghnaesios aro } \\
\hline $\begin{array}{c}\text { dinksi, los } \\
\text { fix }\end{array}$ & $\begin{array}{l}149 \\
180\end{array}$ & $\begin{array}{l}78 \% \\
795 \%\end{array}$ & $\begin{array}{l}80 \% \\
83 \%\end{array}$ & $\begin{array}{l}21.6 \% \\
21.0 \%\end{array}$ & $\begin{array}{l}12.9 \% \\
11.9 \%\end{array}$ & $\begin{array}{r}10.1 \% \\
9.4 \%\end{array}$ \\
\hline rechtes tos & $\frac{109}{1166}$ & $\begin{array}{l}71 \% \\
78 \%\end{array}$ & $\begin{array}{l}79 \% \\
82 \%\end{array}$ & $\begin{array}{l}16.4 \% \\
18,9 \%\end{array}$ & $\begin{array}{l}10.4 \% \\
11.5 \%\end{array}$ & $\begin{array}{l}7.34 \\
9.0 \%\end{array}$ \\
\hline
\end{tabular}

rontiolinatios yan adhaes fiest

\begin{tabular}{|c|c|c|c|c|c|c|}
\hline & iDR & ind $\mathrm{no}$ & $\mathrm{E} / / \mathrm{T}$ & & & \\
\hline 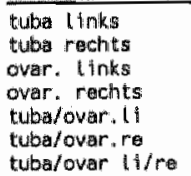 & $\begin{array}{l}408 \\
337 \\
347 \\
390 \\
415 \\
369 \\
475\end{array}$ & $\begin{array}{l}76 \% \\
784 \\
764 \\
811 \\
77 \% \\
784 \\
78 \%\end{array}$ & $\begin{array}{l}82 \% \\
83 \% \\
83 \% \\
84 \% \\
82 \% \\
83 \% \\
83 \%\end{array}$ & $\begin{array}{l}18.8 \% \\
18.4 \% \\
19.2 \% \\
17.9 \% \\
19.1 \% \\
18.4 \% \\
17.9 \%\end{array}$ & $\begin{array}{l}10.3 \% \\
10.3 \% \\
11.0 \% \\
10.3 \% \\
10.7 \% \\
10.8 \% \\
10.2 \%\end{array}$ & $\begin{array}{l}7.8 \% \\
8.0 \% \\
8.4 \% \\
8.3 \% \\
8.2 \% \\
8.4 \% \\
8.0 \%\end{array}$ \\
\hline
\end{tabular}

\section{Konklusies}

a. Indien de tuba (aanwezig is en) bedekt is door adhaesies worden enigszins lagere zwangerschapsresultaten bereikt.

b. Bij adhaesievorming in het algemeen op tuba en/of ovarium bestaat geen duidelijk verschil in resultaten ten opzichte van de patjënten zonder adhaesies. Daarbij is nog op te merken dat adhaesievorming op tubae/ovaria relatief vaak gemeld werd voor patiënten uit ziekenhuis 3 en relatief weinig voor patiënten uit ziekenhuis 4 en ziekenhuis 5 .

d. Indien adhaesies aanwezig zijn, dan ligt het zwangerschapspercentage hoger bij patiënten met weinig adhaesies ten opzichte van patiënten met veel adhaesies; dat geldt zowel woor adhaesies aan de tulba. als aan het ovarium.

e. Indien adhaesies aanwezig zijn, dan bestaat er geen verschil in zwangerschapsresultaten bij splitsing van de patienten naar de aard van de adhaesies.

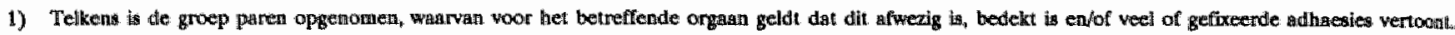


Biilage 3,13. Resultaten, gesplitst naar verzekeringsvorm

\begin{tabular}{|c|c|c|c|c|c|c|c|c|c|}
\hline $\begin{array}{l}\text { Werzelke- } \\
\text { nswom }\end{array}$ & Hormon: & $\begin{array}{l}\text { PUBMTIE } \\
\text { percentage } \\
\text { per hom }\end{array}$ & $\begin{array}{l}\text { ET } \\
\text { percentage } \\
\text { per punkt í }\end{array}$ & $\begin{array}{l}\text { TWANGER } \\
\text { percentage } \\
\text { per ET }\end{array}$ & $\begin{array}{l}\text { ZWHASER } \\
\text { per } \\
\text { punkt io }\end{array}$ & $\begin{array}{l}\text { Dookichand } \\
\text { zwonger } \\
\text { per } \\
\text { zwanger }\end{array}$ & $\begin{array}{c}\text { DoORGAANO } \\
\text { zwangier } \\
\text { per ET }\end{array}$ & 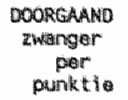 & $\begin{array}{c}\text { DookEAAND } \\
\text { zwangeir } \\
\text { pur } \\
\text { hormion }\end{array}$ \\
\hline 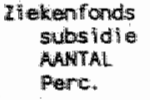 & 1777 & $\begin{array}{l}1426 \\
80.25\end{array}$ & $\frac{1221}{85.62}$ & $\begin{array}{l}23.6 \\
19.33\end{array}$ & 16.55 & 77.54 & $\begin{array}{l}183 \\
14.99\end{array}$ & 12.83 & 10.30 \\
\hline $\begin{array}{l}\text { genen stbss } \\
\text { MANTAL } \\
\text { Perc. }\end{array}$ & 379 & $\begin{array}{l}304 \\
80.21\end{array}$ & $\begin{array}{l}246 \\
80.92\end{array}$ & $\begin{array}{l}45 \\
18.29\end{array}$ & 14.80 & 77.78 & $\begin{array}{l}35 \\
14.23\end{array}$ & 11.51 & 9.23 \\
\hline $\begin{array}{l}\text { totaal } \\
\text { MANTAL } \\
\text { Perc. }\end{array}$ & 2156 & $\begin{array}{l}1730 \\
80.24\end{array}$ & $\begin{array}{l}1467 \\
184.80^{\circ}\end{array}$ & $\begin{array}{l}281 \\
19.15\end{array}$ & 16.24 & 7.58 & $\begin{array}{l}218 \\
14.86\end{array}$ & 12.60 & 10.11 \\
\hline $\begin{array}{l}\text { Particulier } \\
\text { MATAL } \\
\text { Percentage }\end{array}$ & 936 & $\begin{array}{l}736 \\
78.63\end{array}$ & $\begin{array}{l}622 \\
84.51\end{array}$ & $\begin{array}{l}135 \\
21.70\end{array}$ & 18.34 & $\pi .78$ & $\begin{array}{l}105 \\
16.88\end{array}$ & 14.27 & 11.22 \\
\hline $\begin{array}{l}\text { TOTHAL } \\
\text { AHATAL } \\
\text { Parcentage }\end{array}$ & 3092 & $\begin{array}{r}2466 \\
79.75\end{array}$ & $\begin{array}{l}2089 \\
84.71\end{array}$ & $\begin{array}{l}416 \\
19.91\end{array}$ & 16.87 & $\pi .64$ & $\begin{array}{l}323 \\
15.46\end{array}$ & 15.10 & 10.45 \\
\hline
\end{tabular}


Bjlage 3.14.Resultaten, gesplits naar aanwezigheid ovaria: ook gestratificerd naar eerrtel yeruolgbehandeling en per ziekenhuis

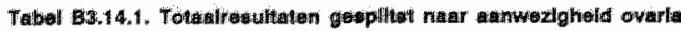

\begin{tabular}{|c|c|c|c|c|c|c|c|c|c|}
\hline $\begin{array}{l}\text { Aartal } \\
\text { guar ba }\end{array}$ & Hots ototh & 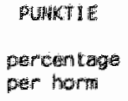 & 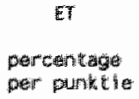 & $\begin{array}{l}\text { TWHEGER } \\
\text { garcentege } \\
\text { por ET }\end{array}$ & 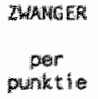 & 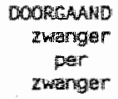 & $\begin{array}{l}\text { Dookitanut } \\
\text { zwanger } \\
\text { per ET }\end{array}$ & $\begin{array}{c}\text { DOORGAAND } \\
\text { thanger } \\
\text { per } \\
\text { punktie }\end{array}$ & 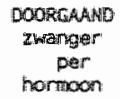 \\
\hline 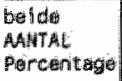 & $2 \sin 40$ & $\begin{array}{l}1994 \\
81.72\end{array}$ & $\begin{array}{l}1704 \\
85.46\end{array}$ & $\begin{array}{l}348 \\
20.42\end{array}$ & 17.45 & 78.45 & $\begin{array}{l}273 \\
16.02\end{array}$ & 13.69 & 11.19 \\
\hline 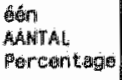 & 652 & $\begin{array}{l}472 \\
72.39\end{array}$ & $\frac{385}{31.57}$ & $\begin{array}{l}68 \\
17.66\end{array}$ & 14.41 & 73.53 & $\frac{50}{72} 99$ & 10.59 & 7.67 \\
\hline $\begin{array}{l}\text { TOTAAL } \\
\text { ANATAL } \\
\text { Paricenkage }\end{array}$ & 3092 & $\begin{array}{c}2466 \\
79.75^{m}\end{array}$ & $\begin{array}{l}2089 \\
04.71^{*}\end{array}$ & $\begin{array}{l}4.6 \\
10.91\end{array}$ & 16.87 & 77.64 & $\begin{array}{l}323 \\
15.46\end{array}$ & 13.10 & $10.45^{4}$ \\
\hline
\end{tabular}

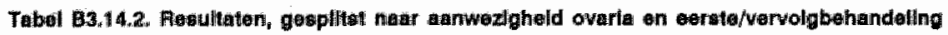

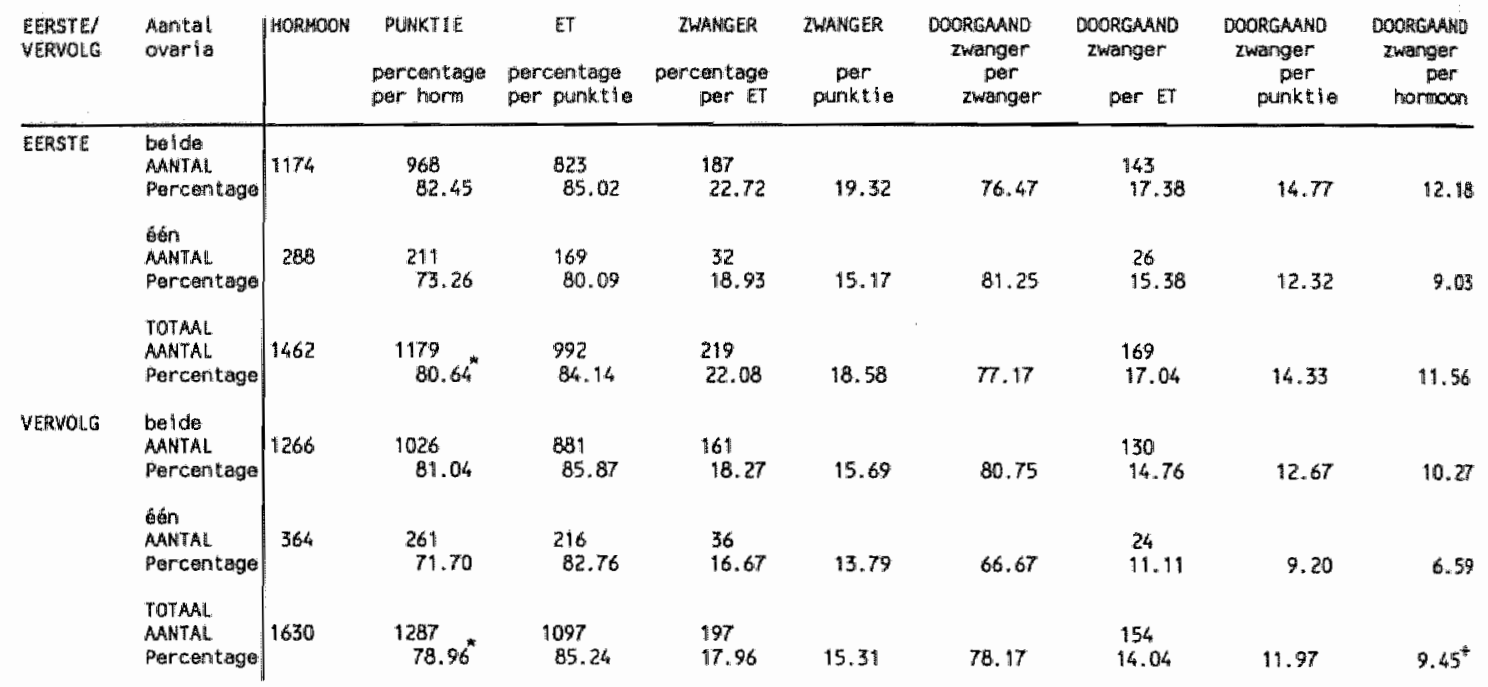




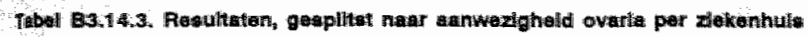

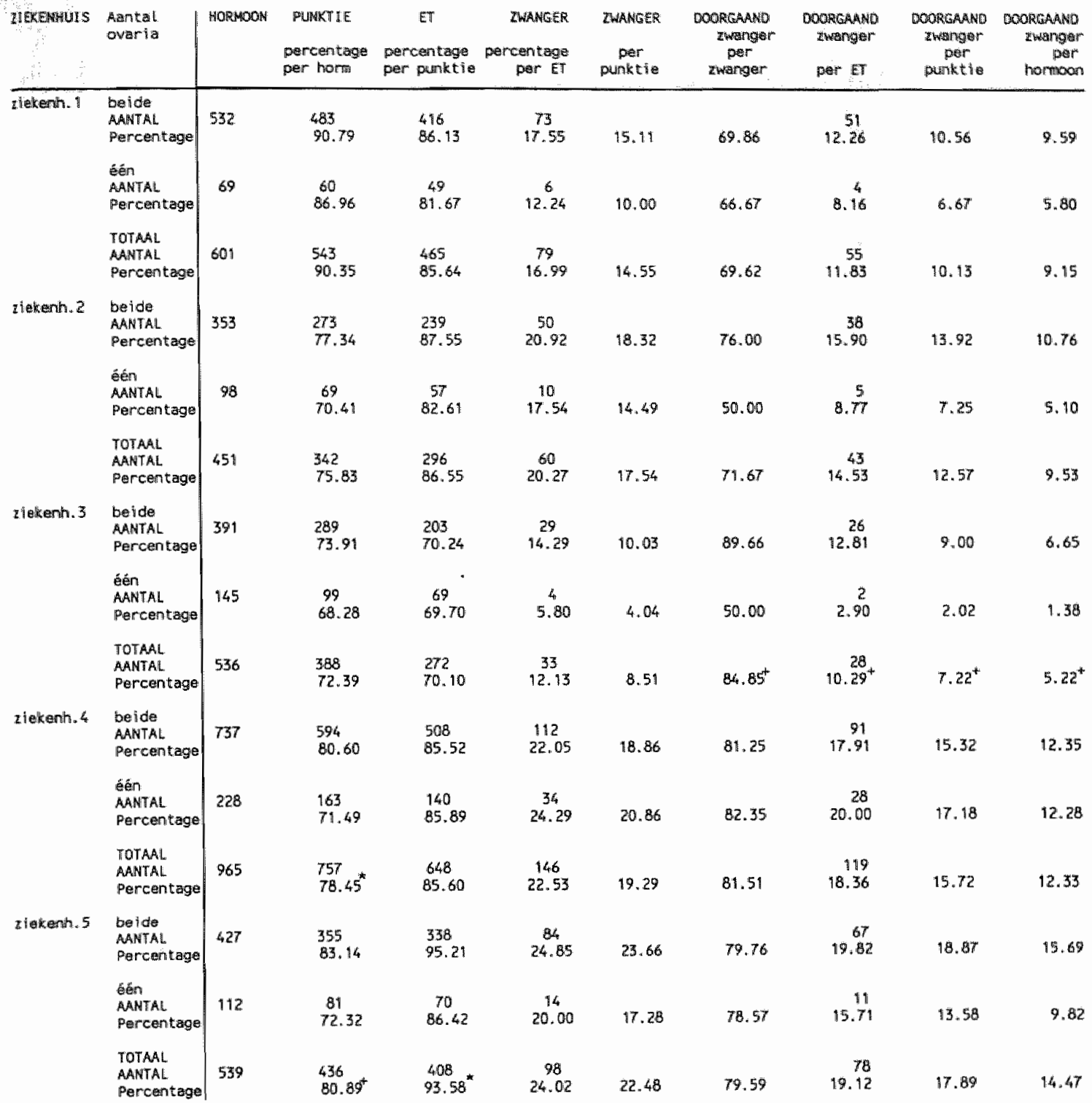


Bijlage 3.15. Susksespercentages, gesplitst naar infertiliteitsduur en graviditeit

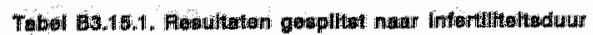

\begin{tabular}{|c|c|c|c|c|c|c|c|c|c|}
\hline $\begin{array}{l}\text { Inforthl } \\
\text { teltidur }\end{array}$ & HOHH WOOH & $\begin{array}{l}\text { PUwkT IE } \\
\text { perecentag } \\
\text { per horth }\end{array}$ & 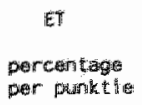 & $\begin{array}{l}\text { ZHAWGER } \\
\text { percertiego } \\
\text { per EV }\end{array}$ & $\begin{array}{c}\text { ZWAKEGER } \\
\text { Der } \\
\text { purket le }\end{array}$ & 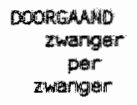 & $\begin{array}{l}\text { DOORGAAMD } \\
\text { Ziwarnger } \\
\text { per ET }\end{array}$ & 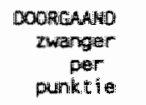 & 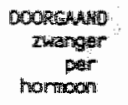 \\
\hline $\begin{array}{l}\text { AHATAL } \\
\text { Porcentage }\end{array}$ & 2 & $\frac{17}{17.27}$ & $\begin{array}{l}13 \\
76.47\end{array}$ & $\frac{2}{15.38}$ & 11.76 & 100.00 & $\frac{2}{15.38}$ & 111.76 & $9.0 \%$ \\
\hline 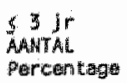 & 835 & $\begin{array}{l}705 \\
84.43\end{array}$ & $\begin{array}{l}630 \\
89.36\end{array}$ & $\begin{array}{l}149 \\
23.65\end{array}$ & 21.13 & 76.51 & $\begin{array}{l}114 \\
18.10\end{array}$ & 16.17 & 13.65 \\
\hline $\begin{array}{l}4-5 \text { j } \\
\text { AMNTAL } \\
\text { Percentage }\end{array}$ & 592 & $\begin{array}{l}484 \\
81.93\end{array}$ & $\begin{array}{l}422 \\
87.01\end{array}$ & $\begin{array}{l}86 \\
20,38\end{array}$ & 17.73 & 80.23 & 69 & 14.23 & 11.66 \\
\hline $\begin{array}{l}26 \mathrm{Jr} \\
\text { AANTAL } \\
\text { Porcentage }\end{array}$ & 1643 & $\frac{1259}{76.63}$ & $\begin{array}{c}102^{k_{4}} \\
81.33\end{array}$ & $\begin{array}{l}179 \\
17.48\end{array}$ & 14.22 & 77.09 & $\begin{array}{l}138 \\
13.48\end{array}$ & 10.96 & 8.40 \\
\hline
\end{tabular}

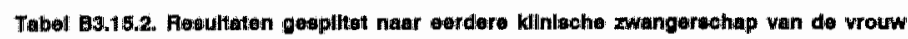

\begin{tabular}{|c|c|c|c|c|c|c|c|c|c|}
\hline $\begin{array}{l}\text { Eordere kl tin. } \\
\text { zwangersehis } \\
\text { yrodst }\end{array}$ & HORHOON & $\begin{array}{l}\text { PUSWKTIE } \\
\text { percentag } \\
\text { per hormit }\end{array}$ & $\begin{array}{l}\text { ET } \\
\text { percentage } \\
\text { per puntitio }\end{array}$ & $\begin{array}{l}\text { ZWAAGER: } \\
\text { percentage } \\
\text { per ET }\end{array}$ & $\begin{array}{c}\text { ZWANGER } \\
\text { per } \\
\text { purvktle }\end{array}$ & $\begin{array}{c}\text { DOORGAAND } \\
\text { zhwanger } \\
\text { per } \\
\text { zwanger }\end{array}$ & $\begin{array}{l}\text { DOORGAMNO } \\
\text { 2wanger } \\
\text { per ET }\end{array}$ & $\begin{array}{c}\text { DoORGAANO } \\
\text { zwanger } \\
\text { per } \\
\text { punktio }\end{array}$ & $\begin{array}{c}\text { Docotchasilo } \\
\text { zhranger } \\
\text { per } \\
\text { hormioon }\end{array}$ \\
\hline $\begin{array}{l}\text { nee } \\
\text { AANTAL. } \\
\text { Percentages }\end{array}$ & 1662 & $\begin{array}{l}1301 \\
78.28\end{array}$ & $\begin{array}{l}1077 \\
82.78\end{array}$ & $\begin{array}{l}199 \\
18.48\end{array}$ & 15.30 & 78.39 & $\begin{array}{l}156 . \\
14.48\end{array}$ & 11.59 & 9.39 \\
\hline $\begin{array}{l}\text { TOTAALL. } \\
\text { AANTAL: } \\
\text { Percientagess }\end{array}$ & 3092 & $\begin{array}{l}2466 \\
79.75^{\circ}\end{array}$ & $\frac{2089}{84.71^{*}}$ & $\begin{array}{l}416 \\
19.91\end{array}$ & $16.87^{+}$ & 77.64 & $\begin{array}{l}323 \\
15.46\end{array}$ & 13.110 & $10.45^{+}$ \\
\hline
\end{tabular}

Tabel B3.15.3. Reaultaten geaplitet naar ardere klinische zwangersehap van hot pear

\begin{tabular}{|c|c|c|c|c|c|c|c|c|c|}
\hline $\begin{array}{l}\text { Eerdere klin. } \\
\text { zwangerschap } \\
\text { paar }\end{array}$ & HORMODN & $\begin{array}{l}\text { PUNKTIE } \\
\text { percentag } \\
\text { per thorm }\end{array}$ & $\begin{array}{l}\text { ET } \\
\text { percentage } \\
\text { par punktie }\end{array}$ & $\begin{array}{l}\text { ZWAMGER } \\
\text { percentage } \\
\text { per ET }\end{array}$ & $\begin{array}{c}\text { ZWANEER } \\
\text { per } \\
\text { punktio }\end{array}$ & $\begin{array}{c}\text { DOORGAAND } \\
\text { zwanger } \\
\text { per } \\
\text { zwanger }\end{array}$ & $\begin{array}{l}\text { DOORGMAND } \\
\text { z'wanger } \\
\text { por ET }\end{array}$ & $\begin{array}{c}\text { COORGAAMID } \\
\text { zwanger } \\
\text { per } \\
\text { punktia }\end{array}$ & $\begin{array}{c}\text { DOCRGAAMD } \\
\text { Zw warger } \\
\text { per } \\
\text { hormoon }\end{array}$ \\
\hline $\begin{array}{l}\text { Ja } \\
\text { AANTAL } \\
\text { Porcentagos }\end{array}$ & 1105 & $\begin{array}{l}914 \\
82.71\end{array}$ & $\begin{array}{l}795 \\
86.98\end{array}$ & $\begin{array}{l}179 \\
22,52\end{array}$ & 19.58 & 7.65 & $\begin{array}{l}139 \\
17.48\end{array}$ & 15.21 & 12.58 \\
\hline $\begin{array}{l}\text { noe } \\
\text { AARTAL } \\
\text { Perceritiagues }\end{array}$ & 1987 & $\begin{array}{l}1552 \\
78.11\end{array}$ & $\begin{array}{r}1294 \\
83.38\end{array}$ & $\begin{array}{l}237 \\
18.32\end{array}$ & 115.27 & 77.64 & $\begin{array}{l}184 \\
14.22\end{array}$ & 11.86 & 9.26 \\
\hline $\begin{array}{l}\text { TOTAAL } \\
\text { AANTAL } \\
\text { Parcintages }\end{array}$ & 3092 & $\begin{array}{c}2466 \\
79.75\end{array}$ & $\frac{2089}{84.71^{+}}$ & $\begin{array}{l}416 \\
99.91^{+}\end{array}$ & $16.87^{+}$ & 77.64 & $\frac{3.23}{15.46^{+}}$ & $13.10^{+}$ & $10.45^{*}$ \\
\hline
\end{tabular}




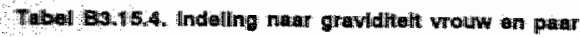

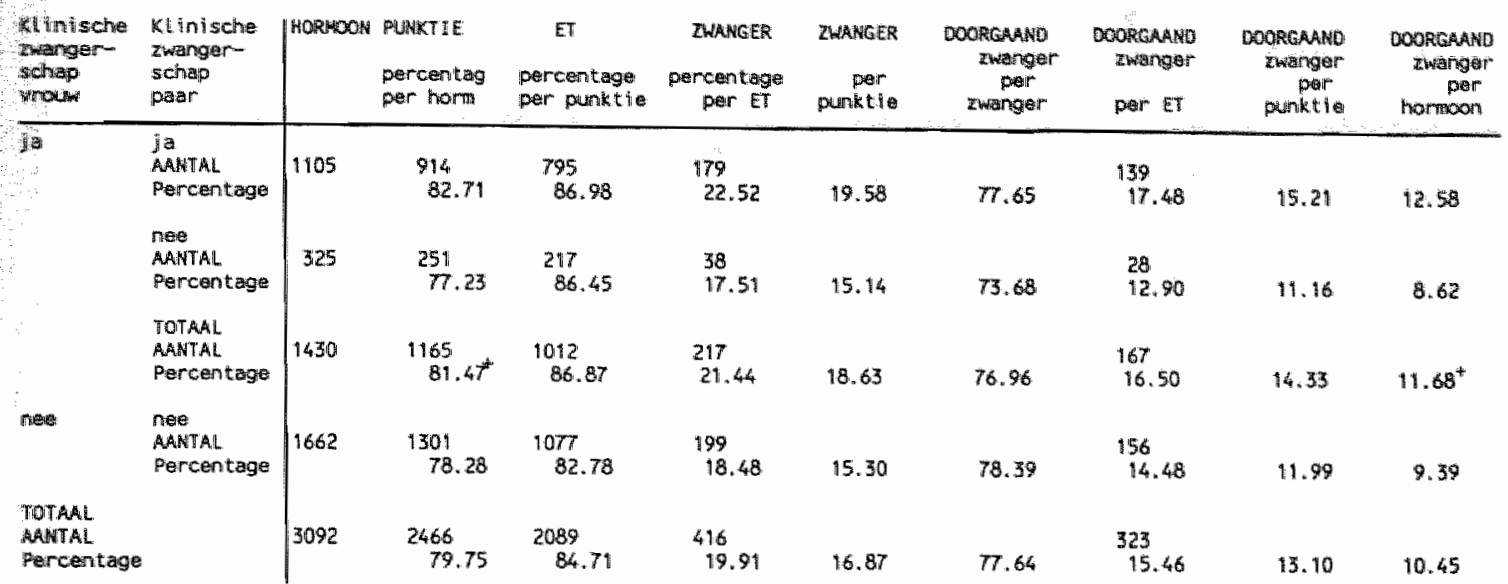

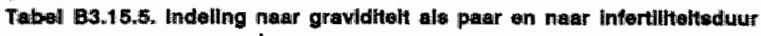

\begin{tabular}{|c|c|c|c|c|c|c|c|c|c|c|}
\hline $\begin{array}{l}\text { Eerdero } \\
\text { lkin, zin. } \\
\text { amar }\end{array}$ & $\begin{array}{l}\text { Infertili- } \\
\text { teitsduur }\end{array}$ & HORMOON & $\begin{array}{l}\text { PUNXTIE } \\
\text { percentag } \\
\text { per homin }\end{array}$ & $\begin{array}{l}\text { ET } \\
\text { percentage } \\
\text { per puniktie }\end{array}$ & $\begin{array}{c}\text { TWANGER } \\
\text { pericentage } \\
\text { per ET }\end{array}$ & $\begin{array}{c}\text { ZWANGER } \\
\text { per } \\
\text { punktie }\end{array}$ & $\begin{array}{c}\text { DOORGAAND } \\
\text { zwanger } \\
\text { pier } \\
\text { zwanger }\end{array}$ & $\begin{array}{c}\text { DOORGANAD } \\
\text { Ewanger } \\
\text { pDer ET }\end{array}$ & $\begin{array}{c}\text { DOORGAAND } \\
\text { Zwanger } \\
\text { per } \\
\text { punktio }\end{array}$ & $\begin{array}{c}\text { DODRGAANO } \\
\text { 2wanger } \\
\text { par } \\
\text { hormoen }\end{array}$ \\
\hline \multirow[t]{4}{*}{ ia } & $\begin{array}{l}\leq 3 \mathrm{j} r \\
\text { AANTAL } \\
\text { PERcen'tage }\end{array}$ & 571 & $\begin{array}{l}494 \\
86.51\end{array}$ & $\begin{array}{l}448 \\
90.69\end{array}$ & $\begin{array}{l}109 \\
24.33\end{array}$ & 22.06 & 79.82 & $\begin{array}{l}87 \\
18.42\end{array}$ & 17.64 & 15.24 \\
\hline & $\begin{array}{l}4-5 \text { Jr } \\
\text { AAMTAL } \\
\text { Percentage }\end{array}$ & 173 & $\begin{array}{c}141 \\
81.50\end{array}$ & $\begin{array}{l}123 \\
87.23\end{array}$ & $\begin{array}{l}23 \\
18.70\end{array}$ & 16.31 & 69.57 & $\begin{array}{l}16 . \\
13.01\end{array}$ & 11.35 & 9.25 \\
\hline & $\begin{array}{l}36 \text { ir } \\
\text { AANTAL } \\
\text { Percentage }\end{array}$ & 361 & $\frac{279}{77.29}$ & $\begin{array}{l}22 x_{k} \\
80.29\end{array}$ & $\begin{array}{l}47 \\
20.98\end{array}$ & 16.85 & 76.60 & $\begin{array}{l}36 \\
16.07\end{array}$ & 12.90 & 9.97 \\
\hline & $\begin{array}{l}\text { TOTAALL } \\
\text { AANTAL } \\
\text { Percentage }\end{array}$ & 1105 & $\begin{array}{l}914 \\
82^{*} .71^{*}\end{array}$ & $\begin{array}{l}795 \\
86.98^{*}\end{array}$ & $\begin{array}{l}179 \\
22.52\end{array}$ & $19.58^{*}$ & 77.65 & $\begin{array}{l}139 \\
17.48\end{array}$ & $15.21^{+}$ & $12.58^{4 n}$ \\
\hline \multirow[t]{5}{*}{ nee } & $\begin{array}{l}\text { AANTAL } \\
\text { Percientage }\end{array}$ & 22 & $\frac{17}{77.27}$ & $\begin{array}{l}13 \\
76.47\end{array}$ & ${ }^{2} 5^{2} .38$ & 11.76 & 100.00 & 15.38 & 11.76 & 9.09 \\
\hline & $\begin{array}{l}\text { \& } 3 \text { jr } \\
\text { ANTAL } \\
\text { Pencentage }\end{array}$ & 264 & $\begin{array}{l}211 \\
79.92\end{array}$ & $\begin{array}{l}182 \\
86.26\end{array}$ & $\begin{array}{l}40 \\
21.98\end{array}$ & 18.96 & 67.50 & $\begin{array}{l}27 \\
14,284\end{array}$ & 12.80 & 10.23 \\
\hline & $\begin{array}{l}4-5 \text { jr } \\
\text { AuntAL. } \\
\text { Percentage }\end{array}$ & 4191 & $\begin{array}{r}3.44 \\
82.10\end{array}$ & 89.92 & $\begin{array}{l}63 \\
21.07\end{array}$ & 18.31 & 24.13 & $\begin{array}{l}53 \\
17,73\end{array}$ & 15.41 & 12.65 \\
\hline & $\begin{array}{l}36 \mathrm{jr} \\
\text { AAMIAL } \\
\text { Percentags }\end{array}$ & 1282 & 980 & $\begin{array}{l}800 \\
81.63\end{array}$ & $\begin{array}{l}132 \\
16.50\end{array}$ & 13.47 & 77.27 & $\begin{array}{l}102 \\
12.75\end{array}$ & 10.41 & 7.96 \\
\hline & $\begin{array}{l}\text { TOTAAL } \\
\text { AAMIAE } \\
\text { Percentage }\end{array}$ & 1987 & $\begin{array}{l}1552 \\
78.11^{*}\end{array}$ & $\begin{array}{r}1294 \\
83.38^{*}\end{array}$ & $\begin{array}{l}237 \\
18.32^{*}\end{array}$ & $15.27^{*}$ & 77.64 & ${ }^{184}, 22^{*}$ & $11.86^{*}$ & $9.26^{4}$ \\
\hline
\end{tabular}

1) Hiler werd getoetst de reswltaten bij een infertiliteitsdur $\leq 3$ jaren versw $\geq 4$ jaren.

2) Hier werd getoetst de resultaten bij een infertiliteitsdu $u r \leq 5$ jaren vergus $\geq 6$ jaren 
Bijlage 3,16. Signifikante korrelaties op patientnivo tussen patientkenmerken en ziekenbuisdummies

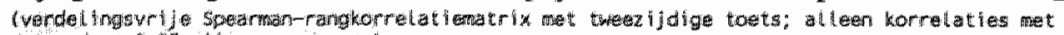

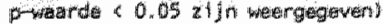

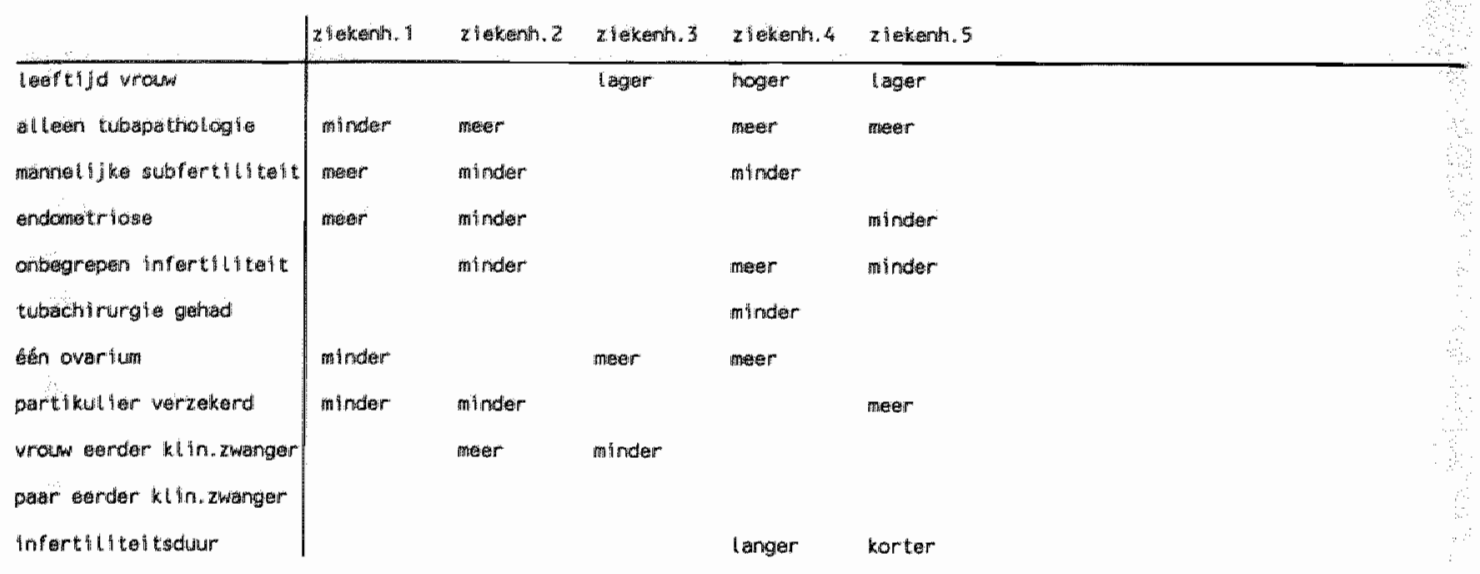

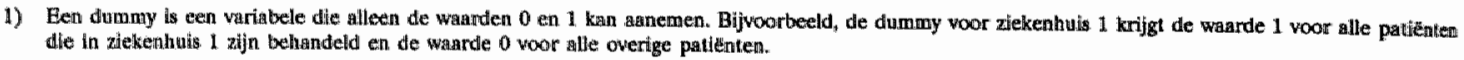


Biilage 3.17. Resultaten, gesplitst naar volgnummer van de hormoonstimulatie

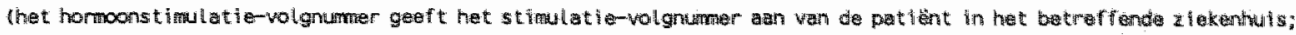

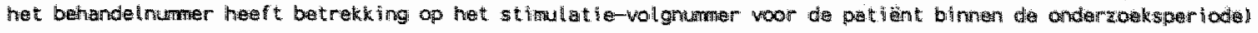

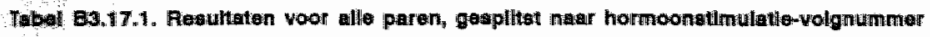

\begin{tabular}{|c|c|c|c|c|c|c|c|c|c|}
\hline 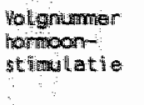 & HORRONN & $\begin{array}{l}\text { PUMKTIE } \\
\text { percentage } \\
\text { per horm }\end{array}$ & $\begin{array}{l}\text { ET } \\
\text { percentage } \\
\text { per punktie }\end{array}$ & $\begin{array}{c}\text { ZwAWGER } \\
\text { percentage } \\
\text { per ET }\end{array}$ & $\begin{array}{c}\text { ZWANGER } \\
\text { per } \\
\text { purntkt ie }\end{array}$ & $\begin{array}{c}\text { DOORGAANO } \\
\text { zwanger } \\
\text { per } \\
\text { zwanger }\end{array}$ & $\begin{array}{l}\text { DOORGAAAND } \\
\text { Jivariger } \\
\text { per ET }\end{array}$ & 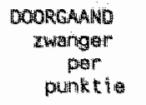 & 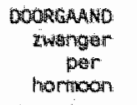 \\
\hline $\begin{array}{l}\text { I } \\
\text { PaNTAL. } \\
\text { Percentige }\end{array}$ & 1158 & $\begin{array}{l}928 \\
80.14\end{array}$ & $\begin{array}{l}787 \\
84.811\end{array}$ & $\begin{array}{l}177 \\
22.49\end{array}$ & 19.07 & 79.66 & $\begin{array}{l}141 \\
17.92\end{array}$ & 15.79 & 12.18 \\
\hline $\begin{array}{l}\text { Z } \\
\text { MANTAL } \\
\text { Marantage }\end{array}$ & 845 & $\begin{array}{l}652 \\
78.34\end{array}$ & $\begin{array}{l}549 \\
82.93\end{array}$ & $\begin{array}{l}113 \\
20.58\end{array}$ & 17.07 & 78.76 & $\begin{array}{l}89 \\
16.21\end{array}$ & 13.44 & 10.53 \\
\hline $\begin{array}{c}3 \\
\text { PandTAL } \\
\text { Pentege }\end{array}$ & 548 & $\begin{array}{l}446 \\
81.39\end{array}$ & $\begin{array}{l}376 \\
84.30\end{array}$ & $\begin{array}{l}75 \\
19.95\end{array}$ & $16 \ldots .2$ & 74.67 & $\begin{array}{l}56 \\
14.89\end{array}$ & 12.56 & 10.22 \\
\hline $\begin{array}{l}2 \text { tezamera } \\
\text { Muktal } \\
\text { Percentage }\end{array}$ & 541 & $\begin{array}{l}430 \\
79.48\end{array}$ & $\begin{array}{l}377 \\
87.67\end{array}$ & $\begin{array}{l}51 \\
13.53\end{array}$ & 11.86 & 72.55 & $\begin{array}{l}37 \\
9.81\end{array}$ & 8.60 & 6.84 \\
\hline $\begin{array}{l}\text { TOTAAL } \\
\text { AMANALAL } \\
\text { Piercentiage }\end{array}$ & 3092 & $\begin{array}{l}2466 \\
79.75\end{array}$ & $\begin{array}{l}2089 \\
84.71\end{array}$ & $\frac{496}{19.91^{*}}$ & $16.87^{*}$ & 77.64 & $\frac{323}{15.46^{*}}$ & $13.10^{+}$ & $10.45^{4}$ \\
\hline 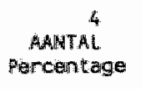 & 281 & $\frac{223}{79.36}$ & $\begin{array}{l}197 \\
88.34\end{array}$ & $\begin{array}{l}25 \\
12.69\end{array}$ & 11.21 & 86.00 & $\begin{array}{l}21 \\
10.66\end{array}$ & 9.42 & 7.47 \\
\hline $\begin{array}{c}5 \\
\text { AANT AuL } \\
\text { Percentage }\end{array}$ & 138 & $\begin{array}{l}190 \\
79.71\end{array}$ & $\begin{array}{l}95 \\
86.36\end{array}$ & $\begin{array}{l}18 \\
18.95\end{array}$ & 16.36 & 72.22 & $\begin{array}{l}13 \\
13.68\end{array}$ & 11.82 & 9.4 .2 \\
\hline $\begin{array}{c}6 \\
\text { PercintaL } \\
\text { Percentage }\end{array}$ & 65 & $\begin{array}{l}52 \\
80.00\end{array}$ & $\begin{array}{l}45 \\
86.54\end{array}$ & $\stackrel{5}{11.11}$ & 9.62 & 60.00 & $\begin{array}{l}3 \\
6.67\end{array}$ & 5.77 & 4.62 \\
\hline $\begin{array}{c}T \\
\text { Mantmit. } \\
\text { Pencentage }\end{array}$ & 26 & $\begin{array}{l}22 \\
84.62\end{array}$ & $\begin{array}{l}21 \\
95.45\end{array}$ & $\frac{1}{4.76}$ & 4.55 & 0.00 & $\begin{array}{l}0 \\
0.00\end{array}$ & 0.00 & 0.00 \\
\hline $\begin{array}{c}8 \\
\text { HANATIL } \\
\text { Percentange }\end{array}$ & 12 & $\frac{8}{66.67}$ & $\frac{6}{75.00}$ & $\begin{array}{l}0 \\
0.00\end{array}$ & 0.00 & . & $\begin{array}{l}0 \\
0.00\end{array}$ & 0.00 & 0.00 \\
\hline 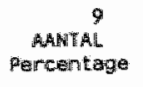 & 7 & $\begin{array}{c}7 \\
100.00\end{array}$ & 85.71 & $\begin{array}{l}0 \\
0.00\end{array}$ & 0.00 & . & $\begin{array}{l}0 \\
0.00\end{array}$ & 0.00 & 0.00 \\
\hline $\begin{array}{c}\text { 30 } \\
\text { AWINTAL } \\
\text { Percentage }\end{array}$ & 12 & $\begin{array}{c}8 \\
66.6 \pi\end{array}$ & $\frac{7}{87.50}$ & $\begin{array}{c}2 \\
28.57\end{array}$ & 25.00 & . & $\begin{array}{l}0 \\
0.00\end{array}$ & 0.00 & 0.00 \\
\hline
\end{tabular}




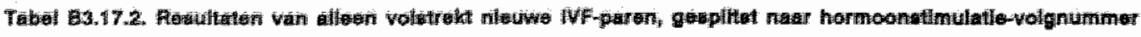

\begin{tabular}{|c|c|c|c|c|c|c|c|c|c|}
\hline 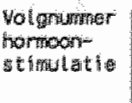 & 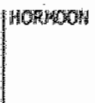 & 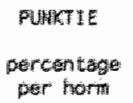 & 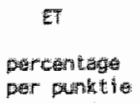 & $\begin{array}{l}\text { ZHAWER } \\
\text { Dercentage } \\
\text { per ET }\end{array}$ & 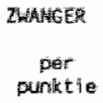 & 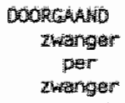 & 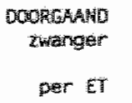 & 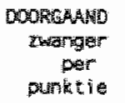 & 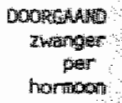 \\
\hline 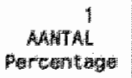 & 1023 & $\frac{79}{79}$ & $\frac{68}{84}$ & $\begin{array}{l}157 \\
22,79\end{array}$ & 19.19 & 80.25 & $\frac{126}{18.29}$ & 15,40 & 12.32 \\
\hline 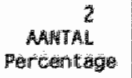 & 396 & $\frac{644}{17}, 59$ & $\begin{array}{l}3.97 \\
8 \%, 4\end{array}$ & $\begin{array}{l}78 \\
20.16\end{array}$ & 16.81 & 84,62 & $\begin{array}{l}6.6 \\
17.05\end{array}$ & 14.22 & $17.6 \%$ \\
\hline $\begin{array}{c}3 \\
\text { ARHothL } \\
\text { Pencerontiong }\end{array}$ & 324 & $\frac{250}{79.63}$ & $\begin{array}{l}216 \\
83.72\end{array}$ & $\begin{array}{l}40 \\
18.52\end{array}$ & 4.5 .50 & $\$ 7.50$ & $\begin{array}{l}27 \\
12.50\end{array}$ & $10: 47$ & B. 愫 \\
\hline $\begin{array}{l}\text { 4 tezamen } \\
\text { AAITAL } \\
\text { PGrcentage }\end{array}$ & 197 & $\begin{array}{l}156 \\
79.19\end{array}$ & $\begin{array}{l}135 \\
04.54\end{array}$ & $\begin{array}{l}18 \\
13.33\end{array}$ & 111.54 & 77.78 & $\begin{array}{l}14 \\
10.37\end{array}$ & 8.97 & 7.19 \\
\hline $\begin{array}{c}\text { TOTAAL } \\
\text { AAMTAL } \\
\text { Porcontago }\end{array}$ & 2142 & $\begin{array}{l}4696 \\
79.18\end{array}$ & $\begin{array}{l}1.427 \\
84,14\end{array}$ & $\begin{array}{l}293 \\
20.53\end{array}$ & 97,28 & 79.52 & $\frac{233}{16.33}$ & 13.74 & 10.8 \\
\hline 4 & & & & & & & & & \\
\hline $\begin{array}{c}\text { AANTAL } \\
\text { ParCENTEG }\end{array}$ & 130 & $\frac{102}{70} 46$ & $\begin{array}{l}88 \\
8.6 .27\end{array}$ & 10.23 & 8.82 & 66.67 & $\begin{array}{l}6 \\
6.82\end{array}$ & 5.88 & 4.62 \\
\hline $\begin{array}{c}5 \\
\text { AAMALAL } \\
\text { Percentago }\end{array}$ & 48 & $\frac{37}{77.08}$ & $\frac{32}{86} .49$ & $\frac{7}{21.88}$ & 18.92 & 85.71 & 18.75 & 16.22 & 12.50 \\
\hline $\begin{array}{c}6 \\
\text { AANTAL } \\
\text { Porcentage }\end{array}$ & 18 & $\begin{array}{l}16 \\
88.89\end{array}$ & $\begin{array}{l}14 \\
87.50\end{array}$ & $\frac{2}{14.29}$ & 12.50 & 100.00 & $\frac{2}{14.29}$ & $9: 2.50$ & 11.11 \\
\hline $\begin{array}{c}7 \\
\text { AANTAL } \\
\text { Pencentiago }\end{array}$ & 当 & $\frac{1}{100.00}$ & 100.00 & $\begin{array}{l}0 \\
0.00\end{array}$ & 0.00 & " & $\begin{array}{l}0 \\
0.00\end{array}$ & 0.00 & 0.00 \\
\hline
\end{tabular}




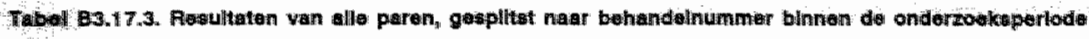

\begin{tabular}{|c|c|c|c|c|c|c|c|c|c|}
\hline 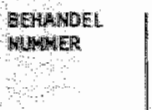 & HORMOON: & $\begin{array}{l}\text { PUNKIE } \\
\text { porcentage } \\
\text { per horm }\end{array}$ & $\begin{array}{l}\text { ET } \\
\text { percentage } \\
\text { per punkt te }\end{array}$ & $\begin{array}{l}\text { DWAMGIER } \\
\text { percentage } \\
\text { per हा }\end{array}$ & 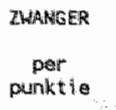 & $\begin{array}{c}\text { Dockgakiki } \\
\text { twarger } \\
\text { per } \\
\text { zwanger }\end{array}$ & 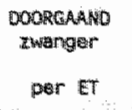 & $\begin{array}{c}\text { DOORGAMANO } \\
\text { 2.waidger } \\
\text { per } \\
\text { punktitio. }\end{array}$ & $\begin{array}{c}\text { bookenawd } \\
\text { twanger" } \\
\text { per } \\
\text { nomoon }\end{array}$ \\
\hline $\begin{array}{c}\text { 1 } \\
\text { MANAMLA } \\
\text { parcentage }\end{array}$ & 1462 & $\begin{array}{l}1179 \\
80.64\end{array}$ & $\begin{array}{l}992 \\
84.14\end{array}$ & $\begin{array}{l}219 \\
22.08\end{array}$ & 18.58 & 77.17 & $\frac{169}{17.04}$ & 14.33 & 11.56 \\
\hline $\begin{array}{c}{ }^{2} \\
\text { MANJAL } \\
\text { Pencentage }\end{array}$ & 869 & $\begin{array}{l}680 \\
78.25\end{array}$ & $\begin{array}{l}580 \\
85.29\end{array}$ & $\begin{array}{l}116 \\
20.00\end{array}$ & 17.06 & 21.90 & $\begin{array}{l}95 \\
16.38\end{array}$ & 13.97 & 10.93 \\
\hline 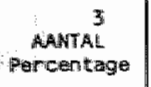 & 4.70 & $\begin{array}{l}378 \\
80,43\end{array}$ & $\begin{array}{l}324 \\
85.71\end{array}$ & $\begin{array}{l}58 \\
17.90\end{array}$ & 15.34 & 70.69 & $\begin{array}{l}44 \\
12.65\end{array}$ & 10.85 & 8.72 \\
\hline $\begin{array}{c}\text { 4 tozanien } \\
\text { MAMTAL } \\
\text { Prententage }\end{array}$ & 291 & $\begin{array}{l}229 \\
78.69\end{array}$ & $\begin{array}{l}193 \\
84.28\end{array}$ & 23 & 10.04 & 78.26 & 98 & 7.86 & 6.19 \\
\hline $\begin{array}{l}\text { TORAAL } \\
\text { AANBAL } \\
\text { Percentage }\end{array}$ & 3092 & $\begin{array}{l}2466 \\
79.75\end{array}$ & $\begin{array}{l}2089 \\
84.71\end{array}$ & $\begin{array}{l}416 \\
19.91^{*}\end{array}$ & $16.87^{\circ}$ & 77.64 & $\frac{3.23}{5.46^{+}}$ & $13 \cdot 10^{*}$ & $10.45^{+}$ \\
\hline $\begin{array}{c}4 \\
\text { ANATAL } \\
\text { Peiricentage }\end{array}$ & 186 & $\begin{array}{l}151 \\
81.18\end{array}$ & $\begin{array}{l}126 \\
83.44\end{array}$ & $\begin{array}{l}13 \\
10.32\end{array}$ & 8.61 & 76.92 & $\frac{10}{7.94}$ & 6.62 & 5.38 \\
\hline $\begin{array}{c}5 \\
\text { PaATIAL } \\
\text { Percentage }\end{array}$ & 72 & $\begin{array}{l}53 \\
73,61\end{array}$ & $\begin{array}{l}45 \\
84.91\end{array}$ & $\stackrel{8}{17.78}$ & 15.09 & 75.00 & $\frac{6}{13.33}$ & 11.32 & 8.33 \\
\hline $\begin{array}{c}{ }^{6} \\
\text { PAMTIIAL } \\
\text { Porcentage }\end{array}$ & 30 & $\frac{23}{76.67}$ & $\begin{array}{l}21 \\
91.30\end{array}$ & $\begin{array}{l}2 \\
9.52\end{array}$ & 8.70 & 100.00 & $\begin{array}{l}2 \\
9,52\end{array}$ & 8.70 & 6.67 \\
\hline $\begin{array}{c}{ }^{7} \\
\text { AMAMTAL } \\
\text { Percentage }\end{array}$ & 3 & $\stackrel{2}{66.67}$ & $\begin{array}{c}1 \\
50.00\end{array}$ & $\begin{array}{l}0 \\
0.00\end{array}$ & 0.00 & . & $\begin{array}{l}0 \\
0.00\end{array}$ & 0.00 & 0.00 \\
\hline
\end{tabular}




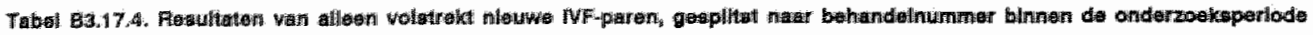

\begin{tabular}{|c|c|c|c|c|c|c|c|c|c|}
\hline 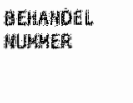 & Horkoch & 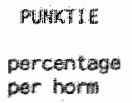 & 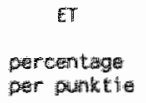 & $\begin{array}{l}\text { PHAHOE } \\
\text { perbentuge } \\
\text { per ET }\end{array}$ & 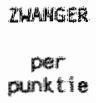 & 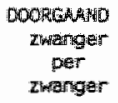 & $\begin{array}{l}\text { Dowhyhut } \\
\text { zwanger } \\
\text { per ET }\end{array}$ & 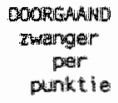 & 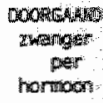 \\
\hline $\begin{array}{c}\text { AkATAL } \\
\text { Percom }\end{array}$ & 1023 & $\begin{array}{l}398 \\
79.96\end{array}$ & $\begin{array}{l}699 \\
84.25\end{array}$ & $\begin{array}{l}1.57 \\
22.79\end{array}$ & 19.19 & 60.25 & $\begin{array}{l}1.26 \\
18.29\end{array}$ & 1540 & 12.32 \\
\hline 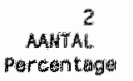 & 598 & $\frac{464}{77}$ & $\begin{array}{l}387 \\
334\end{array}$ & $\begin{array}{l}78 \\
20.16\end{array}$ & 16.81 & 84,62 & $\frac{66}{17.05}$ & 14.22 & 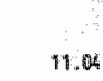 \\
\hline $\begin{array}{c}\text { AANTAL } \\
\text { Porcistagta }\end{array}$ & 324 & $\begin{array}{l}258 \\
79.68\end{array}$ & $\begin{array}{l}216 \\
93.72\end{array}$ & $\begin{array}{l}40 \\
48.52\end{array}$ & 15.50 & 67.50 & $\begin{array}{l}27 \\
42.50\end{array}$ & 10,47 & B 3 \\
\hline 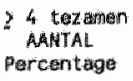 & 197 & $\begin{array}{l}156 \\
7 \% .19\end{array}$ & $\begin{array}{l}135 \\
106.54\end{array}$ & $\begin{array}{l}18 \\
13.33\end{array}$ & 11.54 & 77.78 & $\begin{array}{l}14 \\
10.37\end{array}$ & 13.97 & $7: 11$ \\
\hline $\begin{array}{l}\text { TOTAAL } \\
\text { AANTAL } \\
\text { PGrCEn:tage }\end{array}$ & $214_{2}$ & $\begin{array}{r}1696 \\
79.18\end{array}$ & $\begin{array}{r}1427 \\
84.14\end{array}$ & $\begin{array}{l}293 \\
20.53\end{array}$ & 17.28 & 79.52 & $\begin{array}{l}233 \\
16.33^{+}\end{array}$ & 13.74 & 10.88 \\
\hline $\begin{array}{c}4 \\
\text { AANTAL } \\
\text { Procontege }\end{array}$ & 130 & $\begin{array}{l}102 \\
78.46\end{array}$ & $\begin{array}{l}88 \\
86.27\end{array}$ & $\frac{9}{10.23}$ & 8.82 & 66.67 & $\frac{6}{6.82}$ & 5.88 & 4.62 \\
\hline $\begin{array}{l}\text { MANTAL } \\
\text { Percentage }\end{array}$ & 48 & $\begin{array}{l}37 \\
77.08\end{array}$ & $\begin{array}{l}32 \\
86.49\end{array}$ & $\begin{array}{c}7 \\
21.88\end{array}$ & 1.8 .92 & 85.71 & $\begin{array}{c}6 \\
4.8 .75\end{array}$ & 16.22 & 12.50 \\
\hline $\begin{array}{c}6 \\
\text { AANTAL. } \\
\text { Percentedg! }\end{array}$ & 18 & $\begin{array}{l}16 \\
88.89\end{array}$ & 14.50 & $\frac{2}{1: 4.29}$ & 12.50 & $1000_{n} \mathrm{cos}$ & $\frac{2}{14.29}$ & 12.50 & $y y_{0}: 1$ \\
\hline $\begin{array}{c}7 \\
\text { AAMTAL } \\
\text { PeIrcentage }\end{array}$ & 1 & 100.00 & $\begin{array}{c}1 \\
100,00\end{array}$ & $\begin{array}{l}0 \\
0.00\end{array}$ & 0.00 & . & $\begin{array}{l}0 \\
0.00\end{array}$ & 0.00 & a. \\
\hline
\end{tabular}


Biilage 3.18. Resultaten per ziekenhuis, gesplitst voor eerste behandeling en vervolgbehandelingen binnen de onderzoeksperiode

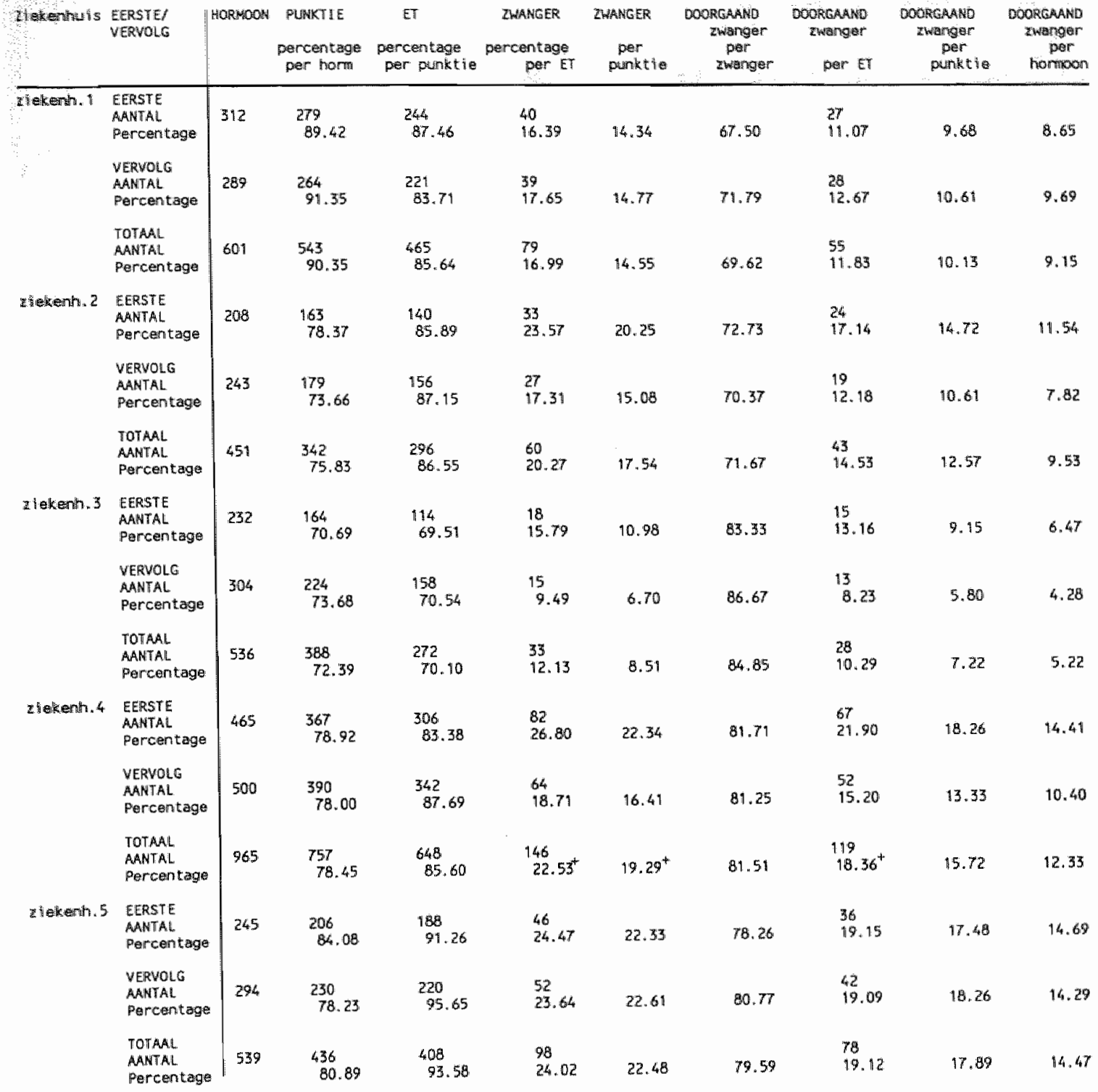


Bijage 3.19. Resultaten, gesplitst naar punktienummer

Tabol B3.19:. Fiseuthaten van alle patron

\begin{tabular}{|c|c|c|c|c|c|c|}
\hline 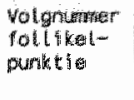 & $\begin{array}{l}\text { punTE } \\
\text { parcentage } \\
\text { per hortin }\end{array}$ & 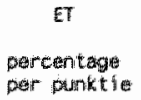 & $\begin{array}{r}\text { DWhated } \\
\text { percentage } \\
\text { per ET }\end{array}$ & $\begin{array}{c}\text { ZWHiter } \\
\text { per } \\
\text { puntere }\end{array}$ & $\begin{array}{l}\text { DOORCANA } \\
\text { Zwaraer } \\
\text { per ET }\end{array}$ & $\begin{array}{c}\text { Coonghath } \\
\text { Iwanger } \\
\text { per } \\
\text { puntint }\end{array}$ \\
\hline $\begin{array}{c}\text { A' } \\
\text { AMhILL } \\
\text { Poresentage }\end{array}$ & 1108 & $\begin{array}{l}925 \\
83.48\end{array}$ & $\begin{aligned} 203 \\
21.95\end{aligned}$ & 18.32 & $\begin{array}{l}163 \\
17.62\end{array}$ & 14.71 \\
\hline $\begin{array}{c}2 \\
\text { AAMTAL } \\
\text { Percientiage }\end{array}$ & 7111 & $\begin{array}{l}595 \\
83.68\end{array}$ & $\begin{array}{l}112 \\
110,82\end{array}$ & 45.75 & $\begin{array}{l}87 \\
14.62\end{array}$ & 12.24 \\
\hline 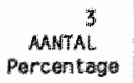 & 405 & $\begin{array}{l}349 \\
86.17\end{array}$ & $\begin{array}{l}68 \\
19.48\end{array}$ & 16.79 & $\begin{array}{l}50 \\
14.33\end{array}$ & 12.35 \\
\hline $\begin{array}{l}24 \text { tezamen } \\
\text { AAvith } \\
\text { Percontage }\end{array}$ & $2 * 2$ & $\begin{array}{l}220 \\
90.91\end{array}$ & $\begin{array}{l}33 \\
15.00\end{array}$ & 13.64 & $\begin{array}{l}23 \\
10.45\end{array}$ & 9.50 \\
\hline $\begin{array}{l}\text { TOTAAL } \\
\text { ANHTAL } \\
\text { Percontage }\end{array}$ & 2466 & $\begin{array}{l}2089 \\
84.71^{*}\end{array}$ & $\begin{array}{l}416 \\
19.91\end{array}$ & 16.87 & $\begin{array}{l}323 \\
15.46^{*}\end{array}$ & 13.10 \\
\hline $\begin{array}{c}4 \\
\text { AaATAL } \\
\text { Percentage }\end{array}$ & 141 & $\begin{array}{l}130 \\
92.20\end{array}$ & $\begin{array}{l}20 \\
15,38\end{array}$ & 14.18 & $\begin{array}{l}17 \\
13.08\end{array}$ & 12.06 \\
\hline $\begin{array}{c}5 \\
\text { AANTAL } \\
\text { Percentaga }\end{array}$ & 53 & $\begin{array}{l}47 \\
88.68\end{array}$ & $\begin{array}{l}7 \\
14.89\end{array}$ & 13.21 & $\begin{array}{l}4 \\
8.59\end{array}$ & 7.55 \\
\hline $\begin{array}{c}6 \\
\text { AAkTAL } \\
\text { Percentage }\end{array}$ & 22 & $\begin{array}{l}19 \\
86.36\end{array}$ & ${ }^{3} 5^{3} .79$ & 13.64 & $\frac{2}{10.53}$ & 9.09 \\
\hline $\begin{array}{c}7 \\
\text { AANTAL } \\
\text { Percentage }\end{array}$ & 10 & $\begin{array}{c}10 \\
100.00\end{array}$ & 10.00 & 10.00 & $\begin{array}{l}0 \\
0.00\end{array}$ & 0.00 \\
\hline $\begin{array}{c}{ }^{8} \\
\text { AAMTAL } \\
\text { Pereontogo }\end{array}$ & 8 & 100.00 & $\begin{array}{l}0 \\
0.00\end{array}$ & 0.00 & $\begin{array}{l}0 \\
0.00\end{array}$ & 0.00 \\
\hline $\begin{array}{c}\text { Aaltal } \\
\text { Prercentago }\end{array}$ & $\xi$ & $\begin{array}{c}3 \\
60.00\end{array}$ & 33.33 & 20.00 & 0.00 & 0.00 \\
\hline $\begin{array}{c}y 10 \\
\text { AANTAL. } \\
\text { Porcentage }\end{array}$ & 3 & 100.000 & $\frac{1}{33.00}$ & 33.00 & $\begin{array}{l}0 \\
0.00\end{array}$ & 0,00 \\
\hline
\end{tabular}




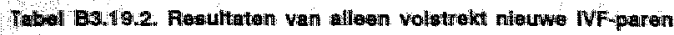

\begin{tabular}{|c|c|c|c|c|c|c|}
\hline $\begin{array}{l}\text { folgnumer } \\
\text { hollowel- } \\
\text { punktive }\end{array}$ & $\begin{array}{l}\text { PUINTIIE } \\
\text { percentage } \\
\text { per horm }\end{array}$ & $\begin{array}{c}\text { ET } \\
\text { percentzage } \\
\text { per punktite }\end{array}$ & $\begin{array}{l}\text { TWALER } \\
\text { percentage } \\
\text { per ET }\end{array}$ & $\begin{array}{c}\text { 2WAKGER } \\
\text { per } \\
\text { punktie }\end{array}$ & $\begin{array}{l}\text { DOORGAAND: } \\
\text { Ewanger } \\
\text { par ET }\end{array}$ & $\begin{array}{c}\text { OOOREAAINO } \\
\text { zwanger } \\
\text { per } \\
\text { puntitio }\end{array}$ \\
\hline $\begin{array}{l}\text { ALTIL } \\
\text { Aencentage }\end{array}$ & 945 & $\begin{array}{l}784 \\
82.96\end{array}$ & $\begin{array}{l}173 \\
22.07\end{array}$ & 18.31 & $\begin{array}{l}139 \\
17.73\end{array}$ & 14.74 \\
\hline${ }^{2}$ & 471 & $\begin{array}{l}400 \\
84.93\end{array}$ & 74.50 & 15.71 & $\begin{array}{l}62 \\
15.50\end{array}$ & 13.16 \\
\hline $\begin{array}{c}3 \\
\text { parcent. } \\
\text { page }\end{array}$ & 215 & $\begin{array}{c}184 \\
85.58\end{array}$ & $\begin{array}{l}37 \\
20.11\end{array}$ & 17.21 & $\frac{24}{13.04}$ & 11.16 \\
\hline $\begin{array}{l}\text { 4. tezamen } \\
\text { MANTAL } \\
\text { Percientige }\end{array}$ & 65 & $\begin{array}{l}59 \\
901.77\end{array}$ & $\stackrel{9}{15.25}$ & 13.85 & $\frac{8}{13.56}$ & 12.31 \\
\hline $\begin{array}{l}\text { TITTARL } \\
\text { AAWTAL } \\
\text { percentage }\end{array}$ & 1696 & $\begin{array}{l}1427 \\
84.14\end{array}$ & $\begin{array}{l}293 \\
20.53\end{array}$ & 97.28 & $\frac{233}{16.33}$ & 13.74 \\
\hline $\begin{array}{c}4 \\
\text { Parcontal } \\
\text { Percege }\end{array}$ & 48 & $\begin{array}{l}44 \\
91.67\end{array}$ & ${ }_{15}^{7} .91$ & 14.56 & 13.64 & 12.50 \\
\hline $\begin{array}{c}5 \\
\text { AANTILL } \\
\text { Percentage }\end{array}$ & 13 & $\begin{array}{l}12 \\
92.31\end{array}$ & $\begin{array}{l}1 \\
8.33\end{array}$ & 7.69 & $\begin{array}{l}\pi \\
8.33\end{array}$ & 7.69 \\
\hline $\begin{array}{r}6 \\
\text { AANTIAL: } \\
\text { Piercentage }\end{array}$ & 4 & $\frac{3}{75.00}$ & $\frac{1}{33.33}$ & 25.00 & $\begin{array}{c}1 \\
33.33\end{array}$ & 25.00 \\
\hline
\end{tabular}


Bilage 3,20. Yarianten voor de berekening van het zwangerschapspercentage via een cohortbenaderimg

\begin{tabular}{|c|c|c|c|c|}
\hline & 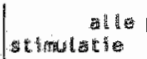 & paris & 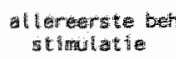 & $\begin{array}{l}\text { (jogg } \\
\text { Nukitio }\end{array}$ \\
\hline 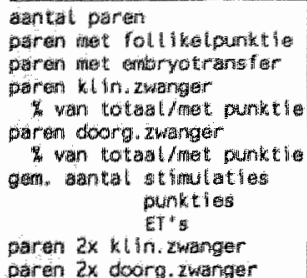 & $\begin{array}{l}552 \\
200 \\
715 \\
253 \\
29.72 / 31.64 \\
203 \\
23.5925 .49 \\
2.51 \\
1.97 \\
1.64 \\
13 \\
1\end{array}$ & 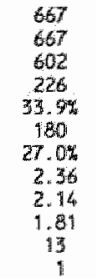 & $\begin{array}{l}532 \\
499 \\
4.40 \\
164 \\
30.84 / 32.9 \% \\
133 \\
25.0 \% / 26.74 \\
0.58 \\
2.02 \\
1.65 \\
10 \\
1\end{array}$ & $\begin{array}{l}495 \\
495 \\
436 \\
163 \\
32.9 \\
133 \\
26.97 \\
2.64 \\
2.17 \\
1.78 \\
10 \\
1\end{array}$ \\
\hline
\end{tabular}

Bijlage 3.21. Frekwenties redenen voortijdige beëindiging IVF $(n=626)$

\begin{tabular}{|c|c|}
\hline Redenen voortijelg ainde & Prokwentide \\
\hline 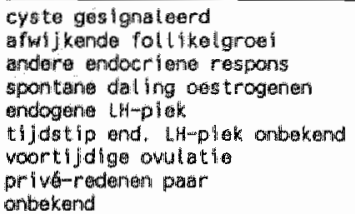 & $\begin{array}{r}79 \\
334 \\
91 \\
97 \\
107 \\
11 \\
60 \\
19 \\
10\end{array}$ \\
\hline
\end{tabular}




\section{Bijlage 3.22. Resultaten per ziekenhuis gesplitst maar gehanteerd medikatieschema}

Onderscheiden zijn de volgende medikatieschema's (naast het gebruik van hCG in ieder schema):

1: alleen hMG; met een maximum van $2 \mathrm{hMG}$ per dag

2 : alleen hMG; met een maximum aan $\mathrm{hMG}$ per dag $>2$

3. hMG en FSH; met een maximum van $2 \mathrm{hMG}$ per dag

4. hMG en FSH; met een maximum aan $\mathrm{hMG}$ per dag $>2$

5. hMG en clomid; met een maximum van $2 \mathrm{hMG}$ per dag

6. hMG en clomid; met een maximum aan hMG per dag $>2$

7 : alleen FSH

8: LHRH lang en $\mathrm{hMG}$; met een maximum van $2 \mathrm{hMG}$ per dag

9: LHRH kort en $\mathrm{hMG}$; met een maximum van $2 \mathrm{hMG}$ per dag

10: LHRH lang en hMG; met een maximum aan $\mathrm{hMG}$ per dag $>2$

11: LHRH kort en hMG; met een maximum aan hMG per dag $>2$

Hieronder wordt voor cellen met een redelijk aantal stimulaties het percentage doorgaande zwangerschappen per hormoonstimulatie weergegeven met tussen haakjes het aantal stimulaties (de resultaten zijn niet getoetst):

\begin{tabular}{|c|c|c|c|c|c|c|}
\hline dedikatio & Totalat & z lekenh. il & zlekenh. 2 & ziekenh. 3 & z t i akenth. 4 & ziekent. 5 \\
\hline Totital & $10.58(3092)$ & $9.2 \%(601)$ & $9.5 \%(451)$ & $5.2 \% 5336$ & $12.3 \%(965)$ & $14,5 \%(5391)$ \\
\hline 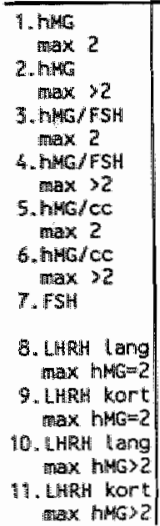 & $\begin{array}{|rr|}8.2 \% & (9.90) \\
11.6 \%(1237) \\
6.5 \% & (535) \\
8.0 \% & (125) \\
1.4 .5 \% & (4.43) \\
2.8 \% & (71) \\
2.0 \% & (49) \\
22.7 \% & (22) \\
1.4 .6 \% & (96) \\
9.2 \% & (1303) \\
9.7 \% & (268)\end{array}$ & $\left(\begin{array}{r}23.8 \%(42) \\
7.7 \times(401) \\
16.78(48)\end{array}\right.$ & $\left(\begin{array}{rr}15.6 \% & (77) \\
8.2 \% & (73) \\
8.9 \% & (79)\end{array}\right.$ & $\begin{array}{l}7.3 \%(248) \\
2.5 \%(121) \\
7.0 \%(71)\end{array}$ & $12.9 \%(8448)$ & $16.48(353)$ \\
\hline
\end{tabular}

Bijlage 3.23. Resultaten per ziekenhuis gesplitst naar interval hMG/FSH - hCG

In onderstaande tabel wordt per cel het klinisch zwangerschapspercentage per follikelpunktie vermeld, indien de cel minimaal circa 100 follikelpunkties bevat; tussen haakjes wordt het betreffend aantal follikelpunkties weergegeven; de resultaten zijn niet getoetst.

\begin{tabular}{|c|c|c|c|c|c|c|}
\hline 2tukentuis: & total & 28 & $28-32$ & $33-38$ & $39-5 ?$ & $52-60$ \\
\hline 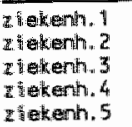 & $\begin{array}{r}14.68(543) \\
17.5 \%(34.2) \\
8.58(388) \\
99.3 \%(757) \\
22.5 \%(436)\end{array}$ & $11.5 \%(148)$ & $\begin{array}{c}8.34(96) \\
17.6 \%(245) \\
6.9 \%(231) \\
23.0 \%(409)\end{array}$ & $\begin{array}{l}20.5 \%(78) \\
20.54(684)\end{array}$ & & $16.14(286)$ \\
\hline
\end{tabular}


Bijlage 3.24. Resultaten, gesplitst nà nivo en patroon van de oestrogenen (de resultaten zijn niet getoetst)

\section{Nivo van de oestrogenen, verdeeld in decielen}

Allereerst is per ziekenhuis gekeken naar het nivo van de oestrogenen op de dag van de HCG. In de zwangerschapsresultaten (\% klinische zwanger/punktie of \% klinisch zwanger/embryotranster) was geen duidelijk verschil waarneembaar tussen de afzonderlijke decielen per ziekenhuis.

Derhalve is overgegaan tot een gedeeltelijke klustering van decielen. De resultaten van ziekenhuis 2 zijn gesplitst in verband met een wijziging in de wijze van oestrogeenbepaling vanaf september 1987. Voor ziekenhuis 3 is de periode van de serum- $E_{2}$-bepalingen (vanaf februari 1988) niet meegenomen in verband met het beperkte aantal waarnemingen.

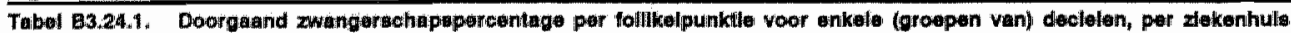

\begin{tabular}{|c|c|c|c|c|c|c|}
\hline & \multirow[t]{2}{*}{ ziregerm. } & \multicolumn{2}{|c|}{ z sekent. 2} & \multirow[t]{2}{*}{ zu akenh. 3} & \multirow[t]{2}{*}{ z 1 efterith 4} & \multirow[t]{2}{*}{2 lekents. 5} \\
\hline & & voor & rea & & & \\
\hline n (\% van alle punkthes) & $475(87 \%)$ & $115(85 \%)$ & $130(63+4)$ & $305(932)$ & $742(98 \%)$ & $312(72 x)$ \\
\hline 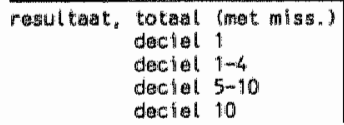 & $\begin{array}{r}10.9 \% \\
6.3 \% \\
5.8 \% \\
14.4 \% \\
21.3 \%\end{array}$ & $\begin{array}{l}8.1 \% \\
0 \\
10.6 \% \\
8.8 \% \\
18.2 \%\end{array}$ & $\begin{array}{l}15.5 \% \\
15.4 \% \\
11.5 \% \\
19.2 \% \\
2 \pi .14\end{array}$ & $\begin{array}{l}6.9 \% \\
3.2 \% \\
5.7 \% \\
8.7 \% \\
13.3 \%\end{array}$ & $\begin{array}{l}15.7 \% \\
10.8 \% \\
13.1 \% \\
17.5 \% \\
13.5 \%\end{array}$ & $\begin{array}{l}17.9 \% \\
12.9 \% \\
16.0 \% \\
20.2 \% \\
16.7 \%\end{array}$ \\
\hline
\end{tabular}

Patroon van de oestrogenen na toediening van de $\mathrm{hCG}$

In het onderstaande is gekeken naar de ontwikkeling van de oestrogenen op de dag ná de HCG ten opzichte van de dag van de HCG-toediening.

Tabel 103.24.2. Doorgaand awangierechapapercentage per follkelpunktle bil dellng plateau on stljging van de oestrogenen 1 tussen haikjes staat het pracen ture aandeel van dal ing, plateau daling in de valta cases)

\begin{tabular}{|c|c|c|c|c|c|c|c|}
\hline & Totalal & $x$ fekenh. 1 & $\begin{array}{c}z \text { ife } \\
\text { voor }\end{array}$ & $\begin{array}{r}h .2 \\
\text { na }\end{array}$ & zlekenh. 3 & ziekenh.4 & z texenh. 5 \\
\hline n $(\%$ van al la punkthes $)$ & $1150(472)$ & $255(4,474)$ & $23(17 \%)$ & $8(4 \%)$ & $283(73 \%)$ & $450(59 \%)$ & $131(30 x)$ \\
\hline $\begin{array}{l}\text { sultaat, daling } 10 \% \\
\text { plateau } \\
\text { stijgings10\% }\end{array}$ & $\begin{array}{r}9.02(9) \\
13.5 \%(18) \\
12.08(73)\end{array}$ & $\begin{array}{l}9 \%(4) \\
16 \%(24) \\
114(71)\end{array}$ & & & $\begin{array}{l}0 \%(3) \\
6 \%(12) \\
98(86)\end{array}$ & $\begin{array}{r}9 \%(12) \\
16 \%(19) \\
17 \%(68)\end{array}$ & $\begin{array}{r}15 \%(15) \\
9 \%(17) \\
1.6 \%(68)\end{array}$ \\
\hline
\end{tabular}


Onderstaand zijn de korrelaties weergegeven tussen echometingen enerzijds (de grootste follikel ( $=$ 'super') en het aantal follikels $\geq 10 \mathrm{~mm}$ (='aantal')) en oestrogeenbepalingen anderzjds (op dezelfde dag als de echometing); hierbij is dag 0 gedefinieerd als de dag van de follikelpunktie. Aangezien de oestrogeenbepalingen van opeenvolgende dagen een sterke positieve korrelatie vertoonden, zijn de korrelluties tussen follikelmetingen enerzijds en oestrogeenbepalingen 1 dag eerder anderzijds niet vermeld; deze zijn soortgelijk als de korrelaties op dezelfde dag.

Voor alle ziekenhuizen was uit de histogrammen af te lezen dat:

- de oestrogeenwaarden niet fraai normal verdeeld waren (bij serumbepalingen iets fraaier dan bij urinebepalingen)

- de follikelmetingen ('super" en "aantal') mogelijk wel normaal verdeeld waren.

Voor alle zekerbeid is voor de bepaling van de korrelaties gebruik gemaakt van de verdelingswrije Spearman rangkorrelatie in plaats van de Pearson-korrelatie (waarbij normaal verdeelde variabelen worden werondersteld).

In de onderstaande tabellen is in de 1 rij de Spearman korrelatie-koefficient weergegeven (zonder 0.) met na die dwarsstreep de p-waarde (eveneens zonder 0.) volgens de éenzijdige Spearman-rangkorrelatietoets. Bij een negatieve korrelatie wordt de p-waarde niet vermeld; $p$-waarden $>0.10$ worden aangegeven met NS (Niet-Signifikant). In de 2 rij wordt het aantal waarnemingen vermeld. Cellen met maximaal 10 waarnemingen wordlen met een . aangegeven. De korrelaties worden per ziekenhuis zowel aangegeven voor alle follikelpunkties tezamen als voor de splitsing naar het aantal verkregen oöcyten.

\begin{tabular}{|c|c|c|c|c|c|c|c|}
\hline & totaal & 1 & 2 & $\begin{array}{c}\text { antal } \\
3\end{array}$ & $\begin{array}{r}x \tan \\
4 \times 6\end{array}$ & $7-10$ & $\times 10$ \\
\hline $\begin{array}{r}\text { suprorloest }-3 \\
-2 \\
-1\end{array}$ & $\begin{array}{c}-051 \ldots \\
523 \\
-92 / \ldots \\
509 \\
-01 / \ldots \\
310\end{array}$ & $\begin{array}{c}38 / 01 \\
34 \\
51 / 00 \\
32 \\
58 / 01 \\
18\end{array}$ & $\begin{array}{c}0 . / N 5 \\
61 \\
22 / 105 \\
56 \\
10 / 155 \\
36\end{array}$ & $\begin{array}{c}-04 / \ldots \\
59 \\
11 / \mathrm{NS} \\
58 \\
26,107 \\
34\end{array}$ & $\begin{array}{c}02 / \mathrm{MS} \\
190 \\
04 / \mathrm{MS} \\
185 \\
11 / 1 \mathrm{NS} \\
109\end{array}$ & $\begin{array}{c}16 / 03 \\
129 \\
19 / 01 \\
129 \\
07 / \mathrm{MS} \\
8.1\end{array}$ & $\begin{array}{c}02 / k S \\
48 \\
02 / 4 S \\
47 \\
31 / 04 \\
31\end{array}$ \\
\hline $\begin{array}{r}\text { apintaloest }-3 \\
-2 \\
-1\end{array}$ & $\begin{array}{l}52 / 00 \\
523 \\
58 / 00 \\
509 \\
62 / 00 \\
310\end{array}$ & $\begin{array}{c}59 / 00 \\
34 \\
55,100 \\
32 \\
39 / 105 \\
18\end{array}$ & $\begin{array}{c}32 / 101 \\
61 \\
38 / 00 \\
56 \\
53 / 100 \\
36\end{array}$ & $\begin{array}{c}06 / N S \\
59 \\
02 / 145 \\
58 \\
52 / 00 \\
34\end{array}$ & $\begin{array}{c}38100 \\
190 \\
32 / 00 \\
105 \\
36 / 100 \\
100\end{array}$ & $\begin{array}{c}25 / 100 \\
129 \\
21 / 101 \\
129 \\
08 / 15 \\
61\end{array}$ & $\begin{array}{c}19 / 10 \\
48 \\
29 / 02 \\
47 \\
30 / 05 \\
31\end{array}$ \\
\hline
\end{tabular}

Konklusies voor ziekenhuis 1:

1. Er bestaat geen korrelatie tussen de oestrogeneenwaarden en de omvang van de grootste follikel (behalve bij 1 oöcyt).

2. Er is sprake van een positieve signifikante korrelatie tussen de oestrogeenwarden en het aantal follikels $\geq 10 \mathrm{~mm}$, zowel bij de totaalopstelling als (meestal) bij de oöcytindeling.

Aangezien ziekenhuis 2 in september 1987 is overgestapt van oestrogenen/kreatinine-bepalingen naar oestron-gluceronide-bepalingen (de waarden van de laatste bepalingen zijn circa $10 \mathrm{x}$ zo hoog als die van de eerste) zijn de behandelingen in zjekenhuis 2 voor deze analyses in tweeén gesplitst: follikelpunkties wóor en ná 1 september 1987. Mede hierdoor is de uitsplitsing naar het aantal verkregen oöcyten niet meer zinvol; het aantal waarmemingen komt dan per cel vrijwel nooit boven 10 à 15 . Het totale aantal follikelpunkties van 342 is te verdelen in 135 vóór 1 september 1987 en 207 erna. 


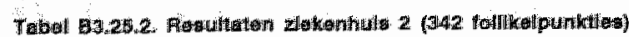

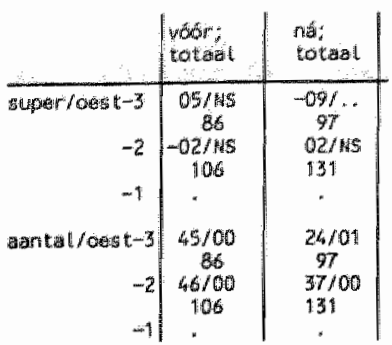

Konklusies voor ziekenhuis .2*

1. Er bestaat geen korrelatie tussen de oestrogeenwaarden en de omvang van de grootste follikel.

2. Er is sprake van een positieve signifikante korrelatie tussen de oestrogeenwaarden en het aantal follikefs $\geq 10 \mathrm{~mm}$.

\begin{tabular}{|c|c|c|c|c|c|c|c|}
\hline & totaral & 1 & 2 & $\frac{\operatorname{aanta}}{3}$ & $\operatorname{sosent}_{4-6}$ & $x-10$ & $\$ 10$ \\
\hline $\begin{array}{r}\text { Supporloos t }-3 \\
-2 \\
-1\end{array}$ & $\begin{array}{c}25 / 00 \\
183 \\
31 / 00 \\
218 \\
-18 / 10 \\
89\end{array}$ & . & $\begin{array}{c}16 / \mathrm{NS} \\
25 \\
40 / 02 \\
30 \\
-53 / \ldots \\
11\end{array}$ & $\begin{array}{c}29107 \\
27 \\
30 / 044 \\
35 \\
27 / N S \\
15\end{array}$ & $\begin{array}{c}15 / \mathrm{NS} \\
70 \\
31 / 00 \\
76 \\
-13 / \\
28\end{array}$ & $\begin{array}{c}18 / N S \\
30 \\
44 / 00 \\
38 \\
-391 \ldots \\
20\end{array}$ & $\begin{array}{c}60 / 00 \\
15 \\
46 / 104 \\
16 \\
.\end{array}$ \\
\hline 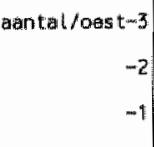 & $\begin{array}{c}38 / 00 \\
183 \\
49 / 00 \\
218 \\
33 / 00 \\
89\end{array}$ & . & $\begin{array}{c}-0 T / \ldots \\
25 \\
09 / \mathrm{NS} \\
30 \\
67 / 01 \\
11\end{array}$ & $\begin{array}{c}-09 / . \\
27 \\
48 / 00 \\
35 \\
53 / 02 \\
15\end{array}$ & $\begin{array}{c}27 / 101 \\
70 \\
28 / 0 \\
76 \\
-127 \\
28\end{array}$ & $\begin{array}{c}34 / 03 \\
30 \\
49 / 100 \\
38 \\
10 / 1 / 5 \\
20\end{array}$ & $\begin{array}{c}70 / 00 \\
15 \\
60 / 01 \\
16 \\
.\end{array}$ \\
\hline
\end{tabular}

Konklusies voor ziekenhuis 3 :

1. Zowel 3 als 2 dagen vóor de follikelpunktie bestaat er een positief signifikant verband tussen de oestrogeenwaarden en de omvang van de grootste follikel; ondanks de kleine aantallen blijft dit beeld voor dag -2 goed overeind bij de onderverdeling naar het aantal verkregen oöcyten.

2. Er is sprake van een positief signifikant verband tussen de oestrogeenwaarden en het aantal follikels $\geq 10 \mathrm{~mm}$, zowell bij het total als bij de splitsing naar het aantal verkregen oöcyten.

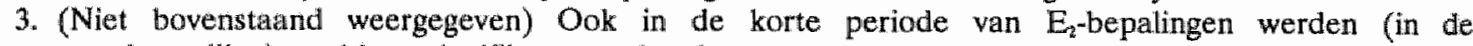
totaliopstilling) positieve signifikante verbanden gevonden tussen het $E_{2}$-nivo en het aantal follikels $\geq 10 \mathrm{~mm}$ (40 valid cases); dat geldt niet voor het verband tussen het $E_{2}$-nivo en de omvang van de grootste follikel. 


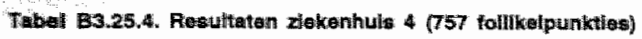

\begin{tabular}{|c|c|c|c|c|c|c|c|}
\hline & totara & $\begin{array}{c}4 \\
1\end{array}$ & $\begin{array}{c}\text { oocytien } \\
2\end{array}$ & 3 & $4-6$ & $7-40$ & 210 \\
\hline $\begin{array}{r}\text { super } x \\
-2 \\
-1\end{array}$ & $\begin{array}{c}-30 / \ldots \\
699 \\
-34 / \ldots \\
729 \\
-\end{array}$ & \multicolumn{6}{|c|}{ 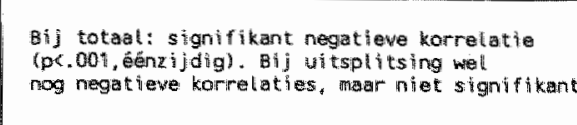 } \\
\hline $\begin{array}{r}-2 \\
-2 \\
-1\end{array}$ & $\begin{array}{c}53,100 \\
699 \\
61 / 00 \\
729 \\
.\end{array}$ & . & $\begin{array}{l}02 / 1 \mathrm{BS} \\
24 \\
14 / \mathrm{NS} \\
26\end{array}$ & $\begin{array}{l}51 / 100 \\
59 \\
47100 \\
67\end{array}$ & $\begin{array}{l}17 / 00 \\
282 \\
26100 \\
291\end{array}$ & $\begin{array}{l}23 / 00 \\
175 \\
25 / 00 \\
179\end{array}$ & $\begin{array}{l}33 / 100 \\
147 \\
35100 \\
154\end{array}$ \\
\hline
\end{tabular}

Konklusies voor ziekenhuis 4:

1. $\mathrm{Er}$ is geen positief verband zichtbaar tussen het $\mathrm{E}_{2}$-nivo en de omvang van de grootste follikel, integendeel.

2. Er is sprake van een positief signifikant verband tussen het $\mathrm{E}_{2}$-nivo en het aantal follikels $\geq 10 \mathrm{~mm}, 20 w e 1$ voor het totaal als voor de splitsing naar het aantal verkregen oöcyten.

Tabel B3.25.5. Resultation zleikenhuls 5 (436 tollkalpunikties)

\begin{tabular}{|c|c|c|c|c|c|c|}
\hline & totalal & $\begin{array}{c}\text { arantal Dösyten } \\
1\end{array} \frac{2}{2}$ & 3 & $4-6$ & $7-10$ & $>10$ \\
\hline $\begin{array}{r}\text { super / oest }-3 \\
-2 \\
-1\end{array}$ & $\begin{array}{c}01 / \mathrm{MS} \\
136 \\
-01 / . \\
86 \\
.\end{array}$ & \multicolumn{5}{|c|}{$\begin{array}{l}\text { Bij totas : geen karrelatie Uitsplitsing niet } \\
\text { zinwol (mede gezien de kleine antallen). }\end{array}$} \\
\hline $\begin{array}{r}\text { artalloest }-3 \\
-2 \\
-1\end{array}$ & $\begin{array}{c}53 / 00 \\
135 \\
59 / 100 \\
86\end{array}$ & . & " & $\begin{array}{c}52100 \\
58 \\
54100 \\
30\end{array}$ & $\begin{array}{c}11 / N S \\
33 \\
43,701 \\
27\end{array}$ & $\begin{array}{c}62 / 100 \\
19 \\
44.107 \\
13\end{array}$ \\
\hline
\end{tabular}

Konklusies voor ziekenhuis 5:

1. Er bestaat geen verband tussen het $E_{2}$-nivo en de omvang van de grootste follikel.

2. Er is sprake van een positief signifikant verband tussen het $E_{2}$-nivo en het aantal follikels $\geq 10 \mathrm{~mm}$, zowel voor het total als voor de kategorieen met meer dan 3 verkregen oöcyten. 
Bijlage 326.Resultaten, gesplitst naar aantal verkregen oöcyten en beoordeling van de maturiteit

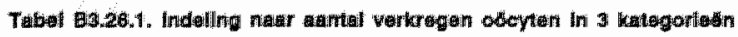

\begin{tabular}{|c|c|c|c|c|c|c|c|}
\hline 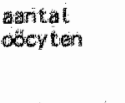 & 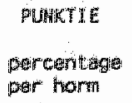 & $\begin{array}{c}\text { ET } \\
\text { percentagu } \\
\text { per punkt }\end{array}$ & 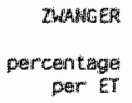 & $\begin{array}{l}\text { DWHAGE } \\
\text { per } \\
\text { pumikt if }\end{array}$ & 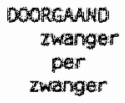 & $\begin{array}{l}\text { Dookend } \\
\text { zwanger } \\
\text { per ET }\end{array}$ & $\begin{array}{c}\text { DOORGAMND } \\
\text { Twanger } \\
\text { per } \\
\text { punkt le }\end{array}$ \\
\hline 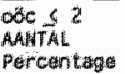 & 351 & $\begin{array}{l}218 \\
62.11\end{array}$ & $\begin{array}{l}25 \\
11.47\end{array}$ & 7.12 & 60.00 & $\begin{array}{l}15 \\
6.88\end{array}$ & 4.27 \\
\hline 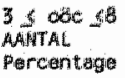 & 1566 & $\begin{array}{l}1356 \\
86.54\end{array}$ & $\begin{array}{l}28.1 \\
19.25\end{array}$ & 16.67 & 78.16 & $\frac{204}{15.04}$ & 13.03 \\
\hline 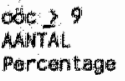 & 549 & $\begin{array}{l}519 \\
92.811\end{array}$ & $\frac{130}{25} .24$ & 23.60 & 80.00 & $\begin{array}{l}104 \\
20,199\end{array}$ & 18,94 \\
\hline $\begin{array}{l}\text { TOTAAL } \\
\text { MANTAL } \\
\text { Poir }\end{array}$ & 2466 & 20899 & $\begin{array}{l}416 \\
19.97^{\circ}\end{array}$ & $16.87^{*}$ & 77.64 & $\frac{323}{15.46^{*}}$ & $13.10^{*}$ \\
\hline
\end{tabular}

Tabol B3.262. Fertillandlegread naar verhouding prima/alle verkregen obeyten lde maturitelt van het cumulus/corona-komplex werd in: navolging van Marrs [1984] al.s prima beoordeeld, trodien de cumulus groot en goed verspreid was, werwil] d da coronia even dunne scheidslillin vertoonde)

\begin{tabular}{|c|c|c|}
\hline * prtima/al lia odcyten & fertillisatiograad & ni \\
\hline $\begin{array}{l}0 y \\
1-33 x \\
34-50 x \\
51-67 x \\
68-99 \% \\
100 x\end{array}$ & $\begin{array}{l}40 \% \\
46 \% \\
52 \% \\
53 \% \\
57 \% \\
62 \%\end{array}$ & $\begin{array}{r}213 \\
124 \\
287 \\
233 \\
468 \\
1109\end{array}$ \\
\hline
\end{tabular}


Biflage 3.27. Resultaten na al dan niet signalering van endogene LH-piek.

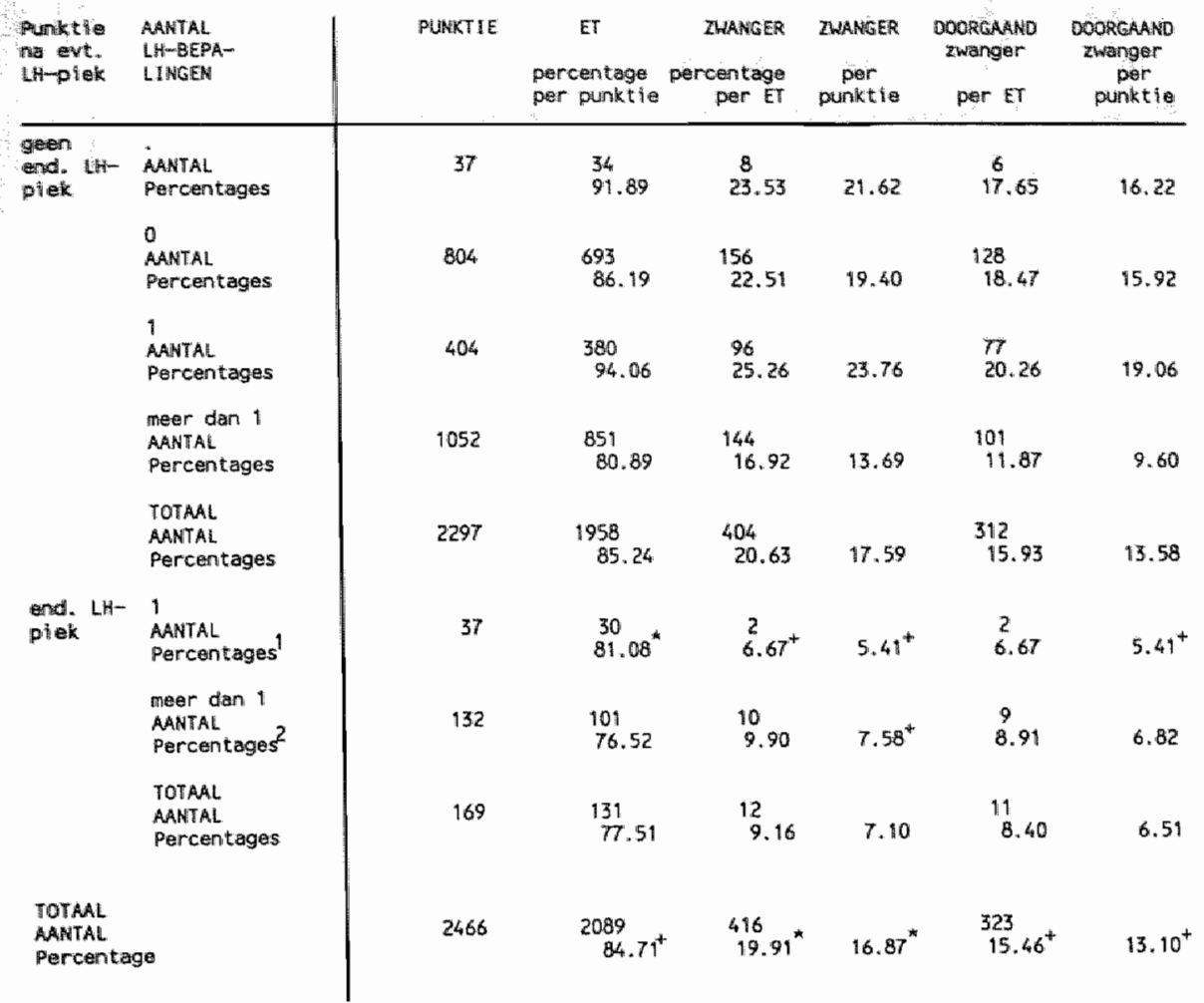

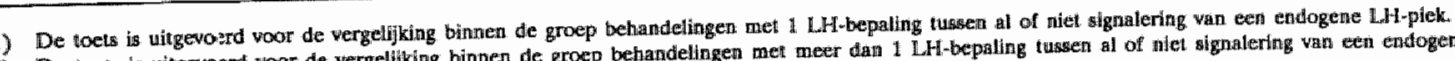

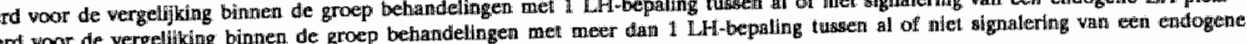
H. Hither 
Bijlage 3.28. Gegevens over resultaten en incidentie met betrekking to spermamotiliteit na opwerking van het semen

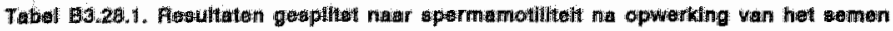

\begin{tabular}{|c|c|c|c|c|c|c|c|}
\hline 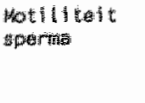 & 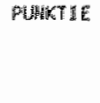 & $\begin{array}{c}\text { Ei } \\
\text { perceritage } \\
\text { per puriktive }\end{array}$ & $\begin{array}{l}\text { Zwhindute } \\
\text { percentoge } \\
\text { per ET }\end{array}$ & $\begin{array}{l}\text { ZWAHEER } \\
\text { per } \\
\text { purnktie }\end{array}$ & 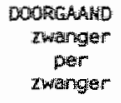 & $\begin{array}{l}\text { DOORGA AHD } \\
\text { Thweringer } \\
\text { Per ET }\end{array}$ & $\begin{array}{c}\text { Doowlinatib } \\
\text { zwanger } \\
\text { per } \\
\text { puniktie }\end{array}$ \\
\hline $\begin{array}{l}\text { MAHAL } \\
\text { Percent tagess }\end{array}$ & 66 & $\begin{array}{l}\text { H } \\
28.79\end{array}$ & $\frac{3}{1.5} \cdot 79$ & 4.55 & 100,00 & $\begin{array}{l}3 \\
15.79\end{array}$ & 4.55 \\
\hline $\begin{array}{l}\text { goes } \\
\text { Partal } \\
\text { Porctontogus }\end{array}$ & 1871 & $\begin{array}{r}1652 \\
848.30\end{array}$ & $\begin{array}{l}327 \\
19.79\end{array}$ & 17.4 & 77.68 & $\begin{array}{l}254 \\
15.38\end{array}$ & 13.58 \\
\hline 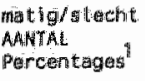 & 290 & $\frac{211}{72.76}$ & $\begin{array}{l}43 \\
20.38\end{array}$ & $14.8 \%$ & 76.42 & $\begin{array}{l}32 \\
15.17\end{array}$ & 11.03 \\
\hline $\begin{array}{l}\text { 4CW } \\
\text { MANTAL } \\
\text { Porcentagras }\end{array}$ & 178 & $\begin{array}{l}154 \\
86.52\end{array}$ & $\begin{array}{l}27 \\
17.53\end{array}$ & 15.17 & $B 1,4,48$ & $\begin{array}{l}22 \\
14.29\end{array}$ & 12.36 \\
\hline $\begin{array}{l}30 \%-40 x \\
\text { AANTAL } \\
\text { Percenteges }\end{array}$ & 10.6 & $\begin{array}{l}13 \\
81.25\end{array}$ & $\frac{3}{23}, 0 B$ & 18.75 & 68.67 & $\frac{2}{15} 38$ & 12.50 \\
\hline $\begin{array}{l}30 \% \\
\text { AANTikL } \\
\text { Percentrages }\end{array}$ & 45 & $\begin{array}{l}40 \\
88.89\end{array}$ & $\begin{array}{l}13 \\
32.50\end{array}$ & 28.89 & 76.92 & $\begin{array}{l}10 \\
25.00\end{array}$ & 22.22 \\
\hline $\begin{array}{l}\text { TOTAAL } \\
\text { AANTAL } \\
\text { PERCENLEgES }\end{array}$ & 2466 & $\begin{array}{l}2089 \\
84.71\end{array}$ & $\begin{array}{l}416 \\
19.91\end{array}$ & 16.87 & $\pi 7.64$ & $\frac{323}{15.46}$ & 13.10 \\
\hline $\begin{array}{l}\text { metig } \\
\text { AANANAL } \\
\text { Percentages }\end{array}$ & 200 & $\frac{962}{77.88}$ & $\begin{array}{l}31 \\
19.14\end{array}$ & 14.90 & 74.19 & $\frac{23}{14.20}$ & 11.06 \\
\hline $\begin{array}{l}\text { slecht } \\
\text { AANTAL. } \\
\text { Percontages }\end{array}$ & 82 & $\begin{array}{l}49 \\
59.76\end{array}$ & $\begin{array}{l}12 \\
24.49\end{array}$ & 14.63 & 75.00 & $\begin{array}{l}9 \\
18.37\end{array}$ & 10.98 \\
\hline
\end{tabular}

1) De toets is uitgevcerd woor de vergelijking met betrekking tot de spermamollitteit wa opwerking van hel semen: goed wersus matlg/slecht. 


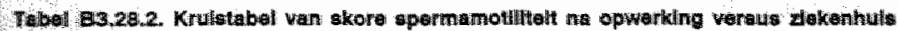

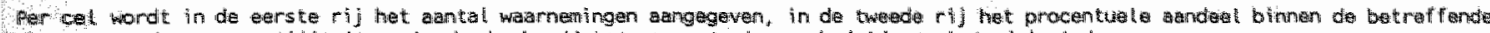

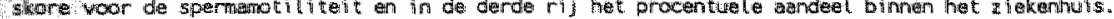

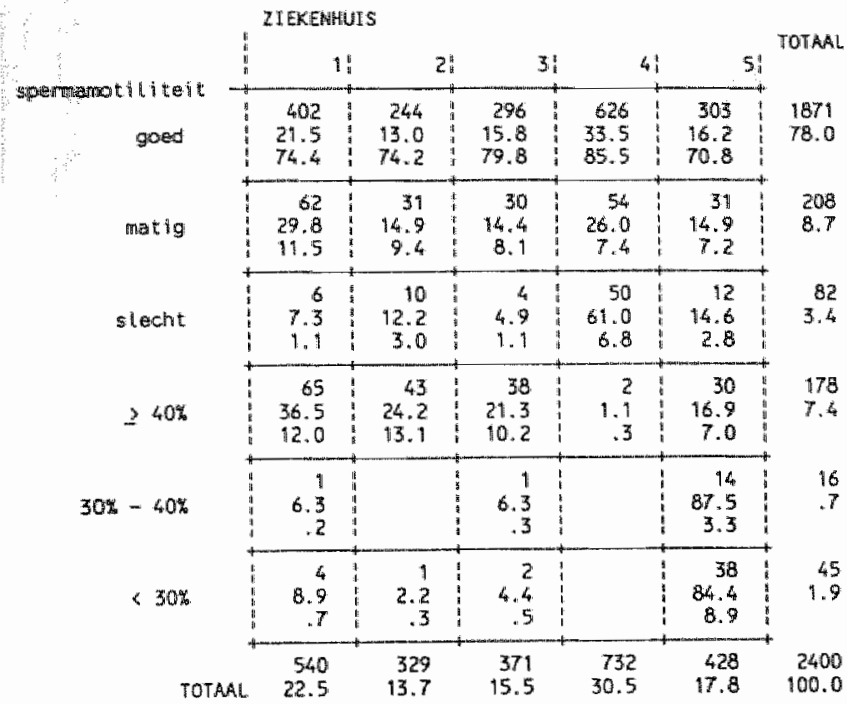




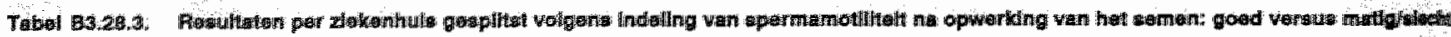

\begin{tabular}{|c|c|c|c|c|c|c|c|c|}
\hline zTEKEWUTS & SEF的和 & PUWHE & $\begin{array}{l}\text { vi } \\
\text { pertentigae } \\
\text { per punktie }\end{array}$ & $\begin{array}{l}\text { ZuAbigieR } \\
\text { pericentage } \\
\text { per ET }\end{array}$ & 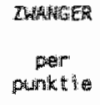 & 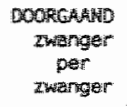 & 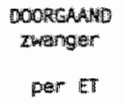 & 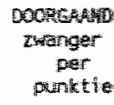 \\
\hline \multirow[t]{4}{*}{ zhaturin. 1} & \multirow{4}{*}{ 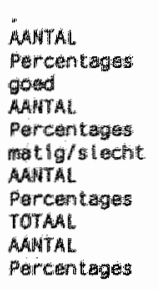 } & 13 & $\begin{array}{l}59 \\
80.82\end{array}$ & $\begin{array}{c}9 \\
15.25\end{array}$ & 12.33 & 66.67 & 10.17 & 8.22 \\
\hline & & 40.2 & $\begin{array}{l}354 \\
88.06\end{array}$ & $\begin{array}{l}69 \\
17,23\end{array}$ & 15.17 & 72.13 & $\begin{array}{l}4.4 \\
12.43\end{array}$ & 10.95 \\
\hline & & $6 B$ & $\begin{array}{l}52 \\
76.4 .7\end{array}$ & $\frac{9}{17.31}$ & 13.24 & 55.56 & $\begin{array}{l}5 \\
9.62\end{array}$ & 7.35 \\
\hline & & 54,3 & $\begin{array}{l}465 \\
85.64\end{array}$ & $\begin{array}{l}79 \\
16.99\end{array}$ & 14.55 & $69.6 ?$ & $\begin{array}{l}55 \\
11.83\end{array}$ & 10.13 \\
\hline \multirow[t]{5}{*}{ z i ekentu. 2} & \multirow{5}{*}{ 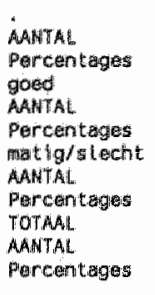 } & & & & & & & \\
\hline & & 57 & $\begin{array}{l}40 \\
70.98\end{array}$ & 15.00 & 10.53 & 83.33 & 12.50 & 8.77 \\
\hline & & 244 & $\begin{array}{l}228 \\
93.44\end{array}$ & $\begin{array}{l}4.7 \\
20.61\end{array}$ & 19.26 & 70.21 & $\begin{array}{l}33 \\
14.47\end{array}$ & 13.52 \\
\hline & & 41 & $\begin{array}{l}28 \\
68.29\end{array}$ & $\begin{array}{c}7 \\
25.00\end{array}$ & 17.07 & 71.43 & 17.86 & 12.20 \\
\hline & & 342 & $\begin{array}{l}296 \\
86.55^{\circ}\end{array}$ & $\begin{array}{l}60 \\
20.27\end{array}$ & 17.54 & 71.67 & $\begin{array}{l}43 \\
14.53\end{array}$ & 12.57 \\
\hline \multirow[t]{5}{*}{$x$ iekenth. 3} & \multirow{5}{*}{ 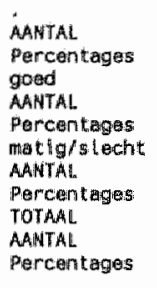 } & 58 & 31 & 6 & & & 6 & \\
\hline & & & 53.45 & 19.35 & 10.34 & 100.00 & 19.35 & 10.34 \\
\hline & & 2916 & $\frac{223}{75.34}$ & $\begin{array}{l}26 \\
11.66\end{array}$ & 8.78 & 80.77 & 9.42 & 7.09 \\
\hline & & 34 & $\begin{array}{l}18 \\
52.94\end{array}$ & $\begin{array}{l}1 \\
5.56\end{array}$ & 2.94 & 100.00 & 5.56 & 2.94 \\
\hline & & 388 & $\begin{array}{l}272 \\
70.10^{+}\end{array}$ & 12.13 & 8.51 & 84,85 & $\begin{array}{l}28 \\
10.29\end{array}$ & 7.22 \\
\hline \multirow[t]{6}{*}{2 lakenth 4} & \multirow{6}{*}{ 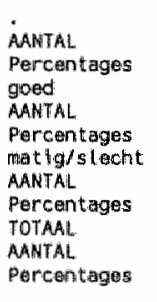 } & 27 & & & & & & \\
\hline & & & 66.67 & 22.22 & 14.81 & 75.00 & 16.67 & 11,11 \\
\hline & & 1626 & $\begin{array}{l}556 \\
88.82\end{array}$ & $\begin{array}{l}124 \\
22.30\end{array}$ & 19.81 & 8. 36 & 102 & \\
\hline & & 104 & & & & WL. & & 10.28 \\
\hline & & & 71.15 & 24.32 & 17.31 & 77.78 & 18.92 & 13.46 \\
\hline & & 757 & $\frac{648}{85.60^{\prime \prime}}$ & $\begin{array}{l}148 \\
22.53\end{array}$ & 19.29 & 81.51 & $\begin{array}{l}119 \\
18.36\end{array}$ & 15.72 \\
\hline \multirow[t]{5}{*}{ z lokenty. 5} & \multirow{5}{*}{ 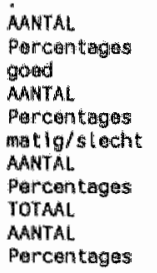 } & 90 & & & & & & \\
\hline & & su & 86.67 & 26.92 & 23.33 & 80.95 & $\begin{array}{l}17 \\
21.79\end{array}$ & 18.89 \\
\hline & & 303 & 291 & $\begin{array}{l}69 \\
23.71\end{array}$ & 22.77 & 78.26 & $\begin{array}{l}54 \\
18.56\end{array}$ & 17.82 \\
\hline & & 43 & $\begin{array}{l}39 \\
90.70\end{array}$ & $\begin{array}{c}8 \\
20.51\end{array}$ & 18.60 & 87.50 & $\frac{7}{17.95}$ & 16.28 \\
\hline & & 436 & $\begin{array}{l}408 \\
93.58\end{array}$ & $\begin{array}{l}98 \\
24.02\end{array}$ & 22.48 & 79.59 & $\begin{array}{l}78 \\
19.12\end{array}$ & 17.89 \\
\hline
\end{tabular}


Bijlage 3.29.Resultaten, gesplitst naar aantal teruggeplaatste embryo's; totaal en per wiekenhuis

\begin{tabular}{|c|c|c|c|c|}
\hline $\begin{array}{l}\text { mattal terug- } \\
\text { geptant ste } \\
\text { monto:s }\end{array}$ & $\mathrm{ET}$ & $\begin{array}{l}\text { TWAMGER } \\
\text { percentage } \\
\text { per IET }\end{array}$ & $\begin{array}{c}\text { DOORGMANo } \\
\text { zwanger } \\
\text { per } \\
\text { zwanger }\end{array}$ & $\begin{array}{l}\text { DOORGAMO } \\
\text { zwanger } \\
\text { per ET }\end{array}$ \\
\hline 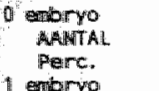 & 13 & $\frac{1}{7.69}$ & 0.00 & $\begin{array}{l}0 \\
0.00\end{array}$ \\
\hline $\begin{array}{l}\text { Maryo } \\
\text { Panc. } \\
\text { 2 Peryo"s }\end{array}$ & 326 & $\begin{array}{r}23 \\
7.06\end{array}$ & 69.57 & $\begin{array}{l}16 \\
4.91\end{array}$ \\
\hline $\begin{array}{l}\text { AAANAL } \\
\text { Pare. } \\
3 \text { entoryo" s }\end{array}$ & 378 & 48.70 & 70.83 & $\begin{array}{l}34 \\
8.99\end{array}$ \\
\hline $\begin{array}{l}\text { ANital } \\
\text { Perc.. } \\
\text { \& mbaryo's }\end{array}$ & 553 & $\begin{array}{l}125 \\
22.60\end{array}$ & 79.20 & $\begin{array}{l}99 \\
17.90\end{array}$ \\
\hline $\begin{array}{l}\text { AMNTAL } \\
\text { Pigrc. } \\
\text { 5. embryo"s }\end{array}$ & 498 & $\begin{array}{l}124 \\
24.90\end{array}$ & 76.61 & $\begin{array}{l}95 \\
19.08\end{array}$ \\
\hline $\begin{array}{l}\text { AALVIIIAL } \\
\text { Perc. } \\
2 \text { onbiryo's }\end{array}$ & 222 & $\begin{array}{l}63 \\
28.38\end{array}$ & 79.37 & $\begin{array}{l}50 \\
22.52\end{array}$ \\
\hline $\begin{array}{l}\text { AnNTAL } \\
\text { Pere. }\end{array}$ & 99 & $\begin{array}{l}32 \\
32.32\end{array}$ & 90.63 & $\begin{array}{l}29 \\
29.29\end{array}$ \\
\hline $\begin{array}{l}\text { TOTAAL } \\
\text { MANTIAL. } \\
\text { Perc. }\end{array}$ & 2089 & $\begin{array}{l}416 \\
19.91^{*}\end{array}$ & 77.64 & $\frac{323}{15.46}$ \\
\hline
\end{tabular}

\begin{tabular}{|c|c|c|c|c|c|}
\hline TEKENHUIS & $\begin{array}{l}\text { aantal terug- } \\
\text { geplaatste } \\
\text { embryo's }\end{array}$ & ET & $\begin{array}{l}\text { ZWANGER } \\
\text { percentage } \\
\text { per ET }\end{array}$ & $\begin{array}{c}\text { DOORGAAND } \\
\text { zwanger } \\
\text { per } \\
\text { zwanger }\end{array}$ & $\begin{array}{c}\text { DOORGAAND } \\
\text { zwanger } \\
\text { per } \mathbb{E T}\end{array}$ \\
\hline atielkenh. 1 & 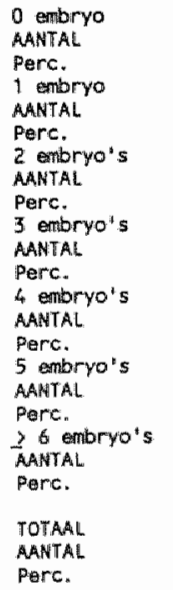 & $\begin{array}{c}82 \\
89 \\
102 \\
75 \\
404 \\
13\end{array}$ & $\begin{array}{l}0 \\
0.00 \\
6 \\
7.32 \\
10 \\
11.24 \\
18 \\
17.65 \\
17 \\
22.67 \\
24 \\
23.76 \\
4 \\
30.77 \\
79 \\
16.99\end{array}$ & $\begin{array}{l}50.00 \\
20.00 \\
72.22 \\
76.47 \\
83.33 \\
100.00\end{array}$ & $\begin{array}{l}0 \\
0.00 \\
3 \\
3.66 \\
2 \\
2.25 \\
13 \\
12.75 \\
13 \\
17.33 \\
20 \\
19.80 \\
4 \\
30.77 \\
155 \\
11.83\end{array}$ \\
\hline
\end{tabular}




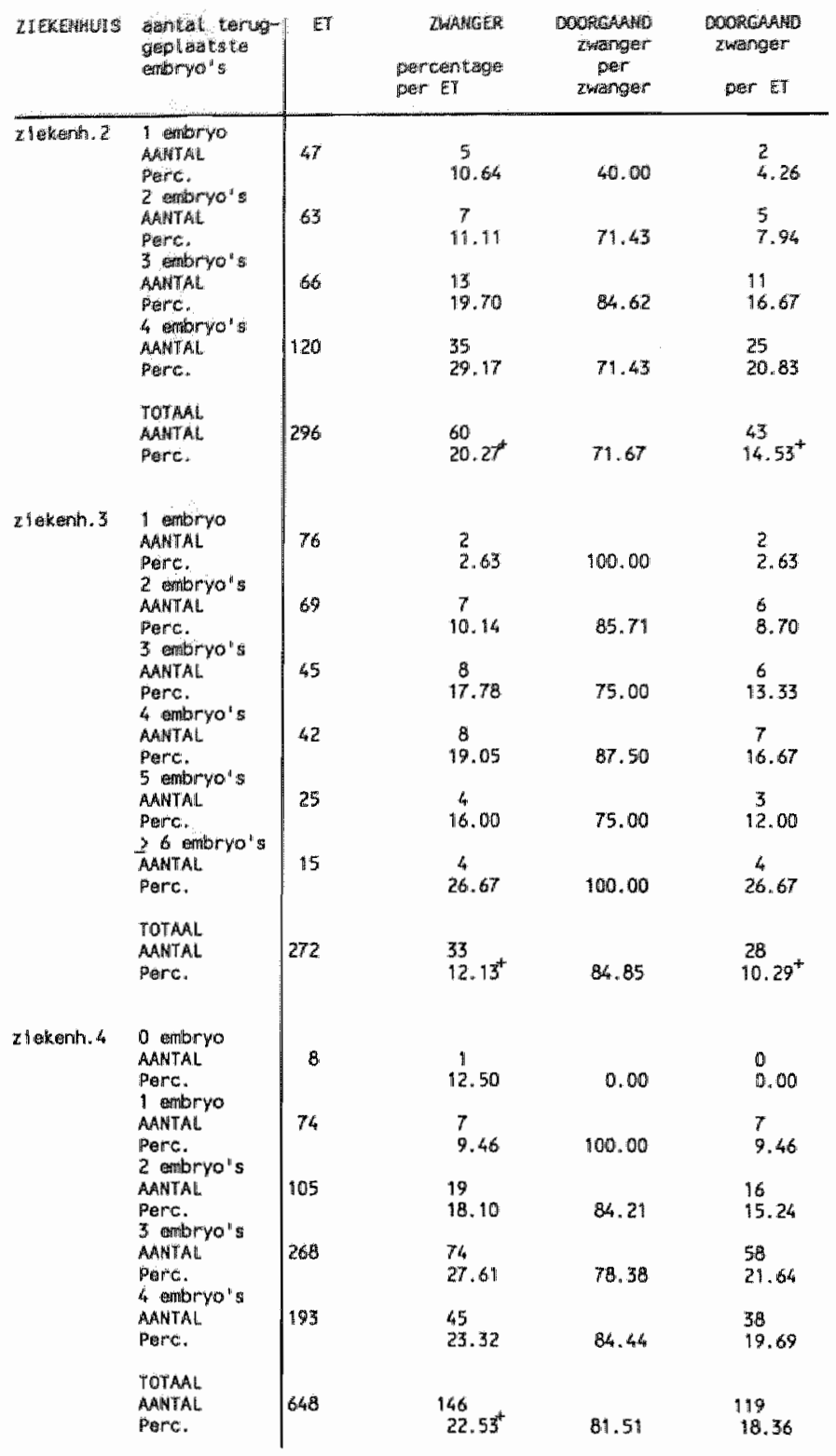




\begin{tabular}{|c|c|c|c|c|c|}
\hline HExpryins & $\begin{array}{l}\text { antal terug- } \\
\text { geplaetste } \\
\text { enbryo's }\end{array}$ & $\mathrm{EI}$ & 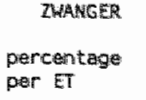 & $\begin{array}{c}\text { DOORGAAND } \\
\text { "WangeI" } \\
\text { per } \\
\text { zwanger }\end{array}$ & $\begin{array}{c}\text { Dookganab } \\
\text { awanger } \\
\text { per }\end{array}$ \\
\hline gielkent. 5 & 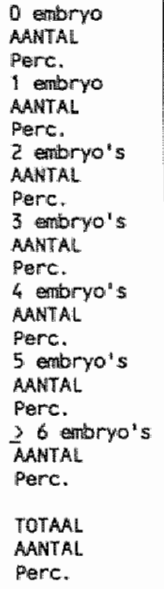 & $\begin{array}{l}2 \\
47 \\
52 \\
72 \\
68 \\
98 \\
71\end{array}$ & $\begin{array}{l}0 \\
0.00 \\
3 \\
6.38 \\
5 \\
9.62 \\
12 \\
16.67 \\
19 \\
27.94 \\
35 \\
36.46 \\
24 \\
33.80\end{array}$ & $\begin{array}{l}66.67 \\
100.00 \\
91.67 \\
63.16 \\
77.14 \\
87.50\end{array}$ & $\begin{array}{l}0 \\
0.00 \\
2 \\
4.26 \\
5 \\
9.62 \\
11 \\
15.28 \\
12 \\
17.65 \\
27 \\
28.12 \\
21 \\
29.58\end{array}$ \\
\hline
\end{tabular}


Bijlage 3.30. Resultaten, gesplitst naar aantal teruggeplaatste embryo's en indeling kwaliteit van deze: embrva's

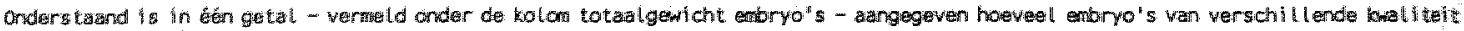

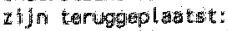

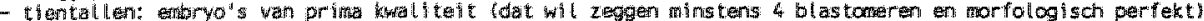

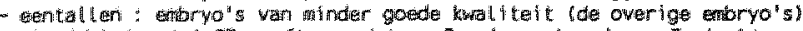

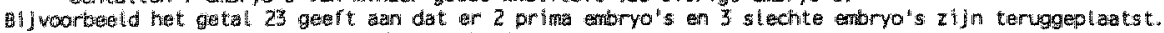

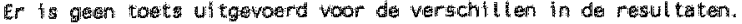

\begin{tabular}{|c|c|c|c|c|}
\hline 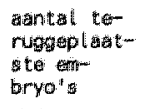 & $\begin{array}{l}\text { totas ge- } \\
\text { whthe ento } \\
\text { bryo's }\end{array}$ & ET & $\begin{array}{l}\text { ZWAHEER } \\
\text { parcentage } \\
\text { per } \mathrm{ET}\end{array}$ & $\begin{array}{l}\text { DOORGAAID } \\
\text { Zwiriget } \\
\text { per ET }\end{array}$ \\
\hline 0 mbryo & $\begin{array}{c}0 \\
\text { AAnTAL } \\
\text { Perc. }\end{array}$ & 13 & $\begin{array}{l}1 \\
7.69\end{array}$ & $\begin{array}{l}0 \\
0.00\end{array}$ \\
\hline \multirow[t]{3}{*}{1 entoryo } & $\begin{array}{l}1 \\
\text { AAMTAL. } \\
\text { PETC }\end{array}$ & 204 & $\begin{array}{l}12 \\
5.88\end{array}$ & $\begin{array}{l}12 \\
5.88\end{array}$ \\
\hline & $\begin{array}{l}10 \\
\text { AANTAL } \\
\text { PEIC. } \\
\text { TOTAAL }\end{array}$ & 122 & $\begin{array}{l}11 \\
9.02\end{array}$ & 3.28 \\
\hline & $\begin{array}{l}\text { ANNAL } \\
\text { Perc. }\end{array}$ & 326 & $\frac{23}{7.06}$ & $\begin{array}{l}16 \\
4.91\end{array}$ \\
\hline \multirow[t]{4}{*}{2 mbryo"s } & $\begin{array}{c}2 \\
\text { AANTAL } \\
\text { PerC. } \\
11\end{array}$ & 219 & $\begin{array}{l}25 \\
11,42\end{array}$ & $\begin{array}{l}18 \\
8.22\end{array}$ \\
\hline & $\begin{array}{l}\text { AANTAL. } \\
\text { PorC. } \\
20\end{array}$ & 94 & 17.02 & $\begin{array}{l}11 \\
11.70\end{array}$ \\
\hline & $\begin{array}{c}\text { AANTAL } \\
\text { PEIC. } \\
\text { TOTAAL }\end{array}$ & 65 & 10.77 & $\frac{5}{7.69}$ \\
\hline & $\begin{array}{l}\text { AMNTAL } \\
\text { Perc. }\end{array}$ & 378 & $\begin{array}{l}418 \\
1.2 .70\end{array}$ & $\begin{array}{l}3.4 \\
8.99\end{array}$ \\
\hline \multirow[t]{5}{*}{3 enbryo's } & $\begin{array}{c}3 \\
\text { AMNITAL } \\
12 \\
\text { Perc. }\end{array}$ & $254_{4}$ & $\begin{array}{l}58 \\
22.83\end{array}$ & $\begin{array}{l}48 \\
18.90\end{array}$ \\
\hline & $\begin{array}{l}\text { AMNTAL } \\
\text { PerC. } \\
21\end{array}$ & 116 & $\begin{array}{l}18 \\
15.52\end{array}$ & $\begin{array}{l}15 \\
12.93\end{array}$ \\
\hline & $\begin{array}{l}\text { AANTAL } \\
\text { PerC. } \\
30\end{array}$ & 87 & $\begin{array}{l}17 \\
19.54\end{array}$ & $\begin{array}{l}13 \\
14.94\end{array}$ \\
\hline & $\begin{array}{c}\text { AANTAL } \\
\text { PerC. } \\
\text { TOTAAL }\end{array}$ & 96 & $\begin{array}{l}32 \\
33.33\end{array}$ & $\begin{array}{l}23 \\
23.96\end{array}$ \\
\hline & $\begin{array}{l}\text { AANTAL } \\
\text { Porc. }\end{array}$ & 553 & $\begin{array}{l}125 \\
22.60\end{array}$ & $\begin{array}{l}99 \\
17.90\end{array}$ \\
\hline \multirow[t]{7}{*}{4 enbryo"s } & 4 & & & \\
\hline & $\begin{array}{l}\text { AANTAL } \\
\text { PORG. } \\
13\end{array}$ & 240 & $\begin{array}{l}53 \\
22.08\end{array}$ & $\begin{array}{l}42 \\
17.50\end{array}$ \\
\hline & $\begin{array}{l}\text { AANTAL. } \\
\text { PQEFC. } \\
22\end{array}$ & 911 & $\begin{array}{l}19 \\
20.88\end{array}$ & $\begin{array}{l}13 \\
14.29\end{array}$ \\
\hline & $\begin{array}{l}\text { AANTAL } \\
\text { Pärc. } \\
31\end{array}$ & 72 & $\begin{array}{l}23 \\
31.94\end{array}$ & $\begin{array}{l}20 \\
27.78\end{array}$ \\
\hline & 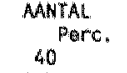 & $5 \cdot 4$ & $\begin{array}{l}18 \\
33.33\end{array}$ & $\begin{array}{l}12 \\
22.22\end{array}$ \\
\hline & $\begin{array}{l}\text { AANTAL } \\
\text { PerC. } \\
\text { TOTAML }\end{array}$ & 41 & $\begin{array}{l}19 \\
26.83\end{array}$ & 19.51 \\
\hline & $\begin{array}{l}\text { AANTAL } \\
\text { POFE. }\end{array}$ & 498 & $\begin{array}{l}124 \\
24.90\end{array}$ & $\begin{array}{l}95 \\
19.08\end{array}$ \\
\hline
\end{tabular}




\begin{tabular}{|c|c|c|c|c|}
\hline 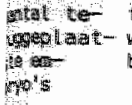 & $\begin{array}{l}\text { totmallge- } \\
\text { which ten- } \\
\text { bryo's }\end{array}$ & ET & $\begin{array}{l}\text { DAfREER } \\
\text { percentage } \\
\text { per ET }\end{array}$ & $\begin{array}{c}\text { DOORGAAND } \\
\text { Twanger } \\
\text { per ET }\end{array}$ \\
\hline \multirow[t]{7}{*}{ estoryo "s } & $\begin{array}{l}5 \\
\text { Perc. } \\
\text { Pantal }\end{array}$ & 32 & $\begin{array}{c}7 \\
21.88\end{array}$ & $\begin{array}{c}6 \\
18.75\end{array}$ \\
\hline & $\begin{array}{l}\text { AAWTAL } \\
\text { Perc. } \\
23^{2}\end{array}$ & 28 & $\frac{5}{17.85}$ & 14.29 \\
\hline & $\begin{array}{l}\text { AANTAL } \\
\text { Perc. } \\
32\end{array}$ & 46 & $\begin{array}{l}12 \\
26.09\end{array}$ & $\begin{array}{l}10 \\
21.74\end{array}$ \\
\hline & $\begin{array}{l}\text { AANTAL } \\
41^{\text {PEITE. }}\end{array}$ & 30 & $\begin{array}{l}12 \\
40.00\end{array}$ & $\begin{array}{c}8 \\
26.67\end{array}$ \\
\hline & $\begin{array}{l}\text { AANTAL } \\
\text { PeTC. } \\
50^{\circ}\end{array}$ & 41 & $\begin{array}{l}15 \\
36.59\end{array}$ & $\begin{array}{l}12 \\
29.27\end{array}$ \\
\hline & $\begin{array}{l}\text { AHMTAL. } \\
\text { PEIC. } \\
\text { TOTAML }\end{array}$ & 4.5 & $\begin{array}{l}12 \\
26.67\end{array}$ & $\begin{array}{l}10 \\
22.22\end{array}$ \\
\hline & $\begin{array}{l}\text { AANTAL } \\
\text { Perc. }\end{array}$ & 222 & $\begin{array}{l}63 \\
28.38\end{array}$ & $\begin{array}{l}50 \\
22.52\end{array}$ \\
\hline \multirow[t]{8}{*}{6 toryo's } & $\begin{array}{c}6 \\
\text { AANTAL } \\
\text { PerC. } \\
15\end{array}$ & 21 & $\frac{7}{33.33}$ & $\begin{array}{c}6 \\
28.57\end{array}$ \\
\hline & $\begin{array}{c}\text { AANTAL } \\
\text { Perc. } \\
24\end{array}$ & 20 & $\frac{3}{15.00}$ & $\frac{3}{15.00}$ \\
\hline & $\begin{array}{l}\text { AANTAL } \\
\text { Perc. } \\
33\end{array}$ & 17 & $\stackrel{8}{47.06}$ & $\begin{array}{c}7 \\
41.18\end{array}$ \\
\hline & $\begin{array}{l}\text { AANTAL } \\
\text { PerC. } \\
42^{2}\end{array}$ & 16 & $\frac{6}{37.50}$ & $\frac{6}{37.50}$ \\
\hline & $\begin{array}{l}\text { AANTAL } \\
51 \\
51^{\text {PerC. }}\end{array}$ & 9 & $\begin{array}{c}4 \\
44.44\end{array}$ & 33.33 \\
\hline & $\begin{array}{l}\text { AANTAL } \\
\text { PerC. } \\
60\end{array}$ & 6 & $\stackrel{2}{33.33}$ & $\frac{2}{33,33}$ \\
\hline & $\begin{array}{l}\text { AAHTAL } \\
\text { PECC. } \\
\text { TOTAAL }\end{array}$ & 10 & ${ }_{20.00}^{2}$ & $\frac{2}{20} .00$ \\
\hline & $\begin{array}{l}\text { AANTAL. } \\
\text { PeIC. }\end{array}$ & 99 & $\begin{array}{l}32 \\
32.32\end{array}$ & $\begin{array}{l}29 \\
29.29\end{array}$ \\
\hline \multicolumn{2}{|l|}{$\begin{array}{l}\text { TOTAAAL } \\
\text { AMGTALL }\end{array}$} & & & \\
\hline \multicolumn{2}{|l|}{$\begin{array}{l}\text { AdTRAL } \\
\text { pere. }\end{array}$} & 2089 & $\begin{array}{l}416 \\
19.91\end{array}$ & $\begin{array}{l}323 \\
15.46\end{array}$ \\
\hline
\end{tabular}


Bijage 3.31 Resultaten, gesplitst naar al dan niet surplus aanwezig bij minstens 3 teruggeplaatste embryo's

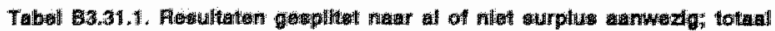

\begin{tabular}{|c|c|c|c|c|}
\hline 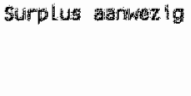 & $E T$ & 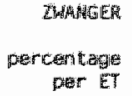 & $\begin{array}{c}\text { WoordaAkC } \\
\text { zwenger } \\
\text { per } \\
\text { zwanger }\end{array}$ & 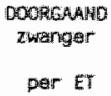 \\
\hline 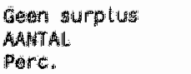 & 795 & $\frac{188}{23.65}$ & 24.04 & $\begin{array}{l}158 \\
19.87\end{array}$ \\
\hline $\begin{array}{l}\text { WOL surplus } \\
\text { ANATAL } \\
\text { Perc. }\end{array}$ & 577 & $\frac{156}{27.04}$ & 73.72 & $\begin{array}{l}115 \\
19.93\end{array}$ \\
\hline $\begin{array}{l}\text { TOTAAL } \\
\text { AHATIAL } \\
\text { PGrC. }\end{array}$ & 1372 & $\frac{344}{25.07}$ & $79.36^{*}$ & $\begin{array}{l}273 \\
19.90\end{array}$ \\
\hline
\end{tabular}

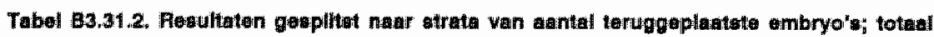

\begin{tabular}{|c|c|c|c|c|c|}
\hline $\begin{array}{l}\text { gantah } \\
\text { terugge- } \\
\text { plavers te } \\
\text { canbiryo's }\end{array}$ & SURPLUS & $\mathrm{ET}$ & $\begin{array}{l}\text { TWANGER } \\
\text { porcentage } \\
\text { per ET }\end{array}$ & $\begin{array}{c}\text { DOORGAAitd } \\
\text { zwamger } \\
\text { per } \\
\text { zwamger }\end{array}$ & $\begin{array}{l}\text { COORIGAARAD } \\
\text { Zwanger } \\
\text { peir ET }\end{array}$ \\
\hline 3 mbiryo's & 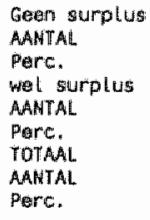 & $\begin{array}{l}371 \\
182 \\
553\end{array}$ & $\begin{array}{l}80 \\
21.56 \\
4.5 \\
24.73 \\
125 \\
22.60\end{array}$ & $\begin{array}{l}85.00 \\
68.89 \\
79.20^{+}\end{array}$ & $\begin{array}{l}68 \\
18.33 \\
31 \\
17.03 \\
99 \\
47.90\end{array}$ \\
\hline 4 moryo's & 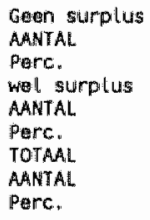 & $\begin{array}{l}270 \\
228 \\
498\end{array}$ & $\begin{array}{l}59 \\
21.85 \\
65 \\
28.51 \\
124 \\
24.90\end{array}$ & $\begin{array}{l}79.68 \\
73.85 \\
76.61\end{array}$ & $\begin{array}{l}47 \\
17.41 \\
48 \\
21.05 \\
95 \\
19.08\end{array}$ \\
\hline 5 mbryo's & 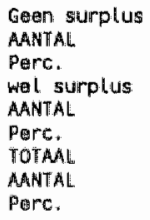 & $\begin{array}{l}110 \\
112\end{array}$ & $\begin{array}{l}35 \\
31.82 \\
28 \\
25.00 \\
63 \\
28.38\end{array}$ & 71.43 & $\begin{array}{l}30 \\
27.27 \\
20 \\
17.86 \\
50 \\
22.52\end{array}$ \\
\hline 26 mibryo" & 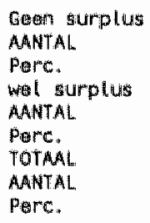 & $\begin{array}{l}44 \\
55\end{array}$ & $\begin{array}{l}14 \\
31.82 \\
18 \\
32.73 \\
32 \\
32.32\end{array}$ & 92.86 & $\begin{array}{l}13 \\
29.55 \\
16 \\
29.09 \\
29 \\
29.29\end{array}$ \\
\hline
\end{tabular}




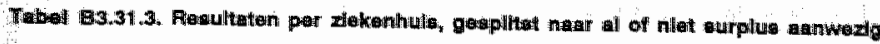

\begin{tabular}{|c|c|c|c|c|c|}
\hline 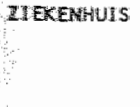 & SURPLUS & $E$ & $\begin{array}{l}\text { ThankER } \\
\text { percentrage } \\
\text { per ET }\end{array}$ & $\begin{array}{c}\text { OnofGAANO } \\
\text { zwanger } \\
\text { per } \\
\text { zwanget }\end{array}$ & 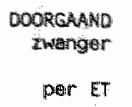 \\
\hline atenth. & $\begin{array}{l}\text { Geen suipplus } \\
\text { AANTAL } \\
\text { FerC. } \\
\text { wel surplus } \\
\text { AANTAL } \\
\text { PerC. } \\
\text { TOTAML } \\
\text { AANTAL } \\
\text { PerC. }\end{array}$ & $\begin{array}{l}217 \\
74\end{array}$ & $\begin{array}{l}46 \\
21.20 \\
17 \\
22.97 \\
63 \\
21.65\end{array}$ & $\begin{array}{l}80.43 \\
76.47\end{array}$ & $\begin{array}{l}37 \\
17.05 \\
13 \\
17.97 \\
50 \\
17.18\end{array}$ \\
\hline Wirenta. 2 & $\begin{array}{l}\text { GeEn surplus } \\
\text { AANTAL } \\
\text { PerC. } \\
\text { WEL surplus } \\
\text { AANTAL } \\
\text { PERC. } \\
\text { TOTALL } \\
\text { AANTAL } \\
\text { PERC. }\end{array}$ & $\begin{array}{c}80 \\
106 \\
186\end{array}$ & $\begin{array}{l}20 \\
25.00 \\
28 \\
26.42 \\
48 \\
25.81\end{array}$ & $\begin{array}{l}80.00 \\
71.43 \\
75.00\end{array}$ & $\begin{array}{l}16 \\
20.00 \\
20 \\
18.87 \\
36 \\
19.35\end{array}$ \\
\hline a jelkenk. 3 & $\begin{array}{l}\text { Geen surplus } \\
\text { AANTAL } \\
\text { Perc. } \\
\text { Wel. SLIPLLUS } \\
\text { AANTAL } \\
\text { Perc. } \\
\text { TOTAAL } \\
\text { AANTAL } \\
\text { Perc. }\end{array}$ & $\begin{array}{r}87 \\
40 \\
127\end{array}$ & $\begin{array}{l}15 \\
17.24 \\
9 \\
22.50 \\
2.4 \\
1.8 .90\end{array}$ & $\begin{array}{l}86.67 \\
77.78 \\
83.33\end{array}$ & $\begin{array}{l}13 \\
14.94 \\
7 \\
17.50 \\
20 \\
115.75\end{array}$ \\
\hline 2 terkenth. 5 & $\begin{array}{l}\text { Geen surplus } \\
\text { AANTAL } \\
\text { PERC. } \\
\text { WEl surplus } \\
\text { AANTAL } \\
\text { PERC. } \\
\text { TOTAAL } \\
\text { AAHTAL } \\
\text { POTC. }\end{array}$ & $\begin{array}{l}197 \\
190 \\
307\end{array}$ & $\begin{array}{l}56 \\
28.43 \\
34 \\
30.91 \\
90 \\
29.32\end{array}$ & 83.93 & $\begin{array}{l}47 \\
23.86 \\
24 \\
21.82 \\
74 \\
23.13\end{array}$ \\
\hline
\end{tabular}




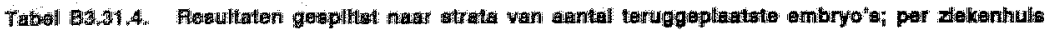

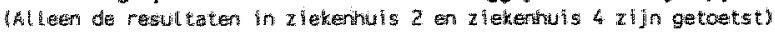

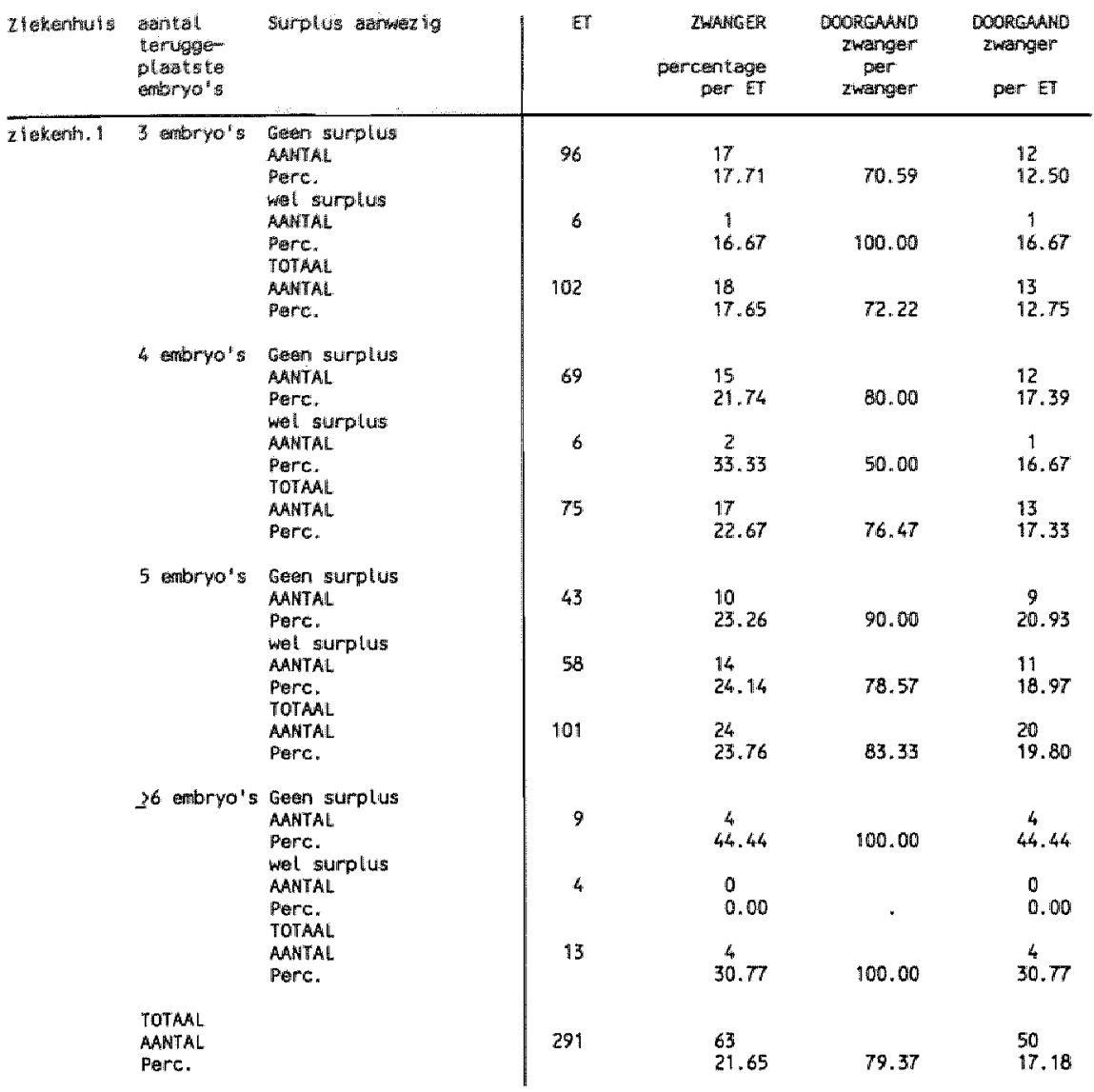




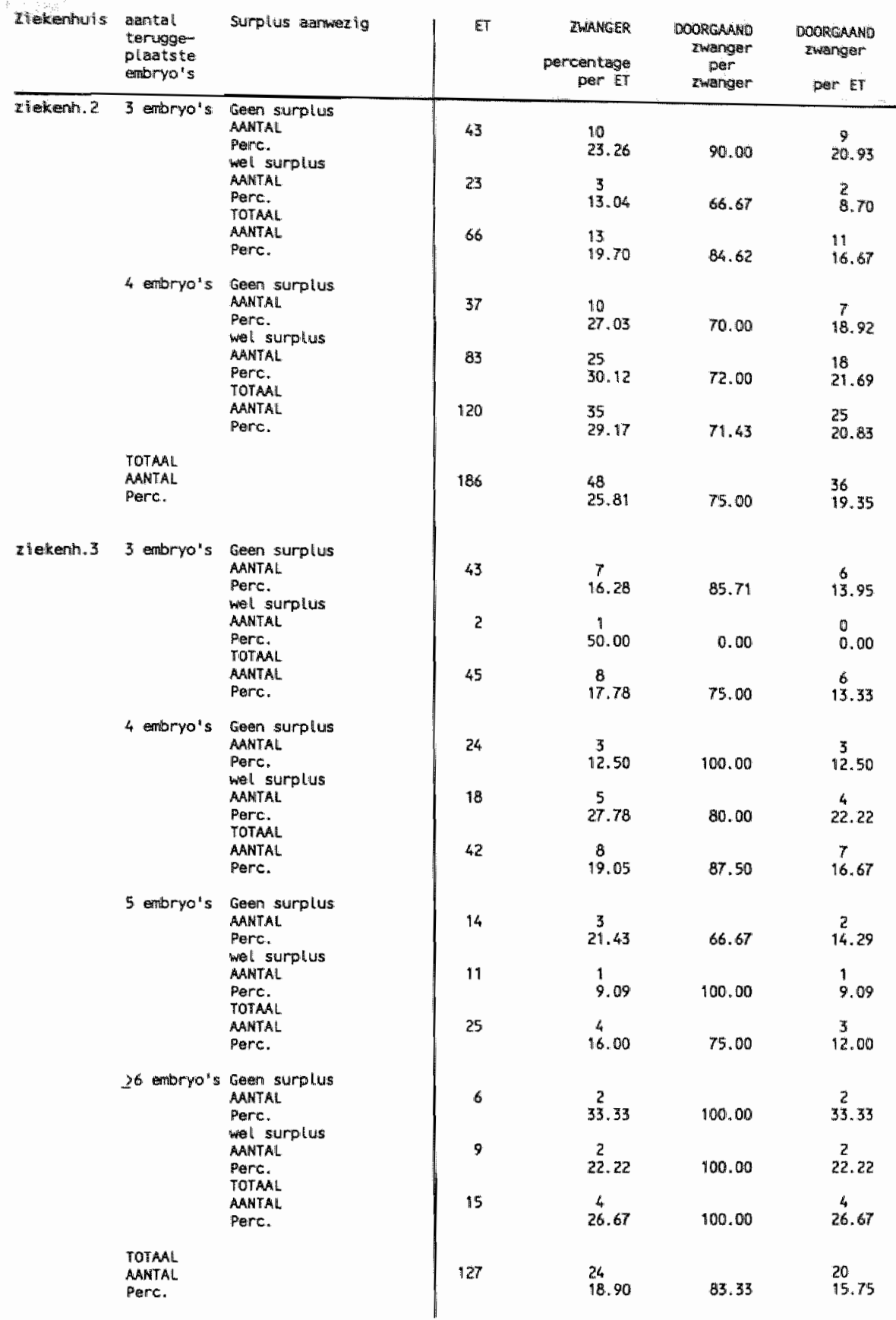




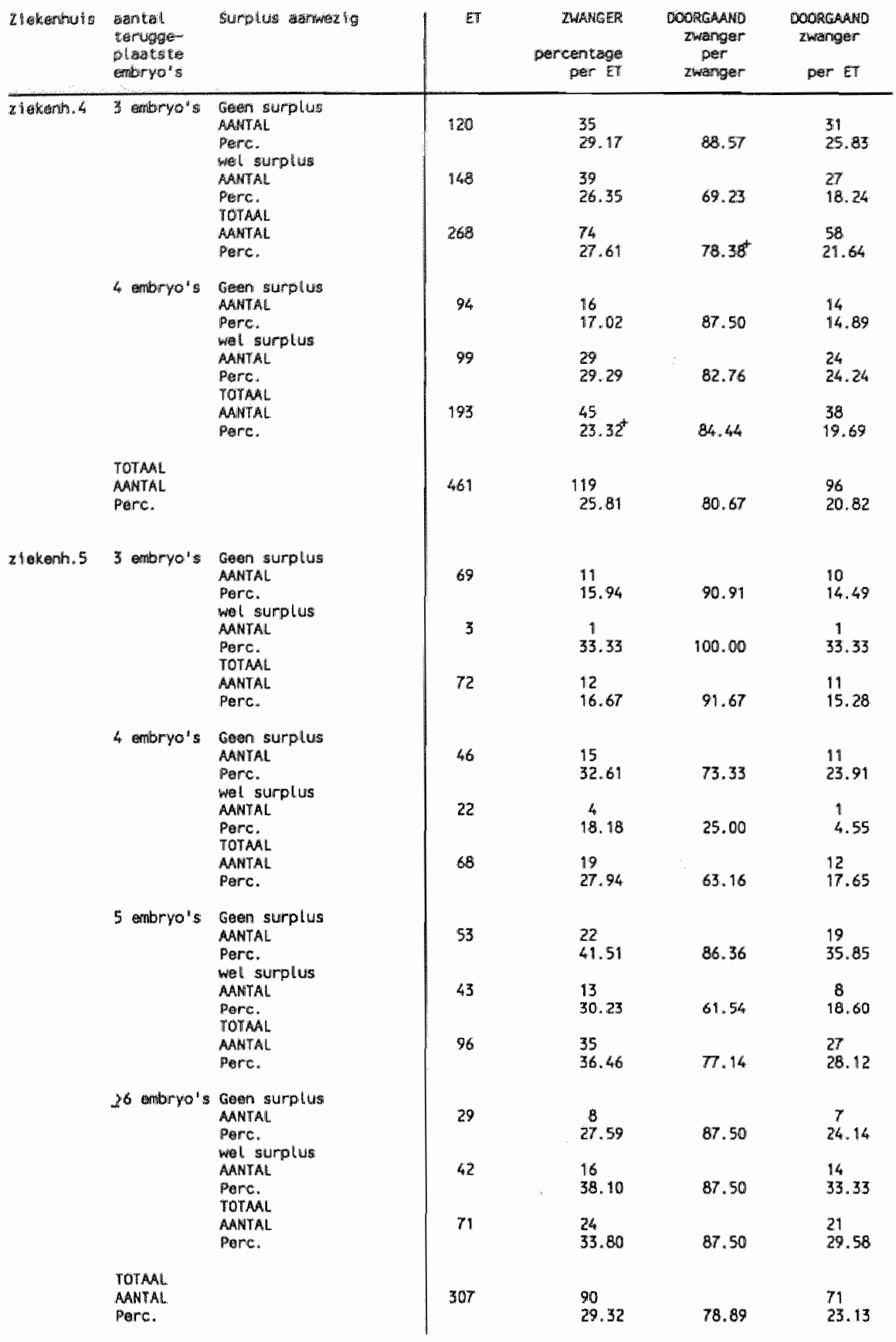




\section{Bijlage 3.32. Resultaten gesplitst naar verloop van de embryotransfer}

\begin{tabular}{|c|c|c|c|c|}
\hline WHER Loop ET & $E T$ & $\begin{array}{r}\text { ZHAMGER } \\
\text { pericentage } \\
\text { prer ET }\end{array}$ & $\begin{array}{c}\text { Dooplatuke } \\
\text { zwanger } \\
\text { per } \\
\text { zwanger }\end{array}$ & $\begin{array}{l}\text { DCofigatikb } \\
\text { zwanger } \\
\text { per teT }\end{array}$ \\
\hline $\begin{array}{l}\text { HAHTALL } \\
\text { Perc. }\end{array}$ & 13 & $\begin{array}{c}3 \\
28.08\end{array}$ & 66.67 & $\frac{2}{15.38}$ \\
\hline $\begin{array}{l}\text { nomal zonder bloed } \\
\text { MANTAL. } \\
\text { Perc. }\end{array}$ & 1675 & $\begin{array}{l}339 \\
20.24\end{array}$ & 76.99 & $\frac{261}{15.58}$ \\
\hline $\begin{array}{l}\text { nonmaal met bloed } \\
\text { AHANTAL } \\
\text { Perc. }\end{array}$ & 195 & $\begin{array}{l}39 \\
20.00\end{array}$ & 87.18 & $\begin{array}{l}34 \\
17.44\end{array}$ \\
\hline $\begin{array}{l}\text { normad totan } \\
\text { ANANTAL } \\
\text { Perte. }\end{array}$ & 1870 & $\begin{array}{l}378 \\
20.21\end{array}$ & 78.04 & $\frac{295}{15.78}$ \\
\hline $\begin{array}{l}\text { moe izzatim zonder bloed } \\
\text { AMNMAL } \\
\text { Peirc. }\end{array}$ & 119 & $\begin{array}{l}23 \\
19.33\end{array}$ & 65.22 & $\begin{array}{l}15 \\
12.61\end{array}$ \\
\hline 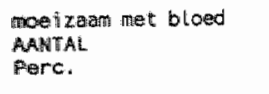 & 87 & $\begin{array}{l}12 \\
13.79\end{array}$ & 91.67 & $\begin{array}{l}11 \\
12.64\end{array}$ \\
\hline $\begin{array}{l}\text { moeizaam totaall } \\
\text { AMNTAL } \\
\text { Pierc. }\end{array}$ & 206 & $\begin{array}{l}35 \\
16.99\end{array}$ & 74.29 & $\begin{array}{l}26 \\
12.62\end{array}$ \\
\hline $\begin{array}{l}\text { TOTAAL } \\
\text { MaNTALE. }\end{array}$ & 2089 & $\begin{array}{l}416 \\
19.91\end{array}$ & 77.64 & $\begin{array}{l}323 \\
15.46\end{array}$ \\
\hline
\end{tabular}

1) Getoetst tijn de werschillem in de resultaten tussen te behandelingen met cen 
Bijage 3.33 . Resultaten naar medikatieschema luteale fase

(de resultaten zijn niet getoetst)

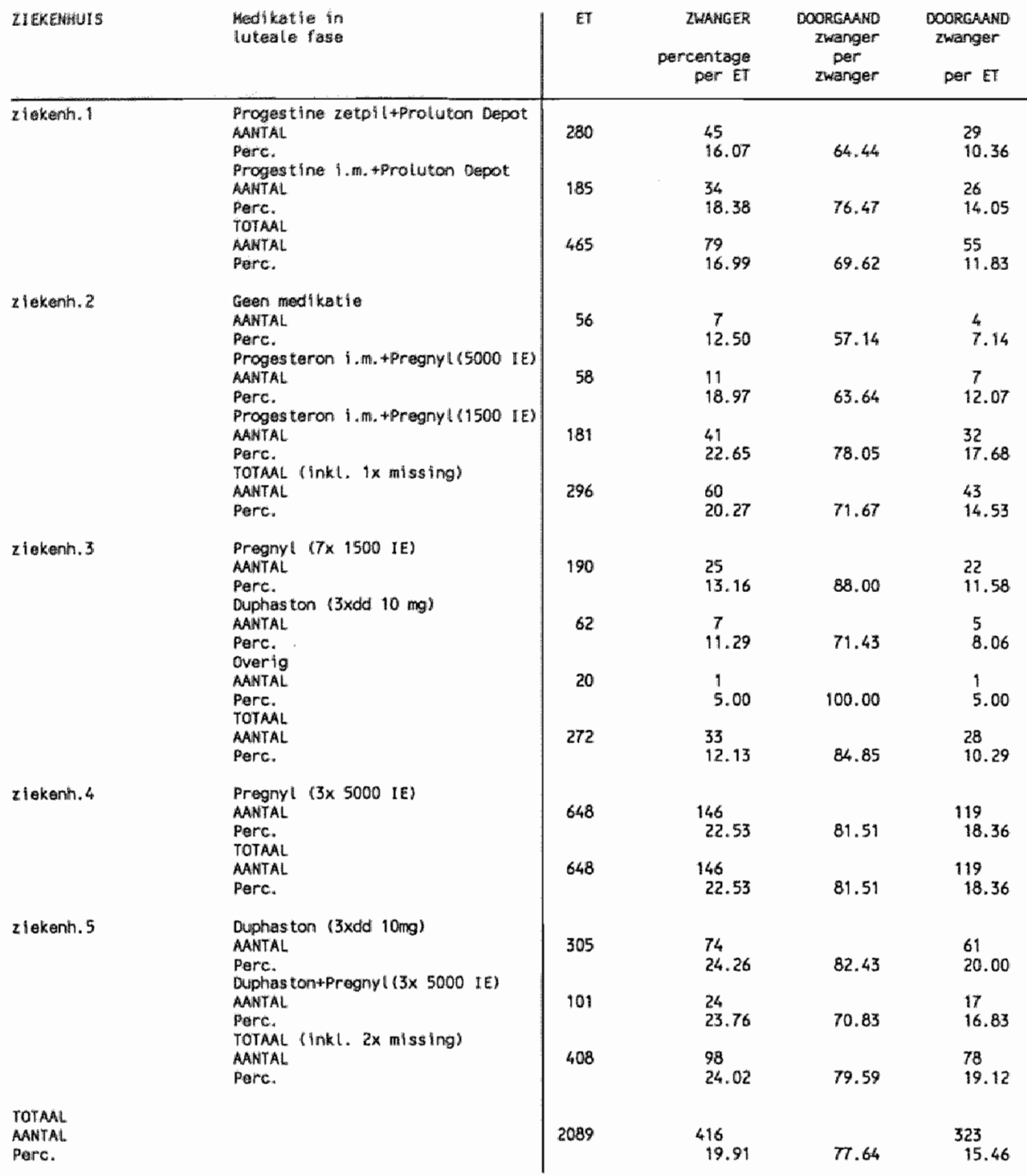




\section{Bijlage 3.34. Gegevens over doorgaande zwangerschappen na IVF}

Tabel B3.34.t. Krulatabel varn aantal teruggeplactste embrya's tegen aantal vrucihtzakken met positleve hartaktla; totaal en per zlekerihuls

Telkens wordt per cel in de eerste rij het aantal warnemingen vermeld. in de tweede $r i j$ het procentuele aandeel bij het betreffende aental teruggeplaatste mbryo's en in de derde rij het procentuele aandeel bij het betreffende aantal wruchtzakken met pasitiovie hartaktie. Van de 323 doorgaande zwangerschappen eindigden er 10 in een partus immaturus; deze zijn niet opgenomen in de onderstarande data.

\begin{tabular}{|c|c|c|c|c|c|c|}
\hline \multirow{8}{*}{$\begin{array}{l}\text { Totaal } \\
\text { aanital } \\
\text { plaats te } \\
\text { embryo' }\end{array}$} & $90-$ & \multicolumn{2}{|c|}{ aental yruchtzak } & \multicolumn{2}{|c|}{ net hartallikt ie } & TOTAAL \\
\hline & 1 & $\begin{array}{r}16 \\
100.0 \\
7.0\end{array}$ & & & & $\begin{array}{r}16 \\
5.1\end{array}$ \\
\hline & 2 & $\begin{array}{r}26 \\
78.8 \\
11.4\end{array}$ & $\begin{array}{r}7 \\
21.2 \\
10.3\end{array}$ & & & $\begin{array}{r}33 \\
10.5\end{array}$ \\
\hline & 3 & $\begin{array}{r}82 \\
82.8 \\
35.8\end{array}$ & $\begin{array}{r}12 \\
12.4 \\
17.6\end{array}$ & $\begin{array}{r}4 \\
4.0 \\
28.6\end{array}$ & $\begin{array}{r}1 \\
1.0 \\
50.0\end{array}$ & $\begin{array}{r}99 \\
31.6\end{array}$ \\
\hline & 4 & $\begin{array}{r}58 \\
65.9 \\
25.3\end{array}$ & $\begin{array}{r}24 \\
27 \cdot 3 \\
35.3\end{array}$ & $\begin{array}{r}5.7 \\
35.7\end{array}$ & $\begin{array}{r}1 \\
1.1 \\
50.10\end{array}$ & $\begin{array}{r}88 \\
28.1\end{array}$ \\
\hline & 5 & $\begin{array}{r}32 \\
65.3 \\
14.0\end{array}$ & $\begin{array}{r}15 \\
30.6 \\
22.1\end{array}$ & $\begin{array}{r}2 \\
4.1 \\
14.3\end{array}$ & & $\begin{array}{r}49 \\
15.7\end{array}$ \\
\hline & $\geq 6$ & $\begin{array}{r}15 \\
53.6 \\
6.6\end{array}$ & $\begin{array}{r}10 \\
35.7 \\
14.7\end{array}$ & $\begin{array}{r}10.3 \\
10.7 \\
21.4\end{array}$ & & $\begin{array}{r}28 \\
8.9\end{array}$ \\
\hline & To & $\begin{array}{r}229 \\
73.2\end{array}$ & $\begin{array}{r}68 \\
21.7\end{array}$ & $\begin{array}{r}14 \\
4.5\end{array}$ & $\begin{array}{r}2 \\
.6\end{array}$ & $\begin{array}{r}313 \\
100.0\end{array}$ \\
\hline
\end{tabular}

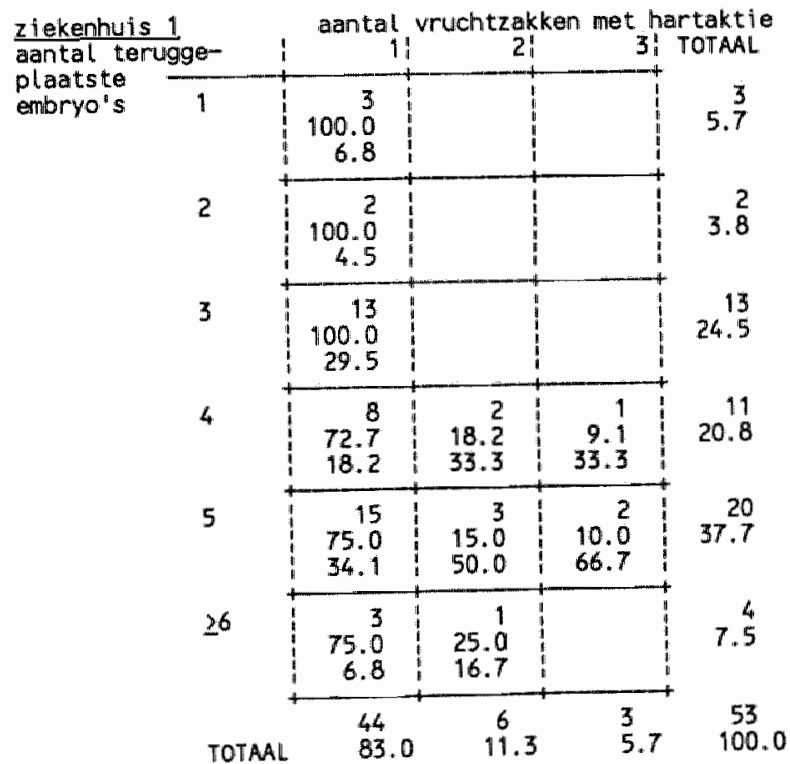




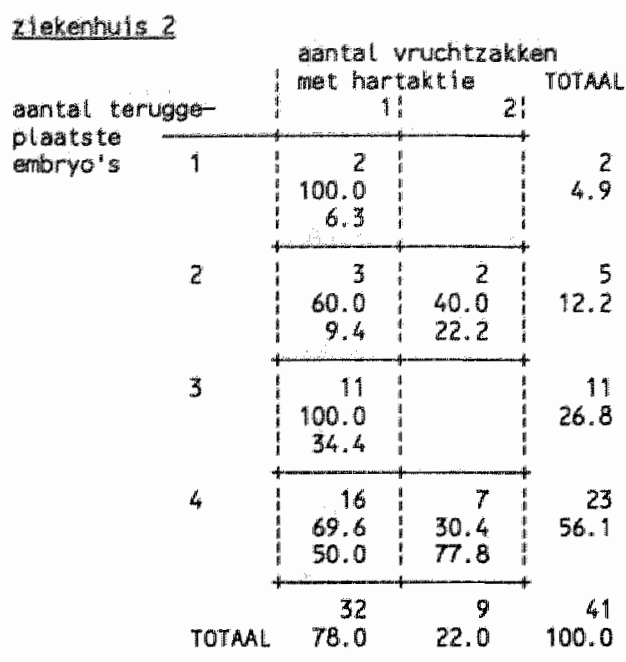

\section{zlekenturis 3}

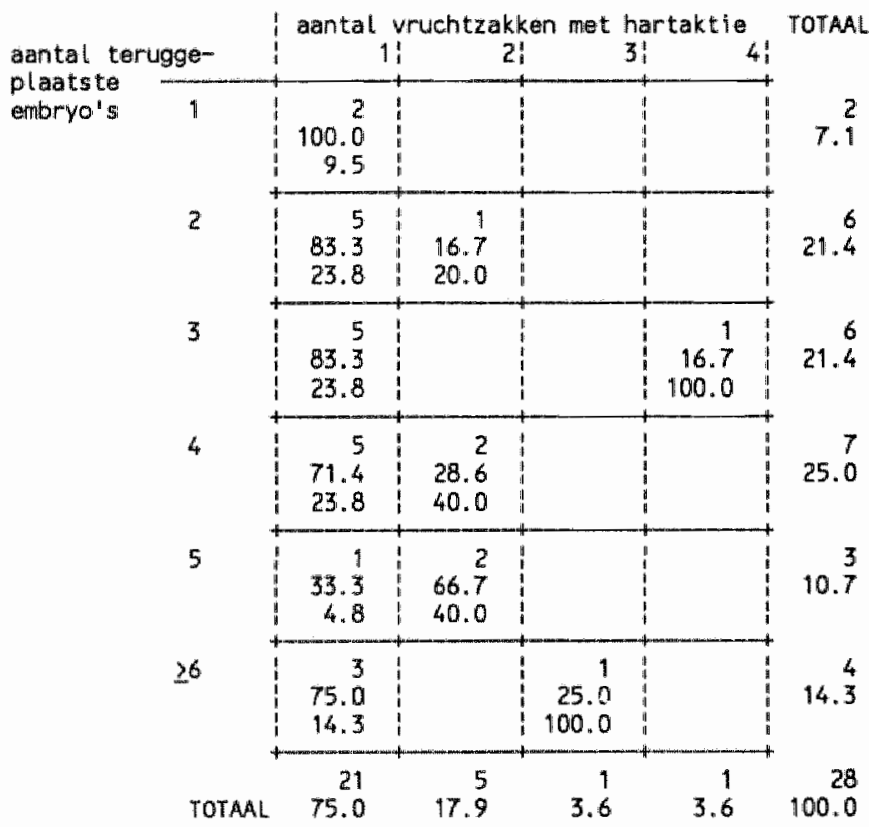




\section{ziekentuis 4}

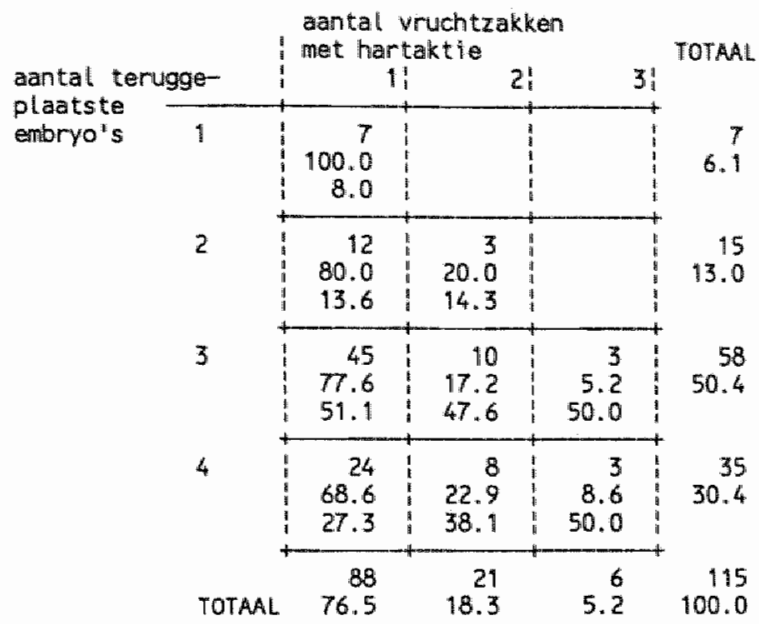

\section{ziekenhuis 5}

\begin{tabular}{|c|c|c|c|c|c|c|}
\hline \multirow{8}{*}{$\begin{array}{l}\text { aantal terus } \\
\text { plaatste } \\
\text { enbryo's }\end{array}$} & g9e- & \multicolumn{4}{|c|}{ aantal vruchtzakken met hartaktie } & TOTAAL \\
\hline & 1 & $\begin{array}{r}2 \\
100.0 \\
4.5\end{array}$ & & & & $\begin{array}{r}2 \\
2.6\end{array}$ \\
\hline & 2 & $\begin{array}{r}4 \\
80.0 \\
9.1\end{array}$ & $\begin{array}{r}1 \\
20.0 \\
3.7\end{array}$ & & & $\begin{array}{r}5 \\
6.6\end{array}$ \\
\hline & 3 & $\begin{array}{r}8 \\
72.7 \\
18.2\end{array}$ & $\begin{array}{r}2 \\
18.2 \\
7.4\end{array}$ & $\begin{array}{r}1 \\
9.1 \\
25.0\end{array}$ & 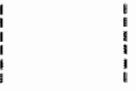 & $\begin{array}{r}11 \\
14.5\end{array}$ \\
\hline & 4 & $\begin{array}{r}5 \\
41.7 \\
11.4\end{array}$ & $\begin{array}{r}5 \\
41.7 \\
18.5\end{array}$ & $\begin{array}{r}1 \\
8.3 \\
25.0\end{array}$ & $\begin{array}{r}1 \\
8.3 \\
100.0\end{array}$ & $\begin{array}{r}12 \\
15.8\end{array}$ \\
\hline & 5 & $\begin{array}{r}16 \\
61.5 \\
36.4\end{array}$ & $\begin{array}{r}10 \\
38.5 \\
37.0\end{array}$ & & & $\begin{array}{r}26 \\
34.2\end{array}$ \\
\hline & 26 & $\begin{array}{r}9 \\
45.0 \\
20.5\end{array}$ & $\begin{array}{r}9 \\
45.0 \\
33.3\end{array}$ & $\begin{array}{r}2 \\
10.0 \\
50.0\end{array}$ & & $\begin{array}{r}20 \\
26.3\end{array}$ \\
\hline & TOT & $\begin{array}{r}44 \\
57.9\end{array}$ & $\begin{array}{r}27 \\
35.5\end{array}$ & $\begin{array}{r}4 \\
5.3\end{array}$ & $\begin{array}{r}1 \\
1.3\end{array}$ & $\begin{array}{r}76 \\
100.0\end{array}$ \\
\hline
\end{tabular}


Tabel B3.34.2. Gegewens van doorgaanide zwangerschappen die thjens de registratieperiode hebben geresulteerd in oen partws van minstens 6 én levendgeboren kind

\begin{tabular}{|c|c|c|c|}
\hline & $\begin{array}{l}\text { totaial } \\
\text { (n=294, partus) } \\
\text { ( } n=393 \text { kinderen) }\end{array}$ & $\begin{array}{l}\text { meer lingen } \\
(n=81 \text { partus }) \\
(65 \times 2 ; 14 \times 3 ; 2 \times 4)\end{array}$ & $\begin{array}{l}\text { alleen eenlingen } \\
\text { (n=213 partus) }\end{array}$ \\
\hline $\begin{array}{l}\text { Zwangerschapshomp likaties } \\
\text { geen } \\
\text { lichte } \\
\text { ernstige }\end{array}$ & $\begin{array}{l}65 \% \\
20 \% \\
115 \%\end{array}$ & $\begin{array}{l}38 \% \\
34 \% \\
28 \%\end{array}$ & \\
\hline $\begin{array}{l}\text { ptaats partus } \\
\text { kt inisch: punikt lez lekenhuis } \\
\text { ander z lekenhuis } \\
\text { polikt in. : punkt iez iekerhuis } \\
\text { ander z jekenhuis }\end{array}$ & $\begin{array}{r}38 \% \\
42 \% \\
5 \% \\
15 \%\end{array}$ & $\begin{array}{l}36 \% \\
61 \% \\
1 \% \\
1 \%\end{array}$ & \\
\hline $\begin{array}{l}\text { wijze van partus } \\
\text { vaginal } \\
\text { sectio caesarea }\end{array}$ & $\begin{array}{l}73 \% \\
27 \%\end{array}$ & $\begin{array}{l}52 \% \\
48 \%\end{array}$ & \\
\hline $\begin{array}{l}\text { gewicht kind } \\
<1000 \mathrm{~g} \\
1000-1499 \mathrm{~g} \\
1500-2499 \mathrm{~g} \\
\geq 2500 \mathrm{~g}\end{array}$ & $\begin{array}{l}1.8 \% \\
5.2 \% \\
31 \% \\
62 \%\end{array}$ & $\begin{array}{l}3.2 \% \\
9.6 \% \\
57 \% \\
31 \%\end{array}$ & $\begin{array}{l}0.6 \% \\
1.2 \% \\
7 \% \\
91 \%\end{array}$ \\
\hline $\begin{array}{l}\text { zwangerschapstermi.jn }{ }^{1} \\
\text { preterm: }<37 \text { weken } \\
\text { (erg pretermk } 32 \text { weken) } \\
\text { a teirm: } 37-41 \text { weken } \\
\text { post-term: }>41 \text { weken }\end{array}$ & $\begin{array}{l}30 \% \\
(5 \%) \\
61 \% \\
10 \%\end{array}$ & $\begin{array}{l}65 \% \\
(11 \%) \\
33 \% \\
1 \%\end{array}$ & $\begin{array}{l}15 \% \\
(2.5 \%) \\
72 \% \\
13 \%\end{array}$ \\
\hline $\begin{array}{l}\text { ges lacht } \\
\text { man } \\
\text { vrouw }\end{array}$ & $\begin{array}{l}52 \% \\
48 \%\end{array}$ & & \\
\hline
\end{tabular}

Neonatale sterfte en kongenitale afwijkingen

Er was $7 \mathrm{x}$ sprake van neonatale sterfte ${ }^{2}$, hetgeen overeenkomt met een neonatale sterftevoet van $1.8 \%(7 / 393)$; het betrof in alle gevallen op een na meerlingzwangerschappen waarbij minstens éen levendgeboren kind nog in leven is.

Bij 6 kinderen is melding gemakt van een kongenitale afwijking (tussen haakjes zijn de LVR-koden vermeld); hiervan zijn 4 kinderen neonataal owerleden:
1. anencefalie (1), $\dagger$
4. vitium cordis $(20), \dagger$
2. anencefalie (1), t
5. darmatresie (44)
3. overige chrom./kong.afwijkingen $(82,84)$, †
6. pes equinovarus (74)

Met uitzondering van de kinderen vermeld bij punt 2 en 6 betrof het kinderen van meerlingzwangerschappen. De gemiddelde leeftijd van de vrouwen met kinderen met een kongenitale afwijking was 33 jaar (range 28-36 jaar).

1) Hierbij is on eeniervermelde redenen uitgegaan van de termijn tussen de dag van de embryotransfer en de dag wa de partus waarbij 2 weken zijn opgeteld. Verder is aangesloten bij de indeling die ook wordt aanbevolen door de $\mathrm{MGO}$ en de WHO (zie ook Verloove-Vanhoorick[1987]).

2) Neonatale sterte gedelinieerd als sterfte van een levendgeboren kind voor 28 volledige levensdagen. 


\section{Bijlage 3.35. Invloed aantal en kwaliteit van embryo's op klinische awangerschap}

Uit eerdere schattingen, waarbij als verklarende variabelen diwerse behandelgegevens werden toegestaan, bleek telkens weer dat alleen de variabelen die betrekking hebben op aantal en kwaliteit van de teruggeplaatste embryo's van signifikant belang waren voor de kans op een klimische zwangerschap. Derhalve zijn deze variabelien nadrukkelijk onder de loupe genomen.

Allereerst is een index gekonstrueerd waarin rekening werd gehouden met zowel aantal als kwaliteit van de teruggeplaatste embryo's: ET-INDEX (2ie paragraaf 3.3.2.3). Hierbij kregen embryo's met een zogenaamde 'prima" kwaliteit een gewicht 1.5 . Vervolgens werden de waarden voor deze index gegroepeerd in 3 groepen $(<3,3-$ $4.5, \geq 4.5$ ) ten behoeve van de konstruktie van de variabele ET-INDEX-I.

Schatting van een model met alleen deze variabele (naast een konstante) als kategorische variabele leverde de volgende resultaten $\left(\mathrm{OR}=\right.$ odds- $\mathrm{ratio}^{3}, \mathrm{BI}=$ betrouwbaarheidsinterval; bij de kolom suksespercentage staat bij de konstante het resultaat voor de 'baseline'-kategorie):

Tabel B3.35.1. Modelschattingen voor model met athankellike varlabele kllnlsche zwangerschap" onathankelijke variabele: ET-INDEX-I kategorlsch

\begin{tabular}{r|l|c|c} 
& OR & BI (95\%) & suksesperc. (voorspeld=wargenonen) \\
\hline ET-INDEX-I=1 & 1.00 & & $10.0 \%$ \\
$=2$ & 2.57 & $2.01-3.28$ & $22.3 \%$ \\
$=3$ & 3.86 & $2.97-5.01$ & $30.1 \%$ \\
konstante & 0.11 & $0.09-0.14$ & $10.0 \%(8.34 \%-12.05 \%)$ \\
\hline
\end{tabular}

De embryotransfers met een ET-INDEX in kategorie 2 hebben een odds op een klinische zwangerschap van ruim $2.5 \mathrm{x}$ ten opzichte van embryotransfers in de laagste kategorie; voor embryotransfers in kategorie 3 geldt een odds-ratio van bijna 4 ten opzichte van kategorie 1. De betrouwbaarheidsintervallen woor de embryotransfers in de kategorieën 2 en 3 vertonen enige overlap.

Blijkens bovenvermelde resultaten is niet volledig voldaan aan de woorwaarde van een lineair verband op een logistische schaal tussen de "risiko-faktor" ET-INDEX-I en de kans op een klinische zwangerschap. Dat bleek ook bij toetsing in een model: de log odds op klinische zwangerschap bleek bij schatting van ET-INDEX-I op intervalschal geen limeair verband te vertonen met deze verklarende variabele.

In de variabele ET-INDEX-I is zowel het aantal embryo's als de kwaliteit van de embryo's verwerkt. Aangezien deze variabele sterk samenhangt met de kans op een klinische zwangerschap is onderzocht of ook de beide komponenten van deze variabele leder afzonderlijk van belang zijn. Hiertoe is eerst gekeken naar de komponent aantal embryo's, waarvoor de variabele EMBRYO- IND werd gekonstrueerd volgens de indeling in onderstaande tabel. In de tabel zijn ook de odds-ratio"s weergegeven woor het geval de variabele EMBRYO-IND als kategorische variabele wordt gehanteerd. de odds-ratiots); in deze konstante term is immers juist de basiskategonie verval. De tevens vermelde zwangerschapspercentages bij de konstante tern (en later bij de ziekenhuisdummies) lvebben dan ook betrekking op deze basiskategorie. 
Tabol B3.35.2. Modelschattingon voor model met afhankeil|ke varlabele lilinisohe zwangerschap: onathenkellike varlabela: EMBAYO-IND kategorllen

\begin{tabular}{r|l|l|l|l} 
& EMBRYO & OR & BI $(95 \%)$ & suksesperc. \\
\hline EMBRYO-1ND=1 & 1 & 1.00 & & $7.1 \%$ \\
$=2$ & 2 & 1.92 & $1.24-2.97$ & $12.7 \%$ \\
$=3$ & 3.4 & 4.09 & $2.81-5.95$ & $23.7 \%$ \\
$=4$ & $7=5$ & 5.54 & $3.68-8.33$ & $29.6 \%$ \\
konstante & & 0.08 & $0.05-0.11$ & $7.41(5.1 \%-9.8 \%)$ \\
\hline
\end{tabular}

Deze resultaten rechtvaardigen in redelijke mate de opname wan EMBRYO-IND als intervall-variabele.

Tabel B3.35,3. Modelschattingen voor moded met afhankellyke varlabelle kllniache zwang|erschap: onafhankelljke varlabele: EMBRYO-IWD Interval

\begin{tabular}{l|l|l|l|l} 
& OR & BI $(95 \%)$ & \\
EMBRYO-IND(intervat) & 1.77 & $1.58-1.94$ & \\
konstante & 0.05 & $0.04-0.07$ & \\
\hline
\end{tabular}

Gekonkludeerd kan worden dat een hogere kategorie van EMBRYO-IND een odds op klinische zwangerschap heeft die bijna $1.8 x$ zo groot is als die bij 1 kategorie lager.

Tenslotte zijn schattingen uiltgevoerd voor een model, waarin separaat aantal en kwaliteit van de teruggeplaatste embryo's als verklarende variabelen zijn opgenomen. Naast de interval-variabele EMBRYO-IND is de dummy-variabele EMBKWAL gekonstrueerd; deze krijgt de waarde 1 indien er minstens 2 prima ${ }^{4}$ embryo's zijn teruggeplaatst en de waarde 0 in alle andere gevallen.

Tabel B3.35,4. Modelschattingen voor model met athankell|ke varlabelle kllunische zwangerachap; onafhankelljke varlabelen: EMBAYO-IND (Interval) on EMIKWAL (dummy)

\begin{tabular}{l|l|l|l} 
& OR & BI $(95 \%)$ \\
\hline EMBRYO-IND & 1.69 & $1.51=1.89$ \\
EMBKWAL & 1.38 & $1.14-1.67$ \\
Konstante & 0.05 & $0.04-0.07$ \\
\hline
\end{tabular}

Gekonkludeerd mag worden dat de kwalliteit van de teruggeplaatste embryo's wel degelijk invloed heeft op de odds op een klinische zwangerschap; bij een embryotransfer van minstens 2 prima embryo's is deze odds - ceteris paribus ${ }^{5}-1,4 x z 0$ groot als bij een embryotransfer met (ook) minder goede embryo's. Bowendien geldt dat de waargenomen suksespercentages binnen ieder stratum van EMBRYO-IND hoger lagen voor $\mathrm{EMBKWAL}=1$ ten opzichte van $\mathrm{EMBKWAL}=0$.

4) Reeds eerder gedefinieerd als minstens 4-celler en morfologisch perfekt.

5) De ceteris paribus-klausule houdt in dit geval ook in: bij gelijkblijwend aantal teruggeplaauste embryo's. Bijvoorbeeld vergelijking van de groepen transfers met 4 embryo's van enerzijds minstens 2 prima enbryo's en anderzijds maximaal 11 prima embryo. 
Bijlage 3.36. Multivariate analyse: van hormoon tot doorgaand zwanger; extri verklarende variabele de interaktieterm van onbegrepen infertiliteit met primaire langdurige infertiliteit

Tabell B3.36.1. Modelschatingen voor model met sthankell|ke varlabelo doorgasnde zwangerechap; onathankelljke varlabelen: pattentkenmerken, behandelvolgnummer eninteraktloterm van onbegrepen infertllitelt met primaire langdurige infertilltelt

\begin{tabular}{|c|c|c|c|}
\hline & $O R$ & BI & \\
\hline $\begin{array}{l}\text { mannelijke subf. } \\
\text { onbegrepen inf. } \\
\text { ovariëctomie } \\
\text { vroum } \geq 36 \\
\text { graw. / irvf. duur } \\
\text { behandelvalgno. } \\
\text { onb. inf*grav./inf. duur } \\
\text { kons tante }\end{array}$ & $\begin{array}{l}0.48 \\
2.69 \\
0.65 \\
0.57 \\
0.69 \\
0.86 \\
0.28 \\
0.22\end{array}$ & $\begin{array}{l}0.32-0.7 \overline{3} \\
1.60-4.52 \\
0.50-0.85 \\
0.45-0.74 \\
0.56-0.86 \\
0.78-0.96 \\
0.11-0.67 \\
0.18-0.28\end{array}$ & $\begin{array}{l}x \text { doorgaand zwanger per behandel ing: } \\
18.24 \%(15.08-21.89)\end{array}$ \\
\hline
\end{tabular}

Bij de introduktie van de interaktieterm onbegrepen infertiliteit * langdurige primaire infertiliteit als extra verklarende variabele in het model blijven de geschatte waarden voor de odds-ratio's van alle andere variabelen nagenoeg ongewijzigd, met uitzondering van de variabele onbegrepen infertiliteit. Voor paren met langdurige, primaire onbegrepen infertiliteit is de odds-ratio nu gelijk aan $2.69 * 0.69 * 0.28=0.52$; ofwel voor deze paren geldt wel degelijk een duidelijk verlaagde sukseskans. 


\section{Billage 3.37. Berekening van gekorrigeerde doorgaand-zwangerschapspercentiges}

Uitgaande van de schattingen in het logistische regressiemodel met als afhankelijke variabele doorgaande zwangerschap en als verklarende variabelen diverse patientkenmerken, het behandelvolgnummer en de ziekenhuisdummies kan een berekening worden gemaakt voor de zwangerschapspercentages in de ziekenhuizen na korrektie voor eventuele verschillen in de samenstelling van de patiëntenpopulaties. Simpel gezegd: wat zouden de zwangerschapspercentages in de verschillende ziekenhuizen zijn geweest als ieder ziekenhuis de "gemiddelde" populatie van het totale databestand in zijn ziekenhuis had behandeld?

Eerder is aangegeven dat:

$$
\log \text { odds }(y)=a+\Sigma\left(b x_{i}\right)
$$

ofwel

$$
\text { odds }(y)=O(y)=e^{\left\{a+\Sigma\left(b_{i} x_{i}\right)\right\}}
$$

Verder geldt:

$$
O(y)=P(y) /\{1-P(y)\}
$$

en dus ook

$$
P(y)=O(y) /\{1+O(y)\}
$$

Voor de totale onderzoekspopulatie is het gemiddeld doorgaand awangerschapspercentage gelijk aan $10.45 \%$, ofwel

$$
\overline{P(y)}=0.1045
$$

Derhalve is met behulp van (B3.37.3) en (B3.37.5) te berekenen

$$
\overline{\mathrm{O}(y)}=0.1167
$$

$\overline{\mathrm{O}(\mathrm{y})}$ is ook te bepalen via vergelijking (B3.37.2). In dat geval geeft $\overline{\Sigma\left(b_{i} x_{i}\right)}$ in die vergelijking de invloed op de doorgaand zwangerschapspercentages weer van de patièntkenmerken en het behandelvolgnummer voor de gemiddelde populatie; de waarde voor a is te beschouwen als de (gewogen) gemiddelde log odds voor de verschillende ziekenhuizen.

Welnu, in het model met de ziekenhuisdummies als (mede) verklarende variabelen werden de volgende schattingen voor de log odds van de ziekenhuisdummies gevonden: 


$$
\begin{aligned}
& a_{1}=-1.6109 \\
& a_{2}=-1.5823 \\
& a_{3}=-2.2222 \\
& a_{4}=-1.2236 \\
& a_{5}=-1.1655
\end{aligned}
$$

Hieruit is a te bepalen als volgt:

$$
\vec{a}=\left\{\Sigma\left(a_{i} n_{i}\right)\right\} / \Sigma n_{i}=-1.5142
$$

Door deze waarde in te vullen in (B3.37.2), gekombineerd met (B3.37.6) volgt:

$$
\overline{\mathrm{O}(\mathrm{y})}=0.1167=\mathrm{e}^{-1.5142+\Sigma\left(\mathrm{b}_{\mathrm{x}}\right)}
$$

dus

$$
\overline{\Sigma\left(b_{i} x_{i}\right)}=-0.63397
$$

Door substitutie van (B3.37.7) en (B3.37.9) in (B3.37.2) is vervolgens voor ieder ziekenhuis de odds op een doorgaande zwangerschap voor de gemiddelde populatie te berekenen, zogezegd de gekorrigeerde odds op een zwangerschap $\left(O_{i, k}\right)$

$$
\begin{aligned}
& O_{1, k}=e^{-1.6109-0.63397}=0.10594 \\
& O_{2, k}=e^{-1.58323-0.63997}=0.10902 \\
& O_{3, k}=e^{.22222-0.663397}=0.05749 \\
& O_{4, k}=e^{-1.2236-0.63397}=0.15605 \\
& O_{5, k}=e^{-1.1655-0.63397}=0.16539
\end{aligned}
$$

Met behulp van (B3.37.4) en (B3.37.10) kunnen tenslotte die gekorrigeerde zwangerschapspercentages $\left(\mathbb{P}_{i, k}\right)$ worden bepaald voor de verschillende ziekenliuizen

$$
\begin{aligned}
& P_{1, k}=9.58 \% \\
& P_{2, k}=9.83 \% \\
& P_{3, k}=5.44 \% \\
& P_{4, k}=13.50 \% \\
& P_{s, k}=14.19 \%
\end{aligned}
$$


Tenslotte dienen nog de betrouwbaarheidintervallen te worden berekend, om precies te zijn de betrouwbaarheidsintervallen woor het verschil tussen de resultaten in het betreffende ziekenhuis en die in het "gemiddelde" ziekenhuis. Hiertoe dient voor leder ziekenhuis de standaarddeviatie (std) bepaald te worden voor het verschil in de geschatte log odds op een zwangerschap tussen het betreffende ziekenhuis en het totaal gemiddelde. Welnu, er geldt

$$
s_{1}=\text { sitd }(\log \text { odds }-\overline{\log \text { odds }})=\sqrt{\left(c_{i}^{\prime \prime} V c_{i}\right)}
$$

warbij

$$
\begin{aligned}
& c_{1}^{\prime}=\left(\begin{array}{llll}
1-n_{2} / n, & n_{2} / n, & n_{3} / n, & n_{4} / n_{3}, \quad n_{5} / n
\end{array}\right)
\end{aligned}
$$

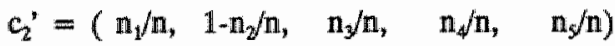

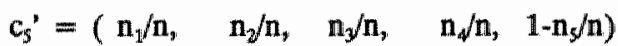

met $\quad n_{i}=$ aantal behandelingen in ziekenhuis $i$

V de covariantiematrix van de log odds van de ziekenhuisdummies

Uit de $n_{1}^{\prime}$ 's in het databestand van het onderzoek is te berekenen

$$
\begin{aligned}
& c_{1}^{\prime}=(0.80563,-0.14586,-0.17335,-0.31210,-0.17432) \\
& c_{2}^{\prime}=(-0.19437,0.85414,-0.17335,-0.31210,-0.17432) \\
& c_{3}^{\prime}=(-0.19437,-0.14586,0.82665,-0.31210,-0.17432) \\
& c_{i}^{\prime}=(-0.19437,-0.14586,-0.17335,0.68790,-0.17432) \\
& c_{5}^{\prime}=(-0.19437,-0.14586,-0.17335,-0.31210,0.82568)
\end{aligned}
$$


Door substitutie van (B3.37.13) in (B3.37.12) volgt

$$
\begin{aligned}
& s_{1}=0.12933 \\
& s_{2}=0.15078 \\
& s_{3}=0.17013 \\
& s_{4}=0.08871 \\
& s_{5}=0.12037
\end{aligned}
$$

Het 95\%-betrouwbaarheidsinterval voor de gekorrigeerde $\log$ odds $\left(\mathrm{BI}\left(\log \mathrm{O}_{\mathrm{L}}\right)\right.$ ) is dan te bepalen uit

$$
\text { BI } \left.\left(\log \mathrm{O}_{\mathrm{i}, \mathrm{k}}\right)\right)=\log \left(\mathrm{O}_{\mathrm{L}, \mathrm{k}}\right) \pm 1.96 \mathrm{~s}_{\mathrm{i}}
$$

Het bijbehorende 95\%-betrouwbaarheidsinterval voor de gekorrigeerde zwangerschapspercentages $\left(\mathrm{BI}\left(\mathrm{P}_{\mathrm{L}}\right)\right)$ is dan met behulp van (B3.37.15), (B3.37.1), (B3.37.2), (B3.37.3) en (B3.37.10) te bepalen. De betrouwbaarheidsintervallen voor de verschillende ziekenhuizen luiden

$$
\begin{aligned}
& \left.\operatorname{BI}\left(\mathrm{P}_{1, \mathrm{k}}\right)\right)=(7.89 \% ; 11.59 \%) \\
& \left.\operatorname{BI}\left(\mathrm{P}_{2, \mathrm{k}}\right)\right)=(7.84 \% ; 12.26 \%) \\
& \left.\operatorname{BI}\left(\mathrm{P}_{3, \mathrm{k}}\right)\right)=(4.16 \% ; 7.07 \%) \\
& \left.\operatorname{BI}\left(\mathrm{P}_{4, \mathrm{k}}\right)\right)=(11.88 \% ; 15.29 \%) \\
& \left.\operatorname{BI}\left(\mathrm{P}_{5, \mathrm{k}}\right)\right)=(11.95 \% ; 16.78 \%)
\end{aligned}
$$


Biflege 3.38. Multuariate analyse; wan hormoon tot doorgaand zwanger; alleen voor de erste behandeling

Tabel B3.38.1. Modelschattingen voor model met afhankeilike variabele doorgaande zwangerschap: onathankelijke varlabelen: patiëntkenmerken en behandelvolgnummer; alleen eerste bohandeling

\begin{tabular}{l|c|c|} 
& OR & $B 1$ \\
\hline mannelij ke subf. & 0.38 & $0.20-0.70$ \\
onbegrepen inf. & 1.21 & $0.67-2.16$ \\
owartectomie & 0.68 & $0.47-0.99$ \\
vroun 236 & 0.66 & $0.47-0.94$ \\
grav./inf.duur & 0.63 & $0.47-0.85$ \\
konstante & 0.19 & $0.16-0.23$
\end{tabular}


Bijlage 3.39. Multivariate analyse: van hormoon tot doorgaand awanger: extra verklarende variabelen: de interkatietermen tussen VERVOLG en de patiëntkenmerken

Om te onderzoeken of de samenhang van de afhankelijke variabele doorgaande zwangerschap met de patiëntkenmerken nog wordt beinnloed door het feit dat een paar meerdere keren in het databestand voorkomt, zullen in het onderstaande de modelschattingen van 2 modellen met elkaar worden vergeleken:

1. Een model vrijwel identiek aan het model van paragraaf 3.4 .5 in de versie met een konstante term; het enige verschil is de opname van een extra verklarende variabele: VERVOLG. Deze variabele krijgt de waarde 0 als het de eerste behandeling van het paar in de onderzoeksperiode betreft en de waarde 1 voor latere behandelingen.

2. Een model waarbij als uitbreiding op het model onder 1 tevens als verklarende variabelen de interaktietermen zijn opgenomen tussen de variabele VERVOLG en de patiëntkenmerken.

Tabel B3.39.1. Modelschattingen voor model met efhankelllke varlabele doorgaande zwangerschap; onafhankelt|ke varilabelen: patlëntkenmerken, behandelwolgnummer on vorvolg (dummy)

\begin{tabular}{|c|c|c|c|}
\hline & $O R$ & 81 & \\
\hline $\begin{array}{l}\text { mannel ijke subf. } \\
\text { onbegrepen inf. } \\
\text { ovariëctomie } \\
\text { vrouw } \$ 36 \\
\text { grav. } / \text { inf. duur } \\
\text { behandelvolgno (4) } \\
\text { vervolg } \\
\text { konstante }\end{array}$ & $\begin{array}{l}0.48 \\
1.54 \\
0.65 \\
0.58 \\
0.64 \\
0.77 \\
1.27 \\
0.25\end{array}$ & $\begin{array}{l}0.31-0.72 \\
1.02-2.33 \\
0.50-0.85 \\
0.45-0.75 \\
0.51-0.78 \\
0.63-0.94 \\
0.89-1.82 \\
0.19-0.32\end{array}$ & $\begin{array}{c}\text { \% doorgaand zwanger per behandel ling: } \\
20.02 \%(16.23-24.43)\end{array}$ \\
\hline
\end{tabular}

Uit de schattingen blijkt dat de variabele VERVOLG terecht is weggelaten uit de schattingen in het gehanteerde basismodel van paragraaf 3.4.5. Naast de verklarende variabele behandelvolgnummer - die wel sigifikante invloed heeft - blijkt er geen signifikant extra invloed te bestaan tussen de eerste behandeling en de volgende behandelingen.

Bij schatting van het tweede model met fakultatieve opname van de interaktietermen tussen vervolg en de patiëntkenmerken werden alle interaktietermen niet opgenomen door het model. De limiet voor de p-waarde om opgenomen te worden in het model was 0.10 , maar de kleinste p-waarde bij de interaktietermen was 0.29 . 
Butlage 3.40. Vergelijking vam de gemiddelde sukseskans van "doorstromers" versus "afwallers"

Centrale vraag voor deze analyses was:

- gegeven het feit dat een behandeling niet heeft geleid tot een doorgaande zwangerschap

- is er dam sprake van selektieve doorstroom naar een wolgende behandeling?

Met andere woorden: hebben degenen die na een behandeling zonder het gewenste eindresultaat erwoor kiezen nog (minstens) een IVF-behandeling te ondergaan een hogere sukseskans dan degenen die in dat geval besluiten te stoppen met de IVFprocedure?

Voor de analyses in deze vergelijking zijn derhalve alleen behandelingen van belang die niet hebben geresulteerd in een doorgaande zwamgerschap. Aangezien het evaluatieonderzoek patiěnten niet oneindig heeft gewolgd en aangezien binnen het onderzoek ook niet eenduidig is vastgelegd of een paar gestopt is met de IVF-procedure is het noodzakelijk op dit punt een nadere afbakening te maken van de uit te voeren analyses. Een belangrijke aanname in de analyse is:

* Een paar is gestopt met de IVF-procedure ten tijde van de laatste IVFbehandeling in het onderzoek.

Maar namrmate de laatste behandeling van het paar binnen het onderzoek dichter tegen het einde van de onderzoeksperiode heeft plaatsgevonden wordt deze premisse uiteraard steeds minder realistisch. Daarom is een verdere afbakening van de analyses doorgevoerd:

* Per ziekenhuis zijn de behandelingen in het laatste half jaar van het onderzoek $(n=794)$ niet meer als nieuwe waarnemingen in deze analyses opgenomen ${ }^{6}$.

Zodoende zijn behandelingen die niet tot wen doorgaande zwangerschap hebben geleid en die zijn uitgevoerd vór een bepaalde datum ingedeeld in twee groepen:

- behandelingen die gevolgd zijin door eem nieuwe TVF-poging; men zou in dat geval kunnen spreken van "doorstromers" ( $n=1492$ behandelingen)

- behandelingen die achteraf de laatste IVF-poging woor het betreffende paar bleken te $z i j n$; in dit zou men kunnen spreken van "afvallers" ( $n=582$ behandelingen).

Op basis van de geschatte parameters in het model is voor ledere aparte behandeling de voorspelde sukseskans bepaald? Vervolgens zijn gestratificeerd naar het behandelvolgnummer de gemiddelde sukseskansen tussen beide groepen van behandelingen vergeleken.

6) Voor cen ziekenhwis, dat tijdens het evaluatie-onderzoek voortijdig is gestopt met IVF-behandelingen, is de gnens gelegd bij 1 november 1987. Voor de overige ziekenhuizen ligt deze grens bij 1 januari 1988 . De behandelingen die na dexe grens zij|n uitgevoend zijn wel in beschouwing genomen om te bepalen of een behandeling die voor deze grens is uitgeword voor dat paar de laatste IVF-poging is geweest.

7) In totaal was de voorspelde sukseskans $22 x$ missing in verband met missing bij een van de patientkenmerken (leefijd vrouw). 


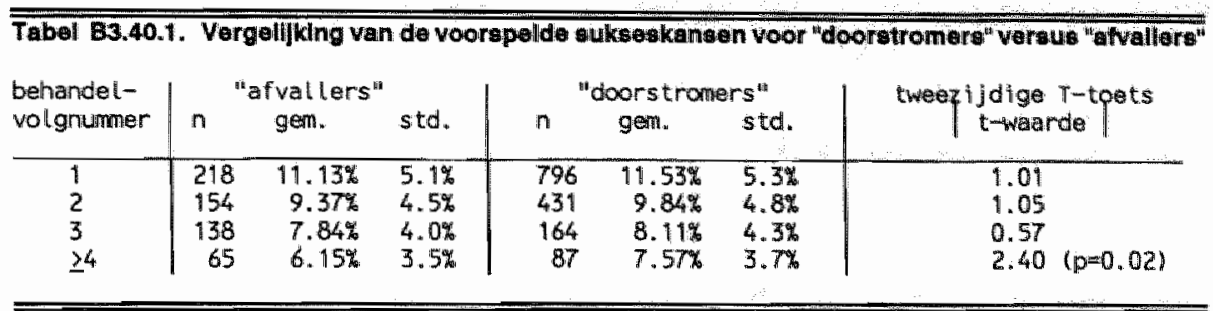

Uit deze tabel blijkt dat de voorspelde sukseskansen tot en met behandelvolgnummer 3 niet verschillen tussen beidle deelpopulaties; met andere woorden, in het databestand van het evaluatie-onderzoek is geen sprake van selektieve doorstroom na een mislukte IVF-poging. Een uitzondering op deze konklusie is de situatie na 3 behandelingen in de onderzoeksperiode. Maar mogelijk speelt hier een verschillende verdeling tussen beide deelpopulaties over de behandelvolgnummers een rol. Nadere splitsing van deze behandelnummers is gezien het klein aantal waarnemingen niet zinvol. 


\section{Bilage 4.1. Raming vain personeelsinzet van verschillende disciplines bij de diverse IVFuaktiviteiten}

De tijdsbestedingen van personen van verschillende disciplines voor de diverse onderdelen van de IVF-behandeling zijn ingeschat op basis van gesprekken met vele betrokkenen tijdens de onderzoeksperiode, observaties in de ziekenhuizen en besprekingen van eerdere schattingen met diverse vertegenwoordigers van de ziekenhuizen. Dit laatste betekent overigens niet, dat de personen in de ziekenhuizen op alle onderdelen instemden met de gepresenteerde cijfers.

De tijdsbesteding is weergegeven voor 6 onderdelen (onderstaand A tot en met F). Daarnaast bestaan er vele werkzaamheden die niet eenvoudig bij een bepaald onderdeel onder te brengen zijn; deze aktiviteiten zijn samengebracht bij punt G. Uiteindelijk wordt een optelsom van de verschillende elementen gepresenteerd (H). Alle tijdlsbestedingen zijn uiteindelijk teruggerekend naar een gestarte IVF-behandeling.

\section{A. Intakegesprek en overige tijd tot de start van de behandeling}

Deze tijd is in principe slechts eenmalig nodig, namelijk alleen vóór de eerste IVFbehandeling. Gemiddeld zal dit voorwerk 1 uur tijd van een arts vragen én 1 uur van een sekretaresse. De bestede tijd aan paren die uiteindelijk niet met IVF worden behandeld is opgenomen bij de post 'overige werkzaamheden'.

De mate waarin aanvullende diagnostiek en endocrinologische screening wordt uitgevoerd, verschilt sterk per centrum. In een aantal klinieken vindt alleen bij twijfel aanvullende diagnostiek plaats, in andere klinieken wordt vrijwel standaard (alsnog) een semenanalyse uitgevoerd of getest op hamster-eicel-bevruchting en op serumagglutinatie. Ook voeren sommige centra standaard een uitgebreide endocrinologische screening uit bij de vrouw (FSH, LH, testosteron, oestrogenen), terwijl andere centra dit alleen op indikatie doen. De vraag hierbij is: hoeveel werk is men bereid te doen om een (kleine) kans op een (klein of groot) risiko uit te sluiten ? Deze vraag wordt blijkbaar in de verschillende centra sterk verschillend beantwoord. Voor de bovenwermelde aktiviteiten wordt een half uur laboratoriumwerk gerekend.

Onder de veronderstelling dat ieder paar gemiddeld 2 IVF-behandelingen ondergaat, geldt een tijdsbesteding per IVF-behandeling van: 0.5 uur arts, 0.5 uur sekretaresse en 0.25 uur bioloog/analist.

\section{B. Stimulatiefase}

\section{B.1 Medikatie}

De injekties worden lang niet altijd in het IVF-ziekenhuis toegediend. Dit verschilt sterk per ziekenhuis ${ }^{1}$. In het algemeen kan men stellen dat volstaan kan worden met een instruktie om patienten zelf te leren spuiten. Dit vergt ongeveer 1 uur instruktietijd van een verpleegkundige. Onder de veronderstelling dat ieder paar gemiddeld 2 IVF-behandelingen ondergaat resulteert een tijdsbesteding per IVFbehandeling van 0.5 uur verpleegkundige. Hoewel deze instruktie niet bij alle patiënten

1) In ziekenhuis 2 en ziekenhuis 3 vinden wrijwel alle injekties buiten het ziekenhuis plaats; dit geldt in lets mindere mate voor ziekenhuis 5 . In ziekenthuis 4 worden de injekties veelal elders gegeven op niet-kontroledagen en in Dijkzigt op kontroledagen. In ziekenhuis. 1 tenslotte vinden bij de helft van de patienten alle injekties in het ziekenhuis plaats en bij de andere helft van de patiënten in een kombinatie ziekenhuis-elders. 
mogelijk is, zall de benodigde tijd per IVF-behandeling bij toediening door een verpleegkundige niet ver afwijken van dit 0.5 uur.

\section{B.2 Kontrole van de cyclus}

Ten aanzien van de uitgevoerde kontroles bestat een groot verschil tussen de ziekenhuizen, waarbij niet geheel duidelijk is wat nodig is en wat niet (welke informatie wordt gebruikt, wordt de informatie gebruikt in de lopende cyclus of vooral in een evenueel volgende cyclus?). In tabel B4.1.1 is onder andere aangegeven hoeveel kontroles er gemiddeld zijn uitgevoerd in de verschillende ziekenhuizen tijdens het laatste jaar van het evaluatie-onderzoek. De gemiddelde aantallen zijn berekend over alle ziekenhuizen en hebben derhalve alleen betekenis voor een kostenberekening.

\section{Trabel B4.1.1. Uitgevoerde aktiviteiten bij IVF}

In onderstaande tabel worden gemiddelde aantal len met standaarddeviat ve verneld voor alle gestarte behandelingen vanaf juli 1987 tot jun 1988.

\begin{tabular}{|c|c|c|c|c|c|c|}
\hline & Totaa: & $z$ i ekenth. 1 & ziekenh.z & ziekenh. 3 & z i iekenth. 4 & ziakent. 5 \\
\hline $\begin{array}{l}\text { serumm-oestradiolbep. } \\
\text { oestr. bep. in urine }\end{array}$ & $\begin{array}{l}3.1(3.6) \\
2.7(3.4)\end{array}$ & $7.7(1.9)$ & $3.2(1.5)$ & $\begin{array}{l}2.2(3.1) \\
3.6(3.4)\end{array}$ & $4.1(1.8)$ & $9.0(1.8)$ \\
\hline echokontroles & $3.1(1.6)$ & $4.7(1.2)$ & $2.7(1.0)$ & $3.2(1.4)$ & $3.2(1,2)$ & $1.3(0.6)$ \\
\hline H-bepal ingen & $3.5(5.5)$ & $3.9(0.1)$ & $3.3(2.3)$ & $15.2(7.6)$ & $0.0(0.1)$ & $0.7(0.4)$ \\
\hline $\begin{array}{r}\text { ampul ten hMG, to taal } \\
\text { geen LHRH } \\
\text { LHRH kort }\end{array}$ & $18.0(10)$. & $10.5(6.7)$ & $\begin{array}{l}20.5(7.8) \\
19.6(6.4) \\
19.7(7.4) \\
24.6(9.4)\end{array}$ & $\begin{array}{l}15.4(8.7) \\
10.6(3.9) \\
23.7(6.4)\end{array}$ & $22+18.3)$ & $\begin{array}{c}19.6(13.5) \\
9.1(3.7) \\
30.0(11.49\end{array}$ \\
\hline $\begin{array}{r}\text { dagen hMG, totaal } \\
\text { geen. LHRH } \\
\text { LHRH kort } \\
\text { LHRH lang }\end{array}$ & $6.7(2.8)$ & $4.9(2.5)$ & $\begin{array}{l}24.0(3.4) \\
8.5(2.3) \\
8.3(1.8) \\
8.3(2.3) \\
9.6(2.7)\end{array}$ & $\begin{array}{l}6.3(2.6) \\
5.2(1.8) \\
8.0(2.3)\end{array}$ & $6.9(2.0)$ & $\begin{array}{l}7.1(3.4) \\
4.5(1.4) \\
9.6(2.9)\end{array}$ \\
\hline $\begin{array}{l}\text { ampul Ien FSH } \\
\text { dagen: FSH }\end{array}$ & $\begin{array}{l}2.0(4.6) \\
0.8(1.8)\end{array}$ & $\begin{array}{l}7.6(6.4) \\
3.2(2.4)\end{array}$ & $\begin{array}{l}0.2(1.8) \\
0.1(0.6)\end{array}$ & $\begin{array}{l}0.9(1.7) \\
0.4(0.8)\end{array}$ & $\begin{array}{l}0.0(0.3) \\
0.0(0.3)\end{array}$ & $\begin{array}{l}0.5(3.2) \\
0.2(1.1)\end{array}$ \\
\hline $\begin{array}{l}\text { tabletten co } \\
\text { dagen cc }\end{array}$ & $\begin{array}{l}1.5(3.5) \\
0.7(1.8)\end{array}$ & $\begin{array}{l}0.3(1.8) \\
0.2(0.9)\end{array}$ & $\begin{array}{l}0.0(0.6) \\
0.0(0.3)\end{array}$ & $\begin{array}{l}4.0(4.9) \\
2.0(2.4)\end{array}$ & $\begin{array}{l}0.4(1.8) \\
0.2(0.9)\end{array}$ & $\begin{array}{l}4.6(5,0) \\
2.3(2,5)\end{array}$ \\
\hline
\end{tabular}

Voor de kostenberekening zal uitgegaan worden van een kontrole-variant, die in de hedendaagse praktijk kan worden betiteld als akseptabel-terughoudend:

- $4 x$ bepaling van de oestrogenen in urine of in bloed (eventueel van meerdere monsters tegelijkertijd); in de praktijk varieerdle dit aantal heel sterk tussen de ziekenhuizen

- $4 \mathrm{x}$ een echoscopische kontrole; ook hier bestond enige spreiding tussen de ziekentuizen

- geen LH-bepaling; de betekenis van deze bepalingen voor de lopende behandelling is dubieus (getuige het beleid in ziekenhuis 4 en ziekenhuis 5); met de introduktie van LHRH-analogen zal de betekenis van deze bepalingen magenoeg verdwijnen.

De bepaling van de oestrogenen vindt niet plaats in het IVF-laboratorium en kost derhalve geen IVF-analisten-tijd. Hoewel bij kostprijsberekeningen (Scholten[1982], 
Limpens[1986]) is aangegeven dat de kostprijs van deze bepaling beduidend lager ligt dan het tarief (ongeveer in de verhouding van $1: 2,5$ ), wordt in verband met veelvuldig weekendwerk en veelal dagelijkse bepalingem toch een bedrag van $f 45$,- per bepaling gehanteerd (inklusief vergoeding voor bloedprikken). Deze kosten zijn opgenomen bij de materiele kosten in paragraaf 4.3 .

Als tijdsbesteding voor een echoscopische kontrole wordt gehanteerd 0.25 uur voor een arts en een verpleegkundige, dus bij 4 echo's 1 uur arts en 1 uur verpleegkundige. In de praktijk wordt de echo ook wel alleen door een arts of een verpleegkundige uitgevoerd, maar dan duurt het onderzoek langer.

\section{Follikelpunktie}

Bijna alle follikelpunkties vinden tegenwoordig echoscopisch plaats. De voorbereiding vergt ongeveer 20 minuten; hierbij zijn 1 arts en 1 a 2 verpleegkundigen aanwezig. De follikelpunktie zelf duurt gemiddeld ook ongeveer 20 minuten in aanwezigheid van 1 arts, 2 verpleegkundigen (of 1 analist en 1 verpleegkundige) en 1 bioloog/analist. Daarna besteden de 2 verpleegkundigen en de arts ieder ongeveer 20 minuten aan opruimen, napraten met het paar, en dergelijke.

Aldus bedraagt de totale tijdsbesteding 1 uur arts, 2 uur verpleegkundige en 20 minuten bioloog/analist ${ }^{2}$ (c.q. 1 uur arts, 1 uur verpleegkundige en 1 uur en 20 minuten bioloog/analist).

\section{Voorbereiding en uitvoering in-vitro-fertilisatie in het laboratorium}

De voorbereiding voor de daadwerkelijke IVF bestaat uit:

- bereiding van het badge-medium; dit vergt 4 uur van een analist. Aangezien het badge-medium gedurende $1 \mathrm{a} 2$ weken wordt gebruikt, geldt een tijdsbesteding per behandeling van 10 a 25 minuten analist (afhankelijk van de omvang van het programma). Indien het medium voor langere tijd wordt gebruikt is extra tijd nodig voor kwaliteitskontrole met behulp van muizentesten: eens per circa 3 weken 8 uur voor cen analist; verondersteld wordt dat deze extra tijd voor muizentesten het langer gebruik van het badge-medium kompenseert.

- bereiding media per patiënte; deze werkzaamheden, vooral het prepareren van het serum, vergen 1.5 uur analist.

De aktiviteiten die daarna volgen en die alle direkt te maken hebben met de daadwerkelijke in-vitro-fertilisatie zijn in te delen in:

- beoordeling en verwerking van de oöcyten, opwerking en beoordeling van het semen en de inseminatie: 1.5 a 2 uur bioloog/analist

- overplaatsing(en) van de oócyten en beoordeling(en) van de fertilisatie c.q. celdeling: circa 0.5 a 1 uur bioloog/analist.

De sterilisatie van het materiaal vergt ongeveer 2 uur per week, hetgeen overeenkomt met een tijdsbesteding per IVF-behandeling van ongeveer 15 minuten bioloog/analist. De totale tijdsbesteding in het laboratorium voor deze fase van de IVF-behandeling bedraagt dus gemiddeld 4 a 5 uur bioloog/analist (mede afhankelijk van de omvang van het programma).

2)Tjd die de analist direkt aansluitend aan de follikelpunktie besteedt aan IVF-aktiviteiten is opgenomen bij onderdeel $D$. 


\section{E. Embryotransfer}

Inklusief woorbereiding en nazorg kan aan tijd worden berekend 0.5 uur arts, 0.5 uur verpleegkundige en 0.5 uur bioloog/analist.

\section{F. Luteale fase}

Het nagesprek wordt gevoerd door een arts en duurt gemiddeld 0.5 uur. De toediening van de luteale ondersteuning wordt niet als aparte IVF-aktiviteit meegenomen. In 2 van de 5 ziekenhuizen wordt voornamelijk orale medikatie voorgeschreven. In de andere ziekenhuizen worden de injekties ook voor een gedeelte buiten hel IVFziekenhuis toegediend (bijwoorbeeld door de patiente zelf of door een huisarts). Indien per zwangerschap een extra tijdbesteding van 1 uur arts wordt geraamd, dan geldt per gestarte behandeling een extra tijdsbesteding van 10 minuten. De totale tijdsbesteding per gestarte behandeling bedraagt derhalwe 40 arts-minuten.

\section{G. Niet-gespecificeerde werkzaamheden}

Hiervan is moeilijk een kompleet overzicht te geven, laat staan een korrekte inschatting van de benodigde tijd. Bovendien bestaan er grote verschillen in de aktiviteiten per ziekenhuis en in de organisatie van de aktiviteiten per ziekenhuis. Hieronder worden de meest voorkomende aktiviteiten benoemd, met een indikatie woor de tijdsbesteding:

- Voorlichting algemeen: 1 uur arts, 1 uur bioloog, 1 uur verpleegkundige en 1 uur sekretaresse per week

- Telefonisch spreekuur: 5 uur per week arts of verpleegkundige

- Patientenbespreking: 15 minuten per behandeling ( 2 artsen, bioloog, analist, verpleegkundige)

- IVF-bespreking algemeen: 2 uur per week ( 2 artsen, bioloog, analist, verpleegkundige(n), sekretaresse)

- Sekretariaatswerk met betrekking tot de behandeling (exkl. registratie): 0.5 uur per behandeling

- Organisatorische werkzaamheden selkretariaat: 8 uur per week

- Verwerking van de registratie: 2 uur verpleegkundige, 2 uur sekretaresse en 2 uur bioloog/analist per week

- Overige organisatorissche werkzaamheden: 6 uur arts en 6 uur bioloog per week

- Bijhouden ontwikkelingen rondom IVF (literatuur, lezingen, symposia) en eigen onderzoek: 8 uur arts en 8 uur bioloog per week

In totaal resulteert hieruit ongeveer een tijdsbesteding per IVF-behandeling van 3 uur arts, 2.25 uur bioloog, 2 uur sekretaresse, 1.25 uur verpleegkundige en 0.75 uur analist. Deze uitkomsten zijn uiteraard afhankelijk van de omvang van het IVF-programma; in deze opstelling is uitgegaan van het programma van jaarlijks 375 behandelingen.

\section{H. Sommatie der elementen}

Op basis van de berekende tijdsbesteding per afzonderlijke aktiviteit is een totaaltelling vast te stellen. Daarbij moeten echter de eerder geplaatste kanttekeningen bij deze benadering goed in het achterhoofd worden gehouden. De weergegeven tijdsbestedingen zijn derhalve te beschouwen als een soort 'netto tijden', na aftrek van onregelmatigheid, periodes van "stilstaan", e.d. 
Per IVF-behandeling geldt het onderstaande totaalplaatje in uren per discipline (aitgaand van een witval vór de follikelpunktie van $20 \%$ en een uitval vóor de embryotransfer vain in totaal. $30 \%{ }^{3}$ ), opgebouwd per onderdeel.

\begin{tabular}{|c|c|c|c|c|}
\hline onderdeel & arts & bfoloog/anatist & verpleegkundige & sekretaresse \\
\hline A. Intike & 0.5 & 0.25 & & 0.5 \\
\hline H. stimulatiefase & 1.0 & & 1.5 & \\
\hline C. Foll t kelpunkt to & 0.8 & 0.25 & 1.6 & \\
\hline D. In-vitro-fertilisatie & & 3.6 & $\therefore$ & \\
\hline E. Embryotranifer & 0.35 & 0.35 & 0.35 & \\
\hline F. Luteale fase & 0.6 & & & \\
\hline G. Overig & 3.0 & 3.0 & 1.25 & 2.0 \\
\hline rotad & 6.25 & 7.45 & 4.70 & 2.5 \\
\hline
\end{tabular}

Indien volstrekt geen rekening zou worden gehouden met leegloop tussen de aktiviteiten en met onregelmatige diensten, perioden warin het IVF-programma stil ligt e.d., dan kan aan de hand van deze getallen worden berekend hoeveel IVF-behandelingen een persoon van een bepaalde discipline per jaar zou kunnen verzorgen. Nogmaals, deze berekening is puur theoretisch en dient alleen om enig zicht te verkrijgen op de, grotendeels aan een IVF-programma inherente, onbenutte personele kapaciteit. Onder de veronderstelling van 2000 werkuren per jaar voor artsen en biologen en 1600 werkuren voor verpleegkundigen, analisten ${ }^{4}$ en sekretaressen bij een full-timeaanstelling is het maximale aantal IVF-behandelingen per full-time equivalent weergegeven in tabel $\mathrm{B} 4.1 .3$.

Tabell B4,1.3. Maximale theoretísche IVF-kapaciteit per persoon van een bepaalde diselpline

$\begin{array}{ll}\text { arts } & 320 \\ \text { bioloog/analist } & 350 \\ \text { verplleggundige } & 340 \\ \text { sekretaresse } & 640\end{array}$

3) Zodoende zijn do tijdsbestedingen bij de onderdelen $C$ en $D$ vermenigvuidigd met een faktor 0.8 en die bij onderdeel the met de faktor 0.7 .

4) Bij de bioloog/analist wordt er in deze globale berekening wanuit gegaan, dat de bioloog $1 / 3$ en de analist $2 / 3$ van de IVF-werkzaamheden verzorgt; dus het asntal werkuren per jaar bedfaagt voor hen (gewogen) geniddeld 186\%. In de praktijk vereist de toezichthoudende taak van de bioloog een rumere annwezigheid/berelkbartheid van iemand wan deze discipline. 
Deze berekening - het zij nogmaals benadrukt - is alleen bedoeld als kader voor de verdere berekeningen in paragraaf 4.2. Ten behoeve van een IVF-programma is de noodzakelijke aanwezigheid van personeel van verschillende disciplines op velerlei tijdstippen van veel groter belang dan de theoretische optelsom van de diverse aktiviteiten. Dit geldt met name voor het laboratorium-personeel. Zelfs voor een relatief klein IVF-programma is een bepaalde minimale bezetting vereist. Bij uitbouw van een IVF-programma is er zeker geen sprake van een evenredige groei in de noodzakelijke personele capaciteit. Deze konstatering wordt getalsmatig nader uitgewerkt in paragraaf 4.2 . 
Biflage 4.2. Berekening van benodigd personeel op basis van noodzakelijke aanwezigheid

Het bezwaar om vanuit een totaaltelling van tijdsbestedingen van diverse disciplines aan specifieke IVF-aktiviteiten te komen tot een raming van de benodigde personele capaciteit geldt in het algemeen. Maar door de personen in de ziekenhuizen werd aangegeven dat dit bezwaar het zwaarste weegt bij een relatief klein IVF-programma van 300 follikelpunkties ( 375 stimulaties) per jaar, aangezien de leeglooptijden dan het grootst zullen zijn. Derhalve is in deze bijlage een berekening opgesteld op basis van beschikbarheid op bepaalde momenten in de week van personen van verschillende disciplines. Deze berekening is opgesteld op basis van de volgende uitgangspunten voor een dergelijk IVF-programma:

1. Het IVF-programma ligt gedurende 1 maand per jaar volledig stil; rondom deze pauze bestaat nog een periode van opstarten en een periode van aflopen. Deze beide perioden tezamen duren ruim een maand. Deze duidelijk rustigere perioden worden in total als $1 / 3$ maand rust voor het IVF-team beschouwd. In de praktijk gelasten de meeste centra zowel in de zomervakantie als rondom de jaarwisseling een pauze in.

Konkreet vertaald betekent dit dat het IVF-programma 325 dagen per jaar op volle toeren zou draaien (365-30-10).

2. Op iedere dag van de week (inklusief de weekenden) moeten 1 arts, 1 verpleegkundige en 1 persoon in het laboratorium de gehele dag aanwezig zijns; daarnaast is in het laboratorium in de ochtenden een extra persoon nodig. In de praktijk dienen er weliswaar vrijwel ieder weekend aktiviteiten te worden verricht, met name in het laboratorium, maar de veronderstelling van een normale weekbezetting ook voor de weekenden is aan de ruime kant.

Konkreet vertaald moet er iedere dag 1 arts, 1 verpleegkundige en 1.5 bioloog/analist aanwezig zijn (ook in de weekenden).

3. Voor de bepaling van de daadwerkelijk beschikbare dagen van een IVFmedewerker worden de volgende uitgangspunten gehanteerd (uitgaande van een full-time-kracht):

- Voor academisch geschoold personeel wordt er vanuit gegaan dat men naast de 5 werkdagen per week in totaal 20 weekenddagen per jaar werkt. Ieder heeft recht op circa 45 vrije dagen ( 25 verlofdagen, 12 ADV-dagen, 8 extra zon- en feestdagen). Verondersteld wordt dat in de periode waarin het IVF-programma draait ieder 20 vrije dagen opneemt en 10 dagen afwezig is in verband met ziekte.

5) Aangezien een sekretaresse in het algemeen geen direkte patientenzorg verleent, behoeft voor deze persoon niet te worden uitgegaan van een beschikbaartheid op bepaalde urem; de taken kunnen in het algemeen binnen de organisatie op redelijk vaste momenten worden ingepast. Derhatve kan voor de berekening van het benodigde sekretariële personeel worden teruggegrepen op de eerdere opstelling in de hoofdtekst.

6) Zeker voor een bioloog geldt dat deze daarnaast in de weekenden vaak bereikbar dient te zijn. 
Konkreet vertaald is een full-time kracht met academische scholing derhalve in de periode waarin het IVF-progranma draait 250 dagen beschikbaar ( $365 \times 5 / 7=260 ; 260+20-20-10=250$ ).

Voor het overige personeel gelden grotendeels dezelfde uitgangspunten. Maar er wordt bovendien verondersteld, dat dit personeel voor weekendwerk 1.5 keer gekompenseerd wordt in vrije dagen (naast de financiele kompensatie). Uitgaande van én weekenddienst $(=2$ volledige dagen) per 3 weken en circa 47 weken waarin het IVF-programma draait, leidt dit tot 24 kompensatiedagen $(47 / 3 \approx 16 ; 16 \times 1.5=24)$. In de praktijk geldt voor dit personeel, dat men in een weekend meestal niet hele dagen aanwezig hoeft te zijn; een kompensatieregeling als deze is zeker niet overal praktijk.

Konkreet vertaald is een full-time, niet-academisch geschoolde kracht derhalve circa 200 dagen beschikbaar in de periode waarin het IVF-programma draait $(365 \times 5 / 7=260 ; 260-20-10-24=206$ ).

4. Onder de gehanteerde veronderstellingen moeten er in een IVF-centrum derhalve per academicus circa 1.3 fte $(325 / 250)$ en per niet-academicus circa 1.6 fte $(325 / 200)$ in dienst zijn om op alle dagen van de week per discipline 1 personeelslid aanwezig te kunnen laten zijn. Voor het IVF-programma van 300 follikelpunkties betekent dit een team bestaande uit 1.3 fte arts, 1.6 fte verpleegkundige en 2.25 fte laboratorium-personeel?

De vertaling vanuit de full-time-equivalenten naar de verdeling van de IVF-taken over meerdere personen met full-time of part-time aanstellingen zal in de praktijk zeker niet eenvoudig zijn. Vandaar dat de speling ten opzichte van de berekeningen in de hoofdtekst niet overdreven groot is. Daarnaast geldt voor de bioloog dat deze veelal aanwezig zal moeten zijn, ook al kunnen de IVF-aktiviteiten in principe worden verricht door een analist; de verantwoordelijkheid blijft berusten bij de bioloog. Hoewel deze situatie strikt genomen ook geldt met betrekking tot de verantwoordelijkheden van een gynaecoloog, geldt daarvoor dat een belangrijk gedeelte van de aktiviteiten kan worden overgenomen door een andere academisch-opgeleide: een basisarts.

7) Uitgaande van de verhouding academicus:niet-academicus $=1: 2$ geldt cen vermenigvuldigingsfaktor van $1.5 ; 1.5 \times 1.5=2.25$. 
Bijlgge 4.3. Prijzen wan medicijnen (inklusief $6 \%$ BTW) in gebruik bil IVFbehandelingen

\begin{tabular}{|c|c|c|c|c|}
\hline Stofnatm & Preparaa tnaam & Aft. worm & Dosis & Prijs per dosis \\
\hline \multicolumn{5}{|l|}{ Progestagenen } \\
\hline Dydrogesteron & Duphaston & tabl. $10 \mathrm{mg}$ & 10 stuks & $f 14.89$ \\
\hline Progesteron. & Progestine & amp. $25 \mathrm{mg}$ & $\|$ stuk & $f 11.17$ \\
\hline Hydroxyproges teron & Proluton Depot & $\begin{array}{l}\text { amp. } 250 \mathrm{mg} \\
\text { amp. } 500 \mathrm{mg}\end{array}$ & $\begin{array}{ll}1 & \text { stuk } \\
1 & \text { stuk }\end{array}$ & $\mid \begin{array}{rr}f & 8.60 \\
f & 11.12\end{array}$ \\
\hline \multicolumn{5}{|l|}{ Ant ihormonen } \\
\hline Clomifeen & $\begin{array}{l}\text { Serophene } \\
\text { cllomid }\end{array}$ & $\begin{array}{l}\text { tabl. } 50 \mathrm{mg} \\
\text { tabl.50 mg }\end{array}$ & $\begin{array}{l}10 \text { stuks } \\
10 \text { stuks }\end{array}$ & $f \begin{array}{ll}f & 37.09 \\
f & 39.20\end{array}$ \\
\hline \multicolumn{5}{|l|}{ Gonadotropinen } \\
\hline $\mathrm{HCG}$ & Profas i & $\begin{array}{l}\text { amp. } 500 \text { IE } \\
\text { amp. } 1500 \text { IE } \\
\text { amp. } 5000 \text { IE } \\
\text { amp. } 5000 \text { IE }\end{array}$ & $\begin{array}{ll}1 & \text { stuk } \\
1 & \text { stuk } \\
1 & \text { stuk } \\
1 & \text { stuk }\end{array}$ & $\begin{array}{rr}f & 2.59 \\
f & 5.04 \\
f & 10.97 \\
f & 10.25\end{array}$ \\
\hline$H M G$ & $\begin{array}{l}\text { Pergonal } \\
\text { Humegon }\end{array}$ & $\begin{array}{l}\text { amp. } 75 \mathrm{IE} \\
\text { amp. } 75 \mathrm{IE}\end{array}$ & $\begin{array}{l}1 \text { stuk } \\
1 \text { stuk. }\end{array}$ & $\begin{array}{l}f 23.32 \\
f 24.76\end{array}$ \\
\hline F\$H & Metrodin & amp. 75 IE & 1 stuk & $f 45.58$ \\
\hline Busereline & Supirefact & $\begin{array}{l}\text { amp. } 5.5 \mathrm{mg} \\
\text { spray } 10 \mathrm{mg}\end{array}$ & $\begin{array}{l}\text { I stuk } \\
\text { i flac. }\end{array}$ & $f \begin{array}{l}f 7.82 \\
f 115.65\end{array}$ \\
\hline
\end{tabular}

Bron: Ziekenfondsraad[1988] . 
Bijlage 4.4. Medikatieschema's met betrekking tot luteale fase-ondersteuning

\section{Ziekenhuis 1}

Schema P (tot zomer 1987):

- Progestine i.m. op poli VeVo of huisarts (LFD $0=$ dag punktie):

LFD 0-4: 12,5 mg, LFD 5-7:25 mg, LFD 8 e.v.: 12,5 mg.

- Proluton Depot i.m. : 1 x per week $250 \mathrm{mg}$ vanaf dag positieve beta-HCO.

Schema B (vanaf augustus 1987):

- Progestine zetpillen (rectaal/vaginaal; 1 zetpil $=25 \mathrm{mg}$ ):

LFD $0: 1$ na punktie, 1 's avonds; LFD $1: 1$ 's morgens, 1 's avonds

LFD $2: 1$ 's morgens, 11.5 uur voor ET; LFD 3-15: 1 's morgens, 1 's avonds

Beëindiging Progestine : $-2 \times$ negatieve beta- HCG.

- (in overleg) na vloeien.

- 3 dagen na 1e toediening Proluton Depot.

Beëindiging Proluton Depot : $13 \mathrm{e}$ à $14 \mathrm{e}$ week.

\section{Ziekenhuis 2}

Schema A: Geen medikatie (bij oneven geboortejaar vrouw).

Schema K: Bij even geboortejaar vrouw en/of gebruik. LHRH-analoog:

- vanaf dag ET 4 dagen $25 \mathrm{mg}$ Progesteron i.m. en $200 \mathrm{mg}$ Progesteron support i.m.

- op 6e dag na ET 5000 IE HCG

Schema P: vanaf augustus '87:

- vanaf dag ET tot menstruatie of hartaktie $200 \mathrm{mg}$ Progesteron support i.m. per dag

- op $4^{e}$ dag na ET 1500 IE HCG (Pregnyl)

\section{Ziekenhuis 3}

Schema A: vanaf dag ET om de dag HCG(Pregnyl) 1500 IE i.m. gedurende 14 dagen ( in totaal $7 x$ ).

Schema B: (vanaf nov. '87); vanaf LFD 0 tm LFD 13 Duphaston oraal, $2 x$ dd $10 \mathrm{mg}$. Schema C: (vanaf nov. '87): vanaf LFD 0 tm LFD 13 Duphaston oraal, 3x dd $10 \mathrm{mg}$.

\section{Ziekenhuis 4}

Schema P: HCG (Pregnyl) 5000 IE i.m. op LFD 0,2 en 4.

(luteale fase dag $0=$ dag punktie).

\section{Ziekenhuis 5}

Schema A: vanaf LFD $0(=$ dag punktie $)$ : Duphaston dagelijks $3 \times 10 \mathrm{mg}$ tot uiltslag HCG (ca. 14 dagen).

Schema B: zowel Duphaston (zie schema A) als Pregnyl (op LFD 3,6 en 9; 5000 lE), indien eerder ondanks Duphaston de luteale fase $<10$ dagen.

Schema P: Pregnyl 5000 IE op LFD 3,6 en 9. 
Bijlage 4.5. Globale schating van de grerige kosten binnen de gezondheidszorg na een IVE-behandeling

Als globale benadering voor de extra kosten in de gezondheidszorg voortkomend wit de IVF-behandelingen zouden de volgende richtgetallen kunnen dienen bij kostentoerekening naar een gestarte IVF-behandeling:

- komplikaties rechtstreeks ten gevolge van de IVF-behandeling $f$ 5,-

- klinische abortus $(f 700 / 43)$

- extra-uteriene graviditeil (f5000/133)

$f 16$,-

- perinatale zorg $(f 15,000 / 50)^{10}$

- zwangerschapsbegeleiding ${ }^{11}$

Volgens deze globale berekening bedragen de extra kosten in de gezondheidszorg na afloop van cen IVF-behandeling gemiddeld $f 360,-$; het grootste gedeelte hiervan komt op thet konto van de neonatale zorg. Dit bedrag komt overeen met circa $15 \%$ van de kosten van de IVF-behandeling zelf.

8) Voor de incidentie wan klinische abortus en EUG ma een IVTH behandeling zij verwezen naar paragraaf 4.5 .

9) De berekening is gebaseerd op en incidentie van $1 \%$ (Ewers [1989]) en opnamekosten van $f 500$,Zoals reeds wermeld in paragraaf 3.3 .2 .1 is weinig bekend omtrent incidentie en opnameduur bij komplikaties van IVF.

10) Voor deze inschatting is uitgegalan wan de weronderstelling dat 1 kind per 5 voldragen zwangerschappen neonaiale zorg behoeft. Per kind dal neonatale zorg behoeft word uitgegaan van een richugetal van $f 15,000, \cdots$.

11) Aangerien niet duidelijk is in hoeverte ex extra zwangerschapsbegeleiding plaatsvindt ten opzichte van een vergelijkbare populatie zijn de bijbehorende eventuele extra kosten niet gekwantüficeerd. 


\section{Bijlage 4.6. Geografische spreiding en reisafstand}

De geografische spreiding van de behandelde paren (bepaald op basis van eerste 2 cijfers postkode; indeling in 7 gebieden (zie figuur B4.6.1)) ziet er als volgt uit:

\begin{tabular}{c|ccl} 
Gebied & $\%$ wachtlijst $\%$ behandeld & Globale gebiedsaanduiding \\
\hline 1 & 25 & 26 & Noord-Holland \\
2 & 28 & 21 & Zuid-Holland \\
3 & 10 & 11 & Utrecht \\
4 & 10 & 7 & Zeeland en deel Noord-Brabant \\
5 & 10 & 12 & deel Noord-Brabant en Limburg \\
6 & 11 & 14 & Gelderland en deel Overijssel \\
7 & 8 & 8 & deel Overijssel, Drenthe, Groningen, Friesland \\
elders & & 1 & buitenland
\end{tabular}

Voor de meeste zickenhuizen geldt dat ruim de helft van hun patientenpopulatie uit de nabije omgeving afkomstig is, dat wil zeggen woonzaam is binnen een straal van circa $50 \mathrm{~km}$. (ziekenhuis $170 \%$, ziekenhuizen 2 en $350 \%$, ziekenhuizen 4 en $540 \%$ ).

De geografische spreiding van de behandelde paren tijdens de onderzoeksperiode is soortgelijk als de geografische spreiding van de wachtlijstpatienten (zie bijlage 5.2).

Figuur B4.6.1: Gebiedsverdeling op basis van de eerste 2 cijfers van de postkode

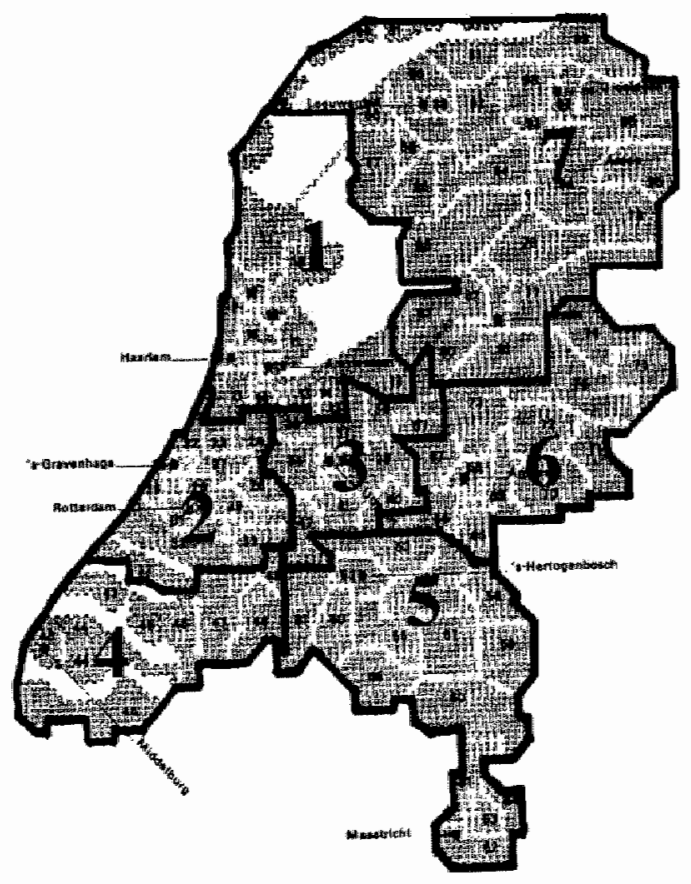


Bijlage 5.1: Bevolkingsprognose

De omvang van de populatie die in verband met fertiliteitsproblemen in aanmerking kan komen voor een behandeling is ons inziens goed in te schatten op basis van de leeftijdskategorieen 25 tot en met 40 jaren voor de vrouw (de leeftijd van de man is in verband met een grotere spreiding voor dit doel minder geschikt).

Tabel B5.1.1. Bevolkingsprognose voor vrouwen volgens de middenvariant ( $x$ 1000)

\begin{tabular}{l|cccccc} 
Leaftije vrow & 1985 & 1990 & 1995 & 2000 & 2005 & 2010 \\
\hline $25-29$ jaren & 591 & 626 & 611 & 540 & 442 & 434 \\
$30-34$ jaren & 560 & 591 & 623 & 609 & 538 & 441 \\
$35-39$ jaren & 573 & 559 & 589 & 621 & 607 & 536 \\
\hline $25-39$ jaren & 1724 & 1776 & 1823 & 1770 & 1587 & 1411
\end{tabular}

Bron: CBS[1986]. 


\section{Bijlage 5.2: Wachtijst-situatie IVF in februari 1987}

Om enig inzicht te verkrijgen in het aantal paren dat in Nederland woor IVFbehandeling op de wachtlijst staat en in de regionale spreiding van de wachtlijst-IVFparen, werd aan de 5 aan het onderzoek deelnemende ziekenhuizen gevraagd de volgende gegevens ${ }^{1}$ te verstrekken:

1.geboortedatum vrouw en eerste 3 letters van de meisjesnaam

2.eerste 2 cijfers van de postkode.

Naar aanleiding van diskussies omtrent eventuele mogelijkheden tot doorbreking van de anonimiteit werd besloten beide gegevensblokken los te koppelen. Ondanks deze loskoppeling weigerde de Registratie Advies Commissie van én ziekenhuis in eerste instantie toestemming te verlenen voor deze gegevensverstrekking. Pas na schriftelijke aanmaning van de kant van de Begeleidingskommissie Evaluatie-onderzoek-IVF ging men overstag. De resultaten van de inventarisatie staan weergegeven in tabel B5.2.1.

Tabel B5.2.1: Aantal paren op de wachtlijst voor IVF in 5 Nederlandse ziekenhuizen (februari 1987)

\begin{tabular}{lccr} 
& $\begin{array}{c}\text { Totale omvang } \\
\text { wachtlijst }\end{array}$ & \multicolumn{2}{c}{ Dubbel } \\
\cline { 1 - 3 } ziekenhuis 1 & 646 & 30 & 5 \\
ziekenhuis 2 & 209 & 37 & 18 \\
ziekenthuis 3 & 281 & 42 & 15 \\
ziekenhuis 4 & 1264 & 94 & 7 \\
ziekenhuis 5 & 172 & 43 & 25 \\
& & & \\
\hline Totaal & 2572 & &
\end{tabular}

Bij de 5 ziekenhuizen bleken rond februari 1987 in totaal bijna 2600 paren op de wachtlijst te staan (inklusief de paren die reeds in IVF-behandeling zijn, maar nog in aanmerking wensen te komen voor een volgende behandelcyclus). Aan de hand van het eerste gegevensblok werd gekeken in hoeverre paren op meerdere wachtlijsten stonden. Globaal was dit het geval bij circa $5 \%$ van de paren ${ }^{2}$. Rekening houdend met deze dubbellellingen resulteert voor de 5 ziekenhuizen tezamen een gekorrigeerde IVFwachtlijst van circa 2400 paren.

1)

Gegevens over indikatie, leeftijd e.d. zijn niet gevraagd. Enerajjds zijn data omtrent indikatie e.d. niet van alle paren op the wachthijst bekend (met name indien alleen mat teletonische asnmelding neef plaatsgevonden). Anderzijds zou het problem wan de privacy-gewoelligheid allecen maar toenemen bij vragen omtrent leeftijd e.d.

2) 97 paren stonden bij 2 ziekenhuizen ingeschreven, 10 paren bij 3 ziekenhuizen, 3 paren bij 4 ziekenhuizen en 2 paren bij alle 5 de zkekenhuizen. Derhalve bligven $2572-97 \cdot(10 \times 2) \times(3 \times 3)$ $(2 \times 4)=2438$ paren over. 
De wachtlijstgegevens betreffen echter zowel paren die nog niet behandeld zijn als paren die al een of meerdere IVF-behandelingen hebben ondergaan. Gedurende de projektperiode zijn er tot en met februari 1987 circa 600 paren behandeld in de 5 ziekenhuizen. Derhalve bedroeg het aantal nog-niet-behandelde paren op de wachtlijsten op dat moment circa 1800.

Voor de geografische spreiding van de paren op de wachtlijsten is noodgedwongen uitgegaan wan de ongekorrigeerde wachtlijstgegevens (niet gekorrigeerd voor dubbeltellingen en reeds behandeld zijn met IVF) in verband met de loskoppeling van de beide gegevensblokken. De eerste 2 cijfers van de postkode waren bekend voor 2221 van de 2572 paren $(86 \%)$. De meeste paren met onbekende postkode kwamen voor op de wachtlijst van eên ziekenhuis ( 342 paren; dit betreft paren die van buitenaf zijn angemeld).

\begin{tabular}{|c|c|c|}
\hline Gebied & * van de wachtlijstparen & Globale gebiedsaanduiding \\
\hline 1 & 25 & Noordm-Hol land \\
\hline 2 & 28 & Zuid-Holl land \\
\hline 3 & 10 & Utrecht \\
\hline 4 & 10 & Zeeland en deel Noord-Brabant \\
\hline 5 & 10 & deel Noord-Brabant en Limburg \\
\hline 6 & 11 & Gelderlland en deel overijssel \\
\hline 7 & 8 & deel Overijssel, Drenthe,Graningen, Frieslland \\
\hline
\end{tabular}




\section{Bijlage 6.1. Argumenten voor en tegen financiering op basis van resultaten.}

Het principe van "no cure, no pay" is zeer ongebruikelijk in de Nederlandse gezondheidszorg. Veelal is een dergelijke financiering ook niet goed mogelijk vanwege de vaststelling van de al dan niet sukseswolle afloop van de behandelling. Voor de IVFbehandeling geldt nu juist bij uilstek dat het resultaat van de behandeling op relatief korte termijn heel duidelijk is; er kan alleen nog enig menigsverschil bestaan over de precieze afbakening van de maatstaf voor sukses van de behandeling.

Bij toepassing van een financiering per bereikte doorgaande zwangerschap wordt een financiële prikkel tot kwaliteitsverbetering ingebouwd: centra met goede resultaten worden goed betaald, centra met slechte resultaten zullen op den duur vanzelf moeten stoppen. Maar deze financiële prikkel zou kumnen leiden tot patiëntselektie: een bepaald centrum tracht patiënten met relatief gunstige prognoses te lokken en patiènten met relatief ongunstige prognoses af te schuiven:

1. naar andere centra

2. naar andere behandelvormen met een financiering per verrichting.

Ad 1.

In de onderzoeksperiode bleek de samenstelling van de patièntenpopulaties voor de 5 ziekenhuizen slechts zeer gedeeltelijk verantwoordelijk te zijn voor de verschillen in de zwangerschapsiesultaten per centrum. In de toekomst zou doorverwijzing tussen IVF-centra beperkt kunnen worden door een verbodsregeling: de aangewezen IVFcentra mogen geen patiënten doorverwijzen voor IVF-behandeling.

Ad 2.

Indien de financieringswijzen voor IVF en eventuele alternatieven zouden verschillen (bijvoorbeeld bij de ene therapie financiering per doorgaande zwangerschap en bij de andere therapie financiering per verrichting) dan geldt wederom dat door de ongelijke yoorwaarden bij beide therapieèn geen optimaal afgewogen besluitvorming zou kunnen plaatsvinden. Dit zou leiden tot inefficient gebruik van middelen. Dus financiering per sukses is bij de IVF-behandeling alleen goed mogelijk indien deze wijze van financiering ook bij andere vormen van fertiliteitsbehandeling zou worden ingevoerd. Bij tubachirurgie doemen dan 2 problemen op:

het zwangerschapsresultaat kan even op zich laten wachten

bij sommige patiëntgroepen zou een gedeelte van de zwangerschappen ook zonder de tubachirurgische ingreep zijn ontstaan.

Naast beide bovengenoemde afschuifmogelijkheden bestaat er voor de gynaecoloog uiteraard nog de mogelijkheid om een paar niet te behandelen, bijwoorbceld in verband met een zeer geringe sukseskans. Deze mogelijkheid dient uit kosteneffectiviteitsoverwegingen ook nadrukkelijk open te blijven. Maar ze zou bij een financiering per doorgaande zwangerschap wel kunnen leiden tot een zeer selectieve uitvoering van de IVF-behandeling.

Al met al kan gesteld worden, dat de optie van financiering per doorgaande zwangerschap uit kosten-effectiviteitsoverwegingen wellicht zinvol zou kunnen zijn. Maar de bezwaren van "adverse selection" zijn in de praktijk onvoldoende te ondervangen, waardoor deze financieringswijze ethisch niet haalbaar is. Voor een iets meer vitgebreide beschrijwing van de reguleringsproblematiek inzake IVF zij verwezen naar Haan[1989b] en Schellekens[1989]. 


\section{CURRICULUM VITAE}

Ger Haan werd geboren op 14 juni 1958 in Heerlen. Hij behaalde zijn diploma Gymnasium-B in 1976 (Bernardinus College, Heerlen). Hij studeerde ekonometrie aan de toenmalige Katholieke Hogeschool Tilburg (tegenwoordig Katholieke Universiteit Brabant). Tijdens zijn studietijd was hij als student-assistent werkzatam bij de vakgroepen Algemene Ekonometrie en Organisatie van de Gezondheidszorg. Het doktoraal examen in de afstudeerrichting algemene ekonometrie werd behaald in augustus 1983. Aansluitend was hij gedurende eén schooljaar docent ekonomische wetenschappen aan het Theresialyceum in Tilburg. Sinds 1984 is hij in dienst van de Rijksuniversiteit Limburg in Maastricht, werkzaam bij de vakgroep Ekonomie van de Gezondheidszorg. Zijn funktie van universitair docent verruilde hij in mei 1986 met die van universitair onderzoeker. Sinds mei 1989 is hij als zodanig binnen de Rijksuniversiteit Limburg werkzaam bimnen het Instituut voor Medische Technology Assessment. 